\title{
Geochemical and Isotopic
} Evaluation of Groundwater Movement in Corrective Action Unit 97: Yucca Flat/Climax Mine, Nevada Test Site, Nevada

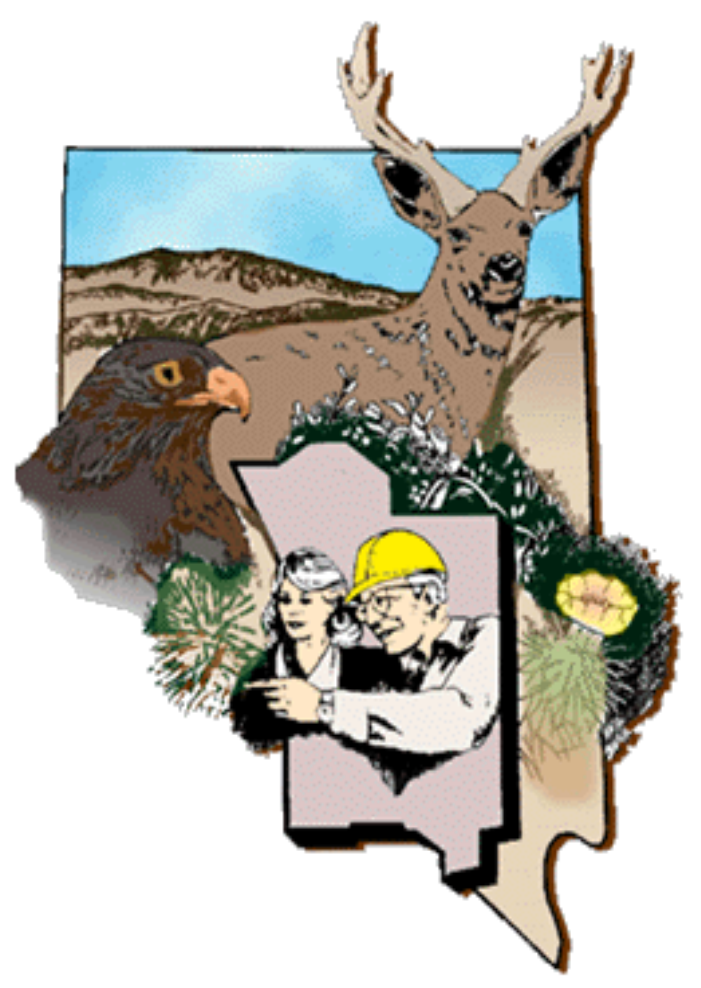

Revision No.: 0

February 2006

Prepared for U.S. Department of Energy under Contract No. DE-AC52-03NA99205. 


\section{GEOCHEMICAL AND ISOTOPIC EVALUATION OF GROUNDWATER MOVEMENT IN CORRECTIVE ACTION UNIT 97: YUCCA FLAT/CLIMAX MINE, NEVADA TEST SITE, NEVADA}

\section{Contributors:}

I.M. Farnham ${ }^{1}$, T.P. Rose $^{2}$, E.M. Kwicklis ${ }^{3}$, R.L. Hershey ${ }^{4}$, J.B. Paces ${ }^{5}$, and W.M. Fryer ${ }^{1}$

${ }^{1}$ Stoller-Navarro Joint Venture, Las Vegas, NV

${ }^{2}$ Lawrence Livermore National Laboratory, Livermore, CA

${ }^{3}$ Los Alamos National Laboratory, Los Alamos, NM

${ }^{4}$ Desert Research Institute, Reno, NV

${ }^{5}$ U.S. Geological Survey, Denver, CO

Revision No.: 0

February 2006

Stoller-Navarro Joint Venture 7710 W. Cheyenne, Building 3

Las Vegas, NV 89129 
GEOCHEMICAL AND ISOTOPIC EVALUATION OF GROUNDWATER MOVEMENT IN CORRECTIVE ACTION UNIT 97: YUCCA FLAT/CLIMAX MINE, NEVADA TEST SITE, NEVADA

Approved by: $\frac{\text { Approved Signature }}{\begin{array}{l}\text { John McCord, UGTA Project Manager } \\ \text { Stoller-Navarro Joint Venture }\end{array}}$ Date: $2-28-06$ 


\section{TABLE OF CONTENTS}

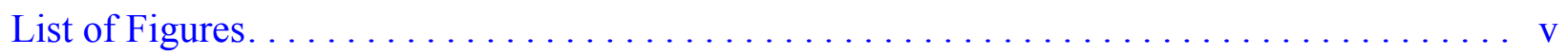

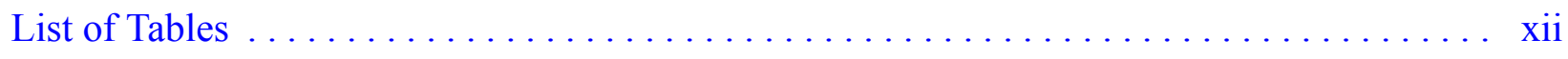

List of Acronyms and Abbreviations ........................... xiv

List of Stratigraphic Unit/Location Abbreviations and Symbols ................ xvi

List of Symbols for Elements and Compounds $\ldots \ldots \ldots \ldots \ldots \ldots \ldots \ldots \ldots \ldots$ xviii

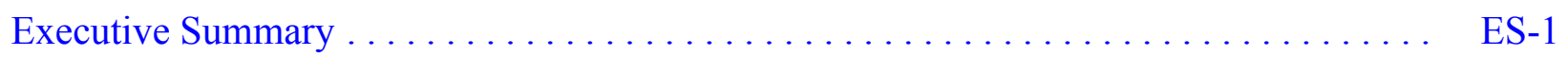

$1.0 \quad$ Introduction $\ldots \ldots \ldots \ldots \ldots \ldots \ldots \ldots \ldots \ldots \ldots \ldots \ldots \ldots \ldots \ldots \ldots \ldots \ldots \ldots \ldots \ldots, 1$

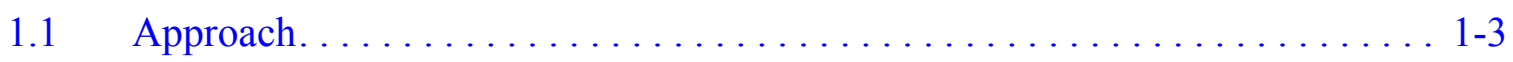

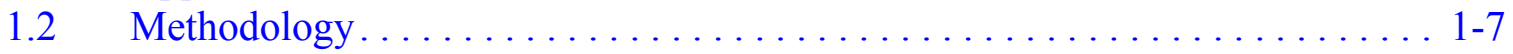

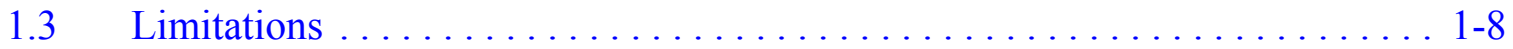

$2.0 \quad$ Hydrogeological and Hydrogeochemical Setting . . . . . . . . . . . . . . . 2-1

$2.1 \quad$ Hydrogeologic Framework......................... 2-1

2.2 Yucca Flat Hydrostratigraphic Framework Model. . . . . . . . . . . . . . . 2 2-6

2.3 Regional-Scale Groundwater Flow. . . . . . . . . . . . . . . . . . 2 2-11

2.4 Groundwater Flow in Yucca Flat ....................... 2-14

2.4.1 Groundwater Elevations in the Yucca Flat Area ............ 2-14

2.5 Stable Isotope Patterns in the Regional Lower Carbonate Aquifer . . . . . . . 2-16

3.0 Yucca Flat/Climax Mine Geochemistry Data................... 3-1

3.1 Data Compilation and Selection of Representative Data for Geochemical Evaluations . . . . . . . . . . . . . . . . . . . . . . . . . 3-1

3.2 Overview of Geochemical Data . . . . . . . . . . . . . . . . . . . . . 3-7

3.2.1 Major-Ion Chemistry ........................ 3-7

3.2.2 Stable Isotopes of Oxygen and Hydrogen . . . . . . . . . . . . 3 3-12

3.2.3 Carbon Isotopes ............................. 3-15

3.2.3.1 Groundwater Age Estimates from

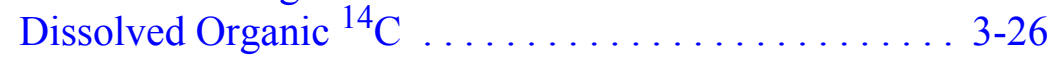

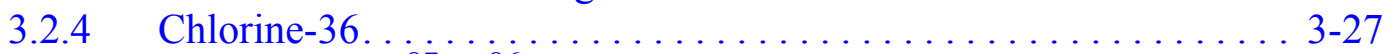

3.2.5 Strontium and ${ }^{87} \mathrm{Sr} /{ }^{86} \mathrm{Sr}$ Values . . . . . . . . . . . . . . . . . 3-30

3.2.6 Uranium and ${ }^{234} \mathrm{U} /{ }^{238} \mathrm{U}$ Activity Ratio . . . . . . . . . . . . . 3-34

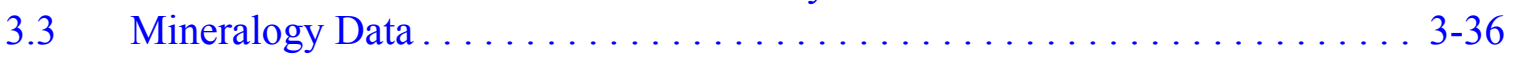

3.3.1 Mineralogy of Volcanic Rocks. ................. . 3-37

3.3.2 Lower Carbonate Aquifer Mineralogy ................ 3-40

3.3.3 Mineralogy of Fractured Granite in the Climax Stock. . . . . . . . 3-41

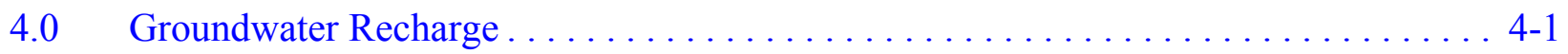




\section{TABLE of CONTENTS (Continued)}

$4.1 \quad$ Isotopic Signature . . . . . . . . . . . . . . . . . . . . . . . 4-1

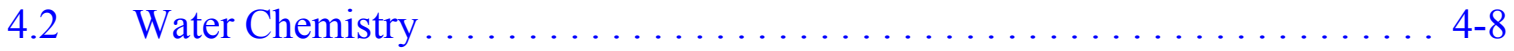

$4.3 \quad$ Summary.........................

$5.0 \quad$ Geochemical Modeling Approach $\ldots \ldots \ldots \ldots \ldots \ldots \ldots \ldots \ldots \ldots \ldots \ldots \ldots$

5.1 Conservative Tracer Modeling . . . . . . . . . . . . . . . . . 5-2

5.2 Strontium and ${ }^{87} \mathrm{Sr} /{ }^{86} \mathrm{Sr}$ Modeling . . . . . . . . . . . . . . . . 5-4

5.3 Geochemical Modeling with NETPATH and PHREEQC . . . . . . . . . . 5-5

5.3.1 Geochemical Models with NETPATH. . . . . . . . . . . . . . . . . . . 5-7

5.3.2 Geochemical Models with PHREEQC. . . . . . . . . . . . . . . 5-14

5.3.2.1 Evaluation of Groundwater Transit Times Using

PHREEQC Model Results . . . . . . . . . . . . 5-17

6.0 Evaluation of Northern Flow Paths $\ldots \ldots \ldots \ldots \ldots \ldots \ldots \ldots \ldots \ldots \ldots \ldots$

6.1 Geochemical Modeling of Well UE-10j. . . . . . . . . . . . . . . 6-3

6.1.1 Conservative Tracer Models for Well UE-10j . . . . . . . . . . . 6-3

6.1.2 Strontium and ${ }^{87} \mathrm{Sr} /{ }^{86} \mathrm{Sr}$ Models for Well UE-10j . . . . . . . . . . . 6-5

6.1 .3 NETPATH Models for Well UE-10j . . . . . . . . . . . . . . . 6-7

6.1 .4 PHREEQC Models for Well UE-10j . . . . . . . . . . . . . . 6-7

6.2 Geochemical Modeling of UE-15d Water Well . . . . . . . . . . . . . . 6-10

6.2.1 Conservative Tracer Models for UE-15d Water Well . . . . . . . . . . . 6-10

6.2.2 Strontium and ${ }^{87} \mathrm{Sr} /{ }^{86} \mathrm{Sr}$ Models for UE-15d Water Well . . . . . . . . 6-12

6.2.3 NETPATH Models for UE-15d Water Well . . . . . . . . . . . . . . 6-14

6.2.4 PHREEQC Models for UE-15d Water Well . . . . . . . . . . . . . 6- 6-15

6.3 Geochemical Modeling of Water Well $2 \ldots \ldots \ldots \ldots \ldots \ldots \ldots \ldots \ldots \ldots$

6.3.1 Conservative Tracer Models for Water Well $2 \ldots . . . \ldots . . .6$ 6-18

6.3.2 PHREEQC Models for Water Well 2. . . . . . . . . . . . . 6 6-19

6.3 .3 Other Models for Water Well $2 \ldots \ldots \ldots \ldots \ldots \ldots \ldots$. . . . . . . . . . . . .

6.4 Geochemical Modeling of Wells ER-12-1 and ER-12-2 . . . . . . . 6-21

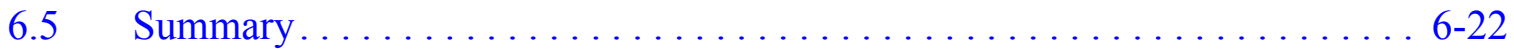

Evaluation of Eastern Flow Paths $\ldots \ldots \ldots \ldots \ldots \ldots \ldots \ldots \ldots \ldots \ldots \ldots \ldots$

7.1 Geochemical Modeling of Well UE-7nS . . . . . . . . . . . . . 7-2

7.1.1 Conservative Tracer Models for Well UE-7nS . . . . . . . . . . . . 7-2

7.1.2 Strontium and ${ }^{87} \mathrm{Sr} /{ }^{86} \mathrm{Sr}$ Models for Well UE-7nS . . . . . . . . . . 7-4

7.1.3 NETPATH Models for Well UE-7nS. . . . . . . . . . . . . . 7-6 . . . . . .

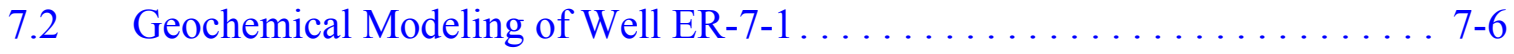

7.2.1 Conservative Tracer Models for Well ER-7-1 . . . . . . . . . . . . . 7-6

7.2.2 Strontium and ${ }^{87} \mathrm{Sr} /{ }^{86} \mathrm{Sr}$ Models for Well ER-7-1 . . . . . . . . . . . 7-7

7.2.3 NETPATH Models for Well ER-7-1 . . . . . . . . . . . . . . . 7-8

7.2.4 PHREEQC Models for Well ER-7-1 . . . . . . . . . . . . . . . . . 7-9

7.3 Geochemical Modeling of Well U-3en \#5 . . . . . . . . . . . . 7-16

7.3.1 Conservative Tracer Modeling Results for Well U-3en \#5 . . . . . . 7-16 


\section{TABLE OF CONTENTS (CONTINUED)}

7.3.2 Strontium and ${ }^{87} \mathrm{Sr} /{ }^{86} \mathrm{Sr}$ Modeling Results for Well U-3cn \#5 . . . . 7-17

7.3.3 NETPATH Modeling Results for Well U-3en \#5 . . . . . . . . . 7-17

7.3.4 PHREEQC Modeling Results for Well U-3en \#5 . . . . . . . . . 7-18

7.4 Geochemical Modeling of Well HTH-E. . . . . . . . . . . . . . 7-20

7.4.1 Conservative Tracer Models for Well HTH-E . . . . . . . . . . . . . 7-20

7.5 Geochemical Modeling of Wells ER-6-1 and ER-6-1 \#2 . . . . . . . . . . 7-21

7.5.1 Conservative Tracer Models for Wells ER-6-1

and ER-6-1\#2 ...................... $7-21$

7.5.2 Strontium and ${ }^{87} \mathrm{Sr} /{ }^{86} \mathrm{Sr}$ Models for Wells ER-6-1

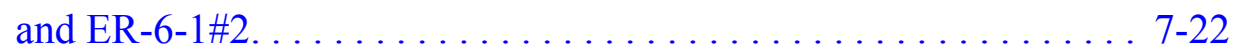

7.5.3 NETPATH Models for Wells ER-6-1 and ER-6-1\#2. . . . . . . . 7-22

7.5.4 PHREEQC Modeling Results for Wells ER-6-1

and ER-6-1\#2 . . . . . . . . . . . . . . . . . . . . . . . . . . 7-23

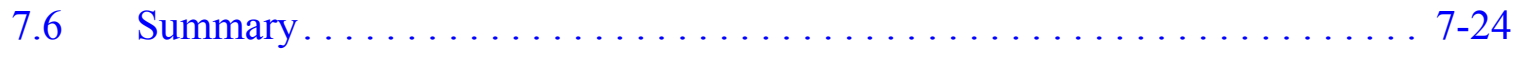

$8.0 \quad$ Evaluation of Southeastern Flow Paths $\ldots \ldots \ldots \ldots \ldots \ldots \ldots \ldots \ldots \ldots \ldots$

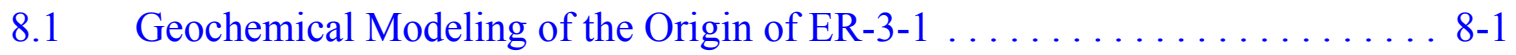

8.1.1 NETPATH Models for ER-3-1 . . . . . . . . . . . . . . . 8-1

8.1.2 PHREEQC Models for ER-3-1 . . . . . . . . . . . . . . 8-2

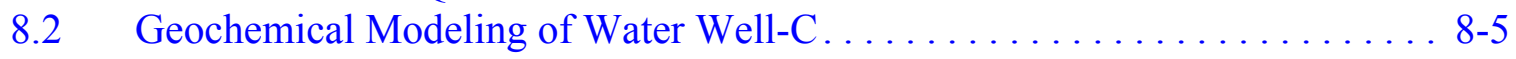

8.2.1 Conservative Tracer Models for Water Well-C . . . . . . . . . . . . . 8-5

8.2.2 NETPATH Models for Water Well-C . . . . . . . . . . . . . . . . 8-6

8.2.3 PHREEQC Models for Water Well-C . . . . . . . . . . . . . . . 8 8-7

8.3 Alternative Models of Water Well-C Involving Local Yucca Flat

8.3.1 Alternative Conservative Tracer Models for Water Well-C . . . . . 8 8-10

8.3.2 Alternative NETPATH Models for Water Well-C. . . . . . . . . . . 8 8-11

8.3.3 PHREEQC Models for Leakage from Overlying

Volcanic Unit to Water Well-C . . . . . . . . . . . . . . . . 8-13

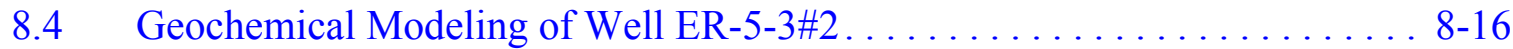

8.4.1 PHREEQC Models for Well ER-5-3 \#2 . . . . . . . . . . . . 8-16

8.4.2 Strontium and ${ }^{87} \mathrm{Sr} /{ }^{86} \mathrm{Sr}$ Modeling Results . . . . . . . . . . . 8-20

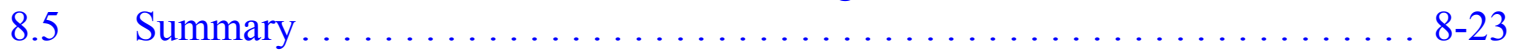

9.0 Evaluation of Western Flow Paths . . . . . . . . . . . . . . . . 9-1

9.1 Geochemical Modeling of Well UE-2ce . . . . . . . . . . . . . . . 9-1

9.1.1 Conservative Tracer Models for Well UE-2ce. . . . . . . . . . . . . . . 9-1

9.1.2 Strontium and ${ }^{87} \mathrm{Sr} /{ }^{86} \mathrm{Sr}$ Models for Well UE-2ce. . . . . . . . . . . . . 9-2

9.1.3 NETPATH Models for Well UE-2ce. . . . . . . . . . . . . . . . 9-2

9.1.4 PHREEQC Models for Well UE-2ce. . . . . . . . . . . . . . . . . . 9-2

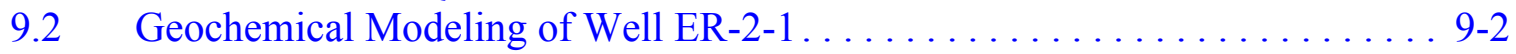

9.2.1 Conservative Tracer Models for Well ER-2-1 . . . . . . . . . . . 9 9-2

9.2.2 Strontium and ${ }^{87} \mathrm{Sr} /{ }^{86} \mathrm{Sr}$ Models for Well ER-2-1 . . . . . . . . . . . 9-4 


\section{TABle of Contents (Continued)}

9.2.3 NETPATH Models for Well ER-2-1 . . . . . . . . . . . . . . . 9-5

9.2.4 PHREEQC Models for Well ER-2-1 . . . . . . . . . . . . . . 9-5

9.3 Geochemical Modeling of Well UE-1h . . . . . . . . . . . . . . 9-6

9.3.1 Conservative Tracer Models for Well UE-1h . . . . . . . . . . . . . 9-6

9.3.2 Strontium and ${ }^{87} \mathrm{Sr} /{ }^{86} \mathrm{Sr}$ Models for Well UE-1h. . . . . . . . . . . . 9-8

9.3.3 NETPATH Models for Well UE-1h. . . . . . . . . . . . . . . 9-8

9.3.4 PHREEQC Models for Well UE-1h. . . . . . . . . . . . . . . . . . . . . . 9-9

9.4 Geochemical Modeling of Well ER-6-2 . . . . . . . . . . . . . . 9-13

9.4.1 Conservative Tracer Models for Well ER-6-2 . . . . . . . . . . . . 9 9-13

9.4.2 Strontium and ${ }^{87} \mathrm{Sr} /{ }^{86} \mathrm{Sr}$ Models for Well ER-6-2 . . . . . . . . . . . 9-13

9.4.3 NETPATH Models for Well ER-6-2 . . . . . . . . . . . . . . . . 9-14

9.4.4 PHREEQC Models for Well ER-6-2 . . . . . . . . . . . . . 9-15

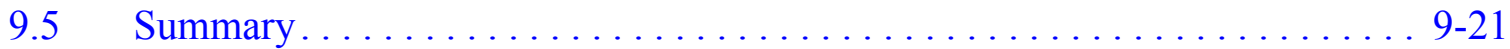

10.0 Evaluation of West-Central Flow Paths . . . . . . . . . . . . . . . . . 10-1

10.1 Geochemical Modeling of Wells TW-D and UE-1q . . . . . . . . . . . 10-3

10.1.1 Conservative Tracer Models for Wells TW-D and UE-1q. . . . . . . . 10-3

10.2 NETPATH Modeling Results . . . . . . . . . . . . . . . . . . . . . . . . . . . 10-4

10.3 PHREEQC Models of High ${ }^{36} \mathrm{Cl}$ LCA Groundwater in West-Central Yucca Flat. . . . . . . . . . . . . . . . . . . . . . . 10-6 . . . . . . 10-9

10.3.1 Strontium and ${ }^{87} \mathrm{Sr} /{ }^{86} \mathrm{Sr}$ Modeling Results $\ldots \ldots \ldots \ldots \ldots \ldots \ldots . \ldots \ldots 10.9 \ldots \ldots \ldots$

10.4 Summary. . . . . . . . . . . . . . . . . . . . . . . 10-11

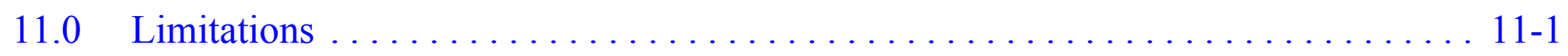

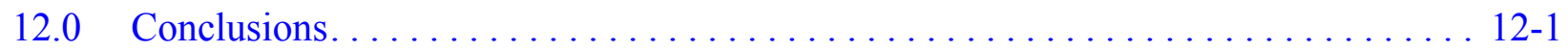

13.0 References. ................................ 13-1

Appendix A - Data Used for Yucca Flat Geochemical Evaluations 


\section{LIST OF FIGURES}

NUMBER

TITLE

PAGE

1-1 Corrective Action Units and Corrective Action Sites at the Nevada Test Site . . . . . . . . . . . . . . . . . . . . . . . . 1-2

1-2 Wells and Springs in the Yucca Flat/Climax Mine Geochemical Investigation Area with Geochemical and/or Isotopic Data. . . . . . . . . . . . . . . 1-4

1-3 Conceptual Flow Paths Evaluated in the Yucca Flat/Climax Mine Geochemical Study. . . . . . . . . . . . . . . . . . . . . .

2-1 Generalized Surface Geologic Map of the Nevada Test Site Area . . . . . . . . . 2-2

2-2 Yucca Flat Surface Hydrostratigraphy and Geochemical Sampling Locations . . . . . . . . . . . . . . . . .

2-3 Hydrostratigraphic Units at the Water Table . . . . . . . . . . . . . . 2-8

2-4 Top of the Lower Carbonate Aquifer, Upper Thrust Plate (LCA3) and Below . . . . . . . . . . . . . . . . . . . . . .

2-5 Top of the Lower Carbonate Aquifer . . . . . . . . . . . . . . . . . . . 2-10

2-6 Top of the Lower Clastic and Mesozoic Granite Confining Units. . . . . . . . . . . . 2-12

2-7 Regional Groundwater Flow Patterns . . . . . . . . . . . . . . . . . . 2-13

2-8 Yucca Flat Groundwater Flow Patterns . . . . . . . . . . . . . . . . 2-15

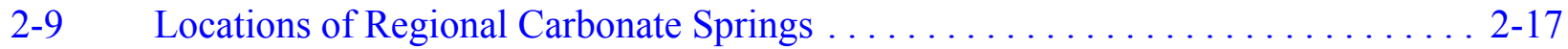

2-10 Plot of $\delta \mathrm{D}$ Versus $\delta^{18} \mathrm{O}$ Values for Groundwater Samples from the Regional Carbonate Aquifer System in East-Central Nevada, Southern Nevada, and Adjacent Parts of Eastern California . . . . . . . . . . . . . 2-18

3-1 Yucca Flat/Climax Mine Geochemistry Study Area . . . . . . . . . . . . . 3-8

3-2 Piper Diagram for Groundwater of Volcanic Aquifers and Confining Units . . . . . . . . . . . . . . . . . . . . . . . 3-10

3-3 Piper Diagram for Groundwater of Alluvial Aquifer and Clastic Confining Units . . . . . . . . . . . . . . . . . . . .

3-4 Piper Diagram for Groundwater of the Lower Carbonate Aquifer . . . . . . . . . 3-13 


\section{LIST OF FIGURES (CONTINUED)}

NUMBER

TITLE

PAGE

3-5 Average $\delta \mathrm{D}$ and $\delta^{18} \mathrm{O}$ Values for Groundwater and Springs Within the Yucca Flat/Climax Mine Geochemistry Study Area . . . . . . . . . . . . . 3-14

3-6 $\quad \delta^{13} \mathrm{C}$ Versus Inverse Alkalinity of Groundwater and Springs in the Yucca Flat Area . . . . . . . . . . . . . . . . . . . . . . . . . 3-16

3-7 Groundwater $\delta^{13} \mathrm{C}$ in (a) Volcanic and Alluvial HSUs and Perched Springs and (b) Clastic Confining Units and the LCA

3-8 Groundwater ${ }^{14} \mathrm{C}$ Versus $\delta^{13} \mathrm{C}$

3-9 Groundwater ${ }^{14} \mathrm{C}$ in (a) Volcanic and Alluvial HSUs and Perched Springs and (b) Pre-Tertiary Clastic Units and the LCA . . . . . . . . 3-21

3-10 Average $\mathrm{Cl}$ Concentrations (mg/L) and ${ }^{36} \mathrm{Cl} / \mathrm{Cl}$ Values for Groundwater Within the Yucca Flat/Climax Mine Study Area . . . . . . . . . . . 3-28

3-11 Average Sr Concentrations (mg/L) and ${ }^{87} \mathrm{Sr} /{ }^{86} \mathrm{Sr}$ Values for Groundwater Within the Yucca Flat/Climax Mine Study Area . . . . . . . . . . . . 3-32

3-12 $\quad{ }^{87} \mathrm{Sr} /{ }^{86} \mathrm{Sr}$ Versus Sr Concentration of Groundwater and Spring in the Yucca Flat Vicinity . . . . . . . . . . . . . . 3-33

3-13 Average U Concentrations $(\mathrm{mg} / \mathrm{L})$ and ${ }^{234} \mathrm{U} /{ }^{238} \mathrm{U}$ Activity Ratios for Groundwater Within the Yucca Flat/Climax Mine Study Area . . . . . . . . . . . 3-35

3-14 Stacked Frequency Distribution for Uranium Concentrations for Groundwater Samples in the Yucca Flat Vicinity . . . . . . . . . . . . . 3-36

3-15 $\quad{ }^{234} \mathrm{U} /{ }^{238} \mathrm{U}$ Activity Ratio Versus Uranium Concentration of Groundwater and Spring in the Yucca Flat Vicinity . . . . . . . . . . 3-37

4-1 Location of Precipitation Sampling Sites at the Nevada Test Site and Perched Springs at the Nevada Test Site, Groom Range, and the Belted Range . . . . . . . . . . . . . . . . . . . . . 4-3

4-2 $\delta \mathrm{D}$ Versus $\delta^{18} \mathrm{O}$ for Precipitation Collected at the NTS

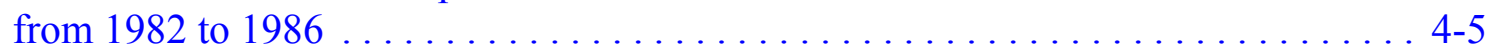

4-3 Weighted Average of $\delta^{18} \mathrm{O}$ from All Precipitation Sampling Sites

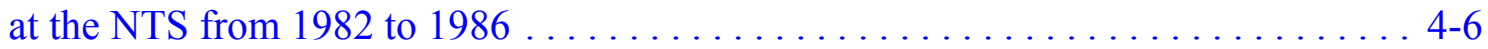




\section{LIST OF FIGURES (CONTINUED)}

NUMBER

4-4 Average Isotopic Values for Spring Discharge at the NTS,

Groom Range, and Belted Range

4-5 Isotopic Values for NTS Perched Springs, Rainier Mesa Tunnels, and the Climax Stock .

4-6 Piper Diagram Showing the Relative Proportions of Major Ions in the NTS Perched Springs, Rainier Mesa Tunnels, and Groundwater in the Recharge Areas of Rainier Mesa and the Eleana Range

4-7 Total Dissolved Solids and Cl Concentrations for NTS Springs, Rainier Mesa Tunnels, and Wells Sampling the Upper Clastic Confining Unit

6-1 Plot of $\delta D$ Versus $\delta^{18} \mathrm{O}$ Values for Regional and Perched

Groundwater Samples in Northern Yucca Flat and Surrounding Areas

6-2 Plot of $\delta \mathrm{D}$ Versus $\mathrm{Cl}$ for Regional and Perched Groundwater Samples

in Northern Yucca Flat and Surrounding Areas

6-3 Relations Between ${ }^{87} \mathrm{Sr} /{ }^{86} \mathrm{Sr}, \mathrm{Sr}, \delta \mathrm{D}, \mathrm{Cl}$, and ${ }^{14} \mathrm{C}$ for Samples of LCA

Water from Different Zones in Well UE-10j . . . . . . . . . . . . . . . 6-6

6-4 Mixing Fractions for UE-10j-3 Models $\ldots \ldots \ldots \ldots \ldots \ldots \ldots \ldots \ldots$

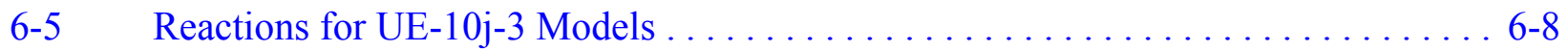

6-6 Relations Between ${ }^{87} \mathrm{Sr} /{ }^{86} \mathrm{Sr}, \mathrm{Sr}, \delta \mathrm{D}$, and $\mathrm{Cl}$ Concentrations for Yucca Flat Groundwaters Emphasizing Samples from Northern Yucca Flat . . . . . . . . . 6-13

6-7 Mixing Fractions for UE-15d Models $\ldots \ldots \ldots \ldots \ldots \ldots \ldots \ldots \ldots$

6-8 Reactions for UE-15d Models $\ldots \ldots \ldots \ldots \ldots \ldots \ldots \ldots \ldots \ldots \ldots \ldots$

6-9 Mixing Fractions for WW-2 Models $\ldots \ldots \ldots \ldots \ldots \ldots \ldots \ldots \ldots \ldots \ldots$

6-10 Reactions for WW-2 Models . . . . . . . . . . . . . . . . . . . . . 6-20

7-1 Plot of $\delta \mathrm{D}$ Versus ${ }^{18} \mathrm{O}$ Values for Groundwater in Yucca Flat and Surrounding Areas...........................

7-2 Plot of $\delta \mathrm{D}$ Versus $\mathrm{Cl}$ Values for Groundwater in Yucca Flat and Surrounding Areas ........................... 7-3 


\section{LIST OF FIGURES (CONTINUED)}

NUMBER

TITLE

PAGE

7-3 Relations Between ${ }^{87} \mathrm{Sr} /{ }^{86} \mathrm{Sr}$, Sr Concentration, $\delta \mathrm{D}$, and $\mathrm{Cl}$

Concentration for Yucca Flat Groundwaters . . . . . . . . . . . . . . 7-5

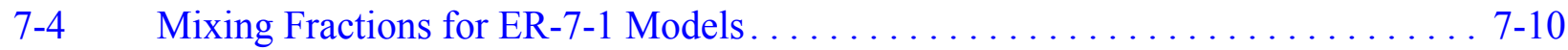

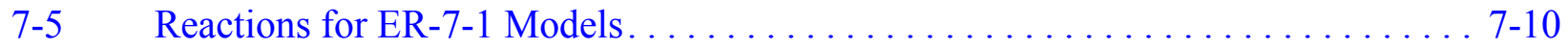

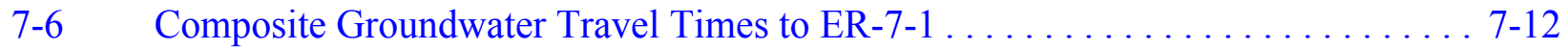

7-7 Mixing Fractions for ER-7-1 Models Using

Pahranagat Spring Groundwater. . . . . . . . . . . . . . . . . . .

7-8 Reactions for ER-7-1 Models Using Pahranagat Spring Groundwater . . . . . . . . 7-13

7-9 Composite Groundwater Travel Times to ER-7-1 for

Models with Pahranagat Springs Groundwater . . . . . . . . . . . . . . . . 7-14

7-10 Mixing Fractions for ER-7-1 Models Using Only

Yucca Flat Groundwaters . . . . . . . . . . . . . . . . . . . . . .

7-11 Reactions for ER-7-1 Models Using Only Yucca Flat Groundwaters . . . . . . . . . 7-15

7-12 Mixing Fractions for U-3cn \#5 Models . . . . . . . . . . . . . . . . . . . 7-19

7-13 Reactions for $\mathrm{U}-3 \mathrm{cn} \# 5$ Models . . . . . . . . . . . . . . . . . . . . . . . . . 7-19

7-14 Composite Groundwater Travel Times to $\mathrm{U}-3 \mathrm{cn} \# 5 \ldots \ldots \ldots \ldots \ldots \ldots \ldots \ldots$

7-15 Mixing Fractions for ER-6-1 Models with Local Upgradient Sources . . . . . . . . 7-25

7-16 Reactions for ER-6-1 Models with Local Upgradient Sources . . . . . . . . . . . . 7-25

7-17 Mixing Fractions for ER-6-1 \#2 Models with Local Upgradient Sources . . . . . . . 7-26

7-18 Reactions for ER-6-1 \#2 Models with Local Upgradient Sources . . . . . . . . . . . . 7-26

7-19 Composite Travel Times to ER-6-1 for Models

with Local Upgradient Sources . . . . . . . . . . . . . . . . . . . 7-27

7-20 Composite Travel Times to ER-6-1\#2 for Models

with Local Upgradient Sources . . . . . . . . . . . . . . . . . . . . . . . 7-27 


\section{LIST OF FIGURES (CONTINUED)}

NUMBER

8-1 Mixing Fractions for ER-3-1 Models with Both Local and Distant Upgradient Sources . . . . . . . . . . . . . . . . . 8 -3

8-2 Reactions for ER-3-1 Models with Both Local and Distant Upgradient Sources . . . . . . . . . . . . . . . . . . 8-3

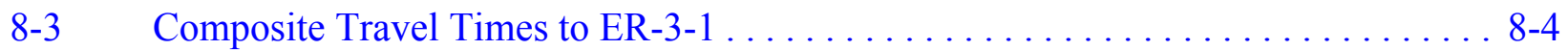

8-4 Mixing Fractions for WW-C Models with Water from North

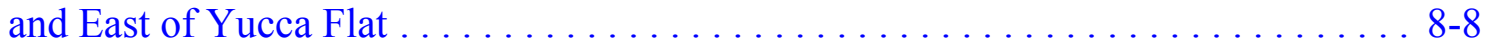

8-5 Reactions for WW-C Models with Water from North and East of Yucca Flat . . . . . . . . . . . . . . . . . . . . . . 8-8

8-6 Composite Travel Times to WW-C for Models with Groundwater from North and East of Yucca Flat. . . . . . . . . . . . . . . . . . . . . 8-9

8-7 Mixing Fractions for WW-C Models with Groundwater from Eastern Yucca Flat. . . . . . . . . . . . . . . . . . . . . . . . . 8-14

8-8 Reactions for WW-C Models with Groundwater from Eastern Yucca Flat. . . . . . . . . . . . . . . . . . . . . . . . . 8-14

8-9 Composite Travel Times to WW-C for Models with Water from Eastern Yucca Flat. . . . . . . . . . . . . . . . . . . . . . . . . . 8-15

8-10 Mixing Fractions for WW-C Models with Groundwater from Western Yucca Flat . . . . . . . . . . . . . . . . . . . . . . . 8-17

8-11 Reactions for WW-C Models with Groundwater from Western Yucca Flat . . . . . . . . . . . . . . . . . . . . . . . 8-17

8-12 Composite Travel Times to WW-C for Models with Groundwater from Western Yucca Flat . . . . . . . . . . . . . . . . . . . . . . . . 8-18

8-13 Mixing Fractions for ER-5-3 \#2 Models . . . . . . . . . . . . . . . . . . . 8 8-19

8-14 Reactions for ER-5-3 \#2 Models . . . . . . . . . . . . . . . . . . . . . . 8-19

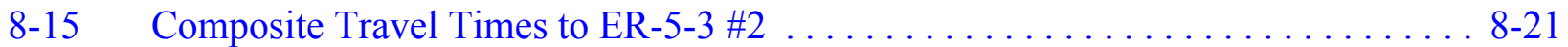




\section{LIST OF FIGURES (CONTINUED)}

NUMBER

TITLE

PAGE

8-16 Relations Between ${ }^{87} \mathrm{Sr} /{ }^{86} \mathrm{Sr}$, Sr Concentration, $\delta \mathrm{D}$, and $\mathrm{Cl}$ Concentration for Yucca Flat Groundwaters

Emphasizing Samples from the Southeastern NTS

9-1 Mixing Fractions for UE-2ce Models. . . . . . . . . . . . . . . . . . . . . . 9-3

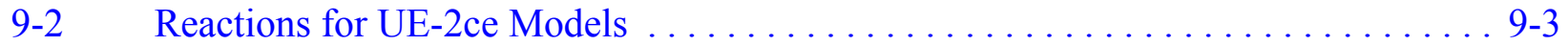

9-3 Mixing Fractions for ER-2-1 Models . . . . . . . . . . . . . . . 9-7

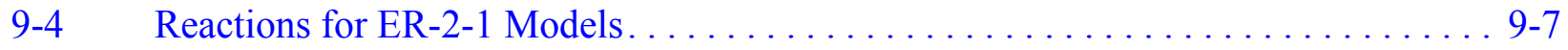

9-5 Relations Between ${ }^{87} \mathrm{Sr} /{ }^{86} \mathrm{Sr}$ Values and Sr Concentration for Yucca Flat

Groundwater Emphasizing Samples from Western Yucca Flat. . . . . . . . . . . . 9-9

9-6 Mixing Fractions for UE-1h Models with HTH-1 Groundwater . . . . . . . . . . . . 9-11

9-7 Reactions for UE-1h Models with HTH-1 Groundwater . . . . . . . . . . . . . . . . 9-11

9-8 Mixing Fractions for UE-1h Models with ER-2-1 Groundwater . . . . . . . . . . . 9 9-12

9-9 Reactions for UE-1h Models with ER-2-1 Groundwater. . . . . . . . . . . . . . . 9-12

9-10 Mixing Fractions for ER-6-2 Models with Local LCA Groundwater . . . . . . . . 9 9-16

9-11 Reactions for ER-6-2 Models with Local LCA Groundwater . . . . . . . . . . . . . . 9-16

9-12 Composite Travel Times for ER-6-2 Models

with Local LCA Groundwater . . . . . . . . . . . . . . . . . . . . . . . . . . . . 9 9-17

9-13 Mixing Fractions for ER-6-2 Models with Rainier Mesa

and Eleana Range Water . . . . . . . . . . . . . . . . . . . . . . . . . . . . . 9 9-18

9-14 Reactions for ER-6-2 Models with Rainier Mesa

and Eleana Range Groundwater. . . . . . . . . . . . . . . . . . 9-18

9-15 Composite Travel Times for ER-6-2 Models with Rainier Mesa

and Eleana Range Groundwater. . . . . . . . . . . . . . . . . . . . . . 9-19

9-16 Mixing Fractions for ER-6-2 Models with CP Basin

and Eleana Range Water . . . . . . . . . . . . . . . . . . . . . . . 9-20 


\section{LIST OF FIGURES (CONTINUED)}

NUMBER

9-17 Reactions for ER-6-2 Models with CP Basin and Eleana Range Groundwater. . . . . . . . . . . . . . . . . .

10-1 Plot of ${ }^{36} \mathrm{Cl} / \mathrm{Cl}$ Ratios Versus Inverse $\mathrm{Cl}$ Values for Groundwater in Yucca Flat and Surrounding Areas . . . . . . . . . . . . . 10-2

10-2 Mixing Fractions for TW-D Models with HTH-1 Groundwater . . . . . . . . . . . 10-7

10-3 Reactions for TW-D Models with HTH-1 Groundwater . . . . . . . . . . . . . . . . 10-7

10-4 Mixing Fractions for TW-D Models with ER-2-1 Groundwater . . . . . . . . . . . 10-8

10-5 Reactions for TW-D Models with ER-2-1 Groundwater . . . . . . . . . . . 10-8

10-6 Mixing Fractions for Well UE-1q Models . . . . . . . . . . . . . . . . . . . . 10-10

10-7 Reactions for Well UE-1q Models . . . . . . . . . . . . . . . . . . 10-10 


\section{LIST OF TABLES}

NUMBER

TITLE

PAGE

2-1 Yucca Flat/Climax Mine Hydrostratigraphic Units. . . . . . . . . . . . . . . 2-3

3-1 Sampling Locations, Collection Dates, and Hydrostratigraphic Units . . . . . . . . 3-2

3-2 Carbon Isotope Data for Yucca Flat Carbonates . . . . . . . . . . . . . 3-22

3-3 Dissolved Organic Carbon Calculated Groundwater Ages . . . . . . . . . . . . . . . 3-27

3-4 Summary of Site-Specific Mineral Phases . . . . . . . . . . . . . . . . . 3-39

4-1 Location and Elevation of Precipitation Sampling Sites at the NTS.

Also Included Are the Average $\delta \mathrm{D}$ and $\delta^{18} \mathrm{O}$ Weighted by

Precipitation Amount for Each Station . . . . . . . . . . . . . . . . 4-4

4-2 Carbon-14 and Tritium Values for NTS Springs. . . . . . . . . . . . . . . 4-9

4-3 Total Dissolved Solids and Chloride Concentrations for NTS

Perched Spring, Rainier Mesa Tunnel, and Climax Stock

Groundwater Samples . . . . . . . . . . . . . . . . . . . . . 4-9

5-1 Mineral Saturation Indices and Other Quantities Calculated by PHREEQC

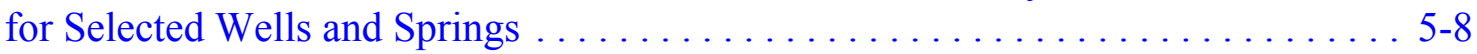

6-1 Results of NETPATH Models for Well UE-10j-3. . . . . . . . . . . 6-7

6-2 Results of NETPATH Models for Well UE-15d . . . . . . . . . . . . . 6-14

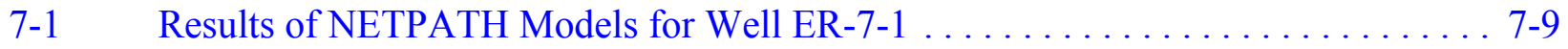

7-2 Travel Times from Individual Wells to ER-7-1 for Models

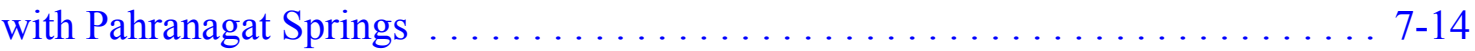

7-3 Mixing Percentages for Well U-3cn \#5 Based on ${ }^{87} \mathrm{Sr} /{ }^{86} \mathrm{Sr}$ Versus $1 / \mathrm{Sr} \ldots \ldots$. . . 7-17

7-4 Mixing Percentages for Well ER-6-1\#2 Based on ${ }^{87} \mathrm{Sr} /{ }^{86} \mathrm{SrVersus} 1 / \mathrm{Sr} \ldots \ldots .7$ 7-22

7-5 NETPATH Modeling Results for Well ER-7-1 Groundwater Reacting with LCA Minerals To Produce Groundwater at Well ER-6-1 \#2 . . . . . . . . . 7-23

7-6 Results of NETPATH Models for Well ER-6-1\#2 and ER-6-1 . . . . . . . . . 7-24

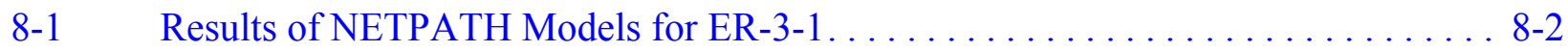




\section{LIST OF TABLES (CONTINUED)}

NUMBER

8-2 Travel Times from Individual Wells to ER-3-1 . . . . . . . . . . . . . 8-4

8-3 Results of NETPATH Models for Water Well C . . . . . . . . . . . . 8-7

8-4 Travel Times from Individual Wells to WW-C . . . . . . . . . . . . . . . . 8-9

8-5 Results of Alternative NETPATH Models for Water Well-C . . . . . . . . . . . 8-12

8-6 Travel Times from Individual Wells to WW-C for Models with Eastern Yucca Flat Waters. . . . . . . . . . . . . . . . . . . . 8-15

8-7 Travel Times from Individual Wells to WW-C for Models with Groundwater from Western Yucca Flat. . . . . . . . . . . . . . . . . . 8-18

9-1 Mixing Percentages Needed To Produce Compositions Observed in ER-6-2 . . . . 9-14

9-2 Results of NETPATH Models for Well ER-6-2 . . . . . . . . . . . . . . 9-15

10-1 Results of NETPATH Models for Test Well - D. . . . . . . . . . . . 10-5

10-2 Results of NETPATH Models for Well UE-1q. . . . . . . . . . . . . . 10-6

10-3 Mixing Percentages for Wells Test Well - D and UE-1q

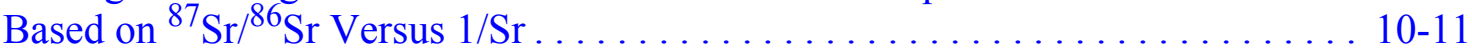

A.1-1 Major-Ion Data for Yucca Flat Geochemical Evaluation $\ldots \ldots \ldots \ldots \ldots \ldots \ldots$ A-1

A.1-2 Isotope Data for Yucca Flat Geochemical Evaluation. . . . . . . . . . . . . . . . A-6

A.1-3 Field Measurement Data for Yucca Flat Geochemical Evaluation . . . . . . . . . . A A-11

A.1-4 Strontium and Uranium Data for Yucca Flat Geochemical Evaluation . . . . . . . . A-16

A.1-5 Select Trace and Minor Element Data for Yucca Flat

Geochemical Evaluation . . . . . . . . . . . . . . . . . . A-20 


\section{LIST OF ACRONYMS AND ABBREVIATIONS}

\begin{tabular}{|c|c|}
\hline amsl & Above mean sea level \\
\hline AMS & Accelerator mass spectrometry \\
\hline bgs & Below ground surface \\
\hline${ }^{\circ} \mathrm{C}$ & Degrees Celsius \\
\hline CAS & Corrective Action Site \\
\hline CAU & Corrective Action Unit \\
\hline DRI & Desert Research Institute \\
\hline FFACO & Federal Facility Agreement and Consent Order \\
\hline $\mathrm{ft}$ & Foot \\
\hline GMWL & Global meteoric water line \\
\hline HFM & Hydrostratigraphic framework model \\
\hline $\mathrm{HGU}$ & Hydrogeologic unit \\
\hline HSU & Hydrostratigraphic unit \\
\hline $\mathrm{km}$ & Kilometer \\
\hline $\mathrm{L}$ & Liter \\
\hline LLNL & Lawrence Livermore National Laboratory \\
\hline LMWL & Local meteoric water line \\
\hline $\mathrm{m}$ & Meter \\
\hline $\mathrm{m} / \mathrm{d}$ & Meters per day \\
\hline $\mathrm{m} / \mathrm{yr}$ & Meters per year \\
\hline $\mathrm{mg}$ & Milligram \\
\hline $\mathrm{mg} / \mathrm{kg}$ & Milligrams per kilogram \\
\hline $\mathrm{mg} / \mathrm{L}$ & Milligrams per liter \\
\hline $\mathrm{mm}$ & Millimeter \\
\hline mmol & Millimole \\
\hline $\mathrm{mmol} / \mathrm{L}$ & Millimoles per liter \\
\hline
\end{tabular}




\section{LIST OF ACRONYMS AND ABBREVIATIONS (Continued)}

mole $/ \mathrm{kg} \quad$ Moles per kilogram

mole/L Moles per liter

N/A Not available

NNSA/NSO U.S. Department of Energy, National Nuclear Security Administration Nevada Site Office

NTS Nevada Test Site

PDB Pee Dee Belemnite

$\mathrm{pCi} / \mathrm{L} \quad$ Picocuries per liter

ppm Parts per million

QXRD Quantitative X-ray diffraction

SI Saturation index

SNJV Stoller-Navarro Joint Venture

Std. Dev. Standard deviation

TDS Total dissolved solids

UGTA Underground Test Area

USAF U.S. Air Force

USGS U.S. Geological Survey

UTM Universal Transverse Mercator

VSMOW Vienna Standard Mean Ocean Water

XPS X-ray photoelectron spectroscopy

$\mu \mathrm{g} / \mathrm{L} \quad$ Micrograms per liter

$\mu \mathrm{S} / \mathrm{cm} \quad$ Microsiemens per centimeter 


\section{LIST OF StRATIGRAPHIC UNIT/LOCATION ABBREVIATIONS AND SYMBOLS}

AA

AR

ATCU

BLFA

BR

BRA

BRCU

CA

$\mathrm{CCU}$

FF

FS

GCU

GR

LCA

LCA3 Lower carbonate aquifer, upper thrust plate

LCCU Lower clastic confining unit

LFA Lava-flow aquifer

LTCU Lower tuff confining unit

LVTA Lower vitric-tuff aquifer

MGCU Mesozoic granite confining unit

OSBCU Oak Spring Butte confining unit

PB Paintbrush

PBR Pre-Belted Range

PBRCM Pre-Belted Range composite unit

PCU Playa confining unit

Pre-Tbg Pre-Grouse Canyon Tuff lava-flow aquifer 


\section{LIST of StRatigRaphic UNIT ABbREVIations AND Symbols (Continued)}

PS Perched spring

PW Pintwater Range

SR Sheep Range

SSV Sand Spring Valley

TCU Tuff confining unit

TM Timber Mountain

TMA Timber Mountain aquifer

TM-LVTA Timber Mountain lower vitric-tuff aquifer

TM-UVTA Timber Mountain upper vitric-tuff aquifer

TM-WTA Timber Mountain welded-tuff aquifer

TSA Topopah Spring aquifer

TUBA Tub Spring aquifer

UCA Upper carbonate aquifer

UCCU Upper clastic confining unit

UTCU Upper tuff confining unit

VA Volcanic aquifer

VCU Volcanic confining unit

VTA Vitric-tuff aquifer

WTA Welded-tuff aquifer

YF Yucca Flat

YF-Playa Yucca Flat Playa

ZC Clinoptilolite 


\section{LIST OF SYMBOLS FOR ELEMENTS AND COMPOUNDS}

\begin{tabular}{|c|c|}
\hline $\mathrm{Al}$ & Aluminum \\
\hline $\mathrm{Al}_{2} \mathrm{Si}_{2} \mathrm{O}_{5}(\mathrm{OH})_{4}$ & Kaolinite \\
\hline $\mathrm{Ar}$ & Argon \\
\hline $\mathrm{Br}$ & Bromide \\
\hline $\mathrm{C}$ & Carbon \\
\hline $\mathrm{Ca}$ & Calcium \\
\hline $\mathrm{CaAl}_{2} \mathrm{Si}_{2} \mathrm{O}_{8}$ & Anorthite \\
\hline $\mathrm{CaCO}_{3}$ & Calcite \\
\hline $\mathrm{CaF}_{2}$ & Fluorite \\
\hline $\mathrm{CaMg}\left(\mathrm{CO}_{3}\right)_{2}$ & Dolomite \\
\hline $\mathrm{CaSO}_{4}$ & Gypsum \\
\hline $\mathrm{Cl}$ & Chloride \\
\hline $\mathrm{CO}_{2}$ & Carbon dioxide \\
\hline $\mathrm{CO}_{3}$ & Carbonate \\
\hline DIC & Dissolved inorganic carbon \\
\hline DOC & Dissolved organic carbon \\
\hline $\mathrm{Fe}$ & Iron \\
\hline $\mathrm{Fe}(\mathrm{OH})_{3}$ & Amorphous iron hydroxide \\
\hline $\mathrm{FeS}_{2}$ & Pyrite \\
\hline $\mathrm{F}$ & Fluoride \\
\hline $\mathrm{H}$ & Hydrogen \\
\hline${ }^{3} \mathrm{H}$ & Tritium \\
\hline $\mathrm{H}_{2} \mathrm{O}$ & Water \\
\hline $\mathrm{HCO}_{3}$ & Bicarbonate \\
\hline
\end{tabular}




\section{LIST OF SYMBOLS FOR ELEMENTS AND COMPOUNDS (CONTINUED)}

K

$\mathrm{KAlSi}_{3} \mathrm{O}_{8}$

$\mathrm{Mg}$

Mn

$\mathrm{Na}$

$\mathrm{NaAlSi}_{3} \mathrm{O}_{8}$

$\mathrm{NaCl}$

$\mathrm{NO}_{3}$

$\mathrm{O}$

pmc

$\mathrm{Rb}$

S

Si

$\mathrm{SiO}_{2}$

$\mathrm{SiO}_{2}(\mathrm{a})$

$\mathrm{SO}_{4}$

$\mathrm{Sr}$

$\mathrm{SrCO}_{3}$

U

$\mathrm{UO}_{2} \mathrm{CO}_{3}$

$\delta \mathrm{D}$

$\delta^{18} \mathrm{O}$
Potassium

K-feldspar

Magnesium

Manganese

Sodium

Albite

Halite

Nitrate

Oxygen

Percent modern carbon

Rubidium

Sulfur

Silicon

Silica

Amorphous silica

Sulfate

Strontium

Strontianite

Uranium

Uranyl carbonate

Delta deuterium

Delta oxygen-18 


\section{EXECUTIVE SUMMARY}

This report describes the results of a comprehensive geochemical evaluation of the groundwater flow system in the Yucca Flat/Climax Mine Corrective Action Unit (CAU). The main objectives of this study are to identify probable pathways for groundwater flow within the study area and to develop constraints on groundwater transit times between selected data collection sites. This work provides an independent means of testing and verifying predictive flow models being developed for this CAU using finite element methods. The Yucca Flat/Climax Mine CAU constitutes the largest of six underground test areas on the Nevada Test Site (NTS) specified for remedial action in the Federal Facility Agreement and Consent Order. A total of 747 underground nuclear detonations were conducted in this CAU. Approximately 23 percent of these detonations were conducted below or near the water table, resulting in groundwater contamination in the vicinity and possibly downgradient of these underground test locations. Therefore, a rigorous evaluation of the groundwater flow system in this CAU is necessary to assess potential long-term risks to the public water supply at downgradient locations.

The present investigation begins with an evaluation of the geochemical characteristics of groundwater in northern Yucca Flat and specifically addresses the proportion of groundwater inflow to Yucca Flat from outlying areas versus local recharge from the surrounding highlands. The study then investigates potential CAU-scale flow paths within the lower carbonate aquifer (LCA). Although very few underground tests were actually conducted in the LCA, it is the most important aquifer within the study area because of its hydraulic continuity with the larger regional flow system. The LCA represents the most likely pathway for contaminant transport beyond the boundaries of the NTS. Three conceptual groundwater flow paths within the LCA were evaluated: flow from north to south along the eastern side of the Yucca Flat basin; flow from north to south along the western side of the basin; and flow entering Yucca Flat along the southeastern basin margin, moving through southern Yucca Flat to Frenchman Flat. Conceptual flow path development was guided by previous hydrologic studies of the groundwater flow system together with observed trends in geochemical parameters. The separation of flow paths in the eastern and western parts of the basin is strongly inferred on the basis of observed hydraulic head relationships, the presence of major geologic structures near the center of the basin, and differences in geochemical parameters in these two areas. 
The approach for the flow path and travel time evaluations included compilation and examination of all currently available geochemical and isotopic data, construction of mixing models using conservative tracers, evaluation of the mixing models with strontium concentration and isotopic data, and modeling of geochemical reactions using the geochemical modeling programs PHREEQC and NETPATH. The chemical modeling codes also provide a means of estimating groundwater travel times based on carbon isotope data. The basis for this geochemical modeling approach is described in the UGTA Project Geochemistry Technical Basis Document.

Groundwater originating from either paleo- or modern recharge within the Yucca Flat basin is a prominent feature of the groundwater system, particularly in western Yucca Flat, where high-elevation recharge areas at Rainier Mesa, the Eleana Range, and Shoshone Mountain lie adjacent to the basin. Locally derived recharge is also prominent in the northeastern part of the basin, but chemical models indicate an additional groundwater component enters the basin from Emigrant Valley through low-permeability siliciclastic rocks in the Halfpint Range. Groundwater also appears to enter northern Yucca Flat along an LCA flow path near the margin of the Climax Stock; however, a lack of data for LCA groundwater north of the NTS precludes a rigorous evaluation.

Modeling results indicate that the groundwater in northern Yucca Flat moves southward along independent flow paths on the eastern and western sides of the basin. However, the models for these north-to-south flow paths were frequently non-unique, and the composition of groundwater at a given downgradient well can often be explained by mixing groundwater from more than one combination of wells. Nevertheless, the models consistently indicate that the groundwater transit times are extremely long. For example, groundwater transit times of approximately 16,000 to 24,000 years are predicted for flow from Well UE-10j in northern Yucca Flat to WW-C in southern Yucca Flat, resulting in estimated linear groundwater velocities of approximately 1.3 to 1.9 meters per year (m/yr) over this 30-kilometer distance. Along a shorter pathlength between Wells ER-7-1 and ER-6-1\#2, groundwater transit times of approximately 6,500 years were predicted, yielding a similar flow velocity of $1.7 \mathrm{~m} / \mathrm{yr}$. Notably, recent hydraulic tests have indicated a high degree of hydraulic continuity between ER-7-1 and ER-6-1\#2. Hence, the long transit times suggest the groundwater flux through the LCA in Yucca Flat may be relatively small. This feature is attributed to the small inflow of groundwater into the basin from the north rather than a low hydraulic conductivity in the highly faulted LCA. 
Influx of LCA groundwater from east of Yucca Flat is not a prominent part of the groundwater system except in the southeastern part of the basin. In this area, groundwater transit times are on the order of 1,000 to 3,000 years between Well ER-3-1 and WW-C, and predicted groundwater flow velocities show a corresponding increase (4.3 to $13 \mathrm{~m} / \mathrm{yr}$ ). The increased flux of groundwater from east of the basin into the southeastern part of Yucca Flat is consistent with the absence of the lower clastic confining unit in the southeast portion of the basin. Flow conditions in this part of the system appear to be more dynamic when compared to the relatively stagnant flow conditions within the upgradient parts of the Yucca Flat basin.

Several wells completed in the LCA near the west-central part of the basin show potential evidence of groundwater leakage from overlying volcanic units. Although it was not possible to uniquely ascribe the observed geochemical signatures to locally derived vertical transport, it is possible that nearby faults have created localized flow paths between the volcanic and carbonate hydrostratigraphic units in this area. Because of a lack of data in other parts of the basin, vertical leakage from overlying volcanic units could not be tested. 


\subsection{InTRODUCTION}

The Yucca Flat/Climax Mine corrective action unit (CAU) constitutes the largest of several geographic areas within the Nevada Test Site (NTS) used for underground nuclear testing (Figure 1-1). Between 1957 and 1992, a total of 747 underground nuclear detonations were conducted in shafts and tunnels in this CAU. The tests included 744 detonations in Yucca Flat proper and three detonations in the Climax Mine tunnel complex (DOE/NV, 2000b). Underground nuclear tests are designated (either individually or as groups) as corrective action sites (CASs) in the Federal Facility Agreement and Consent Order (FFACO) (1996). In some cases, multiple detonations were conducted simultaneously in the same emplacement hole and therefore comprise a single CAS (FFACO, 1996). The location of the 720 CASs within the Yucca Flat/Climax Mine CAU are presented in Figure 1-1.

Announced test yields with the Yucca Flat/Climax Mine CAU range from zero to 500 kilotons and the depth of burial ranges from 58 to 782 meters (m) below ground surface (bgs) (DOE/NV, 2000a,b). Nuclear devices were emplaced in one of four types of geologic media in Yucca Flat and Climax Mine: alluvial deposits, Tertiary volcanics, carbonates, or intrusives (DOE/NV, 2000a). Approximately 23 percent of these detonations were conducted below or near the water table resulting in groundwater contamination in the vicinity and possibly downgradient of the underground test locations (DOE/NV, 2000a).

This report describes a comprehensive evaluation of geochemical and environmental isotope data for groundwater in the Yucca Flat/Climax Mine CAU. The main objective is to identify potential flow paths into and through Yucca Flat that may influence the transport of radionuclides from underground nuclear tests. This study builds upon previous geologic, hydrologic, and geochemical investigations of the Yucca Flat/Climax Mine area that began in the 1950s and have continued to the present day.

Groundwater chemistry data provide a means for determining the origin, flow paths, and time scale of groundwater flow that is independent of estimates based on hydraulic flow analysis. Geochemical and hydraulic data reflect distinct but complimentary aspects of a groundwater flow system, and 


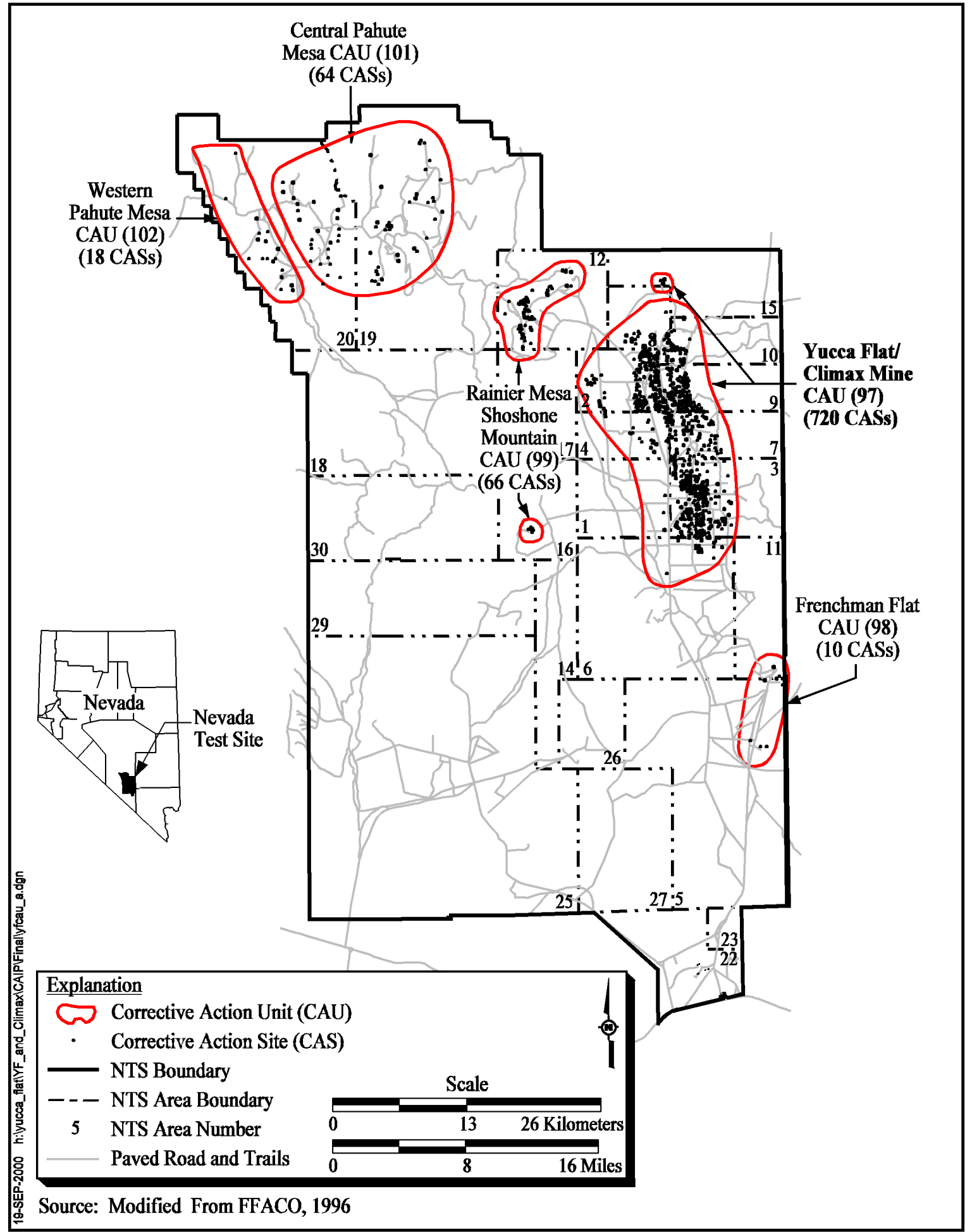

Figure 1-1

Corrective Action Units and Corrective Action Sites at the Nevada Test Site 
should be considered in unison to develop a consistent, comprehensive, and defensible flow system assessment.

The present assessment of groundwater chemistry data for the Yucca Flat/Climax Mine CAU was undertaken to support the development of a CAU-scale groundwater flow model. This work is funded by the Underground Test Area (UGTA) Project, through the Environmental Restoration Division of the U.S. Department of Energy, National Nuclear Administration Nevada Site Office (NNSA/NSO). The dataset used for this study was compiled from a comprehensive database for groundwater geochemical developed by the UGTA Project, Geochem05.mdb (SNJV, 2005b).

A significant amount of time and effort went into qualifying and assessing all existing geochemical data for this CAU. The resulting dataset presented here reflects the highest quality data that are presently available. The flow path and travel time evaluations developed from these data are based on methodologies described in the Geochemistry Technical Basis Document for the UGTA Project (Benedict et al., 2003).

The focus of the evaluations described within this report is on the geochemistry investigation area identified in Figure 1-2, which encompasses the Yucca Flat/Climax Mine CAU and the immediate surrounding area. The boundaries of the geochemistry investigation area were selected so that all wells and springs within the vicinity of the Yucca Flat/Climax Mine CAU with available groundwater chemistry data were included. Data from Pahranagat Valley, Emigrant Valley, the Belted Range, Groom Range, Pintwater Range, and Sheep Range are variously considered as representative source areas for groundwater flowing into the study area. Wells within Frenchman Flat are included in this study area (Figure 1-2) to evaluate possible outflow from Yucca Flat within the lower carbonate aquifer (LCA). A geochemical investigation of the Frenchman Flat CAU was previously documented in Hershey et al. (2005).

\subsection{Approach}

The conceptual flow paths evaluated during this study were guided by previous hydrologic studies of the Yucca Flat groundwater flow system, primarily Winograd and Thordarson (1975) and Laczniak et al. (1996). Groundwater chemistry evolves along a given flow path and the chemistry at any location may reflect both mixing of different groundwaters and water-rock reactions. Pathways between 


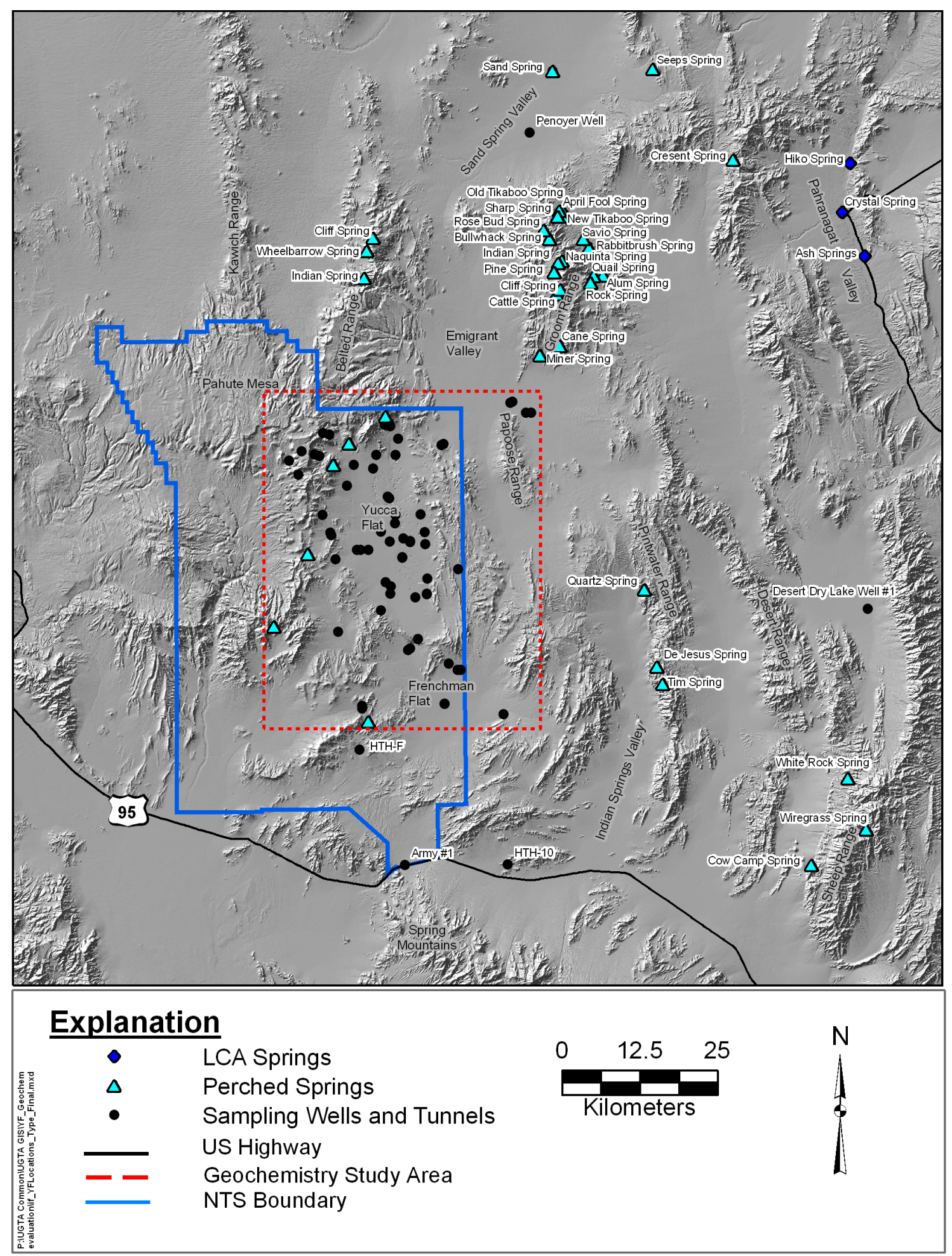

Figure 1-2

Wells and Springs in the Yucca Flat/Climax Mine Geochemical Investigation Area with Geochemical and/or Isotopic Data 
specific upgradient and downgradient locations are considered viable if mixing models and reactive transport models can emulate the water chemistry of the downgradient locations within the bounds imposed by the available data. This involves proportionally mixing the upgradient water with other waters that represent possible additional sources such as local recharge or flow from other hydrostratigraphic units (HSUs).

Figure 1-3 illustrates the conceptual flow paths evaluated during this investigation, and identifies specific wells modeled for each flow path. These flow paths are based on previous investigations of Yucca Flat hydrology that are discussed in Section 2.0. This investigation begins with an evaluation of the geochemical characteristics of groundwater in northern Yucca Flat, and specifically addresses the proportion of groundwater inflow to Yucca Flat from outlying areas versus local recharge from the surrounding highlands (Northern Flow Path, Figure 1-3 and Section 6.0). This includes the evaluation of groundwater moving from the granite of the Climax Stock into Yucca Flat. Three generalized conceptual groundwater flow paths through Yucca Flat within the LCA are then evaluated:

1. Groundwater moving from northern to southern Yucca Flat along the eastern side of the central fault structures (Eastern Flow Path, Figure 1-3 and Section 7.0)

2. Groundwater entering Yucca Flat along the southeastern boundary and moving through southern Yucca Flat to Frenchman Flat (Southeastern Flow Path, Figure 1-3 and Section 8.0)

3. Groundwater moving from north to south along the western side of Yucca Flat (Western Flow Path, Figure 1-3 and Section 9.0). Finally, the nature of groundwater geochemistry in west-central Yucca Flat LCA is evaluated in terms of potential vertical flow from overlying HSUs into the LCA (West Central Flow Path, Figure 1-3)

Lateral flow paths within the volcanic and alluvial aquifers are not considered during this study because lateral continuous pathways do not extend beyond the CAU boundaries within these units, and the dataset for permeable alluvial and volcanic units is insufficient to conduct the analysis. 


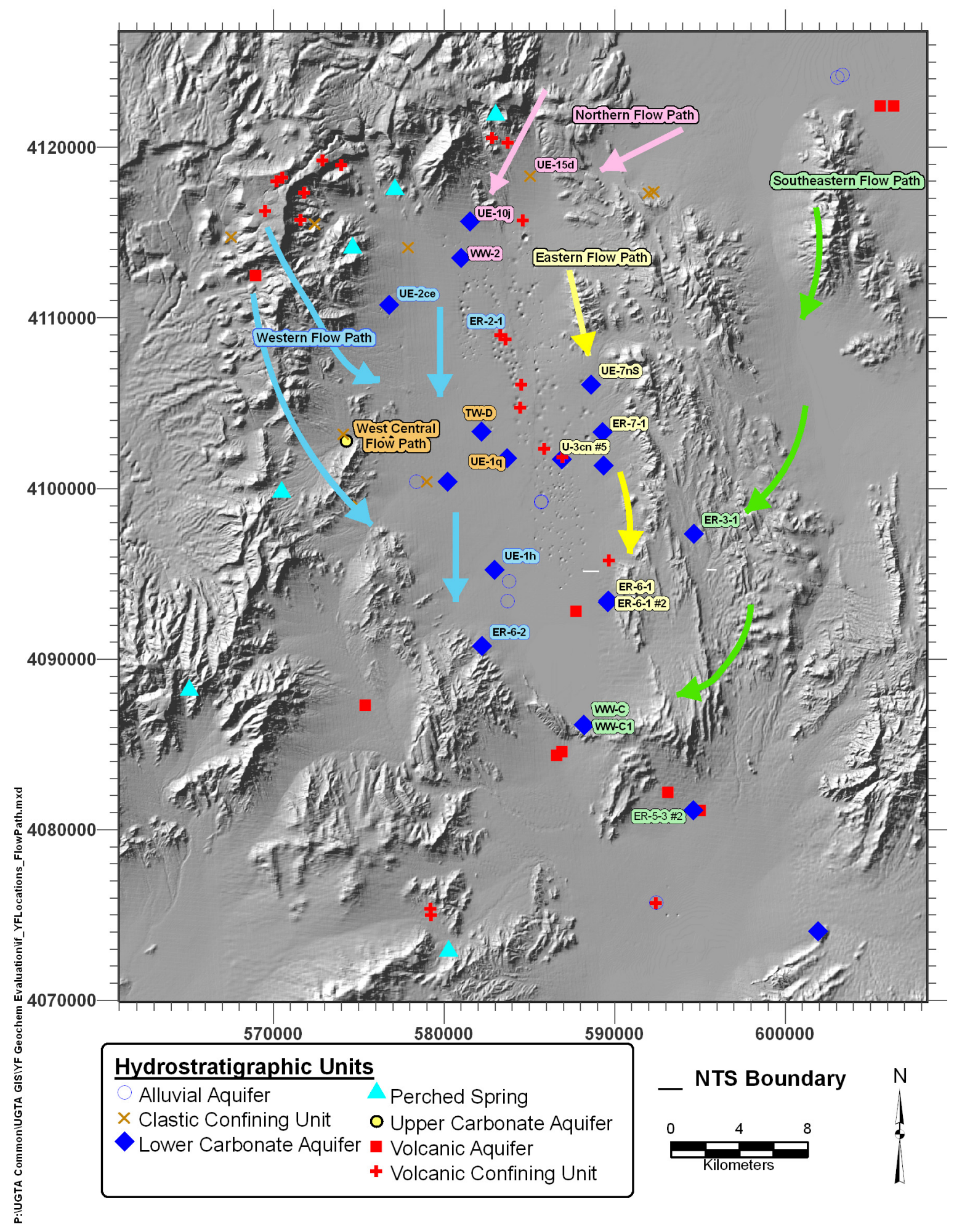

Figure 1-3

Conceptual Flow Paths Evaluated in the Yucca Flat/Climax Mine Geochemical Study 


\subsection{Methodology}

The methodology used in this investigation follows the basic format described in Benedict et al. (2003) and is summarized below:

1. A set of geochemical data from groundwater within the study area was compiled from the comprehensive water-quality database, Geochem $04 . \mathrm{mdb}$, and other available sources. A thorough evaluation of the dataset was then performed to determine representative data for each well and spring included in the study area. Average values were used to represent the isotopic signature and geochemical composition of each well or spring.

2. Groundwater mixing models were tested with conservative tracer data to determine viable flow paths. Conservative tracers are those geochemical species that exhibit little or no tendency to interact with aquifer material and that are transported with the groundwater. Conservative tracers used in this study include isotopes of hydrogen (delta deuterium $[\delta \mathrm{D}]$ ) and oxygen (delta oxygen-18 $\left[\delta^{18} \mathrm{O}\right]$ ), as well as chloride $(\mathrm{Cl})$.

3. Conceptual flow paths were also evaluated by examining strontium ( $\mathrm{Sr}$ ) concentrations and ${ }^{87} \mathrm{Sr} /{ }^{86} \mathrm{Sr}$ isotopic ratios. Strontium is a non-conservative, reactive element that is useful for discriminating the presence of groundwater that has equilibrated with different rock types. As such, the Sr data provide a useful means of assessing a particular flow path that is independent of the conservative tracers.

4. Flow paths with acceptable mixing models were verified using the geochemical modeling program NETPATH (Plummer et al., 1994). This program interprets net geochemical mass-balance reactions between initial and final water compositions along a hydrologic flow path. The NETPATH program also provides estimates of groundwater travel times and corrected radiocarbon ages using carbon isotope data and accounting for isotopic fractionation of carbon isotopes.

5. Flow paths identified as viable using conservative tracers and $\mathrm{Sr}$ data were evaluated using the geochemical modeling program PHREEQC (Parkhurst and Appelo, 1999). This program models mineral saturation states and allows the direct comparison of predicted dissolution-precipitation reactions with the mineral compositions observed in a given HSU. The PHREEQC program provides a means of quantifying uncertainties in mixing ratios and the quantities of the minerals dissolved or precipitated, and permits the development of travel time estimates from carbon isotope data assuming no isotopic fractionation of carbon isotopes. 


\subsection{Limitations}

Geochemical flow path evaluations depend on adequate data coverage, both laterally and vertically, within the study region. Within the Yucca Flat/Climax Mine CAU, the wells with the parameter suite necessary to support geochemical flow path analysis and characterization are irregularly distributed. This is compounded by a sparse representation of groundwater samples collected from most HSUs. The poor data distribution both upgradient and downgradient of Yucca Flat also limits the ability to develop well-constrained geochemical models. As a result, the geochemical models developed in this report are associated with inherent uncertainties that can only be reduced through the acquisition of new data. 


\subsection{HydRogeOLOGICAL AND HYDROGEOCHEMICAL SETTING}

Yucca Flat is a large (approximately 19 kilometers [km] east-west by $35 \mathrm{~km}$ north-south) structural valley in the northeastern corner of the NTS formed by perimeter mountain ranges and interior down dropping by extensional north-south faulting (Figure 2-1). The Yucca Flat basin is topographically closed with a playa at its southern end. Faulted and tilted blocks of Tertiary-age volcanic rocks and underlying Paleozoic and Precambrian sedimentary rocks form low mountain ranges surrounding the basin. Recent alluvial deposits cover the volcanic rocks filling the basin.

\subsection{Hydrogeologic Framework}

The rocks of the NTS have been classified using a two-level classification scheme: hydrogeologic units (HGUs) and HSUs (IT, 1996c; BN, 2002). The HGUs categorize lithologic types according to their ability to transmit groundwater, which is a function of their primary lithologic properties, degree of fracturing, and secondary mineral alteration. Hydrostratigraphic units are groupings of contiguous stratigraphic units that have a particular hydrogeologic character, such as an aquifer or confining unit. An HSU may include units of several HGU types, but is defined so that a single general type of HGU dominates (e.g., mostly welded-tuff aquifers and lava-flow aquifers or tuff confining units). The HGUs of the Yucca Flat/Climax Mine area are presented in Table 2-1.

In general, the most transmissive rocks tend to be moderately to densely welded ash-flow tuffs (welded-tuff aquifer), rhyolite lava flows (lava-flow aquifer), and carbonate rocks (limestone and dolomite). Although their interstitial porosity is low, these competent lithologies tend to be highly fractured and groundwater flow through these rocks is largely through an interconnected network of fractures (Blankennagel and Weir, 1973; GeoTrans, 1995).

The lowest transmissivity values in volcanic rocks at the NTS are typically associated with non-welded ash-flow tuff and bedded tuff (air-fall and reworked tuffs). Although interstitial porosity 

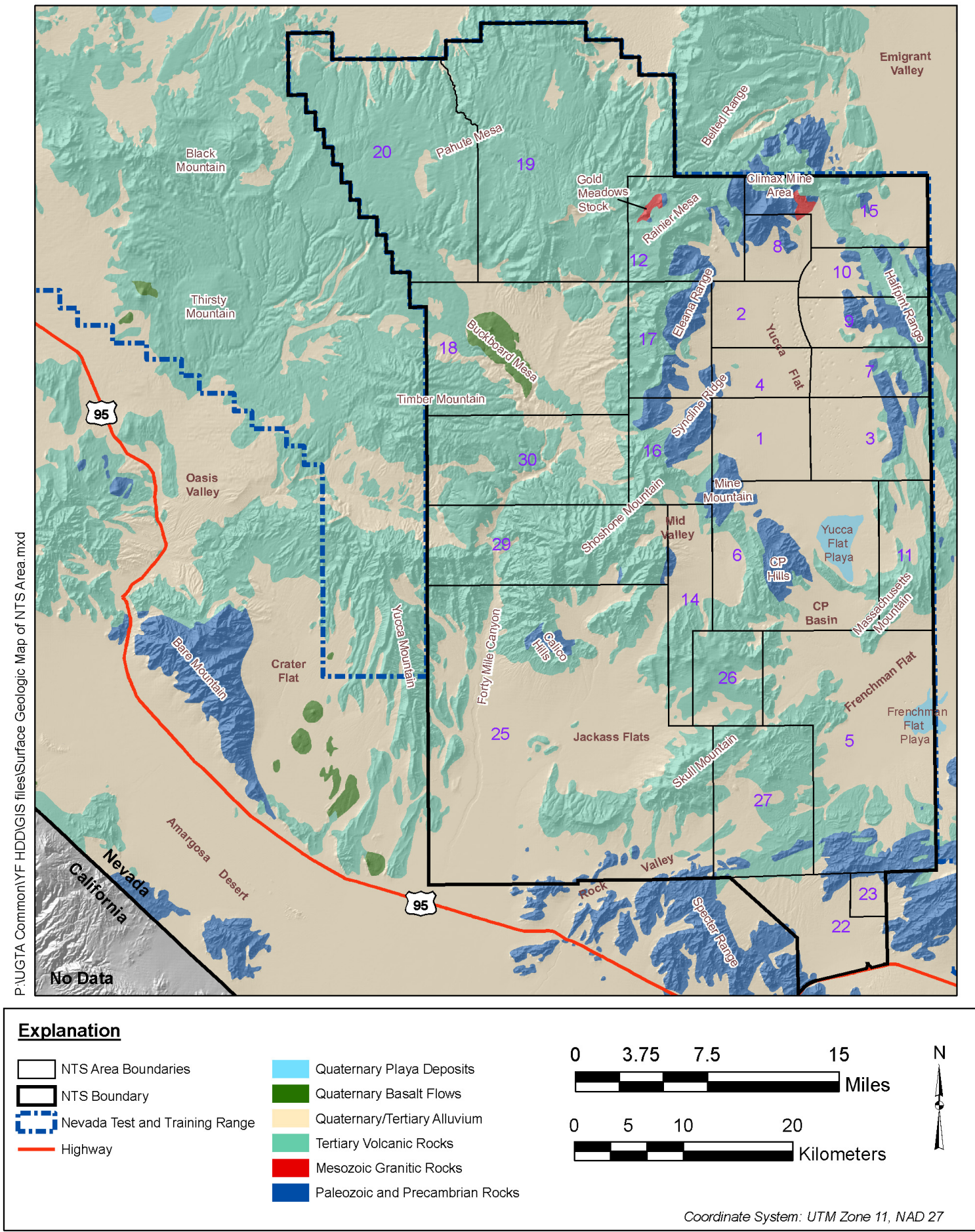

Source: Modified from Nevada Bureau of Mines and Geology, 1996

Figure 2-1

Generalized Surface Geologic Map of the Nevada Test Site Area 
Table 2-1

Yucca Flat/Climax Mine Hydrostratigraphic Units (Page 1 of 3 )

\begin{tabular}{|c|c|c|c|}
\hline $\begin{array}{c}\text { Hydrostratigraphic } \\
\text { Unit }\end{array}$ & $\begin{array}{l}\text { Dominant } \\
\text { Hydrogeologic } \\
\text { Unit }\end{array}$ & Typical Lithologies & Hydrologic Significance \\
\hline $\begin{array}{l}\text { Alluvial aquifer } \\
\qquad(A A)\end{array}$ & $A A$ & $\begin{array}{l}\text { Alluvium: Gravelly sand; } \\
\text { also includes one or } \\
\text { more thin basalt flows, } \\
\text { playa deposits and } \\
\text { eolian sands } \\
\text { (differentiated as } \\
\text { separate HSUs) }\end{array}$ & $\begin{array}{l}\text { The thickness of the alluvium in the middle of the Yucca } \\
\text { Flat basin ranges from about } 30 \mathrm{~m} \text { to just over } 800 \mathrm{~m} \\
\text { (Drellack and Thompson, 1990). Generally unsaturated } \\
\text { except in deepest basins. }\end{array}$ \\
\hline $\begin{array}{l}\text { Playa confining unit } \\
\text { (PCU) }\end{array}$ & PCU & Clayey silt and sandy silt & $\begin{array}{l}\text { Playa units are well above the local water table, but } \\
\text { could impede downward recharge, or intermittently } \\
\text { concentrate local recharge through large surface } \\
\text { cracks. Forms surface and near-surface playas at } \\
\text { Yucca Lake and Papoose Lake and southern West } \\
\text { Emigrant Valley. }\end{array}$ \\
\hline $\begin{array}{l}\text { Basalt lava flow } \\
\text { aquifer (BLFA) }\end{array}$ & $\begin{array}{l}\text { Lava-flow aquifer } \\
\text { (LFA) }\end{array}$ & $\begin{array}{c}\text { Basalt lava flows, minor } \\
\text { sills and associated } \\
\text { dikes }\end{array}$ & $\begin{array}{l}\text { Several (possibly dissected) basalt flows recognized in } \\
\text { the middle of the alluvial section of southwestern Yucca } \\
\text { Flat, at the surface as dikes and sills in the Half Pint } \\
\text { Range and as a dike in the subsurface of eastern } \\
\text { Yucca Flat. Generally unsaturated, but deep feeder } \\
\text { dikes could possibly affect groundwater flow. }\end{array}$ \\
\hline $\begin{array}{l}\text { Timber Mountain } \\
\text { upper vitric-tuff } \\
\text { aquifer (TM-UVTA) }\end{array}$ & $\begin{array}{l}\text { Vitric-tuff aquifer } \\
\text { (VTA) minor } \\
\text { welded-tuff aquifer } \\
\text { (WTA) }\end{array}$ & $\begin{array}{c}\text { Includes vitric } \\
\text { nonwelded to partially } \\
\text { welded ash-flow and } \\
\text { bedded tuff }\end{array}$ & $\begin{array}{l}\text { Typically saturated only in the deepest structural } \\
\text { basins. This HSU comprises only the Ammonia Tanks } \\
\text { Tuff, which stratigraphically overlies the TM-WTA. }\end{array}$ \\
\hline $\begin{array}{l}\text { Timber Mountain } \\
\text { welded-tuff aquifer } \\
\text { (TM-WTA) }\end{array}$ & $\begin{array}{l}\text { WTA } \\
\text { minor VTA }\end{array}$ & $\begin{array}{l}\text { Partially to densely } \\
\text { welded ash-flow tuff; } \\
\text { vitric to devitrified }\end{array}$ & $\begin{array}{l}\text { Typically saturated only in deep structural basins. } \\
\text { Welded zones typically sandwiched between } \\
\text { nonwelded zones. Prolific aquifer when saturated. }\end{array}$ \\
\hline $\begin{array}{l}\text { Timber Mountain } \\
\text { lower vitric-tuff } \\
\text { aquifer (TM-LVTA) }\end{array}$ & VTA & $\begin{array}{l}\text { Nonwelded ash-flow and } \\
\text { bedded tuff; vitric }\end{array}$ & $\begin{array}{l}\text { Typically includes the nonzeolitized, nonwelded lower } \\
\text { portion of the Rainier Mesa Tuff. However, this HSU } \\
\text { can encompass all nonzeolitized, nonwelded and } \\
\text { bedded units below the welded Rainier Mesa Tuff and } \\
\text { above the level of pervasive zeolitization. Unaltered, } \\
\text { nonwelded, and ash-fall tuffs generally are not found at } \\
\text { depths much below the static water-level because the } \\
\text { the tendency to become zeolitized under saturated } \\
\text { conditions drastically reduces permeability. }\end{array}$ \\
\hline $\begin{array}{l}\text { Upper tuff confining } \\
\text { unit (UTCU) }\end{array}$ & $\begin{array}{l}\text { Tuff confining unit } \\
\text { (TCU) }\end{array}$ & Zeolitized bedded tuff & $\begin{array}{l}\text { Defined to encompass the zeolitized bedded tuffs } \\
\text { which stratigraphically overlie the TSA. Although some } \\
\text { geologic units of the UTCU are laterally continuous with } \\
\text { those of the LTCU, the UTCU is limited aerially to } \\
\text { extreme southern Yucca Flat where the welded } \\
\text { Topopah Spring Tuff is an important aquifer present } \\
\text { between the UTCU and LTCU. }\end{array}$ \\
\hline $\begin{array}{l}\text { Topopah Spring } \\
\text { aquifer (TSA) }\end{array}$ & WTA minor VTA & Welded ash-flow tuff & $\begin{array}{l}\text { Distribution in Yucca Flat is limited to extreme southern } \\
\text { portion; south of the N } 828,000 \text { Nevada Test Site (NTS) } \\
\text { grid line. Hydrogeologic properties similar to those of } \\
\text { the TM-WTA. Prolific aquifer when saturated. }\end{array}$ \\
\hline
\end{tabular}


Table 2-1

Yucca Flat/Climax Mine Hydrostratigraphic Units (Page 2 of 3 )

\begin{tabular}{|c|c|c|c|}
\hline $\begin{array}{l}\text { Hydrostratigraphic } \\
\text { Unit }\end{array}$ & $\begin{array}{l}\text { Dominant } \\
\text { Hydrogeologic } \\
\text { Unit }\end{array}$ & Typical Lithologies & Hydrologic Significance \\
\hline $\begin{array}{l}\text { Lower vitric tuff } \\
\text { aquifer (LVTA) }\end{array}$ & VTA & $\begin{array}{l}\text { Nonwelded and bedded } \\
\text { ash-flow tuff; vitric }\end{array}$ & $\begin{array}{l}\text { Relatively thin VTA unit below the TSA. Grouped with } \\
\text { the TM-LVTA where TSA is not present. }\end{array}$ \\
\hline $\begin{array}{l}\text { Belted Range aquifer } \\
\text { (BRA) }\end{array}$ & WTA & Welded ash-flow tuff & $\begin{array}{l}\text { Typically saturated (perched water) only in the Rainier } \\
\text { Mesa area. This HSU comprises only welded Grouse } \\
\text { Canyon Tuff and is limited to the northern portion of the } \\
\text { Yucca Flat model area. }\end{array}$ \\
\hline $\begin{array}{l}\text { Belted Range } \\
\text { confining unit } \\
\quad(\text { BRCU) }\end{array}$ & TCU & Zeolitized bedded tuffs & $\begin{array}{l}\text { Generally includes all zeolitized tuffs between the } \\
\text { (welded) Grouse Canyon Tuff and the (welded) Tub } \\
\text { Spring Tuff. Limited to the northern Yucca Flat } \\
\text { extension area. }\end{array}$ \\
\hline $\begin{array}{l}\text { Pre-Grouse Canyon } \\
\text { Tuff lava-flow aquifer } \\
\quad \text { (Pre-Tbg-LFA) }\end{array}$ & LFA & Lava flow & $\begin{array}{l}\text { Defined to include all the comendite lava-flows } \\
\text { emplaced before the Grouse Canyon Tuff but after the } \\
\text { older Tunnel beds. Limited to the northern Yucca Flat } \\
\text { extension area. }\end{array}$ \\
\hline $\begin{array}{l}\text { Tub Spring aquifer } \\
\text { (TUBA) }\end{array}$ & WTA & Welded ash-flow tuff & $\begin{array}{l}\text { Comprises only the welded Tub Spring Tuff and is thus } \\
\text { limited to the northern Yucca Flat extension area. }\end{array}$ \\
\hline $\begin{array}{l}\text { Lower tuff confining } \\
\text { unit (LTCU) }\end{array}$ & TCU & $\begin{array}{l}\text { Zeolitized bedded tuffs } \\
\text { with interbedded but } \\
\text { less significant } \\
\text { zeolitized, nonwelded to } \\
\text { partially welded ash-flow } \\
\text { tuffs }\end{array}$ & $\begin{array}{l}\text { Generally includes all zeolitized tuffs in the Yucca Flat } \\
\text { area. Stratigraphically, the LTCU may include all units } \\
\text { from the base of the Rainier Mesa Tuff to the top of the } \\
\text { Paleozoic rocks. The strongly argillized older tuffs and } \\
\text { paleocolluvium that immediately overlie the pre-Tertiary } \\
\text { rocks may also be included. The uppermost zeolitized } \\
\text { bedded tuffs overlying the TSA in southern Yucca Flat } \\
\text { form a separate HSU (the UTCU). }\end{array}$ \\
\hline $\begin{array}{l}\text { Oak Spring Butte } \\
\text { confining unit } \\
\text { (OSBCU) }\end{array}$ & TCU & $\begin{array}{l}\text { Devitrified to zeolitic } \\
\text { non- to partially welded } \\
\text { tuffs and intervening } \\
\text { bedded tuffs }\end{array}$ & $\begin{array}{l}\text { Includes altered older ash-flow tuff units and Tunnel } \\
\text { Beds } 1 \text { and } 2 \text {. Welding in the older ash flow units may } \\
\text { increase overall hydraulic conductivity. Devitrification } \\
\text { of the ash flow units may have limited zeolitization. } \\
\text { Differentiated in the Yucca Flat basin. }\end{array}$ \\
\hline $\begin{array}{l}\text { Argillic tuff confining } \\
\text { unit (ATCU) }\end{array}$ & TCU & $\begin{array}{l}\text { Argillic bedded tuffs, } \\
\text { minor paleocolluvium }\end{array}$ & $\begin{array}{l}\text { Includes the argillic, lowermost Tertiary volcanic units } \\
\text { and paleocolluvium that immediately overlie the } \\
\text { pre-Tertiary rocks. Differentiated in Yucca Flat basin. }\end{array}$ \\
\hline $\begin{array}{l}\text { Volcaniclastic } \\
\text { confining unit (VCU) }\end{array}$ & $\begin{array}{l}\text { TCU, minor AA } \\
\text { and carbonate } \\
\text { aquifer (CA) }\end{array}$ & $\begin{array}{l}\text { Siltstones, carbonate } \\
\text { rocks, and tuffaceous } \\
\text { sandstones }\end{array}$ & $\begin{array}{l}\text { Older Tertiary-age sedimentary rocks of variable } \\
\text { lithologies. Present in the southeastern corner of the } \\
\text { model area. }\end{array}$ \\
\hline $\begin{array}{l}\text { Mesozoic granite } \\
\text { confining unit } \\
\text { (MGCU) }\end{array}$ & $\begin{array}{l}\text { Granite confining } \\
\text { unit (GCU) }\end{array}$ & $\begin{array}{l}\text { Granodiorite and quartz } \\
\text { monzonite }\end{array}$ & $\begin{array}{l}\text { Includes two intrusives: Climax and Gold Meadows. } \\
\text { Based on observations at the Climax site, the granite } \\
\text { has very low permeability and is considered to be a } \\
\text { confining unit. Locally, may have perched water } \\
\text { contained within fractures. The two stocks may be } \\
\text { connected at depth and are the suspected contributor } \\
\text { of a hydrologic barrier at the north end of Yucca Flat. }\end{array}$ \\
\hline
\end{tabular}


Table 2-1

Yucca Flat/Climax Mine Hydrostratigraphic Units (Page 3 of 3)

\begin{tabular}{|c|c|c|c|}
\hline $\begin{array}{l}\text { Hydrostratigraphic } \\
\text { Unit }\end{array}$ & $\begin{array}{l}\text { Dominant } \\
\text { Hydrogeologic } \\
\text { Unit }\end{array}$ & Typical Lithologies & Hydrologic Significance \\
\hline $\begin{array}{l}\text { Lower carbonate } \\
\text { aquifer - Yucca Flat } \\
\text { upper plate (LCA3) }\end{array}$ & $\mathrm{CA}$ & Limestone and dolomite & $\begin{array}{l}\text { Includes the Cambrian through Ordovician units that } \\
\text { have been thrust over the Eleana Formation and the } \\
\text { Chainman Shale. Mostly carbonate rocks that occur in } \\
\text { the hanging wall of the Belted Range and CP thrust } \\
\text { faults are designated as lower carbonate aquifer, upper } \\
\text { thrust plate (LCA3). Equivalent stratigraphically to the } \\
\text { LCA, but structurally separated from the LCA by the } \\
\text { Belted Range or CP thrust faults. The LCA3 is patchily } \\
\text { distributed as remnant thrust blocks, particularly along } \\
\text { the western and southern sides of Yucca Flat }\end{array}$ \\
\hline $\begin{array}{l}\text { Lower clastic } \\
\text { confining unit - Yucca } \\
\text { Flat upper plate } \\
\text { (LCCU1 and 2) }\end{array}$ & $\begin{array}{l}\text { Clastic confining } \\
\text { unit } \\
(\mathrm{CCU})\end{array}$ & Quartzite and siltstone & $\begin{array}{l}\text { Includes upper Proterozoic through lower Cambrian } \\
\text { units that have been thrust over younger units. }\end{array}$ \\
\hline $\begin{array}{l}\text { Upper carbonate } \\
\text { aquifer (UCA) }\end{array}$ & CA & Limestone & $\begin{array}{l}\text { Includes the Tippipah Limestone (correlative with the } \\
\text { Bird Spring Formation) that stratigraphically overlies the } \\
\text { Chainman Shale at Syncline Ridge; thus, may contain } \\
\text { perched water. }\end{array}$ \\
\hline $\begin{array}{l}\text { Upper clastic } \\
\text { confining unit } \\
\quad(\text { UCCU) }\end{array}$ & $\mathrm{CCU}$ & Argillite and quartzite & $\begin{array}{l}\text { As much as } 2,740 \mathrm{~m} \text { thick. Typically forms footwalls of } \\
\text { Mesozoic thrust faults in NTS region. Areal extent is } \\
\text { limited to western Yucca Flat and portions of CP Basin. }\end{array}$ \\
\hline $\begin{array}{l}\text { Lower carbonate } \\
\text { aquifer (LCA) }\end{array}$ & CA & Dolomite and limestone & $\begin{array}{l}\text { Important regional aquifer underlying most of southern } \\
\text { Nevada. Composite thickness up to } 4,430 \text { meters. } \\
\text { Transmissivity values differ greatly and are directly } \\
\text { dependent on fracture and fault frequency. }\end{array}$ \\
\hline $\begin{array}{l}\text { Lower clastic } \\
\text { confining unit } \\
\qquad(\text { LCCU })\end{array}$ & $\mathrm{CCU}$ & Quartzite and siltstone & $\begin{array}{l}\text { Significant regional confining unit. Composite } \\
\text { thickness about } 2,870 \mathrm{~m} \text {. May present barrier to deep } \\
\text { regional groundwater flow where structurally high. } \\
\text { (e.g., northeastern Yucca Flat). Hydrologic "basement" } \\
\text { present at great depth in the model area (except } \\
\text { northern Halfpint Range). }\end{array}$ \\
\hline
\end{tabular}

Source: BN, 2006

Note: VCU refers to volcaniclastic confining unit in this table and in Figures 2-1 through 2-6 only.

may be high, the interconnectivity of the pore space is low, and these relatively incompetent rocks tend not to support open fractures. Secondary alteration of these tuffs (most commonly zeolitization) ultimately yields a unit with very low transmissivity. These zeolitized tuffs are considered to be confining units. The equivalent unaltered bedded and non-welded tuffs form vitric-tuff aquifers with intermediate transmissivities. 
The density and character of fractures in the rocks are the primary determinants of their hydraulic properties. Most hydraulic heterogeneity ultimately is related to fracture characteristics such as fracture density, openness, orientation, and other properties. Secondary fracture-filling minerals can drastically obstruct the flow through, or effectively seal, an otherwise transmissive formation (Drellack et al., 1997; IT, 1996d). Fracture density may increase with proximity to faults, potentially increasing the hydraulic conductivity of the formation; however, the hydrologic properties of faults are not well known.

\subsection{Yucca Flat Hydrostratigraphic Framework Model}

A three-dimensional hydrostratigraphic framework model (HFM) of Yucca Flat/Climax Mine has been developed using EarthVision ${ }^{\circledR}$ software (BN, 2006). The HFM is constructed of HSUs and serves as input to the UGTA groundwater modeling process. The HSU classifications and corresponding dominant HGUs defined for the Yucca Flat/Climax Mine HFM are presented in Table 2-1. Note that the designations of aquifer or confining unit are based on the hydraulic properties of the HSU without regard to whether it is completely saturated.

The regionally continuous flow system within the LCA is separated from the shallow aquifers within the basin (alluvial aquifer, lava-flow aquifers [LFAs], volcanic aquifers) by a thick sequence of volcanic confining units (VCUs). The shallow aquifers are replenished by recharge from local precipitation, and hydraulic head data indicate that groundwater moves primarily downwards to the lower carbonate aquifer (LCA) (BN, 2006). The lower clastic confining unit (LCCU), underlying the LCA, is the lower boundary of the regional flow system. There are more than 100 faults included in the HFM, most with north-south orientation; however, many more are thought to be present.

The HSUs at the ground surface of the Yucca Flat/Climax Mine modeling area, the boundaries of the NTS areas, and the geochemistry sampling locations are shown in Figure 2-2. The HSUs at the water table are shown in Figure 2-3. The extent of the LCA and LCA3 (Yucca Flat upper plate of LCA) is shown in Figure 2-4. The top of the LCA is shown in Figure 2-5. Comparison of Figure 2-5 with Figure 2-4 shows how the LCA3 is contiguous with the LCA west of the CP thrust. The LCA extends out of the Yucca Flat model to the west, but is truncated under nearby Rainier Mesa by the Belted Range Thrust. The LCA underlies all of the volcanic HSUs, but is absent where the LCCU is present in the northeast and east of Yucca Flat. The upper clastic confining unit (UCCU) is present along the 


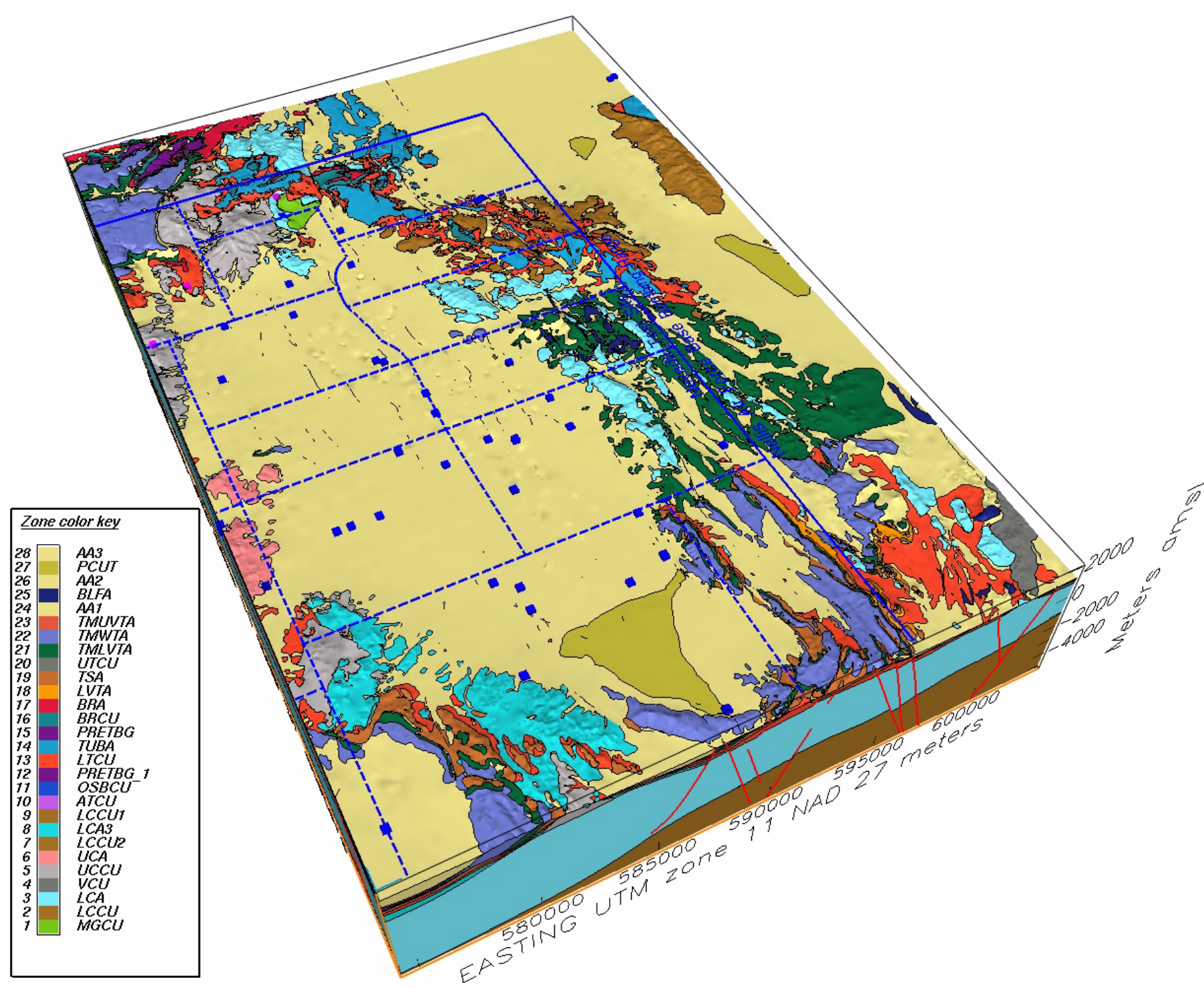

Figure 2-2

Yucca Flat Surface Hydrostratigraphy and Geochemical Sampling Locations 


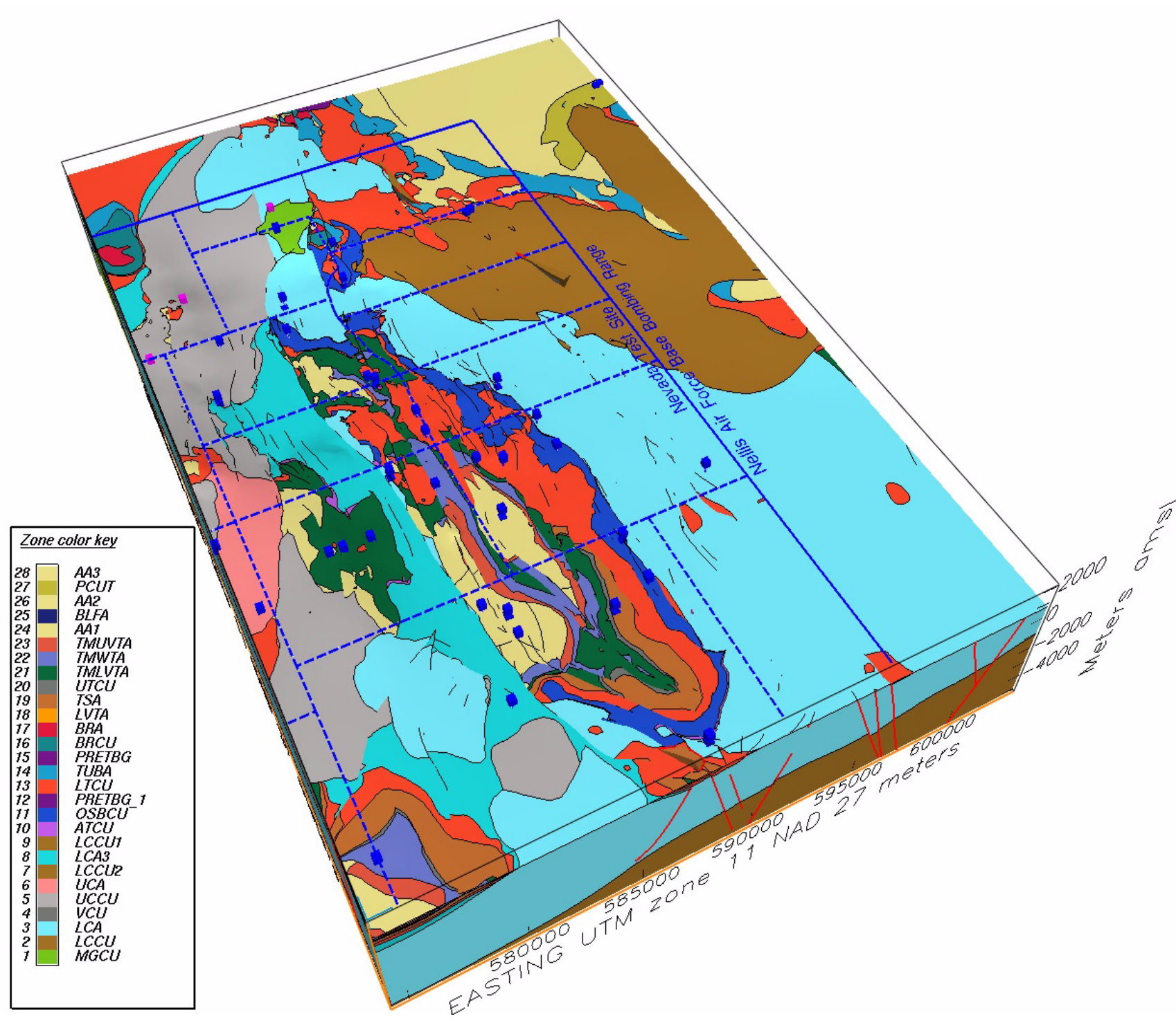

Figure 2-3

Hydrostratigraphic Units at the Water Table 


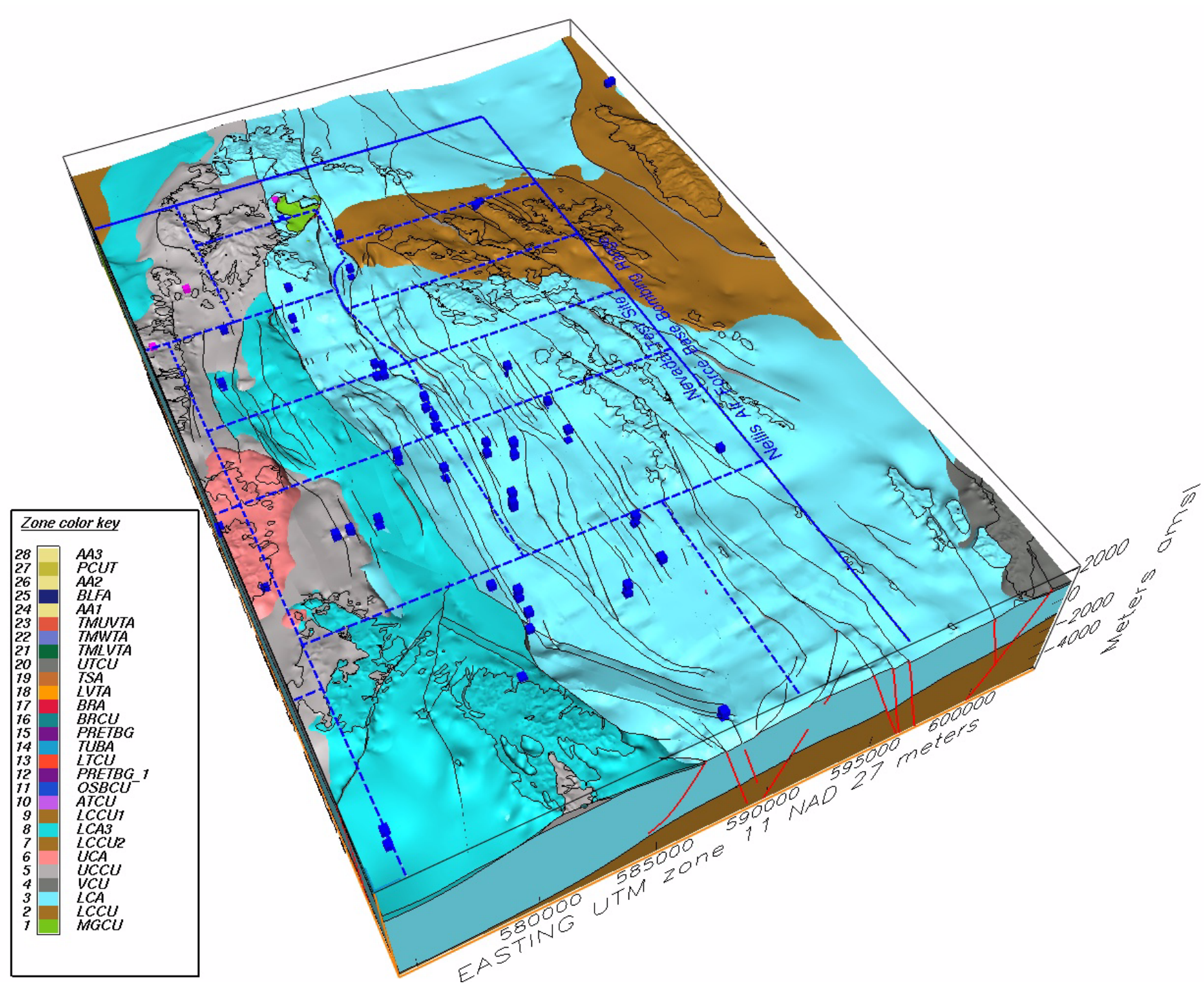

Figure 2-4

Top of the Lower Carbonate Aquifer, Upper Thrust Plate (LCA3) and Below 

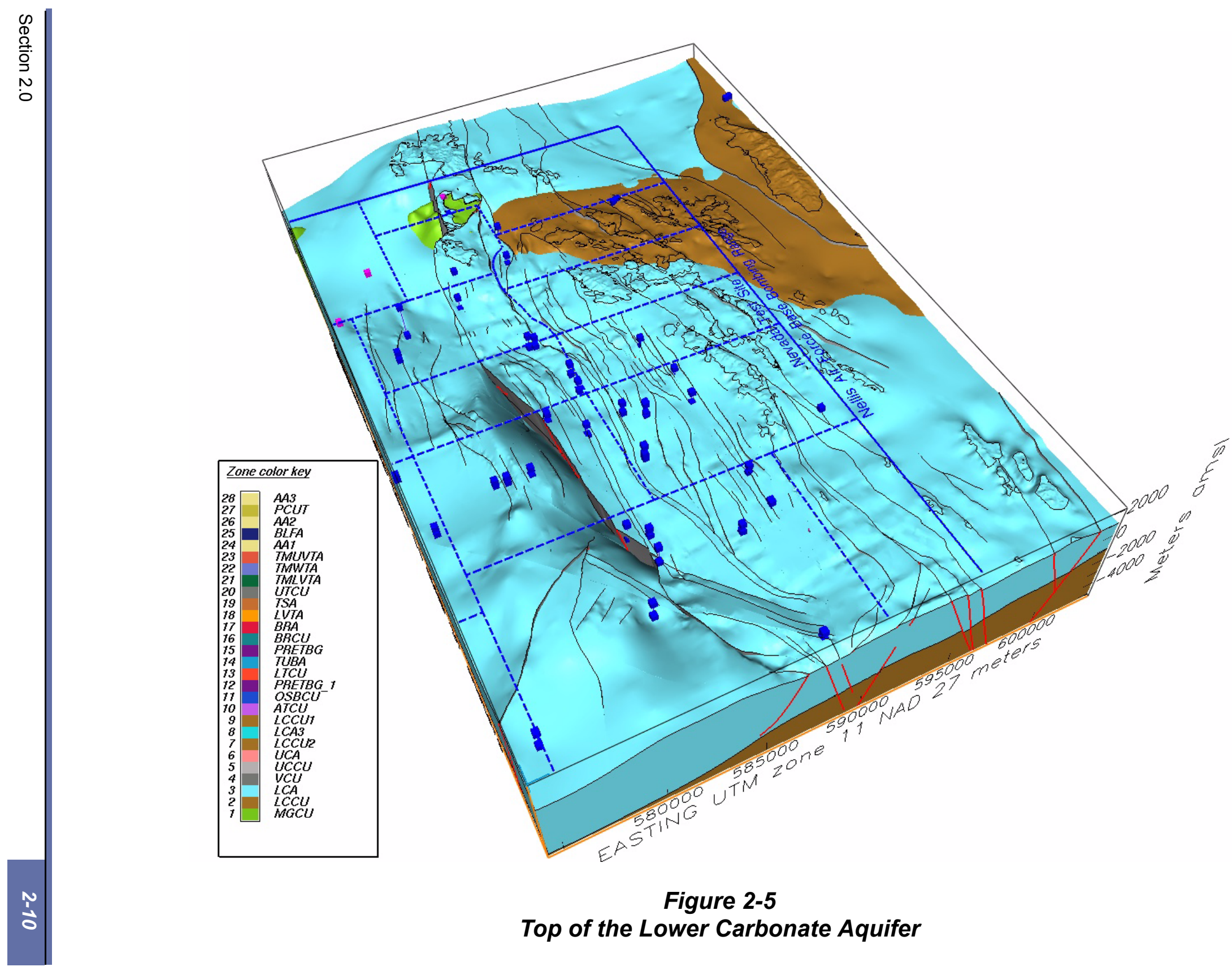

Figure 2-5

Top of the Lower Carbonate Aquifer 
western side of Yucca Flat to some depth below the water table. A wedge of LCA between the Mesozoic granite confining unit (MGCU) and the LCCU may provide a regional pathway into the Yucca Flat basin from the north (Figure 2-5).

The top of the LCCU and MGCU is shown in Figure 2-6. These HSUs are functionally the basement of the flow system, because together they underlie the entire CAU and have very low permeability. The carbonate aquifer thickness is greatly reduced by the instrusive MGCU along the northern border of Yucca Flat (BN, 2006).

\subsection{Regional-Scale Groundwater Flow}

The Death Valley Regional Flow System includes three principal groundwater sub-basins, named for their downgradient discharge areas, as shown in Figure 2-7 (Laczniak et al., 1996). The Yucca Flat/Climax Mine CAU is within the Ash Meadows groundwater sub-basin. The direction of groundwater flow is locally influenced by structural and geologic conditions that affect the distribution and thickness of the LCA through which interbasin groundwater flow occurs. Groundwater elevations decline to the south in successive valleys within the Ash Meadows groundwater sub-basin, indicating that regional flow drains to the south. Groundwater ultimately discharges at Alkali Flat, Ash Meadows and Amargosa Valley areas to the south, and Death Valley to the southwest (Figure 2-7).

The general direction of groundwater flow in the Yucca Flat area of the NTS area is from north to south and east to southwest as indicated in Figure 2-7. Horizontal hydraulic gradients are generally very low to the east and west of the NTS. In other areas, the prevailing flow direction and hydraulic gradients may be locally influenced by the structural position of geologic units with significantly lower permeability than that of the LCA. If the units of low permeability have structural orientations that are perpendicular to flow, large hydraulic gradients may be observed across the units. If their structural orientation is parallel to the prevailing flow direction, the effect may be insignificant. For example, low-permeability sediments along the Funeral Mountains have resulted in a steep hydraulic gradient between Amargosa Desert and Death Valley (Figure 2-7). 

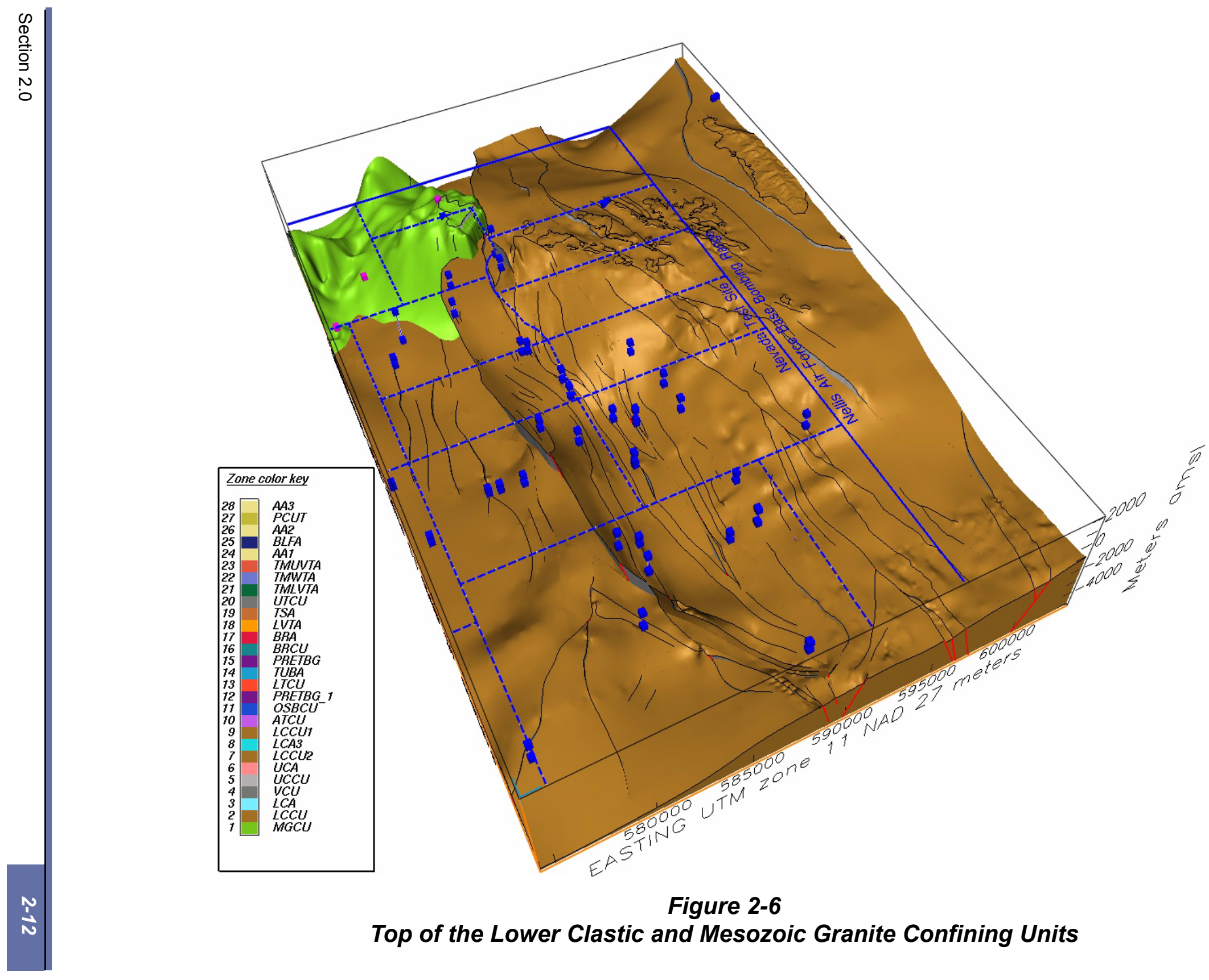

Figure 2-6

Top of the Lower Clastic and Mesozoic Granite Confining Units 

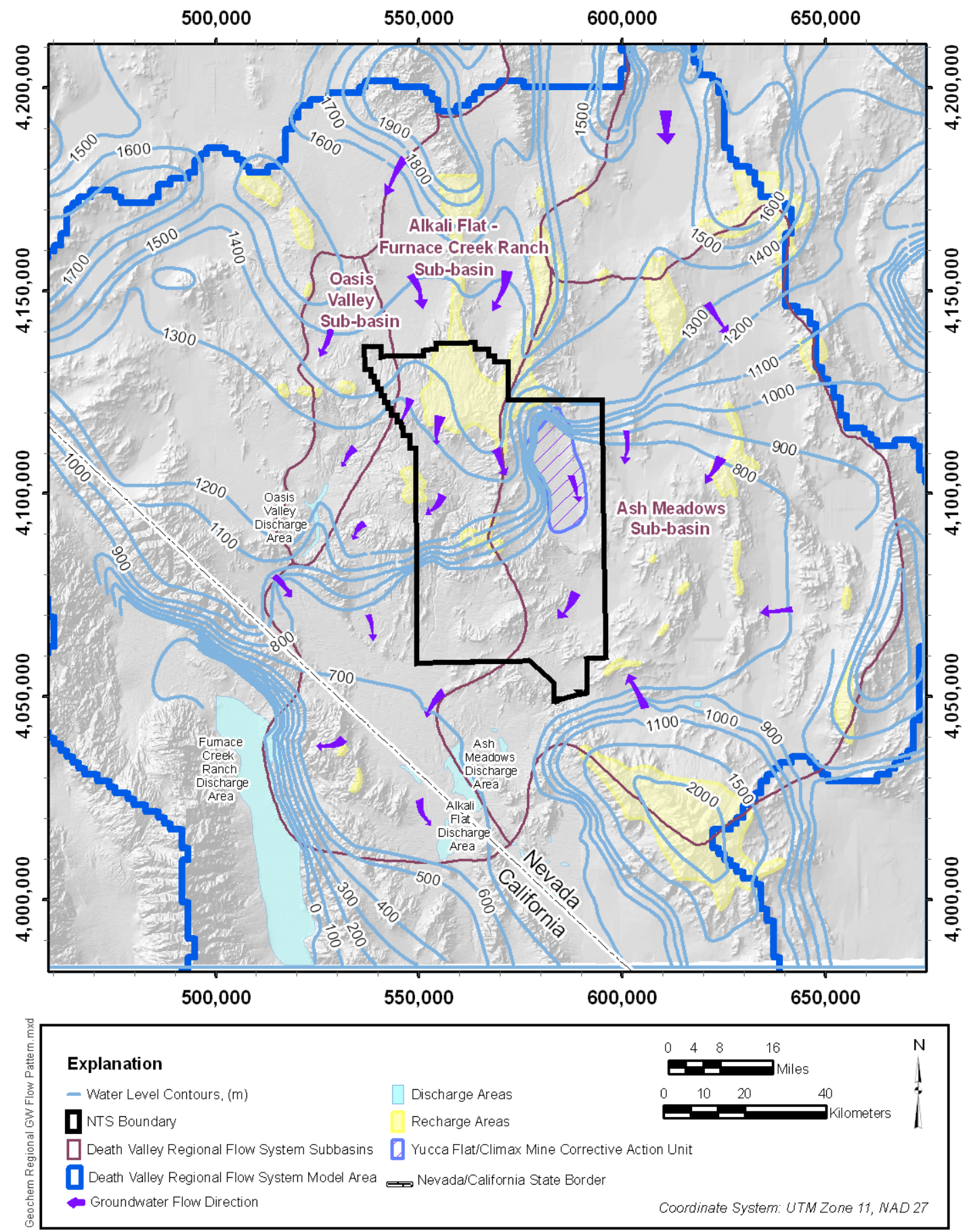

Source: Modified from DOE/NV, 1997 and Laczniak et al., 1996

Figure 2-7

Regional Groundwater Flow Patterns 


\subsection{Groundwater Flow in Yucca Flat}

Regional groundwater elevation contours curve around the west, north, and northeast sides of Yucca Flat, and the gradient of these contours is very steep, reflecting the low transmissivity of connections to the regional system in these areas. The LCA is the only formation that provides a highly transmissive connection with adjoining groundwater basins. However, the LCA is either absent or the thickness is substantially reduced in the areas of steep potentiometric contours. The thickness of the LCA to the north is greatly reduced because of the structurally high position of the MGCU and the LCCU. The LCA pinches out to the northeast as the elevation of the LCCU rises to intersect the water table (Figure 2-3). To the west of Yucca Flat, the LCA is absent throughout the Pahute Mesa volcanic plateau, and the thickness is significantly reduced beneath the bordering Eleana Range. These structural conditions create a hydrologic barrier that results in reduced flow into the Yucca Flat basin.

The local pattern of groundwater flow within Yucca Flat can be inferred from the pre-development LCA groundwater elevation contours shown on Figure 2-8. The two different sets of groundwater contours shown on this map were developed at different scales and are not perfectly coordinated, but indicate the relationship of regional groundwater flow with the local pattern. The LCA groundwater elevation contours within the Yucca Flat basin form a "trough" with the axis running north-south along the center of the basin, and the trough opening to the south. The configuration is consistent with the steep regional water-level contours surrounding Yucca Flat shown on Figure 2-8. The groundwater elevation contours reflect a steep gradient toward the axis of the trough and low gradient southward along the axis of the trough, suggesting lateral flow toward the center of the basin and drainage south from the central basin. The trough alignment is similar to the generalized alignment of the dominant faults, and is consistent with the interpretation of faults as high-conductivity paths for groundwater flow parallel to the fault orientation, with a southerly flow component along each fault.

\subsubsection{Groundwater Elevations in the Yucca Flat Area}

The water table in the Yucca Flat basin is relatively deep, ranging from about $153 \mathrm{~m}$ (elevation $1,199 \mathrm{~m}$ above mean sea level [amsl]) in extreme western Yucca Flat to more than $580 \mathrm{~m}$ (elevation 734 amsl) in north-central Yucca Flat. Throughout much of Yucca Flat, the water table is located within the lower part of the volcanic section in volcanic confining units. In the deeper structural 


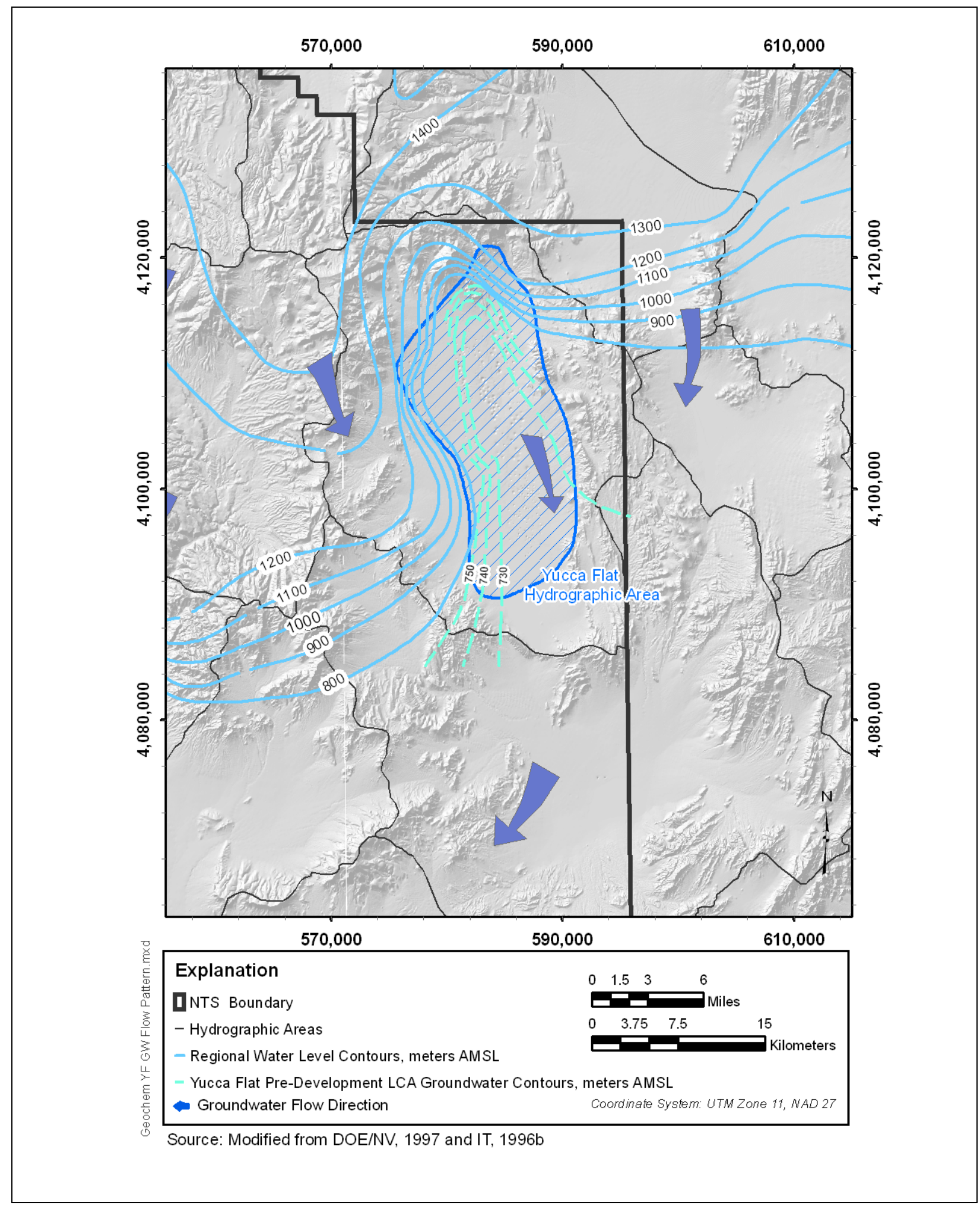

Figure 2-8

Yucca Flat Groundwater Flow Patterns 
sub-basins within Yucca Flat, the water table can be present in volcanic aquifer units and the lower portions of the alluvium (Figure 2-3). The water table is within carbonates and other "basement" rocks around the perimeter of the basin. Water-table elevations are greater than $1,311 \mathrm{~m}$ amsl immediately north, northeast, and west of Yucca Flat compared to elevations less than $738 \mathrm{~m}$ amsl within Yucca Flat proper, reflecting the steep gradients previously noted (Figure 2-8).

Within Yucca Flat, LCA head elevations vary from approximately $736 \mathrm{~m}$ amsl at the northern end (UE-10j) to approximately $726 \mathrm{~m}$ amsl at the southern end at Water Well-C (Fenelon, 2005).

Anomalously high potentiometric head measurements in parts of central Yucca Flat (e.g., within the Tuff Pile area in Areas 3, 4 and 7) are thought to be the result of over-pressurization of the saturated zeolitized tuffs, resulting in increased head with depth (Hawkins et al., 1989; Hale et al., 1995). This phenomenon is believed to be caused by the underground nuclear tests that were conducted in this area.

Water-levels measured in wells completed in the alluvial aquifer and volcanic units in the eastern two-thirds of Yucca Flat are typically about $20 \mathrm{~m}$ higher than in wells completed in the LCA (Winograd and Thordarson, 1975; IT, 1996a and b). The hydrogeology of the HSU structure suggests that the higher elevation of the water table is the result of low-permeability zeolitized tuff confining units overlying the LCA that restricts downward flow to the LCA. The semi-perched water within the alluvial and volcanic aquifers may also move downward to the LCA along one or more of the basin-forming faults in the central portion of the valley.

\subsection{Stable Isotope Patterns in the Regional Lower Carbonate Aquifer}

Stable isotope ( $\delta \mathrm{D}$ and $\left.\delta^{18} \mathrm{O}\right)$ variations in LCA groundwater on a regional scale (Figures 2-9 and 2-10) provide a simple means of identifying potential hydraulic connections between Yucca Flat and the larger regional flow system. Davisson et al. (1999) noted that regional groundwater $\delta^{18} \mathrm{O}$ and $\delta \mathrm{D}$ values show a systematic increase with decreasing latitude in Nevada (between approximately $39^{\circ}$ and $36^{\circ} \mathrm{N}$ ). This pattern almost certainly reflects the higher elevations and cooler mean annual temperatures in central Nevada relative to southern Nevada, but may also reflect regional flow paths along the north-south trending basins in this region. 


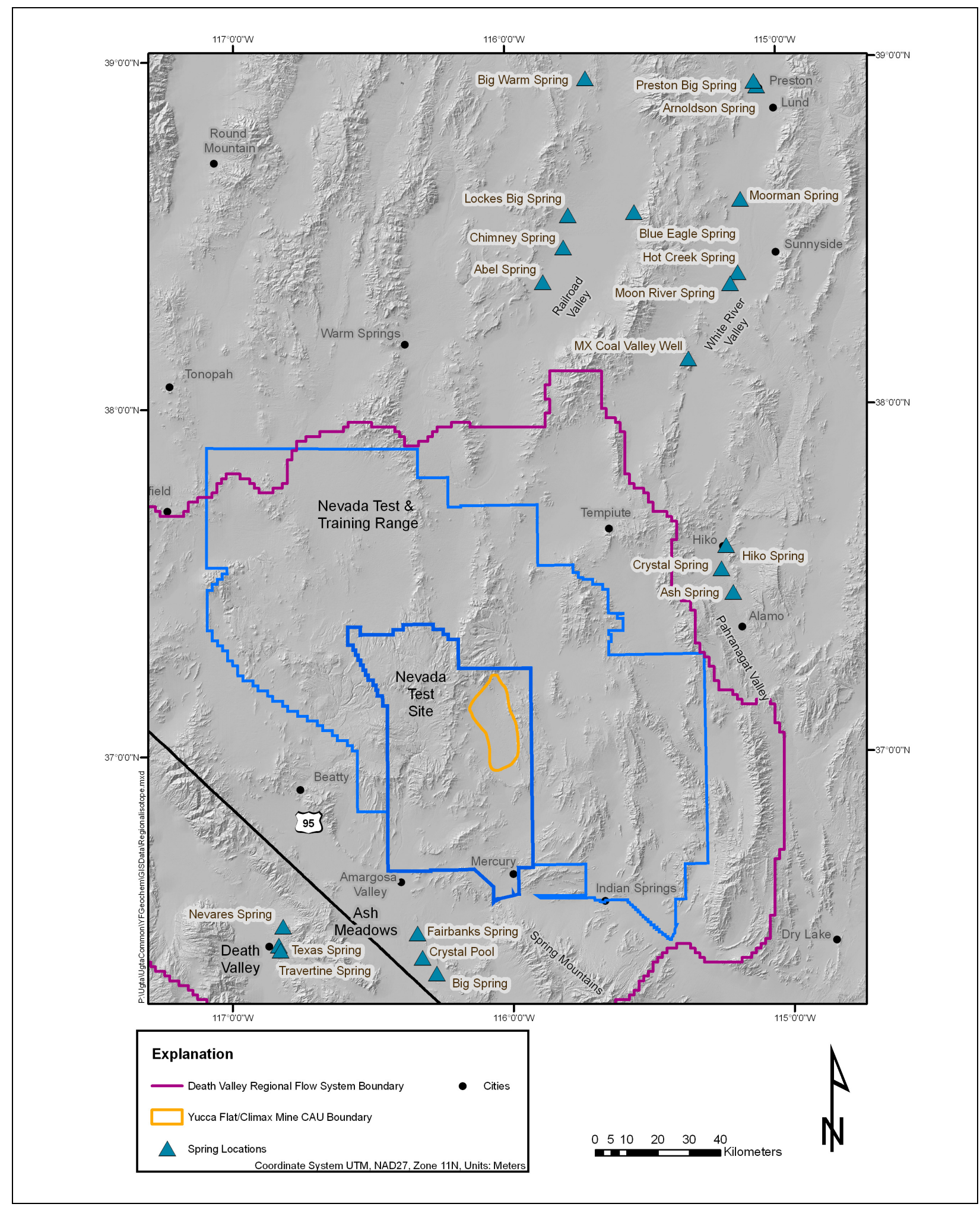

Figure 2-9

Locations of Regional Carbonate Springs 


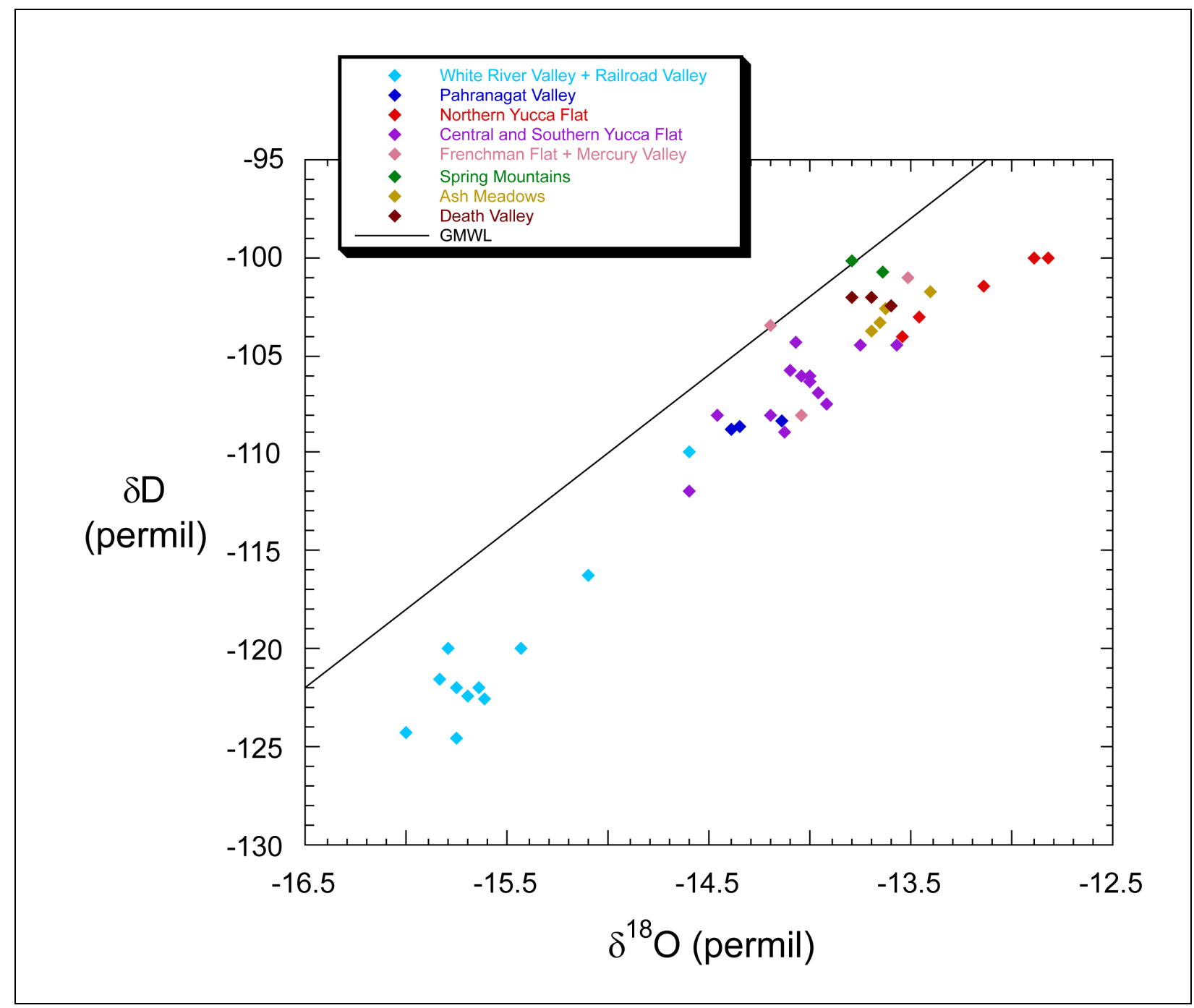

Figure 2-10

Plot of $\delta D$ Versus $\delta^{18} O$ Values for Groundwater Samples from the Regional Carbonate Aquifer System in East-Central Nevada, Southern Nevada, and Adjacent Parts of Eastern California

The Death Valley Regional Flow System is characterized by carbonate-hosted interbasin flow associated with large regional springs (Figures 2-7 and 2-9) (Winograd and Thordarson, 1975; Harrill et al., 1988; Laczniak et al., 1996). The northern boundary of the Death Valley flow system is at approximately $38^{\circ}$ north latitude, but the extent of flow across this boundary from the adjacent White River Valley and Railroad Valley regional flow systems remains poorly constrained (Figure 2-9). The regional carbonate aquifers north and northeast of the NTS are represented by samples from the White River Valley, Railroad Valley, and Pahranagat Valley (Figure 2-9). Most of the White River Valley and Railroad Valley samples are from warm springs located north of about 
$38^{\circ} 20^{\prime} \mathrm{N}$ latitude with one exception. These samples have stable isotope values that are distinctly lower than LCA groundwater from NTS wells. The exception is a sample from the U.S. Geological Survey (USGS)-MX Coal Valley Well in the White River flow system $(\delta \mathrm{D}=-109$ permil; $\delta^{18} \mathrm{O}=-14.6$ permil), which overlaps with the lowest (most depleted) stable isotope values in central Yucca Flat. The Coal Valley Well is the only carbonate aquifer groundwater sample available between latitudes $38^{\circ} 20^{\prime} \mathrm{N}$ and $37^{\circ} 30^{\prime} \mathrm{N}$ in the White River and Railroad Valleys (Figure 2-9). It is likely that the small number of data points with $\delta \mathrm{D}$ values between -110 and -120 permil in Figure 2-10 reflects the paucity of sample locations at this latitude.

The Pahranagat Valley springs are at the southern end of this “sample gap" (latitude 37³0'N, within the White River flow system) and have stable isotope values that overlap with the LCA samples from central and southern Yucca Flat (Figure 2-10). This similarly in composition led Winograd and Friedman (1972) to propose a hydrologic connection between Pahranagat Valley and the eastern NTS. Although more than 30 years have elapsed since this study was conducted, there is still a lack of “intermediate" sampling locations between Pahranagat Valley and the eastern NTS to test this hypothesis. The available stable isotope data are consistent with this flow path. However, it must be emphasized that overlapping stable isotope values do not necessarily indicate that two different waters have the same source.

The regional carbonate aquifers south and southwest of the NTS are represented by the Ash Meadows and Death Valley samples in Figure 2-10. There has been considerable discussion regarding the origin of groundwater discharge at Ash Meadows. Models calibrated using $\delta \mathrm{D}$ values show that Ash Meadows discharge can be modeled as a two component mixture of groundwater derived from Pahranagat Valley (35 to 40 percent) and the Spring Mountains (60 to 65 percent) (Winograd and Friedman, 1972; Thomas et al., 1996). This model suggests that approximately 35 to 40 percent of the spring flow at Ash Meadows may pass beneath the eastern part of the NTS. Although potentiometric data for the LCA are consistent with this interpretation, these flow paths are of such a broad, regional extent that other mixing models may be equally plausible.

Particle-tracking calculations using the UGTA regional flow model predict groundwater in southern Yucca Flat and Frenchman Flat moves southwestward beneath Rock Valley and eastern Jackass Flats to discharge areas in the Amargosa Desert and Death Valley (DOE, 1997; p. 7-96). The model does 
not predict discharge at Ash Meadows. Note that the Ash Meadows and Death Valley springs have very similar stable isotopic compositions (Figure 2-10), and although the Death Valley springs contain more sodium $(\mathrm{Na})$, chloride $(\mathrm{Cl})$, and sulfate $\left(\mathrm{SO}_{4}\right)$ than Ash Meadows (Winograd and Thordarson, 1975), the data do not rule out the possibility that groundwater from the eastern NTS may contribute to the discharge at one or both locations. The absence of intermediate sample locations to understand the chemical evolution of the water along the flow path precludes the development of reliable geochemical models for these regional flow paths. 


\subsection{Yucca flat/Climax Mine Geochemistry Data}

Geochemical evaluation of groundwater within the Yucca Flat/Climax Stock CAU was initiated with a rigorous attempt to capture all available groundwater chemistry data for this investigation area (Figure 3-1). Major-ion chemistry, environmental isotopes, field measured parameters ( $\mathrm{pH}$ and water temperature), and a selected set of trace element and radionuclide data were compiled from the comprehensive water-quality database (Geochem04.mdb); published reports; and unpublished data from Desert Research Institute (DRI), Lawrence Livermore National sLaboratory (LLNL), and USGS laboratory files. Representative data for each well and spring were then selected from this dataset for use in the geochemical models. An overview of the groundwater geochemical data used for this investigation, along with the mineralogy data used for the PHREEQC and NETPATH geochemical models, are presented in this section.

\subsection{Data Compilation and Selection of Representative Data for Geochemical Evaluations}

Data compilation was initiated with a search of Geochem04.mdb using the geographical coordinates illustrated in Figure 1-2. The resulting dataset was then supplemented with additional data obtained following the release of Geochem $04 . \mathrm{mdb}$ as well as additional historical data not present within the database. The well and spring locations, along with the ranges in sample collection dates for the geochemical dataset, are shown in Table 3-1. Groundwater data included in this study represent a time period from the late 1950s to the present, and in many cases (approximately 25 percent of the sampling locations), data for a given well or spring are limited to samples collected more than 20 years ago (Table 3-1). The collection dates for well samples were compared to the well construction dates (Fenelon, 2005) to ensure that sample collection was not during well development, when drilling fluids or cement contamination could occur, and that samples were assigned to the proper formation access interval. This was particularly important for those wells where multiple completion intervals were sampled over time. 
Table 3-1

Sampling Locations, Collection Dates, and Hydrostratigraphic Units

(Page 1 of 5)

\begin{tabular}{|c|c|c|c|c|c|c|c|}
\hline Site Identification & $\begin{array}{c}\text { Abbreviated } \\
\text { Name }\end{array}$ & $\begin{array}{c}\text { UTM } \\
\text { Northing }\end{array}$ & $\begin{array}{c}\text { UTM } \\
\text { Easting }\end{array}$ & $\begin{array}{c}\text { Sample } \\
\text { Collection Dates } \\
\text { (Range) }\end{array}$ & Primary HSUa & $\begin{array}{c}\text { Secondary } \\
\text { HSUb }\end{array}$ & $\begin{array}{c}\text { HSU } \\
\text { Groupc }\end{array}$ \\
\hline Adaven Spring & AdSp & 4221912 & 622569 & $2 / 1997$ & PS & & PS \\
\hline Alum Spring & AISp & 4144504 & 617948 & $5 / 1985$ & PS & & PS \\
\hline April Fool Spring & AFSp & 4155011 & 611444 & $5 / 1985-12 / 1991$ & PS & & PS \\
\hline Army \#1 Water Well & Army-1 & 4049800 & 586120 & $7 / 1962-1 / 2004$ & LCA & & LCA \\
\hline Ash Springs & Ash & 4147634 & 659924 & 5/1966-8/1995 & LCA & & LCA \\
\hline Bullwhack Spring & BwSp & 4150389 & 609341 & $5 / 1985$ & PS & & PS \\
\hline Cane Spring, FF & Cane & 4072861 & 580291 & 1/1981-12/1986 & PS & & PS \\
\hline Cane Spring, GR & CSpG & 4133211 & 610975 & 3/1958-11/1990 & PS & & PS \\
\hline Captain Jack Spring & Cap'n Jack & 4114105 & 574672 & $5 / 1959-6 / 1982$ & PS & & PS \\
\hline Carpenter Spring & CpSp & 4212061 & 621473 & $7 / 1985$ & PS & & PS \\
\hline Cattle Spring & CtSp & 4141531 & 610494 & $5 / 1985$ & PS & & PS \\
\hline Cliff Spring, BR & CfSpB & 4150554 & 581021 & $7 / 2000$ & PS & & PS \\
\hline Cliff Spring, GR & CfSpG & 4142246 & 611103 & 5/1985-8/1992 & PS & & PS \\
\hline Cow Camp Spring & CwSp & 4049813 & 651446 & $10 / 1981-5 / 1983$ & PS & & PS \\
\hline Cresent Spring & CcSp & 4163104 & 638877 & $12 / 1991$ & PS & & PS \\
\hline Crystal Spring & Crystal & 4154692 & 656350 & $4 / 1963-6 / 2003$ & LCA & & LCA \\
\hline De Jesus Spring & DJSp & 4081683 & 626635 & $5 / 1987-12 / 2000$ & PS & & PS \\
\hline Desert Dry Lake Well \#1 & DDL-1 & 4090984 & 660489 & $3 / 1987-5 / 1992$ & AA & & AA \\
\hline ER-12-1 & $12-1$ & 4115493 & 572411 & $4 / 2003-12 / 2004$ & UCCU/LCA3 & & $\mathrm{CCU}$ \\
\hline ER-12-2 & $12-2$ & 4114057 & 577902 & $3 / 2003-4 / 2003$ & UCCU & & $\mathrm{CCU}$ \\
\hline ER-19-1 & $19-1$ & 4114743 & 567542 & $7 / 1996$ & UCCU & & $\mathrm{CCU}$ \\
\hline ER-2-1 & $2-1$ & 4108978 & 583334 & $9 / 2003$ & LTCU & TM-LVTA & VCU \\
\hline ER-3-1 & $3-1$ & 4097339 & 594658 & $4 / 1995-10 / 1996$ & LCA & & LCA \\
\hline ER-5-3 & $5-3$ & 4081118 & 594654 & $2 / 2000-3 / 2001$ & AA/TM-WTA & & VA \\
\hline ER-5-3 \#2 & $5-3 \# 2$ & 4081120 & 594624 & $4 / 2001-5 / 2001$ & LCA & & LCA \\
\hline ER-5-4 & $5-4$ & 4075696 & 592449 & $7 / 2001$ & AA & TM-WTA & AA \\
\hline ER-5-4 \#2 & $5-4 \# 2$ & 4075665 & 592450 & $10 / 2002-11 / 2002$ & LTCU & & VCU \\
\hline ER-6-1 & $6-1$ & 4093419 & 589633 & $10 / 1992-1 / 2004$ & LCA & & LCA \\
\hline ER-6-1 \#2 & $6-1 \# 2$ & 4093357 & 589616 & $1 / 2003-7 / 2004$ & LCA & & LCA \\
\hline ER-6-2 & $6-2$ & 4090745 & 582236 & $7 / 2004-8 / 2004$ & LCA3 & UCCU & LCA \\
\hline ER-7-1 & $7-1$ & 4103275 & 589315 & $7 / 2003$ & LCA & & LCA \\
\hline Hagestad \#1 & Hag & 4116260 & 569542 & 9/1957-12/1958 & LTCU & LCCU1 & VCU \\
\hline Hiko Spring & Hiko & 4162541 & 657633 & 3/1962-8/1995 & LCA & & LCA \\
\hline
\end{tabular}


Table 3-1

Sampling Locations, Collection Dates, and Hydrostratigraphic Units

(Page 2 of 5)

\begin{tabular}{|c|c|c|c|c|c|c|c|}
\hline Site Identification & $\begin{array}{c}\text { Abbreviated } \\
\text { Name }\end{array}$ & $\begin{array}{c}\text { UTM } \\
\text { Northing }\end{array}$ & $\begin{array}{c}\text { UTM } \\
\text { Easting }\end{array}$ & $\begin{array}{c}\text { Sample } \\
\text { Collection Dates } \\
\text { (Range) }\end{array}$ & Primary HSUa & $\begin{array}{c}\text { Secondary } \\
\text { HSU }^{b}\end{array}$ & $\begin{array}{l}\text { HSU } \\
\text { Groupc }\end{array}$ \\
\hline Tndian Spring, BR & ISpB & 4144071 & 579554 & $7 / 2000$ & PS & & PS \\
\hline Marble \#3 & ME-3 & 4120543 & 582855 & $7 / 1959$ & MGCU & & GCU \\
\hline Miner Spring & MiSp & 4131727 & 607795 & $5 / 1985$ & PS & & PS \\
\hline Naquinta Spring & $\mathrm{NaSp}$ & 4146558 & 610798 & $5 / 1985$ & PS & & PS \\
\hline Oak Spring & OakSp & 4121889 & 583030 & 4/1958-4/1982 & PS & & PS \\
\hline Old Tikaboo Spring & OTSp & 4154882 & 610934 & $5 / 1985$ & PS & & PS \\
\hline Penoyer Well & $\mathrm{PnW}$ & 4167459 & 606154 & $2 / 1997$ & AA & & AA \\
\hline Pine Spring & PSp & 4145008 & 610075 & $5 / 1985$ & PS & & PS \\
\hline Pluto 1 & Pto-1 & 4075338 & 579238 & $11 / 1984$ & VCU & & VCU \\
\hline Pluto 5 & Pto-5 & 4074977 & 579263 & 9/1988 & VCU & & VCU \\
\hline Reveille Spring & $\operatorname{ReSp}$ & 4209449 & 573014 & $4 / 1998$ & PS & & PS \\
\hline Rock Spring & RkSp & 4143332 & 615929 & $5 / 1985$ & PS & & PS \\
\hline Rose Bud Spring & RsSp & 4151828 & 608393 & $5 / 1985$ & PS & & PS \\
\hline Sand Spring, PW & SdPW & 4177341 & 609870 & $5 / 1987-12 / 2000$ & PS & & PS \\
\hline Sand Spring, SSV & SdSp & 4177341 & 609870 & $12 / 1991$ & $\overline{A A}$ & & $\mathrm{AA}$ \\
\hline Savio Spring & SvSp & 4150374 & 614822 & $5 / 1985$ & PS & & PS \\
\hline Sharp Spring & SpSp & 4153958 & 610699 & $5 / 1985$ & PS & & PS \\
\hline Spring Above Adaven & SpaAd & 4221481 & 622750 & $7 / 1985$ & PS & & PS \\
\hline Spring at Reville & RvSp & 4209451 & 573135 & $8 / 1967$ & PS & & PS \\
\hline Test Well \#7 (HTH) & TW-7 & 4102301 & 585901 & $2 / 1958$ & LTCU & & VCU \\
\hline The Seeps Spring & Seeps & 4177724 & 625902 & $1 / 1985$ & PS & & PS \\
\hline
\end{tabular}


Table 3-1

Sampling Locations, Collection Dates, and Hydrostratigraphic Units

(Page 3 of 5)

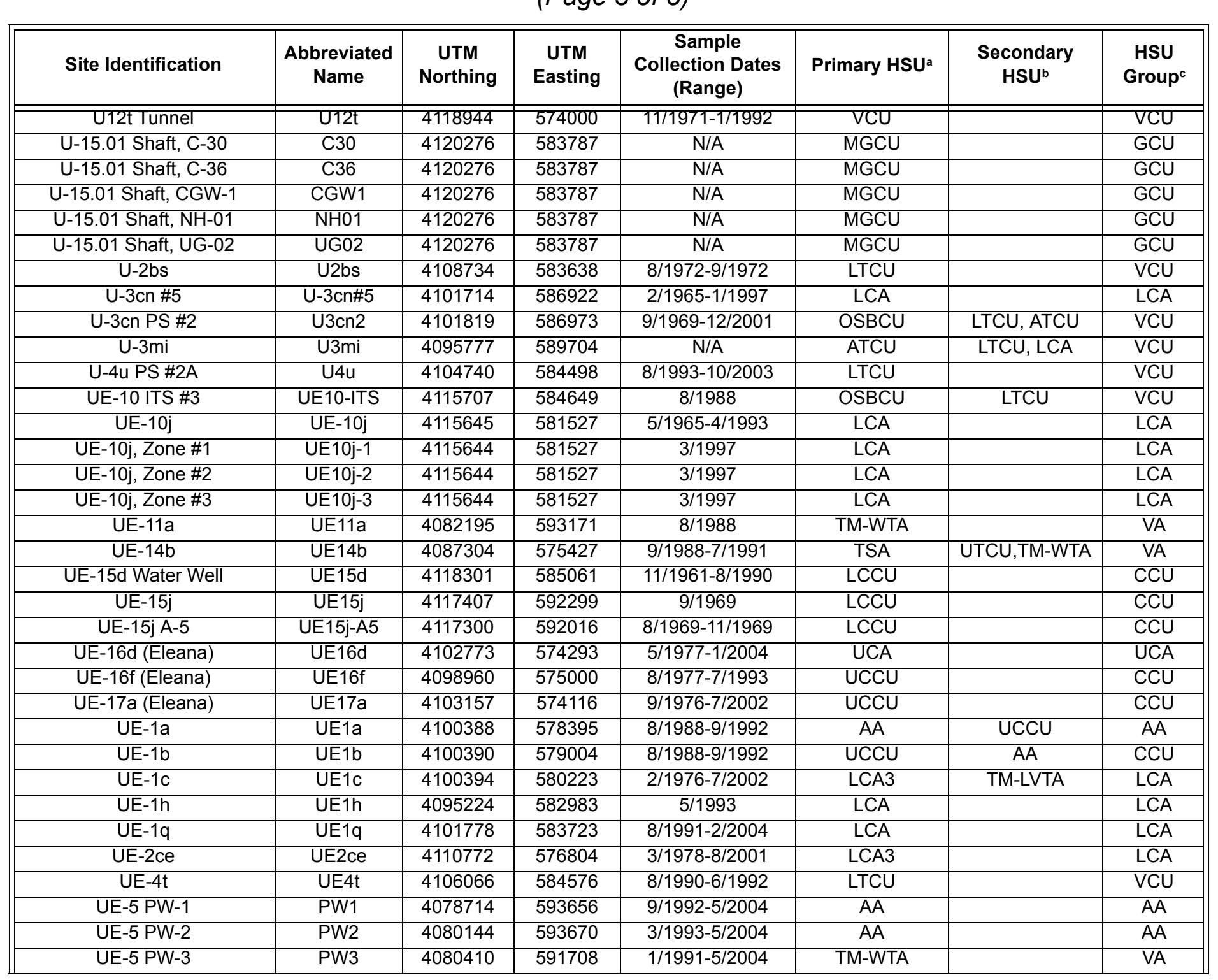


Table 3-1

Sampling Locations, Collection Dates, and Hydrostratigraphic Units

(Page 4 of 5)

\begin{tabular}{|c|c|c|c|c|c|c|c|}
\hline Site Identification & $\begin{array}{c}\text { Abbreviated } \\
\text { Name }\end{array}$ & $\begin{array}{c}\text { UTM } \\
\text { Northing }\end{array}$ & $\begin{array}{c}\text { UTM } \\
\text { Easting }\end{array}$ & $\begin{array}{c}\text { Sample } \\
\text { Collection Dates } \\
\text { (Range) }\end{array}$ & Primary HSUa & $\begin{array}{c}\text { Secondary } \\
\text { HSU }^{b}\end{array}$ & $\begin{array}{l}\text { HSU } \\
\text { Groupc }\end{array}$ \\
\hline UE-5c Water Well & UE5C & 4077008 & 590969 & 3/1971-1/2003 & AA/LTCU & & AA/VA \\
\hline UE-5n & UE5n & 4075285 & 592626 & 6/1986-4/2001 & $\mathrm{AA}$ & & $\mathrm{AA}$ \\
\hline UE-6d & UE6d & 4093397 & 583751 & $6 / 1986$ & YL-PLAYA & TM-LVTA & AA \\
\hline UE-7nS & UE7nS & 4106091 & 588643 & $7 / 1977-4 / 2004$ & LCA & & LCA \\
\hline USGS HTH \#1 & HTH-1 & 4112499 & 569000 & $6 / 1965-3 / 2003$ & PBRCM & & VA \\
\hline USGS HTH \#10 & HTH-10 & 4049903 & 602667 & 2/1963-6/1964 & LCA & & LCA \\
\hline USGS HTH \#3 & HTH-3 & 4074016 & 601932 & 5/1962-6/1990 & LCA & & LCA \\
\hline USGS HTH \#4 & $\mathrm{HTH}-4$ & 4049447 & 607761 & 9/1962 & LCA & & LCA \\
\hline USGS HTH E & HTH-E & 4101336 & 589362 & $7 / 1991$ & LCA & & LCA \\
\hline USGS HTH F & HTH-F & 4068348 & 578858 & $5 / 1961-3 / 1980$ & LCA & & LCA \\
\hline USGS Test Well B & TW-B & 4092816 & 587780 & 1/1963-6/1993 & TSA & & VA \\
\hline USGS Test Well D & TW-D & 4103327 & 582224 & $1 / 1960-2 / 2004$ & LCA & ATCU & LCA \\
\hline USGS Water Well A & WW-A & 4099194 & 585714 & $9 / 1960-2 / 2004$ & AA & & $\mathrm{AA}$ \\
\hline USGS Water Well C & WW-C & 4086125 & 588215 & 9/1961-12/1992 & LCA & & LCA \\
\hline USGS-MX Coal Valley Well & MX-CV & 4222202 & 645602 & $1 / 1981-6 / 2003$ & LCA & & LCA \\
\hline Water Well 1 & WW1 & 4074404 & 597790 & $4 / 1966$ & $\mathrm{AA}$ & & $\mathrm{AA}$ \\
\hline Water Well 2 & WW2 & 4113500 & 581006 & $4 / 1962-2 / 2004$ & LCA & & LCA \\
\hline Water Well 4 & WW4 & 4084571 & 586952 & $9 / 1983-1 / 2004$ & TM-WTA & & VA \\
\hline Water Well 4A & WW4a & 4084373 & 586648 & $4 / 1992-1 / 2004$ & TM-WTA & & VA \\
\hline Water Well 5A & WW5a & 4070380 & 592978 & $4 / 1957-8 / 2000$ & AA & & AA \\
\hline Water Well 5B & WW5b & 4073119 & 591978 & $4 / 1957-2 / 2004$ & $\mathrm{AA}$ & & $\mathrm{AA}$ \\
\hline Water Well 5C & WW5c & 4071749 & 592478 & $4 / 1957-2 / 2004$ & $\mathrm{AA}$ & & $\overline{A A}$ \\
\hline Water Well C-1 & WW-C1 & 4086103 & 588236 & $10 / 1962-1 / 2004$ & LCA & & LCA \\
\hline Watertown 1 & WT-1 & 4122437 & 605605 & 9/1957-8/1995 & TUBA & & VA \\
\hline Watertown 2 & WT-2 & 4122445 & 606421 & 9/1957-9/1969 & TUBA & & VA \\
\hline Watertown 3 & WT-3 & 4124241 & 603382 & 11/1959-8/1995 & $\overline{A A}$ & & $\overline{\mathrm{AA}}$ \\
\hline Watertown 4 & WT-4 & 4124102 & 603063 & 9/1969-8/1995 & $\mathrm{AA}$ & LTCU & $\mathrm{AA}$ \\
\hline Well 3 Water Well & WW3 & 4094555 & 583828 & 4/1957-4/1969 & $\overline{A A}$ & & $\overline{A A}$ \\
\hline Wheelbarrow Spring & WbSp & 4148448 & 579961 & $7 / 2000$ & PS & & PS \\
\hline White Rock Spring, SR & WRS-S & 4063757 & 657303 & 10/1981-5/1983 & PS & & PS \\
\hline Whiterock Spring, YF & WRSp & 4117508 & 577146 & $3 / 1958-12 / 1986$ & PS & & PS \\
\hline Wiregrass Spring & WgSp & 4055487 & 660210 & 11/1966-12/1988 & PS & & PS \\
\hline
\end{tabular}


Table 3-1

Sampling Locations, Collection Dates, and Hydrostratigraphic Units

(Page 5 of 5)

\begin{tabular}{|c|c|c|c|c|c|c|c|}
\hline Site Identification & $\begin{array}{c}\text { Abbreviated } \\
\text { Name }\end{array}$ & $\begin{array}{c}\text { UTM } \\
\text { Northing }\end{array}$ & $\begin{array}{c}\text { UTM } \\
\text { Easting }\end{array}$ & $\begin{array}{c}\text { Sample } \\
\text { Collection Dates } \\
\text { (Range) }\end{array}$ & $\begin{array}{c}\text { Primary HSUa } \\
\text { (Recondary } \\
\text { HSUb }\end{array}$ & $\begin{array}{c}\text { HSU } \\
\text { Groupc }\end{array}$ \\
\hline
\end{tabular}

aPrimary HSU = Hydrostratigraphic unit that comprises the largest section of the well's open completion interval.

bSecondary HSU = Hydrostratigraphic unit that comprises the second largest section of the well's open completion interval.

cHSU Group = Hydrostratigraphic unit group used within the report for evaluation and illustrative purposes.

$\mathrm{AA}=$ Alluvial aquifer

ATCU = Argillic tuff confining unit

$\mathrm{BR}=$ Belted Range

$\mathrm{CCU}=$ Clastic confining unit

$\mathrm{FF}=$ Frenchman Flat

$\mathrm{HSU}=$ Hydrostratigraphic unit

GCU $=$ Granite confining unit

$\mathrm{GR}=$ Groom Range

LCCU $=$ Lower clastic confining unit

$\mathrm{LCA}=$ Lower carbonate aquifer

LCA3 = Lower carbonate aquifer - Yucca Flat upper plate

LTCU = Lower tuff confining unit

MGCU - Mesozoic granite confining unit

$\mathrm{N} / \mathrm{A}=$ Not available

OSBCU = Oak Spring Butte confining unit

PBRCM = Pre-Belted Range composite unit

\author{
PS $=$ Perched spring \\ PW = Pintwater Range \\ $\mathrm{SR}=$ Sheep Range \\ SSV $=$ Sand Spring Valley \\ TM-WTA = Timber Mountain-welded tuff aquifer \\ TSA = Topopah Spring aquifer \\ TUBA = Tub Spring aquifer \\ UCA = Upper carbonate aquifer \\ UCCU = Upper clastic confining unit \\ UTCU = Upper tuff confining unit \\ UTM = Universal Transverse Mercator \\ $\mathrm{VA}=$ Volcanic aquifer \\ VCU = Volcanic confining unit \\ YF = Yucca Flat \\ YL-Playa $=$ Yucca Lake Playa
}


Mean values and standard deviations (Std. Devs.) were calculated for each chemical parameter for each well and spring location. The dataset was then inspected for the presence of outliers that exceeded three Std. Devs. of the mean values. Those values that exceeded these limits were removed from the dataset. The mean values, Std. Devs., and the number of samples are reported in Appendix A.

The HSUs represented by each groundwater sampling location are listed in Table 3-1. Well samples included in the dataset were often collected as composites, either from wells with single completions that transect multiple HSU boundaries, or from wells with multiple completions that were all pumped simultaneously. Many wells draw from a large vertical cross section of saturated media, possibly resulting in homogenization of the water composition within the borehole (Fenelon, 2005). The primary and secondary HSUs are identified in Table 3-1. The primary HSU is the one that reflects the largest effective open interval. The primary HSUs were grouped into a smaller number of categories for the geochemical evaluations and for illustrative purposes (Table 3-1). Abbreviations for each sampling location included in this evaluation are also presented in Table 3-1.

\subsection{Overview of Geochemical Data}

An overview of the geochemical parameters used in this evaluation is provided in this section and includes a discussion of the major-ion data; stable isotopes of oxygen $(\mathrm{O})$, hydrogen $(\mathrm{H})$, and carbon (C); and the radioactive or radiogenic isotopes of $\mathrm{C}, \mathrm{Cl}, \mathrm{Sr}$, and uranium (U). The focus is on geochemical data for the locations within the Yucca Flat geochemistry study area identified in Figures 1-2 and 3-1.

\subsubsection{Major-Ion Chemistry}

The dissolved constituents in groundwater provide a record of the minerals encountered as water moves through geologic materials. Accordingly, major-ion chemistry can be used to characterize the interaction and trace the movement of groundwater through aquifer materials. Evaluation of the major-ion characteristics of groundwater can provide insight on the source areas and flow directions for groundwater movement. 


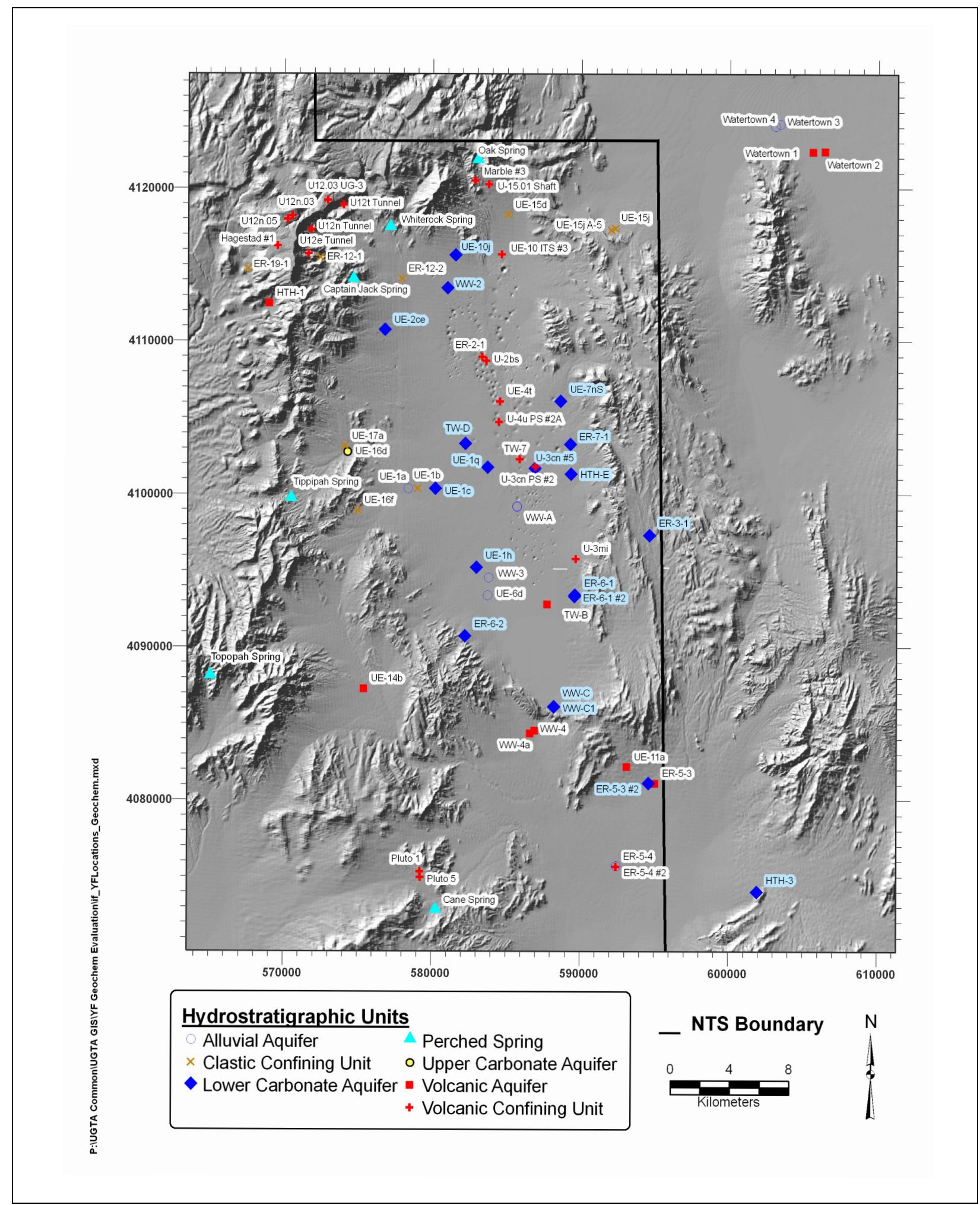

Figure 3-1

Yucca Flat/Climax Mine Geochemistry Study Area 
The major-ion dataset used for this study is presented in Appendix A. Included in this dataset are the mean values, Std. Devs., and number of samples included in the mean calculation. Both field and laboratory measured bicarbonate $\left(\mathrm{HCO}_{3}^{-}\right)$and carbonate $\left(\mathrm{CO}_{3}{ }^{2-}\right)$ concentrations are reported. The charge balance was also calculated as the relative abundance, in equivalents, of cations (sodium $\left[\mathrm{Na}^{+}\right]$, potassium $\left[\mathrm{K}^{+}\right]$, calcium $\left[\mathrm{Ca}^{2+}\right]$, and magnesium $\left.\left[\mathrm{Mg}^{2+}\right]\right)$ and anions $\left(\mathrm{HCO}_{3}^{-}, \mathrm{CO}_{3}{ }^{2-}, \mathrm{SO}_{4}{ }^{2-}\right.$, nitrate $\left[\mathrm{NO}_{3}^{-}\right]$, chloride $\left[\mathrm{Cl}^{-}\right]$, bromide $[\mathrm{Br}-]$, and fluoride $\left.\left[\mathrm{F}^{-}\right]\right)$. The charge balances calculated using both the field and laboratory $\mathrm{HCO}_{3}{ }^{-}$, and $\mathrm{CO}_{3}{ }^{2-}$ values are presented in Appendix A. The field measured values of $\mathrm{HCO}_{3}^{-}, \mathrm{CO}_{3}{ }^{2-}$ and $\mathrm{pH}$ were used for further analyses and geochemical modeling except in those cases where a superior charge balance is observed for the laboratory measured values.

Piper diagrams illustrating the major-ion data for samples collected within the Yucca Flat study area are presented in Figures 3-2 through 3-4. A Piper diagram is a graphical tool used to represent the relative concentrations of major-ions in a sample (Hem, 1985). Ion concentrations are expressed in percent milliequivalents per liter. Piper diagrams can be used to classify groundwaters into distinct hydrochemical water types. Schoff and Moore (1964), Blankennagel and Weir (1973), and Winograd and Thordarson (1975) identified three general water types for the NTS as follows:

- $\mathrm{Na}-\mathrm{K}-\mathrm{HCO}_{3}$ type commonly found in volcanic rock aquifers.

- $\mathrm{Ca}-\mathrm{Mg}-\mathrm{HCO}_{3}$ type commonly occurring in Paleozoic carbonate aquifers.

- $\mathrm{Ca}-\mathrm{Mg}-\mathrm{Na}-\mathrm{HCO}_{3}$ type assumed to be a mixture of the volcanic and carbonate type groundwater.

The source of $\mathrm{Ca}$ and $\mathrm{Mg}$ in the groundwater of carbonate aquifers is dissolution of calcite and dolomite. Groundwater in volcanic HSUs and the alluvial aquifer gains $\mathrm{Na}$ from reaction with volcanic glass and feldspar minerals (White et al., 1980). Bicarbonate is the predominant anionic constituent in the majority of the groundwater and is derived primarily from the dissolution of soil carbon dioxide $\left(\mathrm{CO}_{2}\right)$ gas and reaction with carbonate minerals.

Major-ion data for groundwater samples from the volcanic aquifers (represented by blue symbols) and volcanic confining units (represented by red symbols) are presented in the Piper diagram in Figure 3-2. In addition, this plot includes groundwater samples from the Rainier Mesa tunnels (represented using green symbols) and the Climax Stock (represented using black symbols). The 


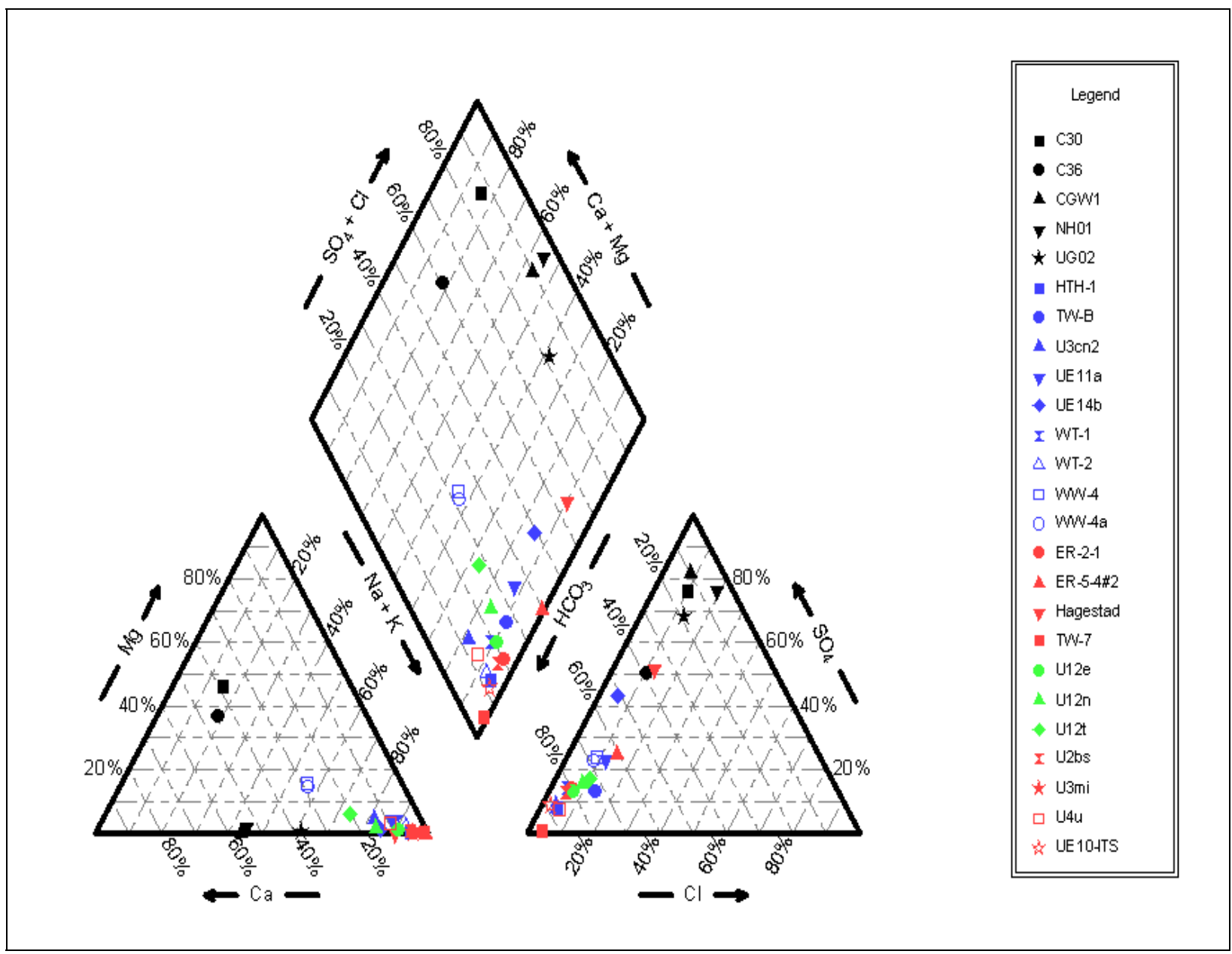

Figure 3-2

Piper Diagram for Groundwater of Volcanic Aquifers and Confining Units

Note: Samples from the Climax Stock, volcanic aquifers, volcanic confining units, and the Rainier Mesa tunnels are represented with black, blue, red, and green symbols, respectively.

majority of these groundwaters are of the $\mathrm{Na}-\mathrm{K}-\mathrm{HCO}_{3}$ type. Sodium is the dominant cation and $\mathrm{HCO}_{3}{ }^{-}$is the dominant anion. The Climax Stock samples are relatively unique when compared to all samples within the study area in that the total solute concentrations are much greater in general (Table 3-4 and Appendix A), and the dominant anion is $\mathrm{SO}_{4}{ }^{2-}$ rather than $\mathrm{HCO}_{3}{ }^{-}$. The high $\mathrm{SO}_{4}{ }^{2-}$ in these samples is inferred to reflect oxidation of the abundant pyrite present along the fractures in the hydrothermally altered granite. One sample from the Climax Stock, C30, is somewhat similar to samples of ER-12-1 groundwater shown in Figure 3-3. The dominant anion and cation in both samples are $\mathrm{SO}_{4}{ }^{2-}\left(343\right.$ milligrams per liter $[\mathrm{mg} / \mathrm{L}]$ in ER-12-1 and $325 \mathrm{mg} / \mathrm{L}$ in C30) and $\mathrm{Ca}^{2+}$ (94 mg/L in ER-12-1 and $126 \mathrm{mg} / \mathrm{L}$ in C30), respectively. The total dissolved solids in the C30 


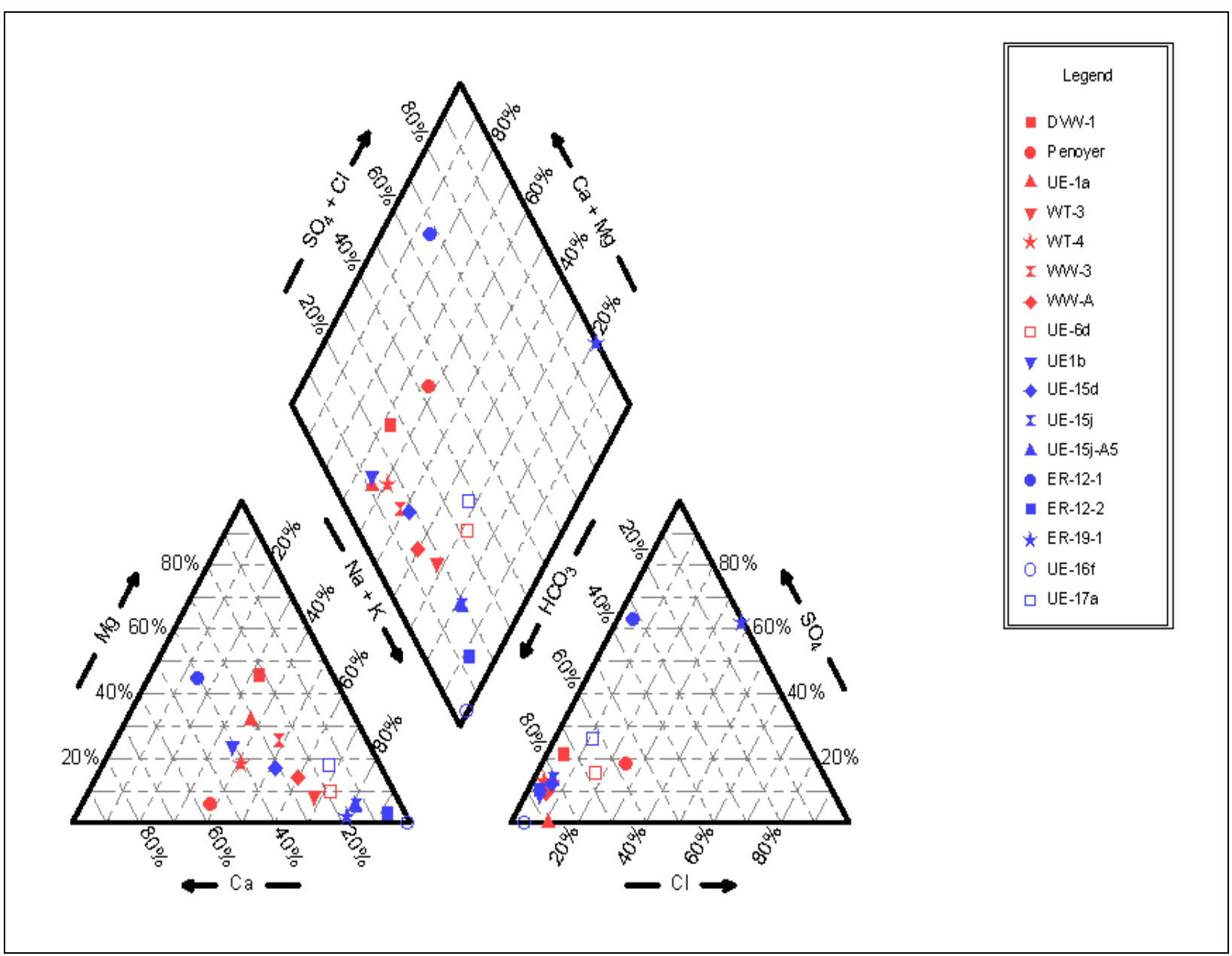

Figure 3-3

Piper Diagram for Groundwater of Alluvial Aquifer and Clastic Confining Units

Note: Samples from the alluvial aquifer and clastic confining units are represented with red and blue symbols, respectively.

sample $(1,150 \mathrm{mg} / \mathrm{L})$ is greater than that of the ER-12-1 sample $(760 \mathrm{mg} / \mathrm{L})$ because of the higher relative concentrations of $\mathrm{So}_{4}{ }^{2-}, \mathrm{Cl}^{-}, \mathrm{Mg}^{2+}, \mathrm{Ca}^{2+}$ and $\mathrm{Na}^{+}$(Appendix A).

A Piper diagram illustrating the major-ion data for the alluvial aquifer (represented by red symbols) and the CCUs (represented by blue symbols) is shown in Figure 3-3. The majority of the groundwaters of the alluvial aquifer are a mixed groundwater type, $\mathrm{Ca}-\mathrm{Mg}-\mathrm{Na}-\mathrm{HCO}_{3}$. Four of the groundwater samples collected from the $\mathrm{CCU}$ are a Na-K-HCO type. Well ER-19-1 groundwater has an anomalously high $\mathrm{pH}(10.7)$, resulting in high concentrations of $\mathrm{CO}_{3}{ }^{2-}$ and no measurable $\mathrm{HCO}_{3}{ }^{-}$. This indicates poor development of this well. Samples collected from ER-19-1 will therefore not be 
considered for further geochemical analyses. Groundwater from Wells UE-15d and UE-1b are mixed-type waters, $\mathrm{Ca}-\mathrm{Mg}-\mathrm{Na}-\mathrm{HCO}_{3}$.

A Piper diagram illustrating the major-ion data for the LCA is shown in Figure 3-4. The groundwater of the LCA ranges from the $\mathrm{Ca}-\mathrm{Mg}-\mathrm{HCO}_{3}$ type (represented by red symbols) to the mixed $\mathrm{Ca}-\mathrm{Mg}-\mathrm{Na}-\mathrm{HCO}_{3}$ type (represented by blue symbols), to the $\mathrm{Na}-\mathrm{K}-\mathrm{HCO}_{3}$ type (represented by black symbols). The majority of LCA groundwater samples included in this study are the mixed type, $\mathrm{Ca}-\mathrm{Mg}-\mathrm{Na}-\mathrm{HCO}_{3}$. Groundwater of the Pahranagat Valley springs (Crystal, Hiko, and Ash springs), all intervals of Well UE-10j, and Army \#1 Water Well are the $\mathrm{Ca}-\mathrm{Mg}-\mathrm{HCO}_{3}$ type. The $\mathrm{Na}-\mathrm{K}-\mathrm{HCO}{ }_{3}$ type groundwaters of Wells UE-1h, Test Well D (TW-D), and UE-7nS could indicate mixing with groundwater of the overlying units, ion-exchange processes, and/or influence by underground testing (in the case of UE-7nS). Piper Diagrams for the perched springs are presented in Section 4.0.

\subsubsection{Stable Isotopes of Oxygen and Hydrogen}

The stable isotopes of hydrogen $\left({ }^{2} \mathrm{H} /{ }^{1} \mathrm{H}\right.$ or $\left.\mathrm{D} /{ }^{1} \mathrm{H}\right)$ and oxygen or $\left({ }^{18} \mathrm{O} /{ }^{16} \mathrm{O}\right)$ are perhaps the most conservative of all environmental tracers because they are intrinsic to the water molecule. In the water cycle, $\mathrm{H}$ and $\mathrm{O}$ isotopes are fractionated (partitioned) between the liquid and vapor phases during evaporation and condensation processes. Once the precipitation has infiltrated to the water table, the stable isotope values are unaffected by water-rock interaction at temperatures below approximately 100 degrees Celsius $\left({ }^{\circ} \mathrm{C}\right)$ (Criss, 1999). These isotopes can be used to trace the groundwater origin and flow path and to quantitatively determine mixing ratios of different water masses.

Isotopic concentrations are reported using delta notation $\left(\delta^{18} \mathrm{O}\right.$ and $\left.\delta \mathrm{D}\right)$ as the measured isotopic ratios of the sample relative to a reference standard. The reference standard for $\delta^{18} \mathrm{O}$ and $\delta \mathrm{D}$ in groundwater is the Vienna Standard Mean Ocean Water (VSMOW). The $\delta$ values are defined in Equations (3-1) and (3-2):

$$
\begin{aligned}
\delta D & =\left[\left({ }^{2} \mathrm{H} /{ }^{1} \mathrm{H}\right)_{\text {sample }} /\left({ }^{2} \mathrm{H} /{ }^{1} \mathrm{H}\right)_{V S M O W}-1.0\right] \cdot 1000 \\
\delta^{18} \mathrm{O} & =\left[\left({ }^{18} \mathrm{O} /{ }^{16} \mathrm{O}\right)_{\text {sample }}\left({ }^{18} \mathrm{O} /{ }^{16} \mathrm{O}\right)_{\text {VSMOW }}-1.0\right] \cdot 1000
\end{aligned}
$$




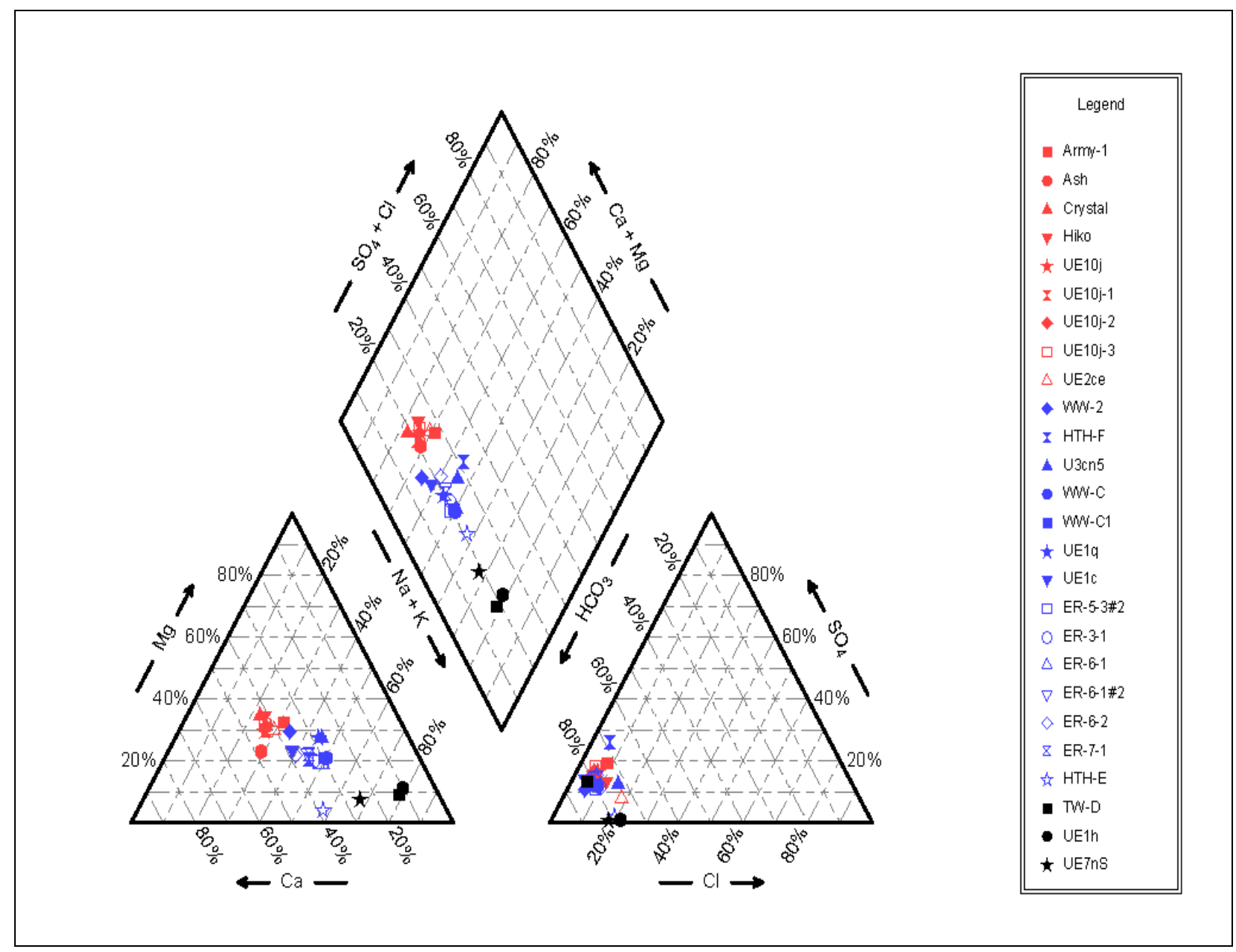

Figure 3-4

Piper Diagram for Groundwater of the Lower Carbonate Aquifer

Note: Samples that are the $\mathrm{Ca}-\mathrm{Mg}-\mathrm{HCO}, \mathrm{Ca}-\mathrm{Mg}-\mathrm{Na}-\mathrm{HCO}_{3}$, and the $\mathrm{Na}-\mathrm{K}-\mathrm{HCO}_{3}$ type are represented by red, blue, and black symbols, respectively.

and are expressed in units of parts per thousand, or permil. The mean $\delta^{18} \mathrm{O}$ and $\delta \mathrm{D}$ values used for this study are presented in Appendix A along with the Std. Devs. and number of samples represented in the mean. The analytical precision of $\delta \mathrm{D}$ and $\delta^{18} \mathrm{O}$ measurements is typically \pm 1 permil and \pm 0.1 permil, respectively. The spatial distributions of $\delta^{18} \mathrm{O}$ and $\delta \mathrm{D}$ values within the study area are shown in Figure 3-5. The $\delta \mathrm{D}$ and $\delta^{18} \mathrm{O}$ values associated with groundwater samples of the LCA are highlighted in blue to easily distinguish them from the other HSUs.

Groundwater in different geographic areas of the Yucca Flat basin show subtle differences in their isotopic composition. For instance, the lowest LCA $\delta \mathrm{D}$ and $\delta^{18} \mathrm{O}$ values tend to occur in the east-southeast part of the flow system (ER-3-1, ER-5-3\#2, WW-C and C1, HTH-E) or in the center of 


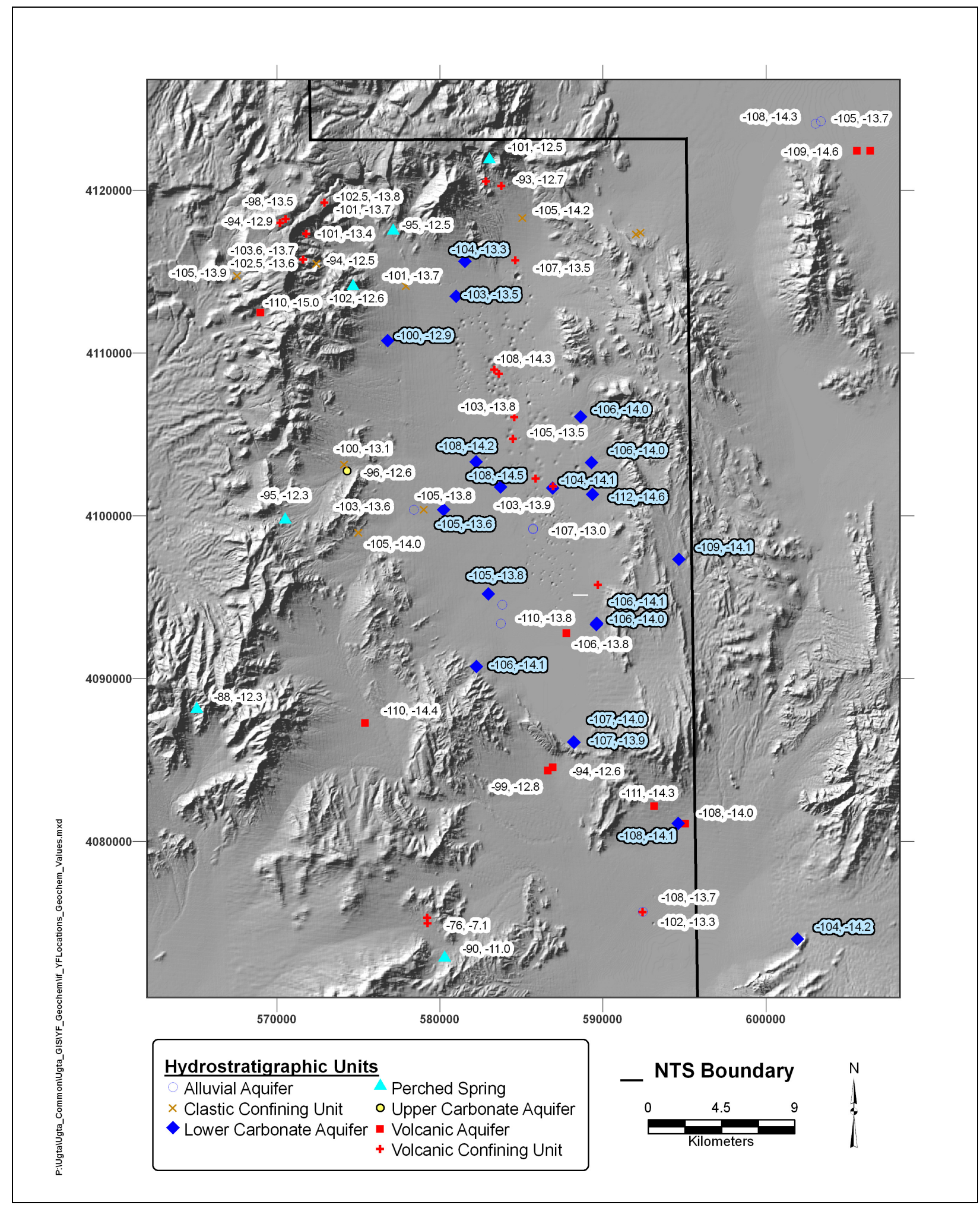

Figure 3-5

Average $\delta \boldsymbol{D}$ and $\delta^{18} \mathrm{O}$ Values for Groundwater and Springs Within the Yucca Flat/Climax Mine Geochemistry Study Area 
the basin (TW-D, UE-1q). These values range from -109 to -106 permil $\delta \mathrm{D}$ and -14.5 to -13.9 permil $\delta^{18} \mathrm{O}$. Somewhat higher values of $\delta \mathrm{D}$ and $\delta^{18} \mathrm{O}$ are observed in LCA groundwaters in other parts of the basin (Figure 3-5), which may reflect mixing with local recharge or with groundwater from the overlying volcanic units. The $\delta \mathrm{D}$ and $\delta^{18} \mathrm{O}$ values for the groundwater in the westernmost part of the basin (e.g. Wells UE-16d, UE-17a, and UE-1a) range from -103 to -96 permil $\delta \mathrm{D}$ and -13.6 to -12.6 permil $\delta^{18} \mathrm{O}$. The higher $\delta \mathrm{D}$ and $\delta^{18} \mathrm{O}$ values for these waters are consistent with a larger component of local recharge. The $\delta \mathrm{D}$ and $\delta^{18} \mathrm{O}$ composition of recharge to the Yucca Flat basin is discussed in Section 4.0.

In general, the major Yucca Flat HSUs have non-unique overlapping $\delta \mathrm{D}$ and $\delta^{18} \mathrm{O}$ values. This compositional overlap is a reflection of common source areas for groundwater recharge as well as mixing of the water masses present in the different HSUs. Detailed analyses of the $\delta \mathrm{D}$ and $\delta^{18} \mathrm{O}$ compositions of groundwater within the study area are described in the subsequent modeling sections.

\subsubsection{Carbon Isotopes}

Naturally occurring carbon isotopes of interest to this study include ${ }^{13} \mathrm{C}$ and ${ }^{14} \mathrm{C}$. Carbon-13 is used to help interpret the mineral sources and water-rock interactions that have affected the dissolved inorganic carbon (DIC) in groundwater, whereas the decrease in ${ }^{14} \mathrm{C}$ along a flow path from radioactive decay can be used to estimate groundwater travel times and velocities in an aquifer (Clark and Fritz, 1997). Carbon-13 abundances are expressed as $\delta^{13} \mathrm{C}$, the ${ }^{13} \mathrm{C} /{ }^{12} \mathrm{C}$ ratio in the sample relative to that in the standard, Pee Dee Belemnite (PDB). Groundwater $\delta^{13} \mathrm{C}$ data are reported as differences in permil relative to PDB. The analytical precision of $\delta^{13} \mathrm{C}$ measurements is typically \pm 0.3 permil. The average $\delta^{13} \mathrm{C}$ and ${ }^{14} \mathrm{C}$ data used for this study are presented in Appendix A. Groundwater $\delta^{13} \mathrm{C}$ data as a function of the inverse alkalinity and also in map view are presented in Figures 3-6 and 3-7, respectively.

Groundwaters (as well as pedogenic carbonates) initially have $\delta^{13} \mathrm{C}$ values that reflect soil gas compositions because most of the carbon initially in groundwater is derived by dissolving $\mathrm{CO}_{2}$ respired by plants in the soil zone. In the Great Basin, soil zone $\mathrm{CO}_{2}$ has $\delta^{13} \mathrm{C}$ values that decrease from about -12 permil at a $900 \mathrm{~m}$ elevation to about -20 permil at 2,700 m elevation for reasons related to plant type and density and moisture availability (Quade et al., 1989). Soil water and pedogenic carbonates precipitated from infiltrating water have $\delta^{13} \mathrm{C}$ values that are about 8 and 9 


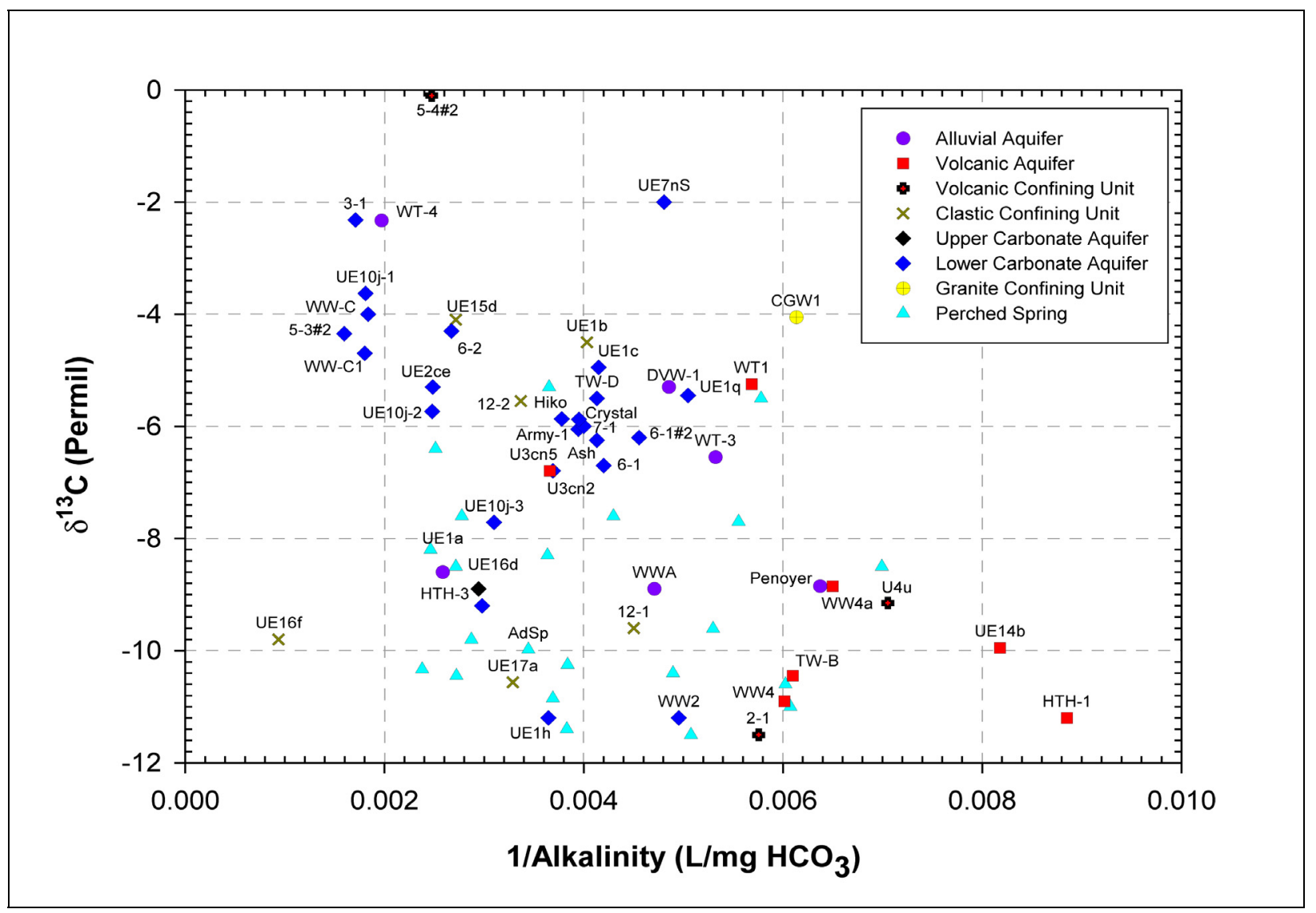

Figure 3-6

$\delta^{13} \mathrm{C}$ Versus Inverse Alkalinity of Groundwater and Springs in the Yucca Flat Area

permil heavier, respectively, than the soil zone $\mathrm{CO}_{2}$ because of equilibrium isotopic fractionation of carbon between the gas, liquid and solid phases (Clark and Fritz, 1997). At the average elevation of Rainier Mesa (approximately 2,300 m), the expected $\delta^{13} \mathrm{C}$ of soil zone $\mathrm{CO}_{2}$, soil water and pedogenic carbonate would be about -18, -10, and -7.6 permil based on these relationships (Quade et al., 1989). Less than complete equilibrium fractionation between soil gas and water, as might occur when rapid infiltration and recharge to the water table takes place, would result in slightly lighter $\delta^{13} \mathrm{C}$ values for the recharge water than those estimated from assumed isotopic equilibrium. Indeed, several springs and groundwaters in the Yucca Flat area have $\delta^{13} \mathrm{C}$ values that are between -10 and -12 permil (Figure 3-6). In the case of $\mathrm{HTH}-1$, this may reflect lighter soil zone $\delta^{13} \mathrm{C}$ from greater plant density and different plant types present under the cooler, wetter climatic conditions. 
Samples from volcanic and alluvial units

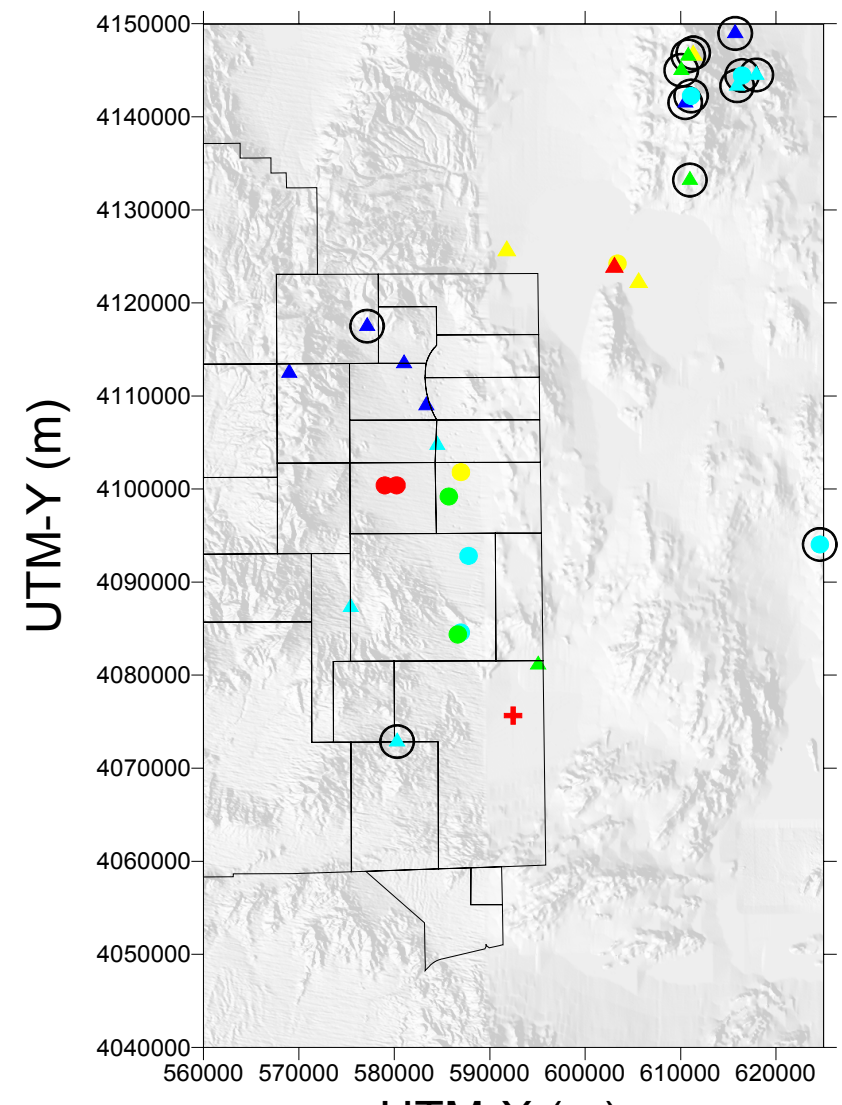

UTM-X (m)

\section{Samples from carbonate and clastic units}

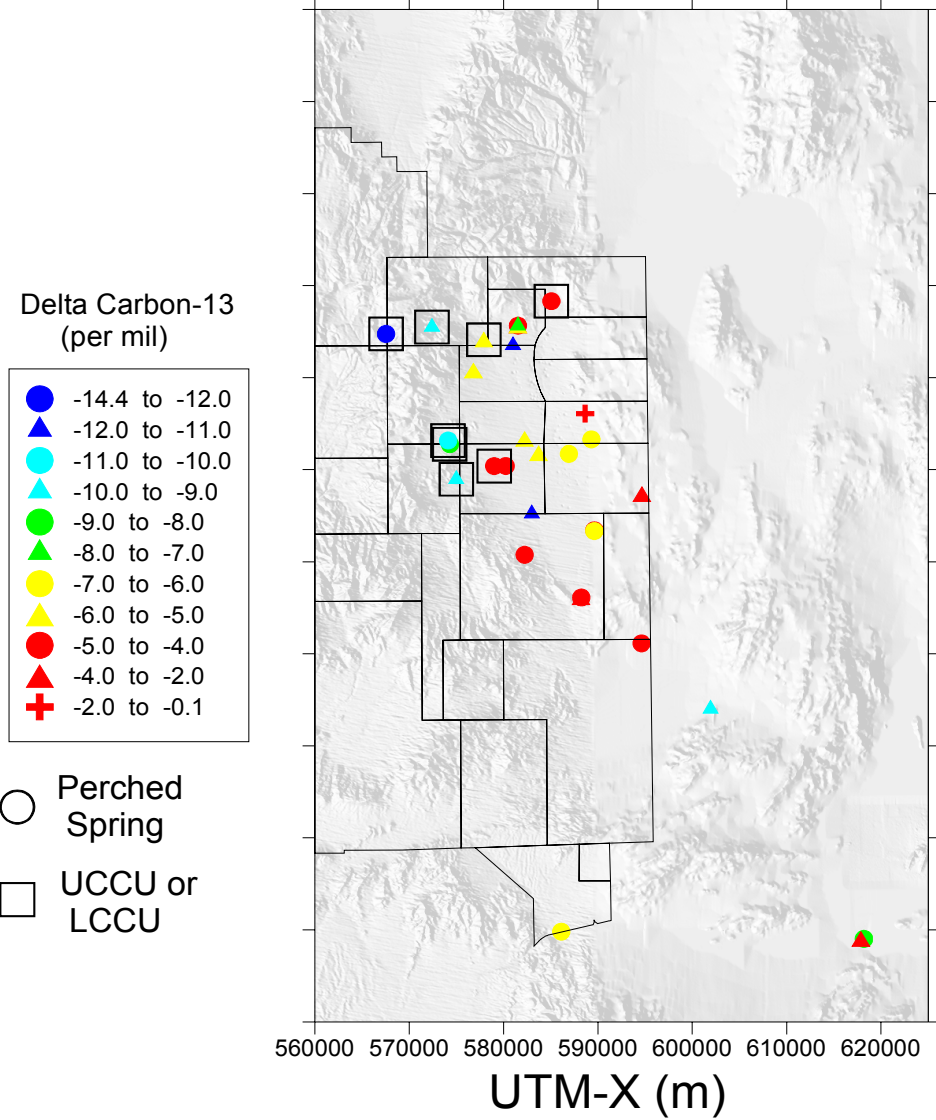

$\operatorname{UTM}-X(\mathrm{~m})$

Figure 3-7

Groundwater $\delta^{13} \mathrm{C}$ in (a) Volcanic and Alluvial HSUs and Perched Springs and (b) Clastic Confining Units and the LCA 
Once groundwater is isolated from soil zone $\mathrm{CO}_{2}$, its $\delta^{13} \mathrm{C}$ is unmodified unless it interacts with carbon-bearing minerals. In this case, the groundwater DIC can be modified through dissolution reactions such as:

$$
\mathrm{CaCO}_{3}+\mathrm{CO}_{2}(\mathrm{aq})+\mathrm{H}_{2} \mathrm{O} \rightarrow \mathrm{Ca}^{2+}+2 \mathrm{HCO}_{3}^{-}
$$

in the case of calcite $\left(\mathrm{CaCO}_{3}\right)$ dissolution. Note that the groundwater DIC includes the contributions from $\mathrm{CO}_{2}(\mathrm{aq}), \mathrm{HCO}_{3}{ }^{-}$and $\mathrm{CO}_{3}{ }^{2-}$ species, whose relative importance shifts as a function of $\mathrm{pH}$. In this case, the isotopically light carbon associated with the dissolved $\mathrm{CO}_{2}$ is mixed with the (usually) heavier carbon associated with calcite, so that the $\delta^{13} \mathrm{C}$ of the DIC in the groundwater is now intermediate between the $\mathrm{CO}_{2}$ and the calcite.

When dolomite $\left[\mathrm{CaMg}\left(\mathrm{CO}_{3}\right)_{2}\right]$ is present, the dissolution of dolomite by calcite-saturated groundwater can occur, with calcite precipitating as the dolomite dissolves (Clark and Fritz, 1997):

$$
\mathrm{CaMg}\left(\mathrm{CO}_{3}\right)_{2}+\mathrm{H}_{2} \mathrm{O} \rightarrow \mathrm{Mg}^{2+}+\mathrm{HCO}_{3}^{-}+\mathrm{CaCO}_{3}+\mathrm{OH}^{-}
$$

In this case, the precipitation of calcite leaves the $\delta^{13} \mathrm{C}$ of the groundwater relatively unchanged, whereas the dissolution of dolomite adds carbon with a $\delta^{13} \mathrm{C}$ of approximately 0 permil (as described below). The $\delta^{13} \mathrm{C}$ of the calcite reflects the groundwater DIC that precipitated it. The presence of calcite fracture coatings in the largely dolomitic formations that constitute the LCA, and the near-saturation of LCA groundwaters with respect to calcite, lend support to the idea that this reaction occurs. In Yucca Flat, the occurrence of some combination of the reactions given in Equations (3-3) and (3-4) is also indicated by greater $\delta^{13} \mathrm{C}$ and alkalinity in LCA groundwater, relative to the groundwater from tuffs or alluvium (Figure 3-6). Only a few of the LCA samples along the northern perimeter of Yucca Flat o(WW-2 and UE-10j-3) have light $\delta^{13} \mathrm{C}$ values indicating that most of the DIC was obtained by interaction with soil zone $\mathrm{CO}_{2}$ (Figure 3-7). In contrast, most of the groundwater from the volcanic and alluvial aquifers, as well as most of the groundwater from the UCCU in the western part of Yucca Flat, have lighter $\delta^{13} \mathrm{C}$ indicating that these groundwaters have had less exposure to isotopically heavier calcite.

Carbon-14 is produced naturally in the upper atmosphere from the bombardment of nitrogen by neutrons generated from cosmic radiation, and more recently, from atmospheric nuclear testing (Clark 
and Fritz, 1997). The ${ }^{14} \mathrm{C}$ is rapidly oxidized to ${ }^{14} \mathrm{CO}_{2}$, which is dissolved in the ocean or incorporated into plants during photosynthesis, and returned to the atmosphere during root respiration and by the decay of vegetation. Before atmospheric nuclear tests, the rate of ${ }^{14} \mathrm{C}$ production and its removal from the atmosphere by dissolution in the oceans, terrestrial burial, and radioactive decay were in approximate equilibrium, so atmospheric levels of ${ }^{14} \mathrm{C}$ have varied only slightly over most of the past 30,000 years. This fact, combined with the relatively high solubility of $\mathrm{CO}_{2}$ in groundwater and the long half-life of ${ }^{14} \mathrm{C}\left(5,730\right.$ years), have made ${ }^{14} \mathrm{C}$ a useful tool for dating groundwaters old enough for the ${ }^{14} \mathrm{C}$ to have undergone significant radioactive decay. The ${ }^{14} \mathrm{C}$ activity is reported as percent modern carbon (pmc) where modern carbon activity is defined as the approximate ${ }^{14} \mathrm{C}$ activity of wood grown in 1890 (13.56 disintegrations per minute per gram of carbon), before the dilution of ${ }^{14} \mathrm{C}$ in the atmosphere by burning fossil fuels. However, with the possible exception of groundwater from a few perched springs, and groundwater taken directly from the sites of underground nuclear explosions, most of the groundwater in the Yucca Flat area is old enough that its ${ }^{14} \mathrm{C}$ is unaffected by either industrial activities or atmospheric nuclear testing.

Groundwater ${ }^{14} \mathrm{C}$ data for the Yucca Flat area are shown as a function of the corresponding $\delta^{13} \mathrm{C}$ data in Figure 3-8 and in map view in Figure 3-9. The data in Figure 3-8 indicate that groundwaters from the volcanic rocks and alluvium generally have higher ${ }^{14} \mathrm{C}$ activities and lighter $\delta^{13} \mathrm{C}$ values than groundwaters from corresponding areas in the LCA. The generally lower ${ }^{14} \mathrm{C}$ activities of the LCA groundwaters, along with their heavier $\delta^{13} \mathrm{C}$ values and higher alkalinities (Figure 3-6), support the interpretation that the LCA groundwaters have interacted to a greater extent with isotopically heavy, ${ }^{14} \mathrm{C}$-free, carbonate minerals than the groundwater from the volcanic and alluvial aquifers.

Conversely, groundwater from the UCCU in western Yucca Flat (typified by samples from Wells ER-12-1, UE-17a, and UE-16f) has ${ }^{14} \mathrm{C}$ activities that are as low as those from the LCA but has $\delta^{13} \mathrm{C}$ values that are as light as those from the volcanic and alluvial aquifers. These characteristics suggest that the low ${ }^{14} \mathrm{C}$ activities measured in groundwater from the UCCU in western Yucca Flat are not the result of carbonate mineral dissolution, but instead, these groundwaters are quite old.

An important aspect of interpreting the groundwater ${ }^{14} \mathrm{C}$ data from Yucca Flat involves measuring the isotopic characteristics of carbonate minerals that are present in Yucca Flat. Ideally, if there are large differences in the $\delta^{13} \mathrm{C}$ of $\mathrm{CO}_{2}$ and the dissolving carbonate minerals (and each of these has a 


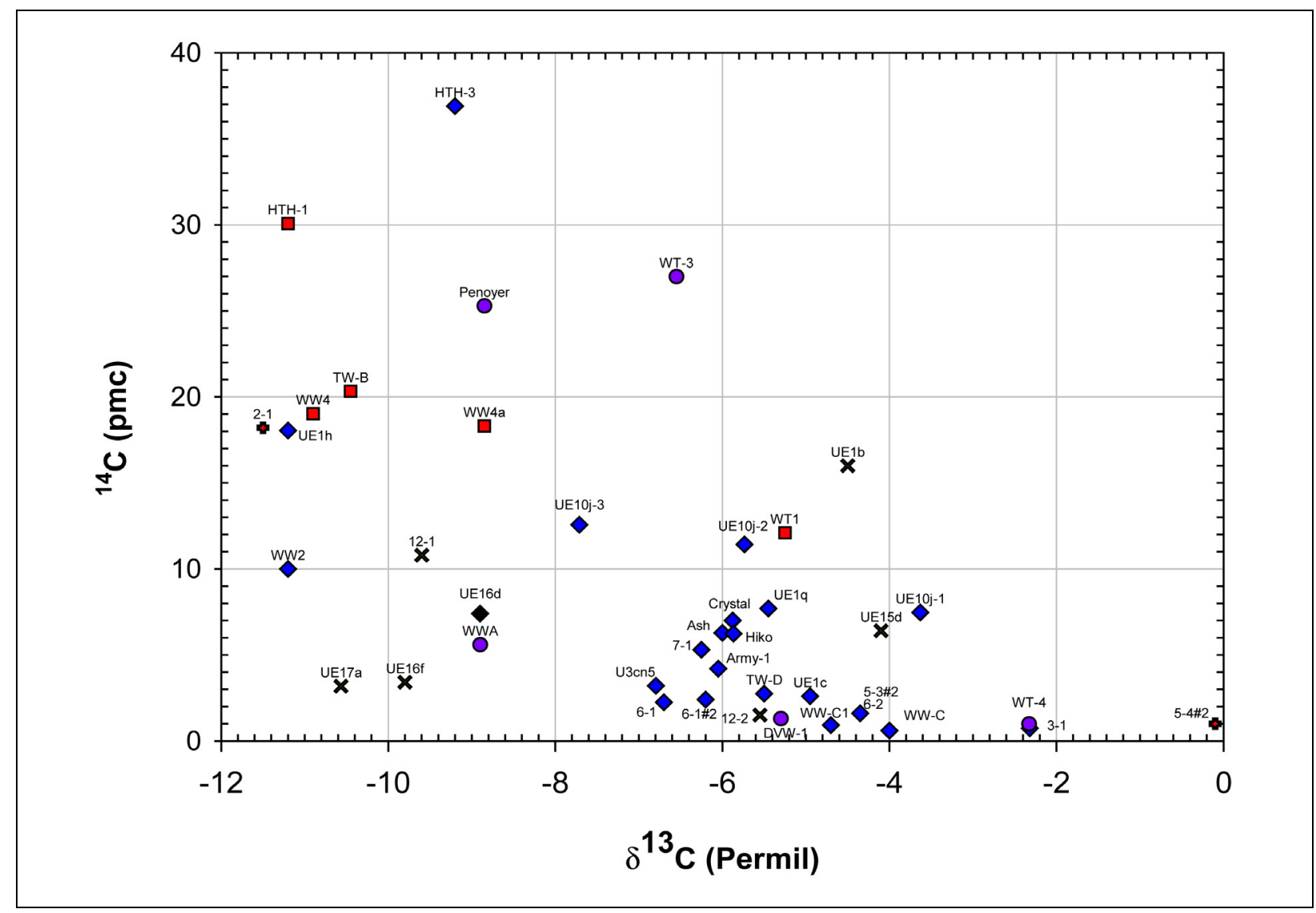

Figure 3-8

Groundwater ${ }^{14} \mathrm{C}$ Versus $\delta^{13} \mathrm{C}$

well-defined range of $\delta^{13} \mathrm{C}$ values), the relative contributions to the groundwater DIC from $\mathrm{CO}_{2}$ and carbonate dissolution are relatively straightforward to estimate. Such would be the case in Yucca Flat if only marine carbonate rock with a relatively narrow range in $\delta^{13} \mathrm{C}$ values $\left(\delta^{13} \mathrm{C}=+0.64 \pm 1.8\right)$ was present (Table 3-2). Unfortunately, the interpretation of groundwater $\delta^{13} \mathrm{C}$ data in Yucca Flat is complicated by the presence of calcite, with intermediate $\delta^{13} \mathrm{C}$ values, that was deposited by past groundwater movement, both as fracture coatings in the tuff confining unit (TCU) and granites $\left(\delta^{13} \mathrm{C}=-2.9 \pm 2.1\right)$, and as matrix crusts in the alluvium $\left(\delta^{13} \mathrm{C}=-3.1 \pm 1.7\right)$ (Table 3-2). As noted by Stoller-Navarro Joint Venture (SNJV) (2004d), the matrix crusts and the fracture coatings in the TCU and granites appear to be derived from downward groundwater movement rather than upward flow from the LCA, based on their light $\delta^{13} \mathrm{C}$ values and groundwater temperatures estimated from the $\delta^{18} \mathrm{O}$ of the calcite. The presence of calcite coatings and crusts with $\delta^{13} \mathrm{C}$ values similar to the present day groundwater makes it more difficult to estimate the impact of water-rock interactions on 


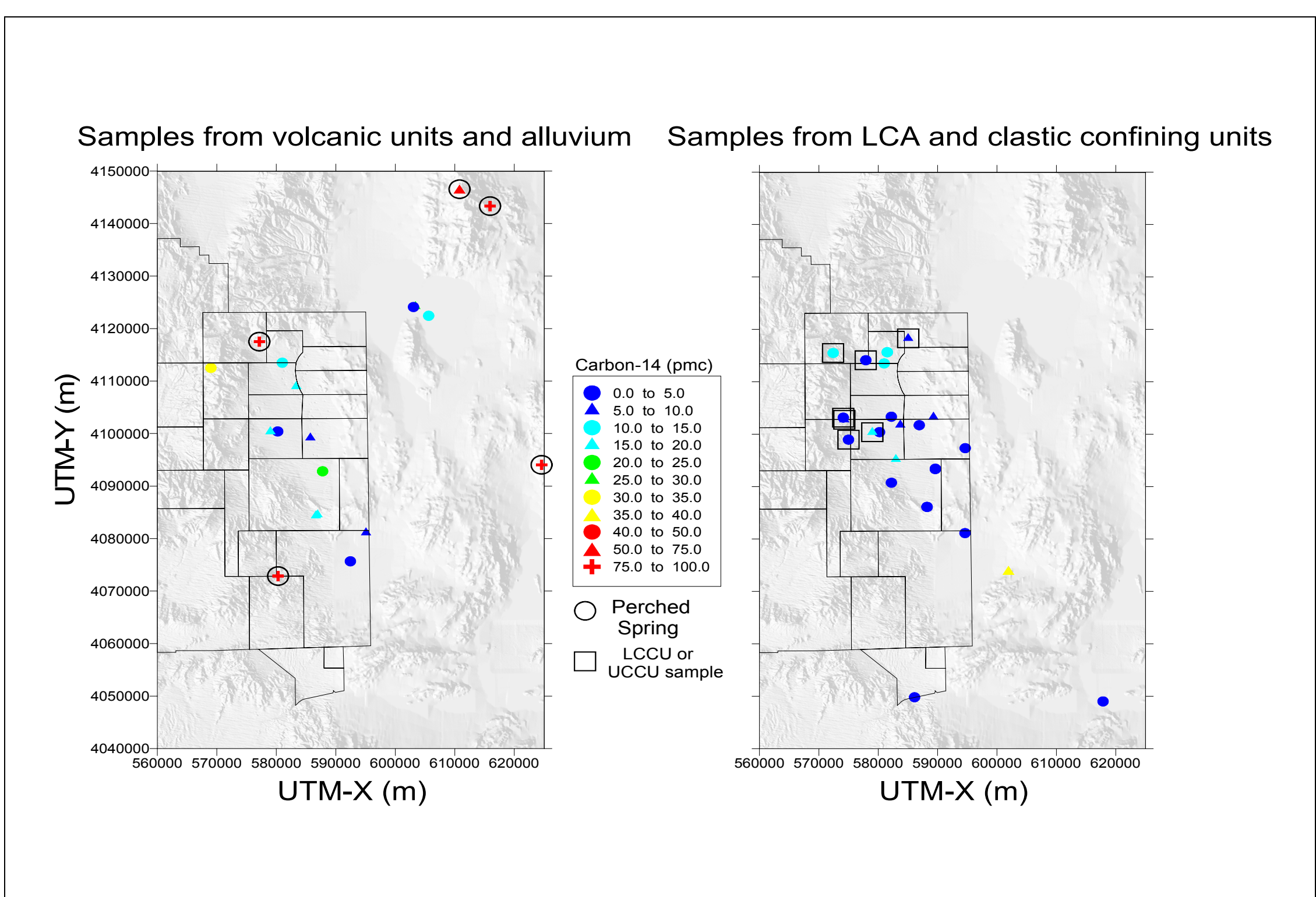

Figure 3-9 
Table 3-2

Carbon Isotope Data for Yucca Flat Carbonates

(Page 1 of 3 )

\begin{tabular}{|c|c|c|}
\hline Sample & Description & $\begin{array}{c}\delta^{13} \mathrm{C} \\
\text { (Permil PDB) }\end{array}$ \\
\hline \multicolumn{3}{|c|}{ Secondary calcite in alluvium; U-1a Complex, Yucca Flat (Rose et al., 2000) } \\
\hline U-1a.01 main drift (4+60) & calcite spar - rind on clast & -3.4 \\
\hline U-1a.01 main drift $(6+00)$ & caliche stringer in matrix & -4.6 \\
\hline U-1a.01 main drift $(7+50)$ & calcareous air fall tuff & -5.6 \\
\hline U-1a.02 (2+50) & caliche stringer in matrix & -3.6 \\
\hline U-1a.02 (2+60) & fault gouge & -5.1 \\
\hline U-1a.03 x-cut D (0+39) & calcite spar in vug & -5.5 \\
\hline U-1a.03 x-cut D (0+39) & alluvial matrix (adjacent to calcite vug) & -4.4 \\
\hline U-1a.03 x-cut B (0+32) & calcite spar - rind on clast & -4.2 \\
\hline U-1a.102C (0+77) sample V1 & fine-grained calcite in alluvial matrix & -1.1 \\
\hline U-1a.102C (0+77) sample V1 & calcite spar - rind on clast & -3.6 \\
\hline U-1a.102C (0+77) sample V2 & fine-grained calcite in alluvial matrix & -3.2 \\
\hline U-1a.102C (0+77) sample V3 & fine-grained calcite in alluvial matrix & -1.3 \\
\hline U-1a.102C (0+77) sample V4 & fine-grained calcite in alluvial matrix & 0.4 \\
\hline U-1a.102C (0+77) sample V5 & fine-grained calcite in alluvial matrix & -2.5 \\
\hline U-1a.102C (0+77) sample V5 & caliche - rind on clast & -3.0 \\
\hline U-1a.102C (0+77) sample H1 & fine-grained calcite in alluvial matrix & -1.2 \\
\hline U-1a.102C (0+77) sample H2 & fine-grained calcite in alluvial matrix & -2.9 \\
\hline U-1a.102C (0+77) sample H3 & fine-grained calcite in alluvial matrix & -1.0 \\
\hline U-1a.102C (0+77) sample H4 & caliche - rind on clast & -3.4 \\
\hline U-1a.102C (0+77) sample H5 & fine-grained calcite in alluvial matrix & -1.3 \\
\hline U-1a.102D (0+21) sample D1 & fine-grained calcite in alluvial matrix & -2.6 \\
\hline U-1a.102D (0+21) sample D2 & calcareous air fall tuff layer & -5.3 \\
\hline \multirow[t]{5}{*}{ Summary Statistics - calcite in alluvium } & mean & -3.1 \\
\hline & std. dev. & 1.7 \\
\hline & $\mathrm{n}$ & 22 \\
\hline & $\min$ & -5.6 \\
\hline & $\max$ & 0.4 \\
\hline \multicolumn{3}{|c|}{ Fracture-Lining Calcite - Yucca Flat Tuff Confining Unit (SNJV, 2004d) } \\
\hline UE7az (1,105.6 ft bgs) & $3 \mathrm{~mm}$ open cavity w/ calcite, zeolites, opal & 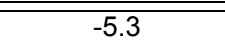 \\
\hline UE7az $(2,027 \mathrm{ft}$ bgs $)$ & 1 to $2 \mathrm{~mm}$ wide joint, filled with calcite + quartz & 0.4 \\
\hline UE7az $(2,129 \mathrm{ft}$ bgs $)$ & $1 \mathrm{~mm}$ wide joint, filled with calcite & -1.5 \\
\hline UE7az $(2,134.7 \mathrm{ft}$ bgs $)$ & $10 \mathrm{~mm}$ wide calcite vein; cleavable masses & 0.2 \\
\hline UE7ba $(2,224.8 \mathrm{ft}$ bgs $)$ & $3 \mathrm{~mm}$ wide joint filled $\mathrm{w} /$ quartz + minor calcite & -4.4 \\
\hline UE7ba (2,242 ft bgs) & $3 \mathrm{~mm}$ wide joint, quartz + calcite filling & -2.0 \\
\hline UE7ba $(2,265.5 \mathrm{ft}$ bgs $)$ & 2 to $4 \mathrm{~mm}$ wide joint, filled with calcite & -2.7 \\
\hline UE7ba $(2,271.7 \mathrm{ft}$ bgs $)$ & 4 to $9 \mathrm{~mm}$ wide joint, massive brown calcite filling & -2.0 \\
\hline UE7ba $(2,360.6 \mathrm{ft}$ bgs $)$ & $3 \mathrm{~mm}$ wide joint filled $\mathrm{w} / \mathrm{smectite} ; \sim 1$ percent calcite & -4.2 \\
\hline UE7ba $(2,370.5 \mathrm{ft}$ bgs $)$ & $3 \mathrm{~mm}$ wide joint filled $\mathrm{w} /$ illite + smectite; minor calcite & -3.0 \\
\hline
\end{tabular}


Table 3-2

Carbon Isotope Data for Yucca Flat Carbonates

(Page 2 of 3)

\begin{tabular}{|c|c|c|}
\hline Sample & Description & $\begin{array}{c}\delta^{13} \mathrm{C} \\
\text { (Permil PDB) }\end{array}$ \\
\hline UE7bc (2,546.6 ft bgs) & $10 \mathrm{~mm}$ wide fracture w/ calcite, quartz, K-spar, zeolites & -3.6 \\
\hline UE7bc $(2,590.5 \mathrm{ft}$ bgs $)$ & 3 to $10 \mathrm{~mm}$ wide massive calcite vein & -4.3 \\
\hline UE7f $(1,260.6 \mathrm{ft}$ bgs $)$ & 2 to $3 \mathrm{~mm}$ partially open vein $\mathrm{w} /$ euhedral calcite $x l s(<1 \mathrm{~mm})$ & -0.6 \\
\hline UE7f $(1,388.5 \mathrm{ft}$ bgs $)$ & $10 \mathrm{~mm}$ partially open vein; blocky calcite xls to $3 \mathrm{~mm}$ & -7.3 \\
\hline UE7f $(2,475.8 \mathrm{ft}$ bgs $)$ & $3 \mathrm{~mm}$ open joint $\mathrm{w} /$ euhedral, bladed calcite, analcime, $\mathrm{Mn}-\mathrm{ox}$ & -0.3 \\
\hline UE7f $(2,482.5 \mathrm{ft}$ bgs $)$ & 1 to $2 \mathrm{~mm}$ calcite replacement vein in Fe-oxide stained tuff & -1.0 \\
\hline \multicolumn{3}{|c|}{ Fracture-Lining Calcite - Climax Stock (SNJV, 2004c) } \\
\hline U-15b-2 (1,531 ft bgs) & calcite fracture lining in granitic rock & -5.4 \\
\hline $\mathrm{U}-15 \mathrm{~b}-2(1,598.5 \mathrm{ft}$ bgs $)$ & calcite fracture lining in granitic rock & -1.0 \\
\hline UE-15g (367 ft bgs) & calcite fracture lining in granitic rock & -4.1 \\
\hline UE-15g (499.4 ft bgs) & calcite fracture lining in granitic rock & -3.0 \\
\hline UE-15g (525 ft bgs) & calcite fracture lining in granitic rock & -3.7 \\
\hline UE-15g (596 ft bgs) & calcite fracture lining in granitic rock & -5.6 \\
\hline \multirow[t]{5}{*}{ Summary Statistics - fracture lining calcite } & mean & -2.9 \\
\hline & std. dev. & 2.1 \\
\hline & $\mathrm{n}$ & 22 \\
\hline & $\min$ & -7.3 \\
\hline & $\max$ & 0.4 \\
\hline \multicolumn{3}{|c|}{ Carbonate bedrock samples (LCA) (Rose et al., 2000) } \\
\hline Army Well \#1 (1,134ft bgs) & limestone whole rock & 4.3 \\
\hline Army Well \#1 (1,134 ft bgs) & calcite fracture lining & 2.6 \\
\hline UE-1a (515 ft bgs) & limestone whole rock & -1.8 \\
\hline WW-C $(1,550-1,555 \mathrm{ft}$ bgs $)$ & limestone whole rock & -0.7 \\
\hline WW-C1 $(1,580-1,590 \mathrm{ft}$ bgs $)$ & limestone whole rock & -0.4 \\
\hline ER-3-1 (2,580 ft bgs $)$ & calcite vein & -0.7 \\
\hline ER-3-1 (2,600 ft bgs) & calcite vein & -0.6 \\
\hline ER-6-1 (2,640 ft bgs $)$ & dolomite whole rock & 0.7 \\
\hline ER-6-1 (2,808 ft bgs $)$ & dolomite whole rock & 0.8 \\
\hline ER-6-1 (3,136 ft bgs) & calcite spar on fracture surface & -1.3 \\
\hline ER-6-1 (3,137.5 ft bgs $)$ & calcite spar on fracture surface & -2.6 \\
\hline UE7f $(2,822.1 \mathrm{ft}$ bgs $)$ & LCA bedrock & -1.1 \\
\hline UE7f $(2,822.1 \mathrm{ft}$ bgs $)$ & calcite vein in LCA bedrock & -2.7 \\
\hline UE-10j $(2,110 \mathrm{ft}$ bgs $)$ & dolomite whole rock & 0.3 \\
\hline UE-10j $(2,280 \mathrm{ft}$ bgs $)$ & dolomite whole rock & 0.4 \\
\hline UE-15d (5,998 ft bgs) & dolomite whole rock & -1.2 \\
\hline UE-15i (263 ft bgs) & limestone whole rock & -0.04 \\
\hline UE-16d (996 ft bgs) & limestone whole rock & 5.6 \\
\hline \multicolumn{3}{|c|}{ Carbonate bedrock samples (LCA) (Thomas et al., 1996) } \\
\hline Yellowpine Limestone & calcite & 2.5 \\
\hline
\end{tabular}


Table 3-2

Carbon Isotope Data for Yucca Flat Carbonates

(Page 3 of 3)

\begin{tabular}{|c|c|c|}
\hline Sample & Description & $\begin{array}{c}\delta^{13} \mathrm{C} \\
\text { (Permil PDB) }\end{array}$ \\
\hline Ely Springs Dolomite & dolomite & 0.6 \\
\hline Nopah Dolomite & dolomite & 0.4 \\
\hline Upper Cambrian Limestone & calcite & 3.4 \\
\hline Simonson Dolomite & dolomite & 0.4 \\
\hline Sevy Dolomite & dolomite & -1.4 \\
\hline Sevy Dolomite & dolomite & -0.1 \\
\hline Sevy Dolomite & dolomite & -0.1 \\
\hline Laketown Dolomite & dolomite & 0.2 \\
\hline Lower Pogonip Group Limestone & calcite & -0.5 \\
\hline Upper Cambrian Limestone & calcite & -0.4 \\
\hline Blue Diamond road cut & & 2.7 \\
\hline Test Well D & & 3.7 \\
\hline Well U-3cn \#5 & & 0.4 \\
\hline Army Well \#1 & & 0.6 \\
\hline Test Well 4 & & 2.1 \\
\hline Test Well 2 & & 2.3 \\
\hline Test Well F & & 0.9 \\
\hline Test Well 3 & & 1.0 \\
\hline Test Well 1 & & 0.3 \\
\hline Well UE-15d & & 2.3 \\
\hline Tracer Well 3 & & 2.2 \\
\hline Water Well C-1 & & 0.6 \\
\hline Water Well C & & 1.2 \\
\hline \multirow[t]{5}{*}{ Summary Statistics - LCA bedrock } & mean & 0.6 \\
\hline & std. dev. & 1.8 \\
\hline & $\mathrm{n}$ & 42 \\
\hline & $\min$ & -2.7 \\
\hline & $\max$ & 5.6 \\
\hline
\end{tabular}

$\mathrm{ft}$ bgs $=$ Feet below ground surface

max $=$ Maximum value

$\min =$ Minimum value

$\mathrm{mm}=$ Millimeter

$\mathrm{n}=$ Number of samples 
groundwater ${ }^{14} \mathrm{C}$ values from the $\delta^{13} \mathrm{C}$ data alone. This is especially true because, unlike 300-million-year-old marine carbonate rock, calcite fracture coatings, and matrix crusts deposited by recent groundwater could have small but non-zero ${ }^{14} \mathrm{C}$ activities.

The foregoing discussions have focused on the impact that carbonate dissolution reactions have on groundwater ${ }^{14} \mathrm{C}$ and $\delta^{13} \mathrm{C}$ data. However, groundwater ${ }^{14} \mathrm{C}$ and $\delta^{13} \mathrm{C}$ data are also affected, although to a lesser extent, when calcite is precipitated by groundwater. During calcite precipitation, the heavier carbon isotopes $\left({ }^{14} \mathrm{C}\right.$ and $\left.{ }^{13} \mathrm{C}\right)$ become preferentially incorporated into the calcite by isotope fractionation so that the ${ }^{14} \mathrm{C}$ and ${ }^{13} \mathrm{C}$ concentrations of the groundwater are lower than before precipitation. However, these effects on ${ }^{14} \mathrm{C}$ and $\delta^{13} \mathrm{C}$ are secondary compared to the other uncertainties that affect the interpretation of groundwater ${ }^{14} \mathrm{C}$ data. For example, based on fractionation factors in Clark and Fritz (1997), if groundwater with a ${ }^{14} \mathrm{C}$ activity of $10 \mathrm{pmc}$ and a $\delta^{13} \mathrm{C}$ of -5.0 permil lost 20 percent of its DIC during calcite precipitation, the DIC remaining in the groundwater would have a ${ }^{14} \mathrm{C}$ of $9.95 \mathrm{pmc}$ and a $\delta^{13} \mathrm{C}$ of -5.2 permil. Although more significant than for ${ }^{14} \mathrm{C}$, isotope fractionation of ${ }^{13} \mathrm{C}$ during calcite precipitation introduces relatively little error when interpreting ${ }^{14} \mathrm{C}$ ages compared to the uncertainties in not knowing the specific $\delta^{13} \mathrm{C}$ values of the dissolving carbonate phases.

Other factors potentially affecting the groundwater ${ }^{14} \mathrm{C}$ activities involve the diffusion of ${ }^{14} \mathrm{C}$ (as $\mathrm{H}^{14} \mathrm{CO}_{3}^{-}$) into the relatively stagnant groundwater in the matrix or dead-end fractures of fractured rocks, and the sorption or exchange of $\mathrm{H}^{14} \mathrm{CO}_{3}{ }^{-}$onto fracture-lining calcite (Mozeto et al., 1984; Maloszewski and Zuber, 1991; Sanford, 1997; Sheppard et al., 1998; Hershey et al., 2005; Ware et al., 2005; Reimus et al., 2005). Laboratory experiments have indicated that diffusion of $\mathrm{H}^{14} \mathrm{CO}_{3}{ }^{-}$from fractures into the rock matrix can be expected to occur in Yucca Flat in both nonwelded tuffs and carbonate rocks, with diffusive effects being far more significant in the nonwelded tuffs because of their larger porosity (Ware et al., 2005). Based on these experiments, considerable delay of $\mathrm{H}^{14} \mathrm{CO}_{3}{ }^{-}$ breakthrough from the tuff confining units into the LCA and during subsequent flow within the LCA can be expected to occur. Various studies have attempted to correct groundwater ${ }^{14} \mathrm{C}$ ages at the NTS and at other sites to correct for the effects of these diffusive processes (Maloszewski and Zuber, 1991; Sanford, 1997; Hershey et al., 2005). However, because diffusion arising from Brownian motion affects all molecular species including water (as would be evident if tritiated water or "heavy" water had been used as tracers in these experiments), the migration of $\mathrm{H}^{14} \mathrm{CO}_{3}{ }^{-}$in Yucca Flat as interpreted 
through the calculated groundwater ages and velocities in this report provides a useful analog regarding the migration of other dissolved species, provided its sorption and exchange behavior is understood.

Isotopic tracer experiments designed to examine the interaction of $\mathrm{H}^{13} \mathrm{CO}_{3}{ }^{-}$with non-NTS calcites in calcite-saturated water have demonstrated that these interactions consist of an initial period during which the rapid sorption of $\mathrm{H}^{13} \mathrm{CO}_{3}$ - onto high-energy surface sites dominates, followed by a more prolonged period in which $\mathrm{H}^{13} \mathrm{CO}_{3}^{-}$becomes incorporated into the calcite through dissolution and re-precipitation of the calcite surfaces (Mozeto et al., 1984). By analogy, $\mathrm{H}^{14} \mathrm{CO}_{3}{ }^{-}$probably sorbs and undergoes isotopic exchange with calcite through similar processes. The second process is accounted for in this study by modeling the evolution of groundwater $\delta^{13} \mathrm{C}$ as the groundwater interacts with the dolomite and calcite in the LCA. The evolution of groundwater $\delta^{13} \mathrm{C}$ reflects both bulk dissolution of calcite and dolomite, as well as the isotope exchange that results from calcite re-crystallization. The modeling approaches used in this study would not account for the sorption of $\mathrm{H}^{14} \mathrm{CO}_{3}{ }^{-}$onto calcite fracture coatings in the LCA if this process were to occur. However, recent batch and column experiments that used natural fracture-lining calcite from the LCA in Yucca Flat have indicated little or no sorption of $\mathrm{H}^{14} \mathrm{CO}_{3}{ }^{-}$onto the calcite (Ware et al., 2005). Based on these results, this study assumes that sorption has not affected the migration of $\mathrm{H}^{14} \mathrm{CO}_{3}{ }^{-}$in the LCA.

\subsubsection{Groundwater Age Estimates from Dissolved Organic ${ }^{14} \mathrm{C}$}

Dissolved organic carbon (DOC) analyzed for $\delta^{13} \mathrm{C}\left(\mathrm{DO}^{13} \mathrm{C}\right)$ and ${ }^{14} \mathrm{C}\left(\mathrm{DO}^{14} \mathrm{C}\right)$ provides an independent estimate of groundwater age that can be compared to groundwater travel times calculated using $\mathrm{DI}^{14} \mathrm{C}$. Whereas $\mathrm{DI}^{14} \mathrm{C}$ travel times represent mean groundwater travel time along a flow path, $\mathrm{DO}^{14} \mathrm{C}$ groundwater ages more closely reflect the average time elapsed since groundwater recharge occurred. Thus, $\mathrm{DO}^{14} \mathrm{C}$ ages should be the same or greater than $\mathrm{DI}^{14} \mathrm{C}$ ages. Because volcanic and carbonate aquifers in southern Nevada have very low organic content, $\mathrm{DO}^{14} \mathrm{C}$ ages do not have to be corrected for organic-carbon reactions in the aquifer like $\mathrm{DI}^{14} \mathrm{C}$ groundwater travel times are adjusted for water-rock interactions.

Because $\mathrm{DO}^{14} \mathrm{C}$ estimation of groundwater age is a relatively new technique, very little DOC isotopic data are available for wells and springs within the study area. However, DOC isotopic data do exist for the more recently drilled ER wells (Table 3-3). The $\mathrm{DO}^{14} \mathrm{C}$ ages range from 1,000 to 20,000 years 
for groundwater in the Yucca Flat area. These ages assume than an initial $\mathrm{DO}^{14} \mathrm{C}$ value during recharge is similar to that measured in UE-29a \#1 and UE-29a \#2 in Fortymile Wash (66 pmc), because no other modern samples are available for the NTS area. The data indicate that groundwater in the recharge area near ER-12-2 is very young, the groundwater of the LTCU at ER-2-1 is older than recent recharge but younger than most groundwater in the LCA. Improvements in the ability to estimate the initial $\mathrm{DO}^{14} \mathrm{C}$ input to the aquifers in this region will reduce the uncertainty in the interpretation of these data.

Table 3-3

Dissolved Organic Carbon Calculated Groundwater Ages

\begin{tabular}{|c|c|c|c|c||}
\hline Well & $\begin{array}{c}\text { DOC } \\
\text { (mg/L) }\end{array}$ & $\begin{array}{c}\text { DO' }^{13} \mathbf{C} \\
\text { (permil) }\end{array}$ & $\begin{array}{c}\text { DO'14C } \\
(\mathbf{p m c})\end{array}$ & $\begin{array}{c}\text { Age } \\
\text { (years) }\end{array}$ \\
\hline \hline ER-12-2 & 0.2 & -22.7 & 60.7 & 1,000 \\
\hline ER-2-1 & 0.7 & -32.8 & 31.4 & 6,000 \\
\hline ER-7-1 & 0.1 & -24.5 & 31.7 & 6,000 \\
\hline ER-6-1\#2 & 0.7 & -35.0 & 11.1 & 15,000 \\
\hline ER-6-1 & 2.1 & -34.6 & 3.3 & 20,000 \\
\hline
\end{tabular}

$\mathrm{mg} / \mathrm{L}=$ Milligrams per liter

pmc $=$ Percent modern carbon

\subsubsection{Chlorine-36}

Chlorine has one long-lived radioactive isotope, ${ }^{36} \mathrm{Cl}$, with a half-life of 301,000 years. Chloride concentrations and the available ${ }^{36} \mathrm{Cl} / \mathrm{Cl}$ ratios for groundwater within the Yucca Flat are presented in Figure 3-10. Natural production of ${ }^{36} \mathrm{Cl}$ occurs in three ways: 1) Cosmic-ray spallation of argon $\left({ }^{40} \mathrm{Ar}\right)$ and neutron activation of ${ }^{36} \mathrm{Ar}$ in the atmosphere, 2) Cosmic-ray spallation of $\mathrm{K}$ and $\mathrm{Ca}$ on and near the earth's surface (primarily ${ }^{39} \mathrm{~K}$ and ${ }^{40} \mathrm{Ca}$ ), and 3) Neutron activation of ${ }^{35} \mathrm{Cl}$ (from uranium-thorium series decay) at depth over long periods of time (Bentley et al., 1986; Phillips, 2000).

The ocean has a ${ }^{36} \mathrm{Cl} / \mathrm{Cl}$ ratio below the detection limit $\left(1 \times 10^{-15}\right)$ of accelerator mass spectrometry (AMS), and ${ }^{36} \mathrm{Cl} / \mathrm{Cl}$ ratios in precipitation tend to vary with distance from the ocean. The lowest ratios are recorded along coastal regions $\left(15 \times 10^{-15}\right)$ and the highest ratios are found in the continental interior (up to $1 \times 10^{-12}$ for the continental U.S. [Bentley et al., 1986]). For the study area, published estimates of the initial ${ }^{36} \mathrm{Cl} / \mathrm{Cl}$ ratio in precipitation are in the range of $4 \times 10^{-13}$ to $5 \times 10^{-13}$ (Hainsworth et al., 1994, Bentley et al., 1986; Fabryka-Martin et al., 1993). 


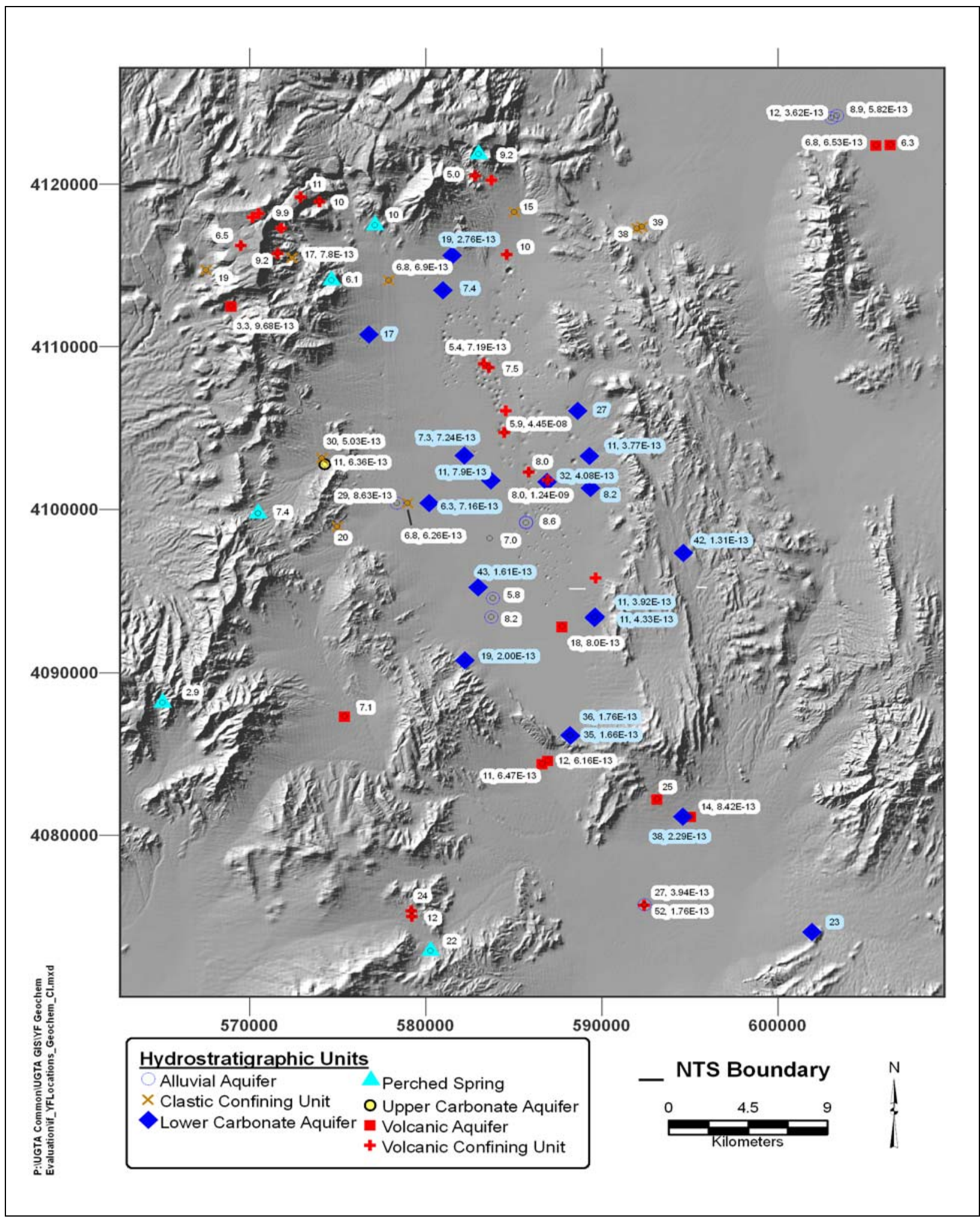

Figure 3-10

Average $\mathrm{Cl}$ Concentrations (mg/L) and ${ }^{36} \mathrm{Cl} / \mathrm{Cl}$ Values for Groundwater Within the Yucca Flat/Climax Mine Study Area 
Chloride is a conservative anion in groundwater under most conditions. Changes to the ${ }^{36} \mathrm{Cl} / \mathrm{Cl}$ ratio in groundwater may occur along a flow path by decay of ${ }^{36} \mathrm{Cl}$ and subsurface production of ${ }^{36} \mathrm{Cl}$ from neutron capture on ${ }^{35} \mathrm{Cl}$ in water and water-rock interaction (addition of low ${ }^{36} \mathrm{Cl} / \mathrm{Cl}$ chloride from the dissolution of minerals). The low $\mathrm{Cl}$ concentrations and relatively short subsurface residence times of groundwater in the NTS region suggest that subsurface production and decay processes are negligible. Hence, the dominant factors controlling the observed ${ }^{36} \mathrm{Cl} / \mathrm{Cl}$ ratios and $\mathrm{Cl}$ concentrations are the initial values inherited during recharge, the progressive dissolution of low ${ }^{36} \mathrm{Cl}$ along groundwater flow paths, and mixing with water of a different ${ }^{36} \mathrm{Cl} / \mathrm{Cl}$ ratio. Mixing processes yield intermediate compositions forming linear trends on a ${ }^{36} \mathrm{Cl} / \mathrm{Cl}$ vs. 1/Cl plot (Moran and Rose, 2003).

Typical ${ }^{36} \mathrm{Cl} / \mathrm{Cl}$ ratios of common rocks range from $4 \times 10^{-15}$ for limestone to $50 \times 10^{-15}$ for granite (Andrews et al., 1986; Bentley et al., 1986). Dissolution of carbonate rock material, which is relatively rich in $\mathrm{Cl}$, is likely the most important process controlling the ${ }^{36} \mathrm{Cl} / \mathrm{Cl}$ ratios in the LCA. Kenneally (1995) performed leaching experiments on NTS drill core samples and found that carbonate rocks tend to be higher (22 to 93 milligrams per kilogram [mg/kg]) in leachable $\mathrm{Cl}$ than volcanic rocks ( 0.5 to $24 \mathrm{mg} / \mathrm{kg}$ ). Dissolution of $\mathrm{Cl}$ from the carbonate rock will result in progressively lower ${ }^{36} \mathrm{Cl} / \mathrm{Cl}$ ratios and higher $\mathrm{Cl}$ concentrations along a given flow path in the LCA. On a plot of ${ }^{36} \mathrm{Cl} / \mathrm{Cl}$ vs. $1 / \mathrm{Cl}$, many of the LCA samples plot along an apparent mixing trend between a high ${ }^{36} \mathrm{Cl} / \mathrm{Cl}$ recharge end-member and a low ${ }^{36} \mathrm{Cl} / \mathrm{Cl}$ carbonate rock end-member (Section 5.0).

The production rate of cosmogenic ${ }^{36} \mathrm{Cl}$ ratio in the upper atmoshpere varies on 1,000- to 10,000 -year time scales due primarily to variations in the intensity of the earth's magnetic field (Plummer et al., 1997). Tyler et al. (1996) examined variations in ${ }^{36} \mathrm{Cl} / \mathrm{Cl}$ ratios with depth in soil water samples taken from the UE-5 PW-1, UE-5 PW-2, and UE-5 PW-3 boreholes in northern Frenchman Flat. Measured ratios as high as approximately $9.5 \times 10^{-13}$ were observed at $10 \mathrm{~m}$ depth, and elevated ratios persisted with increasing depth (e.g., ${ }^{36} \mathrm{Cl} / \mathrm{Cl}=7 \times 10^{-13}$ at $213 \mathrm{~m}$ depth in UE-5 PW-1). The ${ }^{36} \mathrm{Cl} / \mathrm{Cl}$ ratios in all three boreholes were significantly higher than the estimated modern ratio of approximately $5 \times 10^{-13}$ measured in the soil zone at Yucca Mountain (Fabryka-Martin et al., 1993). Tyler et al. (1996) note that the elevated ratios are consistent with predicted increases in atmospheric ${ }^{36} \mathrm{Cl}$ production during late Pleistocene time, corresponding to periods of significantly reduced strength in the earth's magnetic field. 
Atmospheric ${ }^{36} \mathrm{Cl}$ production rates 20,000 years ago were estimated to be a factor of 1.6 higher than the modern value, implying an initial ratio of $8 \times 10^{-13}$ in southern Nevada at that time. The NTS groundwater from alluvial, volcanic, and clastic units frequently exhibits ${ }^{36} \mathrm{Cl} / \mathrm{Cl}$ ratios that are greater than $6 \times 10^{-13}$ and can range as high as $9.7 \times 10^{-13}$. These waters are interpreted to reflect a paleoclimatic ${ }^{36} \mathrm{Cl}$ signature, inherited from groundwater recharge that occurred during the last pluvial period, when the climate in southern Nevada was notably less arid relative to current conditions (e.g., Mifflin and Wheat, 1979; Spaulding, 1985; Quade et al., 1995). Elevated ${ }^{36} \mathrm{Cl} / \mathrm{Cl}$ ratios are also observed in LCA groundwater from a few wells and may reflect mixing with high ${ }^{36} \mathrm{Cl}$ water from overlying HSUs (downward transport). In particular, wells UE-1q, TW-D, and UE-1c exhibit anomalously high ${ }^{36} \mathrm{Cl} / \mathrm{Cl}$ ratios relative to other LCA groundwaters. These wells are all located near major north-south trending structures close to the center of Yucca Flat, on the west side of the Topgallant Fault.

\subsubsection{Strontium and ${ }^{87} \mathrm{Sr} /{ }^{86} \mathrm{Sr}$ Values}

Natural Sr comprises four isotopes $\left({ }^{84} \mathrm{Sr},{ }^{86} \mathrm{Sr},{ }^{87} \mathrm{Sr}\right.$, and $\left.{ }^{88} \mathrm{Sr}\right)$, three of which are non-radiogenic and have fixed abundances in terrestrial materials. In contrast, ${ }^{87} \mathrm{Sr}$ is formed by $\beta$ decay of rubidium $\left({ }^{87} \mathrm{Rb}\right)$, which has a half-life of $4.88 \times 10^{10}$ years. The abundance of ${ }^{87} \mathrm{Sr}$, therefore, varies in geologic materials depending on their age, their initial $\mathrm{Sr}$ isotopic composition, and their $\mathrm{Rb} / \mathrm{Sr}$ ratio.

Groundwater ${ }^{87} \mathrm{Sr} /{ }^{86} \mathrm{Sr}$ values reflect interactions with soil and rocks during recharge and subsequent flow. Because of the low dissolved Sr content of precipitation, infiltration will rapidly adjust to the ${ }^{87} \mathrm{Sr} /{ }^{86} \mathrm{Sr}$ composition of the most soluble soil components. Like other cations, the Sr content of groundwater generally increases along a flow path from dissolution of aquifer rocks. $\mathrm{The}{ }^{87} \mathrm{Sr} /{ }^{66} \mathrm{Sr}$ composition of the water may change significantly if the aquifer host rock contains large $\mathrm{Sr}$ concentrations in chemically reactive sites. Conversely, the ${ }^{87} \mathrm{Sr} /{ }^{86} \mathrm{Sr}$ may be buffered from substantial modification following recharge if the aquifer consists of rocks with low Sr content.

Groundwater samples from the Yucca Flat vicinity have a wide range of Sr concentrations that are broadly correlated with aquifer type (Figures 3-11 and 3-12). The lowest Sr concentrations are present in the volcanic aquifer (15 to 158 micrograms per liter $[\mu \mathrm{g} / \mathrm{L}])$ and volcanic confining unit (0.2 to $64 \mu \mathrm{g} / \mathrm{L}$ ) samples (Figure 3-12). Low concentrations of $\mathrm{Mg}, \mathrm{Ca}$, and $\mathrm{Sr}$ in these waters are likely caused by sorption of alkali-earth elements by zeolites present in altered tuffs. Strontium in 
these samples is typically non-radiogenic with ${ }^{87} \mathrm{Sr} /{ }^{86} \mathrm{Sr}$ values between 0.7089 and 0.7113 . Exceptions include volcanic aquifer water from Watertown \#1 (WT-1) in Emigrant Valley, which has an elevated ${ }^{87} \mathrm{Sr} /{ }^{86} \mathrm{Sr}$ value $(0.71566)$ and volcanic confining unit water from U-3mi in southeastern Yucca Flat with both elevated $\mathrm{Sr}$ concentration $(660 \mu \mathrm{g} / \mathrm{L})$ and ${ }^{87} \mathrm{Sr} /{ }^{86} \mathrm{Sr}(0.71386)$.

Compared to water from volcanic units within the Yucca Flat basin, LCA groundwaters have higher Sr concentrations and ${ }^{87} \mathrm{Sr} /{ }^{86} \mathrm{Sr}$ values. Samples of LCA water on the southeastern side of the Yucca Flat basin (ER-3-1, WW-C, WW-C1, ER-5-3\#2, and HTH-3) have high Sr concentrations (704 to $926 \mu \mathrm{g} / \mathrm{L})$ and elevated ${ }^{87} \mathrm{Sr} /{ }^{86} \mathrm{Sr}(0.71328$ to 0.71824$)$ (Figure 3-12). In contrast, LCA water sampled throughout most of the Yucca Flat basin have lower Sr concentrations (89 to $470 \mu \mathrm{g} / \mathrm{L}$ ) and less radiogenic ${ }^{87} \mathrm{Sr} /{ }^{86} \mathrm{Sr}(0.7113$ to 0.7146$)$. However, all of these LCA waters have ${ }^{87} \mathrm{Sr} /{ }^{86} \mathrm{Sr}$ values higher than expected from water-rock interaction with unaltered Paleozoic marine limestones (0.707 to 0.709 [Peterman et al., 1970; Burke et al., 1982]). Higher ${ }^{87} \mathrm{Sr} /{ }^{86} \mathrm{Sr}$ values indicate that ${ }^{87} \mathrm{Sr}$ from sources with more radiogenic Sr has been introduced, either through ground-water mixing or interaction with ${ }^{87} \mathrm{Sr}$-enriched aquifer rock. Samples from two Yucca Flat wells penetrating the LCA in southwestern Yucca Flat (UE-1h and UE-1c) have substantially lower ${ }^{87} \mathrm{Sr} /{ }^{86} \mathrm{Sr}$ than other Yucca Flat LCA wells (0.70932 and 0.70988, respectively) and are closer to values expected for marine carbonates. Many water samples from other HSUs in the same area of southwestern Yucca Flat have similar non-radiogenic ${ }^{87} \mathrm{Sr} /{ }^{86} \mathrm{Sr}$ values compared to samples further east and north.

Samples of LCA water that is upgradient and downgradient from the NTS are only available from several distant areas (Figure 3-12). Lower carbonate aquifer water in Pahranagat Valley (Hiko, Crystal, and Ash springs) and in Indian Springs Valley tend to have lower ${ }^{87} \mathrm{Sr} /{ }^{86} \mathrm{Sr}$ values ( 0.7100 to 0.7112 ) that are more typical of marine ${ }^{87} \mathrm{Sr} /{ }^{86} \mathrm{Sr}$ values relative to Yucca Flat LCA samples. Lower carbonate aquifer water from Army\#1 Water Well at the southern edge of the NTS has $\mathrm{Sr}$ concentrations and ${ }^{87} \mathrm{Sr} /{ }^{86} \mathrm{Sr}$ intermediate between the two groups of LCA water described above (central Yucca Flat and eastern NTS) and likely represents a mixture of Frenchman Flat and Spring Mountain water (Hershey et al., 2005, p. 59; Hershey and Archeampong, 1997, p. 28).

Water samples from the UCCU and LCCU have intermediate to high Sr concentrations (199 to $1250 \mu \mathrm{g} / \mathrm{L}$ ) and a wide range in ${ }^{87} \mathrm{Sr} /{ }^{86} \mathrm{Sr}$ values (black crosses in Figure 3-12). Samples of the UCCU on the west margin of the Yucca Flat basin have lower ${ }^{87} \mathrm{Sr} /{ }^{86} \mathrm{Sr}$ values $(0.7095$ to 0.7117$)$ than the one 


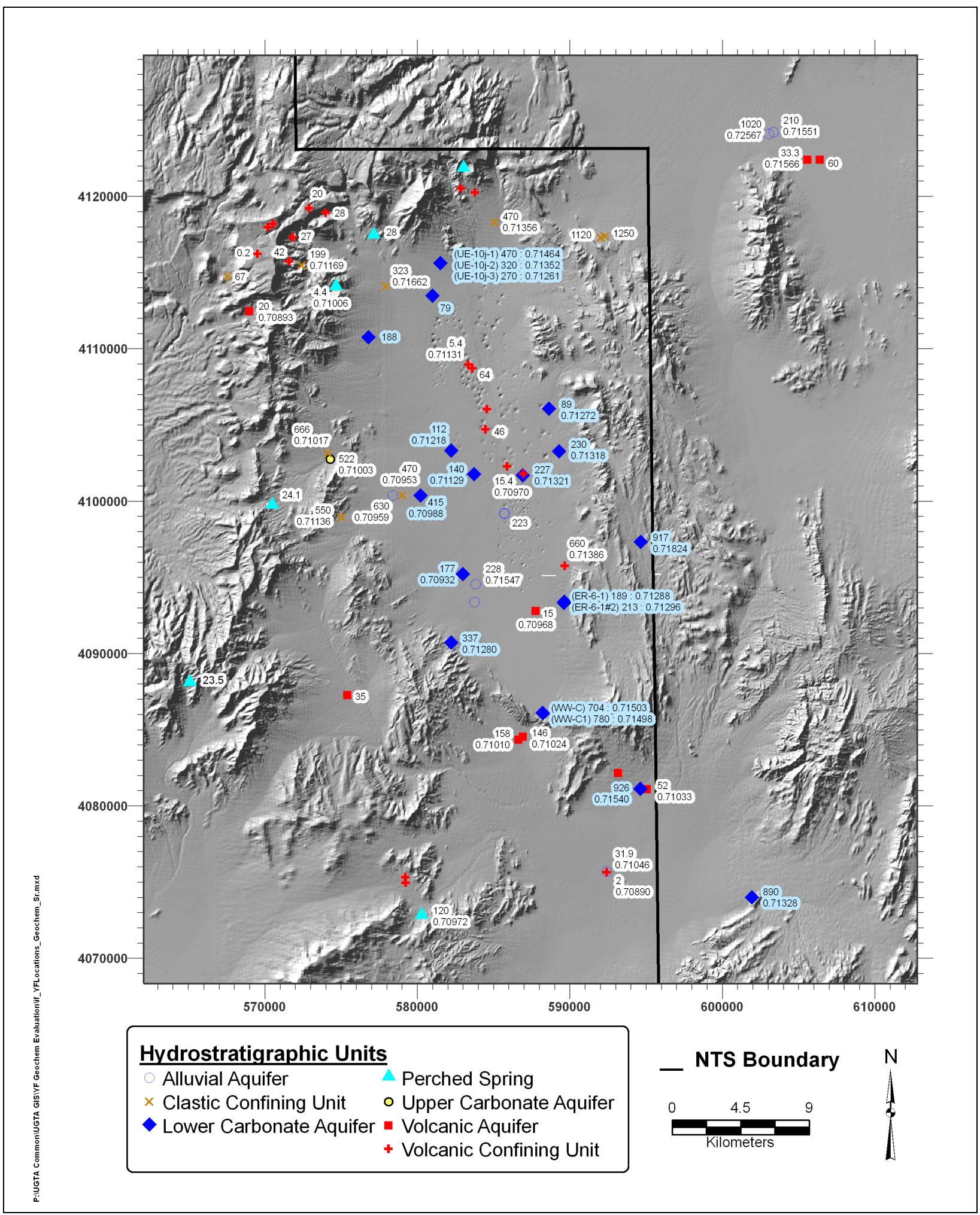

Figure 3-11

Average Sr Concentrations ( $\mu \mathrm{g} / \mathrm{L}$ ) and ${ }^{87} \mathrm{Sr} /{ }^{86} \mathrm{Sr}$ Values for Groundwater Within the Yucca Flat/Climax Mine Study Area 


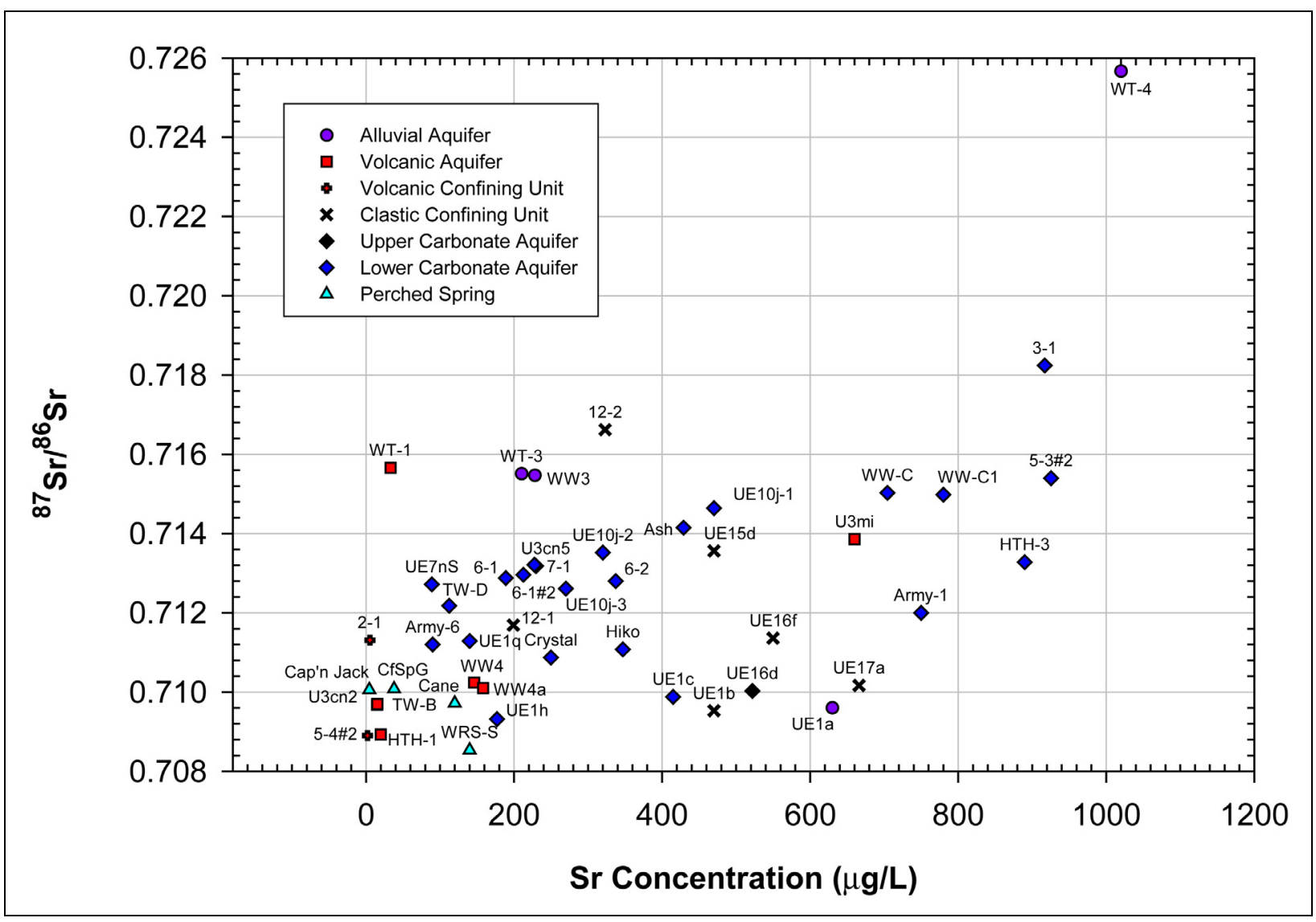

Figure 3-12

${ }^{87} \mathrm{Sr} /{ }^{86} \mathrm{Sr}$ Versus Sr Concentration of Groundwater and Spring in the Yucca Flat Vicinity

analysis of LCCU water on the far northeastern margin of the basin (UE-15d with ${ }^{87} \mathrm{Sr} /{ }^{86} \mathrm{Sr}$ of 0.71356). A UCCU groundwater sample from ER-12-2 in northwestern Yucca Flat has the most radiogenic $\mathrm{Sr}$ with a ${ }^{87} \mathrm{Sr} /{ }^{86} \mathrm{Sr}$ value of 0.71662 .

The alluvial aquifer is represented by a small number of samples scattered through Yucca Flat and adjacent areas. Strontium concentrations are typically intermediate (223 to $770 \mu \mathrm{g} / \mathrm{L})$ with the highest concentration present in Watertown \#4 (WT-4) in Emigrant Valley $(1,020 \mu \mathrm{g} / \mathrm{L})$. The value for ${ }^{87} \mathrm{Sr} /{ }^{86} \mathrm{Sr}$ in this sample is also substantially higher $(0.72567)$ than any other water measured $(\leq 0.71824)$ as part of this study. 
Strontium concentrations in samples from perched springs in the Yucca Flat vicinity vary from 4.4 to $760 \mu \mathrm{g} / \mathrm{L}$ with a median value of $130 \mu \mathrm{g} / \mathrm{L}$ (18 analyses). Perched aquifer rock type likely controls dissolved Sr concentrations. However, available ${ }^{87} \mathrm{Sr} /{ }^{86} \mathrm{Sr}$ data (6 samples) are restricted to values between 0.70854 and 0.71097 with a median value of 0.70997 .

\subsubsection{Uranium and ${ }^{234} U /{ }^{238} U$ Activity Ratio}

Natural U consists of two radioactive isotopes with half lives greater than 700 million years $\left({ }^{235} \mathrm{U}\right.$ and $\left.{ }^{238} \mathrm{U}\right)$ and a minor, short-lived radioactive isotope $\left({ }^{234} \mathrm{U}\right.$, half life of 0.25 million years $)$ derived from the decay of ${ }^{238} \mathrm{U}$. Although the atomic ${ }^{238} \mathrm{U} /{ }^{235} \mathrm{U}$ is constant in rocks and water, ${ }^{234} \mathrm{U} /{ }^{238} \mathrm{U}$ ratios in natural water can vary widely (Osmond \& Cowart, 1976; Rosholt, 1983). Alpha-recoil processes associated with decay of ${ }^{238} \mathrm{U}$ result in preferential dissolution of ${ }^{234} \mathrm{U}$ from solid surfaces and ${ }^{234} \mathrm{U} / 238 \mathrm{U}$ activity ratios in migrating water that are greater than 1.0. Inputs from rock weathering and recoil processes play a dominant role in the evolution of ${ }^{234} \mathrm{U} / 238 \mathrm{U}$ activity ratios in groundwater systems; however, other factors may also contribute (Porcelli and Swarzenski, 2003). Although these processes lead to spatial variability of ${ }^{234} \mathrm{U} / 238 \mathrm{U}$ activity ratios in groundwater systems in southern Nevada (1.02 to 8.06 for 177 analyses in Paces et al., 2002), values at a given sampling site likely remain constant over long periods of time (minimal variation in initial ${ }^{234} \mathrm{U} /{ }^{238} \mathrm{U}$ activity ratios for the 600,000-year calcite record at Devils Hole, Nevada; Ludwig et al., 1992).

Uranium concentration and ${ }^{234} \mathrm{U} / 238 \mathrm{U}$ activity ratio data are available from a limited subset of samples (Figure 3-13). Concentrations of dissolved $U$ depend strongly on the oxidation state of the groundwater. Uranium is highly soluble as uranyl carbonate $\left(\mathrm{UO}_{2} \mathrm{CO}_{3}\right)$ complexes in oxidized alkaline groundwater (Langmuir, 1978, p. 556), typical of southern Nevada. Uranium concentrations in groundwaters in the vicinity of Yucca Flat typically range from about 0.3 to $7 \mu \mathrm{g} / \mathrm{L}$ with a large degree of overlap between different HSUs (Figure 3-14). The median concentration of $2.6 \mu \mathrm{g} / \mathrm{L}$ for

the 70 samples reported in Appendix A is identical to the median value calculated for 177 samples of southern Nevada groundwater reported by Paces and others (2002). Only one sample from Yucca Flat (ER-12-2 from the UCCU) has an anomalously low U concentration of $0.017 \mu \mathrm{g} / \mathrm{L}$, implying the presence of reducing conditions at this site. 


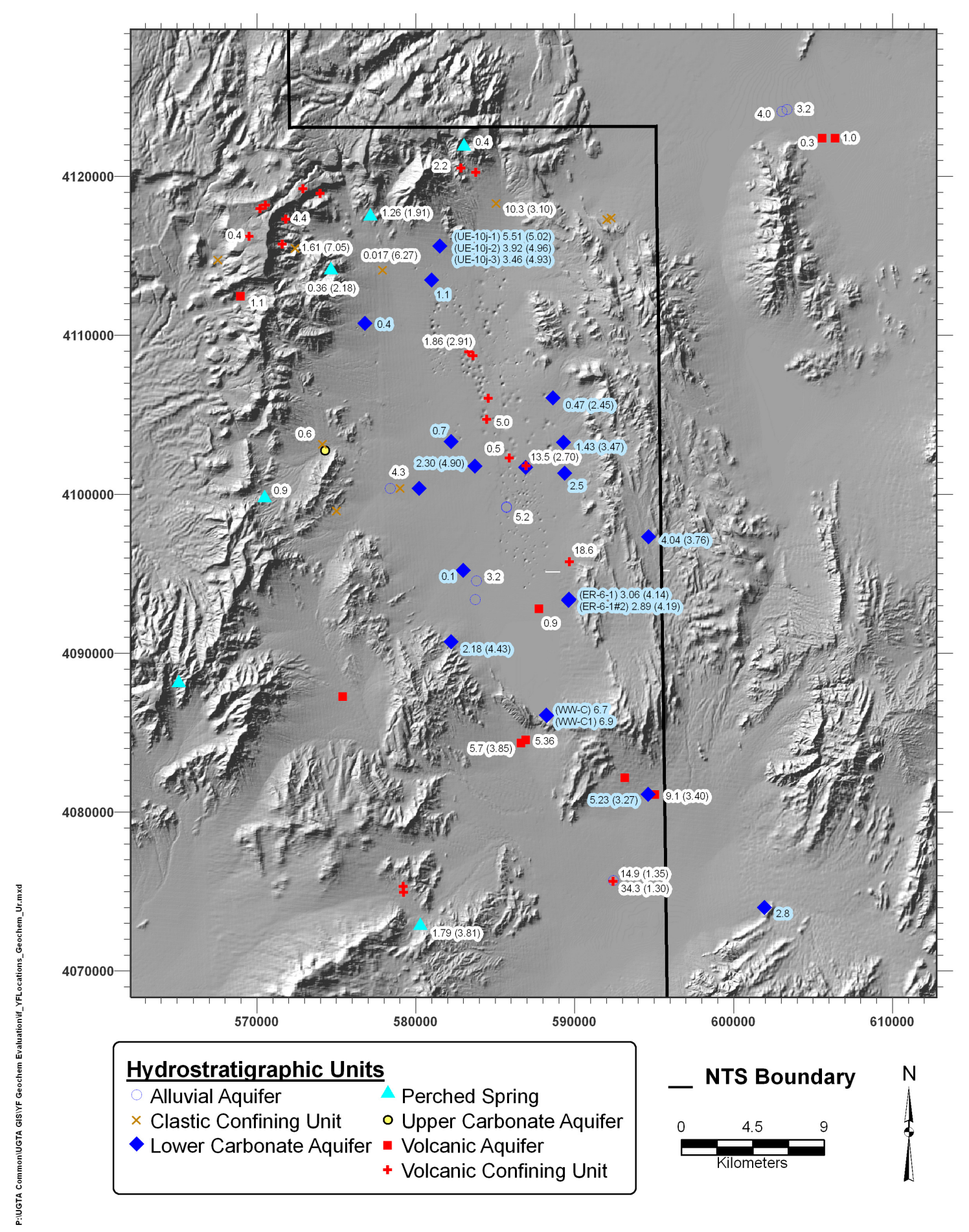

Figure 3-13

Average $U$ Concentrations ( $\mu$ g/L) and ${ }^{234} U /{ }^{238} U$ Activity Ratios for Groundwater Within the Yucca Flat/Climax Mine Study Area 


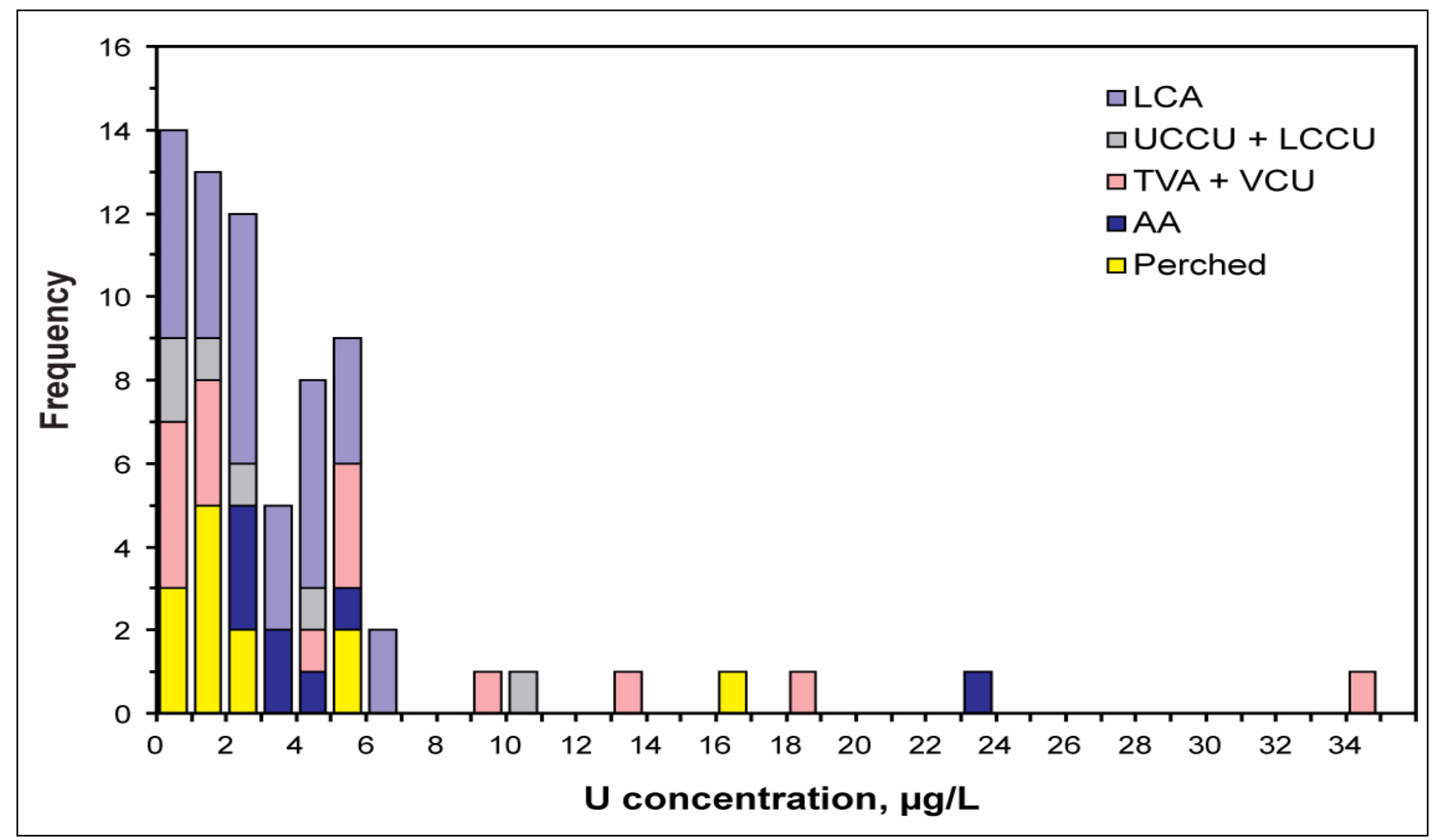

Figure 3-14

Stacked Frequency Distribution for Uranium Concentrations for Groundwater Samples in the Yucca Flat Vicinity

Values of ${ }^{234} \mathrm{U} /{ }^{238} \mathrm{U}$ activity ratio for groundwater samples collected within the study area vary from 1.30 to 7.05 (Figure 3-15). Patterns of $U$ concentration and ${ }^{234} \mathrm{U} / 238 \mathrm{U}$ activity ratio variation between the different HSUs are not diagnostic of flow paths and mixing processes, although water from the perched springs and volcanic aquifer and volcanic confining unit wells tends to have higher $\mathrm{U}$ concentrations and lower ${ }^{234} \mathrm{U} /{ }^{238} \mathrm{U}$ activity ratio relative to water from the LCA and clastic confining units.

\subsection{Mineralogy Data}

Geochemical models are used to simulate the water-rock interactions and the resulting changes of the chemical composition of groundwater. The degree to which the simulated geochemistry conforms to known groundwater geochemistry at various points along the flow path is a measure of the viability of each pathway. Information on the mineralogy of the aquifer matrix and fracture-surface coatings provides necessary constraints on the compositions of reactive phases. Considering that fracture flow 


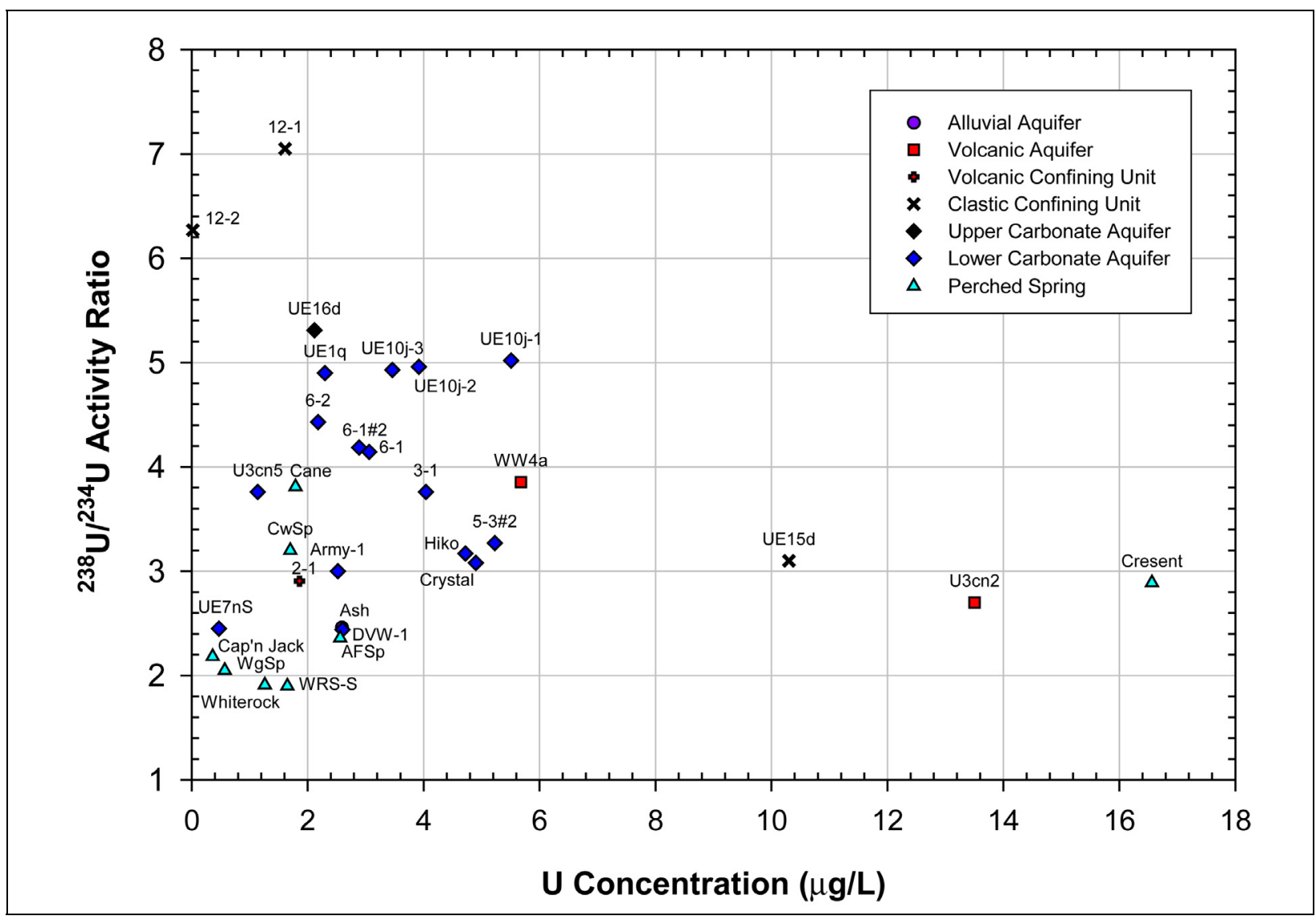

Figure 3-15

\section{${ }^{234} \mathrm{U} / 238 \mathrm{U}$ Activity Ratio Versus Uranium Concentration of Groundwater and Spring in the Yucca Flat Vicinity}

predominates in the volcanic and carbonate aquifers in the Yucca Flat/Climax Mine area, fracture-coating mineral phases are likely to exert significant influence on the composition of through-going water. Information is presented in this section on the mineralogy of volcanic, carbonate, and granite rocks present in the Yucca Flat basin.

\subsubsection{Mineralogy of Volcanic Rocks}

The chemical compositions of mineral and glass phases in volcanic rocks at the NTS have been characterized by electron microprobe analysis (Rose et al., 2002; Warren et al., 1998; IT, 1998). Although much of this work was performed on samples from Pahute Mesa boreholes, the volcanic stratigraphy beneath Yucca Flat is largely derived from the same sequence of caldera-forming eruptions. Hence, the volcanic rocks in both areas are expected to exhibit similar mineralogical characteristics. Average glass and feldspar mineral compositions were calculated from these datasets 
and are reported in Table 3-4. The number of glass and feldspar analyses included in the average for each of the major hydrogeologic units is as follows: Timber Mountain Aquifer (TMA): 76 glass, 263 feldspar; Paintbrush (PB) Group: 65 glass, 189 feldspar; Belted Range (BR) Group: 9 glass, 12 feldspar; and Pre-Belted Range (PBR) Composite Unit: 7 glass, 60 feldspar.

Glass and feldspar minerals constitute the principal reactive phases that are present in the bulk rock. However, groundwater flow through the volcanic units is largely controlled by fractures. Therefore, it is also important to consider data for reactive fracture-lining minerals, particularly clay and zeolite minerals. Fracture-mineral characterization studies were conducted on Pahute Mesa core samples to support earlier geochemical investigations (IT, 1998; Benedict et al., 2000). These studies included some quantitative chemical analyses of secondary fracture-lining phases, principally clays and zeolites (clinoptilolite and mordenite). These results were combined with supplementary mineral data contained in Warren et al. (1998) to obtain the clay and zeolite mineral compositions reported in Table 3-4.

Qualitative descriptions of fracture-coating phases reported by IT (1998) and Benedict et al. (2000) are as follows: In the TMA, fracture-lining minerals were characterized by calcite + mixed illite/smectite + opaline silica in the unsaturated zone (based on two samples) and calcite + mixed illite/smectite + quartz + feldspars + zeolites + iron $(\mathrm{Fe})$ - and manganese $(\mathrm{Mn})$-oxyhydroxides in the saturated zone (based on six samples). Fracture-coating phases representing the PBR consisted of Ca-Mg-Fe carbonate minerals + pyrite + chlorite + epidote + mixed illite/smectite + local Fe-oxides. In one sample from the BR aquifer, Fe- and Mn-oxyhydroxides were the dominant fracture phases, with subordinate amounts of calcite + quartz + feldspars + mixed illite/smectite.

Recent mineralogical studies of the TCU beneath Yucca Flat are described in Prothro (2005) and SNJV (2004d). Prothro (2005) identified three mineralogic zones within the TCU based on the relative abundances of primary and secondary mineral assemblages. The upper zone, the ZC zone, is dominated by the zeolite mineral clinoptilolite (ZC) with lesser amounts of felsic (FS) and clay (argillic) (AR) minerals. Relative mineral abundances in the ZC zone are generally represented as $\mathrm{ZC}>>\mathrm{FS}>>\mathrm{AR}$ and roughly corresponds to the LTCU HSU. The middle zone, the FS Zone, is dominated by felsic minerals (principally feldspar and quartz) with relative mineral abundances typically observed as FS $>\mathrm{ZC}>>$ AR. The FS zone roughly correlates with the OSBCU HSU. The 
Table 3-4

Summary of Site-Specific Mineral Phases

\begin{tabular}{|c|c|c|}
\hline $\begin{array}{c}\text { Phase } \\
\text { Name }^{1,2}\end{array}$ & Formula & PHREEQC Dissolution Reaction ${ }^{3}$ \\
\hline TMglass $^{3,4}$ & $\overline{\mathrm{K}_{0.368}} \mathrm{Na}_{0.383} \mathrm{Ca}_{0.024} \mathrm{Mg}_{0.005} \mathrm{Fe}_{0.026} \mathrm{Al}_{0.789} \mathrm{Si}_{4.173} \mathrm{O}_{10}$ & $\begin{array}{l}\mathrm{K}_{0.368} \mathrm{Na}_{0.383} \mathrm{Ca}_{0.024} \mathrm{Mg}_{0.005} \mathrm{Fe}_{0.026} \mathrm{Al}_{0.789} \mathrm{Si}_{4.173} \mathrm{O}_{10}+6.719 \mathrm{H}_{2} \mathrm{O}+3.254 \mathrm{H}^{+}=0.368 \mathrm{~K}^{+}+0.383 \mathrm{Na}^{+}+0.024 \mathrm{Ca}^{+2}+ \\
0.005 \mathrm{Mg}^{+2}+0.026 \mathrm{Fe}^{+3}+0.789 \mathrm{Al}^{+3}+4.173 \mathrm{H}_{4} \mathrm{SiO}_{4}\end{array}$ \\
\hline TMfeldspar ${ }^{3,4}$ & $\mathrm{~K}_{0.555} \mathrm{Na}_{0.428} \mathrm{Ca}_{0.021} \mathrm{Fe}_{0.006} \mathrm{Al}_{1.007} \mathrm{Si}_{2.980} \mathrm{O}_{8}$ & $\begin{array}{l}\mathrm{K}_{0.555} \mathrm{Na}_{0.428} \mathrm{Ca}_{0.021} \mathrm{Fe}_{0.006} \mathrm{Al}_{1.007} \mathrm{Si}_{2.980} \mathrm{O}_{8}+3.928 \mathrm{H}_{2} \mathrm{O}+4.064 \mathrm{H}^{+}=0.555 \mathrm{~K}^{+}+0.428 \mathrm{Na}^{+}+0.021 \mathrm{Ca}^{+2}+0.006 \mathrm{Fe}^{+3} \\
+1.007 \mathrm{Al}^{+3}+2.980 \mathrm{H}_{4} \mathrm{SiO}_{4}\end{array}$ \\
\hline TMclay $^{3,4}$ & $\mathrm{~K}_{0.017} \mathrm{Na}_{0.161} \mathrm{Ca}_{0.141} \mathrm{Mg}_{0.138} \mathrm{Fe}_{0.050} \mathrm{Al}_{2.438} \mathrm{Si}_{3.462} \mathrm{O}_{10}$ & $\begin{array}{l}\mathrm{K}_{0.017} \mathrm{Na}_{0.161} \mathrm{Ca}_{0.1414} \mathrm{Mg}_{0.138} \mathrm{Fe}_{0.055} \mathrm{Al}_{2.438} \mathrm{Si}_{3.462} \mathrm{O}_{10}+2.824 \mathrm{H}_{2} \mathrm{O}+8.200 \mathrm{H}^{+}=0.017 \mathrm{~K}^{+}+0.161 \mathrm{Na}^{+}+0.141 \mathrm{Ca}^{+2}+0.138 \\
\mathrm{Mg}^{+2}+0.050 \mathrm{Fe}^{+3}+2.438 \mathrm{Al}^{+3}+3.462 \mathrm{H}_{4} \mathrm{SiO}_{4}\end{array}$ \\
\hline TMclinopt $^{3}$ & $\mathrm{~K}_{0.295} \mathrm{Na}_{0.217} \mathrm{Ca}_{0.083} \mathrm{Al}_{0.735} \mathrm{Si}_{4.278} \mathrm{O}_{10}$ & $\begin{array}{l}\mathrm{K}_{0.295} \mathrm{Na}_{0.217} \mathrm{Ca}_{0.083} \mathrm{Al}_{0.735} \mathrm{Si}_{4.278} \mathrm{O}_{10}+7.1145 \mathrm{H}_{2} \mathrm{O}+2.883 \mathrm{H}^{+}=0.295 \mathrm{~K}^{+}+0.217 \mathrm{Na}^{+}+0.083 \mathrm{Ca}^{+2}+0.735 \mathrm{Al}^{+3}+ \\
4.278 \mathrm{H}_{4} \mathrm{SiO}_{4}\end{array}$ \\
\hline PBglass $^{3,4}$ & $\mathrm{~K}_{0.369} \mathrm{Na}_{0.423} \mathrm{Ca}_{0.026} \mathrm{Mg}_{0.003} \mathrm{Fe}_{0.034} \mathrm{Al}_{0.816} \mathrm{Si}_{4.123} \mathrm{O}_{10}$ & $\begin{array}{l}\mathrm{K}_{0.366} \mathrm{Na}_{0.422} \mathrm{Ca}_{0.026} \mathrm{Mg}_{0.003} \mathrm{Fe}_{0.034} \mathrm{Al}_{0.816} \mathrm{Si}_{4.123} \mathrm{O}_{10}+6.546 \mathrm{H}_{2} \mathrm{O}+3.400 \mathrm{H}^{+}=0.369 \mathrm{~K}^{+}+0.423 \mathrm{Na}^{+}+0.026 \mathrm{Ca}^{+2}+0.003 \\
\mathrm{Mg}^{+2}+0.034 \mathrm{Fe}^{+3}+0.816 \mathrm{Al}^{+3}+4.123 \mathrm{H}_{4} \mathrm{SiO}_{4}\end{array}$ \\
\hline PBfeldspar ${ }^{3,4}$ & $\mathrm{~K}_{0.490} \mathrm{Na}_{0.479} \mathrm{Ca}_{0.024} \mathrm{Fe}_{0.007} \mathrm{Al}_{1.003} \mathrm{Si}_{2.982} \mathrm{O}_{8}$ & $\begin{array}{l}\mathrm{K}_{0.490} \mathrm{Na}_{0.479} \mathrm{Ca}_{0.024} \mathrm{Fe}_{0.007} \mathrm{Al}_{1.003} \mathrm{Si}_{2.982} \mathrm{O}_{8}+3.928 \mathrm{H}_{2} \mathrm{O}+4.072 \mathrm{H}^{+}=0.490 \mathrm{~K}^{+}+0.479 \mathrm{Na}^{+}+0.024 \mathrm{Ca}^{+2}+0.007 \mathrm{Fe}^{+3}+ \\
1.003 \mathrm{Al}^{+3}+2.982 \mathrm{H}_{4} \mathrm{SiO}_{4}\end{array}$ \\
\hline PBclay ${ }^{3,4}$ & $\mathrm{~K}_{0.017} \mathrm{Na}_{0.161} \mathrm{Ca}_{0.141} \mathrm{Mg}_{0.138} \mathrm{Fe}_{0.050} \mathrm{Al}_{2.438} \mathrm{Si}_{3.462} \mathrm{O}_{10}$ & $\begin{array}{l}\mathrm{K}_{0.017} \mathrm{Na}_{0.161} \mathrm{Ca}_{0.141} \mathrm{Mg}_{0.138} \mathrm{Fe}_{0.050} \mathrm{Al}_{2.438} \mathrm{Si}_{3.462} \mathrm{O}_{10}+2.824 \mathrm{H}_{2} \mathrm{O}+8.200 \mathrm{H}^{+}=0.017 \mathrm{~K}^{+}+0.161 \mathrm{Na}^{+}+0.141 \mathrm{Ca}^{+2}+ \\
0.138 \mathrm{Mg}^{+2}+0.050 \mathrm{Fe}^{+3}+2.438 \mathrm{Al}^{+3}+3.462 \mathrm{H}_{4} \mathrm{SiO}_{4}\end{array}$ \\
\hline PBclinopt $^{3}$ & $\mathrm{~K}_{0.295} \mathrm{Na}_{0.217} \mathrm{Ca}_{0.083} \mathrm{Al}_{0.735} \mathrm{Si}_{4.278} \mathrm{O}_{10}$ & $\begin{array}{l}\mathrm{K}_{0.295} \mathrm{Na}_{0.217} \mathrm{Ca}_{0.083} \mathrm{Al}_{0.735} \mathrm{Si}_{4.278} \mathrm{O}_{10}+7.1145 \mathrm{H}_{2} \mathrm{O}+2.883 \mathrm{H}^{+}=0.295 \mathrm{~K}^{+}+0.217 \mathrm{Na}^{+}+0.083 \mathrm{Ca}^{+2}+0.735 \mathrm{Al}^{+3}+ \\
4.278 \mathrm{H}_{4} \mathrm{SiO}_{4}\end{array}$ \\
\hline BRglass $^{3,4}$ & $\mathrm{~K}_{0.399} \mathrm{Na}_{0.458} \mathrm{Ca}_{0.004} \mathrm{Mg}_{0.000} \mathrm{Fe}_{0.008} \mathrm{Al}_{0.705} \mathrm{Si}_{4.175} \mathrm{O}_{10}$ & $\begin{array}{l}\mathrm{K}_{0.399} \mathrm{Na}_{0.458} \mathrm{Ca}_{0.004} \mathrm{Mg}_{0.000} \mathrm{Fe}_{0.008} \mathrm{Al}_{0.705} \mathrm{Si}_{4.175} \mathrm{O}_{10}+6.848 \mathrm{H}_{2} \mathrm{O}+3.004 \mathrm{H}^{+}=0.399 \mathrm{~K}^{+}+0.458 \mathrm{Na}^{+}+0.004 \mathrm{Ca}^{+2}+0.000 \\
\mathrm{Mg}^{+2}+0.008 \mathrm{Fe}^{+3}+0.705 \mathrm{Al}^{+3}+4.175 \mathrm{H}_{4} \mathrm{SiO}_{4}\end{array}$ \\
\hline BRfeldspar 3,4 & $\mathrm{~K}_{0.427} \mathrm{Na}_{0.592} \mathrm{Ca}_{0.002} \mathrm{Mg}_{0.000} \mathrm{Fe}_{0.012} \mathrm{Al}_{0.969} \mathrm{Si}_{3.009} \mathrm{O}_{8}$ & $\begin{array}{l}\mathrm{K}_{0.427} \mathrm{Na}_{0.592} \mathrm{Ca}_{0.002} \mathrm{Mg}_{0.000} \mathrm{Fe}_{0.012} \mathrm{Al}_{0.969} \mathrm{Si}_{3.009} \mathrm{O}_{8}+4.035 \mathrm{H}_{2} \mathrm{O}+3.966 \mathrm{H}^{+}=0.427 \mathrm{~K}^{+}+0.592 \mathrm{Na}^{+}+0.002 \mathrm{Ca}^{+2}+0.000 \\
\mathrm{Mg}^{+2}+0.012 \mathrm{Fe}^{+3}+0.969 \mathrm{Al}^{+3}+3.009 \mathrm{H}_{4} \mathrm{SiO}_{4}\end{array}$ \\
\hline BRclay 3,4 & $\mathrm{~K}_{0.597} \mathrm{Na}_{0.090} \mathrm{Ca}_{0.060} \mathrm{Mg}_{0.057} \mathrm{Fe}_{0.540} \mathrm{Al}_{2.067} \mathrm{Si}_{3.453} \mathrm{O}_{11}$ & $\begin{array}{l}\mathrm{K}_{0.597} \mathrm{Na}_{0.090} \mathrm{Ca}_{0.060} \mathrm{Mg}_{0.057} \mathrm{Fe}_{0.540} \mathrm{Al}_{2.067} \mathrm{Si}_{3.453} \mathrm{O}_{11}+2.535 \mathrm{H}_{2} \mathrm{O}+8.742 \mathrm{H}^{+}=0.597 \mathrm{~K}^{+}+0.090 \mathrm{Na}^{+}+0.060 \mathrm{Ca}^{+2}+0.057 \\
\mathrm{Mg}^{+2}+0.540 \mathrm{Fe}^{+3}+2.067 \mathrm{Al}^{+3}+3.453 \mathrm{H}_{4} \mathrm{SiO}_{4}\end{array}$ \\
\hline BRclinopt $^{3}$ & $\mathrm{~K}_{0.295} \mathrm{Na}_{0.217} \mathrm{Ca}_{0.083} \mathrm{Al}_{0.735} \mathrm{Si}_{4.278} \mathrm{O}_{10}$ & $\begin{array}{l}\mathrm{K}_{0.295} \mathrm{Na}_{0.217} \mathrm{Ca}_{0.083} \mathrm{Al}_{0.735} \mathrm{Si}_{4.278} \mathrm{O}_{10}+7.1145 \mathrm{H}_{2} \mathrm{O}+2.883 \mathrm{H}^{+}=0.295 \mathrm{~K}^{+}+0.217 \mathrm{Na}^{+}+0.083 \mathrm{Ca}^{+2}+0.735 \mathrm{Al}^{+3}+ \\
4.278 \mathrm{H}_{4} \mathrm{SiO}_{4}\end{array}$ \\
\hline PBRglass $^{3,4}$ & $\mathrm{~K}_{0.332} \mathrm{Na}_{0.408} \mathrm{Ca}_{0.023} \mathrm{Mg}_{0.002} \mathrm{Sr}_{0.001} \mathrm{Fe}_{0.014} \mathrm{Al}_{0.772} \mathrm{Si}_{4.187} \mathrm{O}_{10}$ & $\begin{array}{l}\mathrm{K}_{0.332} \mathrm{Na}_{0.408} \mathrm{Ca}_{0.023} \mathrm{Mg}_{0.002} \mathrm{Sr}_{0.001} \mathrm{Fe}_{0.014} \mathrm{Al}_{0.772} \mathrm{Si}_{4.187} \mathrm{O}_{10}+6.799 \mathrm{H}_{2} \mathrm{O}+3.150 \mathrm{H}^{+}=0.332 \mathrm{~K}^{+}+0.408 \mathrm{Na}^{+}+0.023 \mathrm{Ca}^{+2}+ \\
0.002 \mathrm{Mg}^{+2}+0.001 \mathrm{Sr}^{+2}+0.014 \mathrm{Fe}^{+3}+0.772 \mathrm{Al}^{+3}+4.187 \mathrm{H}_{4} \mathrm{SiO}_{4}\end{array}$ \\
\hline PBRfeldspar ${ }^{3,4}$ & $\mathrm{~K}_{0.392} \mathrm{Na}_{0.408} \mathrm{Ca}_{0.018} \mathrm{Sr}_{0.001} \mathrm{Fe}_{0.006} \mathrm{Al}_{0.972} \mathrm{Si}_{2.822} \mathrm{O}_{8}$ & $\begin{array}{l}\mathrm{K}_{0.392} \mathrm{Na}_{0.408} \mathrm{Ca}_{0.018} \mathrm{Sr}_{0.001} \mathrm{Fe}_{0.000} \mathrm{Al}_{0.972} \mathrm{Si}_{2.822} \mathrm{O}_{8}+3.758 \mathrm{H}_{2} \mathrm{O}+3.772 \mathrm{H}^{+}=0.392 \mathrm{~K}^{+}+0.408 \mathrm{Na}^{+}+0.018 \mathrm{Ca}^{+2}+0.001 \\
\mathrm{Sr}^{+2}+0.006 \mathrm{Fe}^{+3}+0.972 \mathrm{Al}^{+3}+2.822 \mathrm{H}_{4} \mathrm{SiO}_{4}\end{array}$ \\
\hline PBRclay $^{3,4}$ & $\mathrm{~K}_{0.658} \mathrm{Na}_{0.022} \mathrm{Ca}_{0.014} \mathrm{Mg}_{0.209} \mathrm{Fe}_{0.514} \mathrm{Al}_{1.352} \mathrm{Si}_{3.422} \mathrm{O}_{11}$ & $\begin{array}{l}\mathrm{K}_{0.655} \mathrm{Na}_{0.022} \mathrm{Ca}_{0.014} \mathrm{Mg}_{0.209} \mathrm{Fe}_{0.514} \mathrm{Al}_{1.352} \mathrm{Si}_{3.422} \mathrm{O}_{11}+3.482 \mathrm{H}_{2} \mathrm{O}+6.724 \mathrm{H}^{+}=0.658 \mathrm{~K}^{+}+0.022 \mathrm{Na}^{+}+0.014 \mathrm{Ca}^{+2}+0.209 \\
\mathrm{Mg}^{+2}+0.514 \mathrm{Fe}^{+3}+1.352 \mathrm{Al}^{+3}+3.422 \mathrm{H}_{4} \mathrm{SiO}_{4}\end{array}$ \\
\hline PBRclinopt $^{3}$ & $\mathrm{~K}_{0.295} \mathrm{Na}_{0.217} \mathrm{Ca}_{0.083} \mathrm{Al}_{0.735} \mathrm{Si}_{4.278} \mathrm{O}_{10}$ & $\begin{array}{l}\mathrm{K}_{0.295} \mathrm{Na}_{0.217} \mathrm{Ca}_{0.083} \mathrm{Al}_{0.735} \mathrm{Si}_{4.278} \mathrm{O}_{10}+7.1145 \mathrm{H}_{2} \mathrm{O}+2.883 \mathrm{H}^{+}=0.295 \mathrm{~K}^{+}+0.217 \mathrm{Na}^{+}+0.083 \mathrm{Ca}^{+2}+0.735 \mathrm{Al}^{+3}+ \\
4.278 \mathrm{H}_{4} \mathrm{SiO}_{4}\end{array}$ \\
\hline
\end{tabular}

${ }_{1} \mathrm{TM}=$ Timber Mountain, $\mathrm{PB}=$ Paintbrush, $\mathrm{BR}=$ Belted Range, $\mathrm{PBR}=$ Pre-Belted Range

${ }^{2}$ Clinopt $=$ Combined mordenite/clinoptilolite compositions, Clay $=$ Illite/smectite compositions

क 3 IT, 1998

${ }^{4}$ Warren et al., 1998 
lowest of the three zones is the basal AR zone, with relative abundances of AR $>F S>>Z C$. The AR zone roughly correlates with the ATCU HSU.

The composition and distribution of minerals in the rock matrix and along potential fast groundwater pathways (faults and fractures) within the Yucca Flat TCU were recently investigated by SNJV (2004d). A total of 39 core samples from four vertical exploratory boreholes (UE-7az, UE-7ba, UE-7bc, and UE-7f) were investigated. These boreholes were among those that Prothro (2005) used to identify mineral zonations within the TCU. The secondary minerals in the TCU are typical of the assemblages that develop during low temperature alteration of tuffaceous volcanic rocks. In approximate order of decreasing abundance these include: clinoptilolite, illite/smectite, erionite/mordenite, alkali feldspar, silica (quartz), calcite, analcime, and secondary Mn- and Fe-oxides. Calcite $\delta^{13} \mathrm{C}$ results for 18 samples from the four Yucca Flat boreholes are reported in Table 3-2. Fracture lining calcite $\delta^{18} \mathrm{O}$ analyses indicated maximum alteration temperatures of approximately $80^{\circ} \mathrm{C}$. Although quantitative electron microprobe analyses were not performed for these samples, this study showed that the suite of secondary minerals present in the volcanic tuffs beneath Yucca Flat is very similar to that found at Pahute Mesa.

\subsubsection{Lower Carbonate Aquifer Mineralogy}

The LCA consists of thick sequences of Middle Cambrian-age through Upper Devonian-age carbonate rocks (Winograd and Thordarson, 1975; BN, 2006). Carbonate rocks consist of mostly calcite and dolomite, with minor amounts of chert $\left(\mathrm{SiO}_{2}\right)$ and clay minerals. Fracture-lining minerals in LCA core samples from wells ER-6-1 and ER-6-2 in southern Yucca Flat were found to contain Fe-oxides (limonite and hematite) and trace amounts of Mn-oxides, carbonaceous clays, secondary calcite, and rarely dolomite (IT, 1996c). It was noted that silica cements are rare and restricted to fractures in interbedded quartzite lithologies. The extensional fractures, which had measurable apertures, were typically lined with crystalline calcite or, less often, dolomite. Clay-filling was almost exclusively associated with shear fractures, and the clay is probably authigenic. The shear fractures were observed to be completely filled with no observable open spaces.

Bulk rock LCA samples from eleven different depth intervals (2,240 to 3,125 ft bgs) in ER-6-1 were analyzed by Reimus et al. (2005) using quantitative X-ray diffraction (QXRD). The results indicated that dolomite was dominant (71 to 99 percent) in all but one sample. Calcite ( 0.1 to 25 percent) and 
minor amounts of quartz ( 0 to 3.7 percent), apatite ( 0 to 2 percent), and illite ( 0 to 5.5 percent) were also present. The sample from the deepest zone (3,125 ft bgs) consisted of approximately 98.6 percent quartz and 1.5 percent calcite and presumably reflects a quartzite interlayer. In addition to the QXRD analysis, Reimus et al. (2005) used X-ray photoelectron spectroscopy (XPS) to characterize the surface mineralogy of several samples from ER-6-1. The dominant minerals within the seven samples analyzed by XPS included calcite, dolomite, alkali feldspar, Fe oxides, and "aluminosilicates" (presumably clay minerals). These results are consistent with earlier observations reported by IT (1996c).

\subsubsection{Mineralogy of Fractured Granite in the Climax Stock}

Secondary fracture-coating minerals occurring in the Climax Stock at the north end of Yucca Flat were characterized using micrographic and stable isotope ratio analytical methods (SNJV, 2004c). A total of 12 core samples were selected from two vertical exploratory boreholes located within the Climax Stock, UE-15g (353 to $504 \mathrm{ft}$ bgs) and U-15b\#2 (1495.5 to $1604.5 \mathrm{ft} \mathrm{bgs).} \mathrm{Two} \mathrm{distinct} \mathrm{suites}$ of secondary minerals were observed. The earliest-formed assemblage is typical of hydrothermal alteration associated with porphyry sulfide mineralization and includes quartz, feldspar (albite and adularia), sericite (muscovite), epidote, and sulfide minerals (mainly pyrite, with minor molybdenite and chalcopyrite). Previous studies have suggested that the hydrothermal minerals formed at maximum temperatures of 365 to $450^{\circ} \mathrm{C}$ (Connolly, 1981; Ryerson and Qualheim, 1983).

The early formed hydrothermal mineral assemblage is overprinted by a later-formed, low temperature suite of secondary alteration minerals. These include clay minerals, chlorite, calcite, and secondary Fe- and Mn-oxides (SNJV, 2004c; see also Ryerson and Beiriger, 1985; Blouin et al., 2003). Calcite $\delta^{13} \mathrm{C}$ results for samples from U-15b \#2 and UE-15g are reported in Table 3-2. With one exception, the calcite $\delta^{13} \mathrm{C}$ values appear to be consistent with a pedogenic (soil zone) carbonate source. The development of secondary minerals in the Climax Stock is extensive only along joints and fractures. Isherwood et al. (1982) note that high-angle fractures in the tunnels associated with the Pile Driver test (1,380 ft depth) contain abundant calcite, with some Fe-oxides, clays, and chlorite whereas subhorizontal fractures in the same workings more commonly contain quartz and pyrite. The predominance of low temperature minerals along the near-vertical fractures may reflect the downward percolation of oxidizing groundwater from the surface. 


\subsection{Groundwater Recharge}

This chapter describes the chemical and isotopic composition of modern groundwater recharge in the Yucca Flat study area. Recharge is an important component of many geochemical models developed during this study, particularly in the northern part of Yucca Flat. However, defining the composition of recharge has proven to be problematic. The geochemical modeling process revealed that a single recharge composition could not be defined that would satisfy every model. The chemical and isotopic heterogeneity of the different groundwater masses within the basin required flexibility in the recharge composition used in the models. This variability in recharge composition probably reflects the spatial and temporal variability of precipitation and recharge processes within the study area.

Most recharge within Yucca Flat results from precipitation at the higher elevation on Rainier Mesa and in the Belted Range (Laczniak et al., 1996). Rocks exposed at the surface to the east, north, and northeast of Yucca Flat typically have low permeabilities and are classified as confining units. Infiltration is low due to semi-arid climate conditions and low surface permeability. Much of the precipitation results in runoff to ephemeral streams, which dissipates at lower elevations through infiltration into the streambeds. Infiltration and recharge may also occur on the floor of the basin. Once recharged to the water table, groundwater may move downward from the shallower alluvium and volcanic rocks to the deeper LCA. A steep water-level gradient exists between the surrounding highlands and Yucca Flat because of the presence of confining units overlying the LCA in this area (Figures 2-5, 2-7 and 2-8). The rate of recharge from precipitation within the Yucca Flat basin is low due to the low rate of precipitation as well as the low rate of infiltration (Tyler et al., 1996; Russell and Minor, 2002; Hevesi et al., 2003).

\subsection{Isotopic Signature}

The $\delta \mathrm{D}$ and $\delta^{18} \mathrm{O}$ values of precipitation are strongly dependent on temperature, and vary with latitude, elevation, and distance from the ocean (Dansgaard, 1964). As a storm system moves inland from the Pacific Ocean, the removal of precipitation gradually depletes the system of its heavy 
isotopes (Ingraham and Taylor, 1991). Water molecules are partitioned between the vapor (cloud) and liquid (raindrop) according to differences in mass. Molecules containing heavy isotopes have a greater tendency to go into the liquid phase, whereas molecules containing light isotopes tend to remain in the vapor. This process is referred to as isotopic fractionation. In general, cooler temperatures produce larger fractionation effects. For example, as a saturated air mass rises up a mountain range and cools, the $\delta \mathrm{D}$ and $\delta^{18} \mathrm{O}$ values of its precipitation decrease with increasing altitude. These isotopic signatures are preserved once the precipitation infiltrates to the saturated groundwater zone. It is therefore possible to use $\delta \mathrm{D}$ and $\delta^{18} \mathrm{O}$ values to establish the recharge location for a groundwater, particularly in areas with significant topographic relief.

Long-term variations in the isotopic composition of precipitation and recharge may complicate the interpretation of groundwater isotope signatures in Yucca Flat. Proxy paleoclimate records are consistent with greater effective moisture in the Great Basin during the late Pleistocene. For example, the widespread occurrence of paleospring deposits marks episodes of increased recharge and higher water tables during the late Pleistocene (Quade et al., 1995, 1998). Increased recharge rates imply a significant volume of groundwater was added to the regional aquifers at that time. The extent to which this water persists today is largely a function of groundwater flow velocities and turnover rates for individual sub-basins. Previous isotope hydrology studies in the Oasis Valley-Yucca Mountain-Amargosa Desert region (central Death Valley Regional Flow System) concluded that most groundwater in south-central Nevada was probably recharged following the last major cycle of the pluvial period (Claassen, 1986; White and Chuma, 1987; Benson and Klieforth, 1989).

To evaluate the $\delta \mathrm{D}$ and $\delta^{18} \mathrm{O}$ compositions of modern precipitation on the NTS, samples for isotopic analysis were collected between 1982 and 1986 from the 14 precipitation stations shown in Figure 4-1. The coordinates, elevations, and weighted average values of $\delta \mathrm{D}$ and $\delta^{18} \mathrm{O}$ for each station are presented in Table 4-1. The $\delta \mathrm{D}$ and $\delta^{18} \mathrm{O}$ pairs for all samples collected during this period are shown in Figure 4-2. A local meteoric water line (LMWL) representing the observed correlations in $\delta^{18} \mathrm{O}-\delta \mathrm{D}$ values was estimated based on these data (Ingraham et al., 1990 and 1991). The LMWL, shown in Figure 4-2, is defined by the equation $\delta \mathrm{D}=6.87 \delta^{18} \mathrm{O}-6.5$. The global meteoric water line (GMWL), also shown in Figure 4-2, represents the observed correlations in $\delta^{18} \mathrm{O}-\delta \mathrm{D}$ values of precipitation samples from around the world and is defined by the equation $\delta \mathrm{D}=8 \delta^{18} \mathrm{O}+10$ 


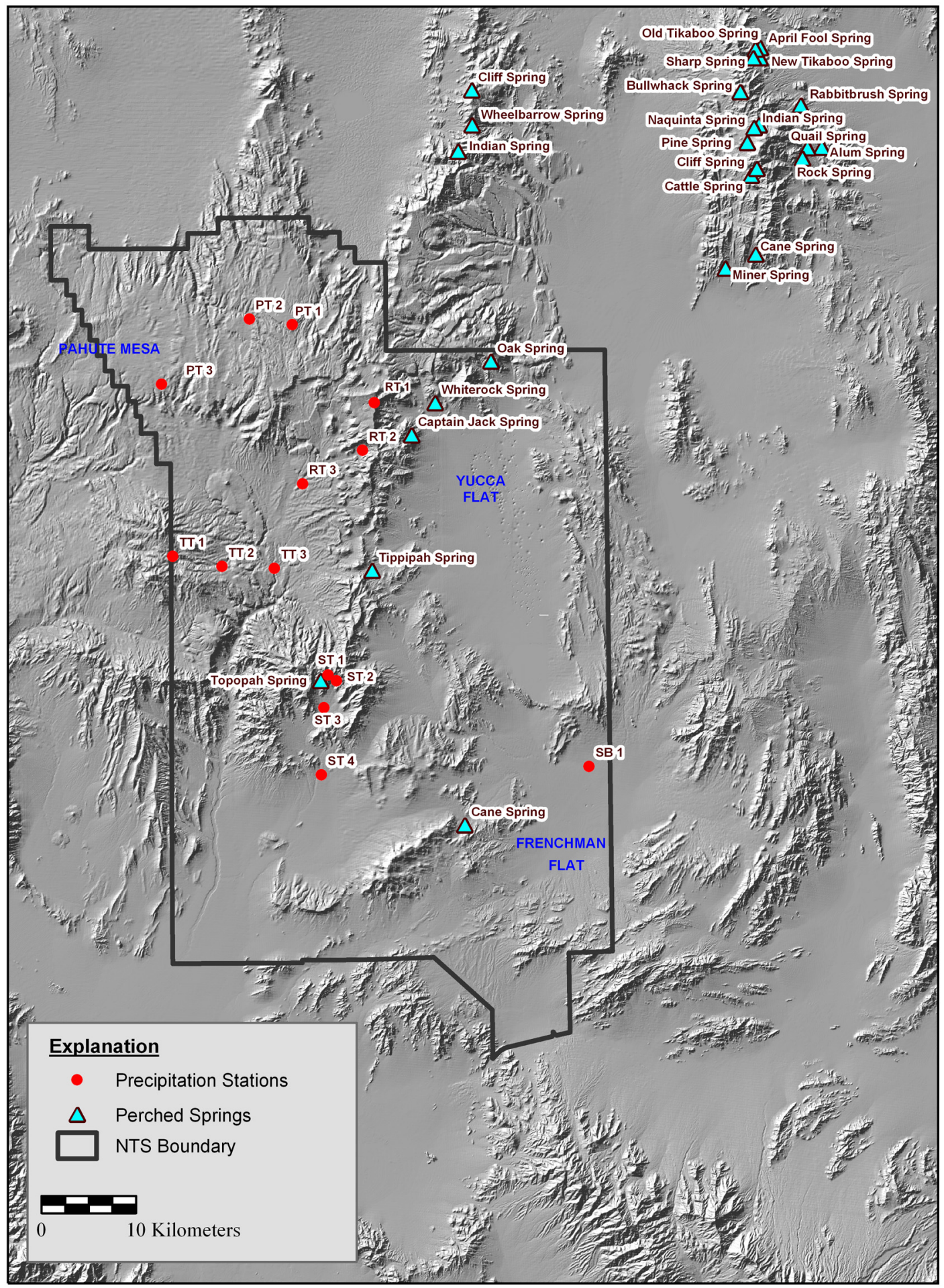

Figure 4-1

Location of Precipitation Sampling Sites at the Nevada Test Site and Perched Springs at the Nevada Test Site, Groom Range, and the Belted Range 
Table 4-1

Location and Elevation of Precipitation Sampling Sites at the NTS. Also Included Are the Average $\delta D$ and $\delta^{18} O$ Weighted by Precipitation Amount for Each Station

\begin{tabular}{||c|c|c|c|c|c|}
\hline Station & $\begin{array}{c}\text { Elevation } \\
\mathbf{( m )}\end{array}$ & $\begin{array}{c}\text { UTM } \\
\text { Northing }\end{array}$ & $\begin{array}{c}\text { UTM } \\
\text { Easting }\end{array}$ & $\begin{array}{c}\delta^{\mathbf{1 8}} \mathbf{O} \\
\text { (Permil) }\end{array}$ & $\begin{array}{c}\delta \mathbf{D} \\
\text { (Permil) }\end{array}$ \\
\hline \hline PT1 & 2,200 & $4,125,835$ & 562,094 & -12.5 & -92.6 \\
\hline PT2 & 2,060 & $4,126,429$ & 557,552 & -13.2 & -96.9 \\
\hline PT3 & 1,890 & $4,119,540$ & 548,282 & -12.2 & -91.7 \\
\hline RT1 & 2,235 & $4,117,577$ & 570,716 & -12.7 & -92.0 \\
\hline RT2 & 1,900 & $4,112,545$ & 569,485 & -12.9 & -95.4 \\
\hline RT3 & 1,590 & $4,109,018$ & 563,189 & -11.0 & -81.8 \\
\hline SB1 & 960 & $4,079,109$ & 593,401 & -9.5 & -73.4 \\
\hline ST1 & 2,135 & $4,088,794$ & 565,881 & -12.5 & -90.3 \\
\hline ST2 & 1,830 & $4,088,188$ & 566,767 & -12.4 & -90.4 \\
\hline ST3 & 1,525 & $4,085,319$ & 565,436 & -11.7 & -85.6 \\
\hline ST4 & 1,225 & $4,078,218$ & 565,156 & -11.6 & -86.6 \\
\hline TT1 & 1,840 & $4,101,352$ & 549,473 & -10.3 & -76.2 \\
\hline TT2 & 1,630 & $4,100,274$ & 554,657 & -11.3 & -82.4 \\
\hline TT3 & 1,400 & $4,100,080$ & 560,204 & -11.4 & -86.8 \\
\hline
\end{tabular}

Source: Ingraham et al., 1990

$\mathrm{m}=$ Meter

UTM = Universal Transverse Mercator

(Craig, 1961). The LMWL has a slightly lower slope than the GMWL, demonstrating the effect of evaporation by southern Nevada's semi-arid climate on warm season precipitation (Figure 4-2)

The weighted averages for $\delta \mathrm{D}$ and $\delta^{18} \mathrm{O}$ values for precipitation collected from the 14 stations ranged from -96.9 to -73.4 permil $\delta \mathrm{D}$ and -13.2 to -9.5 permil $\delta^{18} \mathrm{O}$ (Table 4-1). The weighted average takes into account the variable volumes of sample collected. Note that the lowest (most negative) $\delta \mathrm{D}$ and $\delta^{18} \mathrm{O}$ values tend to occur at the highest elevation stations, in accordance with the temperature dependence of stable isotope fractionation (Criss, 1999). Seasonally, the isotopic signature of precipitation varies with heavier isotopic content in the warmer part of the year and lighter isotopic content in the cooler part (Figure 4-3) as expected from seasonal changes in temperature and climatic water-vapor sources (Winograd et al., 1998).

The timing and extent of groundwater recharge is known to vary seasonally. Stable isotope studies suggest that most of the recharge in southern Nevada occurs during the melting of the winter snowpack, when evapotranspiration rates are low. Warm season precipitation is estimated to contribute only 10 to 40 percent of the recharge budget in this area (Winograd et al., 1998; Hershey 


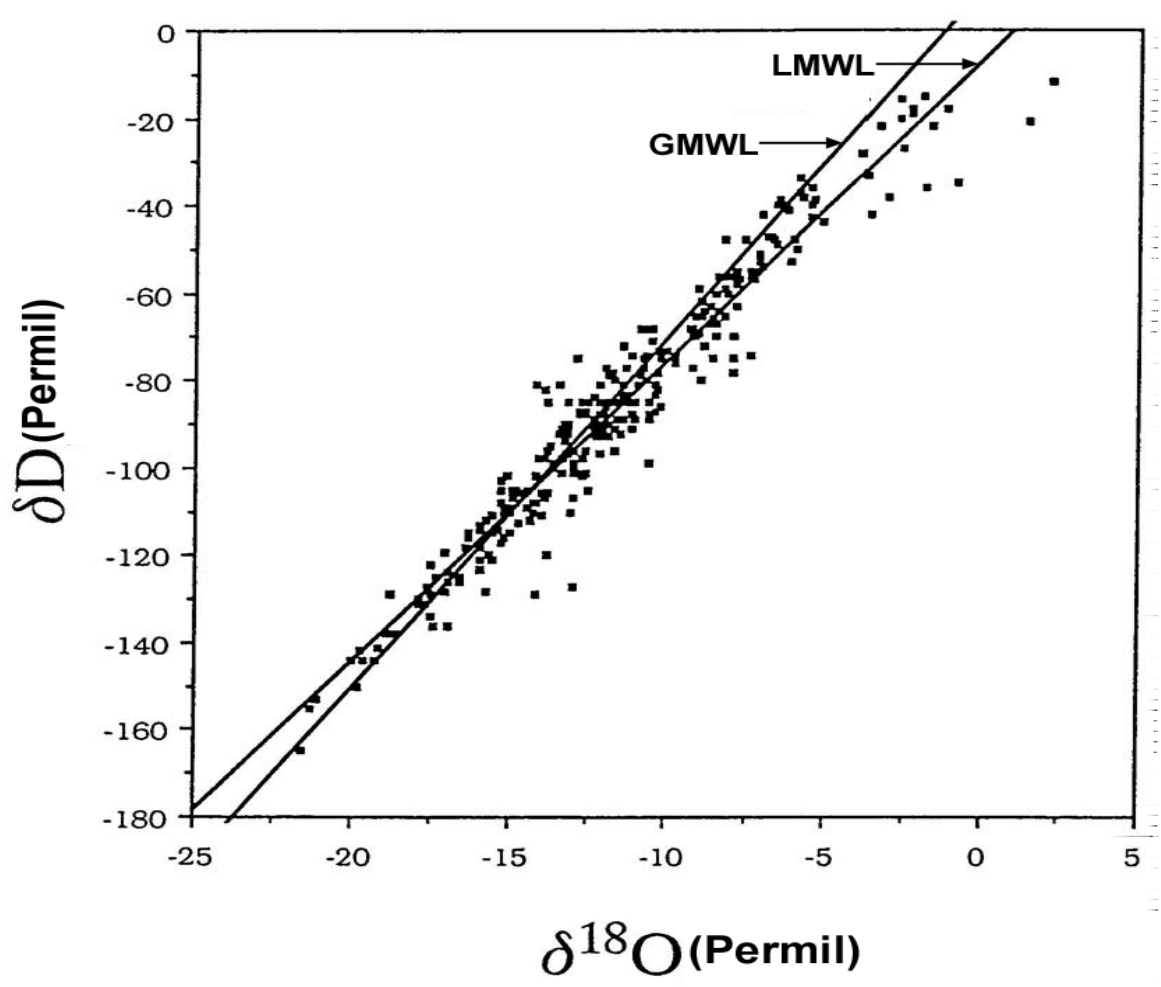

Figure 4-2

$\delta D$ Versus $\delta^{18} O$ for Precipitation Collected at the NTS from 1982 to 1986

Note: Also shown are the GMWL and the LMWL. Modified from Ingraham et al., 1991

et al., 1991). Because groundwater recharge tends to be dominated by cool season precipitation, the $\delta \mathrm{D}$ and $\delta^{18} \mathrm{O}$ values of the recharge will tend to be somewhat lower (more negative) than the mean annual precipitation value (Rose et al., 2003).

Perched groundwater associated with small springs and seeps can be used as a proxy for the average composition of local recharge if the water has not experienced large amount of post-discharge evaporation (Rose et al., 2003). Six perched springs with isotopic data are located immediately surrounding or near to Yucca Flat (Figure 4-1). Additionally, 19 perched springs with isotopic data are located north of Yucca Flat in the Belted and Groom Ranges (Figure 4-1). Of the six springs on the NTS, two (Cane and Whiterock Springs) have six years of monthly to bimonthly grab samples collected for $\delta \mathrm{D}$ and $\delta^{18} \mathrm{O}$ analyses (Lyles et al., 1990). The other NTS springs and springs in the Belted and Groom Ranges have, at most, one to three samples analyzed for $\delta \mathrm{D}$ and $\delta^{18} \mathrm{O}$. 


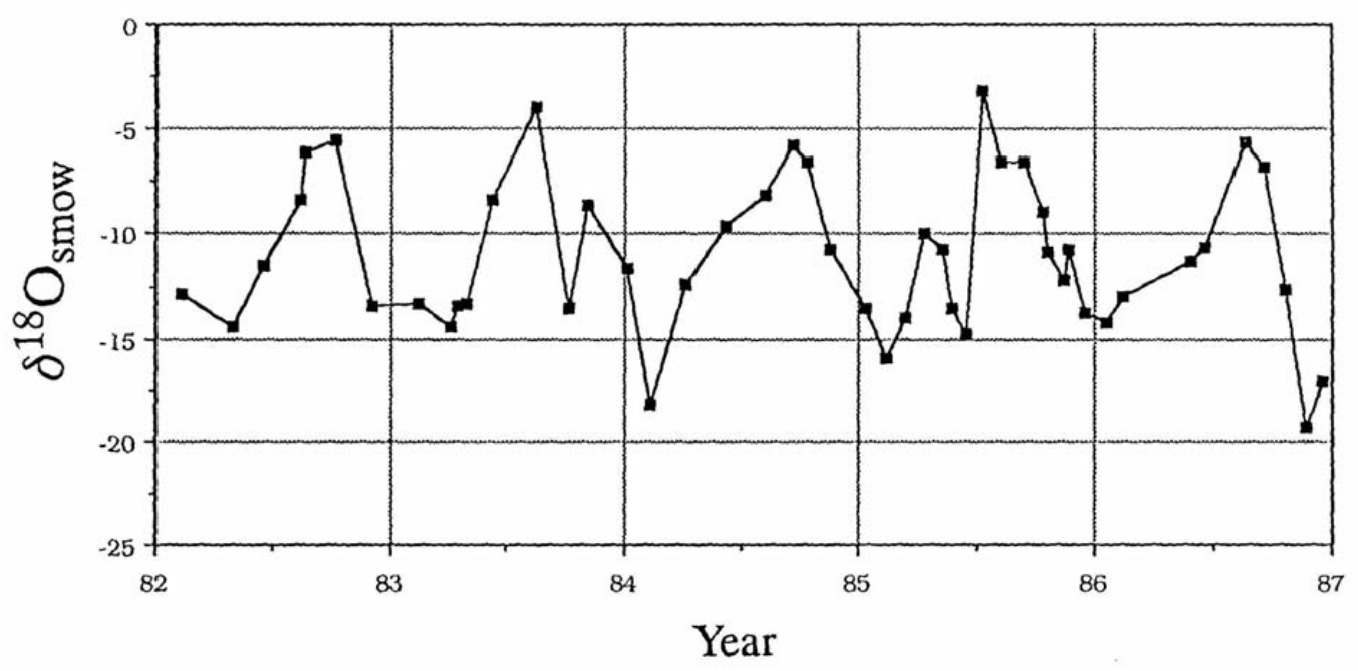

Figure 4-3

Weighted Average of $\delta^{18} \mathrm{O}$ from All Precipitation Sampling Sites at the NTS from 1982 to 1986 (Ingraham et al., 1991)

The average $\delta \mathrm{D}$ and $\delta^{18} \mathrm{O}$ content for the perched springs are shown in Figure 4-4. The spring data plot along an evaporation line with a characteristic slope of $\sim 3.5$, which reflects a kinetic isotope exchange process with water vapor in the air (Craig et al., 1963). A regression line through the spring data intersects the LMWL at approximately -97.7 permil $\delta \mathrm{D}$ and -13.3 permil $\delta^{18} \mathrm{O}$ (the intersection with the GMWL gives slightly lower values). These values represent the approximate composition of groundwater recharge in the northern NTS region before any evaporation effects.

Note that evaporation may occur either during infiltration (Barnes and Allison, 1983; Allison et al., 1983; DePaolo et al., 2004) or after spring discharge. The extent of pre-recharge vs. post-discharge evaporation is unknown for the perched spring dataset that was used in the current study. However, given that nearly all of the $\delta \mathrm{D}-\delta^{18} \mathrm{O}$ data for southern Nevada groundwater plot below the meteoric water line, it would appear that pre-recharge evaporation is a significant process in this area (Davisson et al., 1999). Post-discharge evaporation at NTS springs has also been documented (Hansen et al. 1997; Ingraham et al., 1991; and Lyles et al., 1990). 


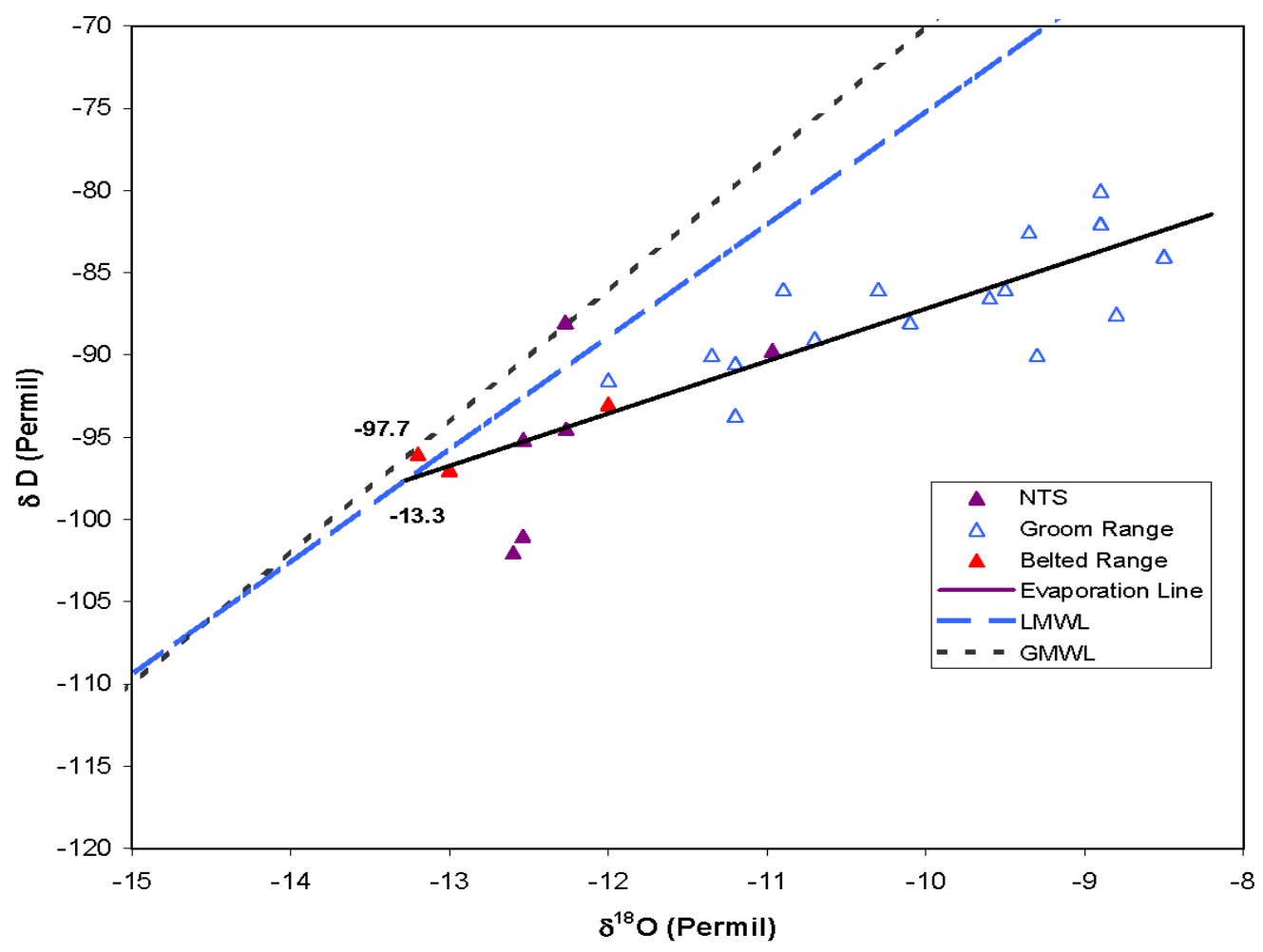

Figure 4-4

Average Isotopic Values for Spring Discharge at the NTS, Groom Range, and Belted Range

Note: Evaporation line intersects the LMWL at -13.3 permil $\delta^{18} \mathrm{O}$ and -97.7 permil $\delta \mathrm{D}$.

Another source of information regarding groundwater recharge in the Yucca Flat region is available from mining activities for nuclear testing at Rainier Mesa and the Climax Stock. Stable isotope data for tunnel seeps are plotted in Figure 4-5 together with data for springs the northwestern part of Yucca Flat. Although there is some variability between the different tunnels (E, N, and T Tunnels), the tunnel waters are not significantly evaporated and plot close to the LMWL. Several tunnel samples collected in 1999 from impounded water behind the sealed bulkheads are somewhat isotopically lighter than the average isotopic composition of non-evaporated groundwater recharge (approximately -13.5 permil $\delta^{18} \mathrm{O}$ and -98 permil $\delta \mathrm{D}$ on the GMWL). The Climax Stock sample falls along the LMWL and is similar in composition to the NTS springs (Figure 4-5). 


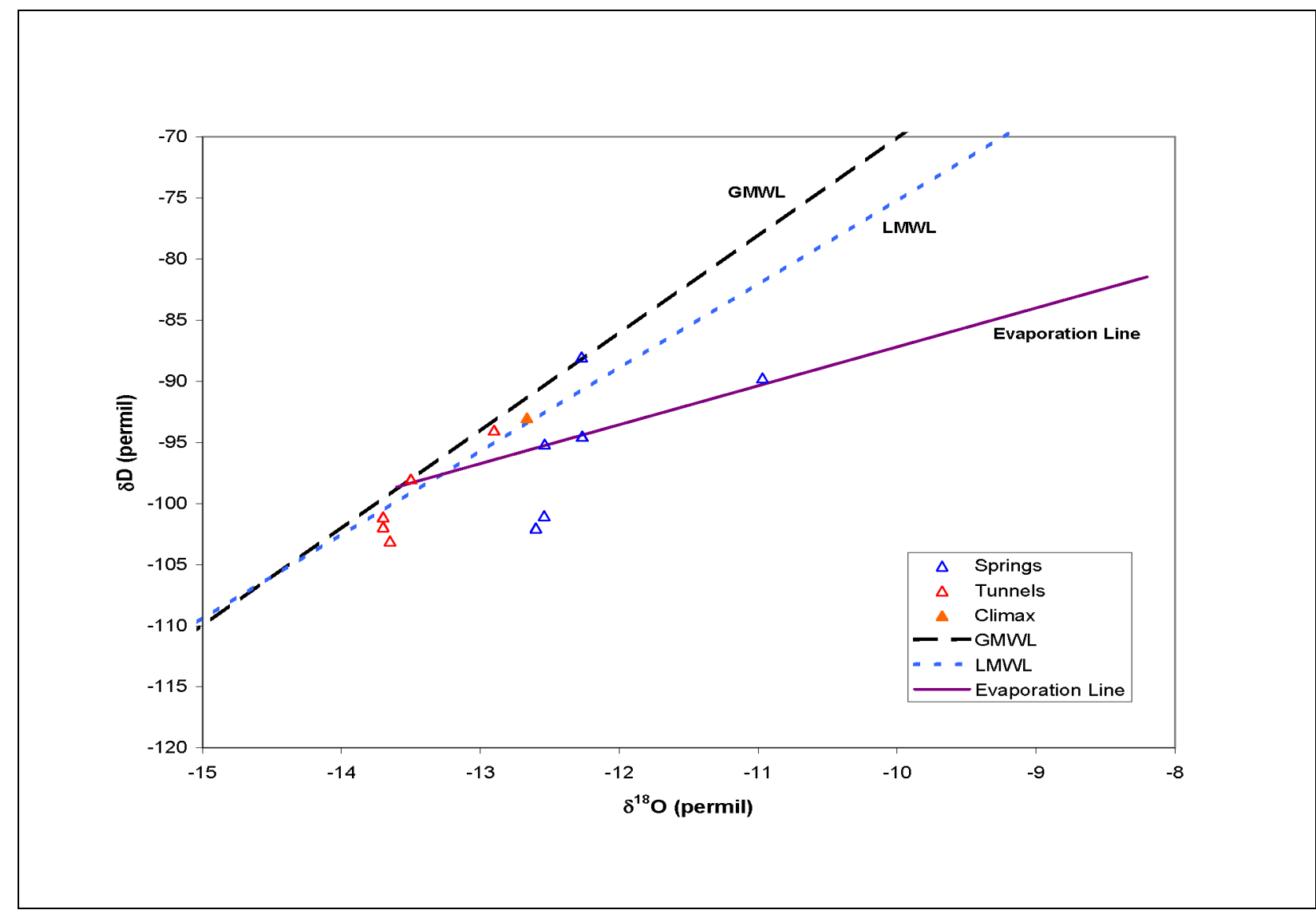

Figure 4-5

Isotopic Values for NTS Perched Springs, Rainier Mesa Tunnels, and the Climax Stock

Carbon-14 and tritium $\left({ }^{3} \mathrm{H}\right)$ values for samples collected from the six NTS springs are shown in Table 4-2. All of the springs except for Cane Spring had measurable amounts of ${ }^{3} \mathrm{H}$, confirming that a least a portion of the spring discharge is derived from recent recharge (since the 1950s). Whiterock Spring had a small amount of measurable ${ }^{3} \mathrm{H}$ and a significant amount of modern ${ }^{14} \mathrm{C}$ giving an uncorrected age of 800 years. Although no measurable ${ }^{3} \mathrm{H}$ was observed in Cane Spring, a large amount of modern ${ }^{14} \mathrm{C}$ was present giving an uncorrected age of 1,600 years.

\subsection{Water Chemistry}

The chemistry of the NTS springs is used to represent the composition of recent recharge to the groundwater system in Yucca Flat. The NTS springs are relatively dilute (Table 4-3 ); calculated total dissolved solids (TDS) for five of the six NTS springs range from 113 to $191 \mathrm{mg} / \mathrm{L}$. Cane Spring, the most evaporated NTS spring as indicated by $\delta^{18} \mathrm{O}$ and $\delta \mathrm{D}$, has the highest TDS, $326 \mathrm{mg} / \mathrm{L}$. The 
Table 4-2

Carbon-14 and Tritium Values for NTS Springs

\begin{tabular}{|c|c|c|}
\hline Spring & $\begin{array}{c}{ }^{3} \mathrm{H} \\
(\mathbf{p C i} / \mathbf{L})\end{array}$ & $\begin{array}{c}{ }^{14} \mathbf{C} \\
(\mathbf{p m c})\end{array}$ \\
\hline \hline Cane & $<6.0$ & 86 \\
\hline Captain Jack & 185 & $\mathrm{~N} / \mathrm{A}$ \\
\hline Oak & 67 & $\mathrm{~N} / \mathrm{A}$ \\
\hline Tippipah & 50 & $\mathrm{~N} / \mathrm{A}$ \\
\hline Topopah & 74 & $\mathrm{~N} / \mathrm{A}$ \\
\hline Whiterock & 41 & 91 \\
\hline
\end{tabular}

$\mathrm{N} / \mathrm{A}=$ Not available

$\mathrm{pCi} / \mathrm{L}=$ Picocuries per liter

pmc $=$ Percent modern carbon

Table 4-3

Total Dissolved Solids and Chloride Concentrations for NTS Perched Spring, Rainier Mesa Tunnel, and Climax Stock Groundwater Samples

\begin{tabular}{|l|c|c|}
\hline \multicolumn{1}{|c|}{ Name } & $\begin{array}{c}\text { TDS } \\
\text { (mg/L) }\end{array}$ & $\begin{array}{c}\text { Chloride } \\
\text { (mg/L) }\end{array}$ \\
\hline \hline Cane Spring & 326 & 22.4 \\
\hline Captain Jack Spring & 132 & 6.1 \\
\hline Oak Spring & 184 & 9.2 \\
\hline Tipippah Spring & 170 & 7.4 \\
\hline Topopah Spring & 113 & 2.9 \\
\hline Whiterock Spring & 191 & 10.3 \\
\hline U12e Tunnel & 247 & 9.2 \\
\hline U12n Tunnel & 247 & 9.9 \\
\hline U12t Tunnel & 215 & 10.4 \\
\hline ER-12-1 & 690 & 17.2 \\
\hline ER-12-2 & 333 & 6.8 \\
\hline HTH-1 & 139 & 3.3 \\
\hline UE-16d & 408 & 11 \\
\hline UE-16f & 907 & 19.7 \\
\hline UE-17a & 495 & 30.4 \\
\hline U-15.01 Shaft, CGW-1 & 1,772 & 77 \\
\hline U-15.01 Shaft, NH-01 & 1,543 & 160 \\
\hline U-15.01 Shaft, UG-02 & 991 & 70 \\
\hline U-15.01 Shaft, C-30 & 1,296 & 77 \\
\hline U-15.01 Shaft, C-36 & 819 & 52 \\
\hline
\end{tabular}

$\mathrm{mg} / \mathrm{L}=$ Milligrams per liter

TDS $=$ Total dissolved solid 
highest TDS and $\mathrm{Cl}$ values are observed in samples from the U-15.01 tunnel complex (Table 4-3). The chemistry of these tunnel seeps probably reflect vadose zone water-rock reactions with the highly mineralized Climax granitic stock (Isherwood et al., 1982).

The major-ion chemistry of the six perched springs at the NTS considered for this study is of two types. One is a Na-K-HCO 3 type water for which sodium plus potassium $(\mathrm{Na}+\mathrm{K})$ are the dominant cations, and the other is a $\mathrm{Ca}-\mathrm{Na}-\mathrm{K}-\mathrm{HCO}_{3}$ type water for which near equal proportions of $\mathrm{Na}+\mathrm{K}$ and $\mathrm{Ca}$ are present. The dominant anion in both water types is $\mathrm{HCO}_{3}$. These chemical differences are shown on Figure 4-6. Four springs (Captain Jack, Tippipah, Oak, and Whiterock) discharge from the contact between the overlying Indian Trails (volcanic confining unit) and underlying Eleana (UCCU) formations (Lyles et al., 1990). With the exception of Oak Spring, these waters are the $\mathrm{Na}-\mathrm{K}-\mathrm{HCO}_{3}$ type. Oak, Cane, and Topopah Springs have relatively greater $\mathrm{Ca}$ and are $\mathrm{Ca}-\mathrm{Na}-\mathrm{K}-\mathrm{HCO}_{3}$ type waters.

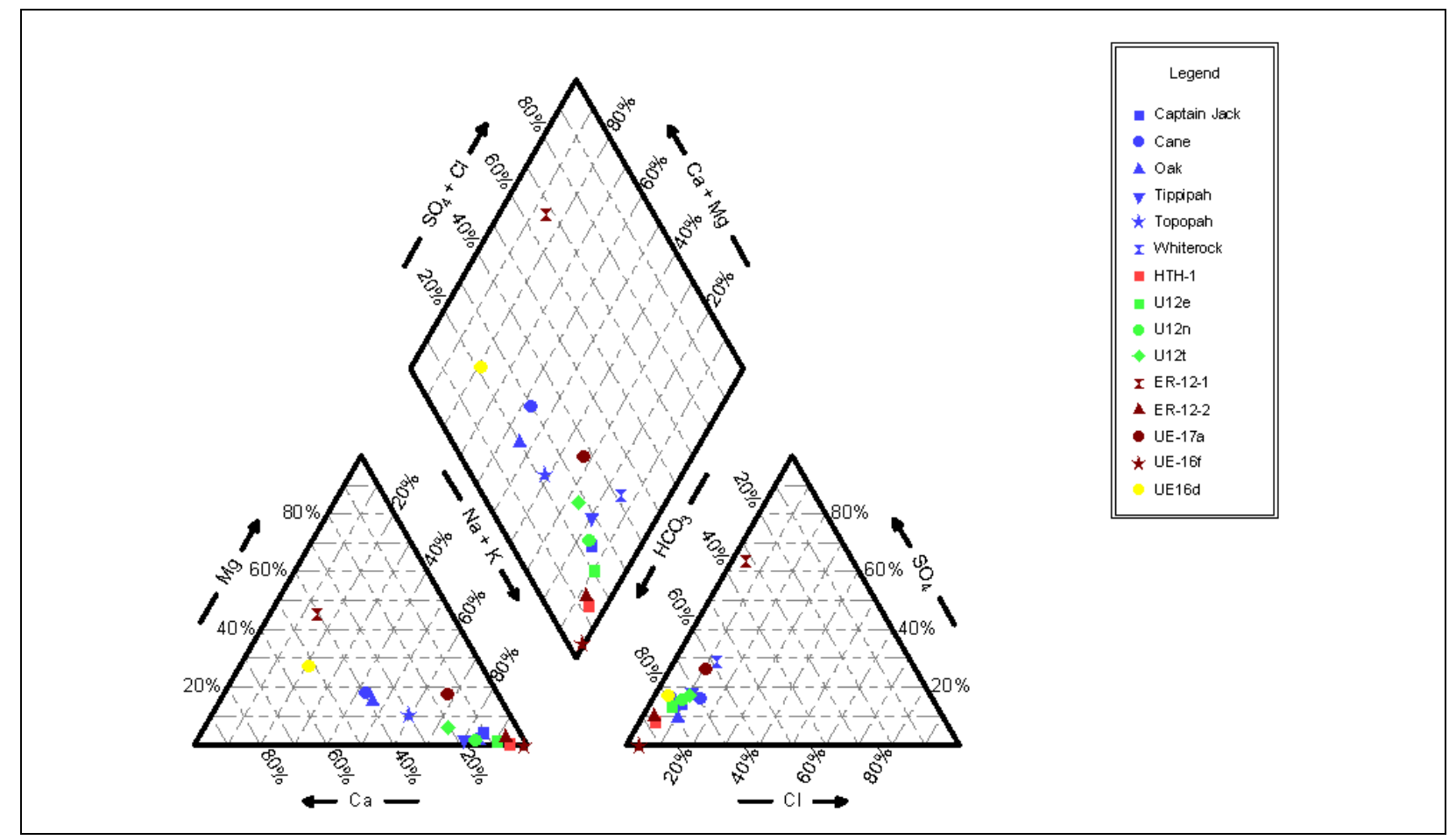

Figure 4-6

Piper Diagram Showing the Relative Proportions of Major lons in the NTS Perched Springs, Rainier Mesa Tunnels, and Groundwater in the Recharge Areas of Rainier Mesa and the Eleana Range 
The Rainier Mesa tunnels (U12e, U12n, and U12t) and the $\mathrm{Na}-\mathrm{K}-\mathrm{HCO}_{3}$ type perched springs (Captain Jack, Tippipah, and Whiterock) have relatively similar major-ion compositions, as shown in Figure 4-6. Similarly, wells completed in the regional flow system near the recharge areas of Rainier Mesa and the Eleana Range (Wells ER-12-2, UE-16f, and UE-17a) also produce Na-K-HCO type water. Calcium plus magnesium $(\mathrm{Ca}+\mathrm{Mg})$ are the dominant cations in the groundwater of Wells UE-16d and ER-12-1, both of which are associated with carbonate rocks.

A comparison of $\mathrm{Cl}$ versus TDS in perched springs and groundwater in the recharge areas shows two distinct trends (Figure 4-7). The perched springs define a lower slope trend $(\mathrm{m}=11)$ while the Eleana Range groundwaters (mostly from the UCCU) show a higher slope trend $(\mathrm{m}=43)$. The observed increase in $\mathrm{Cl}$ and TDS in the perched springs may result from varying amounts of evaporation at the different spring discharge areas. For example, Cane Spring has the most evaporated stable isotope signature of the perched springs and also shows the highest TDS and $\mathrm{Cl}$ values. The higher slope TDS versus $\mathrm{Cl}$ trend in the Eleana Range groundwaters reflects the dissolution of minerals as groundwater flows from the recharge areas to the regional aquifers (and aquitards). Well HTH-1, completed in a volcanic aquifer, has low $\mathrm{Cl}$ and TDS, implying that dissolution of minerals in volcanic aquifers is fairly slow. Wells completed in the UCCU or the UCA generally show higher $\mathrm{Cl}$ and TDS because minerals tend to dissolve more quickly in a marine carbonate mineral dominated environment - although there are some exceptions (e.g., UE-17a). The Rainier Mesa tunnel samples, from the volcanic confining unit, plot just above the perched spring trend, implying a greater extent of water-rock reaction with the volcanic rocks compared to HTH-1.

\subsection{Summary}

Modern groundwater recharge factors prominently in a number of the geochemical models developed in the chapters that follow. Review of the available data for precipitation and perched groundwaters shows that the chemical and isotopic signatures of these recharge proxies vary spatially and temporally within the study area. These variations are due to seasonal fluctuations in temperature, precipitation rate, and evapotranspiration rate, as well as differences in chemical evolution that result from different water-rock reactions along different recharge pathways. As a result, it is not possible 


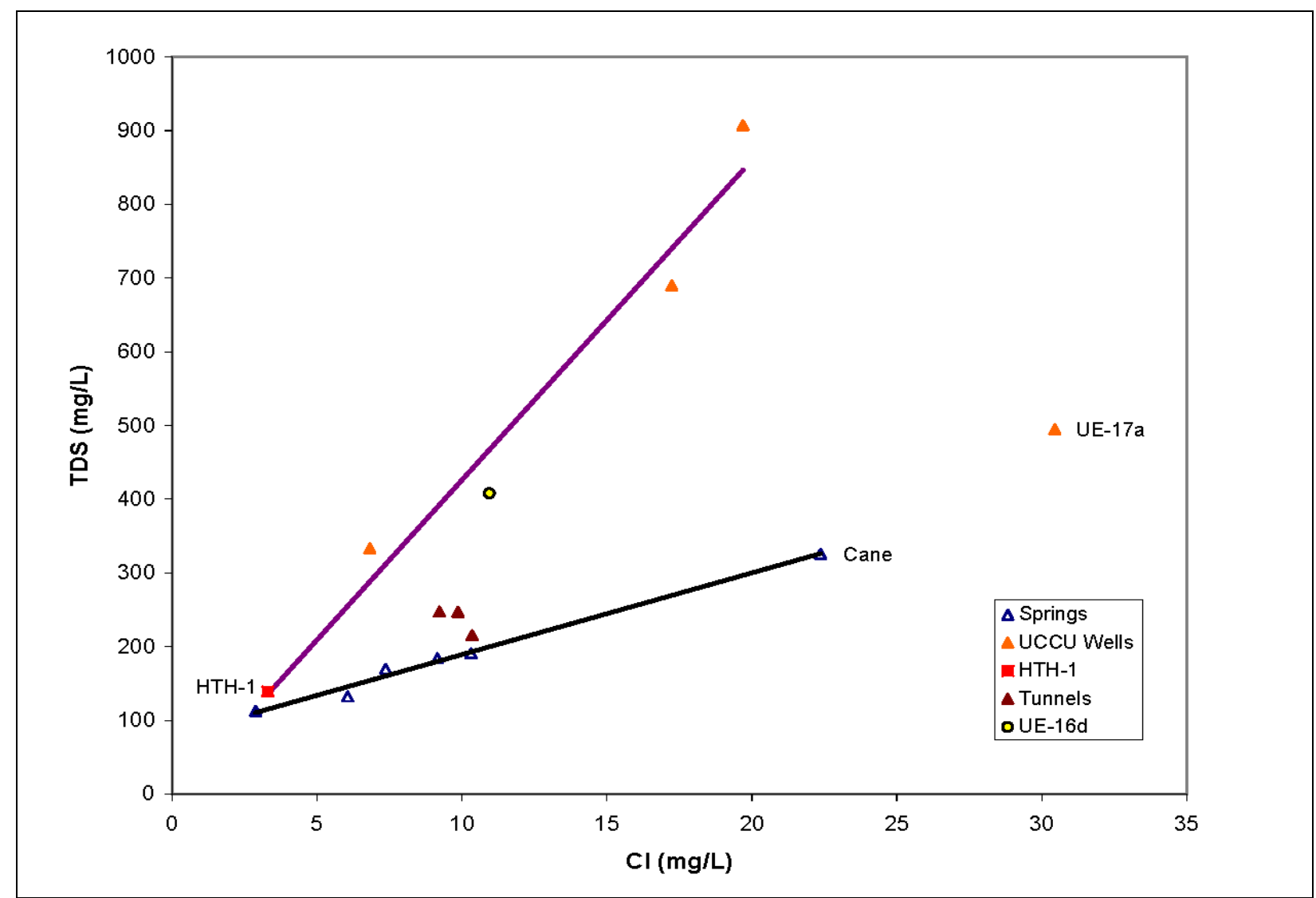

Figure 4-7

Total Dissolved Solids and Cl Concentrations for NTS Springs, Rainier Mesa Tunnels, and Wells Sampling the Upper Clastic Confining Unit

to define a single representative geochemical composition to represent recharge in the geochemical models. Instead, the models will be tested using a range in possible compositions that are constrained by the observations described here. 


\subsection{Geochemical Modeling Approach}

Initially, geochemical modeling of Yucca Flat groundwater movement examined the conservative, or non-reactive, species to identify potential groundwater source areas, flow paths, and mixing relationships (Benedict et al., 2003). Preliminary conceptual models were developed from a combination of stable isotope and $\mathrm{Cl}$ data. In most cases, a mixture of groundwater from two or three upgradient sources was required to obtain an observed downgradient water composition. Viable models developed using conservative tracers were tested using $\mathrm{Sr}$ concentrations and ${ }^{87} \mathrm{Sr} /{ }^{86} \mathrm{Sr}$ isotopic ratios. Strontium, a divalent cation, substitutes readily for $\mathrm{Ca}$ in rock-forming minerals and behaves similarly to $\mathrm{Ca}$ in aqueous environments. Because different rock types at the NTS have different ${ }^{87} \mathrm{Sr} r{ }^{86} \mathrm{Sr}$ ratios, these data are particularly useful as a tracer of groundwater movement between different HSUs.

In cases where the conservative tracers and $\mathrm{Sr}$ data provide consistent evidence for a possible groundwater flow path, NETPATH and PHREEQC models are used to corroborate those flow paths by modeling changes in reactive species. The NETPATH and PHREEQC models attempt to explain the geochemical evolution of groundwater along a flow path by identifying the net changes in reactive species occurring in the aquifer between the upgradient and downgradient wells. The mixing relations in these models are determined primarily on the basis of the conservative isotopic tracers ( $\delta \mathrm{D}$ and $\delta^{18} \mathrm{O}$ ), while the extent and nature of water-rock reactions are estimated from the changes in dissolved reactive species ( $\mathrm{pH}$, cations, anions, silica, alkalinity, and $\delta^{13} \mathrm{C}$ ). The reactive components considered by the NETPATH and PHREEQC models, therefore, potentially limit the number of possible mixing models identified in the conservative tracer and $\mathrm{Sr}$ analyses to a subset of models for which plausible water-rock interaction models can also be found.

Carbon-14 of DIC and DOC in groundwater was then used to estimate groundwater travel times. Estimation of water-rock interactions that have affected the DIC in groundwater, based on $\delta^{13} \mathrm{C}$ and/or DIC data, are used to correct the ages calculated using $\mathrm{DI}^{14} \mathrm{C}$ data. These corrected ages are calculated by NETPATH (Section 5.3.1) and calculated from PHREEQC results as described in 
Section 5.3.2.1. Because it is assumed that no water-rock reactions that impact the $\mathrm{DO}^{14} \mathrm{C}$ in groundwater along the flow path take place, no corrections are applied when calculating groundwater ages based on $\mathrm{DO}^{14} \mathrm{C}$ data (Section 3.2.3.1). Groundwater ages are calculated based only on the decay of dissolved organic ${ }^{14} \mathrm{C}$. Where DOC data are available, DOC travel times (Table 3-3) were compared to the DIC travel times.

The geochemical modeling codes (NETPATH and PHREEQC) allow a range in uncertainty for each parameter. In NETPATH, uncertainties are assumed when selecting the models; in PHREEQC, parameter uncertainties are input directly. In addition to uncertainties in individual parametric values, there are also uncertainties in the range of compositions within a particular geographic area or HSU. Each well or spring provides only a small, discrete sample of the total groundwater volume for a given area. Many wells sample large vertical cross sections of saturated media, possibly resulting in homogenization of the water composition within the borehole. The observed compositional variations within each region imply that local chemical heterogeneities are common. Hence, while the following models provide quantitative mixing ratios for specific groundwater compositions, the range of possible mixing ratios along a given flow path is likely to be more variable.

\subsection{Conservative Tracer Modeling}

Mixing models are tested by solving a simultaneous set of mixing equations for each tracer and determining whether a convergent condition exists. For models involving two mixing components, the final mixed tracer composition $\left(\mathrm{C}_{\text {mix }}\right)$ is determined from Equation (5-1):

$$
C_{\text {mix }}=X_{1} C_{1}+X_{2} C_{2}
$$

where $\mathrm{X}$ is the fractional amount of each tracer in the mixture, $\mathrm{C}$ is its corresponding concentration (or $\delta$-value), and $X_{1}+X_{2}=1$. For models that require the mixing of three groundwater components to derive the final mixed composition, two of these mixing equations are combined algebraically to arrive at an equation that depends on the tracer concentration of all mixing components. Let $\mathrm{C}_{\text {final }}=$ the final (mixed) tracer concentration to model:

$$
C_{\text {final }}=X_{\text {mix } 1} C_{\text {mix } 1}+X_{3} C_{3}
$$


where $\mathrm{X}_{\text {mix } 1}$ is the combined mixing fraction of $\mathrm{X}_{1}$ and $\mathrm{X}_{2}$ in the final mix, $\mathrm{C}_{\text {mix } 1}=\mathrm{X}_{1} \mathrm{C}_{1}+\mathrm{X}_{2} \mathrm{C}_{2}$ from Equation (5-1), $\mathrm{X}_{3}$ is the mixing fraction of the third component, and $\mathrm{C}_{3}$ is its corresponding concentration (or $\delta$-value). Given that $\mathrm{X}_{3}=1-\mathrm{X}_{\mathrm{mix} 1}$ :

$$
C_{\text {final }}=X_{\text {mix } 1} C_{\text {mix } 1}+\left(1-X_{\text {mixl }}\right) C_{3}
$$

which can then be algebraically solved for $\mathrm{X}_{\text {mix }}$.

$$
\left.X_{\text {mix } 1}=\left(C_{\text {final }}-C_{3}\right) \Lambda\left(X_{1} C_{1}+X_{2} C_{2}-C_{3}\right)\right]
$$

Equation (5-4) depends on the concentrations (or $\delta$-values) of all three mixing components as well as the final (mixed) concentration. Three of these equations (one for each tracer) are then solved iteratively by varying $\mathrm{X}_{1}$ and $\mathrm{X}_{2}$ to find a "convergent" value for $\mathrm{X}_{\text {mix }}$, or to minimize the variance between the $\mathrm{X}_{\text {mix } 1}$ values for each tracer.

For example, assume that Well 4 is a mixture of three groundwater components, such that Well $4=$ Well $1+$ Well $2+$ Well 3, and the measured tracer concentrations in each well are shown as follows:

\begin{tabular}{|c|c|c|c|}
\hline Sample & $\delta \mathrm{D}$ (permil) & $\delta^{18} \mathrm{O}$ (permil) & $\mathrm{Cl}(\mathrm{mg} / \mathrm{L})$ \\
\hline \hline Well 4 & -108 & -14.5 & 16.5 \\
\hline Well 1 & -100 & -13.5 & 15 \\
\hline Well 2 & -85 & -11 & 5 \\
\hline Well 3 & -125 & -17 & 24 \\
\hline
\end{tabular}

Simultaneously solving equation (5-4) for each tracer $\left(\delta \mathrm{D}, \delta^{18} \mathrm{O}\right.$, and $\left.\mathrm{Cl}\right)$, a condition is identified where the value of $\mathrm{X}_{\text {mix } 1}$ is identical for all three tracers:

$$
\begin{aligned}
& \left.X_{\text {mix } 1}=\left(C_{4}-C_{3}\right) \Lambda\left(X_{1} C_{1}+X_{2} C_{2}\right)-C_{3}\right] \\
& \delta \mathrm{D} \quad 0.5=[(-108)-(-125)] /[[(0.4)(-100)+(0.6)(-85)]-(-125)] \\
& \delta^{18} \mathrm{O} \quad 0.5=[(-14.5)-(-17)] /[[(0.4)(-13.5)+(0.6)(-11)]-(-17)] \\
& \mathrm{Cl} \quad 0.5=[(16.5)-(24)] /[[(0.4)(15)+(0.6)(5)]-(24)]
\end{aligned}
$$


The final mixing fractions of Wells 1 and 2 can then be calculated from the product of $\left(\mathrm{X}_{\text {mix } 1}\right)\left(\mathrm{X}_{1}\right)$ and $\left(\mathrm{X}_{\text {mix } 1}\right)\left(\mathrm{X}_{2}\right)$, respectively, and the mixing fraction of Well 3 is equal to $\left(1-\mathrm{X}_{\text {mix } 1}\right)$.

$$
\begin{gathered}
\text { Well } 4=(0.4)(0.5) \text { Well } 1+(0.6)(0.5) \text { Well } 2+(1-0.5) \text { Well } 3 \\
\text { Well } 4=(20 \%) \text { Well } 1+(30 \%) \text { Well } 2+(50 \%) \text { Well } 3
\end{gathered}
$$

In many cases, there is no convergent solution for all three tracers, but it is still possible to minimize the variance in $\mathrm{X}_{\text {mix } 1}$ values through iterative testing. It is important to note that uncertainties in reported tracer compositions are not directly accommodated through this process. While it is possible to model parameter uncertainty by substituting new values for each tracer, this process is laborious.

\subsection{Strontium and ${ }^{87} \mathrm{Sr} /{ }^{86} \mathrm{Sr}$ Modeling}

Values of ${ }^{87} \mathrm{Sr} /{ }^{86} \mathrm{Sr}$ are useful as natural tracers of groundwater flow because the $\mathrm{Sr}^{+2}$ ion is soluble in aqueous solutions at levels allowing high-precision isotope measurement, wide variations in $\mathrm{Rb} / \mathrm{Sr}$ ratios in different rock types result in large differences in ${ }^{87} \mathrm{Sr} /{ }^{86} \mathrm{Sr}$ in different aquifers, and fractionation of heavy radiogenic isotopes $\left({ }^{87} \mathrm{Sr}\right.$ from $\left.{ }^{86} \mathrm{Sr}\right)$ is negligible during geologic processes (McNutt, 2000). However, Sr is not necessarily conserved during groundwater flow because of water-rock interactions. The behavior of $\mathrm{Sr}$ and ${ }^{87} \mathrm{Sr} /{ }^{86} \mathrm{Sr}$ in dynamic groundwater flow systems depends on a number of factors including flow length, water-rock ratio, reaction rates, concentrations of Sr, and isotopic compositions in both mineral phases and fluid, flow velocity, advective or dispersive fluid mixing, and dispersion and ion exchange (Johnson and DePaolo, 1994, 1997). Groundwater flow through LCA and welded-tuff aquifers is dominated by secondary porosity developed along fractures, joints, and faults (Winograd and Thordarson, 1975, p. C14) resulting in large flow velocities, large water-rock ratios and small rates of reaction relative to systems dominated by matrix flow. In this type of system, groundwater ${ }^{87} \mathrm{Sr} /{ }^{86} \mathrm{Sr}$ values are less likely to be impacted by changes in rock ${ }^{87} \mathrm{Sr} /{ }^{86} \mathrm{Sr}$ values along a given flow path (Johnson et al., 2000). Therefore, in HSUs dominated by fracture flow, Sr may be useful as a tracer of water from upgradient sources (Johnson and DePaolo, 1994, p. 1576), at least at the length-scale covering the Yucca Flat basin.

Chemical processes resulting in non-conservative behavior of $\mathrm{Sr}$ impact concentration data to a greater extent than ${ }^{87} \mathrm{Sr} /{ }^{86} \mathrm{Sr}$ data. Losses of $\mathrm{Sr}$ from solution due to sorption and mineral precipitation will not impact the ${ }^{87} \mathrm{Sr} /{ }^{86} \mathrm{Sr}$ ratio in the remaining fluid. Furthermore, desorption or cation exchange 
from reactive mineral surfaces along flow paths may not significantly impact ${ }^{87} \mathrm{Sr} /{ }^{86} \mathrm{Sr}$ values if the dynamics of flow and sources of Sr have remained unchanged over long periods of time (steady-state flow conditions). In contrast, rock dissolution can add $\mathrm{Sr}$ containing very different isotopic compositions to the resulting solution, particularly if groundwater that is chemically unsaturated with respect to calcite or dolomite flows into the LCA. The resulting impact on ${ }^{87} \mathrm{Sr} /{ }^{86} \mathrm{Sr}$ in solution depends greatly on the concentrations and isotope compositions in both water and solid phases.

In general, concentrations and ${ }^{87} \mathrm{Sr} /{ }^{86} \mathrm{Sr}$ compositions of aquifer rocks along flow paths in the Yucca Flat vicinity are not well known. Both Sr concentrations and ${ }^{87} \mathrm{Sr} /{ }^{86} \mathrm{Sr}$ values in LCA carbonate rocks in the NTS vicinity can vary widely from compositions inherited from Paleozoic marine sources to compositions enriched in radiogenic ${ }^{87} \mathrm{Sr}$ introduced from crustal fluids that circulated through the carbonate rocks in the past (Peterman et al., 1994; Kenneally, 1995). Nevertheless, similar trends are commonly observed between ${ }^{87} \mathrm{Sr} /{ }^{86} \mathrm{Sr}$ and more conservative tracers such as $\delta \mathrm{D}$ and $\mathrm{Cl}$ for samples from the LCA. These relations indicate that $\mathrm{Sr}$ does not behave as a highly reactive constituent in groundwater that is chemically saturated with respect to carbonate phases. Ratios of ${ }^{87} \mathrm{Sr} /{ }^{86} \mathrm{Sr}$ are treated as a conservative tracer and simple mixing models are developed between two or three end members using mixing equations described elsewhere (Faure, 1986, Section 9.2). Because water-rock reactions are not included in these evaluations, mixing proportions derived from $\mathrm{Sr}$ isotope data are considered qualitative rather than quantitative. These results are more useful for discriminating between competing flow-path models based on other data than they are for defining mixing relations by themselves.

\subsection{Geochemical Modeling with NETPATH and PHREEQC}

Geochemical inverse models created with NETPATH and PHREEQC attempt to identify the fractions of groundwaters from different upgradient areas that could be present in groundwater at a downgradient location. The mixing models express the composition of groundwater at the downgradient site as a function of groundwater compositions at one or more upgradient sites, plus water-rock reactions. For example, the model (Well $4=\mathrm{f}_{1}$ Well $1+\mathrm{f}_{2}$ Well $2+\mathrm{f}_{3}$ Well $3+$ reactions) expresses the composition of groundwater at Well 4 as a function of groundwater compositions at Wells 1,2 , and 3 plus reactions. The coefficients $f_{1}, f_{2}$ and $f_{3}$ are the fractions of groundwater from these upgradient wells that are present in groundwater at the downgradient well (Well 4). 
Mineral compositions from the Yucca Flat flow system considered by the NETPATH and PHREEQC models were given in Table 3-4. These mineral compositions were measured in discrete rock samples from the Pahute Mesa flow system and then compiled into composite chemical compositions for specific HSUs. Many of the volcanic HSUs in the Pahute Mesa flow system also exist in Yucca Flat. Maps showing the geographic extent of various HSUs for the Yucca Flat flow system $(\mathrm{BN}, 2006)$ indicate that the Timber Mountain (TM) units form the uppermost volcanic units found in Yucca Flat. Because downward moving water would be expected to react most strongly with the first volcanic units it encountered, mineral phases for the TM HSU were used in the models. Experience in developing inverse geochemical models for the Pahute Mesa flow system indicates that small differences in the compositions of the mineral phases listed in Table 3-4 do not result in major changes in model results (Kwicklis et al., 2005). The relatively minor effect of mineral composition variability is attributed to the small quantities of alumino-silicate minerals involved in the reactions identified by the models. Generally, element balances were accommodated primarily through mixing, with only a fraction of a millimole per liter $(\mathrm{mmol} / \mathrm{L})$ of any mineral phase dissolved or precipitated. Mineral dissolution and precipitation constraints were imposed in the models to limit the reactions to those that were considered thermodynamically plausible. Limiting reactions are based on mineral saturation indices and mineralogic studies from the NTS area that have described textural relations between primary and secondary minerals (e.g., Bish, 1989; Broxton et al., 1987). Based on these studies, glass and feldspar were permitted to dissolve, and clay and clinoptilolite were allowed to precipitate.

In addition to the site-specific mineral compositions listed in Table 3-4, the PHREEQC and NETPATH models summarized in this report considered precipitation or dissolution of calcite $\left[\mathrm{CaCO}_{3}\right]$, dissolution of dolomite $\left[\mathrm{CaMg}\left(\mathrm{CO}_{3}\right)_{2}\right]$, dissolution of halite $[\mathrm{NaCl}]$, dissolution of gypsum $\left[\mathrm{CaSO}_{4}\right]$, precipitation or dissolution of silica $\left[\mathrm{SiO}_{2}\right]$, and exchange of $\mathrm{Ca}$ and $\mathrm{Mg}$ in solution for $\mathrm{Na}$ initially sorbed onto exchange sites of unspecified minerals. The PHREEQC models also included dissolution of $\mathrm{K}$-feldspar $\left(\mathrm{KAlSi}_{3} \mathrm{O}_{8}\right)$ and amorphous silica $\left[\left(\mathrm{SiO}_{2}(\mathrm{a})\right]\right.$, exchange of $\mathrm{K}$ in solution for $\mathrm{Na}$, precipitation or dissolution of fluorite $\left(\mathrm{CaF}_{2}\right)$, and oxidation and dissolution of pyrite $\left(\mathrm{FeS}_{2}\right)$ to form amorphous iron hydroxide $\left[\mathrm{Fe}(\mathrm{OH})_{3}\right]$. The potential for the dissolution of dolomite, $\mathrm{K}$-feldspar, amorphous silica, and fluorite by Yucca Flat groundwater is indicated by the saturation indices (SIs) calculated with PHREEQC for these minerals (Table 5-1). 
Thermodynamic data do not exist for composite compositions of the Yucca Flat site-specific minerals listed in Table 3-4, so SIs could not be calculated for these minerals. However, the undersaturation of all groundwaters, with respect to albite $\left(\mathrm{NaAlSi}_{3} \mathrm{O}_{8}\right), \mathrm{K}$-feldspar and anorthite $\left(\mathrm{CaAl}_{2} \mathrm{Si}_{2} \mathrm{O}_{8}\right)$ (not shown in Table 5-1), indicates that the site-specific feldspars with the composite compositions listed in Table 3-4 are probably also undersaturated in Yucca Flat area groundwaters. Calcite saturation indices are more variable, and indicate the potential for calcite dissolution or calcite precipitation, depending on the groundwater under consideration. When multiple upgradient sources with different tendencies to dissolve or precipitate a mineral are included in an inverse model, it is possible that each groundwater behaves differently as it flows toward the downgradient well. However, because only the net reaction for the mineral is considered and the reaction depends on the fractions of the upgradient groundwater present in the downgradient mixture, it is not always possible to know $a$ priori whether the inverse model should consider dissolution or precipitation as potential reactions. This is particularly true in the case of calcite, where other geochemical processes such as Ca sorption, dolomite dissolution, or gypsum dissolution could also alter the tendency of the groundwater to dissolve or precipitate calcite as it travels from the upgradient to the downgradient well. Generally, pore-water data from the unsaturated zone at Yucca Mountain (Yang et al., 1996; 1998) and Rainier Mesa (White et al., 1980) indicate that $\mathrm{Ca}^{2+}, \mathrm{Mg}^{2+}$, and $\mathrm{K}^{+}$in solution are exchanged for $\mathrm{Na}^{+}$initially on the exchange sites of minerals.

\subsubsection{Geochemical Models with NETPATH}

NETPATH calculates the net mass transfer of major dissolved ions from water-rock reactions along a proposed flow path and the fractionation of carbon isotopes as carbon-containing phases are dissolved or precipitated. By modeling the isotopic evolution of carbon along a flow path, groundwater travel times are calculated. Mineral dissolution and precipitation reactions used in NETPATH are constrained by thermodynamic calculations. These calculations determine the saturation state of minerals in groundwater. Minerals that have been identified in the aquifer and are undersaturated can only dissolve, whereas those that are supersaturated can only precipitate or form by incongruent dissolution. The geochemical reactions modeled with NETPATH are limited by knowledge of the minerals and gases that are present in the aquifer and their chemical and isotopic compositions, and the availability of groundwater chemistry data along potential flow paths. The geochemical model solutions are non-unique, so more than one model can describe changes in water 
Table 5-1

Mineral Saturation Indices and Other Quantities Calculated by PHREEQC for Selected Wells and Springs

(Page 1 of 5)

\begin{tabular}{|c|c|c|c|c|c|c|c|c|c|c|c|}
\hline Site ID & 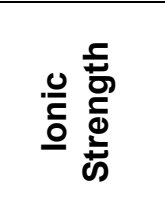 & 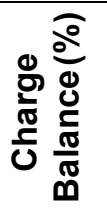 & 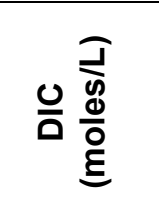 & $\frac{\pi}{4} \frac{\text { D্}}{\frac{y}{2}}$ & 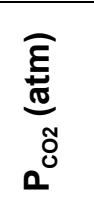 & 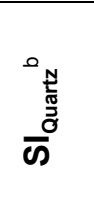 & $\frac{0}{\frac{\sqrt{\pi}}{\pi}}$ & $\frac{\circ}{\frac{ \pm 0}{\alpha}}$ & 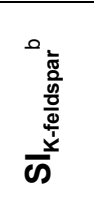 & ڤே & 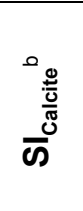 \\
\hline \multicolumn{12}{|c|}{ Perched Springs } \\
\hline April Fool Spring & 1.344E-02 & $\overline{-0.8}$ & $\overline{7.637 E-03}$ & 0.03 & -1.78 & 0.37 & -0.52 & -3.25 & -1.63 & 0.16 & 0.09 \\
\hline Bullwhack Spring & 1.418E-02 & 1.3 & $6.575 \mathrm{E}-03$ & 0.66 & -2.34 & 0.17 & -0.67 & -2.97 & -1.59 & 1.92 & 0.87 \\
\hline Cane Spring (Frenchman Flat) & $6.038 \mathrm{E}-03$ & 2.6 & $3.861 \mathrm{E}-03$ & 0.01 & -1.80 & 0.72 & -0.16 & -2.63 & -0.96 & -1.93 & -0.78 \\
\hline Cane Spring (Groom Range) & $1.324 \mathrm{E}-02$ & 0.0 & $6.221 \mathrm{E}-03$ & 0.07 & -2.14 & 0.24 & -0.64 & -3.26 & -1.77 & 0.65 & 0.36 \\
\hline Captain Jack Spring & 1.945E-03 & 1.2 & 1.444E-03 & 0.01 & -2.48 & 0.49 & -0.40 & -2.96 & -1.55 & -4.12 & -1.82 \\
\hline Cattle Spring & $7.451 \mathrm{E}-03$ & 0.7 & 4.324E-03 & 0.2 & -2.65 & 0.39 & -0.48 & -2.24 & -0.68 & 0.66 & 0.56 \\
\hline Cliff Spring (Belted Range) & 3.030E-03 & -1.8 & 1.832E-03 & 0.5 & -2.86 & 0.31 & -0.53 & -2.28 & -1.80 & -1.48 & -0.45 \\
\hline Cliff Spring (Groom Range) & 7.991E-03 & -1.3 & 4.632E-03 & 0.06 & -2.35 & 0.36 & -0.52 & -3.02 & -1.83 & 0.07 & 0.36 \\
\hline Cow Camp Spring & 8.530E-03 & 1.9 & $5.028 \mathrm{E}-03$ & 0.1 & -2.23 & 0.12 & -0.77 & -3.53 & -2.55 & 0.18 & 0.09 \\
\hline Cresent Spring & $9.205 \mathrm{E}-03$ & -0.8 & $6.772 \mathrm{E}-03$ & 0.01 & -1.83 & 0.72 & -0.16 & -2.68 & -1.02 & -0.46 & 0.16 \\
\hline De Jesus Spring & 8.317E-03 & 1.8 & $4.360 \mathrm{E}-03$ & 2.6 & -2.57 & 0.11 & -0.77 & -2.14 & -0.45 & 0.67 & 0.32 \\
\hline Indian Spring (Belted Range) & 4.537E-03 & 0.4 & 2.834E-03 & 0.01 & -2.38 & 0.74 & -0.15 & -2.50 & -0.55 & -1.36 & -0.37 \\
\hline Oak Spring & 3.006E-03 & -0.6 & $2.323 E-03$ & 0.01 & -2.01 & 0.66 & -0.22 & -3.04 & -1.08 & -2.92 & -1.25 \\
\hline Pyramid Spring & 6.037E-03 & 5.6 & $3.418 \mathrm{E}-03$ & 400 & -2.61 & 0.45 & -0.46 & 1.63 & 2.62 & -0.79 & 0.06 \\
\hline Quartz Spring & 1.293E-02 & 0.5 & 7.154E-03 & 0.05 & -2.16 & 0.60 & -0.27 & -1.98 & -0.84 & 0.96 & 0.50 \\
\hline Sand Spring (Pintwater Range) & 8.017E-03 & 1.8 & 4.402E-03 & 2.6 & -2.90 & -0.03 & -0.87 & -2.97 & -1.24 & 1.91 & 0.71 \\
\hline Spring Above Adaven & 8.301E-03 & 0.3 & 5.704E-03 & 0.04 & -2.08 & 0.37 & -0.51 & -3.33 & -1.64 & 0.07 & 0.15 \\
\hline Spring at Reville & $6.127 \mathrm{E}-03$ & -0.1 & $3.830 \mathrm{E}-03$ & 45 & -2.40 & 0.62 & -0.31 & 1.18 & 2.21 & -1.82 & -0.10 \\
\hline Tim Spring & 5.352E-03 & 5.4 & $2.357 \mathrm{E}-03$ & 0.24 & -3.02 & 0.27 & -0.61 & -2.90 & -1.09 & 0.24 & -0.06 \\
\hline Tippipah Spring & $2.780 \mathrm{E}-03$ & -3.0 & $2.214 \mathrm{E}-03$ & 259 & -2.10 & 0.57 & -0.31 & 1.47 & 2.76 & -3.83 & -1.46 \\
\hline Topopah Spring & 1.397E-03 & -0.2 & 1.123E-03 & 0.01 & -2.23 & 0.59 & -0.29 & -3.52 & -1.33 & -4.58 & -2.05 \\
\hline Wheelbarrow Spring (Belted Range) & $4.546 \mathrm{E}-03$ & 0.8 & $2.710 \mathrm{E}-03$ & 0.2 & -2.96 & 0.37 & -0.51 & -2.22 & -0.81 & -0.20 & 0.11 \\
\hline White Rock Spring, Sheep Range & 7.172E-03 & 1.0 & $4.845 \mathrm{E}-03$ & 0.02 & -2.15 & 0.58 & -0.30 & -2.89 & -0.70 & -0.18 & -0.13 \\
\hline Whiterock Spring (Yucca Flat) & $2.774 \mathrm{E}-03$ & 2.8 & 1.396E-03 & 322 & -2.54 & 0.59 & -0.29 & 1.73 & 3.39 & -3.81 & -2.05 \\
\hline Wiregrass Spring & $9.224 \mathrm{E}-03$ & 1.2 & 6.817E-03 & 0.03 & -1.85 & 0.05 & -0.85 & -4.95 & -2.65 & -0.26 & -0.02 \\
\hline
\end{tabular}


Table 5-1

Mineral Saturation Indices and Other Quantities Calculated by PHREEQC for Selected Wells and Springs

(Page 2 of 5 )

\begin{tabular}{|c|c|c|c|c|c|c|c|c|c|c|c|}
\hline Site ID & 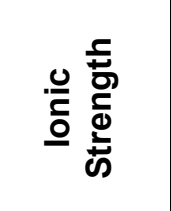 & 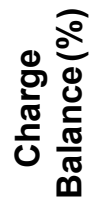 & 음 $\frac{\text { J }}{\frac{\Phi}{0}}$ & 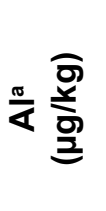 & 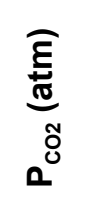 & $\frac{0}{\text { बे }}$ & $\frac{0}{\overline{\frac{\pi}{\pi}}}$ & 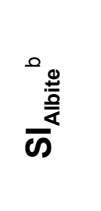 & 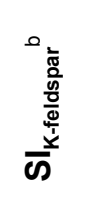 & 这 & 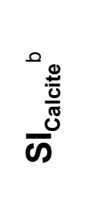 \\
\hline \multicolumn{12}{|c|}{ Alluvial Wells } \\
\hline Desert Valley (Dry Lake) Well \#1 & 6.622E-03 & $\overline{1.3}$ & 3.597E-03 & 0.2 & -2.71 & 0.52 & -0.34 & -1.99 & -0.35 & 0.61 & $\overline{0.11}$ \\
\hline ER-5-3 & 4.871E-03 & -8.0 & $3.026 \mathrm{E}-03$ & 53 & -3.11 & 0.44 & -0.39 & 0.19 & 1.36 & 0.57 & 0.36 \\
\hline Marble \#3 & $8.159 \mathrm{E}-03$ & 1.3 & 5.114E-03 & 200 & -2.46 & 0.47 & -0.38 & 0.45 & 2.24 & 1.09 & 0.25 \\
\hline Penoyer Well & $6.038 \mathrm{E}-03$ & -1.5 & $2.874 \mathrm{E}-03$ & 60 & -2.18 & 0.84 & -0.04 & 1.60 & 3.68 & -1.86 & -0.43 \\
\hline Sand Spring (Sand Spring Valley) & $4.616 \mathrm{E}-03$ & -5.3 & $2.798 \mathrm{E}-03$ & 5.5 & -4.17 & 0.30 & -0.56 & -1.11 & 0.81 & 2.29 & 1.08 \\
\hline UE-1b & 6.136E-03 & -0.2 & 4.186E-03 & 0.2 & -2.30 & 0.66 & -0.17 & -1.88 & -0.02 & 0.44 & 0.25 \\
\hline UE-6d & $5.503 \mathrm{E}-03$ & 0.0 & 2.174E-03 & 162 & -4.99 & -0.24 & -1.08 & -1.19 & 0.38 & 2.79 & 1.43 \\
\hline USAF Watertown 3 & 4.601E-03 & 0.5 & $3.118 \mathrm{E}-03$ & 15 & -2.65 & 0.68 & -0.16 & 0.52 & 1.98 & -0.37 & -0.02 \\
\hline USAF Watertown 4 & $1.298 \mathrm{E}-02$ & 0.7 & 1.023E-02 & 0.2 & -1.19 & 0.05 & -0.77 & -3.44 & -1.70 & -0.03 & 0.06 \\
\hline USGS Water Well A & 5.005E-03 & 0.8 & $3.435 \mathrm{E}-03$ & 588 & -2.58 & 0.63 & -0.21 & 1.81 & 3.37 & 0.15 & 0.13 \\
\hline Well 3 Water Well & 4.935E-03 & 1.3 & $3.206 \mathrm{E}-03$ & 102 & -2.64 & 0.61 & -0.24 & 0.99 & 2.65 & 0.14 & 0.02 \\
\hline \multicolumn{12}{|c|}{ Volcanic Aquifer Wells } \\
\hline U-3cn PS \#2 & 5.905E-03 & 3.8 & 4.554E-03 & 682.1 & -2.12 & 0.40 & -0.41 & 1.21 & 2.76 & -0.45 & -0.13 \\
\hline UE-11a & $6.298 \mathrm{E}-03$ & -0.8 & $3.561 \mathrm{E}-03$ & 0.4 & -2.78 & 0.53 & -0.31 & -1.27 & -0.28 & -0.34 & -0.08 \\
\hline UE-14b & $4.925 \mathrm{E}-03$ & 1.6 & 1.934E-03 & 1.5 & -3.44 & 0.39 & -0.45 & -1.27 & -0.67 & -0.56 & 0.15 \\
\hline UE-1c & $6.314 \mathrm{E}-03$ & -0.6 & 4.305E-03 & 100 & -1.91 & 0.71 & -0.12 & 1.06 & 2.93 & -0.39 & -0.17 \\
\hline USAF-Watertown 1 & 4.105E-03 & 0.0 & 2.952E-03 & 10 & -2.56 & 0.68 & -0.17 & 0.41 & 1.84 & -1.52 & -0.69 \\
\hline USAF-Watertown 2 & 4.516E-03 & 0.8 & $3.457 \mathrm{E}-03$ & 0.8 & -2.96 & 0.60 & -0.23 & -0.96 & 0.40 & -0.49 & -0.14 \\
\hline USGS HTH \#1 & $2.460 \mathrm{E}-03$ & 3.7 & $1.684 \mathrm{E}-03$ & 11.9 & -4.12 & -0.01 & -0.85 & -1.68 & -1.24 & -0.74 & -0.03 \\
\hline USGS Test Well B & $4.128 \mathrm{E}-03$ & -0.5 & 2.697E-03 & 0.9 & -3.02 & 0.06 & -0.80 & -2.34 & -1.28 & -1.32 & -0.43 \\
\hline Water Well 4 & 5.179E-03 & 1.9 & 2.837E-03 & 0.2 & -2.37 & 0.53 & -0.30 & -2.02 & -0.72 & -0.50 & -0.21 \\
\hline Water Well 4A & $5.022 \mathrm{E}-03$ & 8.5 & $2.398 \mathrm{E}-03$ & 4.4 & -2.74 & 0.58 & -0.26 & -0.47 & 0.89 & -0.10 & 0.02 \\
\hline \multicolumn{12}{|c|}{ Volcanic Confining Unit Wells } \\
\hline U12e Tunnel & 3.995E-03 & 1.3 & 2.796E-03 & 812 & -2.93 & 0.49 & -0.38 & 2.01 & 3.13 & -1.74 & -0.45 \\
\hline
\end{tabular}


Table 5-1

Mineral Saturation Indices and Other Quantities Calculated by PHREEQC for Selected Wells and Springs

(Page 3 of 5)

\begin{tabular}{|c|c|c|c|c|c|c|c|c|c|c|c|}
\hline Site ID & 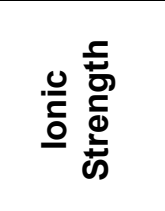 & 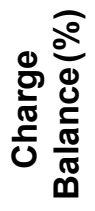 & 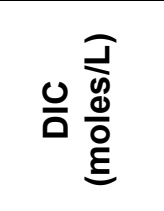 & $\frac{\pi}{4} \frac{\text { के }}{\frac{1}{3}}$ & 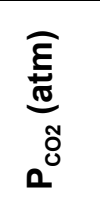 & 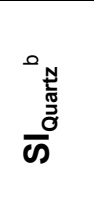 & $\frac{\sqrt{\frac{\pi}{\pi}}}{\frac{\infty}{\infty}}$ & $\frac{\circ}{\frac{ \pm 0}{\sigma}}$ & 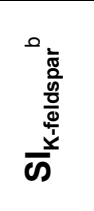 & 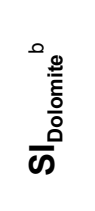 & 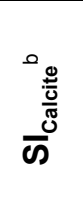 \\
\hline U12n Tunnel & ב3.966E-03 & 0.3 & 2.750E-03 & 163 & 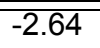 & 0.58 & -0.29 & 1.48 & 2.99 & -1.94 & $\overline{-0.51}$ \\
\hline U12.03 UG-3 & 3.544E-03 & -1.2 & 2.344E-03 & 131 & -2.28 & 0.59 & -0.25 & 0.77 & 2.41 & -1.39 & -0.52 \\
\hline U12t Tunnel & 3.379E-03 & -3.2 & $2.246 \mathrm{E}-03$ & 81 & -2.63 & 0.61 & -0.26 & 1.13 & 2.71 & -1.83 & -0.66 \\
\hline Pluto 1 & 5.916E-03 & 5.9 & 2.464E-03 & 0.4 & -2.84 & 0.50 & -0.34 & -1.89 & -0.22 & 0.38 & 0.32 \\
\hline Pluto 5 & 7.647E-03 & 7.4 & 3.609E-03 & 0.3 & -2.59 & 0.53 & -0.31 & -2.07 & -0.51 & 0.93 & 0.49 \\
\hline Water Well 2 & 5.322E-03 & 2.4 & 3.395E-03 & 533 & -2.15 & 0.41 & -0.40 & 0.62 & 2.21 & 0.05 & -0.04 \\
\hline ER-2-1 & 3.872E-03 & 2.2 & 2.416E-03 & 139 & -4.09 & 0.50 & -0.35 & 1.13 & 2.33 & -0.13 & 0.26 \\
\hline U-2bs & 4.229E-03 & -2.9 & 3.750E-03 & 85 & -1.80 & 0.49 & -0.35 & 0.71 & 1.92 & -3.47 & -1.52 \\
\hline UE-10 ITS \#3 & 1.070E-02 & -0.3 & 8.878E-03 & 0.7 & -2.59 & 0.55 & -0.29 & -0.73 & 0.62 & -0.17 & 0.38 \\
\hline Test Well \#7 (HTH) & $5.128 \mathrm{E}-03$ & 0.3 & $5.084 \mathrm{E}-03$ & 100 & -1.52 & -1.53 & -2.24 & -6.16 & -5.68 & -2.46 & -1.13 \\
\hline ER-5-4 \#2 & 1.507E-02 & 1.8 & 5.969E-03 & 1326 & -3.10 & 0.45 & -0.35 & 2.06 & 2.54 & -0.92 & -0.64 \\
\hline \multicolumn{12}{|c|}{ Upper Clastic Confining Unit } \\
\hline ER-12-1 & 1.623E-02 & 2.2 & 3.683E-03 & 0.5 & -2.40 & 0.07 & -0.77 & -3.06 & -1.73 & 0.97 & 0.40 \\
\hline ER-12-2 & 5.965E-03 & -0.8 & 4.890E-03 & 1.4 & -2.08 & 0.00 & -0.81 & -2.60 & -1.95 & -1.08 & -0.52 \\
\hline UE-17a & 1.085E-02 & 10.0 & 5.109E-03 & 0.7 & -2.36 & -0.10 & -0.95 & -2.75 & -1.87 & 0.54 & 0.18 \\
\hline UE-16f & 1.876E-02 & -5.3 & 1.614E-02 & 10.8 & -2.45 & -0.55 & -1.39 & -2.59 & -2.42 & 0.46 & 0.28 \\
\hline \multicolumn{12}{|c|}{ Lower Clastic Confining Unit } \\
\hline UE-15d & 9.316E-03 & 1.2 & 6.225E-03 & 639 & -2.00 & 0.23 & -0.58 & 0.60 & 2.12 & $\overline{0.88}$ & 0.46 \\
\hline UE-15j A-5 & 1.959E-02 & -1.1 & 1.741E-02 & 300 & -0.85 & 0.08 & -0.70 & 0.05 & 1.40 & 0.21 & 0.15 \\
\hline UE-15j & $2.034 \mathrm{E}-02$ & -1.3 & $2.108 \mathrm{E}-02$ & 100 & -0.54 & 0.11 & -0.66 & -0.54 & 0.83 & -0.37 & -0.14 \\
\hline \multicolumn{12}{|c|}{ Lower and Upper Carbonate Aquifers } \\
\hline Ash Springs & $6.995 \mathrm{E}-03$ & -0.3 & $4.840 \mathrm{E}-03$ & 0.3 & -1.55 & 0.14 & -0.67 & -3.50 & -1.92 & -0.56 & -0.23 \\
\hline Hiko Spring & $7.472 \mathrm{E}-03$ & 1.4 & 4.346E-03 & 0.8 & -2.59 & 0.26 & -0.57 & -2.47 & -0.72 & 1.32 & 0.05 \\
\hline Crystal Spring & 7.117E-03 & 0.4 & 4.452E-03 & 0.3 & -1.99 & 0.13 & -0.70 & -3.36 & -1.73 & 0.11 & 0.02 \\
\hline Test Well \#10 & $5.138 \mathrm{E}-03$ & 0.7 & 3.356E-03 & 120 & -1.80 & -0.62 & -1.30 & -4.83 & -3.65 & 1.31 & 0.63 \\
\hline Test Well \#3 & $9.868 \mathrm{E}-03$ & 2.4 & 5.641E-03 & 1.1 & -1.84 & -0.04 & -0.84 & -3.01 & -1.78 & 0.55 & 0.24 \\
\hline
\end{tabular}


Table 5-1

Mineral Saturation Indices and Other Quantities Calculated by PHREEQC for Selected Wells and Springs

(Page 4 of 5)

\begin{tabular}{|c|c|c|c|c|c|c|c|c|c|c|c|}
\hline Site ID & 으 응 & 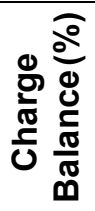 & 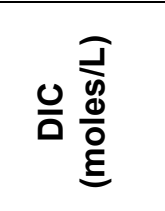 & 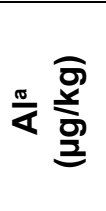 & 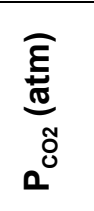 & $\frac{\stackrel{0}{N}}{\stackrel{0}{0}}$ & $\frac{\sqrt{\pi}}{\frac{\pi}{\pi}}$ & 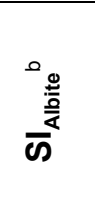 & 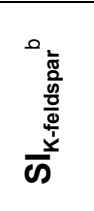 & 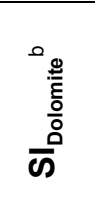 & 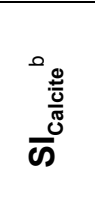 \\
\hline ER-3-1 & $1.612 \mathrm{E}-02$ & 6.5 & $1.362 \mathrm{E}-02$ & 0.3 & -0.75 & 0.13 & -0.66 & -3.16 & -1.89 & 0.00 & -0.03 \\
\hline ER-5-3 \#2 & 1.545E-02 & -1.5 & 1.168E-02 & 9.0 & -1.28 & 0.14 & -0.67 & -1.34 & 0.02 & 0.71 & 0.35 \\
\hline ER-6-1 & 6.193E-03 & -1.5 & $3.978 \mathrm{E}-03$ & 3.0 & -2.28 & 0.04 & -0.74 & -2.70 & -1.32 & 0.84 & -0.06 \\
\hline ER-6-1 \#2 & $6.152 \mathrm{E}-03$ & 1.9 & $3.990 \mathrm{E}-03$ & 0.7 & -1.77 & 0.13 & -0.66 & -3.06 & -1.66 & -0.31 & -0.20 \\
\hline USGS HTH-E & $1.575 \mathrm{E}-03$ & 2.2 & 9.952E-04 & 20 & -3.61 & -0.85 & -1.69 & -4.50 & -3.15 & -1.21 & -0.16 \\
\hline ER-7-1 & 6.382E-03 & -0.2 & $4.048 \mathrm{E}-03$ & 6.8 & -2.16 & 0.03 & -0.74 & -2.59 & -1.32 & 1.03 & 0.11 \\
\hline UE-7nS & 4.645E-03 & -3.7 & $3.533 \mathrm{E}-03$ & 1.4 & -2.22 & -0.01 & -0.82 & -2.91 & -1.78 & -0.46 & -0.08 \\
\hline Water Well C-1 & 1.439E-02 & -0.8 & 1.149E-02 & 522 & -1.09 & 0.13 & -0.67 & 0.30 & 1.56 & 0.28 & 0.10 \\
\hline Water Well C & 1.414E-02 & 2.0 & 1.005E-02 & 628 & -1.33 & 0.21 & -0.60 & 0.69 & 1.99 & 0.57 & 0.24 \\
\hline Army 6 & 4.901E-03 & -0.5 & $3.081 \mathrm{E}-03$ & 100 & -2.64 & -0.41 & -1.25 & -2.92 & -1.26 & 0.58 & 0.17 \\
\hline U-3cn \#5 & 7.505E-03 & -1.6 & 4.690E-03 & 700 & -1.76 & 0.30 & -0.47 & 0.44 & 1.77 & 0.30 & 0.01 \\
\hline Army \#1 & 7.766E-03 & 0.8 & $4.449 \mathrm{E}-03$ & 501 & -1.88 & 0.01 & -0.81 & -0.39 & 1.04 & 0.00 & -0.07 \\
\hline UE-1q & 5.369E-03 & 3.5 & $3.154 \mathrm{E}-03$ & 0.9 & -2.91 & 0.44 & -0.39 & -1.72 & -0.16 & 1.06 & \\
\hline UE-1h & 7.227E-03 & $0.0^{c}$ & $4.479 \mathrm{E}-03$ & 43 & -2.78 & -0.20 & -1.03 & -1.48 & 0.23 & 0.72 & 0.29 \\
\hline ER-6-2 & $9.865 \mathrm{E}-03$ & -2.7 & $6.355 \mathrm{E}-03$ & 8.6 & -1.99 & 0.15 & -0.66 & -1.64 & -0.18 & 1.08 & -0.18 \\
\hline USGS Test Well D & 5.554E-03 & 1.1 & 3.945E-03 & 60 & -2.54 & 0.43 & -0.41 & 0.51 & 1.85 & -0.26 & -0.08 \\
\hline UE-10j & 1.160E-02 & 9.4 & 7.037E-03 & 0.1 & -1.44 & 0.26 & -0.57 & -3.15 & -1.59 & 0.01 & 0.00 \\
\hline UE-10j, Zone \#1 & 1.573E-02 & 4.3 & $1.543 \mathrm{E}-02$ & 0.06 & -0.64 & 0.30 & -0.52 & -3.49 & -1.95 & -0.53 & -0.29 \\
\hline UE-10j, Zone \#2 & 1.093E-02 & -3.3 & $9.016 \mathrm{E}-03$ & 0.09 & -1.07 & 0.25 & -0.56 & -3.48 & -1.94 & -0.49 & -0.28 \\
\hline UE-10j, Zone \#3 & $9.406 \mathrm{E}-03$ & 0.9 & $6.045 \mathrm{E}-03$ & 0.22 & -1.56 & 0.20 & -0.62 & -3.26 & -1.70 & 0.04 & -0.02 \\
\hline USGS Test Well F (HTH) & $8.226 \mathrm{E}-03$ & 2.6 & $4.471 \mathrm{E}-03$ & 100 & -1.63 & -0.07 & -0.80 & -1.97 & -0.89 & 0.75 & 0.36 \\
\hline UE-2ce & $9.290 \mathrm{E}-03$ & 0.0 & $6.597 \mathrm{E}-03$ & 0.13 & -1.43 & 0.36 & -0.45 & -2.98 & -1.02 & -0.15 & 0.06 \\
\hline UE-16d & 1.001E-02 & 1.4 & $6.012 \mathrm{E}-03$ & 20 & -1.92 & 0.30 & -0.56 & -0.73 & 0.99 & 0.29 & 0.15 \\
\hline USGS-MX Coal Valley Well & $6.195 \mathrm{E}-03$ & -2.4 & $4.224 \mathrm{E}-03$ & 0.11 & -2.04 & 0.35 & -0.49 & -3.11 & -1.36 & -0.21 & -0.12 \\
\hline
\end{tabular}


Table 5-1

Mineral Saturation Indices and Other Quantities Calculated by PHREEQC for Selected Wells and Springs

(Page 5 of 5)

\begin{tabular}{|c|c|c|c|c|c|c|c|c|c|c|c|}
\hline Site ID & 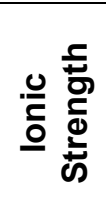 & 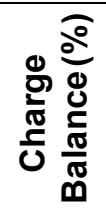 & 음 $\frac{\text { J }}{\frac{d}{o}}$ & $\frac{\sqrt{2}}{\frac{y}{5}}$ & 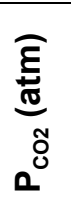 & $\frac{\stackrel{0}{0}}{\stackrel{0}{0}}$ & 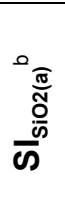 & 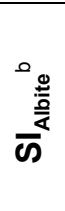 & 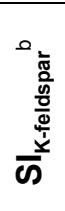 & 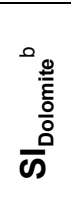 & ๘ \\
\hline
\end{tabular}

a Al concentrations include both estimated and measured values.

b $\mathrm{SI}=$ Saturation index - Negative values indicate undersaturation, and positive values indicate oversaturation.

c The charge balance for Well UE-1h is zero, because the sulfate concentration was estimated by balancing the charges (no sulfate data were available).

atm $=$ Atmospheres

DIC = Dissolved inorganic carbon

moles $/ \mathrm{L}=$ Moles per liter

$\mu \mathrm{g} / \mathrm{kg}=$ Microgram per kilogram

$\mathrm{P}=$ Pressure 
chemistry along a given flow path. The reactive or exchangeable phases used in NETPATH modeling included calcite, dolomite, gypsum, halite, and silica; $\mathrm{Ca}$ and $\mathrm{Mg}$ exchange for $\mathrm{Na}$; and composite glass, feldspar, clay, and clinoptilolite (a composite of the most prevalent zeolites, mordenite and clinoptilolite). The chemical compositions of the composite volcanic glass, feldspar, clay, and clinoptilolite represent average compositions for these phases as measured for the TM HSU in the Pahute Mesa CAU (Table 3-4). The TM volcanic unit is prevalent in Yucca Flat. Because of the complex structure in Yucca Flat, for modeling purposes, it was assumed that along most flow paths, groundwater would contact both volcanic and carbonate HSUs. Therefore, water-rock reactions in the volcanic and carbonate units were modeled simultaneously; no attempt was made to model sequential movement of groundwater from one unit to the other.

NETPATH also calculates the $\delta^{13} \mathrm{C}$ value of the groundwater at the end of a proposed flow path using all carbon-containing phases involved in the geochemical reactions and the associated $\delta^{13} \mathrm{C}$ fractionation of each reaction. The $\delta^{13} \mathrm{C}$ values calculated by NETPATH should match the $\delta^{13} \mathrm{C}$ values measured in the final water for the modeled flow path to be considered a valid representation of the geochemical reactions along that flow path. Average $\delta^{13} \mathrm{C}$ values for carbonate minerals used in NETPATH modeling were calculated from carbonate bedrock samples from wells at the NTS only as listed in Table 3-2 (calcite $=+1.0$ permil, dolomite $=+0.1$ permil $)$.

Because NETPATH is a deterministic modeling program and cannot incorporate uncertainty within the model calculations, uncertainty must be accommodated by limiting what is considered reasonable net changes in mineral phases. For a set of geochemical reactions along a proposed flow path to be considered a valid representation of the flow path, net changes in mineral phases greater than $1 \mathrm{mmol} / \mathrm{L}$ were assumed to indicate unrealistically large amounts of material moving in to, or out of, solution. For example, dissolution of 1 millimole (mmol) of calcite would add 40 milligrams $(\mathrm{mg})$ of Ca to a 1-liter (L) solution. Additionally, sometimes, NETPATH will ignore the setting of a mineral's saturation state (e.g., feldspar will be allowed to precipitate even though it was set to only dissolve) to produce a possible model. Net changes of mineral phases against their thermodynamic saturation state were limited to less than $0.1 \mathrm{mmol} / \mathrm{L}$. For example, dissolution of $0.1 \mathrm{mmol}$ of composite clay would add $0.6 \mathrm{mg}$ of $\mathrm{Ca}$ to a $1-\mathrm{L}$ solution. The mineral saturation states are listed in Table 5-1. 
In addition to limiting the net changes in mineral phases, uncertainty is also considered for modeled values of $\delta \mathrm{D}, \delta^{18} \mathrm{O}$, and $\mathrm{Cl}$. A model derived final water was required to have a calculated $\delta \mathrm{D}$ within 3 permil of the measured $\delta \mathrm{D}$; a calculated $\delta^{18} \mathrm{O}$ within 1 permil; and a calculated $\mathrm{Cl}$ concentration equal to, or less than, the measured concentration of the final water. The latter requirement assumes that a $\mathrm{Cl}$-containing phase is present along the flow path and that this phase may dissolve, adding $\mathrm{Cl}$ to the groundwater.

Finally, uncertainty was also considered for modeled values of $\delta^{13} \mathrm{C}$. A model with calculated $\delta^{13} \mathrm{C}$ values that differed by more than 1 permil of the final downgradient water suggested a poor representation of the reactions for the carbonate containing phases along this flow path. Values of $\delta^{13} \mathrm{C}$ that varied by more than 1 permil suggested that: (1) the carbon-containing phases in the model are not all accounted for; (2) the $\delta^{13} \mathrm{C}$ values used for calcite and dolomite in the simulations are not representative of the rock units or they have greater variability than measured; (3) the groundwaters chosen for the simulation are not representative of the actual mixture; or (4) some combination of the above factors.

In addition to changes in $\delta^{13} \mathrm{C}$, NETPATH also tracks the changes in ${ }^{14} \mathrm{C}$ caused by mixing, precipitation and dissolution of carbon containing phases, isotopic fractionation of carbon during phase changes, and radioactive decay. Groundwater travel times calculated by NETPATH for a given flow path were presented when all of the uncertainty criteria were met and the modeled $\delta^{13} \mathrm{C}$ of the final water was within 1 permil of the measured value. If any of the uncertainty criteria were not met, or if $\delta^{13} \mathrm{C}$ and/or ${ }^{14} \mathrm{C}$ data were not available for all wells in the model, ${ }^{14} \mathrm{C}$ derived groundwater ages were not calculated. Note that PHREEQC performs similar mass balance calculations as NETPATH but does not account for isotopic fractionation of $\delta^{13} \mathrm{C}$ and ${ }^{14} \mathrm{C}$ and does not calculate groundwater travel times directly.

\subsubsection{Geochemical Models with PHREEQC}

PHREEQC v. 2.8 (Parkhurst and Appelo, 1999) was used because it accommodates uncertainty in geochemical parameters such as dissolved chemical concentrations, isotope ratios of dissolved species, and isotopic compositions of potentially reactive phases, and it propagates these uncertainties through the analysis. The uncertainty in groundwater compositions is expressed in the model results through the identification of multiple possible mixing and reaction models, each involving 
groundwater from different wells or different water-rock interactions, and uncertainty bounds on the mixing fractions and reactions identified for each particular model. The uncertainty in mixing proportions and reactions associated with multiple possible models generally is considerably greater than the uncertainty bounds provided by PHREEQC for any one particular model. It is also important to note that when multiple plausible models are identified, the true model may be a linear combination of these models.

The uncertainties generally attributed to various groundwater species in the PHREEQC models for Yucca Flat are:

- $\mathrm{pH}-0.20 \mathrm{pH}$ units

- Ions, alkalinity, and silica $\left(\mathrm{SiO}_{2}\right)-10$ percent of their measured values

- $\quad \delta \mathrm{D}-1.0$ permil

- $\quad \delta^{18} \mathrm{O}$ and $\delta^{13} \mathrm{C}-0.2$ permil (but sometimes as low as 0.1 permil for $\delta^{18} \mathrm{O}$ and as high as 0.5 permil for $\delta^{13} \mathrm{C}$ )

- $\mathrm{Al}$ and $\mathrm{Fe}$ - At wells for which no $\mathrm{Al}$ or Fe concentrations were available, Al concentrations were estimated from assumed equilibrium with kaolinite $\left[\mathrm{Al}_{2} \mathrm{Si}_{2} \mathrm{O}_{5}(\mathrm{OH})_{4}\right]$ and $\mathrm{Fe}^{3+}$ concentrations were estimated from assumed equilibrium with amorphous iron hydroxide $\left[\mathrm{Fe}(\mathrm{OH})_{3}\right]$. The uncertainty in $\mathrm{Al}$ and $\mathrm{Fe}$ concentrations was generally assigned to be 20 percent of either the measured or estimated value. However, if all geochemical and isotopic constraints for a particular inverse model were satisfied except $\mathrm{Al}$ or Fe, the uncertainty in these elements was increased to as high as 50 percent to reduce the dependence of the model results on their concentrations. This was done to insure that models were not rejected because of excessively restrictive constraints on the estimated Al or Fe concentrations, and in recognition that representative mineral compositions used in the models do not reflect the total range in compositions for a given mineral in the Yucca Flat flow domain.

PHREEQC is free to adjust the measured ion concentrations and isotope ratios in each groundwater contained in the model within these uncertainties to satisfy the mass-balance constraints for each element and isotope.

The use of $\delta^{13} \mathrm{C}$ as a constraint in the models requires that the $\delta^{13} \mathrm{C}$ of carbon-bearing minerals such as calcite and dolomite also be defined. Based on measurements of fracture-lining carbonate minerals from Pahute Mesa and Yucca Flat discussed in Section 3.3.2, the $\delta^{13} \mathrm{C}$ of dissolving calcite was assumed to be $0.0 \pm 4.0$ permil and the $\delta^{13} \mathrm{C}$ of dolomite was assumed to be $0.0 \pm 2.0$ permil. The $\delta^{13} \mathrm{C}$ 
of precipitating calcite was assumed to be $-4.0 \pm 4.0$ permil, which corresponds to the approximate range of $\delta^{13} \mathrm{C}$ in high-alkalinity LCA groundwater where the calcite deposition was presumed to occur. The Sr concentrations and isotope ratios of rocks and fracture-lining minerals in the Yucca Flat area were not characterized well enough that Sr isotopes could be used directly as a constraint in the numerical models, but model results are evaluated to identify preferred models. Likewise, although evidence exists suggesting the dissolution of halite along a flow path, ${ }^{36} \mathrm{Cl} / \mathrm{Cl}$ isotopic ratios are not available at enough wells to be used directly as constraints in the geochemical models.

Generally, multiple inverse models involving different combinations of wells and water-rock interactions explain the groundwater composition at a downgradient well, so the fractions of groundwater from different upgradient wells that contribute groundwater to that well will span a range of values. Individual models also have some uncertainty in the mixing fractions and amounts of water-rock interaction because of the uncertainty associated with the groundwater isotopic and chemical data. The graphical summaries of the inverse models shown in this report illustrate how similar groundwaters can substitute for each other in the models and how even distinct groundwaters can combine in different ways to produce the groundwater composition at the downgradient well.

The PHREEQC models investigated are generally based on the mixing models identified using conservative tracers; however, alternative models were investigated when PHREEQC could not balance elements and isotopes using the proposed mixing end-members. These alternative models were identified by considering groundwaters from other upgradient parts of the flow system with a suitable composition. Because the PHREEQC models consider uncertainty in the measured groundwater chemical and isotopic data, mixing fractions determined with PHREEQC may be different from those calculated from the conservative tracer and NETPATH models. Often, PHREEQC will find models by adjusting reported data within their allowable uncertainty to obtain a fit, rather than by considering additional end-member compositions. These adjustments can result in the models that are substantially different from the conservative tracer and NETPATH models, especially when the end-members are not widely separated in parameter space or when three or more end-members lie along a line; in the latter case, some of the end-members can be expressed in terms of mixing of the other end-members, rendering the problem mathematically non-unique. 


\subsubsection{Evaluation of Groundwater Transit Times Using PHREEQC Model Results}

Groundwater transit times in the Yucca Flat area were estimated in EXCEL using the results of the PHREEQC mixing and water-rock interaction models and the groundwater ${ }^{14} \mathrm{C}$ activities measured at the wells involved in the mixture. The radioactive decay equation to calculate groundwater transit time from ${ }^{14} \mathrm{C}$ decay along a flow path can be written as:

$$
t=(1 / \lambda) \ln \left({ }^{14} C_{u} \cdot q_{D I}{ }^{14} C_{d}\right)
$$

Where $\lambda$ is the radioactive decay constant for ${ }^{14} \mathrm{C}\left(1.21 \cdot 10^{-4}\right.$ years $\left.^{-1}\right) ;{ }^{14} C_{u}$ is the ${ }^{14} \mathrm{C}$ activity that results when groundwater at the upgradient wells are mixed in the proportions identified in the PHREEQC inverse models; $q_{D I C}$ is the ${ }^{14} \mathrm{C}$ dilution factor that accounts for the addition of ${ }^{14} \mathrm{C}$-free carbon to groundwater from water-rock interaction; and ${ }^{14} \mathrm{C}_{d}$ is the groundwater ${ }^{14} \mathrm{C}$ activity at the downgradient well.

For flow paths along which the PHREEQC inverse models identified mixing as an important control on the downgradient groundwater chemistry, the values of ${ }^{14} C_{u}$ and $q_{\text {DIC }}$ were calculated as follows:

$$
\begin{gathered}
{ }^{14} C_{u}=\left(f_{1}{ }^{14} C_{1} D I C_{1}+f_{2}{ }^{14} C_{2} D I C_{2}+\ldots+f_{i}{ }^{14} C_{i} D I C_{i}\right) /\left(f_{1} D I C_{1}+f_{2} D I C_{2}+\ldots+f_{i} D I C_{i}\right) \\
\text { and } \\
q_{D I C}=\left(f_{1} D I C_{1}+f_{2} D I C_{2}+\ldots+f_{i} D I C_{i}\right) /\left(f_{1} D I C_{1}+f_{2} D I C_{2}+\ldots+f_{i} D I C_{i}+D I C_{\text {carbonate }}\right)
\end{gathered}
$$

Where $f_{i}$ is the fraction of groundwater from upgradient well $i$ in the mixture, $D I C_{i}$ is the total DIC in the groundwater at well $i$, and $D I C_{\text {carbonate }}$ is the groundwater DIC acquired from carbonate dissolution reactions. The term $q_{\mathrm{DIC}}$ accounts for the decrease in ${ }^{14} \mathrm{C}$ activity, which results from water-rock interactions rather than radioactive decay.

The equations do not consider the effects of $\mathrm{CO}_{2}$ degassing or dissolution, or calcite precipitation on the ${ }^{14} \mathrm{C}$ activity. These omissions are acceptable simplifications because the fractionation factor for ${ }^{14} \mathrm{C}$ is small (Clark and Fritz, 1997), and the small amount of ${ }^{14} \mathrm{C}$ (or ${ }^{13} \mathrm{C}$ ) in the $\mathrm{CO}_{2}$ or calcite exiting the groundwater should leave the carbon isotopes remaining in the groundwater relatively unchanged. Gas dissolution by the groundwater should not occur in most instances because the $\log P_{\mathrm{CO} 2}$ of the groundwater in the Yucca Flat area (Table 5-1) is higher than that expected in the overlying 
unsaturated zone based on measurements elsewhere in the NTS area (e.g., Thorstenson et al., 1998). Although isotope exchange reactions are not explicitly considered in these equations, the PHREEQC models are constrained by the groundwater $\delta^{13} \mathrm{C}$ data. In many cases, the geochemical inverse models predicted the simultaneous dissolution of dolomite and precipitation of calcite, reactions that together mimic the isotope exchange process.

The groundwater transit times estimated from the ${ }^{14} \mathrm{C}$ decay equation provide an estimate of the average or "composite" transit time for the mixture to the downgradient well. These estimates can be useful when the upgradient wells are close to each other relative to their distance from the downgradient well, but these estimates become less useful when the upgradient wells are widely separated geographically or lie along different trajectories to the downgradient well. To obtain estimates of groundwater transit time from individual wells to the downgradient well, the transit time estimates obtained with the radioactive decay equation were decomposited by recognizing that variations in these composite transit times for individual inverse models can be expressed as a function of the transit times from the individual wells in the mixture and their mixing fractions:

$$
\begin{aligned}
& \mathrm{f}_{1 \mathrm{a}} \mathrm{tt}_{1}+\mathrm{f}_{2 \mathrm{a}} \mathrm{tt}_{2}+\ldots+\mathrm{f}_{\mathrm{na}} \mathrm{tt}_{\mathrm{n}}=\mathrm{tt}_{\mathrm{a}} \\
& \mathrm{f}_{1 \mathrm{~b}} \mathrm{tt}_{1}+\mathrm{f}_{2 \mathrm{~b}} \mathrm{tt}_{2}+\ldots+\mathrm{f}_{\mathrm{nb}} \mathrm{tt}_{\mathrm{n}}=\mathrm{tt}_{\mathrm{b}} \\
& \mathrm{f}_{1 \mathrm{~m}} \mathrm{tt}_{1}+\mathrm{f}_{2 \mathrm{~m}} \mathrm{tt}_{2}+\ldots+\mathrm{f}_{\mathrm{nm}} \mathrm{tt}_{\mathrm{n}}=\mathrm{tt}_{\mathrm{m}}
\end{aligned}
$$

Where $f_{i j}$ is the mixing fraction of well $i(i=1$ to $n)$ in inverse model $j(j=1$ to $m), t t_{i}$ is the transit time from well $i$ to the downgradient well, and $t t_{j}$ is the composite groundwater transit times calculated from the radioactive decay equation for inverse model $j(j=1$ to $m)$. This matrix equation expresses variations in composite transit time $\left(\mathrm{tt}_{\mathrm{j}}\right)$ among the models as a function of the variations in the mixing fractions $\left(\mathrm{f}_{\mathrm{ij}}\right)$ and the transit times from individual wells to the downgradient well $\left(\mathrm{tt}_{\mathrm{i}}\right)$.

Generally, there are many more inverse models than there are wells with non-zero mixing fractions in a set of models, so the unknowns (i.e., the transit times from individual wells $\left[\mathrm{tt}_{\mathrm{i}}\right]$ ) are estimated from multiple linear regression within EXCEL rather than by direct inversion of the system of equations. The slopes estimated from the regression are the unknown travel times from individual wells to the downgradient well. The 95 percent confidence limits on the estimates of the slopes provide the uncertainty bounds on the travel times. 


\section{0 evaluation of northern flow Paths}

Upland areas surrounding the northern part of Yucca Flat are largely comprised of low permeability rocks with steep water-level gradients across the HSUs (Figure 2-8), suggesting limited regional groundwater flow into the basin from the north, northeast, and west. Geochemical models for northern Yucca Flat were used to evaluate the relative contributions of local recharge, groundwater inflow from the LCA, and groundwater inflow from the alluvium and volcanic units in areas north and northeast of the Yucca Flat basin. The relative contributions from these different sources must be delineated so that downgradient changes in the groundwater chemistry can be interpreted.

Unfortunately, data for wells and springs to the north (and particularly, northeast) of Yucca Flat are limited in both quantity and quality. This lack of data makes it difficult to clearly identify "end-member" compositions. The only regional groundwater data in the area immediately northeast of Yucca Flat are from alluvial and volcanic aquifers sampled by the Watertown wells in Emigrant Valley (Figure 3-1). Although some additional data are available for perched springs in the Groom and Belted Ranges, an examination of the $\delta \mathrm{D}-\delta^{18} \mathrm{O}$ data suggests that modern recharge from these ranges cannot account for the compositions of the Watertown wells (Figure 6-1). The nearest LCA sampling location north of Yucca Flat is in Pahranagat Valley - more than 80 km away.

Conservative tracer data $\left(\delta \mathrm{D}, \delta^{18} \mathrm{O}, \mathrm{Cl}\right)$ for northern Yucca Flat and surrounding areas are plotted in Figures 6-1 and 6-2. The data shown in Figures 6-1 and 6-2 are divided into HSU groups and also into major geographic source areas lying outside the basin. The plots also include the weighted average precipitation data from the two precipitation stations, RT 1 and RT 2, on Rainier Mesa. As discussed in Section 4.0, highly evaporated waters plot along a low slope $\delta \mathrm{D}-\delta^{18} \mathrm{O}$ trajectory that lies below the meteoric water line (an evaporative trend is shown in Figure 6-1). The least evaporated samples of the perched spring and Rainier Mesa tunnel water show a broad range in $\delta \mathrm{D}$ and $\delta^{18} \mathrm{O}$ values that do not appear to be strongly related to differences in geographic location. For this reason, it is difficult to define a single composition that uniquely represents the $\delta \mathrm{D}$ and $\delta^{18} \mathrm{O}$ compositions of local recharge in this area. Average compositions of individual perched springs 


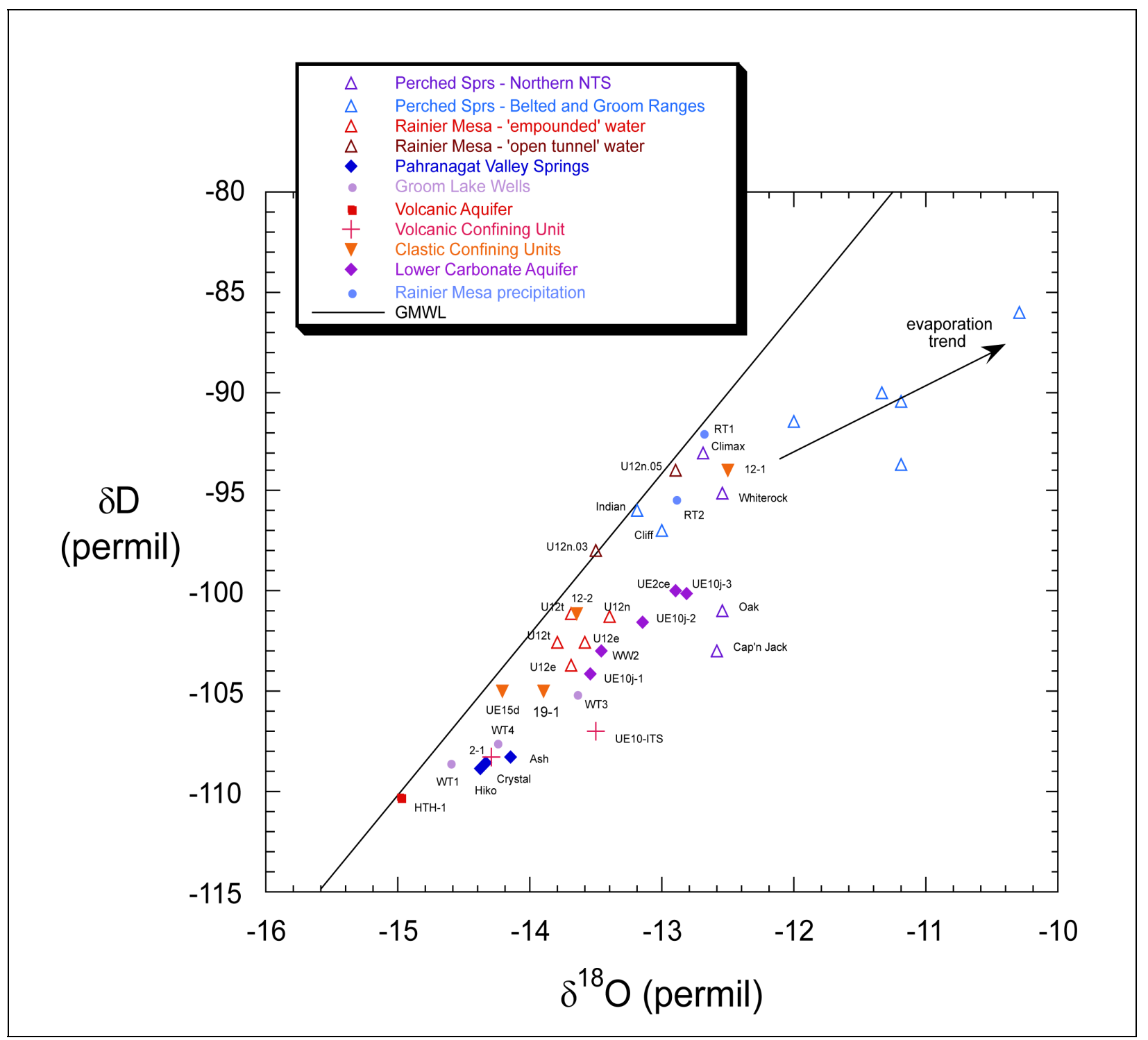

Figure 6-1

Plot of $\delta D$ Versus $\delta^{18} O$ Values for Regional and Perched Groundwater Samples in Northern Yucca Flat and Surrounding Areas

are used to represent local recharge in most geochemical models. These models sometimes require a combination of two perched water sources to accommodate the observed downgradient water composition. 


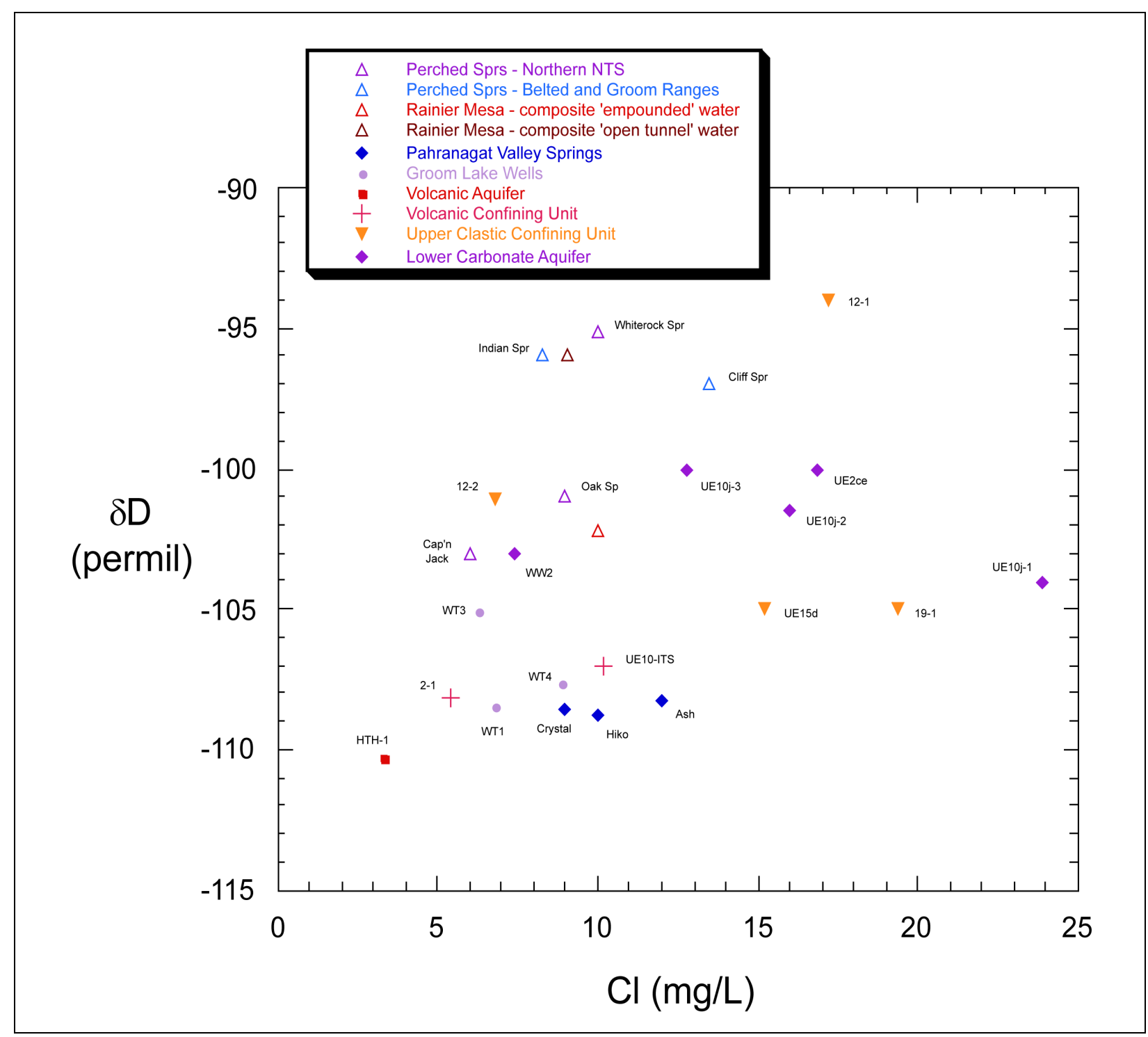

Figure 6-2

Plot of $\delta D$ Versus Cl for Regional and Perched Groundwater Samples in Northern Yucca Flat and Surrounding Areas

\subsection{Geochemical Modeling of Well UE-10j}

\subsubsection{Conservative Tracer Models for Well UE-10j}

Well UE-10j is the northernmost Yucca Flat well completed in the LCA. This well was constructed such that discrete groundwater samples could be collected at three depth intervals: 765.0 to $773.0 \mathrm{~m}$ (UE-10j-1); 732.3 to $740.1 \mathrm{~m}$ (UE-10j-2); and 691.1 to $699.0 \mathrm{~m}$ (UE-10j-3) (IT, 1995, Figure 7-1). 
All three zones are completed within the Banded Mountain Member of the Cambrian Bonanza King Formation (IT, 1995, Figure 4-1).

The UE-10j data show a systematic variation in $\delta \mathrm{D}, \delta^{18} \mathrm{O}$, and $\mathrm{Cl}$ values as a function of depth (Figures 6-1 and 6-2) that suggests mixing of locally derived groundwater recharge with LCA groundwater. The origin of the deep LCA groundwater in UE-10j-1 cannot be determined with the existing dataset, as illustrated by the $\delta \mathrm{D}$ versus $\mathrm{Cl}$ data in Figure 6-2. UE-10j-1 has the highest $\mathrm{Cl}$ concentration of any groundwater in northern Yucca Flat. This high $\mathrm{Cl}$ concentration precludes the development of mixing models using known upgradient water compositions. The UE-10j-1 stable isotope composition could be accommodated by mixing upgradient water with local springs, but the nearest upgradient LCA sample locations are more than $80 \mathrm{~km}$ away at the Pahranagat Valley springs, and these springs have dilute $\mathrm{Cl}$ values (Figure 6-2). It is conceivable that the elevated $\mathrm{Cl}$ in UE-10j-1 reflects carbonate rock dissolution along an LCA flow path, but the lack of nearby data for LCA groundwater north of the NTS does not permit testing this hypothesis with confidence. Because of this uncertainty in source identity, the origin of deep LCA groundwater at UE-10j will not be considered further. Nevertheless, this water composition factors prominently in many groundwater mixing scenarios.

Assuming end-member mixing of deep UE-10j-1 with local perched waters, the following mixing models were obtained for UE-10j-3 groundwater (the shallowest production interval):

$\begin{array}{ccccc}\text { Tracer } & \text { Mixing Comp. } 1+\text { Mixing Comp. } 2+ & \text { Mixing Comp. } 3 & \text { Final Composition } \\ & \text { UE-10j-1 } & \text { Oak Spring } & \text { Whiterock Spring } & \text { UE-10j-3 } \\ \delta D & 23.6 & 48.7 & 27.7 & \\ \delta^{18} \mathrm{O} & 28.7 & 59.1 & 12.2 & \\ \mathrm{Cl} & 23.6 & 48.7 & 27.7 & \\ & & & & \text { UE-10j-3 } \\ \delta \mathrm{D} & \text { UE-10j-1 } & \text { Oak Spring } & \text { Cliff Spring } & \\ \delta^{18} \mathrm{O} & 15.2 & 50.6 & 34.2 & \\ \mathrm{Cl} & 17.2 & 57.6 & 25.2 & \end{array}$

These results suggest that between 71 and 85 percent of the UE-10j-3 groundwater is derived from local recharge, and only 15 to 29 percent is from "undiluted" LCA groundwater in the lower portion of the well (UE-10j-1). 


\subsubsection{Strontium and ${ }^{87} \mathrm{Sr} /{ }^{86} \mathrm{Sr}$ Models for Well UE-10j}

The UE-10j samples have progressively lower Sr concentrations and lower ${ }^{87} \mathrm{Sr} /{ }^{86} \mathrm{Sr}$ values with decreasing depth, and form a linear trend on a ${ }^{87} \mathrm{Sr} /{ }^{86} \mathrm{Sr}$ versus $1 / \mathrm{Sr}$ plot (Figure 6-3A). This relation suggests mixing between an LCA and a more dilute local recharge end- member similar to results based on conservative tracers. Unfortunately, $\mathrm{Sr}$ and ${ }^{87} \mathrm{Sr} /{ }^{86} \mathrm{Sr}$ data are not available for Oak or Whiterock springs to test the same models that were tested with conservative tracers (Appendix A, Table A.1-5). Therefore, $\mathrm{Sr}$ concentrations and ${ }^{87} \mathrm{Sr} /{ }^{86} \mathrm{Sr}$ values representative of local recharge must be estimated by an alternative means. Six samples of perched water with ${ }^{87} \mathrm{Sr} /{ }^{86} \mathrm{Sr}$ data (Appendix A, Table A.1-5), have a narrow range of ${ }^{87} \mathrm{Sr} /{ }^{86} \mathrm{Sr}$ values with a mean of 0.70987 ( \pm 0.00157 [2 standard deviations]). Strontium concentrations for the 18 perched-water samples listed in Table A.1-4 show a much wider range ( 4.4 to $760 \mu \mathrm{g} / \mathrm{L}$ ) with a mean of 233 and a median of $130 \mu \mathrm{g} / \mathrm{L}$. Assuming that the mean ${ }^{87} \mathrm{Sr} /{ }^{86} \mathrm{Sr}$ value of perched water represents the composition of local recharge, linear relations between ${ }^{87} \mathrm{Sr} /{ }^{86} \mathrm{Sr}$ and $1 / \mathrm{Sr}$ for three UE-10j samples define a local recharge $\mathrm{Sr}$ concentration of about $169 \mu \mathrm{g} / \mathrm{L}$, which falls between the mean and median values measured in perched-water samples.

Binary mixing relations using $\mathrm{Sr}$ concentrations and ${ }^{87} \mathrm{Sr} /{ }^{86} \mathrm{Sr}$ compositions (Figure 6-3A) imply that shallower groundwater in UE-10j represent mixtures of UE-10j-1 and average local recharge in proportions of approximately 50:50 (UE-10j-1:local recharge) to derive UE-10j-2 groundwater and 30:70 to derive UE-10j-3 groundwater. These results based on $\mathrm{Sr}$ data are consistent with mixing relations obtained using ${ }^{87} \mathrm{Sr} r{ }^{86} \mathrm{Sr}$ versus $\delta \mathrm{D}$ (Figure 6-3B), and ${ }^{87} \mathrm{Sr} /{ }^{86} \mathrm{Sr}$ versus $\mathrm{Cl}$ data (Figure 6-3C) based on estimates of $\delta \mathrm{D}$ and $\mathrm{Cl}$ concentration values determined in mean local recharge ( $\delta \mathrm{D}$ value of -98.5 permil given in Section 4.1; $\mathrm{Cl}$ concentration of $8.12 \mathrm{mg} / \mathrm{L}$ representing the average of five perched spring and three perched water samples from Rainier Mesa Tunnels from Table 4-3). Relations between ${ }^{87} \mathrm{Sr} /{ }^{86} \mathrm{Sr}$ and ${ }^{14} \mathrm{C}$ in UE-10j samples imply that the local recharge end-member has a ${ }^{14} \mathrm{C}$ composition of approximately $15 \mathrm{pmc}$, similar to values expected for late Pleistocene recharge. For comparison, groundwater from the volcanic aquifer sampled at Water Well 4a (WW-4a) located in the CP basin (south of Yucca Flat) is similar to the theorized local recharge component in terms of Sr characteristics (Figure 6-1). However, volcanic aquifer groundwater sampled with similarly elevated Sr concentrations has not been identified in northern Yucca Flat. 

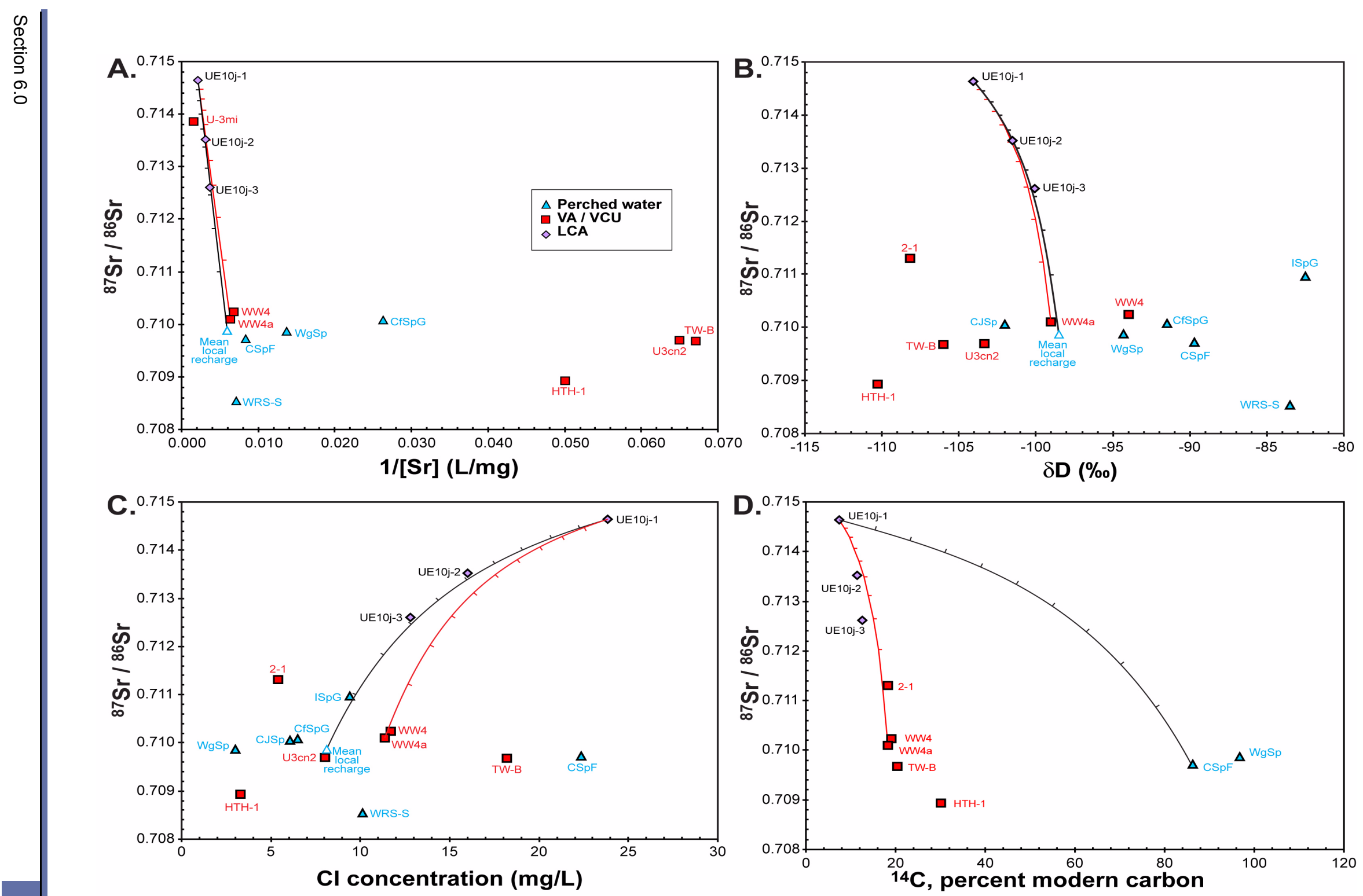

Figure 6-3

Relations Between ${ }^{87} \mathrm{Sr} /{ }^{86} \mathrm{Sr}, \mathrm{Sr}, \delta \mathrm{D}, \mathrm{Cl}$, and ${ }^{14} \mathrm{C}$ for Samples of LCA Water from Different Zones in Well UE-10j

Note: Simple mixing lines are shown between model end-members with 10 percent mixing increments. 


\subsubsection{NETPATH Models for Well UE-10j}

The NETPATH modeling results are presented in Table 6-1. The only reasonable NETPATH models produced for UE-10j-3 resulted in 70 percent Oak Spring, 5 percent Cliff Spring, and 25 percent UE-10j-1 (deepest LCA well completion interval). Note that reasonable models were only produced with $\delta^{18} \mathrm{O}$ data. Ideally, there should be good agreement between models with $\delta^{18} \mathrm{O}$ and $\delta \mathrm{D}$ data. Although conservative tracer modeling indicated a local recharge component similar to Whiterock spring present in UE-10j-3, NETPATH modeling of water-rock interactions did not support this mixture. Nevertheless, the relative mixing proportion of LCA (UE-10j-1) and local recharge in UE-10j-3 is very similar for the conservative tracer, Sr isotope, and NETPATH models.

The water-rock reactions in the NETPATH models include precipitation of calcite, dissolution of dolomite, dissolution of gypsum, $\mathrm{Na}$ exchange with $\mathrm{Ca}$ and $\mathrm{Mg}$, and various combinations of dissolution of composite feldspar and glass with precipitation of composite clay and zeolites. Because of the lack of $\delta^{13} \mathrm{C}$ and ${ }^{14} \mathrm{C}$ data for Oak and Cliff springs, $\delta^{13} \mathrm{C}$ was not modeled and travel times could not be calculated.

Table 6-1

Results of NETPATH Models for Well UE-10j-3

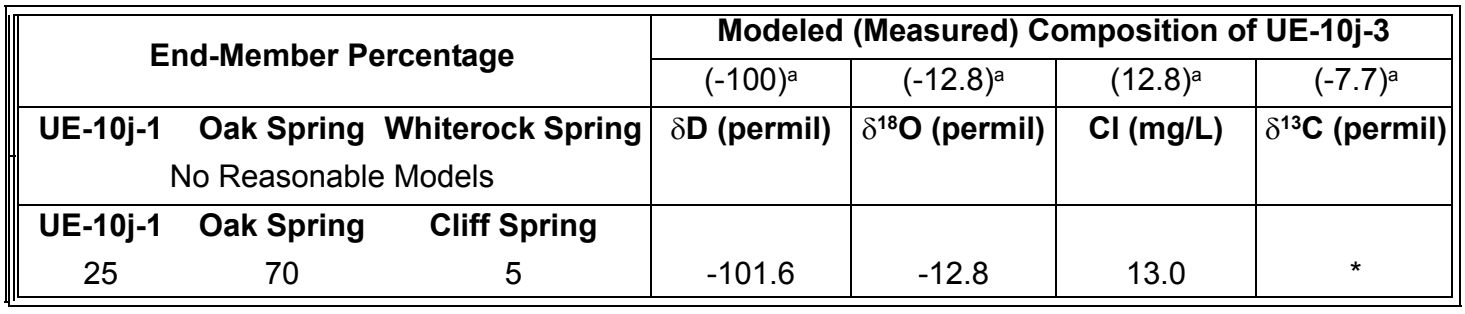

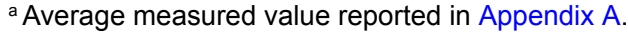

${ }^{*} \delta^{13} \mathrm{C}$ could not be modeled because of the lack of $\delta^{13} \mathrm{C}$ data for Oak Spring and Cliff Spring.

\subsubsection{PHREEQC Models for Well UE-10j}

The mixing fractions and water-rock reactions identified by the PHREEQC inverse models for UE-10j-3 are shown in Figures 6-4 and 6-5. These models consist of mixtures of local recharge using Oak and Cliff spring mixed with deep LCA water from UE-10j-1 to make the shallower depth LCA water at UE-10j-3. Note that these models did not use $\delta^{13} \mathrm{C}$ as a constraint because no $\delta^{13} \mathrm{C}$ data exist for either Oak or Cliff Springs. When $\delta^{13} \mathrm{C}$ was not used as a constraint, Whiterock Spring water 


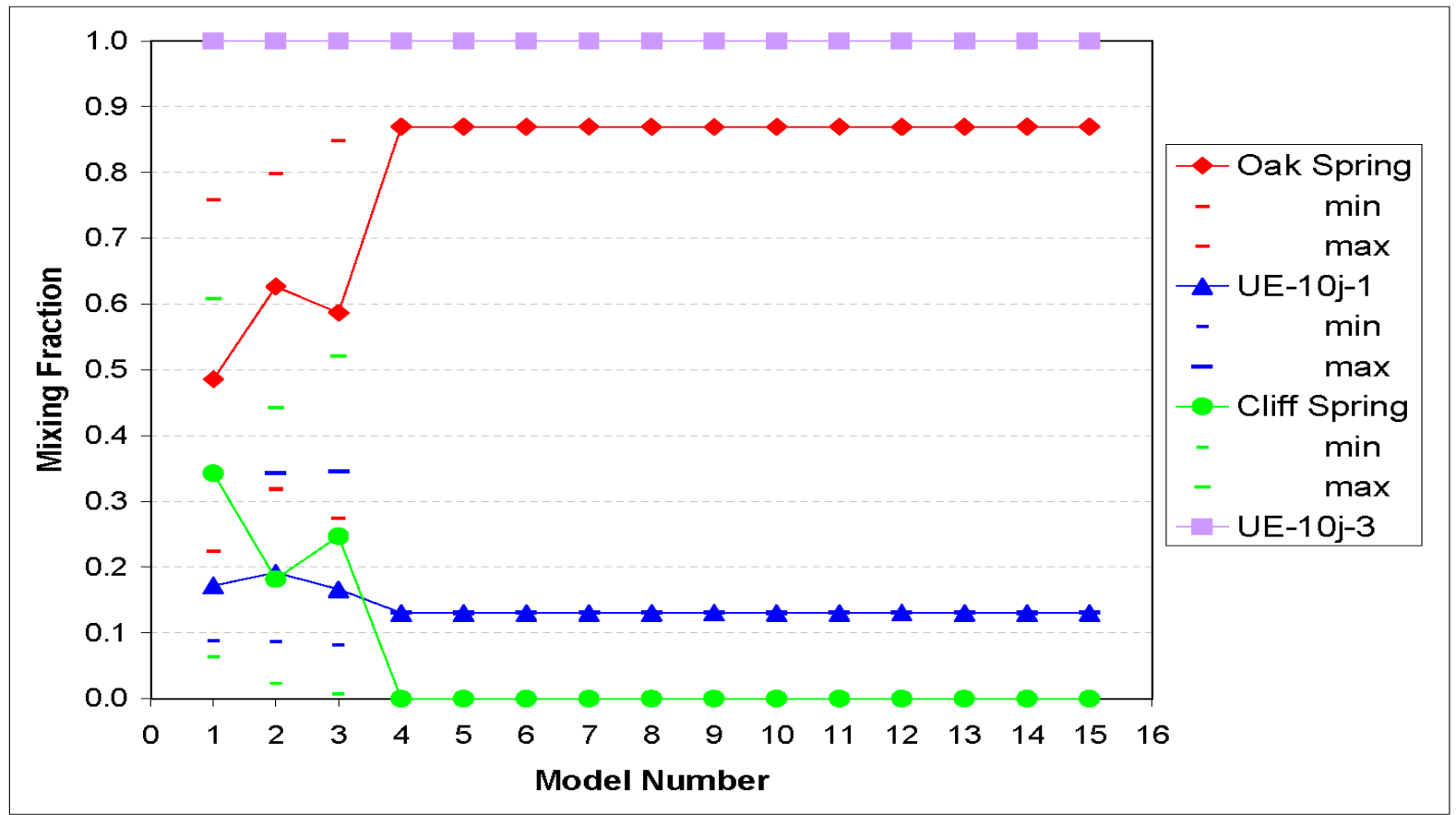

Figure 6-4

Mixing Fractions for UE-10j-3 Models

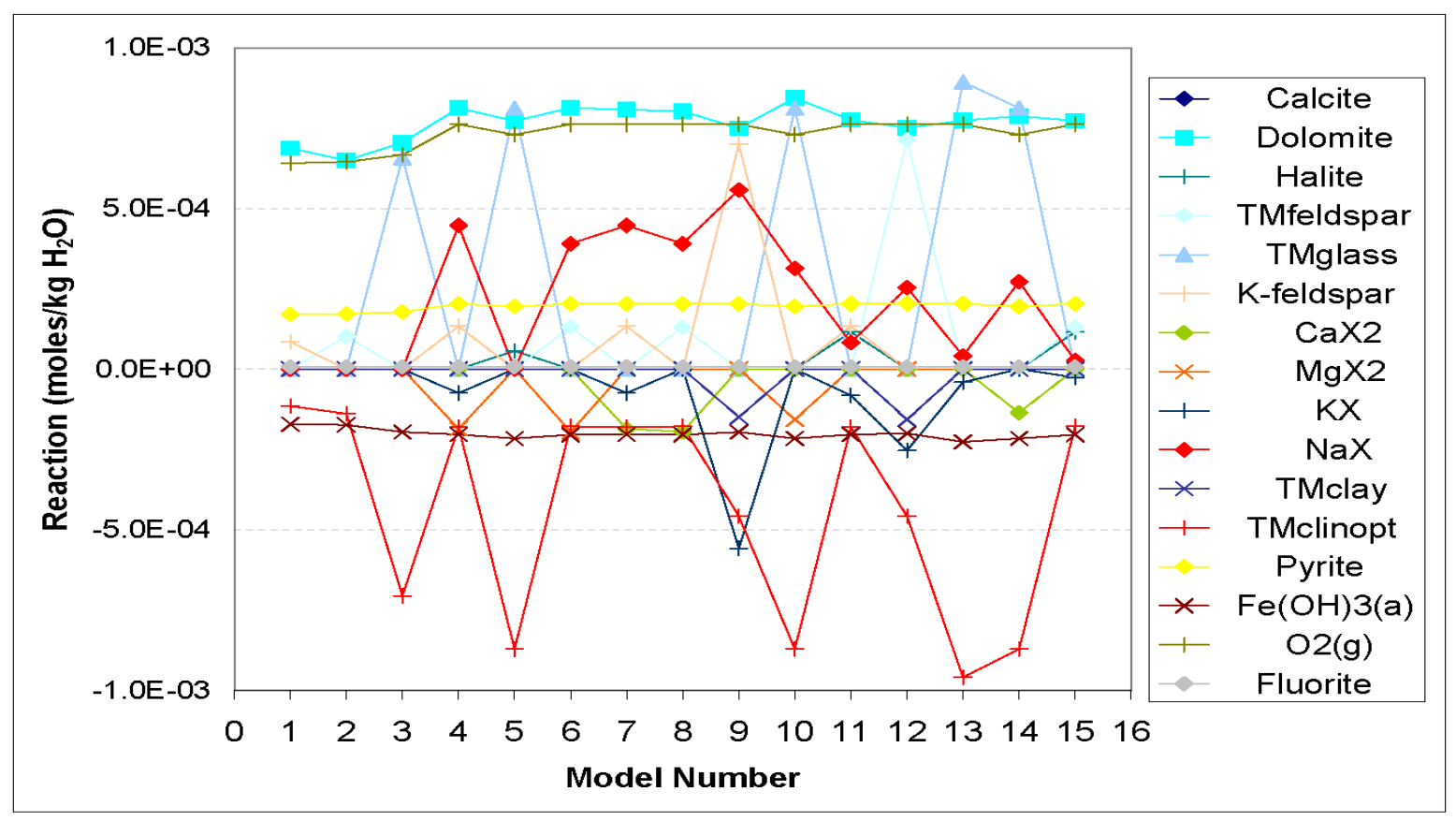

Figure 6-5

Reactions for UE-10j-3 Models

Note: Positive values indicate the mineral phase or element is entering into solution by dissolution or exchange, whereas negative values indicate the phase is leaving the solution by precipitation or exchange. 
could be successfully substituted for Cliff Springs water in these models, in which case it could form up to 50 percent of the mixture.

The mixing fractions calculated for this set of 15 models highlight the differences between the mixing models that do not consider uncertainty in conservative tracer compositions, and those calculated by PHREEQC when uncertainty is incorporated. Although the first three models include a contribution of roughly 20 to 30 percent from Cliff Spring, in good agreement with the conservative tracer models, the remaining models do not require the Cliff Spring component to be present in groundwater at UE-10j-3. For the models with no Cliff Spring component, mass-balance in the conservative tracer species (primarily $\delta \mathrm{D}$ and $\delta^{18} \mathrm{O}$ ) are achieved by adjusting the $\delta \mathrm{D}$ and $\delta^{18} \mathrm{O}$ of each groundwater sample within the specified uncertainties, rather than by including an additional end-member that will satisfy the mass-balance for $\delta \mathrm{D}$ and $\delta^{18} \mathrm{O}$ using the reported values exactly. While this may seem imprecise, it is important to remember that PHREEQC simultaneously solves mass-balance equations for sulfur (S), Cl, F, C, Ca, Mg, Na, K, Al, Fe, Si (and generally $\delta^{13} \mathrm{C}$ ) in addition to $\delta \mathrm{D}$ and $\delta^{18} \mathrm{O}$. The small deviations from the reported solution compositions are recognition that the chosen end-members are not necessarily a precise representation of groundwater present along a given flow path, and that the end-member compositions themselves are subject to analytical uncertainty. Using this approach, it is possible to obtain models that are constrained to honor elemental mass-balances for more than a dozen elements.

The most significant reactions for the UE-10j-3 inverse models involve the dissolution of dolomite, the oxidation of pyrite to amorphous iron, the dissolution of feldspars or glass, the precipitation of clay or zeolites, and ion exchange (Figure 6-5). From Figure 6-5, it is apparent that multiple inverse models can be created for a more or less constant set of mixing ratios by substituting one set of alumino-silicate reactions for another. It is important to recognize that these are the reactions necessary to achieve mass balance between the end-member and the target groundwater once the mixing ratios have been established from the conservative tracers. 


\subsection{Geochemical Modeling of UE-15d Water Well}

\subsubsection{Conservative Tracer Models for UE-15d Water Well}

Well UE-15d is perhaps the best location for testing the hypothesis of inflow from regional aquifers into northern Yucca Flat. Well UE-15d is completed to a depth of 1,800 $\mathrm{m}$ and is located in the extreme northeastern part of Yucca Flat, immediately south of the Climax Stock. Well UE-15d intersects a 1,100 m section of Precambrian quartzite constituting the LCCU HSU from depths of about $550 \mathrm{~m}$ to $1,600 \mathrm{~m}$ and highly transmissive Precambrian Noonday Dolomite in the lowermost $120 \mathrm{~m}$ of the borehole from which groundwater samples were obtained. Although UE-15d is located in a block of the LCCU, the HFM for Yucca Flat indicates that areas surrounding this block are dominantly carbonate rock (Figures 2-4 and 2-5). Thus, if groundwater from Emigrant Valley enters Yucca Flat along its northwestern margin, it is most likely to do so in the vicinity of UE-15d, making this well suitably located to evaluate this hypothesis. If there is a regional groundwater flux from Emigrant Valley into Yucca Flat through the LCCU or along the margin of the Climax Stock, it may be possible to develop mixing models for UE-15d using the Watertown Well compositions.

Well UE-15d plots near the GMWL (Figure 6-1), which limits the choice of mixing end-members, because two of the three mixing compositions must also lie close to this line. Choice of end-members is further limited by the absence of samples from the LCA or LCCU located directly upgradient from UE-15d. However, assuming that a chemically evolved LCA water similar to that sampled in UE-10j-1 is present in Emigrant Valley, mixing models were successfully developed using a combination of Watertown \#1 Well (WT-1), UE-10j-1, and various perched water samples. The models with the best agreement between all tracers made use of data from a seep (sample CGW-1, MGCU HSU) collected at $420 \mathrm{~m}$ depth in the Climax Stock U-15.01 tunnel complex (Isherwood et al., 1982):

\begin{tabular}{|c|c|c|c|c|c|c|c|}
\hline & WT-1 & + & UE-10j-1 & + & CGW-1 & $=$ & UE-15d \\
\hline$\delta \mathrm{D}$ & 59.4 & & 25.2 & & 15.4 & & \\
\hline$\delta^{18} \mathrm{O}$ & 66.6 & & 28.3 & & 5.1 & & \\
\hline $\mathrm{Cl}$ & 66.6 & & 28.3 & & 5.1 & & \\
\hline
\end{tabular}

An alternative model for UE-15d involves mixing of WT-1 groundwater (TUBA HSU) with two different locally derived perched waters: 


\begin{tabular}{|c|c|c|c|c|c|c|c|}
\hline & WT-1 & + & Oak Spring & + & CGW-1 & $=$ & UE-15d \\
\hline$\delta \mathrm{D}$ & 73.5 & & 7.6 & & 18.9 & & \\
\hline$\delta^{18} \mathrm{O}$ & 80.0 & & 8.3 & & 11.7 & & \\
\hline $\mathrm{Cl}$ & 80.0 & & 8.3 & & 11.7 & & \\
\hline
\end{tabular}

Both models suggest a large fraction (59 to 80 percent) of WT-1 groundwater is needed to generate the observed compositions at UE-15d. It should be noted that the CGW-1 sample has fairly high solute concentrations ( $\mathrm{SO}_{4}$ in particular) from reactions with minerals present in the Climax Stock. Hence, these models will require chemical modeling for verification.

Other models for UE-15d were less successful because reasonable agreement could not be attained for all three conservative tracers. The best of these models uses U12n.03 tunnel water (Rainier Mesa, volcanic confining unit HSU) as the perched water mixing component:

$\begin{array}{ccccc} & W T-1 & \text { UE-10j-1 } & + & \text { U12n.03 } \\ \delta \mathrm{D} & 64.0 & 4.5 & 31.5 \\ \delta^{18} \mathrm{O} & 64.0 & 4.5 & 31.5\end{array}$

This model under-predicts the $\mathrm{Cl}$ concentration for $\mathrm{UE}-15 \mathrm{~d}$, but once again suggests a large mixing fraction of WT-1 groundwater. Substituting ER-12-2 in the place of U12n.03 gives another possible model for UE-15d.

\begin{tabular}{|c|c|c|c|c|c|c|c|}
\hline & WT-1 & + & UE-10j-1 & + & ER-12-2 & $=$ & UE-15d \\
\hline$\delta \mathrm{D}$ & 32.1 & & 47.0 & & 20.8 & & \\
\hline$\delta^{18} \mathrm{O}$ & 58.7 & & 28.6 & & 12.7 & & \\
\hline $\mathrm{Cl}$ & 32.1 & & 47.1 & & 20.8 & & \\
\hline
\end{tabular}

In this model, the $\delta \mathrm{D}$ and $\mathrm{Cl}$ mixing ratios are the same, but the $\delta^{18} \mathrm{O}$ model requires greater amounts of WT-1 because of the relatively low $\delta^{18} \mathrm{O}$ value of UE-15d groundwater.

In general, the conservative tracer models developed for UE-15d are consistent with a regional groundwater influx from Emigrant Valley to northern Yucca Flat. However, all of the models developed here imply that a large proportion of the groundwater sampled from the UE-15d LCCU is derived from the shallow volcanic aquifer (represented by WT-1) that must traverse through or around a thick section of quartzite constituting the LCCU. 


\subsubsection{Strontium and ${ }^{87} \mathrm{Sr} /{ }^{86} \mathrm{Sr}$ Models for UE-15d Water Well}

The ${ }^{87} \mathrm{Sr} /{ }^{86} \mathrm{Sr}$ ratio of groundwater associated with the LCCU at UE-15d (0.71356) is higher than UCCU water sampled from west-central Yucca Flat (0.7095 to 0.7114 , Figure 6-6). Elevated ${ }^{87} \mathrm{Sr} /{ }^{86} \mathrm{Sr}$ in UE-15d water is consistent with the older rocks constituting the Precambrian LCCU compared to Mississippian and Devonian rocks constituting the UCCU. The elevated ${ }^{87} \mathrm{Sr} /{ }^{86} \mathrm{Sr}$ in UE- $15 \mathrm{~d}$ is also consistent with high ${ }^{87} \mathrm{Sr} /{ }^{86} \mathrm{Sr}$ values observed in samples of volcanic and alluvial aquifer groundwater pumped from Watertown Wells in Emigrant Valley. Additional evidence supporting at least some flow into northern Yucca Flat from Emigrant Valley may exist in boreholes UE-15j and UE-15j A-5 located between Yucca Flat and Emigrant Valley at the north end of the Half Pint Range (Figure 3-1). Strontium concentrations in groundwater from these sites (Appendix A, Table A.1-4) are anomalously high $(1,250$ and 1,120 $\mu \mathrm{g} / \mathrm{L})$ relative to other Yucca Flat samples, but similar to the $\mathrm{Sr}$ concentration in a sample of alluvial aquifer water from WT-4 $(1,020 \mu \mathrm{g} / \mathrm{L})$. Unfortunately, ${ }^{87} \mathrm{Sr} /{ }^{86} \mathrm{Sr}$ data are not available for the UE- $15 \mathrm{j}$ samples to further test this possibility.

Strontium concentrations in UE-15d are too high to fit binary mixing curves (Figure 6-6A) between local recharge and either Emigrant Valley volcanic aquifer water with low Sr concentrations (WT-1) or alluvial aquifer water with higher Sr concentrations (WT-3 or WT-4). Chloride present in UE-15d is similarly underestimated in these binary mixing models. Three-component mixing that includes an LCA end-member with elevated $\mathrm{Sr}$ and $\mathrm{Cl}$ concentrations (UE-10j-1) results in mixtures with sufficient $\mathrm{Cl}$ (Figure 6-6D), but $\mathrm{Sr}$ in UE-15d remains higher than predicted (Figure 6-6B). Mixing models derived from conservative tracers require substantial amounts of WT-1 water (59 to 80 percent), which predict mixtures with lower $\mathrm{Sr}$ concentrations and higher ${ }^{87} \mathrm{Sr} /{ }^{86} \mathrm{Sr}$ than those observed in samples of UE-15d. Therefore, if a WT-1 component constitutes a substantial proportion of water in UE-15d, reaction with LCCU is required to obtain the measured Sr concentration. The impact of adding rock $\mathrm{Sr}$ on the ${ }^{87} \mathrm{Sr} /{ }^{86} \mathrm{Sr}$ of UE-15d water is uncertain because of the unknown isotopic composition in these rocks. Analyses of younger Eleana Argillite from borehole UE-25a\#3 at Yucca Mountain have Sr concentrations of 51 to $205 \mu \mathrm{g} / \mathrm{g}$ and ${ }^{87} \mathrm{Sr} /{ }^{86} \mathrm{Sr}$ of 0.71494 to 0.72369 (Peterman, 2004; USGS, unpublished data). Addition of this rock Sr to the mixture determined by conservative tracers would result in higher ${ }^{87} \mathrm{Sr} /{ }^{86} \mathrm{Sr}$ values than those observed in UE-15d water. Alternatively, true upgradient end-members may not have been identified from the extremely limited number of sampling opportunities north of Yucca Flat. 

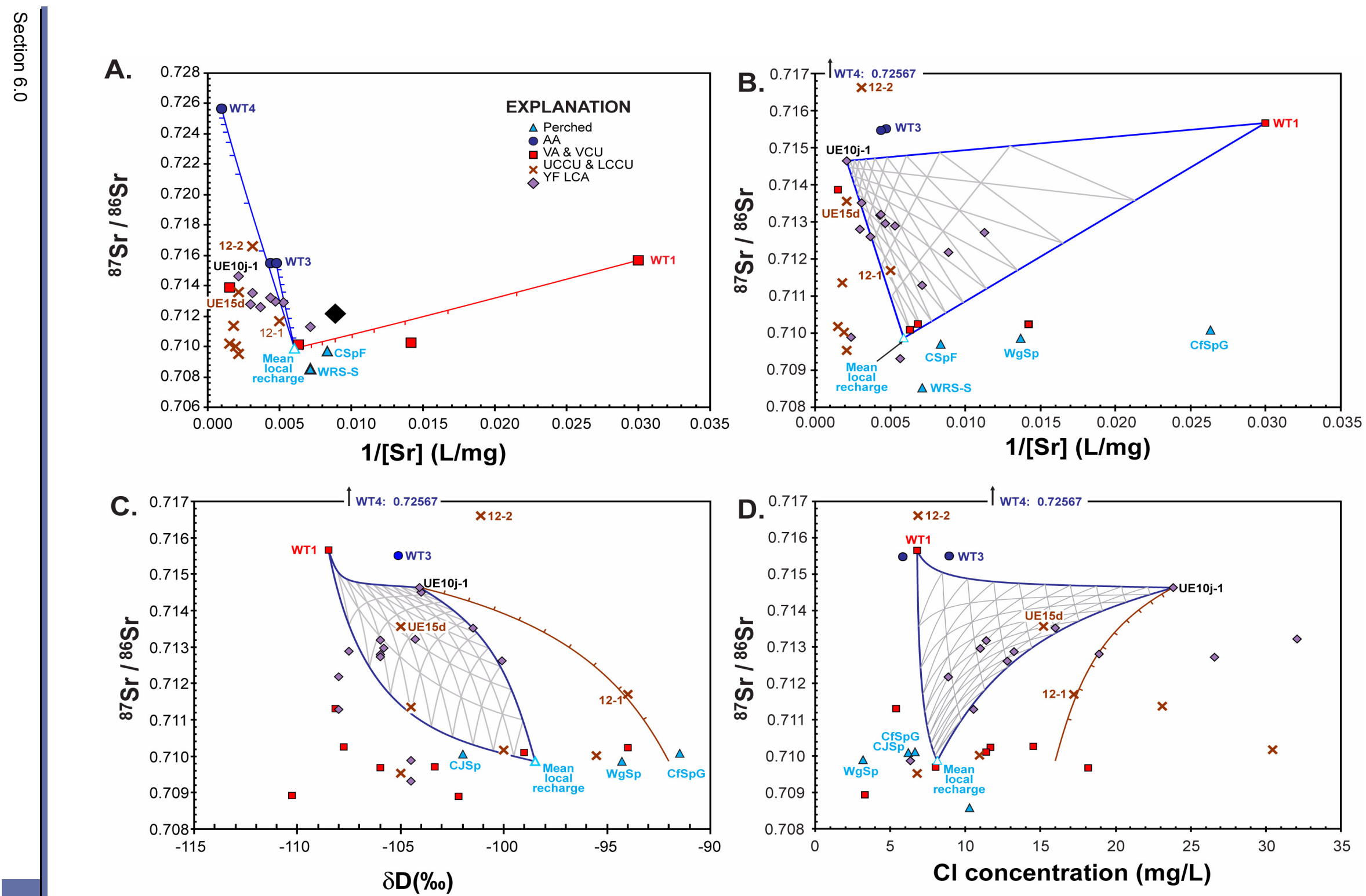

Figure 6-6

Relations Between ${ }^{87} \mathrm{Sr} /{ }^{86} \mathrm{Sr}, \mathrm{Sr}, \delta \mathrm{D}$, and $\mathrm{Cl}$ Concentrations for Yucca Flat Groundwaters Emphasizing Samples from Northern Yucca Flat

Note: Plot A shows simple binary mixing lines between Emigrant Valley groundwater and local recharge plots B, C, and D show three-component mixing results between LCA water from UE-10j-1, volcanic aquifer water from WT-1, and the estimate of mean local recharge. 


\subsubsection{NETPATH Models for UE-15d Water Well}

The NETPATH modeling results (Table 6-2), regardless of local recharge component, are consistent with significant contributions of Emigrant Valley (WT-1) water to northern Yucca Flat at UE-15d (37 to 74 percent). Correspondingly, the contribution of local recharge water is small ( 0 to 35 percent) with contributions from deep LCA water like UE-10j-1 ranging from 23 to 29 percent. This is in general agreement with conservative tracer modeling; however, NETPATH modeling did not support contributions of local recharge from Oak Spring.

Table 6-2

Results of NETPATH Models for Well UE-15d

\begin{tabular}{|c|c|c|c|c|c|c|c|}
\hline \multirow{2}{*}{\multicolumn{3}{|c|}{ End-Member Percentage }} & \multicolumn{4}{|c|}{ Modeled (Measured) Composition of UE-15d } & \multirow{2}{*}{$\begin{array}{l}\text { Travel Time } \\
\text { (Years) }\end{array}$} \\
\hline & & & $(-105)^{a}$ & $(-14.2)^{a}$ & $(15.2)^{a}$ & $(-4.1)^{a}$ & \\
\hline WT-1 & UE-10j-1 & CGW-1 & $\delta \mathbf{D}$ (permil) & $\delta^{18} \mathrm{O}$ (permil) & $\mathrm{Cl}(\mathrm{mg} / \mathrm{L})$ & $\delta^{13} \mathbf{C}$ (permil) & \\
\hline $72-74$ & $25-28$ & $0-1$ & -107 to -106 & -14.3 to -14.2 & 11.8 to 12.1 & -3.8 to -3.7 & 1,900 to $2, \angle$ \\
\hline \multicolumn{8}{|c|}{$\begin{array}{c}\text { WT-1 Oak Spring CGW-1 } \\
\text { No Reasonable Models }\end{array}$} \\
\hline WT-1 & UE-10j-1 & $U-12 n$ & & & & & \\
\hline $37-74$ & $26-29$ & $0-35$ & -107 to -105 & -14.3 to -14.0 & 11.2 to 12.8 & -3.7 & 2,000 \\
\hline WT-1 & UE-10j-1 & ER-12-2 & & & & & \\
\hline $60-64$ & $23-26$ & $10-17$ & -107 to -106 & -14.3 to -14.2 & 10.7 to 11.2 & -4.0 to -3.8 & 900 to 1,600 \\
\hline
\end{tabular}

${ }^{\text {a }}$ Average measured value reported in Appendix A.

The NETPATH modeling shows the contribution of water from the Climax Stock (CGW-1) to downgradient groundwater at UE-15d is negligible ( 0 to 1 percent). The handful of major-ion analyses from the Climax Stock is highly variable; CGW-1, a sample from a fracture in the roof of the underground workings, was selected because it is the only sample with $\delta \mathrm{D}$ and $\delta^{18} \mathrm{O}$ analyses. Well CGW-1 has high TDS (1,854 mg/L) with $\mathrm{Na}, \mathrm{Ca}, \mathrm{Cl}$, and $\mathrm{SO}_{4}$ concentrations substantially higher than recharge waters and Yucca Flat groundwaters $(250,283,77$, and 1,060 mg/L, respectively). Another sample, collected from a borehole in the floor of the underground workings (UG-02), is thought to represent water from the saturated zone in the Climax Stock, and has lower TDS, Na, Ca, and $\mathrm{SO}_{4}(1,074,214,114,480 \mathrm{mg} / \mathrm{L}$, respectively) but similar $\mathrm{Cl}(70 \mathrm{mg} / \mathrm{L})$. The NETPATH simulations were rerun using the major-ion chemistry of UG-02 and the $\delta \mathrm{D}$ and $\delta^{18} \mathrm{O}$ analyses of CGW-1. Modeling results using UG-02 were similar to CGW-1 results and did not increase the contribution of Climax Stock water to the mixture at UE-15d. 
The water-rock reactions in the reasonable NETPATH models included dissolution of calcite, dolomite, and $\mathrm{NaCl}$; $\mathrm{Na}$ exchange with $\mathrm{Ca}$ and $\mathrm{Mg}$; and various combinations of dissolution of composite feldspar and glass with precipitation of composite clay and zeolites. Because CGW-1, Oak Spring, and U12n do not have ${ }^{14} \mathrm{C}$ data available, travel times could not be calculated except in models where their contribution to the mixture was negligible ( 0 to 1 percent). Travel times for mixtures of Emigrant Valley and local recharge to UE-15d ranged from 1,900 to 2,200 years.

\subsubsection{PHREEQC Models for UE-15d Water Well}

The PHREEQC inverse models in northern Yucca Flat were also used to investigate the possibility that groundwater from Emigrant Valley enters Yucca Flat from the northeast, in the vicinity of UE-15d. Data available from Emigrant Valley is restricted to wells WT-1 and WT-2 producing water from the TUBA HSU and WT-3 and WT-4 producing water from the alluvial aquifer. Considerable compositional variability exists among these four relatively closely spaced wells (Figures 3-2 and 3-3), making it difficult to identify a representative groundwater for Emigrant Valley from these data alone. Furthermore, groundwater from deeper HSUs has not been sampled. Nevertheless, conservative tracer data implies that groundwater having compositions similar to WT-1 may represent a possible mixing end-member present in Emigrant Valley that provides a substantial contribution to UE-15d groundwater.

The PHREEQC inverse models were created to further investigate the possible presence of groundwater from WT-1 at UE-15d. Models that used Climax Stock seep groundwater together with UE10j-1 groundwater as the remaining end-members found that no more than 1 or 2 percent of Climax Stock seep water is present at UE-15d. The absence of more significant percentages of Climax Stock seep water at UE-15d is precluded by the high $\mathrm{Ca}$ and $\mathrm{SO}_{4}$ concentrations (283 and $1,060 \mathrm{mg} / \mathrm{L}$, respectively) of water from the Climax Stock seep, which is only slightly unsaturated with respect to gypsum or anhydrite. Sodium and $\mathrm{Cl}$ are also high in Climax Stock seep water (250 and $77 \mathrm{mg} / \mathrm{L}$, respectively). Consequently, other models were created that used groundwater from either Cliff Spring or ER-12-2 in addition to UE-10j-1 to produce UE-15d groundwater. The results from the models that include ER-12-2 groundwater are shown in Figures 6-7 and 6-8. The results of these PHREEQC models are in very good agreement with the general conclusions of the conservative tracer models in that they indicate that UE-15d groundwater includes a significant 


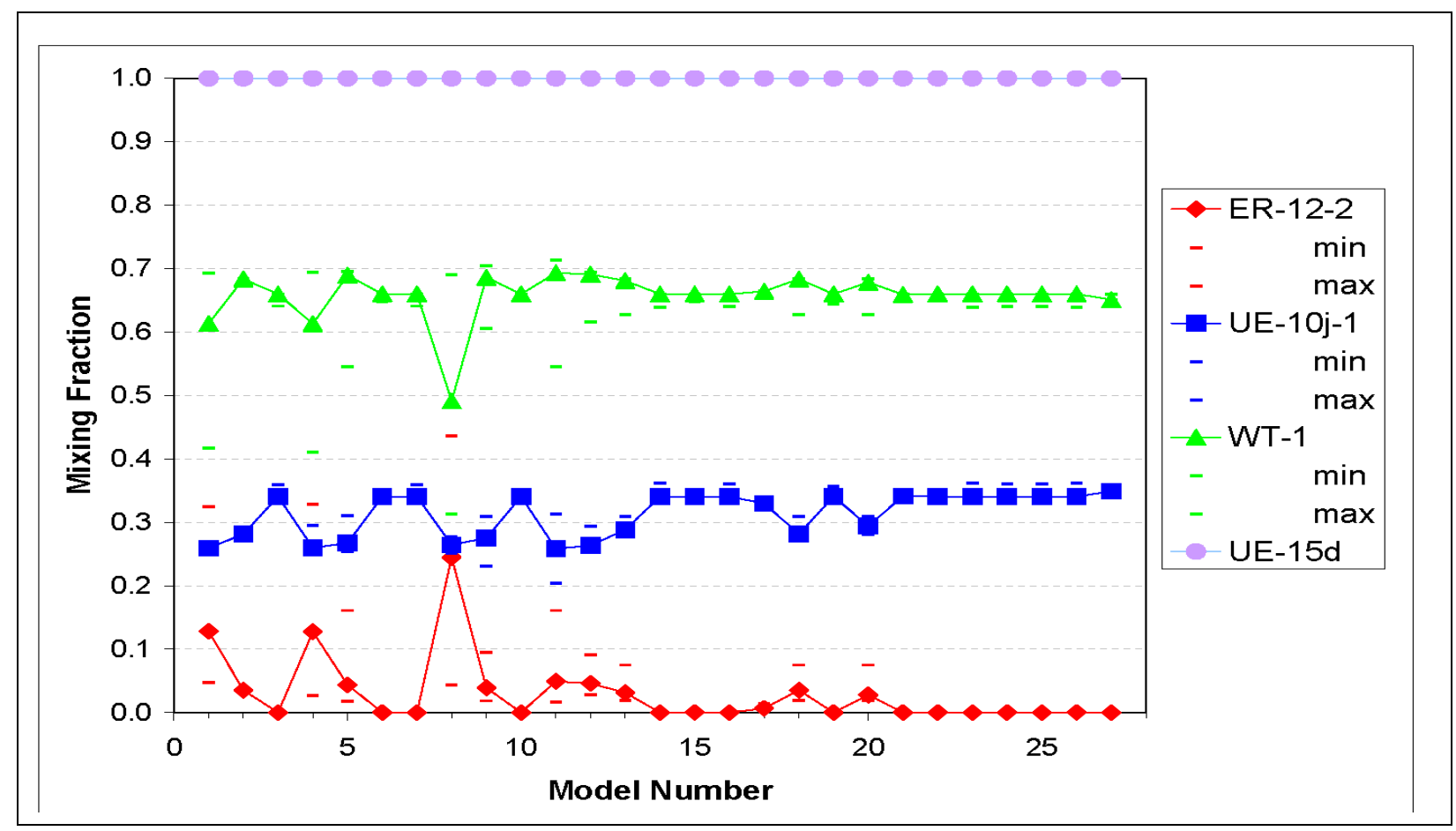

Figure 6-7

Mixing Fractions for UE-15d Models

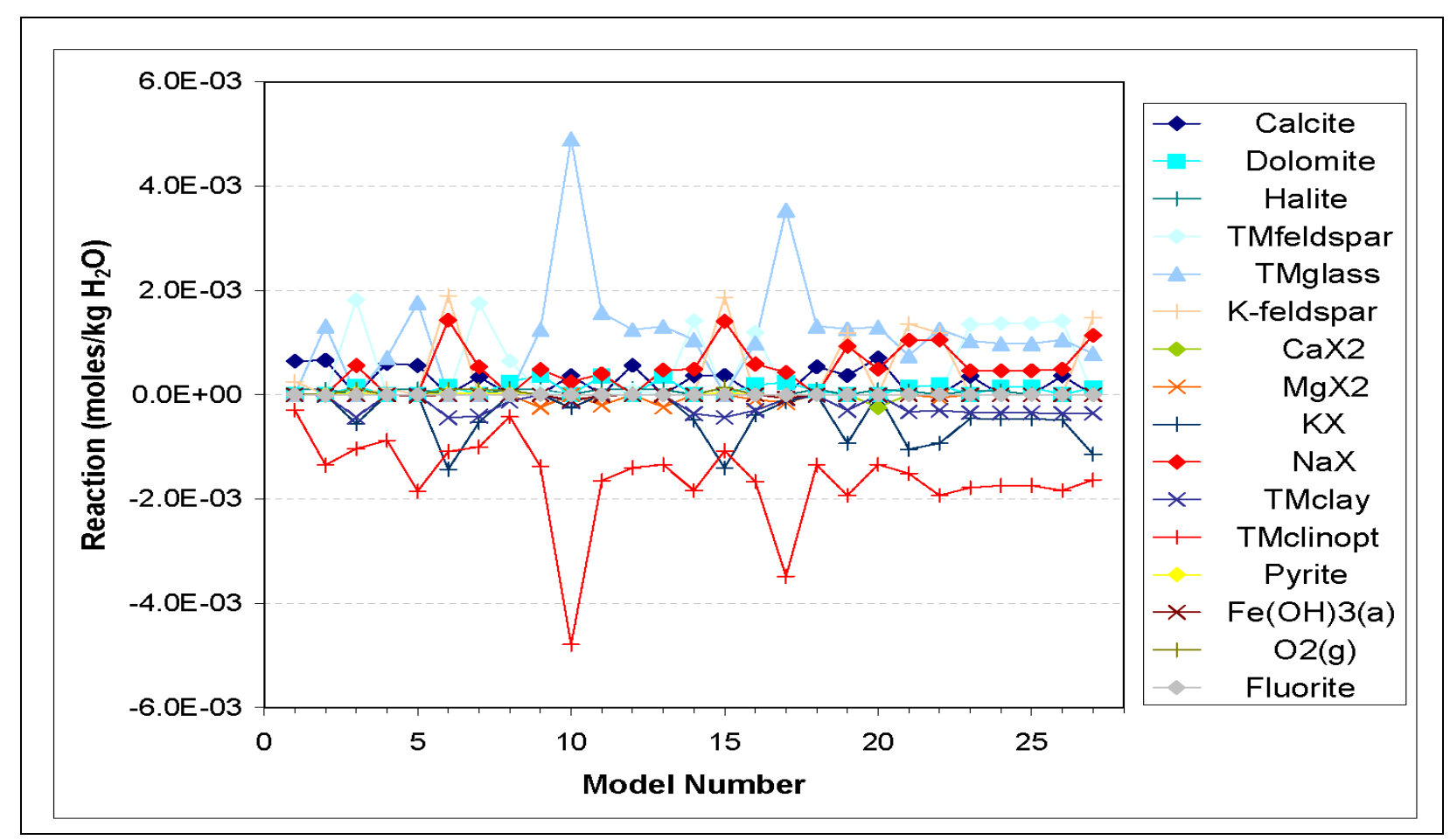

Figure 6-8

Reactions for UE-15d Models

Note: Positive values indicate the mineral phase or element is entering into solution by dissolution or exchange, whereas negative values indicate the phase is leaving the solution by precipitation or exchange. 
proportion (50 to 70 percent) of groundwater like that found at WT-1, with smaller contributions from the LCA at UE-10j-1 and local recharge. The PHREEQC models that included perched groundwater from Cliff Spring instead of ER-12-2 groundwater produced very similar results to the models shown in Figures 6-7 and 6-8.

Sr isotope and concentration data were not used in the construction of the PHREEQC inverse models shown in Figures 6-7 and 6-8 because the isotopic ratios and concentrations of $\mathrm{Sr}$ in the rocks in northeast Yucca Flat have not been measured. However, to determine the nature and extent of water/rock interactions that would be required in these models to also match the Sr data at well UE-15d WW, the models were rerun using both $\mathrm{Sr}$ concentrations and ${ }^{87} \mathrm{Sr} /{ }^{86} \mathrm{Sr}$ ratios as constraints in the models and with strontianite $\left(\mathrm{SrCO}_{3}\right)$ added as a potentially reactive mineral phase. Although the actual sources of Sr are probably minerals other than strontianite, the use of strontianite as a surrogate source of dissolved Sr provides a means of estimating the unmeasured concentrations and ${ }^{87} \mathrm{Sr} /{ }^{86} \mathrm{Sr}$ ratios of $\mathrm{Sr}$ in the rocks in northeast Yucca Flat without making assumptions about rock compositions that could bias the model results. Using this approach, the estimated ${ }^{87} \mathrm{Sr} /{ }^{86} \mathrm{Sr}$ ratio of $\mathrm{Sr}$ in the rock is simply the ${ }^{87} \mathrm{Sr} /{ }^{86} \mathrm{Sr}$ estimated for the strontianite in the model, whereas the concentration of $\mathrm{Sr}$ in the rock depends on both the amount of strontianite and other more likely Sr-bearing mineral phases dissolved in the model. For instance, if the amount of Sr dissolved in strontianite is $3.35 \times 10^{-6}$ mole $/ \mathrm{kg} \mathrm{H}_{2} \mathrm{O}$ and the amount of composite feldspar dissolved in the same reaction model is $1.43 \times 10^{-3}$ moles per kilogram (mole $/ \mathrm{kg}$ ) $\mathrm{H}_{2} \mathrm{O}$, then the amounts of $\mathrm{Sr}$ in the strontianite (87.62 grams Sr per mole strontianite) and the formula weight of the feldspar (324.24 grams Sr per mole feldspar) suggest that Sr concentrations in the feldspar would need to be about $400 \mathrm{ppm}$ if feldspar were considered as the sole source of the required rock Sr.

Using this approach, the rocks in northeast Yucca Flat are required by the models to have a ${ }^{87} \mathrm{Sr} /{ }^{86} \mathrm{Sr}$ ratio of $0.71275 \pm 0.00021$ ( 1 Std. Dev). The rock (or mineral) concentrations of Sr depend on which minerals are assumed to be the source of the $\mathrm{Sr}$ in the models. Based on the amounts of strontianite and either calcite or dolomite dissolved in the models, the carbonate rocks would be required to have Sr concentrations of 4,100 to $10,400 \mathrm{ppm}$,. These Sr concentrations are several orders of magnitude higher than have been measured in carbonate rocks in the NTS area (Kenneally, 1995) and probably rule out carbonate rocks as the source of the Sr required by the models. A more likely possibility is either plagioclase, glass, or potassium feldspar associated with either the volcanic rocks or the 
Precambrian clastic rocks in the area. If plagioclase or volcanic glass is the source of the $\mathrm{Sr}$, a mineral (or glass) concentration of between 185 to $2,100 \mathrm{ppm}$ is required by the models. If $\mathrm{K}$-feldspar is the source of the strontium, the inverse models require the $\mathrm{Sr}$ concentrations to be between about 600 and 10,000 ppm. The lower end of the range of plagioclase or glass compositions overlaps with the range of $\mathrm{Sr}$ concentrations measured on unaltered vitric and devitrified tuffs from the Yucca Mountain area (Peterman et al., 1996), suggesting that plagioclase or glass could have provided the $\mathrm{Sr}$ required by the models. However, in the absence of measured rock and mineral compositions in northeast Yucca Flat, these results are somewhat speculative.

\subsection{Geochemical Modeling of Water Well 2}

\subsubsection{Conservative Tracer Models for Water Well 2}

Water Well 2 (WW-2) is located immediately south of UE-10j and is completed in the LCA. A number of mixing models were attempted for WW-2 with limited success. Surprisingly, the best model developed using mixing sources that are (more-or-less) upgradient did not require any LCA groundwater from well UE-10j:

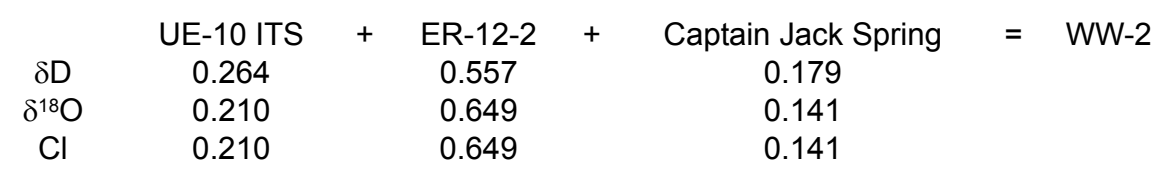

This model should be tested using water-rock reaction codes to determine whether it is reasonable for WW-2 to contain a large fraction of ER-12-2 groundwater. If the requirement that mixing sources must be located upgradient of the target well is relaxed, several additional models for WW-2 can be developed. For example, HTH-1 (PBRCM HSU) is located just south of Rainier Mesa, and an argument could be made that the groundwater from this well is chemically similar to that found in other volcanic units in northern Yucca Flat (e.g., UE-10 ITS and ER-2-1, volcanic confining unit HSUs) except for its very light isotopic signature. The following models for WW-2 were developed by mixing HTH-1, UE-10j-3, and local perched groundwater.

By the same reasoning, if ER-2-1 is substituted for HTH-1 in the model above, the following result is obtained: 


\begin{tabular}{|c|c|c|c|c|c|c|c|}
\hline & HTH-1 & + & UE-10j-3 & + & Oak Spring & $=$ & WW-2 \\
\hline$\delta D$ & 21.8 & & 2.4 & & 75.8 & & \\
\hline$\delta^{18} \mathrm{O}$ & 37.6 & & 4.2 & & 58.2 & & \\
\hline $\mathrm{Cl}$ & 30.3 & & 3.4 & & 66.3 & & \\
\hline & HTH-1 & + & UE-10j-3 & + & Whiterock Spring & $=$ & WW-2 \\
\hline$\delta \mathrm{D}$ & 46.2 & & 17.6 & & 36.2 & & \\
\hline$\delta^{18} \mathrm{O}$ & 36.5 & & 13.9 & & 49.6 & & \\
\hline $\mathrm{Cl}$ & 46.2 & & 17.6 & & 36.2 & & \\
\hline & ER-2-1 & + & UE-10j-3 & + & Whiterock Spring & $=$ & WW-2 \\
\hline$\delta \mathrm{D}$ & 58.8 & & 3.8 & & 37.4 & & \\
\hline$\delta^{18} \mathrm{O}$ & 52.3 & & 3.3 & & 44.4 & & \\
\hline $\mathrm{Cl}$ & 58.8 & & 3.8 & & 37.4 & & \\
\hline
\end{tabular}

Note that the LCA mixing contribution from UE-10j-3 is relatively small (2 to 18 percent).

Moreover, previous mixing models showed that the upper interval in UE-10j is dominated by local recharge. Hence, these models suggest WW-2 groundwater is principally derived from the mixing of volcanic and local perched water sources in northern Yucca Flat.

\subsubsection{PHREEQC Models for Water Well 2}

The mixing fractions calculated by PHREEQC for WW-2 are in good agreement with mixing fractions predicted by the previous mixing models involving HTH-1, UE-10j-3 and Oak Spring end-members (Figures 6-9 and 6-10). Because groundwater from UE-10j-3 appears to derive less than 20 percent of its water from inflow through the LCA (Figure 6-4), the inverse model results shown in Figure 6-9 imply that only 4 percent or less of the groundwater at WW-2 is derived by inflow through the LCA, as represented by groundwater from UE-10j-1. These findings are also in good agreement with some of the previous mixing models that found it possible to model groundwater at WW-2 using no LCA groundwater components.

The groundwater at WW-2 is characterized by extremely light $\delta^{13} \mathrm{C}(-11.2$ permil), which eliminates groundwater from the LCA at UE-10j or from the LCCU at well UE-15d WW as a significant mixing component in the models. The light groundwater $\delta^{13} \mathrm{C}$ value at $\mathrm{WW}-2$ strongly resembles the $\delta^{13} \mathrm{C}$ values at wells HTH-1 and ER-2-1 (Figures 3-6 and 3-8), consistent with the PHREEQC model results that indicate most of the groundwater at WW-2 originates from volcanic HSUs. The PHREEQC model results used $\delta^{13} \mathrm{C}$ as a constraint, even though no $\delta^{13} \mathrm{C}$ value is available for Oak Spring. An estimated value of -15.0 permil for $\delta^{13} \mathrm{C}$ was required for these models to work. This $\delta^{13} \mathrm{C}$ 


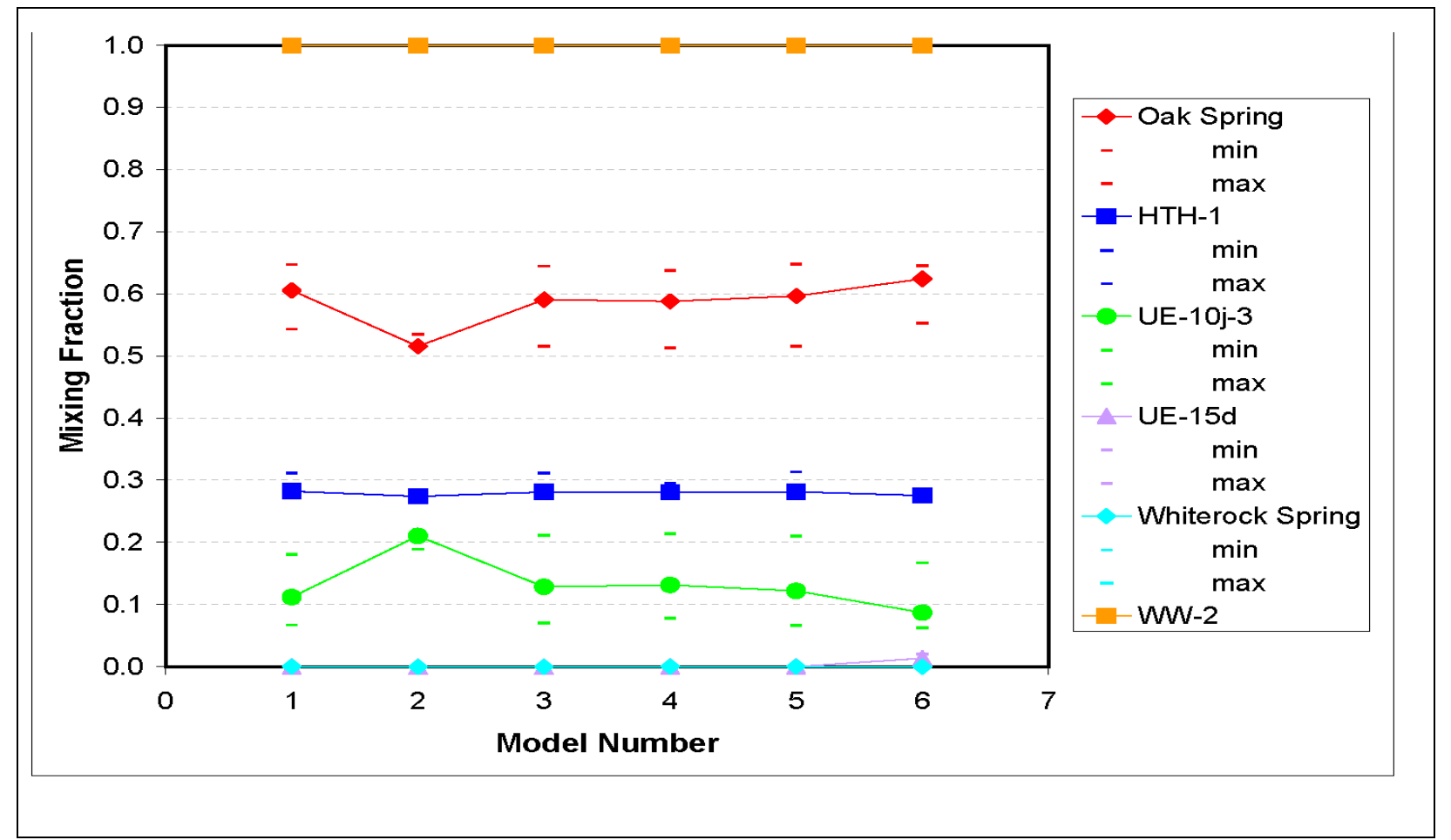

Figure 6-9

Mixing Fractions for WW-2 Models

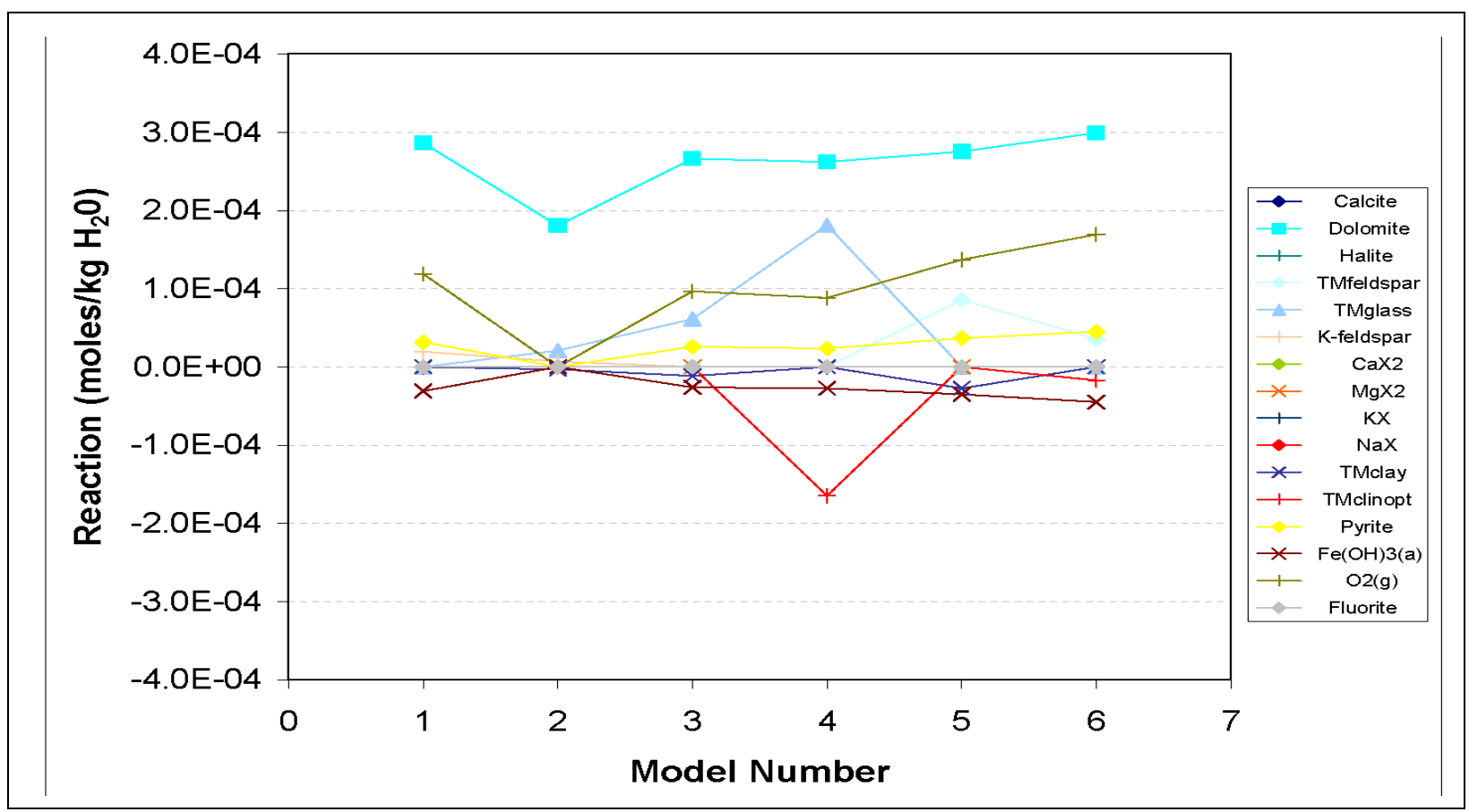

Figure 6-10

Reactions for WW-2 Models

Note: Positive values indicate the mineral phase or element is entering into solution by dissolution or exchange, whereas negative values indicate the phase is leaving the solution by precipitation or exchange. 
value is at the lower limit of values observed in the dataset for the Yucca Flat area. Despite the unusually light value estimated for the Oak Spring end member, the use of this light $\delta^{13} \mathrm{C}$ value for Oak Spring only reinforces the conclusion that the fraction of isotopically heavy groundwater from the LCA must be small in groundwater pumped from WW-2.

PHREEQC failed to identify any inverse models for WW-2 involving groundwater from ER-2-1 when it was substituted for groundwater from HTH-1 as a possible mixing component. Despite their similar $\delta^{13} \mathrm{C}, \delta \mathrm{D}$ and $\delta^{18} \mathrm{O}$ compositions and $\mathrm{Cl}$ concentrations, differences in other dissolved species, such as the much higher $\mathrm{Na}$ and $\mathrm{SiO}_{2}$ concentrations at ER-2-1, preclude groundwater from ER-2-1 as a component of groundwater at WW-2 (Appendix A). The higher $\mathrm{Na}$ and $\mathrm{SiO}_{2}$ concentrations of groundwater at ER-2-1 and the finding (discussed in Section 9.2) that groundwater from ER-2-1 evolves in large part from groundwater like that at HTH-1, suggests that groundwater at ER-2-1 may be a related, but more evolved example of the groundwater which contributed to WW-2.

\subsubsection{Other Models for Water Well 2}

No $\mathrm{Sr}$ or ${ }^{87} \mathrm{Sr} /{ }^{86} \mathrm{Sr}$ data are available for WW-2 to test possible flow paths to this well. The NETPATH modeling did not produce reasonable models for WW-2 using any of the springs modeled in the previous sections. A lack of successful models resulted mostly because of the high amounts of $\mathrm{SiO}_{2}$ in WW-2 relative to the other sources requiring excessive amounts of quartz to be dissolved (greater than one micromole).

\subsection{Geochemical Modeling of Wells ER-12-1 and ER-12-2}

In the northwestern part of the basin, wells ER-12-1 and ER-12-2 both intersect rocks constituting the UCCU HSU (Mississippian Chainman Shale and/or Mississippian and Upper Devonian Eleana Formation) (Russell et al., 1996; NNSA/NSO, 2004). In addition, ER-12-1 produced water samples from the most transmissive zone in the borehole present between depths of 518 and $555 \mathrm{~m}$. This interval consists of a thin sliver of Upper Simonson or Lower Guilmette Formation dolostone that is tectonically sandwiched between Eleana Formation clastic rocks. Therefore, ER-12-1 groundwater is likely to have stronger geochemical affinities to other LCA samples in Yucca Flat compared to groundwater from ER-12-2. Both samples have $\delta \mathrm{D}, \delta^{18} \mathrm{O}$, and $\mathrm{Cl}$ signatures that are consistent with a Rainier Mesa source. Well ER-12-1 appears to have a slightly evaporated stable isotope composition 
similar to that of Whiterock Spring, whereas ER-12-2 overlaps in composition with "impounded" tunnel water samples (Figure 6-1). The fact that water levels are anomalously high in ER-12-2 may suggest that lateral transport of groundwater recharge from Rainier Mesa is impeded by the low permeability UCCU rocks in this area. Although groundwater in ER-12-2 is not thought to be perched, the relatively high water levels at ER-12-2 and the similarity of its $\delta \mathrm{D}$ and $\delta^{18} \mathrm{O}$ to that of seeps in the tunnels at Rainier Mesa suggest it can be used to represent local recharge from the west in northern Yucca Flat.

The ${ }^{87} \mathrm{Sr} /{ }^{86} \mathrm{Sr}$ value for water from ER-12-2 (0.71662) is higher than both recharge through Rainier Mesa (represented by Captain Jack Spring ${ }^{87} \mathrm{Sr} /{ }^{86} \mathrm{Sr}=0.71006$ and $\mathrm{HTH}-1{ }^{87} \mathrm{Sr} /{ }^{86} \mathrm{Sr}=0.70893$ ) and other groundwater sources in northern Yucca Flat and Emigrant Valley (i.e., UE-10j-1, UE-15d, WT-1; Figure 6-6B). Addition of radiogenic Sr derived from UCCU rocks, with compositions described in Section 6.2.2, to recharge through Rainier Mesa is consistent with both the stable isotope and $\mathrm{Sr}$ isotope characteristics of ER-12-2 water.

In contrast, ER-12-1 groundwater is produced from an interval within the UCCU that contains a sliver of LCA rock and has a lower ${ }^{87} \mathrm{Sr} /{ }^{86} \mathrm{Sr}$ value (0.71169) and $\mathrm{Sr}$ concentration compared to water from ER-12-2. Alternatively, ER-12-1 groundwater may originate from mixing of upgradient LCA water with local recharge. The planned development of new LCA wells on Rainier Mesa will help address this question.

\subsection{Summary}

Conservative tracer data indicate UE-10j-1 groundwater cannot be derived from other water types in northern Yucca flat, based on existing data. It may, therefore, be linked to a regional LCA flow path north of Yucca Flat. However, the origin of deep LCA water at UE-10j-1 in northern Yucca Flat cannot be determined because of a lack of upgradient LCA data outside Yucca Flat. Although the various models for UE-10j-3 differ somewhat; they are nonetheless in good agreement with the general conclusion that shallow LCA groundwater from UE-10j-3 contains a dominant component of local recharge that has mixed with a much smaller percentage of deeper LCA groundwater as represented by groundwater from UE-10j-1. Estimates of the local recharge component at UE-10j-3 ranges from about 50 to 90 percent depending on the model used. Travel times could not be 
calculated for this flow path because $\delta^{13} \mathrm{C}$ and ${ }^{14} \mathrm{C}$ data are not available for most local recharge waters.

Geochemical models for UE-15d are consistent with a large component of groundwater from Emigrant Valley (anywhere from 37 to 80 percent) with lesser amounts of deep LCA water ( 5 to 35 percent) and local recharge (0 to 35 percent). However, it is important to note that Sr mixing models do not support large contributions of groundwater at UE-15d from the Watertown wells within Emigrant Valley unless water-rock reactions are invoked. The data necessary to precisely identify the rock Sr isotopic ratios and concentrations have not been measured. Although conservative tracer modeling suggested as much as 20 percent of the groundwater at UE-15d could be derived from upgradient water found in the Climax Stock, NETPATH and PHREEQC modeling have ruled out this possibility because of high $\mathrm{Ca}, \mathrm{Na}, \mathrm{SO}_{4}$, and $\mathrm{Cl}$ concentrations in Climax Stock water. Groundwater travel times from 1,900 to 2,200 years were calculated with NETPATH for water flowing from Emigrant Valley, mixing with deep LCA water like that present at UE-10j-1, and flowing to northern Yucca Flat at UE-15d. Travel times were not determined for models involving significant amounts of local recharge due to a lack of carbon isotope data for perched waters.

Water Well 2, another well in northern Yucca Flat completed in the LCA, appears to have very little deep LCA water contributing to its geochemical makeup. Conservative tracer and PHREEQC modeling indicate that WW-2 is composed predominantly of local recharge with a component of groundwater with a volcanic geochemical signature. However, NETPATH modeling did not produce any reasonable models and the flowpath could not be tested with $\mathrm{Sr}$ because of a lack of data. Travel times could not be calculated for this flow path because $\delta^{13} \mathrm{C}$ and ${ }^{14} \mathrm{C}$ data are not available for most local recharge waters. Conservative tracer and $\mathrm{Sr}$ data indicate that groundwater in Wells ER-12-1 and ER-12-2 is essentially derived from local recharge sources in the Rainier Mesa area. 


\section{0 evaluation of Eastern flow Paths}

The next series of geochemical models focuses on flow paths in eastern Yucca Flat. A north-south pathway is inferred for this part of Yucca Flat on the basis of water-level responses during a recent aquifer test at ER-6-1 \#2 (SNJV, 2005a). During this test, drawdown was observed almost immediately at ER-7-1, approximately $10 \mathrm{~km}$ north of the ER-6-1 well cluster. This implies a high permeability connection and is consistent with the north-south trending fault alignment in this region.

Geochemical models were developed for selected groundwaters in eastern Yucca Flat to investigate the relative contributions of groundwater moving southward from northern Yucca Flat and groundwater flowing southwest from Emigrant Valley and beyond through the Halfpint Range. Groundwater originating from northern Yucca Flat is represented by Wells UE-10j and UE-15d and various perched springs, whereas Emigrant Valley is represented by WT-1 and WT-3. In addition, groundwater from Crystal Spring in the Pahranagat Valley was considered as a possible LCA mixing component in a few models.

A series of wells have been completed in the LCA along a north-south trend on the eastern side of Yucca Flat. These include Wells UE-7nS, ER-7-1, U-3cn \#5, HTH-E, ER-6-1, and ER-6-1 \#2. Most of these sites are reasonably well-characterized in terms of their groundwater chemistry and are suitable for evaluating conceptual flow path models. Note, however, that UE-7nS and U-3cn \#5 may have been influenced by nearby underground testing.

Figures 7-1 and 7-2 show plots of $\delta \mathrm{D}$ versus $\delta^{18} \mathrm{O}$ and $\delta \mathrm{D}$ versus $\mathrm{Cl}$ for groundwater samples from Yucca Flat and surrounding areas. The data suggest a variety of groundwater mixing models can be developed to account for the observed compositions in Wells ER-7-1, ER-6-1, and ER-6-1 \#2. Models for the other three Wells (UE-7nS, U-3cn \#5, HTH-E) are more problematic because of somewhat "extreme" values for one or more of the tracers. 


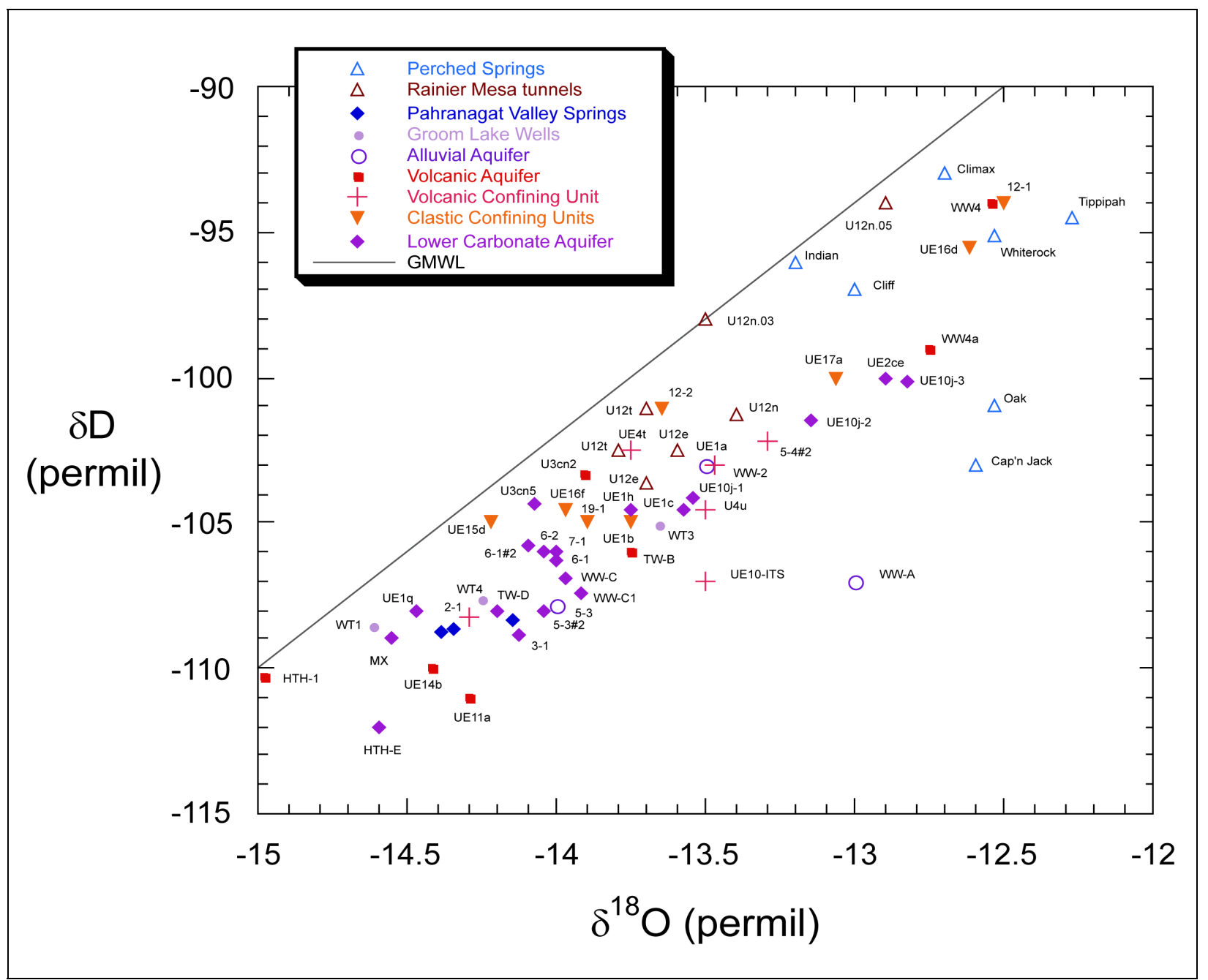

Figure 7-1

Plot of $\delta D$ Versus ${ }^{18} \mathrm{O}$ Values for Groundwater in Yucca Flat and Surrounding Areas

\subsection{Geochemical Modeling of Well UE-7nS}

\subsubsection{Conservative Tracer Models for Well UE-7nS}

Well UE-7nS (LCA HSU) is the northernmost well in the group of eastern Yucca Flat LCA wells to be evaluated. The $\delta \mathrm{D}$ and $\delta^{18} \mathrm{O}$ values for UE-7nS are identical to those found nearby at ER-7-1 (LCA HSU), and the two data points plot on top of one another in Figure 7-1. In contrast, UE-7nS groundwater has more $\mathrm{Cl}(27 \mathrm{mg} / \mathrm{L})$ than ER-7-1 (11 mg/L). This condition made it impossible to develop $\mathrm{Cl}$ mixing models for UE-7nS using upgradient sources. 


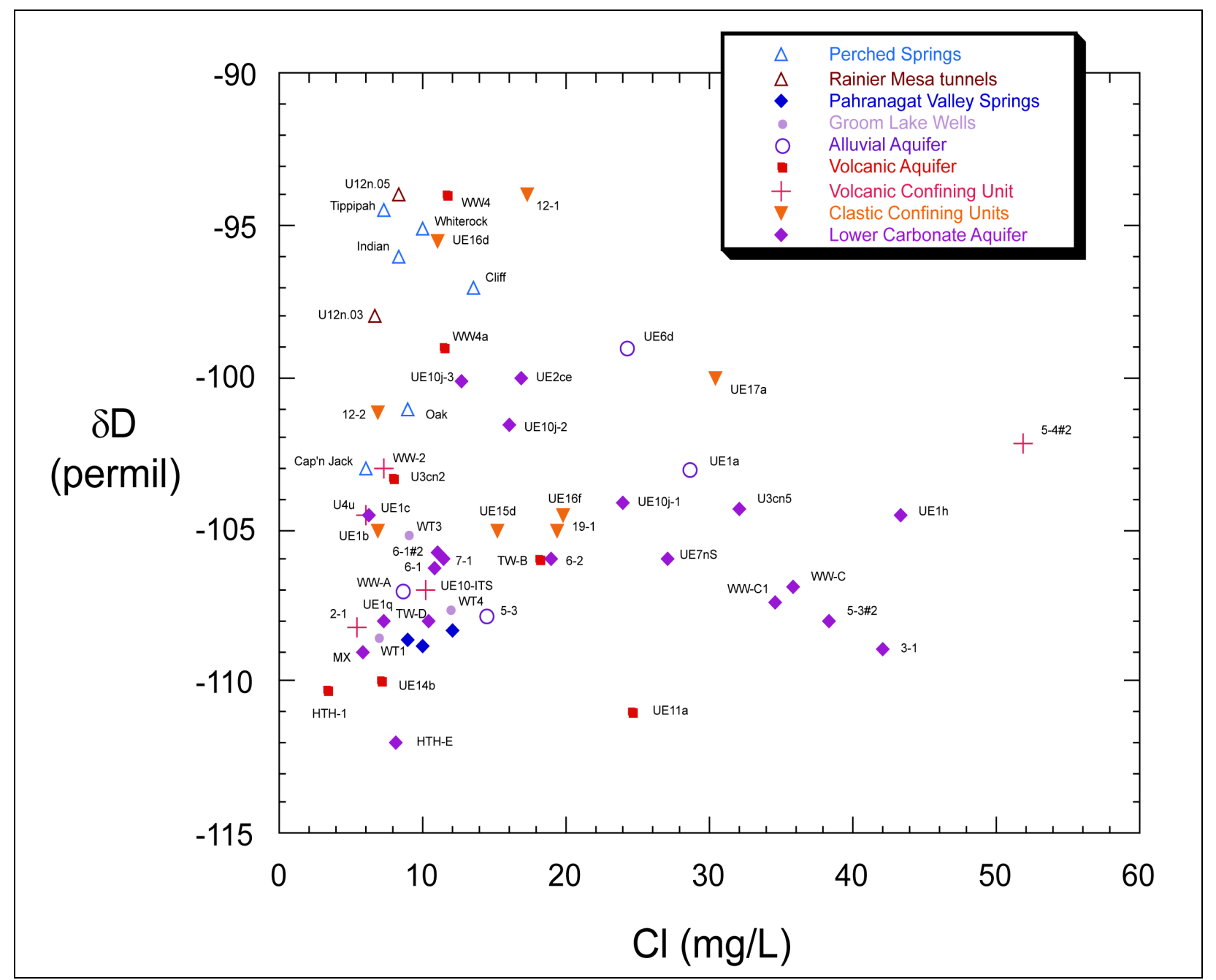

Figure 7-2

Plot of $\delta D$ Versus Cl Values for Groundwater in Yucca Flat
and Surrounding Areas

The following model yielded acceptable stable isotope results, but underpredicted the UE-7nS Cl value by several $\mathrm{mg} / \mathrm{L}$.

$\begin{array}{ccccc} & \text { WT-1 } & +\quad \text { UE-10j-1 } & +\quad \text { UE-15d } \\ \delta \mathrm{D} & 43.1 & 56.5 & 0.4 \\ \delta^{18} \mathrm{O} & 41.8 & 57.8 & 0.4\end{array}$

The model suggests that groundwater of UE-7nS may be a mixture of LCA groundwater from northern Yucca Flat (UE-10j-1) and regional influx from Emigrant Valley (WT-1). Well UE-15d is almost excluded from this model, and is probably an unnecessary mixing component. 
The elevated $\mathrm{Cl}$ concentration in $\mathrm{UE}-7 \mathrm{nS}$ can be modeled if the assumption is made that Cl-rich LCA groundwater enters the system from the east. Well ER-3-1 (LCA HSU) is located approximately $6 \mathrm{~km}$ southeast of UE-7nS and produces groundwater with very high $\mathrm{Cl}$ values $(42 \mathrm{mg} / \mathrm{L})$. If water similar to ER-3-1 were to enter Yucca Flat at the latitude of UE-7nS, then the following models may be tenable:

\begin{tabular}{|c|c|c|c|c|c|c|c|}
\hline & WT-1 & + & UE-10j-1 & + & ER-3-1 & $=$ & UE-7nS \\
\hline$\delta \mathrm{D}$ & 14.9 & & 59.2 & & 25.9 & & \\
\hline$\delta^{18} \mathrm{O}$ & 21.7 & & 40.7 & & 37.6 & & \\
\hline $\mathrm{Cl}$ & 21.7 & & 40.7 & & 37.6 & & \\
\hline & UE-15d & + & UE-10j-1 & + & ER-3-1 & $=$ & UE-7nS \\
\hline$\delta \mathrm{D}$ & 38.5 & & 29.1 & & 32.4 & & \\
\hline$\delta^{18} \mathrm{O}$ & 37.4 & & 28.2 & & 34.4 & & \\
\hline $\mathrm{Cl}$ & 37.1 & & 28.0 & & 34.9 & & \\
\hline
\end{tabular}

The second model in particular shows good agreement between all three tracers, and suggests that northern Yucca Flat groundwater (UE-15d and UE-10j-1) may move southward, mixing with a smaller fraction of high $\mathrm{Cl}$ water from the LCA in the east (ER-3-1). Note, however, that it is not clear whether LCA groundwater can enter Yucca Flat from the east in the vicinity of UE-7nS. The low permeability LCCU is present at the water table in the Halfpint Range just to the east of the NTS. Moreover, it is unclear why UE-7nS might contain a substantial mixing component of high Cl LCA water while nearby ER-7-1 does not (ER-7-1 is located $3 \mathrm{~km}$ south-southeast of UE-7nS).

\subsubsection{Strontium and ${ }^{87} \mathrm{Sr}{ }^{86} \mathrm{Sr}$ Models for Well UE-7nS}

Strontium isotope data for $\mathrm{UE}-7 \mathrm{nS}$ is similar to other groundwater samples from eastern Yucca Flat having ${ }^{87} \mathrm{Sr} /{ }^{86} \mathrm{Sr}$ values intermediate between the high value observed in UE-10j-1 (0.71464) and low values typical of the volcanic HSUs and perched springs of Yucca Flat (typically 0.709 to 0.711) (Figure 7-3). While $\mathrm{Cl}$ concentrations are elevated in the groundwater of UE-7nS with respect to other LCA groundwaters of eastern Yucca Flat, the concentration of Sr is lower (Figure 7-3). Mixtures of water from WT-1, UE-10j-1, and UE-15d cannot produce the water sampled at UE-7nS without addition of non-radiogenic $\mathrm{Sr}$ through water-rock reaction because all of these mixing constituents have ${ }^{87} \mathrm{Sr} /{ }^{86} \mathrm{Sr}$ values greater than that observed in UE-7nS. Likewise, flow of LCA groundwater from ER-3-1 to UE-7nS is unlikely because of the elevated Sr concentration and radiogenic ${ }^{87} \mathrm{Sr} /{ }^{86} \mathrm{Sr}$ in ER-3-1. 

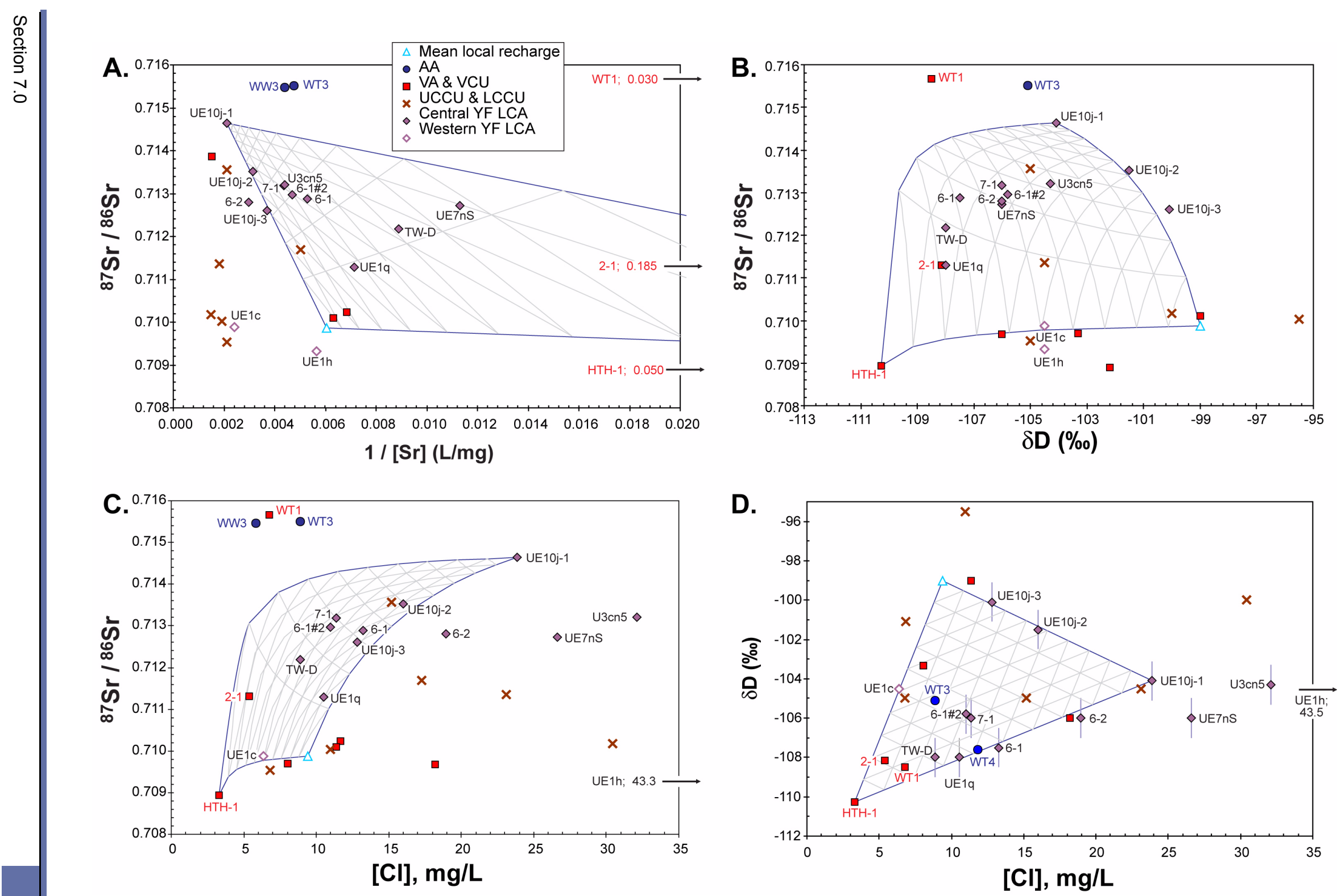
Addition of rock $\mathrm{Sr}$ is not capable of producing the lower concentrations and ${ }^{87} \mathrm{Sr} /{ }^{86} \mathrm{Sr}$ values required to derive UE-7nS Sr data for any of the models involving ER-3-1 listed in Section 7.1.1. Instead, an additional mixing component with low $\mathrm{Sr}$ concentration and ${ }^{87} \mathrm{Sr} /{ }^{86} \mathrm{Sr}$ is required to produce $\mathrm{Sr}$ data observed in UE-7nS. The Sr data are consistent with mixing models involving 5 to 12 percent of UE-10j-1 groundwater; 10 to 25 percent of mean local recharge, and 70 to 80 percent of either HTH-1, ER-2-1, or WT-1. Mixing results are similar regardless of which volcanic end member is used, despite the wide range in ${ }^{87} \mathrm{Sr} /{ }^{86} \mathrm{Sr}$ compositions possible from different volcanic aquifer end-members $(0.70893$ to 0.71566$)$. This relative insensitivity of the particular volcanic aquifer end-member on the resulting mixing proportions is because of the minimal influence that end-members with low Sr concentrations have on the resulting Sr mass balance in the mixture. Mixing results obtained for ${ }^{87} \mathrm{Sr} /{ }^{86} \mathrm{Sr}$ versus $\delta \mathrm{D}$ (Figure 7-3B) are similar to those obtained for ${ }^{87} \mathrm{Sr} /{ }^{86} \mathrm{Sr}$ versus $1 / \mathrm{Sr}$ using WT-1 or ER-2-1 as end members.

\subsubsection{NETPATH Models for Well UE-7nS}

The NETPATH models including water-rock reactions for UE-7nS were unsuccessful. Models tested included various mixtures with WT-1, UE-10j-1, UE-15d, and ER-3-1. Successful water-rock reactions could not be balanced because of high dissolved concentrations of $\mathrm{Ca}, \mathrm{Na}, \mathrm{K}, \mathrm{HCO}_{3}$, and $\mathrm{SiO}_{2}$ in upgradient mixing waters relative to lower concentrations in $\mathrm{UE}-7 \mathrm{nS}$. High $\mathrm{Cl}$ concentrations in UE-7nS were also problematic. The PREEQC models were not tested for UE-7nS.

\subsection{Geochemical Modeling of Well ER-7-1}

\subsubsection{Conservative Tracer Models for Well ER-7-1}

Conservative tracer models for ER-7-1 tend to support the conceptual model of southward flow paths leading from northeastern Yucca Flat. Although a number of models are possible, the best model (on the basis of uniformity in mixing ratios for all three tracers) involves a combination of groundwater from Wells WT-1, UE-10j-1, and Oak Spring.

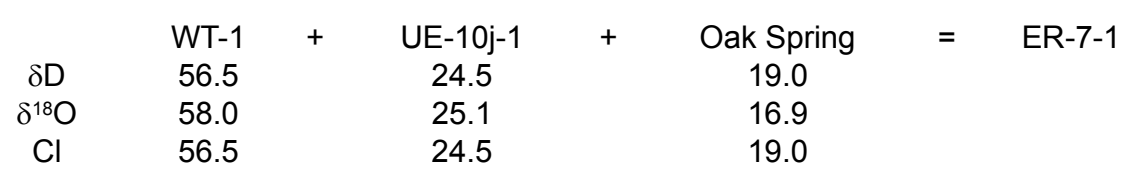


This model is consistent with the mixing models for UE-15d that indicate a regional groundwater influx from Emigrant Valley. A similar model can be developed using WT-1, UE-10j-3, and UE-15d groundwaters but with poor agreement in the tracer mixing fractions.

$\begin{array}{ccccc} & \text { WT-1 } & \text { UE-10j-3 } & \text { UE-15d } \\ \delta \mathrm{D} & 55.3 & 19.1 & 25.6 \\ \delta^{18} \mathrm{O} & 37.6 & 26.6 & 35.8 \\ \mathrm{Cl} & 37.6 & 26.6 & 35.8\end{array}$

An alternative set of models were also identified that called for a LTCU mixing component, as represented by ER-2-1. In essence, ER-2-1 substitutes for WT-1 in these models.

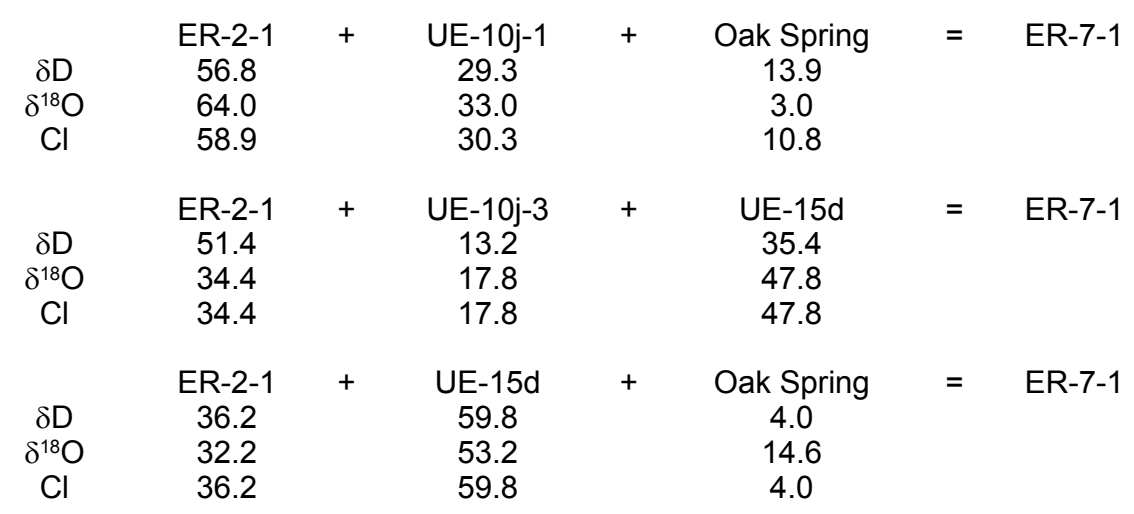

Note that none of these models require a dominant LCA groundwater source from UE-10j. A majority of the groundwater originates either from volcanic units (WT-1 or ER-2-1) or the LCCU (UE-15d). In addition, only one of these models does not require a groundwater contribution from Emigrant Valley, either explicitly (WT-1) or implicitly (UE-15d).

\subsubsection{Strontium and ${ }^{87} \mathrm{Sr} /{ }^{86} \mathrm{Sr}$ Models for Well ER-7-1}

Mixing models for ER-7-1 based on end-members derived from conservative tracers are permissible based on ${ }^{87} \mathrm{Sr} /{ }^{86} \mathrm{Sr}$ versus $1 / \mathrm{Sr}$ data, though mixing proportions deviate from those derived from $\delta \mathrm{D}$, $\delta^{18} \mathrm{O}$, and $\mathrm{Cl}$. The Sr data for ER-7-1 imply the following mixing proportions based on volcanic aquifer, LCA, and mean local recharge end-members.

${ }^{87} \mathrm{Sr} / 86 \mathrm{Sr}$ vs. $1 / \mathrm{Sr}$

$\begin{array}{ccc}\text { WT-1 } & \text { UE-10j-1 } \\ 25 & 32 & +\begin{array}{c}\text { Mean local } \\ \text { recharge } \\ 43\end{array}\end{array}=$ ER-7-1


Similar results are obtained if HTH-1 or ER-2-1 compositions are substituted for WT-1 as the shallow volcanic aquifer end-member. These mixing relations based on $\mathrm{Sr}$ data underestimate the amount of WT-1 indicated by conservative tracer models and may reflect addition of rock $\mathrm{Sr}$ with an ${ }^{87} \mathrm{Sr} /{ }^{86} \mathrm{Sr}$ composition of about 0.7116 .

Other mixing relations based on $\mathrm{Sr}$ data are also permissive using end-members derived in conservative tracer models.

\begin{tabular}{|c|c|c|c|c|c|c|c|}
\hline & WT-1 & + & UE-10j-3 & + & UE-15d & $=$ & ER-7-1 \\
\hline \multirow{2}{*}{${ }^{87} \mathrm{Sr} /{ }^{86} \mathrm{Sr}$ vs. $1 / \mathrm{Sr}$} & 35 & & 43 & & 22 & & \\
\hline & ER-2-1 & + & UE-15d & + & $\begin{array}{c}\text { Mean local } \\
\text { recharge }\end{array}$ & $=$ & ER-7-1 \\
\hline${ }^{87} \mathrm{Sr} /{ }^{86} \mathrm{Sr}$ vs. $1 / \mathrm{Sr}$ & 42 & & 44 & & 14 & & \\
\hline
\end{tabular}

The mixing proportions obtained from these models are similar, but not identical, to those derived using conservative tracer data. The overall similarities in results offers support to the concept that $\mathrm{Sr}$ is not highly reactive within the eastern Yucca Flat flow systems.

\subsubsection{NETPATH Models for Well ER-7-1}

The results of the NETPATH simulations for ER-7-1 are presented in Table 7-1. Few reasonable models for ER-7-1 were produced when incorporating water-rock reactions with $\delta \mathrm{D}$ and $\delta^{18} \mathrm{O}$. Many NETPATH water-rock reaction models were rejected because of excess precipitation of dolomite and/or excess addition of $\mathrm{Na}$ to groundwater by cation exchange accompanied by unrealistic amounts of dissolution of feldspars, glass, and quartz and/or precipitation of clays, zeolites, and quartz. Of the reasonable NETPATH models using only water-rock reactions but not considering $\delta \mathrm{D}$ and $\delta^{18} \mathrm{O}$, local recharge (Oak Spring) was a significant component (49 to 62 percent) mixing with volcanic waters (either ER-2-1 or WT-1) and a small proportion of deep LCA water like observed at UE-10j-1 (8 to 14 percent). One simulation using Crystal Spring from the Pahranagat Valley, as originally hypothesized by Winograd and Thordarson (1975), did not produce any reasonable models. Groundwater travel times for mixtures flowing to ER-7-1 could not be calculated because of the significant contribution of local recharge like Oak Spring, which does not have any $\delta^{13} \mathrm{C}$ or ${ }^{14} \mathrm{C}$ data. 
Table 7-1

Results of NETPATH Models for Well ER-7-1

\begin{tabular}{|c|c|c|c|c|c|c|c|}
\hline \multirow{2}{*}{\multicolumn{3}{|c|}{ End-Member Percentage }} & \multicolumn{4}{|c|}{ Measured (Modeled) Composition of ER-7-1 } & \multirow{2}{*}{$\begin{array}{c}\text { Travel Time } \\
\text { (Years) }\end{array}$} \\
\hline & & & \multicolumn{2}{|c|}{$(-106)^{\mathrm{a}} \quad(-14.0)^{\mathrm{a}}$} & $(11.4)^{\mathrm{a}}$ & \multirow{3}{*}{$\frac{(-6.3)^{\mathrm{a}}}{\delta^{13} \mathbf{C}(\text { permil })}$} & \\
\hline WT-1 & UE-10j-1 & Oak Spring & $\delta \mathrm{D}$ (permil) & $\delta^{18} \mathrm{O}$ (permil) & $\mathrm{Cl}(\mathrm{mg} / \mathrm{L})$ & & \multirow{2}{*}{ * } \\
\hline $29-43$ & $8-9$ & $49-62$ & -106 to -104 & -13.6 to -13.2 & 9.2 to 9.7 & & \\
\hline WT-1 & UE-10j-3 & UE-15d & & & & & \\
\hline \multicolumn{8}{|c|}{ No Reasonable Models } \\
\hline WT-1 & & & & & & & \\
\hline \multicolumn{8}{|c|}{ No Reasonable Models } \\
\hline WT-1 & & Crystal Spring & & & & & \\
\hline \multicolumn{8}{|c|}{ No Reasonable Models } \\
\hline ER-2-1 & UE-10j-1 & Oak Spring & & & & & \\
\hline $31-34$ & $13-14$ & $52-56$ & -105 to -103 & -13.3 to -13.1 & 9.6 to 10.1 & * & * \\
\hline ER-2-1 & UE-10j-3 & UE-15d & & & & & \\
\hline \multicolumn{3}{|c|}{ No Reasonable Models } & & & & & \\
\hline
\end{tabular}

a Average measured value reported in Appendix $A$.

${ }^{*} \delta^{13} \mathrm{C}$ could not be modeled and travel times could not be calculated because of the lack of $\delta^{13} \mathrm{C}$ and ${ }^{14} \mathrm{C}$ data for Oak Spring and ${ }^{14} \mathrm{C}$ data for UE-7nS.

\subsubsection{PHREEQC Models for Well ER-7-1}

The first set of inverse models for ER-7-1 included UE-15d, the Watertown Wells, and the shallow and deep zones of Well UE-10j as potential upgradient end-members. The results from this set of models (Figures 7-4 and 7-5) indicate that groundwater at ER-7-1 can originate by mixing volcanic aquifer groundwater like WT-1 (48 to 58 percent) with shallow LCA groundwater like UE-10j-3 (39 to 44 percent). Only a minor percentage (approximately 5 percent) of the groundwater at ER-7-1 is derived from groundwater similar to UE-15d or WT-3. The dominant reactions for this set of models involve calcite dissolution, feldspar weathering, zeolite precipitation, and ion exchange (Figure 7-5). Most of mass-balance for carbon and $\delta^{13} \mathrm{C}$ is accommodated through mixing.

These models are in general agreement with the conservative tracer models in that they suggest that groundwater like WT-1 is a major component of the groundwater at ER-7-1 (49 to 58 percent) along with lesser amounts of LCA groundwater from northern Yucca Flat like UE-10j. Although UE-15d is a possible mixing component in this set of models, its mixing proportion in ER-7-1 groundwater is small. This is somewhat surprising given that groundwater at UE-15d appears to be a mixture of groundwater similar to WT-1 and UE-10j-1 (Figure 6-7). This suggests that groundwater in Emigrant Valley like WT-1 may flow southwest toward ER-7-1 through the Halfpint Range, rather than 


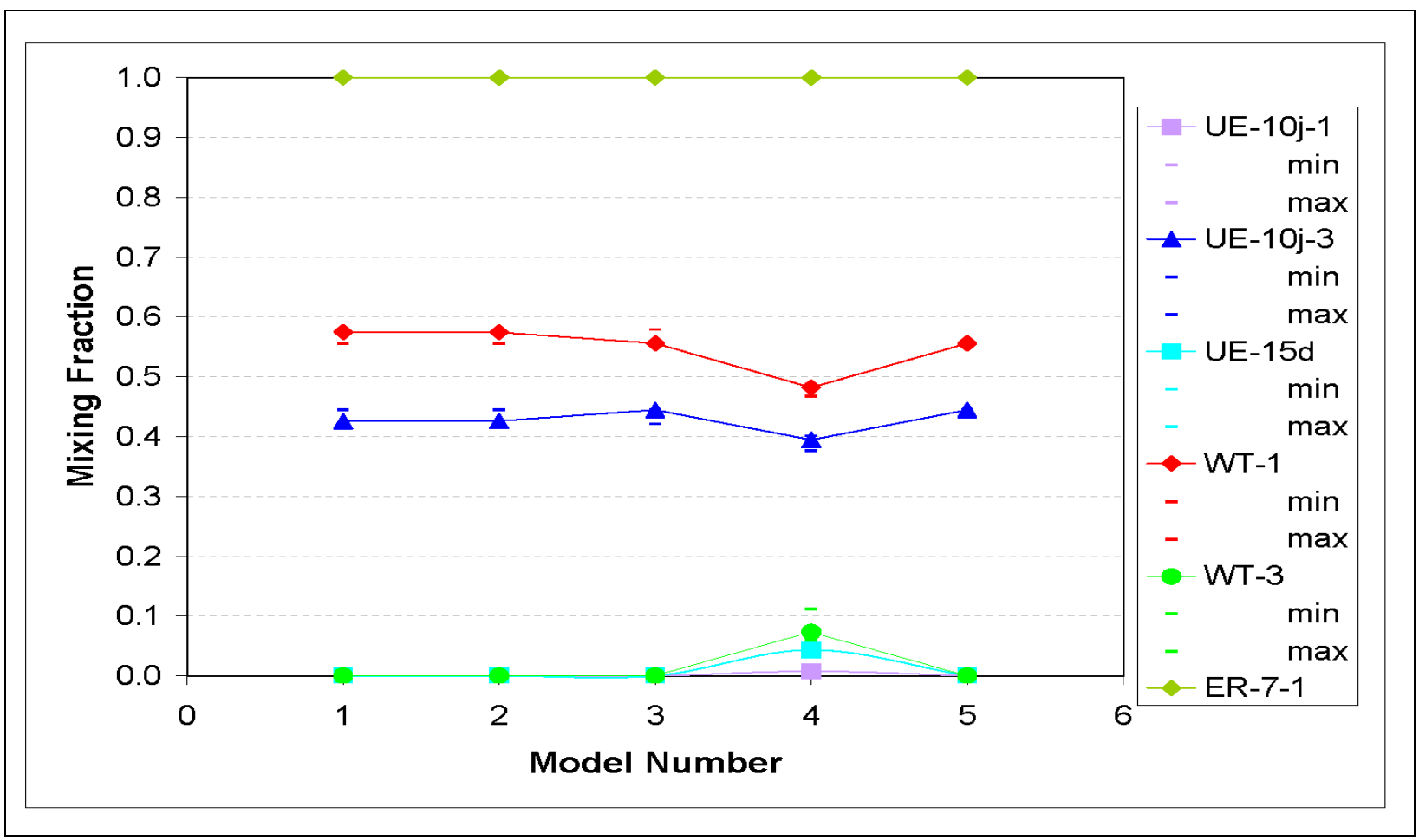

Figure 7-4

Mixing Fractions for ER-7-1 Models

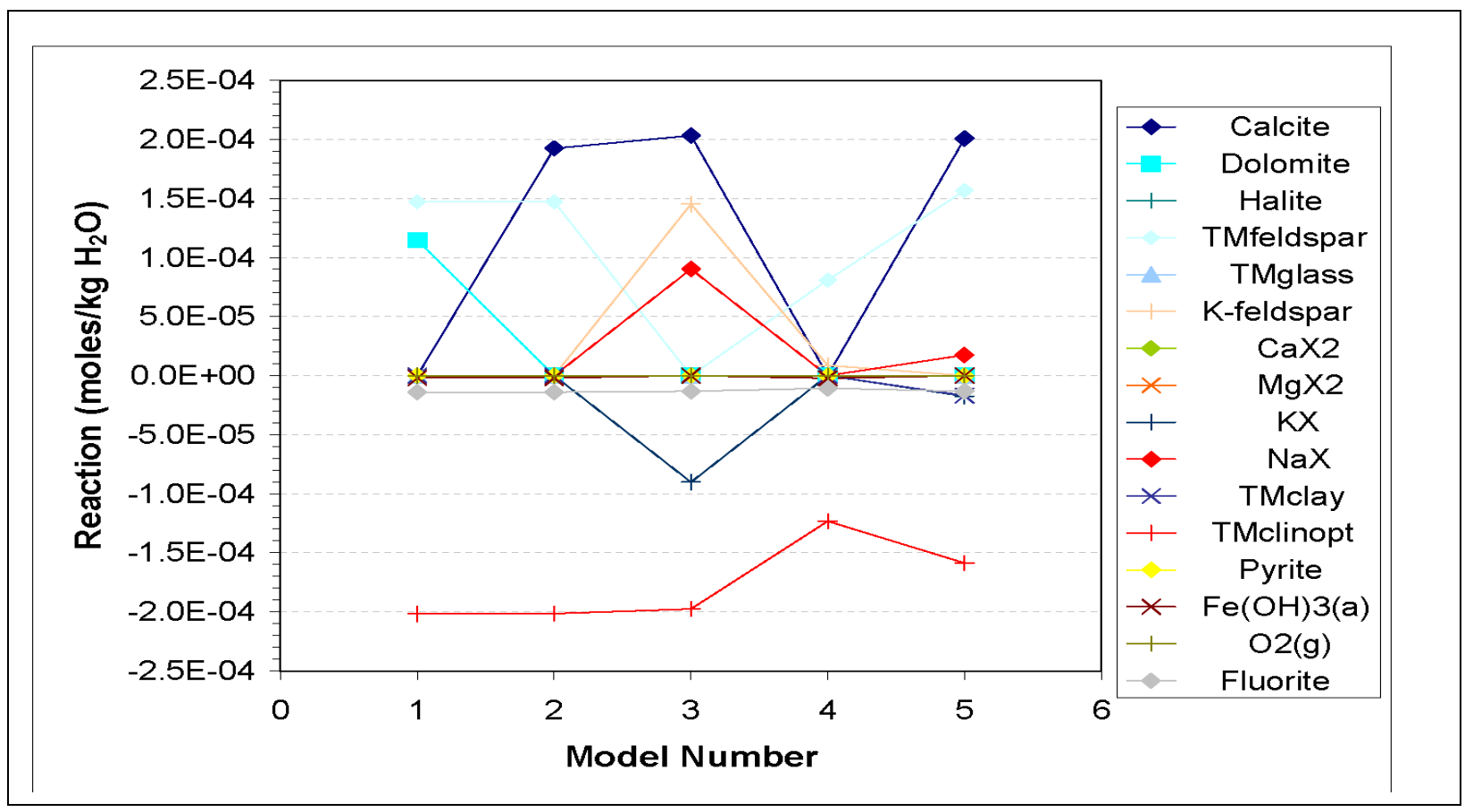

Figure 7-5

Reactions for ER-7-1 Models

Note: Positive values indicate the mineral phase or element is entering into solution by dissolution or exchange, whereas negative values indicate the phase is leaving the solution by precipitation or exchange. 
westward and then south to ER-7-1 through the vicinity of UE-15d. Note, however, that Sr data and NETPATH models suggest that the proportion of groundwater from Emigrant Valley like WT-1 is somewhat less (27 to 43 percent) than PHREEQC models and conservative tracer models (38 to 58 percent). Composite travel times calculated from PHREEQC modeling results ranged from about 6,600 to 7,200 years for this set of models (Figure 7-6). Attempts to estimate travel times from individual wells from these composite travel times using multiple regression did not yield meaningful results, perhaps because of the small variability in the composite travel times and mixing fractions and the relatively few models that were generated.

Strontium isotope and concentration data were not used in the construction of the PHREEQC inverse models for Well ER-7-1 because of the absence of rock Sr data in northeast Yucca Flat. However, by using strontianite as a surrogate for the actual source of $\mathrm{Sr}$, an estimate can be made of the rock $\mathrm{Sr}$ concentrations and ${ }^{87} \mathrm{Sr} /{ }^{86} \mathrm{Sr}$ ratios that would need to exist for the PHREEQC models to match the measured groundwater Sr concentrations and isotopic ratio at Well ER-7-1. Using the approach outlined in Section 6.2.4, the ${ }^{87} \mathrm{Sr} /{ }^{86} \mathrm{Sr}$ ratio of $\mathrm{Sr}$ in the rock would need to be $0.71344 \pm 0.00003$ (1 Std. Dev.) and the concentrations of Sr in feldspars would need to be about 2,100 to 2,500 parts per million (ppm). The ${ }^{87} \mathrm{Sr} /{ }^{86} \mathrm{Sr}$ ratio of the rock estimated with the ER-7-1 model is very similar to the ${ }^{87} \mathrm{Sr} /{ }^{86} \mathrm{Sr}$ ratio of $0.71275 \pm 0.00021$ calculated for the UE-15d models (Section 6.2.4), although the $\mathrm{Sr}$ concentrations are at the high end of the range previously estimated for rocks in the UE-15d area. These Sr concentrations result in a formula weight in the feldspar of about 0.007, which indicates that for this model to be valid, the feldspars reacting with the groundwater must be in the LCCU and not tuffaceous HSUs, because the latter HSUs have relatively minor amounts of divalent cations such as $\mathrm{Ca}$ and Sr (Table 3-4). Unfortunately, no Sr data on feldspars in the LCCU exist to evaluate this model.

A second set of inverse models was developed using groundwater from Crystal Spring in the Pahranagat Valley. Although it is a considerable distance from Yucca Flat, Crystal Spring was selected to represent inflow from the northeast because it is the closest available upgradient LCA sample, and it has a $\delta \mathrm{D}$ and $\delta^{18} \mathrm{O}$ composition and $\mathrm{Cl}$ concentration similar to WT-1. Results for this set of PHREEQC models (Figures 7-7 and 7-8) show that groundwater from Crystal Spring and WT-1 can substitute for one another; changes in their relative proportions are accommodated by changes in the percentage of UE-10j-3 groundwater, and the amount and type of water-rock interactions. Note, 


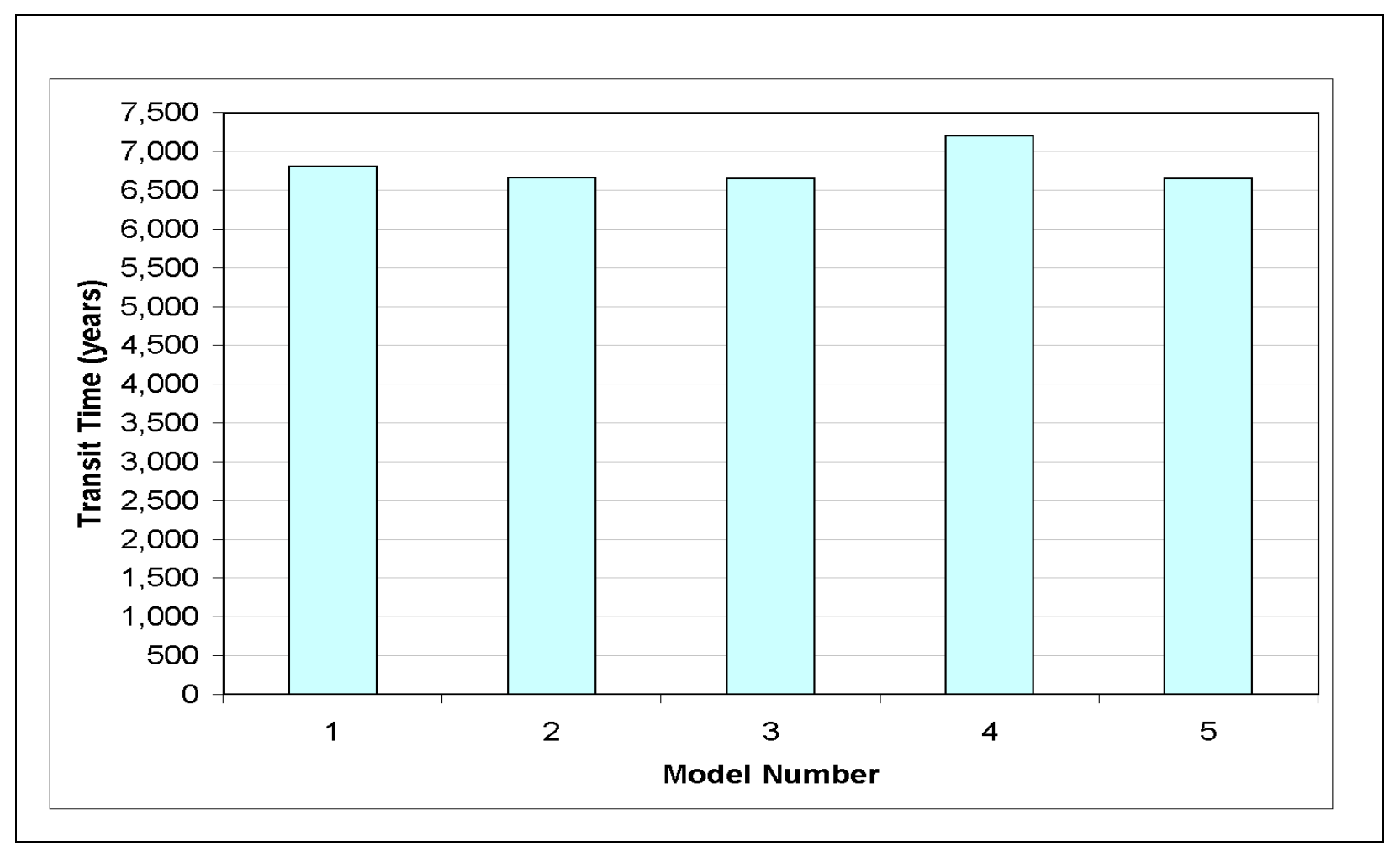

Figure 7-6

Composite Groundwater Travel Times to ER-7-1

however, that the major-ion chemistry of these two groundwaters are substantially different (Figures 3-2 and 3-4); Crystal Spring is a carbonate water with predominantly $\mathrm{Ca}+\mathrm{Mg}$ cations while WT-1 is a volcanic water with predominantly $\mathrm{Na}+\mathrm{K}$. Models with Crystal Spring as the principal mixing component require substantial precipitation of calcite (greater than $1 \mathrm{mmol}$ ). These models do not require the presence of a WT-1 groundwater component to be present at ER-7-1 (Figure 7-7). The composite travel times calculated for this set of models range between approximately 3,700 to 6,800 years (Figure 7-9). Groundwater travel times from individual wells to ER-7-1 (Table 7-2) range from approximately 2,900 to 3,600 years for Crystal Spring, 5,400 to 7,800 years for UE-10j-3, approximately 0 to 3,400 years for UE-15d, and 6,000 to 7,800 years for WT-1 (Table 7-2).

The large uncertainty in the travel times from UE- $15 \mathrm{~d}$ is understandable given that only one model contains even a minor (approximately 10 percent) component of groundwater from UE-15d. Assuming that groundwater flows beneath the Halfpint Range from Emigrant Valley to ER-7-1 in eastern Yucca Flat, travel time estimates indicate groundwater velocities over this $25-\mathrm{km}$ pathway of 3.2 to 4.2 meters per year $(\mathrm{m} / \mathrm{yr})$. Similarly, the range of travel times of approximately 5,400 to 


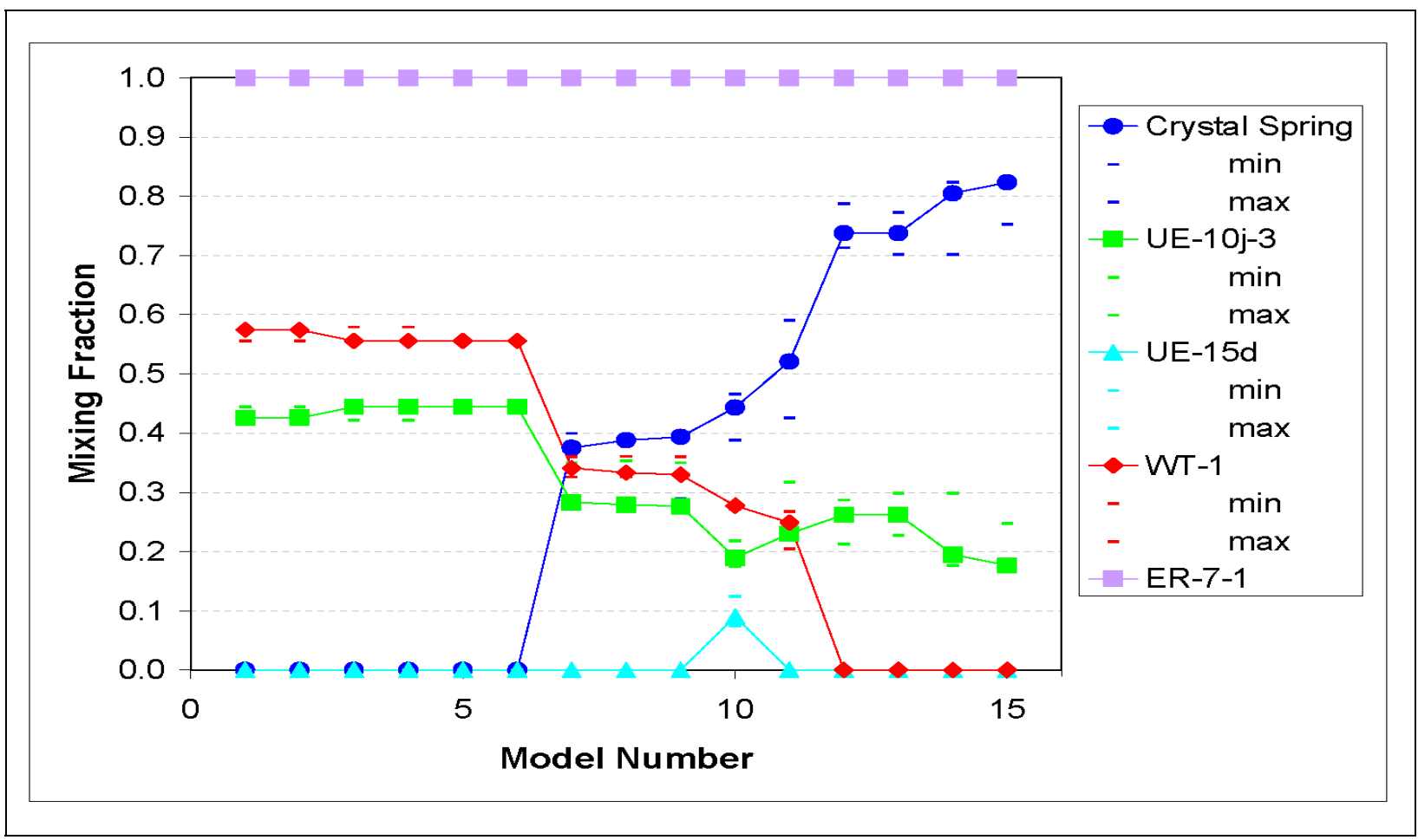

Figure 7-7

Mixing Fractions for ER-7-1 Models Using Pahranagat Spring Groundwater

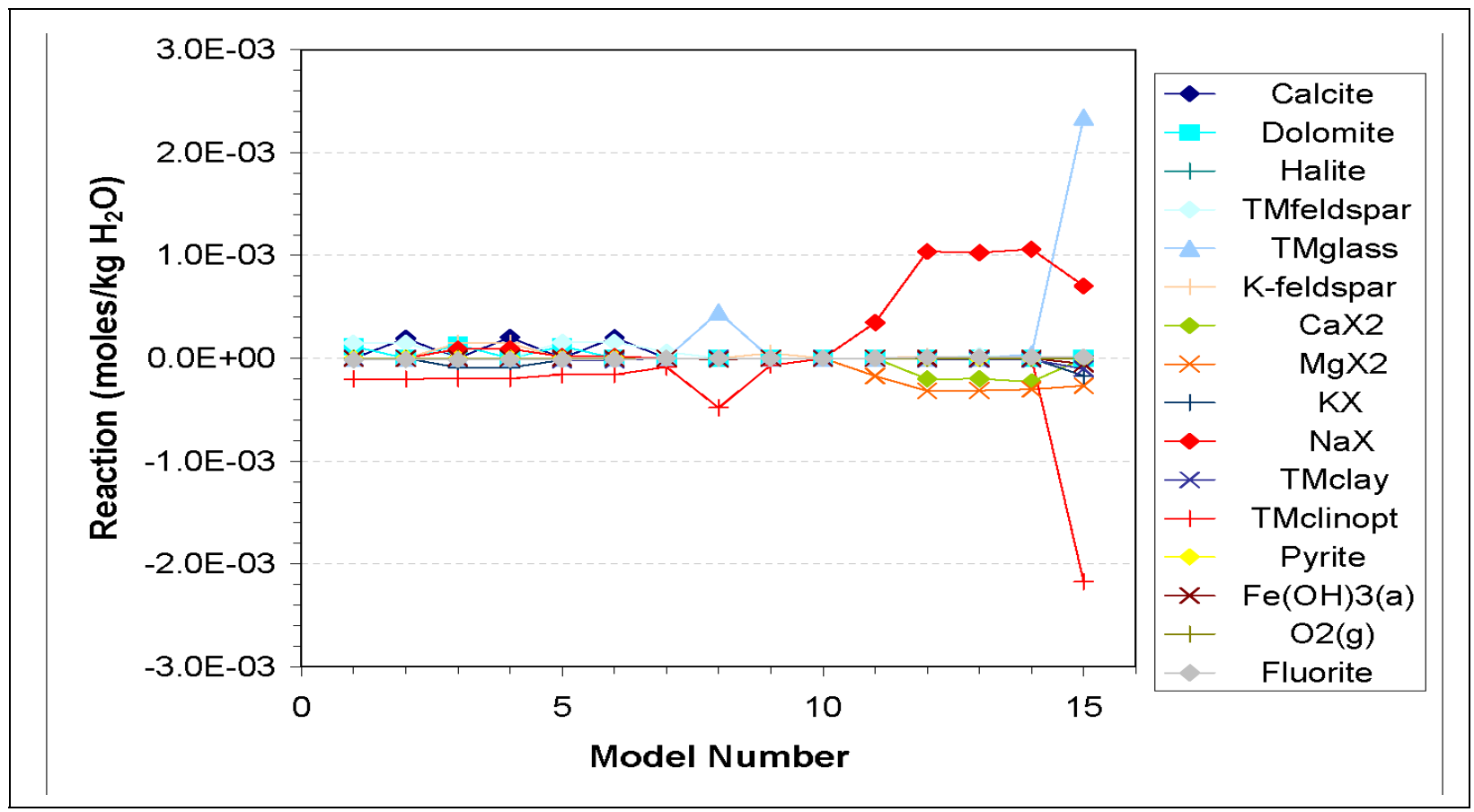

Figure 7-8

Reactions for ER-7-1 Models Using Pahranagat Spring Groundwater

Note: Positive values indicate the mineral phase or element is entering into solution by dissolution or exchange, whereas negative values indicate the phase is leaving the solution by precipitation or exchange. 


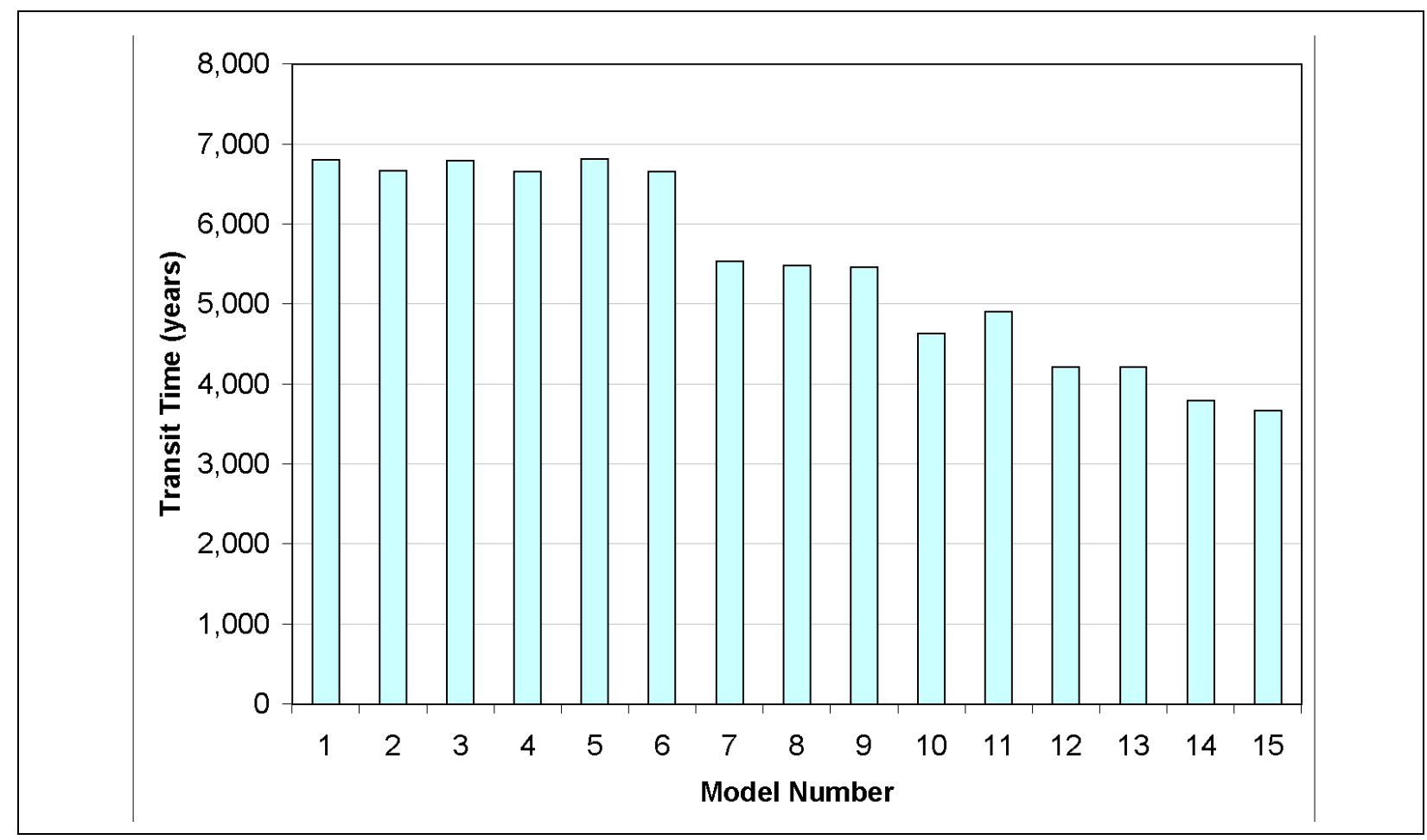

Figure 7-9

Composite Groundwater Travel Times to ER-7-1 for Models with Pahranagat Springs Groundwater

Table 7-2

Travel Times from Individual Wells to ER-7-1 for Models with Pahranagat Springs

\begin{tabular}{|c|c|c|c|c|}
\hline Site & Travel Time (Years) & Standard Error & Lower 95\% & Upper 95\% \\
\hline \hline Crystal Spring & 3,252 & 143 & 2,938 & 3,565 \\
\hline UE-10j-3 & 6,576 & 540 & 5,388 & 7,764 \\
\hline UE-15d & 329 & 1,396 & $-2,744$ & 3,403 \\
\hline WT-1 & 6,896 & 404 & 6,007 & 7,785 \\
\hline
\end{tabular}

7,800 years from northern Yucca Flat to ER-7-1 produces average groundwater velocities from about 1.9 to $2.7 \mathrm{~m} / \mathrm{yr}$ over $14.6 \mathrm{~km}$. The relatively low groundwater velocities in the LCA between Wells UE-10j and ER-7-1 may reflect the limited inflow in the LCA in northern Yucca Flat.

A third set of inverse models for Well ER-7-1 was run with PHREEQC using only wells from within Yucca Flat (Figures 7-10 and 7-11). Like the conservative tracer and NETPATH models, the PHREEQC models indicate that the groundwater at Well ER-7-1 can be derived from local recharge and other upgradient groundwaters within the Yucca Flat basin. In both PHREEQC models, the 


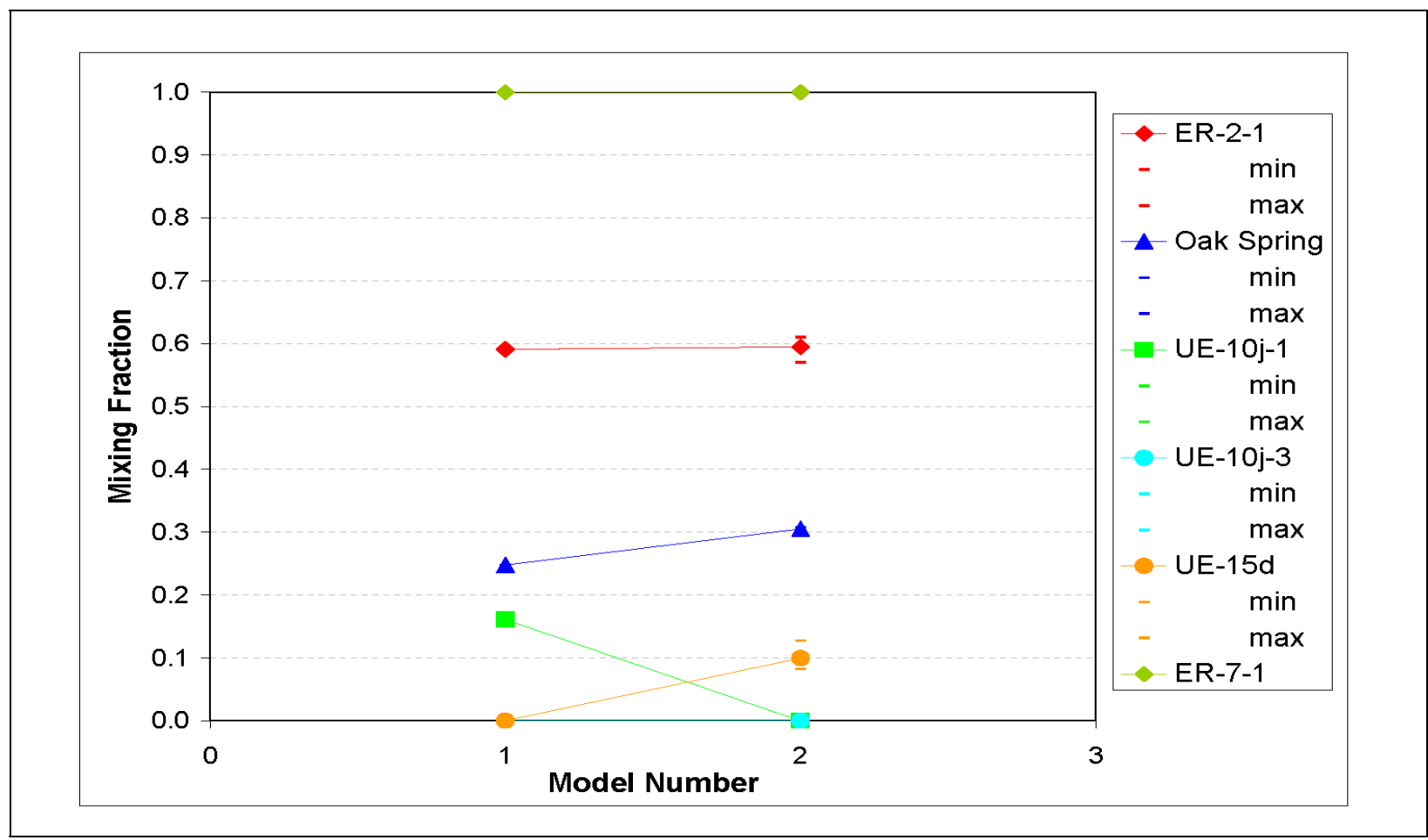

Figure 7-10

Mixing Fractions for ER-7-1 Models Using Only Yucca Flat Groundwaters

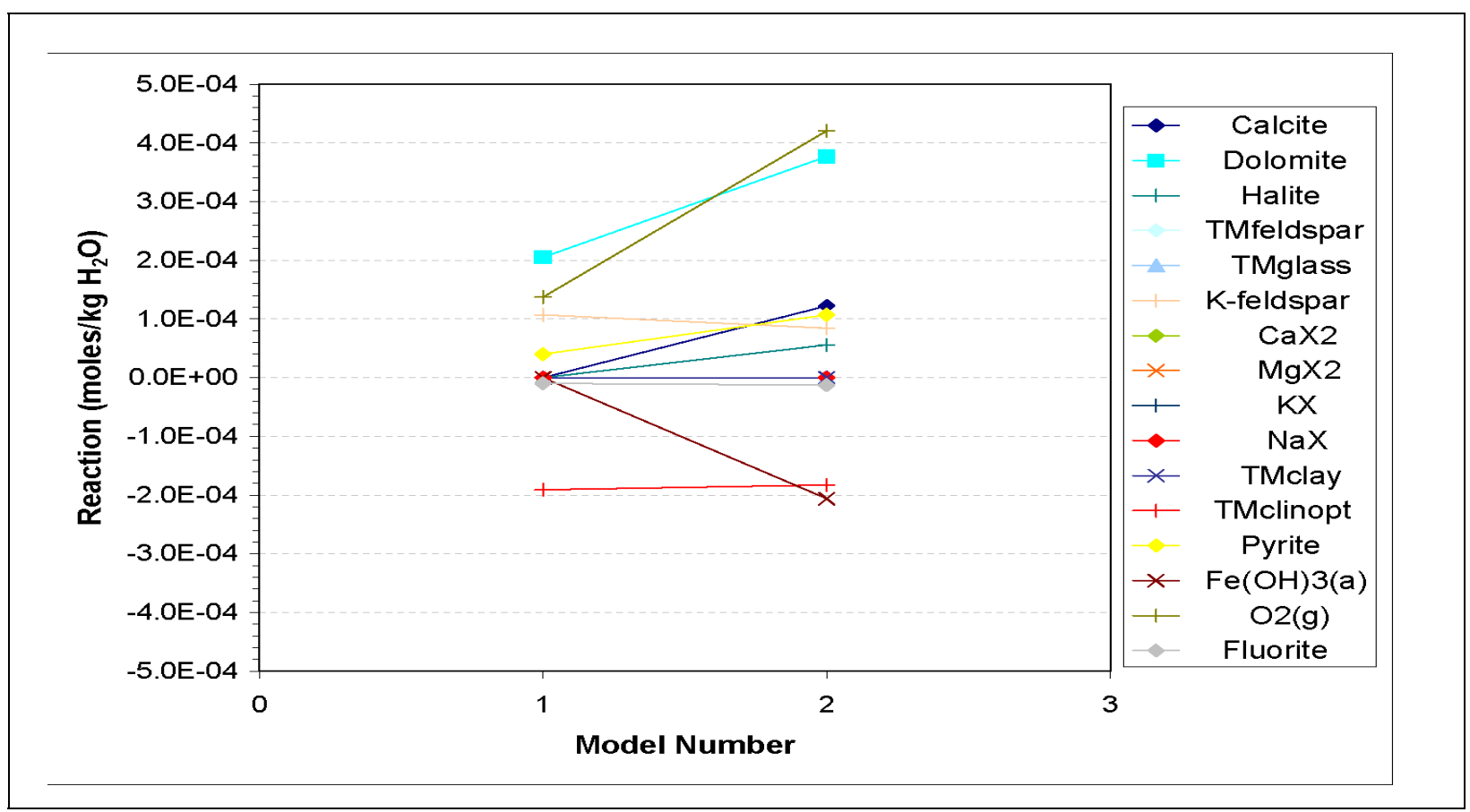

Figure 7-11

Reactions for ER-7-1 Models Using Only Yucca Flat Groundwaters

Note: Positive values indicate the mineral phase or element is entering into solution by dissolution or exchange, whereas negative values indicate the phase is leaving the solution by precipitation or exchange. 
dominant mixing components are groundwater from the volcanic confining unit at ER-2-1 and local recharge, as represented by water from Oak Spring. Groundwater from either UE-10j-1 or UE-15d constituted no more that 10 to 15 percent of the groundwater at Well ER-7-1. For this set of models, the absence of $\delta^{13} \mathrm{C}$ and ${ }^{87} \mathrm{Sr} /{ }^{86} \mathrm{Sr}$ data from Oak Spring prohibited these isotope ratios from being used as constraints in the models. The absence of ${ }^{14} \mathrm{C}$ data from Oak Spring also prevented the estimation of travel times to ER-7-1 from the upgradient wells.

\subsection{Geochemical Modeling of Well U-3cn \#5}

\subsubsection{Conservative Tracer Modeling Results for Well U-3cn \#5}

Well U-3cn \#5 is located approximately $3 \mathrm{~km}$ southwest of ER-7-1, but several north-south trending faults are mapped between the wells, and the groundwater at these two sites may not represent the same flow path. The U-3cn \#5 groundwater is more enriched in $\delta \mathrm{D}$ and contains more $\mathrm{Cl}$ than ER-7-1 (Figure 7-2), which supports the idea of separate pathways. As with UE-7nS, U-3cn \#5 (LCA HSU) is located in close proximity to an underground nuclear test (Bilby). It is problematic to model U-3cn \#5 groundwater because it lies outside the compositional range of most other wells in this region (see Figure 7-2). Several mixing models were tested (using ER-3-1 as the high Cl end-member), but none were successful. If $\mathrm{Cl}$ is removed from the mixing equations, the following models are developed:

\begin{tabular}{|c|c|c|c|c|c|c|c|}
\hline$\delta \mathrm{D}$ & $\begin{array}{c}\text { UE-15d } \\
57.7\end{array}$ & + & $\begin{array}{c}\text { UE-10j-1 } \\
24\end{array}$ & + & $\begin{array}{c}\text { U-3cn PS\#2 } \\
39.9\end{array}$ & $=$ & U-3cn \#5 \\
\hline$\delta^{18} \mathrm{O}$ & 57.7 & & 2.4 & & 39.9 & & \\
\hline & UE-15d & + & ER-7-1 & + & U-3cn PS\#2 & $=$ & U-3cn \#5 \\
\hline$\delta \mathrm{D}$ & 54.0 & & 3.0 & & 43.0 & & \\
\hline$\delta^{18} \mathrm{O}$ & 54.0 & & 3.0 & & 43.0 & & \\
\hline
\end{tabular}

The mixing ratios are quite similar for both models, and the contribution from upgradient LCA sources (UE-10j-1 and ER-7-1) is surprisingly small. Well U-3cn PS\#2 (volcanic confining unit HSU) is a post-shot hole that was drilled into the Bilby test cavity. It produces groundwater from the volcanic units that overlie the LCA at U-3cn \#5. These results suggest that U-3cn \#5 groundwater is predominantly a mixture of northeastern Yucca Flat (UE-15d) and local volcanic aquifer groundwater. It is notable that the stable isotope mixing model developed for UE-7nS (using WT-1 + 
UE-10j-1 + UE-15d) could not be used to model U-3cn \#5, suggesting that these waters may not have well-correlated sources.

\subsubsection{Strontium and ${ }^{87} \mathrm{Sr} r{ }^{86} \mathrm{Sr}$ Modeling Results for Well U-3cn \#5}

The results of the U-3cn \#5 models developed using Sr data are shown in Table 7-3. Derivation of U-3en \#5 from mixtures of LCCU (UE-15d) and OSBCU (U-3cn PS\#2) groundwater yields relatively low deviations between conservative tracer and $\mathrm{Sr}$ data; however, the $\mathrm{Sr}$ concentrations and ${ }^{87} \mathrm{Sr} /{ }^{86} \mathrm{Sr}$ compositions of U-3cn \#5 and ER-7-1 are nearly identical, causing large discrepancies between mixing proportions based on conservative tracers and $\mathrm{Sr}$ data. The ${ }^{87} \mathrm{Sr} /{ }^{86} \mathrm{Sr}$ versus $1 / \mathrm{Sr}$ relations shown in Figure 7-3 suggest that ER-7-1 may consist of 28 percent of the volcanic aquifer water of HTH-1 (or 27 percent WT-1), 8 to 12 percent LCA groundwater (UE-10j-1), and 28 to 38 percent "mean local recharge."

Table 7-3

Mixing Percentages for Well U-3cn \#5 Based on ${ }^{87} \mathrm{Sr} /{ }^{86} \mathrm{Sr}$ Versus $1 / \mathrm{Sr}$

\begin{tabular}{|c|c|c|}
\hline \multicolumn{3}{|c|}{ Percentage / Deviation of Mixing Component } \\
\hline \hline UE-15d & UE-10j-1 & U-3cn PS\#2 \\
$47^{\mathrm{a}} /-11$ & $0^{\mathrm{a}} /-2$ & $53^{\mathrm{a}} /+13$ \\
\hline UE-15d & ER-7-1 & U-3cn PS\#2 \\
$0^{\mathrm{b}} /-54$ & $99^{\mathrm{b}} /+96$ & $0^{\mathrm{b}} /-43$ \\
\hline
\end{tabular}

a Final composition falls outside the three-way mixing triangle, but close to a binary mixture.

${ }^{\mathrm{b}}$ Final composition has nearly identical strontium concentrations and ${ }^{87} \mathrm{Sr} /{ }^{86} \mathrm{Sr}$ to one of the mixing components.

\subsubsection{NETPATH Modeling Results for Well U-3cn \#5}

The NETPATH models including water-rock reactions for U-3cn \#5 were unsuccessful. Models tested included various mixtures with UE-15d, UE-10j-1, ER-7-1, and U-3cn PS\#2. Successful water-rock reactions could not be balanced because of high dissolved concentrations of $\mathrm{Ca}, \mathrm{Na}, \mathrm{K}$, $\mathrm{HCO}_{3}$, and $\mathrm{SO}_{4}$ in upgradient mixing waters relative to lower concentrations in U-3cn \#5. Additionally, as noted in the conservative tracer section, high $\mathrm{Cl}$ in $\mathrm{U}-3 \mathrm{cn} \# 5$ relative to the other mixing components contributed to the lack of successful water-rock reaction models. High concentrations of $\mathrm{Ca}$ and $\mathrm{HCO}_{3}$ produced excessive precipitation of calcite, and large differences in $\mathrm{SiO}_{2}$ produced unrealistic amounts of dissolution of feldspars, glass, and quartz and/or precipitation of clays, zeolites, and quartz. 


\subsubsection{PHREEQC Modeling Results for Well U-3cn \#5}

The PHREEQC models indicated the groundwater at Well U-3cn \#5 originates from the vicinity of Well ER-7-1 (80 to 90 percent) with secondary contributions from northern Yucca Flat at Well UE-10j-3 (about 15 percent) or from UE-15d (0 to 9 percent). Additionally, a small amount ( 0 to 4 percent) of groundwater from the overlying volcanic units may be present, as represented by the U-3cn PS \#2 groundwater sample (Figure 7-12).

The small amounts of water-rock interactions required for this set of inverse models (Figure 7-13) indicate that most of the downgradient changes in chemistry were accommodated through mixing. An interesting aspect of this set of models is that although strontianite was included in these models as a potential mineral phase, the $\mathrm{Sr}$ and ${ }^{87} \mathrm{Sr} r{ }^{86} \mathrm{Sr}$ measured at U-3cn $\# 5$ were matched entirely through mixing. This is in agreement with the observation made earlier that the $\mathrm{Sr}$ and ${ }^{87} \mathrm{Sr} r{ }^{86} \mathrm{Sr}$ data at U-3cn \#5 and ER-7-1 are nearly identical.

The PHREEQC models interpret the higher $\mathrm{Cl}$ in the groundwater at $\mathrm{U}-3 \mathrm{cn} \# 5$ to be the result of halite dissolution. However, although halite dissolution can explain the high $\mathrm{Cl}$ at $\mathrm{U}-3 \mathrm{cn} \# 5$, the groundwater ${ }^{36} \mathrm{Cl} / \mathrm{Cl}$ ratio at $\mathrm{U}-3 \mathrm{cn} \# 5$ does not decrease relative to the ER-7-1 and UE-10j-1 endmembers (Figure 3-10), as would be expected if the halite were free of ${ }^{36} \mathrm{Cl}$. The groundwater at $\mathrm{U}-3 \mathrm{cn} \mathrm{PS} \# 2$ has a ${ }^{36} \mathrm{Cl} / \mathrm{Cl}$ ratio of $1,240,000 \cdot 10^{-15}$ as a result of nuclear weapons testing. This value is more than a million times higher the ${ }^{36} \mathrm{Cl} / \mathrm{Cl}$ ratio of nearby groundwater in the LCA. Thus, even a small amount of groundwater from U-3 cn PS\#2 would be sufficient to counter any decrease in the ${ }^{36} \mathrm{Cl} / \mathrm{Cl}$ ratio that would accompany halite dissolution.

The PHREEQC models suggest that groundwater from the vicinity of ER-7-1 does, in fact, constitute most of the groundwater found at U-3 $\mathrm{cn} \# 5$. This is consistent with water-level contours that suggest groundwater flows from the perimeter of the basin toward the basin center (Figure 2-8). The composite travel time for the mixture to travel to U-3cn \#5 is about 6,000 years (Figure 7-14). 


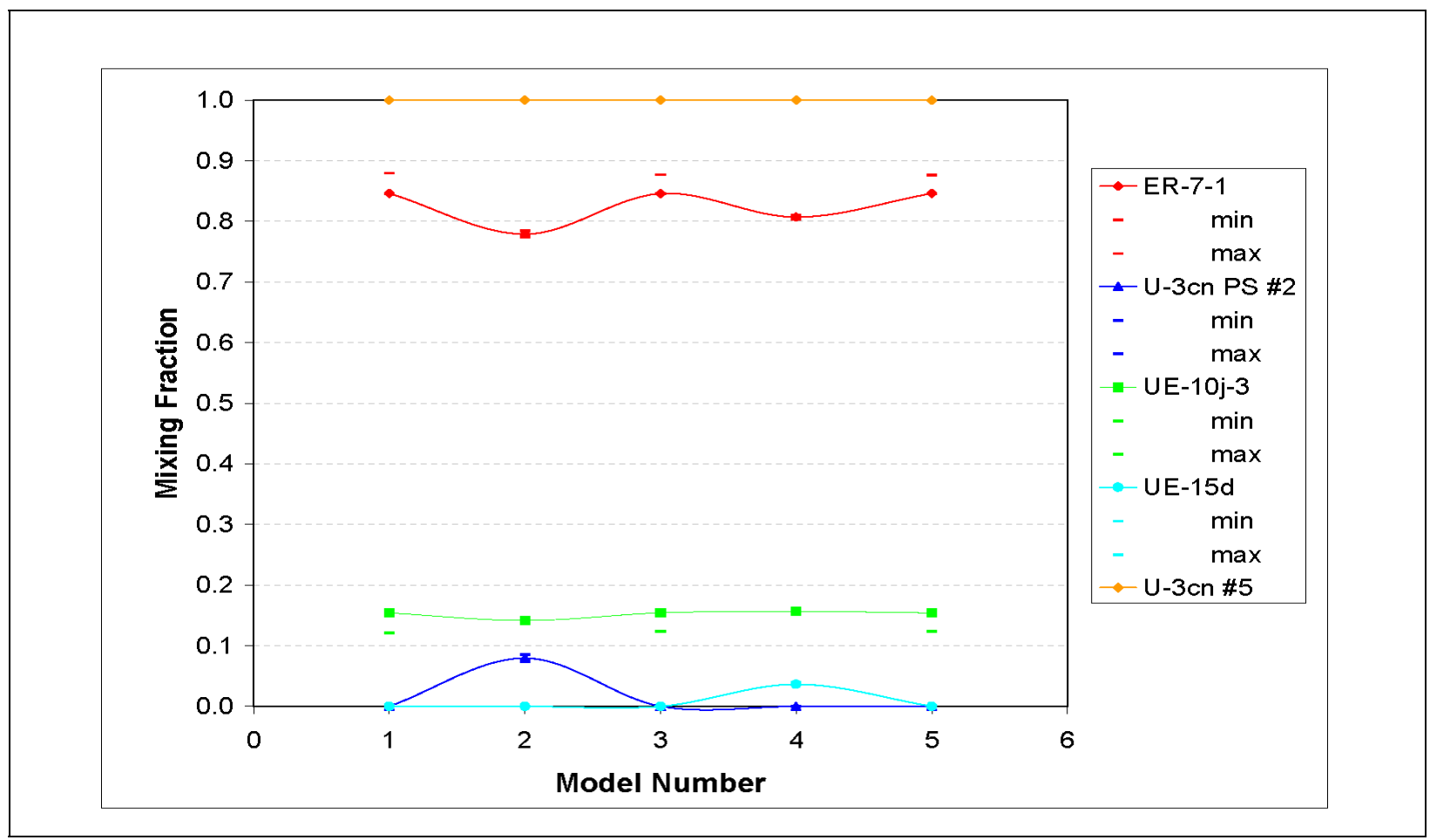

Figure 7-12

Mixing Fractions for U-3cn \#5 Models

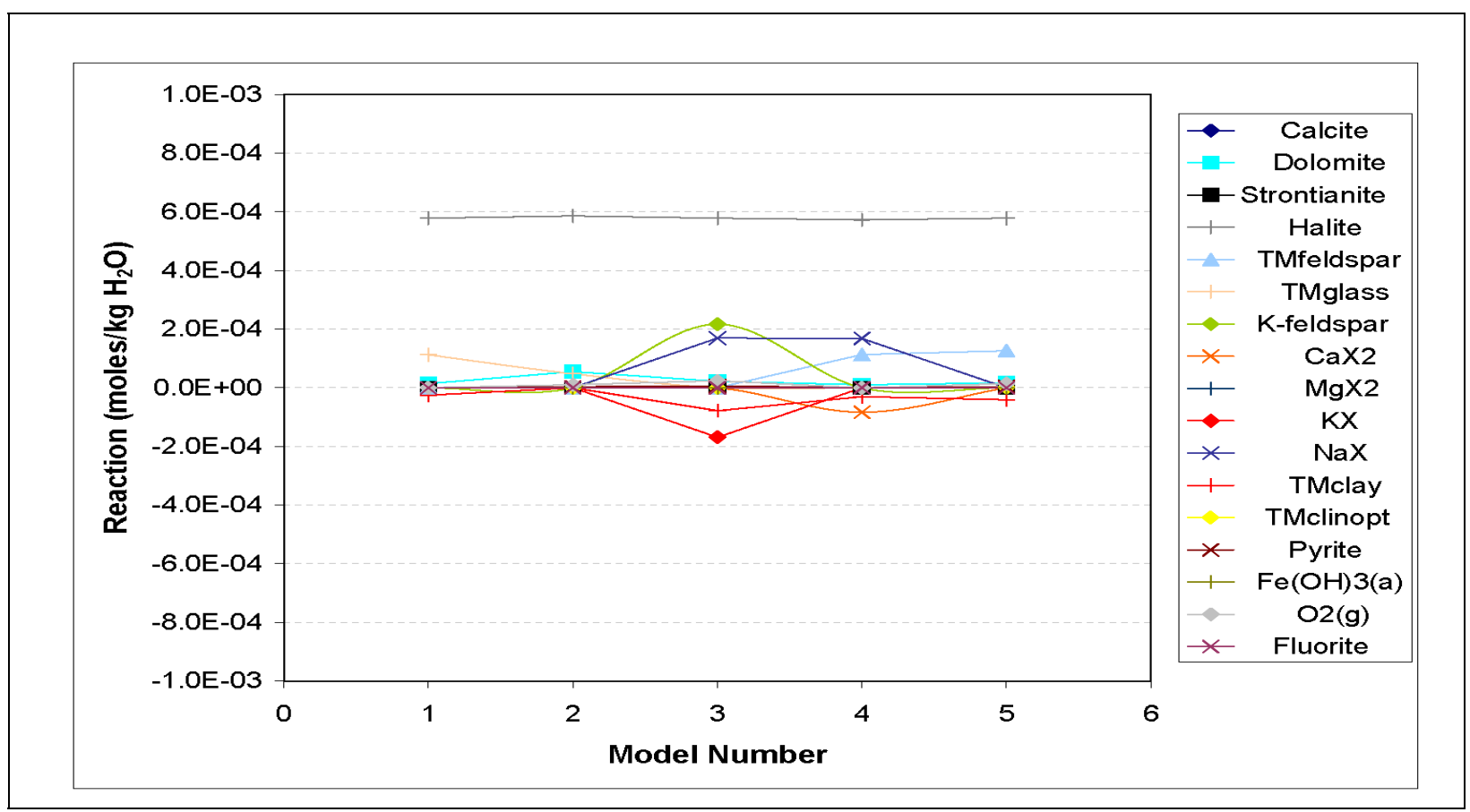

Figure 7-13

Reactions for U-3cn \#5 Models

Note: Positive values indicate the mineral phase or element is entering into solution by dissolution or exchange, whereas negative values indicate the phase is leaving the solution by precipitation or exchange. 


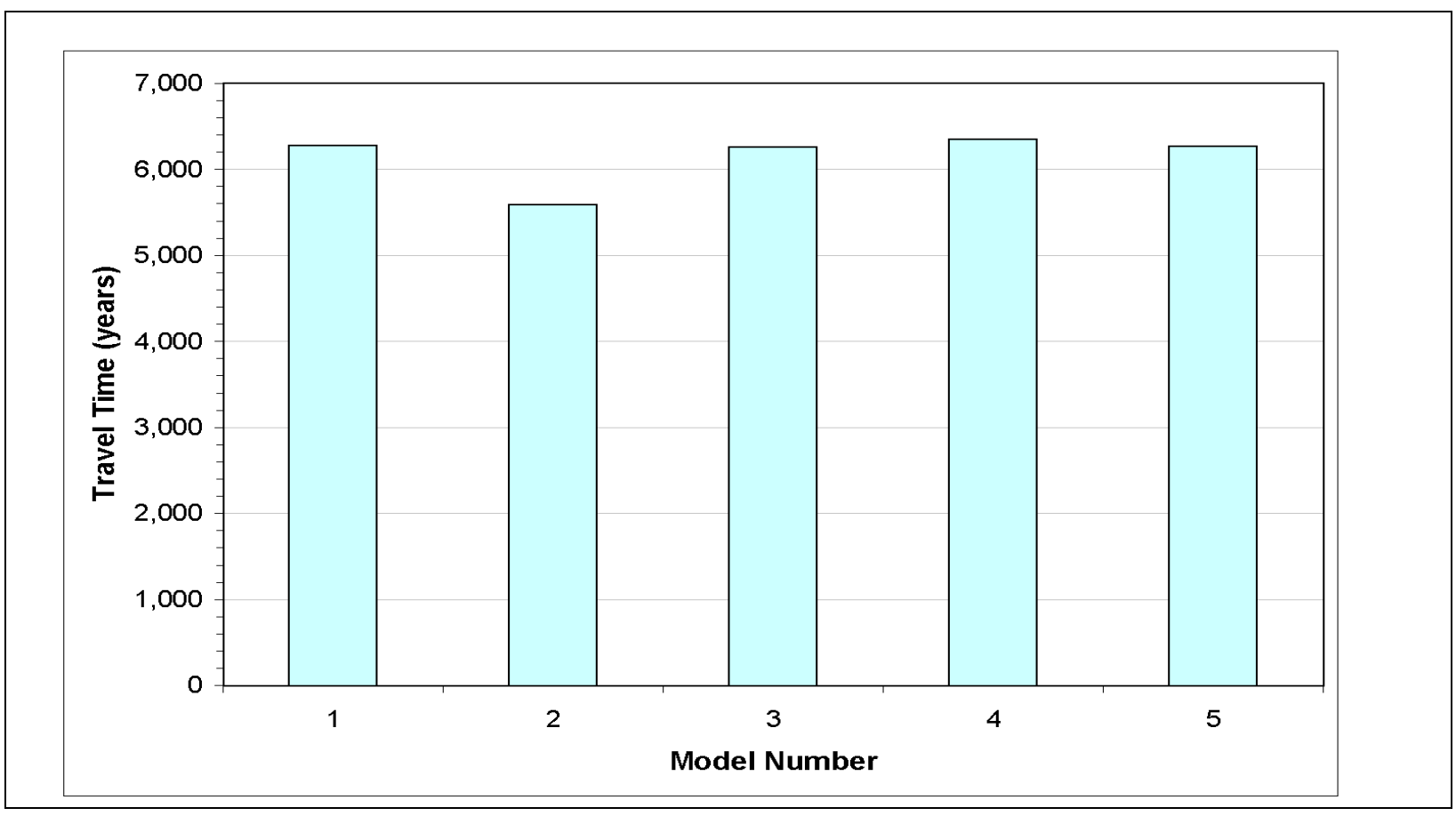

Figure 7-14

Composite Groundwater Travel Times to U-3cn \#5

\subsection{Geochemical Modeling of Well HTH-E}

\subsubsection{Conservative Tracer Models for Well HTH-E}

Well HTH-E is located approximately $2 \mathrm{~km}$ due south of ER-7-1, and both wells appear to be completed in the same LCA structural block. Well HTH-E was originally drilled in 1960 to a depth of 2,620 ft bgs. The Raytheon "Redbook" reports the well was destroyed in 1963, but DRI collected water samples from the bottom of the cased interval (1,970 ft bgs) in 1991. Carbonate bedrock was encountered at 1,690 ft bgs in ER-7-1 (SNJV, 2004a), and the static water level was measured at $1,854 \mathrm{ft}$ bgs. This suggests the HTH-E samples should have come from the LCA. However, the $\delta \mathrm{D}$ and $\delta^{18} \mathrm{O}$ values for HTH-E groundwater are much lower (more negative) than those of ER-7-1

(Figure 7-1). In fact, they are the lowest stable isotope values observed among all Yucca Flat LCA waters. For this reason, groundwater mixing models to account for the origin of the water cannot be developed. It is notable that the HTH-E water chemistry is unusually dilute compared with other LCA water samples, which raises concerns that this sample may reflect water that leaked into the well from an overlying (possibly perched) zone. 


\subsection{Geochemical Modeling of Wells ER-6-1 and ER-6-1 \#2}

\subsubsection{Conservative Tracer Models for Wells ER-6-1 and ER-6-1\#2}

Wells ER-6-1 and ER-6-1 \#2 are the southernmost of the LCA wells located along the eastern margin of the basin. As previously discussed, a recent aquifer test revealed a strong hydraulic connection between the ER-6-1 well cluster and ER-7-1 (SNJV, 2005a). Connection between these sites is reflected in their groundwater $\delta \mathrm{D}, \delta^{18} \mathrm{O}$, and $\mathrm{Cl}$ values (Figures 7-1 and 7-2), which are nearly the same for all three wells. These data suggest that groundwater in the ER-6-1 wells may flow southward from ER-7-1. To test this hypothesis, conservative tracer models developed for ER-7-1 (using Emigrant Valley and northeastern Yucca Flat water compositions) were used to evaluate the groundwater composition at ER-6-1 \#2. In general, the models predicted a very similar range in mixing compositions for both wells. For the sake of brevity, only two representative examples are presented here.

One of the best mixing models for ER-7-1 required 56.5 to 58.0 percent WT-1, 24.5 to 25.1 percent UE-10j-1, and 16.9 to 19.0 percent Oak Spring water. The same model was tested for ER-6-1 \#2 with the following results:

$\begin{array}{ccccc} & \text { WT-1 } & + \text { UE-10j-1 } & + & \text { Oak Spring } \\ \delta \mathrm{D} & 55.2 & 21.4 & 23.4 & \text { ER-6-1\#2 } \\ \delta^{18} \mathrm{O} & 63.1 & 24.5 & 12.4 \\ \mathrm{Cl} & 55.7 & 21.6 & 22.7\end{array}$

Compared to the ER-7-1 results, this model predicts a slightly larger range in mixing fractions, but the relative proportion of groundwater from each location is nearly identical in both models. An alternative ER-7-1 model with a different set of mixing end-members called for 34.4 to 51.4 percent ER-2-1, 13.2 to 17.8 percent UE-10j-3, and 35.4 to 47.8 percent UE-15d groundwater. Running the same model for ER-6-1 \#2 gave the following results:

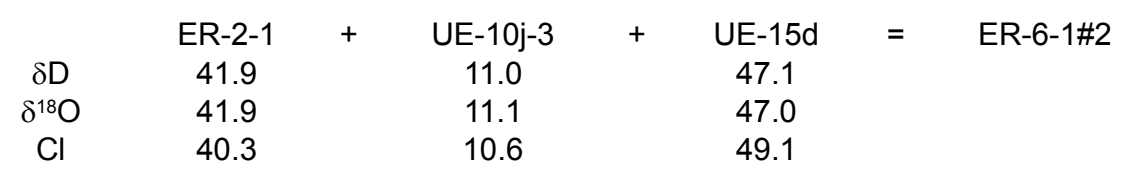


Once again, the relative mixing proportions are fairly similar for both models, but in this case the ER-6-1 \#2 model predicts a tighter range in mixing fractions. From these conservative tracer modeling results, and the geochemical similarities between ER-6-1, ER-6-1 \#2, and ER-7-1, all three wells appear to lie along a contiguous flow path with a common origin in northeastern Yucca Flat.

\subsubsection{Strontium and ${ }^{87}$ Sr/36 Sr Models for Wells ER-6-1 and ER-6-1\#2}

Differences between mixing proportions derived from conservative tracers and Sr data are greater for ER-6-1\#2 (Table 7-4). Nevertheless, the strong similarities in Sr data between ER-7-1, U-3cn \#5, ER-6-1, and ER-6-1\#2 (Figure 7-3) support the conclusion that samples from the LCA in east-central Yucca Flat are genetically related to each other, with common origins in northern Yucca Flat. The ${ }^{87} \mathrm{Sr} /{ }^{86} \mathrm{Sr}$ versus 1/Sr relations shown in Figure 7-3 suggest that the groundwaters of ER-6-1 and ER-6-1\#2 may consist of 26 to 37 percent volcanic aquifer water of HTH-1 (or WT-1), 23 to 30 percent northern Yucca Flat LCA groundwater (UE-10j-1), and 36 to 46 percent mean local recharge (Table 7-4).

Table 7-4

Mixing Percentages for Well ER-6-1\#2 Based on ${ }^{87} \mathrm{Sr} /{ }^{86} \mathrm{Sr}$ Versus $1 / \mathrm{Sr}$

\begin{tabular}{|ccc|}
\hline \multicolumn{3}{|c|}{ Percentage / Deviation of Mixing Component } \\
\hline WT-1 & UE-10j-1 & Oak Spring \\
$26 /-32$ & $28 /+6$ & $46 /+27$ \\
\hline ER-2-1 & UE-10j-3 & UE-15d \\
$34 /-7$ & $49 /+38$ & $17 /-31$ \\
\hline
\end{tabular}

\subsubsection{NETPATH Models for Wells ER-6-1 and ER-6-1\#2}

The similarity of $\delta \mathrm{D}$ and $\delta^{18} \mathrm{O}$ values for ER-7-1, ER-6-1, ER-6-1 \#2, U-3cn \#5, and UE-7nS (Figure 7-1) suggest a common origin. Interestingly, water chemistry varies somewhat for several of these wells in the LCA in eastern Yucca Flat. For example, $\mathrm{Cl}$ is high in U-3cn \#5 and UE-7nS relative to the other LCA wells in the vicinity. This variation in water chemistry limits the successful NETPATH models for this flow path. The first successful flow path shows that groundwater at ER-6-1 \#2 can be produced by simply allowing upgradient ER-7-1 to react with aquifer minerals (Table 7-5). This model produces a travel time of 6,500 years. 
Table 7-5

NETPATH Modeling Results for Well ER-7-1 Groundwater Reacting with LCA Minerals To Produce Groundwater at Well ER-6-1 \#2

\begin{tabular}{|c|c|c|}
\hline Mineral Phase & $\begin{array}{l}\text { Dissolved } \\
\text { (mmol/L) }\end{array}$ & $\begin{array}{l}\text { Precipitated } \\
\text { (mmol/L) }\end{array}$ \\
\hline Calcite & & 0.01 \\
\hline $\mathrm{SiO}_{2}$ & 0.71 & \\
\hline Feldspar & 0.01 & \\
\hline Clay & & 0.22 \\
\hline$\delta^{13} \mathrm{C}$ & $\begin{array}{c}-6.3 \text { permil } \\
\text { (Measured) }\end{array}$ & $\begin{array}{l}\text {-6.2 permil } \\
\text { (Modeled) }\end{array}$ \\
\hline Travel Time & \multicolumn{2}{|c|}{6,500 years } \\
\hline
\end{tabular}

Other successful NETPATH models for ER-6-1 \#2 show mixtures of predominantly upgradient LCA water from ER-7-1 with lesser amount of higher TDS LCA waters from U-3cn \#5, UE-7nS, and/or ER-3-1 (Table 7-6). Models producing ER-6-1 have similar mixing ratios (Table 7-6). Travel times could not be calculated for these mixtures because of a lack of ${ }^{14} \mathrm{C}$ data for $\mathrm{U}-3 \mathrm{cn} \# 5$ and UE-7nS.

As shown by conservative tracers and Sr data, the LCA groundwater at ER-6-1 \#2 can also be produced by mixing various northern Yucca Flat LCA groundwaters with volcanic groundwater and local recharge. In agreement with $\mathrm{Sr}$ data, a few successful NETPATH modeling produced mixtures composed of about 35 percent volcanic groundwater like WT-1 plus a small component of northern Yucca Flat deep LCA groundwater like UE-10j-1 with a major component of local recharge (54-58 percent) like Oak Spring (Table 7-6). Attempts to model ER-6-1 \#2 water with water-rock reactions using other groundwaters tested with conservative tracer models were unsuccessful.

\subsubsection{PHREEQC Modeling Results for Wells ER-6-1 and ER-6-1\#2}

Inverse mixing and reaction models were created with PHREEQC to test whether the groundwater from the vicinity of ER-7-1 may be flowing southward along the fault zone toward Wells ER-6-1 and ER-6-1 \#2. Other wells from the area such as U-3cn \#5, UE-7nS and ER-3-1 were included to determine whether groundwater from these areas may also be contributing groundwater to this part of Yucca Flat. The inverse model results for groundwater from both ER-6-1 (Figures 7-15 and 7-16) and ER-6-1 \#2 (Figures 7-17 and 7-18) indicate that groundwater from these wells is derived almost exclusively from the area of ER-7-1 with only minor water-rock reactions along the flow path (Figures 7-16 and 7-18). Inverse models for both wells indicate that no more than 1 percent of the 
Table 7-6

Results of NETPATH Models for Well ER-6-1\#2 and ER-6-1

\begin{tabular}{|c|c|c|c|c|c|c|c|c|}
\hline \multirow{2}{*}{\multicolumn{4}{|c|}{ End-Member Percentage }} & \multicolumn{4}{|c|}{ Teasured (Modeled) Composition of ER-6-1\#2 } & \multirow{2}{*}{$\begin{array}{c}\begin{array}{c}\text { Travel Time } \\
\text { (Years) }\end{array} \\
\end{array}$} \\
\hline & & & & $(-106)^{a}$ & $(-14.1)^{\mathrm{a}}$ & $(11.0)^{\mathrm{a}}$ & $(-6.2)^{a}$ & \\
\hline ER-7-1 & U-3cn \#5 & UE-7nS & ER-3-1 & $\delta \mathbf{D}$ (permil) & $\delta^{18} \mathrm{O}$ (permil) & $\mathrm{Cl}(\mathrm{mg} / \mathrm{L})$ & $\delta^{13} \mathbf{C}$ (permil) & \\
\hline $71-83$ & $0-12$ & $15-17$ & $0-2$ & -107 to -106 & -14.1 to -14.0 & 14.4 to 16.5 & -5.7 to -5.5 & \\
\hline ER-7-1 & U-3cn \#5 & UE-7nS & & & & & & \\
\hline $70-74$ & $11-13$ & $14-17$ & & -106 to -105 & -14.0 to -13.9 & 15.7 to 16.2 & -5.8 to -5.7 & * \\
\hline WT-1 & UE-10j-1 & Oak Spring & & & & & & \\
\hline $32-37$ & $9-10$ & $54-58$ & & -104 to -103 & -13.4 to -13.1 & 9.5 to 9.8 & * & * \\
\hline $\begin{array}{r}\text { ER-2-1 } \\
N\end{array}$ & & \multicolumn{7}{|c|}{ No Reasonable Models } \\
\hline \multicolumn{4}{|c|}{ End-Member Percentage } & \multicolumn{4}{|c|}{ Measured (Modeled) Composition of ER-6-1 } & $\begin{array}{c}\text { Travel Time } \\
\text { (Years) }\end{array}$ \\
\hline ER-7-1 & UE-7nS & ER-3-1 & & & & & & \\
\hline $74-76$ & $24-26$ & 0 & & -106 & -14.0 & 15.1 to 15.9 & -5.4 to -5.3 & * \\
\hline
\end{tabular}

a Average measured value reported in Appendix A.

${ }^{*} \delta^{13} \mathrm{C}$ could not be modeled and travel times could not be calculated because of the lack of $\delta^{13} \mathrm{C}$ and ${ }^{14} \mathrm{C}$ data for Oak Spring and ${ }^{14} \mathrm{C}$ data for UE-7nS.

groundwater at these wells originates from the vicinity of ER-3-1. Small differences in the results of the inverse models for ER-6-1 and ER-6-1 \#2 may be the result of groundwater $\delta^{13} \mathrm{C}$ at ER-6-1 being slightly lighter $\left(\delta^{13} \mathrm{C}=-6.7\right.$ permil $)$ than that at ER-6-1 $\# 2\left(\delta^{13} \mathrm{C}=-6.2\right.$ permil $)$. In spite of these small differences, the models for ER-6-1 and ER-6-1 \#2 are similar in that they result in estimated composite travel times of approximately 5,800 to 7,300 years over the 10-km distance between Wells ER-7-1 and either ER-6-1 (Figure 7-19) or ER-6-1 \#2 (Figure 7-20). These travel times can be used to calculate linear transport velocities of approximately 1.4 to $1.7 \mathrm{~m} / \mathrm{yr}$ in the LCA between these two areas in eastern Yucca Flat, in rough agreement with the velocities of 1.9 to 2.7 calculated between UE-10j and ER-7-1.

\subsection{Summary}

North-to-south flow paths in eastern Yucca Flat are inferred from the predominant orientation of major faults and water-level responses upgradient of the ER-6-1 well complex during aquifer testing. Conservative tracers suggest that groundwater at $\mathrm{UE}-7 \mathrm{nS}$, the northernmost well in this area, may be composed of volcanic groundwater from Emigrant Valley, LCA groundwater from northern Yucca Flat, and/or LCCU groundwater from eastern Yucca Flat. On the other hand, Sr data suggest that groundwater at UE-7nS is composed of volcanic groundwater from either Emigrant Valley or Yucca 


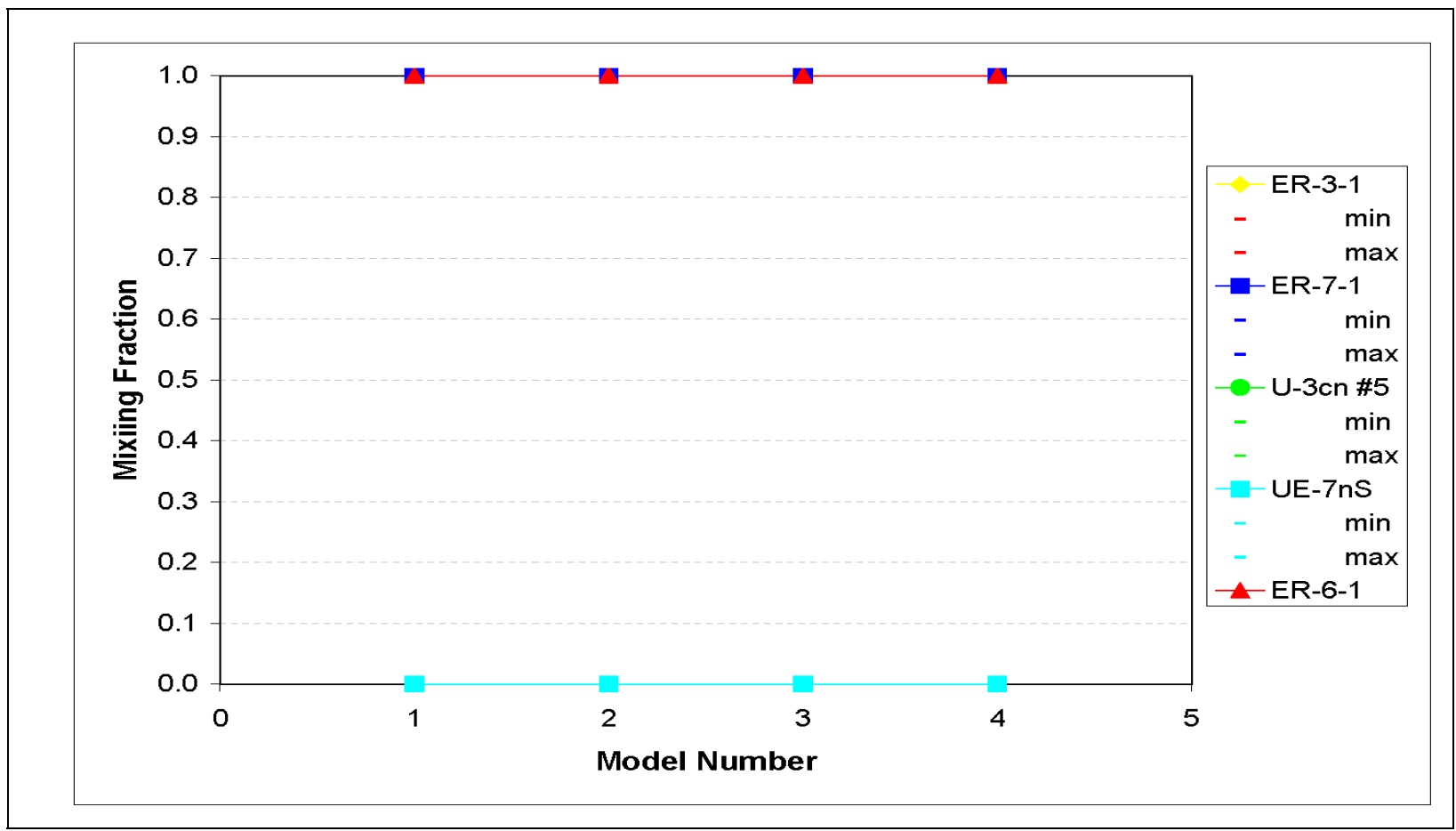

Figure 7-15

Mixing Fractions for ER-6-1 Models with Local Upgradient Sources

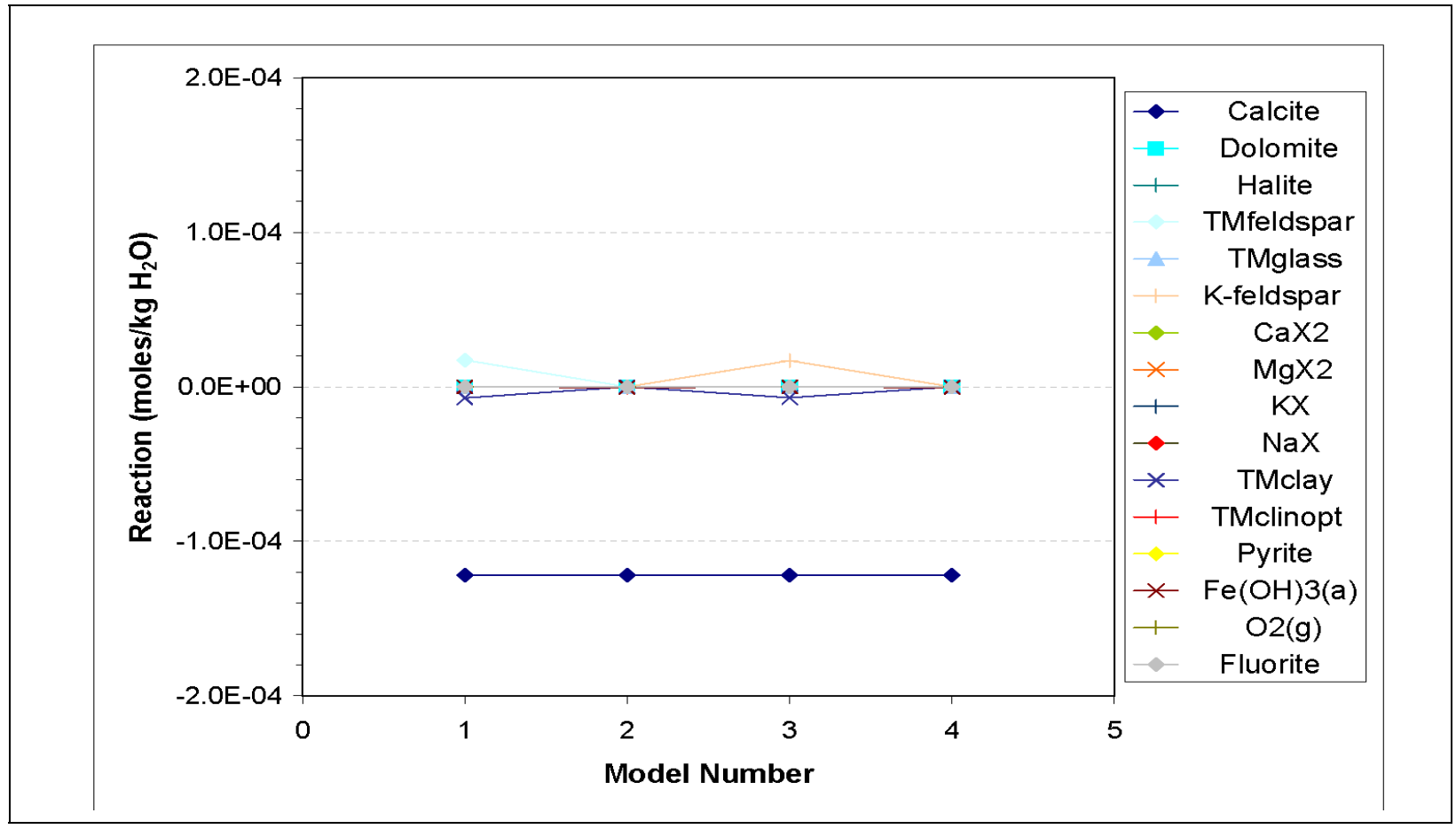

Figure 7-16

Reactions for ER-6-1 Models with Local Upgradient Sources

Note: Positive values indicate the mineral phase or element is entering into solution by dissolution or exchange, whereas negative values indicate the phase is leaving the solution by precipitation or exchange. 


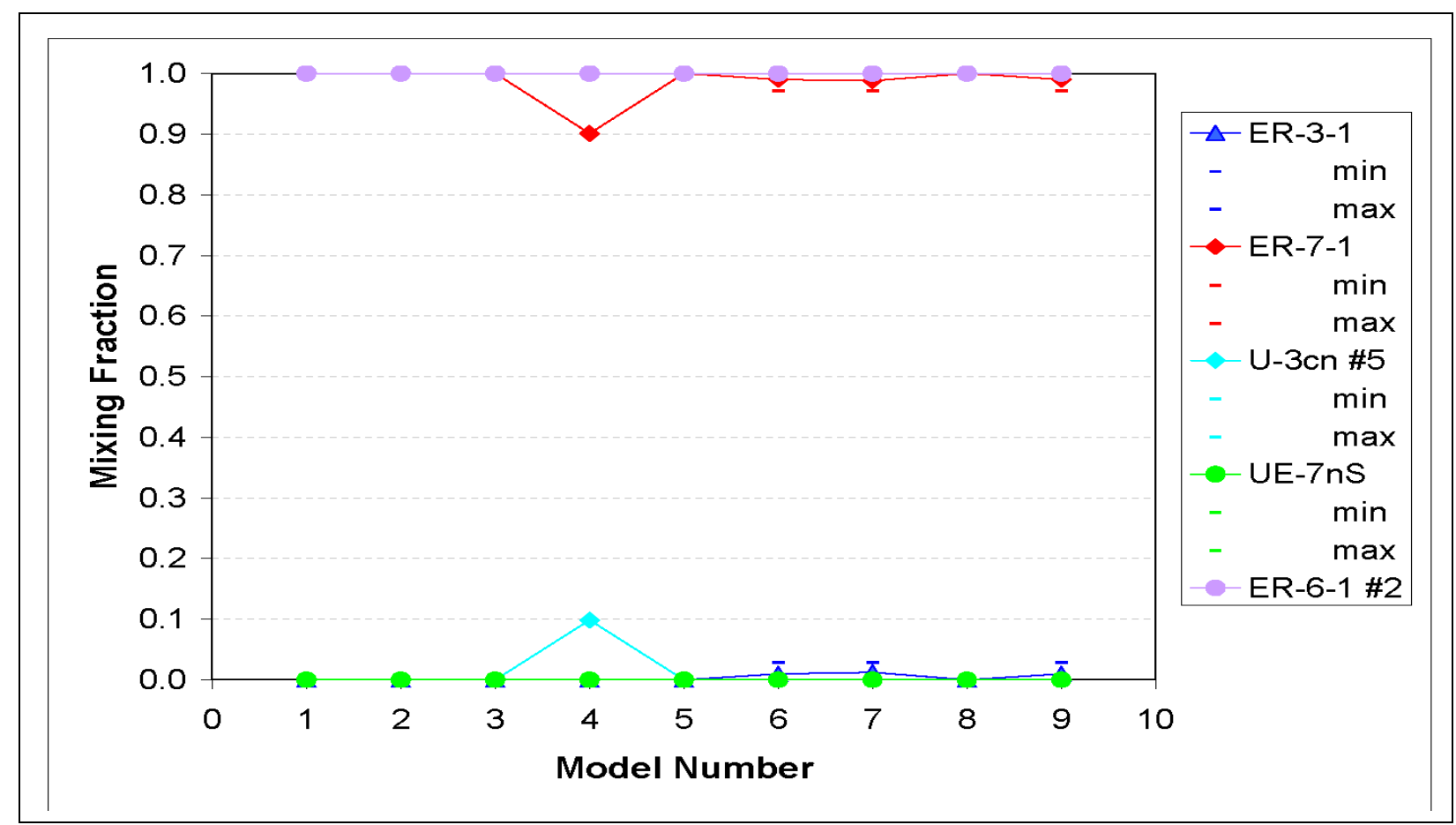

Figure 7-17

Mixing Fractions for ER-6-1 \#2 Models with Local Upgradient Sources

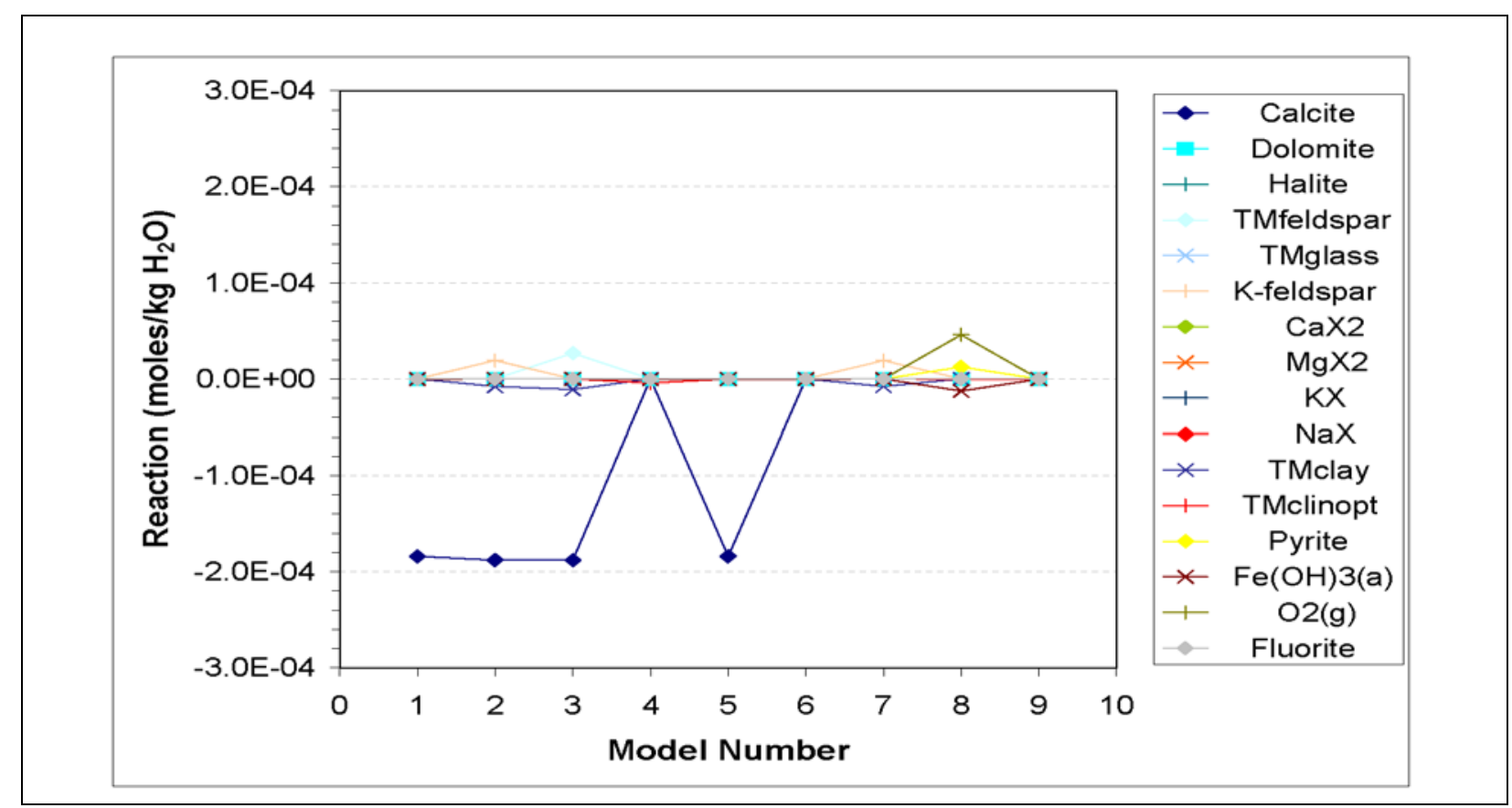

Figure 7-18

Reactions for ER-6-1 \#2 Models with Local Upgradient Sources

Note: Positive values indicate the mineral phase or element is entering into solution by dissolution or exchange, whereas negative values indicate the phase is leaving the solution by precipitation or exchange. 


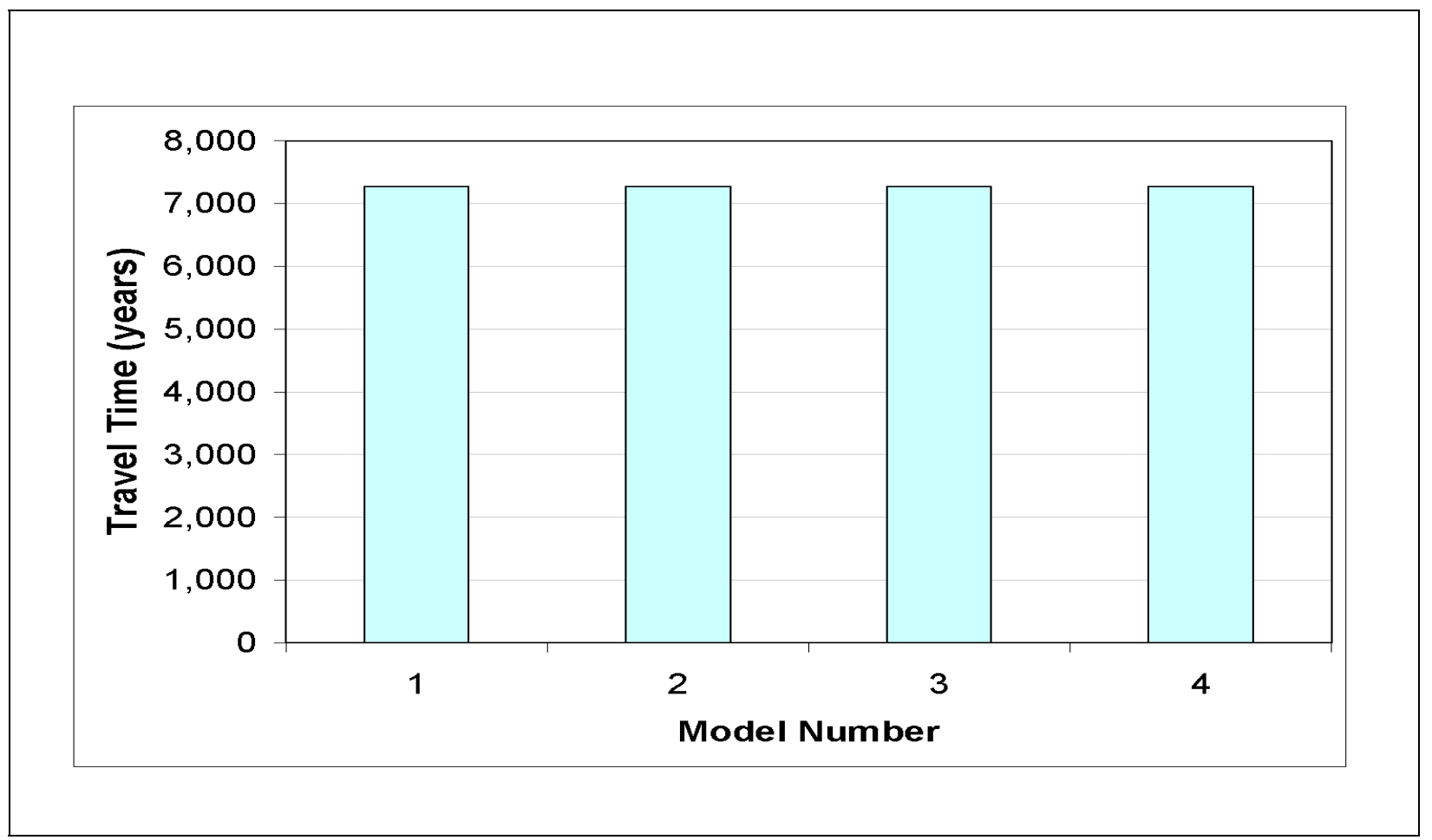

Figure 7-19

Composite Travel Times to ER-6-1 for Models with Local Upgradient Sources

Note: Travel times for the first four models are minimum travel times because the ${ }^{14} \mathrm{C}$ is assumed to be 0 pmc for UE-7nS.

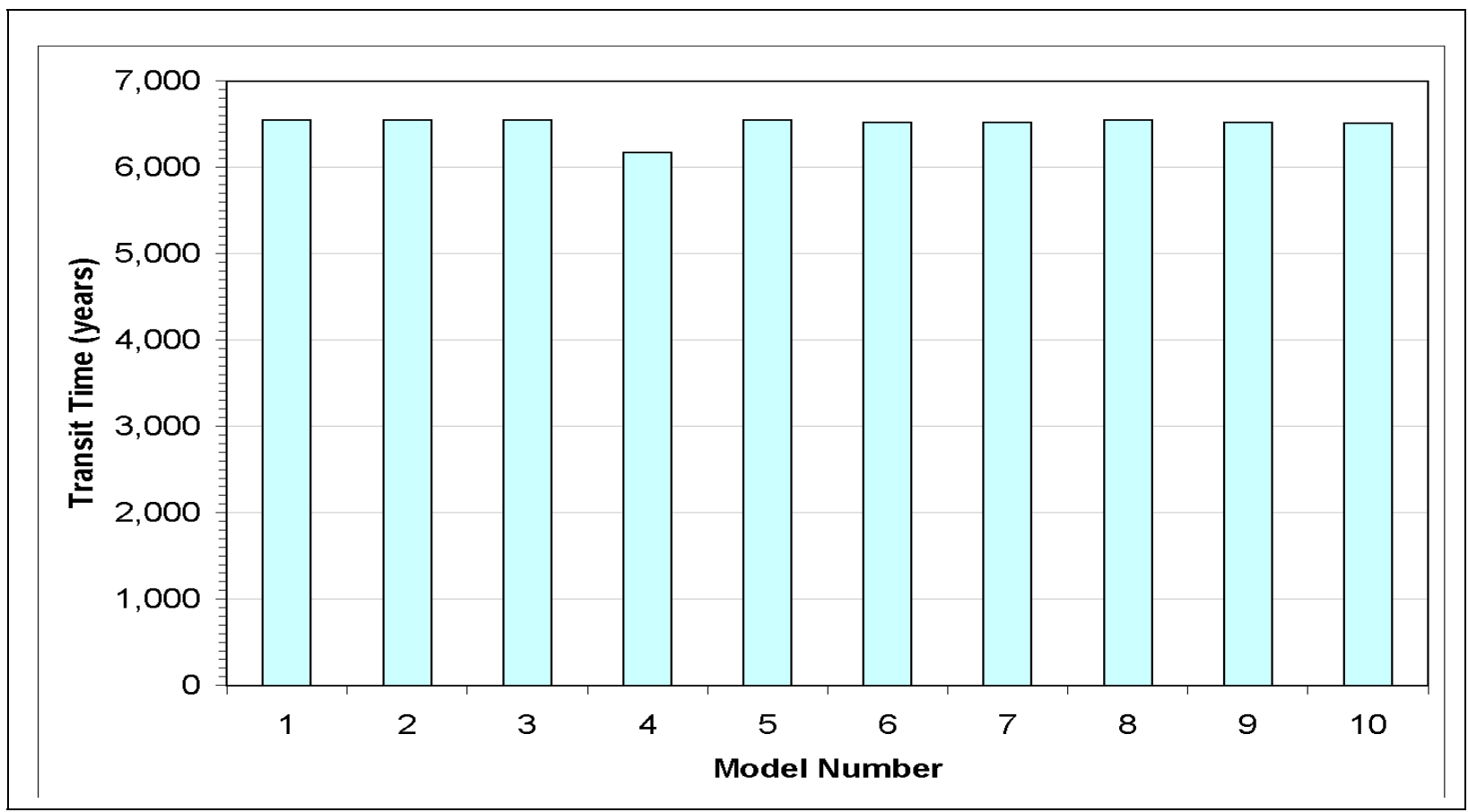

Figure 7-20

Composite Travel Times to ER-6-1\#2 for Models with Local Upgradient Sources 
Flat, LCA groundwater from northern Yucca Flat, and local recharge. However, when adding water-rock reactions, NETPATH and PHREEQC did not produce any reasonable models for UE-7nS, primarily because of the anomalously low $\mathrm{SO}_{4}(0.8 \mathrm{mg} / \mathrm{L})$ and heavy $\delta^{13} \mathrm{C}(2.0$ permil $)$ reported for this well.

Groundwater at ER-7-1, the next LCA well south of UE-7nS, can be modeled a variety of ways. Conservative tracers and PHREEQC models suggest a large component of volcanic water from Emigrant Valley (38-58 percent) with smaller proportions of northern Yucca Flat LCA groundwater and local recharge. The Sr data and NETPATH models show smaller proportions of Emigrant Valley groundwater (25-43 percent) with greater proportions of northern Yucca Flat LCA and local recharge (43-62 percent). The PHREEQC models that attempted to model the Sr data at Well ER-7-1 through both mixing and water-rock interactions estimated that feldspars associated with the LCCU would need a ${ }^{87} \mathrm{Sr} /{ }^{86} \mathrm{Sr}$ ratio of between $0.71344 \pm 0.00003$ (1 Std. Dev.) and $\mathrm{Sr}$ concentrations of about 2,100 to 2,500 ppm in order for Emigrant Valley groundwater to be present at ER-7-1 in the proportions estimated with conservative tracers. Unfortunately, rock $\mathrm{Sr}$ data are presently unavailable from the LCCU to evaluate this model. Conservative tracers and $\mathrm{Sr}$ data indicate ER-7-1 groundwater can also be modeled by substituting a Yucca Flat volcanic groundwater (ER-2-1) in place of Emigrant Valley groundwater with similarly wide variations in mixing proportions. Groundwater travel times ranged from 6,600 to 7,200 years for the ER-7-1 models. The PHREEQC and NETPATH models for ER-7-1 were also constructed using LCA groundwater from Pahranagat Valley. The NETPATH models were unsuccessful but PHREEQC models showed a wide range of possible proportions of Pahranagat Valley groundwater from 0 to 82 percent. Groundwater travel times for this flowpath had a wide range, from 3,700 to 6,800 years, because of the wide range in contribution from Pahranagat Valley.

Well U-3cn \#5 is located southwest of ER-7-1, but is separated by several north-south trending faults and has substantially different chemical composition from other LCA wells. Because of high $\mathrm{Cl}$ concentrations, conservative tracer models could only be developed using $\delta \mathrm{D}$ and $\delta^{18} \mathrm{O}$. The Sr data supported one conservative tracer model, but because of similar Sr data for U-3en \#5 and ER-7-1, did not agree with the other model. The NETPATH models incorporating water-rock reactions were unsuccessful. The PHREEQC models, which account for uncertainty in chemical and isotopic measurements, indicated the groundwater at Well U-3cn $\# 5$ originates from the vicinity of Well ER-7-1 (80 to 90 percent) with secondary contributions from northern Yucca Flat at Well 
UE-10j-3 (about 15 percent) or from UE-15d (0 to 9 percent). Additionally, a small amount ( 0 to 4 percent) of groundwater from the overlying volcanic units may be present, as represented by the U-3cn PS \#2 groundwater sample. The models required halite dissolution, but otherwise, relatively small amounts of water-rock interactions were required for this set of inverse models, indicating that most of the other downgradient changes in chemistry could be accounted for through mixing. The results of these PHREEQC models are in agreement with $\mathrm{Sr}$ data which indicate the $\mathrm{Sr}$ and ${ }^{87} \mathrm{Sr} /{ }^{86} \mathrm{Sr}$ data at Wells U-3cn \#5 and ER-7-1 are nearly identical. Thus, it appears that at least some groundwater from the vicinity of ER-7-1 flows toward the center of the basin, as indicated by the hydraulic gradients for the LCA.

Rapid water-level decline in ER-7-1 when pumping ER-6-1 indicates a hydraulic connection between these wells in eastern Yucca Flat. Conservative tracer modeling, Sr data, and NETPATH modeling show a variety of mixtures are possible to produce the chemical composition of the ER-6-1 wells. Of these models that agreed on end-member compositions, there was a wide range in possible mixing ratios; Emigrant Valley volcanic water from 26 to 55 percent, northern Yucca Flat LCA water from 9 to 28 percent, and local recharge from 12 to 58 percent. Other mixtures involving Yucca Flat volcanic groundwater, different northern Yucca Flat LCA groundwater, and eastern Yucca Flat LCA groundwater were possible but there was poor agreement between the conservative tracer, $\mathrm{Sr}$, and NETPATH models. The best NETPATH and PHREEQC models reacted ER-7-1 groundwater with a mineral assemblage while flowing to ER-6-1 \#2. Groundwater travel times for this flowpath ranged from 5,800 to 7,300 years, resulting in calculated groundwater velocities of about 1.4 to $1.7 \mathrm{~m} / \mathrm{yr}$ over this $10-\mathrm{km}$ distance. 


\section{0 evaluation of Southeastern flow Paths}

Four wells in southeastern Yucca Flat and northeastern Frenchman Flat produce LCA groundwater with a distinct set of geochemical characteristics that may indicate a separate flow path in this region. These wells are ER-3-1, Water Well C (WW-C), Water Well C1 (WW-C1), and ER-5-3 \#2. All four waters have similar stable isotope values (Figure 7-1) but have high solute concentrations, including $\mathrm{Cl}$ concentrations that range from 35 to $42 \mathrm{mg} / \mathrm{L}$ (Figure 7-2). Regional water-level contours (Figure 2-7) suggest that this water originates northeast of the NTS. However, geochemical data for this area are limited with the nearest upgradient samples from Emigrant and Pahranagat Valleys, approximately 25 and $80 \mathrm{~km}$ from ER-3-1, respectively. Although the stable isotope compositions of these upgradient waters are similar to the southeastern Yucca Flat groundwater, their solute concentrations are considerably more dilute. Hence, conservative tracer mixing models to account for groundwater sources beyond the NTS boundaries cannot be developed. Despite this limitation, reactive transport models were developed that yield insight into water-rock reactions and travel times from possible distal upgradient locations.

\subsection{Geochemical Modeling of the Origin of ER-3-1}

Well ER-3-1 penetrates the LCA just east of Yucca Flat in the southern portion of the Halfpint Range (Figure 3-1). Regional water-level contours indicate groundwater flow toward the vicinity of ER-3-1 from either the north or northeast (Figure 2-7). Well ER-3-1 has the highest $\mathrm{Cl}$ and the lowest $\delta \mathrm{D}$ and $\delta^{18} \mathrm{O}$ values of the southeastern Yucca Flat wells and is located the furthest upgradient. Therefore, it can be used as an end-member composition for examining mixing processes at the downgradient wells.

\subsubsection{NETPATH Models for ER-3-1}

The NETPATH models were used to evaluate potential water-rock reactions and mixing processes that may account for the high TDS groundwater at ER-3-1. Possible upgradient sources included 
LCA groundwater from Pahranagat Valley and northern Yucca Flat, and groundwater from Emigrant Valley. Models were produced using Ash Spring, UE-10j-1, and alluvial aquifer water (WT-4) from Emigrant Valley (Table 8-1).

Successful models required a significant amount of $\mathrm{NaCl}$ dissolution $(0.7 \mathrm{mmol} / \mathrm{L})$ to increase the $\mathrm{Cl}$ concentration close to the levels seen in ER-3-1 with accompanying dissolution of calcite and dolomite and exchange of $\mathrm{Na}$ for $\mathrm{Ca}$ and $\mathrm{Mg}$ to increase the $\mathrm{Na}$ concentrations. Because of similar $\mathrm{SiO}_{2}$ concentrations in all of the wells, the required dissolution of feldspars and glass, and precipitation of clays and zeolites, was small. Composite travel times are relatively long because of the very low amount of ${ }^{14} \mathrm{C}$ in ER-3-1 (0.74 pmc) relative to that in Ash Spring and UE-10j-1 (6.2 and 7.5 pmc, respectively), which make up the majority of the mixture. However, calcite and dolomite dissolution is expected to add ${ }^{14} \mathrm{C}$-absent $\mathrm{DIC}$ to the water, and the travel time estimates will therefore represent maximum values.

Table 8-1

Results of NETPATH Models for ER-3-1

\begin{tabular}{|c|c|c|c|c|c|c|c|}
\hline \multicolumn{3}{|c|}{ End-Member Percentage } & \multicolumn{4}{|c|}{ Modeled (Measured) Composition of ER-3-1 } & \multirow{2}{*}{$\begin{array}{c}\text { Travel Time } \\
\text { (Years) }\end{array}$} \\
\hline & & & $(-109)^{a}$ & $(-14.1)^{\mathrm{a}}$ & $(42)^{\mathrm{a}}$ & $(-2.3)^{a}$ & \\
\hline Ash Spring & UE-10j-1 & WT-4 & $\begin{array}{c}\delta D \\
\text { (permil) }\end{array}$ & $\begin{array}{c}\delta^{18} \mathrm{O} \\
\text { (permil) }\end{array}$ & $\begin{array}{c}\mathrm{Cl} \\
(\mathrm{mg} / \mathrm{L})\end{array}$ & $\begin{array}{c}\delta^{13} \mathbf{C} \\
\text { (permil) }\end{array}$ & \\
\hline $23-24$ & $55-58$ & $18-22$ & -106 & -13.9 & 37.3 to 37.5 & -3.2 & $\begin{array}{c}16,500 \text { to } \\
16,800\end{array}$ \\
\hline
\end{tabular}

${ }^{a}$ Average measured value reported in Appendix $A$.

\subsubsection{PHREEQC Models for ER-3-1}

The PHREEQC models that were developed for ER-3-1 used the same set of upgradient water compositions as the NETPATH models described in the preceding section. Based on the inverse models shown in Figures 8-1 and 8-2, composite travel times to ER-3-1 were calculated (Figure 8-3). Models that do not have a component of Ash Springs groundwater have travel times of 3,800 to 4,300 years. For models involving components of Ash Spring groundwater, model ages range from 5,800 to 8,400 years, presumably reflecting the larger travel distances from the Pahranagat Range to ER-3-1. Travel times from individual wells to ER-3-1 (Table 8-2) were calculated as approximately 


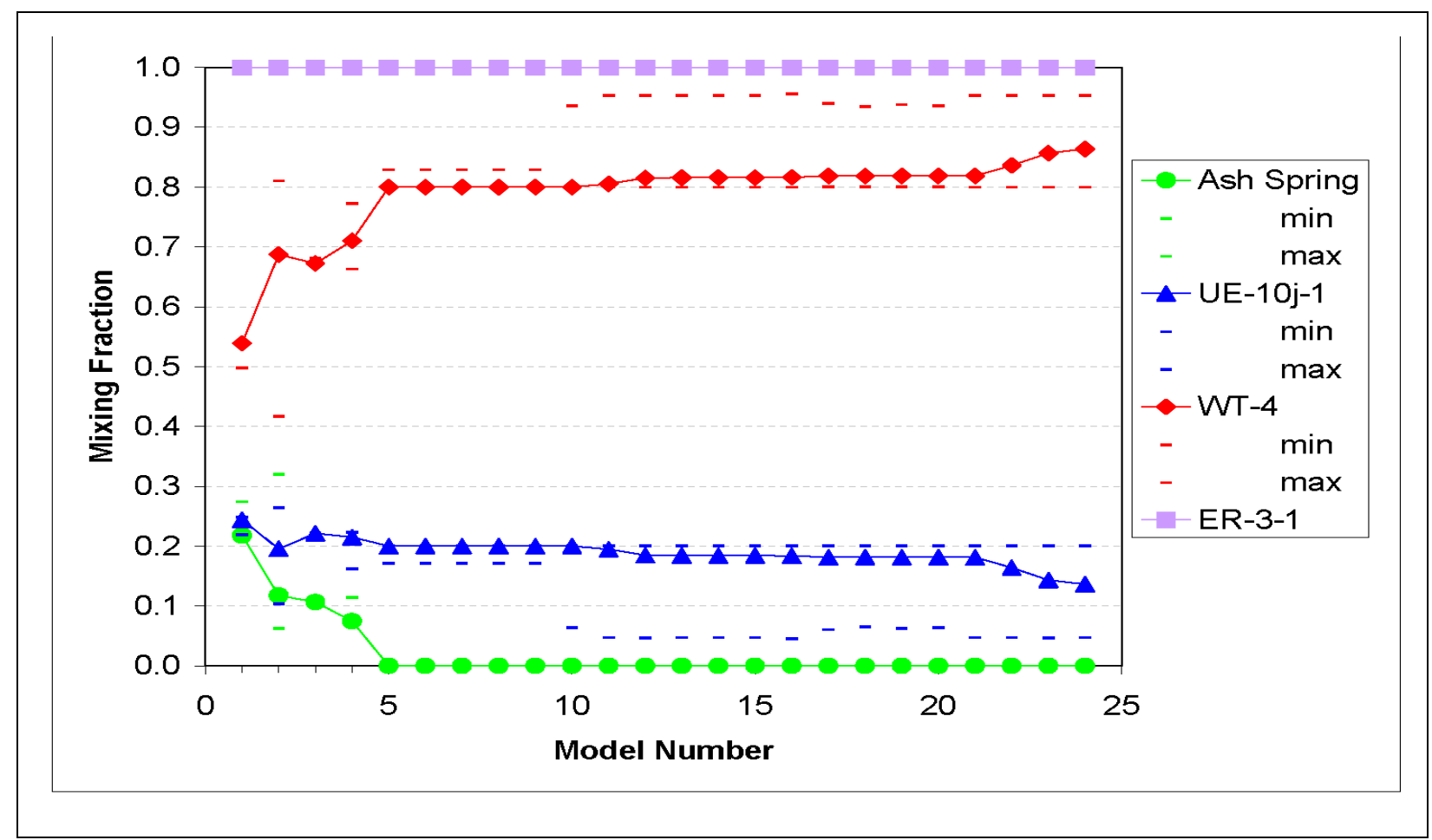

Figure 8-1

Mixing Fractions for ER-3-1 Models with Both Local and Distant Upgradient Sources

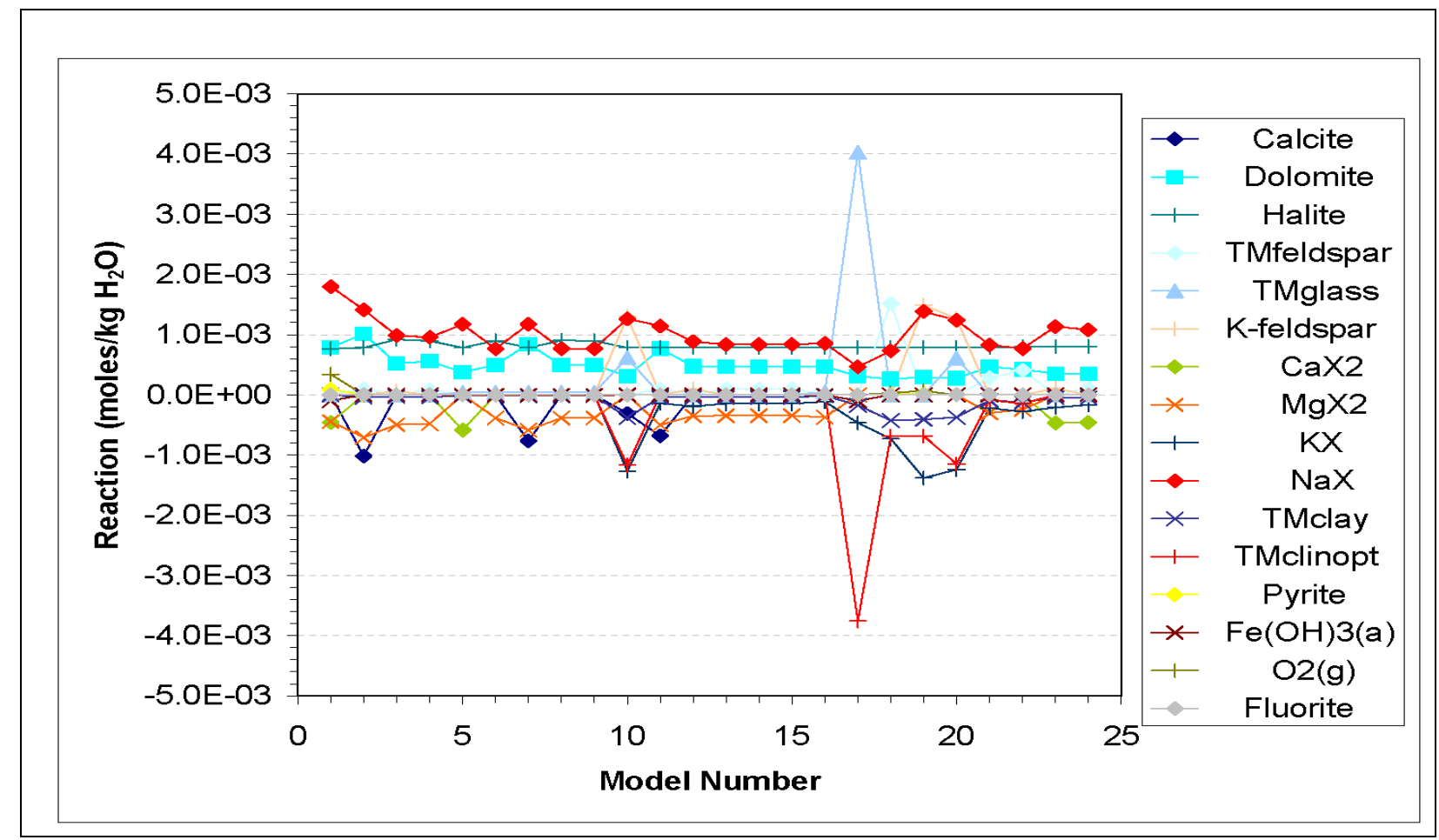

Figure 8-2

Reactions for ER-3-1 Models with Both Local and Distant Upgradient Sources 


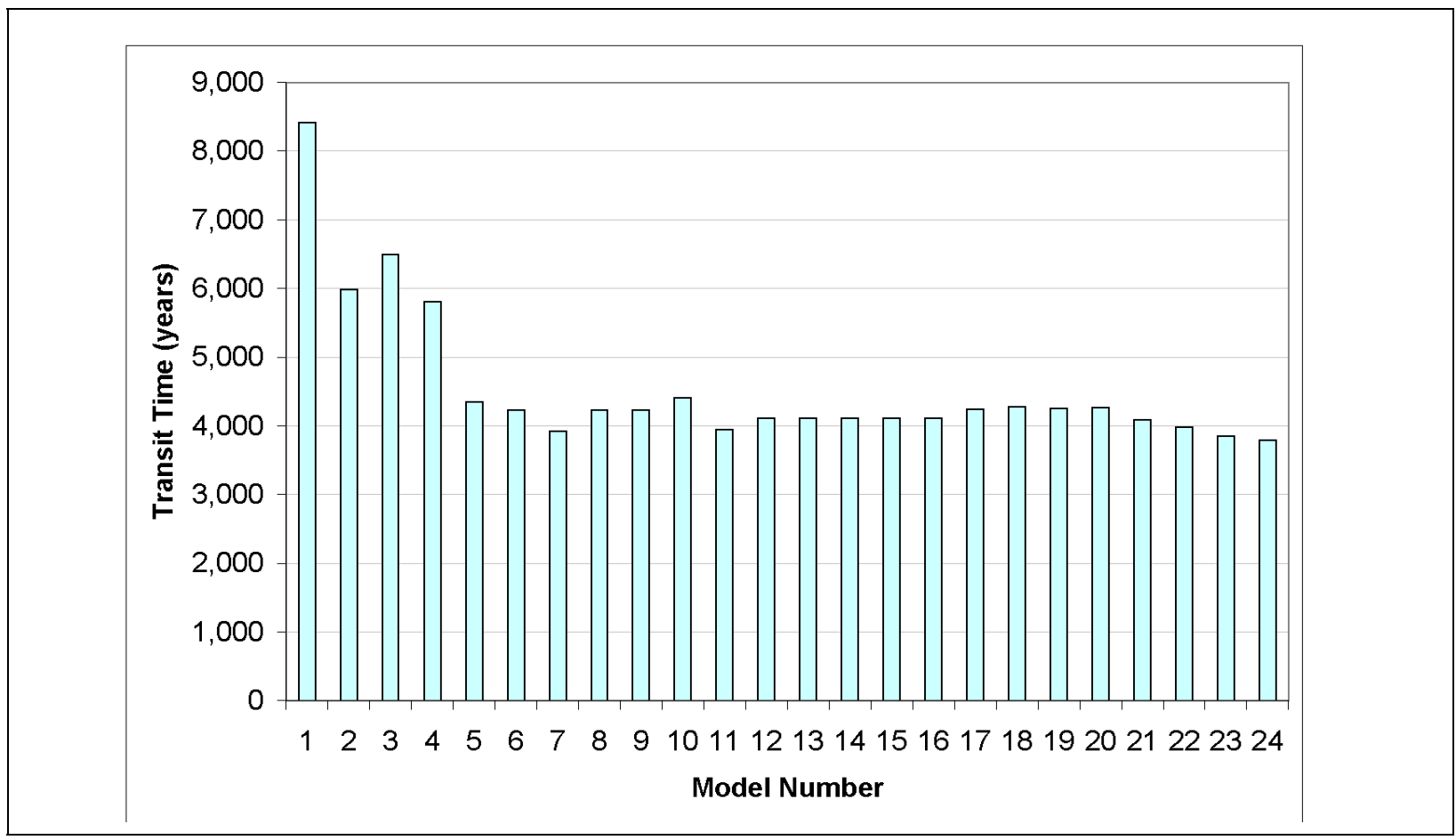

Figure 8-3

Composite Travel Times to ER-3-1

Table 8-2

Travel Times from Individual Wells to ER-3-1

\begin{tabular}{|c|c|c|c|c|}
\hline Site & $\begin{array}{c}\text { Travel Time } \\
\text { (Years) }\end{array}$ & Standard Error & Lower 95\% & Upper 95\% \\
\hline \hline Ash Spring & 20,272 & 987 & 18,220 & 22,325 \\
\hline UE-10j-1 & 10,287 & 1,476 & 7,218 & 13,356 \\
\hline WT-4 & 2,751 & 333 & 2,058 & 3,444 \\
\hline
\end{tabular}

18,200 to 22,300 years from Ash Spring, 7,200 to 13,400 years from UE-10j-1, and 2,100 to 3,400 years from WT-4.

Well WT-4 has high Sr concentrations and ${ }^{87} \mathrm{Sr} /{ }^{86} \mathrm{Sr}$ ratios relative to Well ER-3-1 (Figure 3-11). In order for the models shown in Figures 8-1 and 8-2 to satisfy constraints imposed by the Sr data, it would be necessary for both $\mathrm{Sr}$ concentrations and ${ }^{87} \mathrm{Sr} /{ }^{86} \mathrm{Sr}$ ratios to decrease as groundwater flowed southward from Emigrant Valley toward Well ER-3-1. This simultaneous reduction in both $\mathrm{Sr}$ concentrations and ${ }^{87} \mathrm{Sr} /{ }^{86} \mathrm{Sr}$ ratios could not result from simple mineral dissolution, as described for Well UE-15d WW in Chapter 6 or Well ER-7-1 in Chapter 7, but would require that Sr with a high 
${ }^{87} \mathrm{Sr} /{ }^{86} \mathrm{Sr}$ ratio be removed by sorption even as new $\mathrm{Sr}$ with a low ${ }^{87} \mathrm{Sr} /{ }^{86} \mathrm{Sr}$ ratio was added through additional dissolution reactions. To explore this model of $\mathrm{Sr}$ isotopic evolution, the models involving just WT-4 and UE-10j-1 in Figure 8-1 were tested by allowing Sr with a ${ }^{87} \mathrm{Sr} /{ }^{86} \mathrm{Sr}$ ratio equal to that of groundwater at Well WT-4 (0.72567) to sorb while simultaneously allowing Sr with a ${ }^{87} \mathrm{Sr} /{ }^{86} \mathrm{Sr}$ ratio of about 0.713 to dissolve. (The value of 0.713 was previously identified in the UE-15d and ER-7-1 models as the rock ${ }^{87} \mathrm{Sr} /{ }^{86} \mathrm{Sr}$ ratio required by the Sr inverse models for these wells.) The resulting models for Well ER-3-1 required a wide range of rock Sr concentrations, only some of which are considered remotely plausible for the LCCU (in the range of 400 to $1,300 \mathrm{ppm}$ ). Despite the success of these models in replicating the measured $\mathrm{Sr}$ and ${ }^{87} \mathrm{Sr} /{ }^{86} \mathrm{Sr}$ ratio of groundwater at Well ER-3-1, the necessity of invoking two simultaneous water/rock reactions to reconcile Sr data with the PHREEQC inverse model results renders these models somewhat more speculative, even if they might be physically possible. Thus, the PHREEQC models involving flow from WT-4 to Well ER-3-1 are considered to be possible but nonetheless highly uncertain.

\subsection{Geochemical Modeling of Water Well-C}

Wells WW-C and WW-C1 are located at the southernmost margin of Yucca Flat, approximately $12 \mathrm{~km}$ southwest of ER-3-1, and also draw water from the LCA. Water-level contours for the LCA in Yucca Flat (Figure 2-8) indicate that groundwater in the eastern, northern, and western parts of the Yucca Flat basin converges toward faults in the center of the basin and probably exits the basin in the vicinity of these wells. The two wells are only about $30 \mathrm{~m}$ apart, and both are completed to nearly the same depth in Cambrian limestone of the Carrera Formation (Winograd and Thordarson, 1975). Hence, both wells should produce groundwater that is essentially identical in composition. Small differences in the average stable isotope and $\mathrm{Cl}$ values are observed, but these differences are within the range of analytical uncertainty. Because the reported mean values for WW-C are based on a larger sample population, its composition was modeled.

\subsubsection{Conservative Tracer Models for Water Well-C}

The water composition at WW-C was modeled as a simple mixture of groundwater from northern Yucca Flat and ER-3-1. Reasonably good mixing models were developed using Wells UE-15d, UE-10j (-1 or -3$)$, and ER-3-1 as follows: 


\begin{tabular}{|c|c|c|c|c|c|c|c|}
\hline & UE-15d & + & UE-10j-1 & + & ER-3-1 & $=$ & WW-C \\
\hline$\delta \mathrm{D}$ & 5.0 & & 37.6 & & 57.4 & & \\
\hline$\delta^{18} \mathrm{O}$ & 3.8 & & 28.1 & & 68.1 & & \\
\hline \multirow[t]{2}{*}{$\mathrm{Cl}$} & 3.8 & & 28.1 & & 68.1 & & \\
\hline & UE-15d & + & UE-10j-3 & + & ER-3-1 & $=$ & WW-C \\
\hline$\delta \mathrm{D}$ & 11.8 & & 17.5 & & 70.7 & & \\
\hline$\delta^{18} \mathrm{O}$ & 8.7 & & 12.9 & & 78.4 & & \\
\hline $\mathrm{Cl}$ & 8.7 & & 12.9 & & 78.4 & & \\
\hline
\end{tabular}

These models suggest that WW-C is dominated by the ER-3-1 end-member ( 57 to 78 percent), with the remainder of the mixture being made up of northern Yucca Flat groundwater.

\subsubsection{NETPATH Models for Water Well-C}

Initial NETPATH modeling of groundwater flow from northern Yucca Flat to southeastern Yucca Flat at WW-C considered the same mixing components as the conservative tracer models. The model involving UE-10j-1 groundwater required substantially more groundwater from UE-15d and much less from ER-3-1 compared to the conservative tracer models (Table 8-3). When substituting shallow LCA groundwater from UE-10j-3, NETPATH model results more closely matched conservative tracer models, but NETPATH models were non-unique with a wide range of possible mixtures. Chemical reactions occurring in valid NETPATH models included precipitation of calcite, dissolution of dolomite, dissolution of halite, $\mathrm{Na}$ exchange for $\mathrm{Ca}$ and $\mathrm{Mg}$ in solution, dissolution of small amounts of composite glass or feldspar, and precipitation of small amounts of composite clay or clinoptilolite. However, most of the NETPATH models underestimated the amount of $\mathrm{Cl}$ in solution at WW-C. Travel times from northern Yucca Flat to southeastern Yucca Flat ranged from 11,700 to 18,900 years.

In addition to the mixing scenarios tested above, models were also tested for WW-C that involved mixing of groundwater from Emigrant Valley (WT-4) with northern and eastern Yucca Flat groundwater. In one model, UE-15d and UE-10j-1 were the dominant mixing components, while WT-4 and UE-10j-3 were minor components (Table 8-3). In another model, UE-15d was absent and the dominant mixing components were from ER-3-1 and UE-10j-3, with a small mixing portion from Emigrant Valley. Valid models required precipitation of calcite, dissolution of dolomite, dissolution of halite, and $\mathrm{Na}$ exchange for $\mathrm{Ca}$ and $\mathrm{Mg}$ in solution. These models more closely matched measured $\mathrm{Cl}$ concentrations at WW-C. Once again, however, the models had a wide range in mixing 
Table 8-3

Results of NETPATH Models for Water Well C

\begin{tabular}{|c|c|c|c|c|c|c|c|c|}
\hline \multicolumn{4}{|c|}{ End-Member Percentage } & \multicolumn{4}{|c|}{ Modeled (Measured) Composition of WW-C } & \multirow{2}{*}{$\begin{array}{c}\text { Travel Time } \\
\text { (years) }\end{array}$} \\
\hline & & & & $(-107)^{a}$ & $(-14.0)^{\mathrm{a}}$ & $(35.9)^{\mathrm{a}}$ & $(-4.0)^{a}$ & \\
\hline UE-15d & UE-10j-1 & ER-3-1 & & $\delta \mathbf{D}$ (permil) & $\delta^{18} \mathrm{O}$ (permil) & $\mathrm{Cl}$ (mg/L) & $\delta^{13} \mathbf{C}$ (permil) & \\
\hline $64-65$ & $29-30$ & $4-7$ & & -106 to -104 & -14.0 to -13.9 & 18.7 to 19.6 & -3.4 & 18,700 to 18,900 \\
\hline UE-15d & UE-10j-3 & ER-3-1 & & & & & & \\
\hline $0-43$ & $4-42$ & $53-58$ & & -107 to -105 & -14.0 to -13.5 & 29.3 to 29.9 & -3.6 to -2.9 & 11,700 to 14,700 \\
\hline UE-15d & UE-10j-1 & UE-10j-3 & WT-4 & & & & & \\
\hline $58-64$ & $30-33$ & $3-5$ & $0-7$ & -107 & -13.9 & 35.2 & -3.5 & 14,200 to 14,600 \\
\hline UE-15d & ER-3-1 & UE-10j-3 & WT-4 & & & & & \\
\hline 0 & $47-58$ & $39-42$ & $0-14$ & -105 to -104 & -13.6 to -13.5 & 26.4 to 29.7 & -3.6 to -3.4 & 19,000 to 19,500 \\
\hline
\end{tabular}

proportions and produce non-unique results. Travel times for these models ranged from 14,200 to 19,500 years.

\subsubsection{PHREEQC Models for Water Well-C}

Inverse models for WW-C were also tested with PHREEQC using groundwaters from Wells UE-10j, UE-15d, and WT-4 (Figures 8-4 and 8-5). The results of these models show that groundwater compositions at WW-C can be explained either by (1) mixing groundwater from UE-10j-1 and UE-15d, or (2) mixing diluted LCA groundwater at UE-10j-3 with groundwater from UE-15d and ER-3-1. In one model, groundwater from Emigrant Valley at WT-4 can substitute for groundwater from ER-3-1, a result that is compatible with models that indicate groundwater at ER-3-1 may be largely composed of groundwater from the vicinity of WT-4 (Figure 8-1). Note that 10 of the models require significant (greater than $1 \mathrm{mmol} / \mathrm{L}$ ) dissolution and/or precipitation of one or more mineral phases for the mixing model to balance. Most of the models with large dissolution/precipitation amounts involved a two-component mixture of UE-15d groundwater with smaller amounts of UE-10j-1 groundwater.

The composite travel times for this set of models range from approximately 11,000 to 15,400 years (Figure 8-6). Decomposition of the composite travel times for this set of models (Table 8-4) indicates that travel times from northern Yucca Flat to WW-C in southern Yucca Flat are approximately 16,000 to 24,000 years for groundwater from the two intervals at UE-10j and from 14,300 to 15,600 years for 


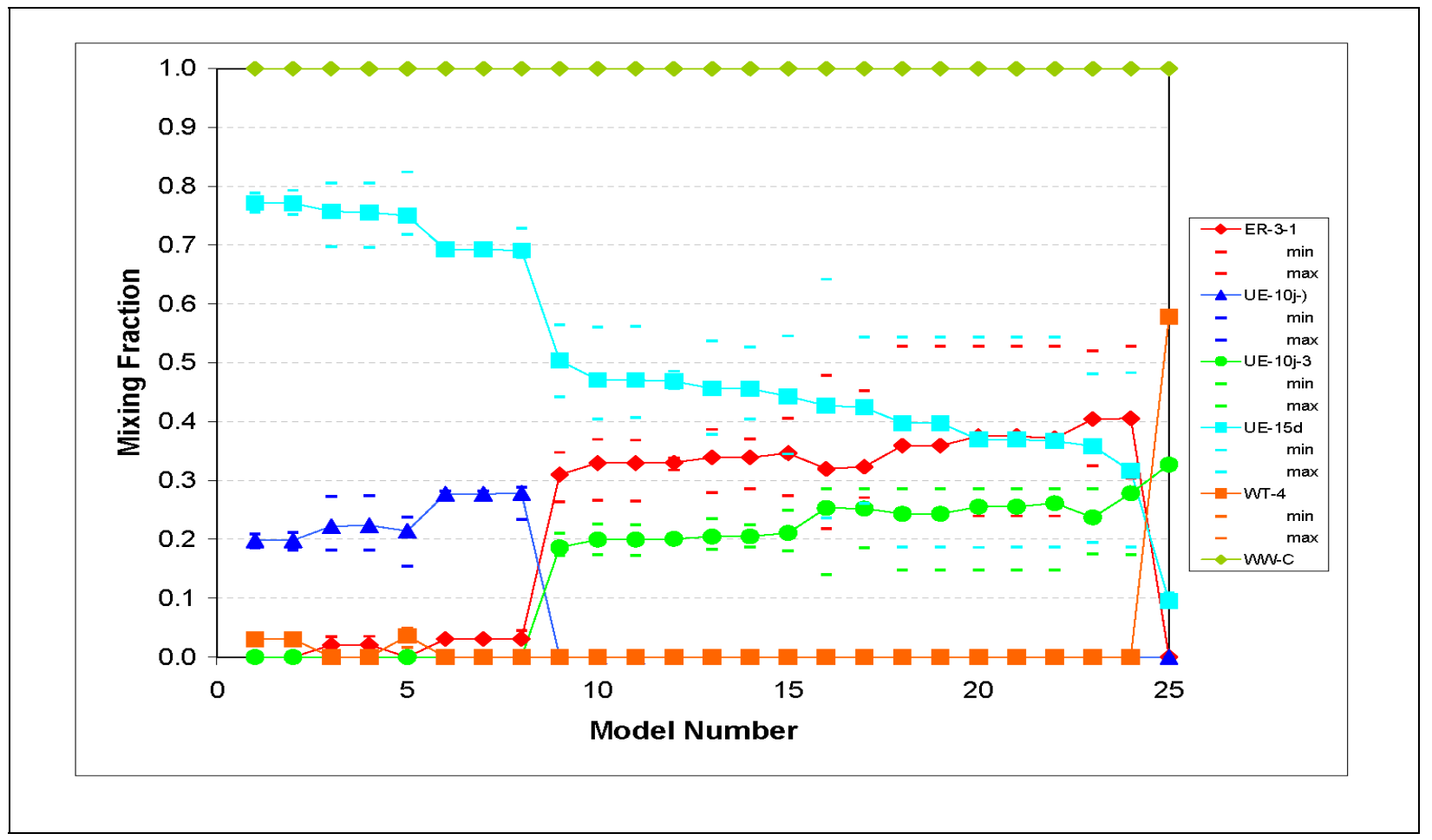

Figure 8-4

Mixing Fractions for WW-C Models with Water from North and East of Yucca Flat

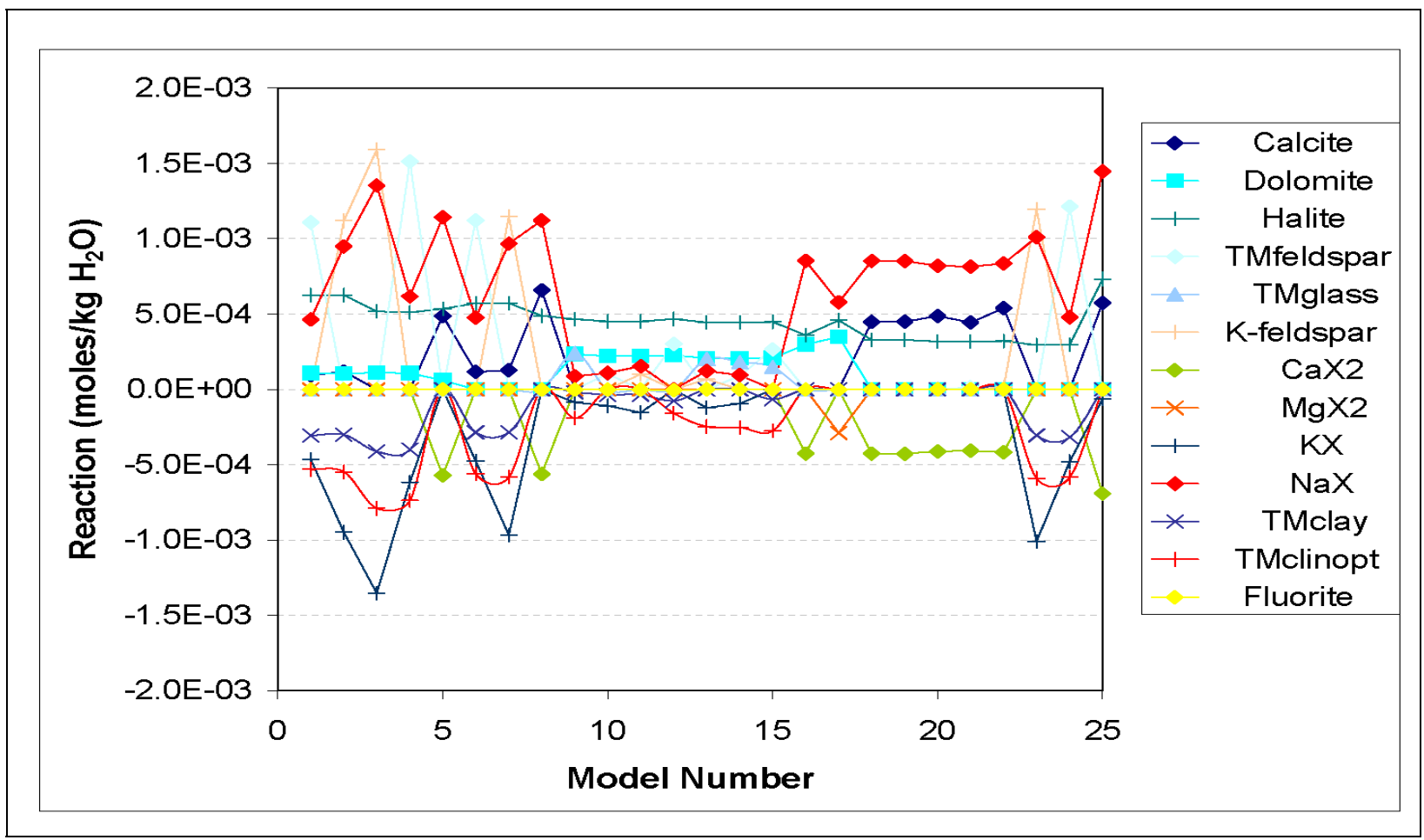

Figure 8-5

Reactions for WW-C Models with Water from North and East of Yucca Flat 
groundwater at UE-15d. For the approximately $30 \mathrm{~km}$ distance between Wells UE-10j and WW-C, this range of travel times implies that average linear velocities in the LCA are approximately 1.3 to 1.9 m/yr. Relatively short travel times were calculated for groundwater from ER-3-1 (2,600 years, with 95 percent confidence limits of -300 to 5,600 years) and from WT-4 (3,000 to 7,900 years).

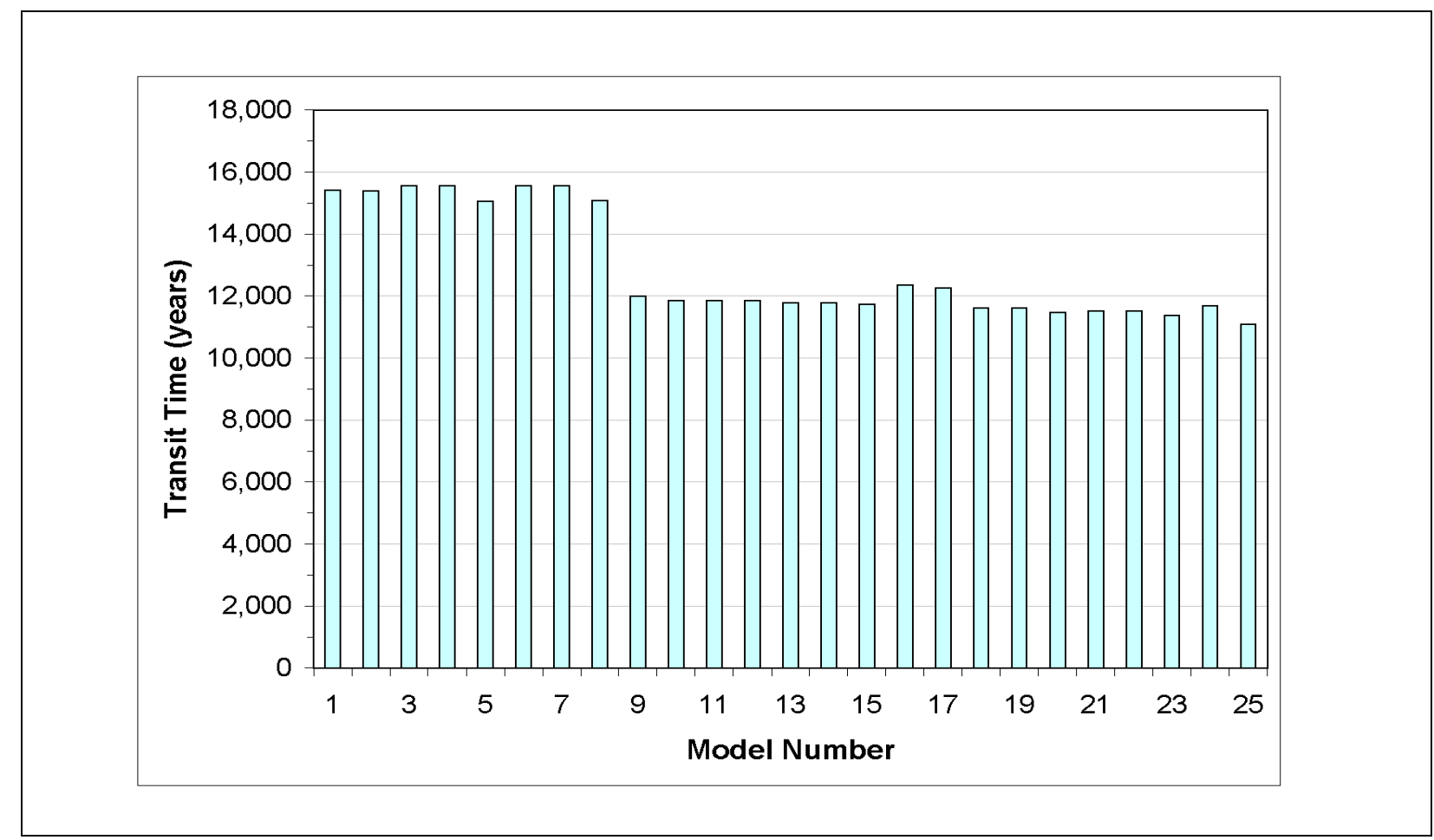

Figure 8-6

Composite Travel Times to WW-C for Models with Groundwater from North and East of Yucca Flat

Table 8-4

Travel Times from Individual Wells to WW-C

\begin{tabular}{||l|c|c|c|c||}
\hline \multicolumn{1}{|c|}{ Site } & $\begin{array}{c}\text { Travel Time } \\
\text { (Years) }\end{array}$ & $\begin{array}{c}\text { Standard } \\
\text { Error }\end{array}$ & Lower 95\% & Upper 95\% \\
\hline \hline ER-3-1 & 2,615 & 1,413 & -334 & 5,563 \\
UE-10j-1 & 18,088 & 946 & 16,115 & 20,062 \\
UE-10j-3 & 19,900 & 1,972 & 15,785 & 24,014 \\
UE-15d & 14,978 & 317 & 14,317 & 15,638 \\
WT-4 & 5,442 & 1,163 & 3,016 & 7,868 \\
\hline
\end{tabular}




\subsection{Alternative Models of Water Well-C Involving Local Yucca Flat Groundwater}

Additional mixing models were developed for WW-C that considered more localized flow paths involving groundwater from wells within Yucca Flat. These included north-south pathways along both the eastern and western sides of the basin, as well as potential contributions from the overlying volcanic units.

\subsubsection{Alternative Conservative Tracer Models for Water Well-C}

An alternative mixing model was created for WW-C using ER-6-1 \#2 as a surrogate for northern Yucca Flat groundwater can be developed, but in this case a mixing component from the western part of Yucca Flat (UE-1h) must also be included:

$\begin{array}{ccccc} & \text { ER-6-1 \#2 } & \text { UE-1h } & \text { ER-3-1 } \\ \delta \mathrm{D} & 21.1 & 30.6 & 48.3 \\ \delta^{18} \mathrm{O} & 27.5 & 39.9 & 32.6 \\ \mathrm{Cl} & 21.1 & 30.6 & 48.3\end{array}$

In this model, the mixing fraction from eastern Yucca Flat at ER-3-1 is reduced because of the addition of high-Cl LCA groundwater from UE-1h (Figure 7-2). It is notable that the northern Yucca Flat mixing fraction represented by ER-6-1 \#2 is similar to the sum of UE-15d and UE-10j-3 in the first set of conservative tracer models.

Alternative models that exclude the northern Yucca Flat mixing component were also evaluated. For example, the possibility that groundwater from the overlying Tertiary volcanic aquifer may leak downward to the LCA was tested by substituting TW-B for ER-6-1 \#2 in the previous model. This model yielded reasonably good results:

$\begin{array}{ccccc} & \text { TW-B } & \text { UE-1h } & \text { ER-3-1 } \\ \delta \mathrm{D} & 27.2 & & 27.5 & 45.3 \\ \delta^{18} \mathrm{O} & 21.0 & & 21.1 & 57.9 \\ \mathrm{Cl} & 27.2 & & 27.5 & 45.3\end{array}$


Another alternative model is produced by substituting LCA groundwater from ER-6-2 in the place of TW-B:

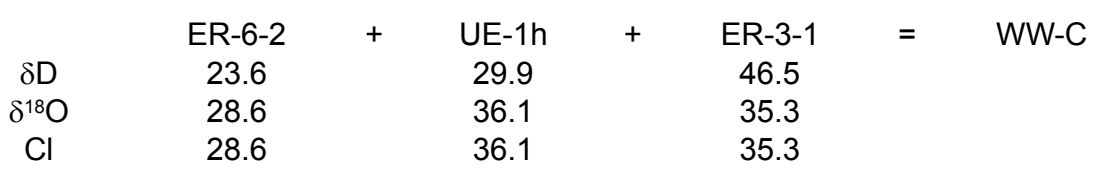

This model differs from the previous WW-C models in that it requires a dominant mixing source from the western side of the basin. Many additional models can be developed for $\mathrm{WW}-\mathrm{C}$ if $\mathrm{Cl}$ is excluded from the conservative tracer mixing models. Chloride may be added along a flow path by water-rock interaction in the absence of mixing. This approach frees the dependence on using the high-Cl groundwater at ER-3-1 or UE-1h in every model. However, the conservative tracer models become so poorly constrained that it is difficult to know which models are realistic. The NETPATH and PHREEQC models incorporating water-rock reactions, described in Sections 8.3.2 and 8.3.3, consider the addition of $\mathrm{Cl}$ for alternate WW-C flow paths.

\subsubsection{Alternative NETPATH Models for Water Well-C}

The NETPATH models were successfully developed for WW-C by mixing ER-3-1 groundwater with either ER-6-1 \#2 or TW-B, but the contribution of UE-1h to these models was minimal (Table 8-5). The mixing fraction of groundwater from ER-6-1 \#2 or TW-B in the NETPATH models was in good agreement with the conservative tracer models, but the contribution of UE-1h in the conservative tracer models was assumed by ER-3-1 in NETPATH models. Valid models required precipitation of calcite, dissolution of dolomite, dissolution of halite, dissolution of gypsum, and $\mathrm{Na}$ exchange for $\mathrm{Ca}$ and $\mathrm{Mg}$ in solution. These models reproduced the $\delta \mathrm{D}, \delta^{18} \mathrm{O}$, and $\mathrm{Cl}$ concentrations at WW-C. However, NETPATH models were slightly outside the 1 permil uncertainty limit for $\delta^{13} \mathrm{C}$, indicating that the modeled water-rock reactions for carbon-containing minerals are not well constrained. Because of the poor agreement with measured $\delta^{13} \mathrm{C}$ values at WW-C, calculated travel times should be interpreted cautiously.

Another model for WW-C, incorporating ER-6-1 \#2, ER-3-1, TW-B, and UE-1q (LCA HSU central Yucca Flat) was considered. The results of this model (Table 8-5) are similar to the other models described in Section 8.3.1 where ER-3-1 and TW-B are the main components of the mixture at 
Table 8-5

Results of Alternative NETPATH Models for Water Well-C

\begin{tabular}{|c|c|c|c|c|c|c|c|c|}
\hline \multirow{2}{*}{\multicolumn{4}{|c|}{ End-Member Percentage }} & \multicolumn{4}{|c|}{ Modeled (Measured) Composition of WW-C } & \multirow{2}{*}{$\begin{array}{c}\text { Travel Time } \\
\text { (years) }\end{array}$} \\
\hline & & & & $(-107)^{a}$ & $(-14.0)^{a}$ & $(35.9)^{a}$ & $(-4.0)^{a}$ & \\
\hline ER-6-1 \#2 & UE-1h & ER-3-1 & & $\delta \mathrm{D}$ (permil) & $\delta^{18} \mathrm{O}$ (permil) & $\mathrm{Cl}(\mathrm{mg} / \mathrm{L})$ & $\delta^{13} \mathbf{C}$ (permil) & \\
\hline 32 & 1 & 67 & & -108 & -14.0 & 32.1 & -2.8 & 3,800 to 4,000 \\
\hline TW-B & UE-1h & ER-3-1 & & & & & & \\
\hline 26 & $2-3$ & $71-72$ & & -109 to -108 & -14.1 to -13.9 & 35.9 to 36.3 & -2.9 & 10,500 \\
\hline ER-6-1 \#2 & UE-1q & ER-3-1 & TW-B & & & & & \\
\hline 0 & 0 & 72 & 28 & -109 & -14.4 & 31.2 & -2.8 & 10,200 \\
\hline ER-6-2 & UE-1h & ER-3-1 & & & & & & \\
\hline 27 & 12 & 60 & & -107 & -13.8 & 35.5 & -3.0 & 7,300 \\
\hline ER-2-1 & ER-6-2 & UE-10j-1 & & & & & & \\
\hline $42-44$ & 0 & $56-58$ & & -106 & -13.9 & 15.7 to 16.1 & -3.8 & $\begin{array}{c}20,700 \text { to } \\
20,900\end{array}$ \\
\hline
\end{tabular}

WW-C. As with the earlier models, $\delta^{13} \mathrm{C}$ values are slightly over the 1 permil uncertainty limit. A travel time of 10,200 years was calculated by NETPATH for this model.

The NETPATH models were also used to test the possibility of groundwater flow paths from the western part of Yucca Flat to southeastern Yucca Flat to WW-C. Two scenarios were considered: (1) carbonate water from ER-6-2 on the western margin of the basin mixed with LCA water at UE-1h, and (2) carbonate ER-6-2 mixed with volcanic water from ER-2-1. The first scenario tested the conservative tracer model involving a mixture of LCA groundwaters from ER-6-2, UE-1h, and ER-3-1. The NETPATH results are in relatively good agreement with conservative tracers except that NETPATH had a larger contribution from ER-3-1 and less from UE-1h (Table 8-5). One valid model included precipitation of calcite, dissolution of dolomite, dissolution of gypsum, $\mathrm{Na}$ exchange for $\mathrm{Ca}$ and $\mathrm{Mg}$ in solution, and a very small amount of composite glass precipitation which is against the thermodynamic saturation index value indicating glass dissolution only. The NETPATH calculated travel time for this model was 7,300 years.

The other mixing scenario tested with NETPATH substituted volcanic groundwater at ER-2-1 in western Yucca Flat for UE-1h and LCA groundwater at UE-10j-1 in northern Yucca Flat for ER-3-1. In this mixture, the LCA groundwater component from western Yucca Flat (ER-6-2) is insignificant but volcanic groundwater (ER-2-1) contributes more than 40 percent to the chemical signature at 
WW-C, and northern Yucca Flat LCA groundwater from UE-10j-1 comprises the remaining 60 percent of the mix (Table 8-5). Valid models included dissolution of dolomite, dissolution of halite, dissolution of gypsum, $\mathrm{Na}$ exchange for $\mathrm{Ca}$ and $\mathrm{Mg}$ in solution, and combinations of dissolution of feldspars, glass, and quartz and/or precipitation of clays, zeolites, and quartz. These models reproduced the $\delta \mathrm{D}, \delta^{18} \mathrm{O}$, and $\delta^{13} \mathrm{C}$ values at WW-C but substantially underestimated the amount of $\mathrm{Cl}$ (Table 8-5). The NETPATH calculated travel times for this mixture were over 20,000 years.

\subsubsection{PHREEQC Models for Leakage from Overlying Volcanic Unit to Water Well-C}

The PHREEQC was used to test the previously described models for WW-C. Well TW-B was included as a potential end-member to determine whether vertical leakage from the volcanic aquifer to the LCA is possible. The PHREEQC model results show that groundwater from ER-3-1 can combine with either the volcanic aquifer groundwater at TW-B or with relatively dilute LCA groundwater from ER-6-1 \#2 to form the groundwater at WW-C (Figures 8-7 and 8-8). However, five of the models require significant (greater than $1 \mathrm{mmol} / \mathrm{L}$ ) dissolution and/or precipitation of one or more mineral phases for the mixing models to balance. These five models all include ER-6-1 \#2 as a mixing component. If these five models are excluded, ER-6-1 \#2 is an insignificant contributor to the groundwater at WW-C with the makeup then composed only of ER-3-1 and TW-B. The composite travel times for this set of wells have a wide range of values, depending on the end-members involved in the mixture (Figure 8-9). Travel times calculated from models involving groundwater from ER-6-1\#2 range from approximately 4,600 to 5,600 years, whereas travel times associated with models involving groundwater from TW-B range from 13,700 to 15,000 years.

Decomposition of the composite travel times using multiple regression (Table 8-6) indicates the possibility of a relatively rapid travel time from ER-3-1 to WW-C (1,000 years, with 95 percent confidence limits of $-3,700$ to 5,800 years), somewhat longer travel times from ER-6-1 \#2 (4,600 to 10,400 years), and very long travel times for groundwater in the volcanic aquifer at TW-B (24,000 to 35,000 years). The relatively rapid travel time from ER-3-1, compared to ER-6-1 \#2, results from the similar ${ }^{14} \mathrm{C}$ values between ER-3-1 (0.7 pmc) and WW-C (0.6 pmc) as compared to ER-6-1 \#2 (2.4 pmc). This may reflect the fact that ER-6-1 \#2 is in a relatively stagnant part of the flow system due to limited inflow through that part of the Halfpint Range that is underlain by the LCCU. 


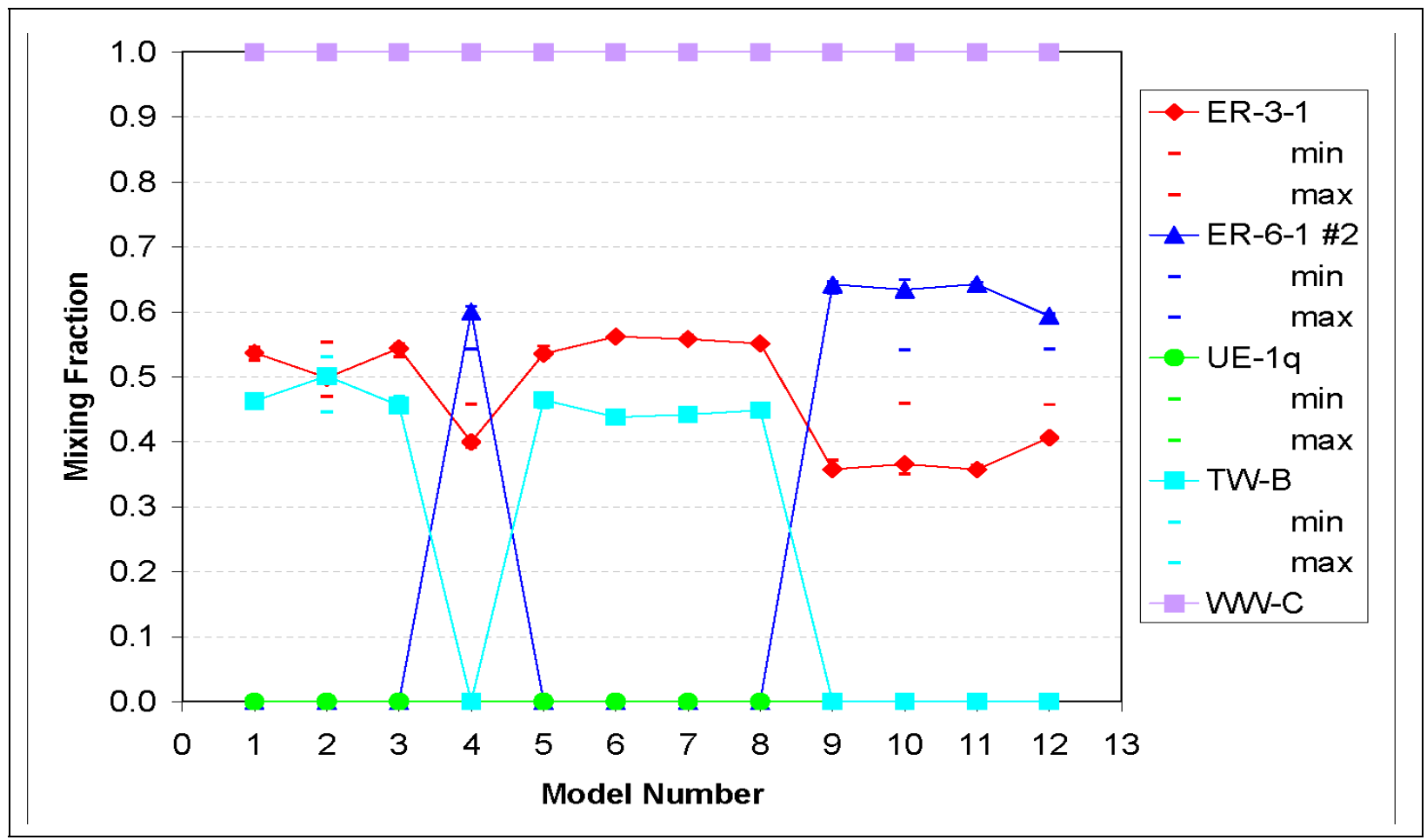

Figure 8-7

Mixing Fractions for WW-C Models with Groundwater from Eastern Yucca Flat

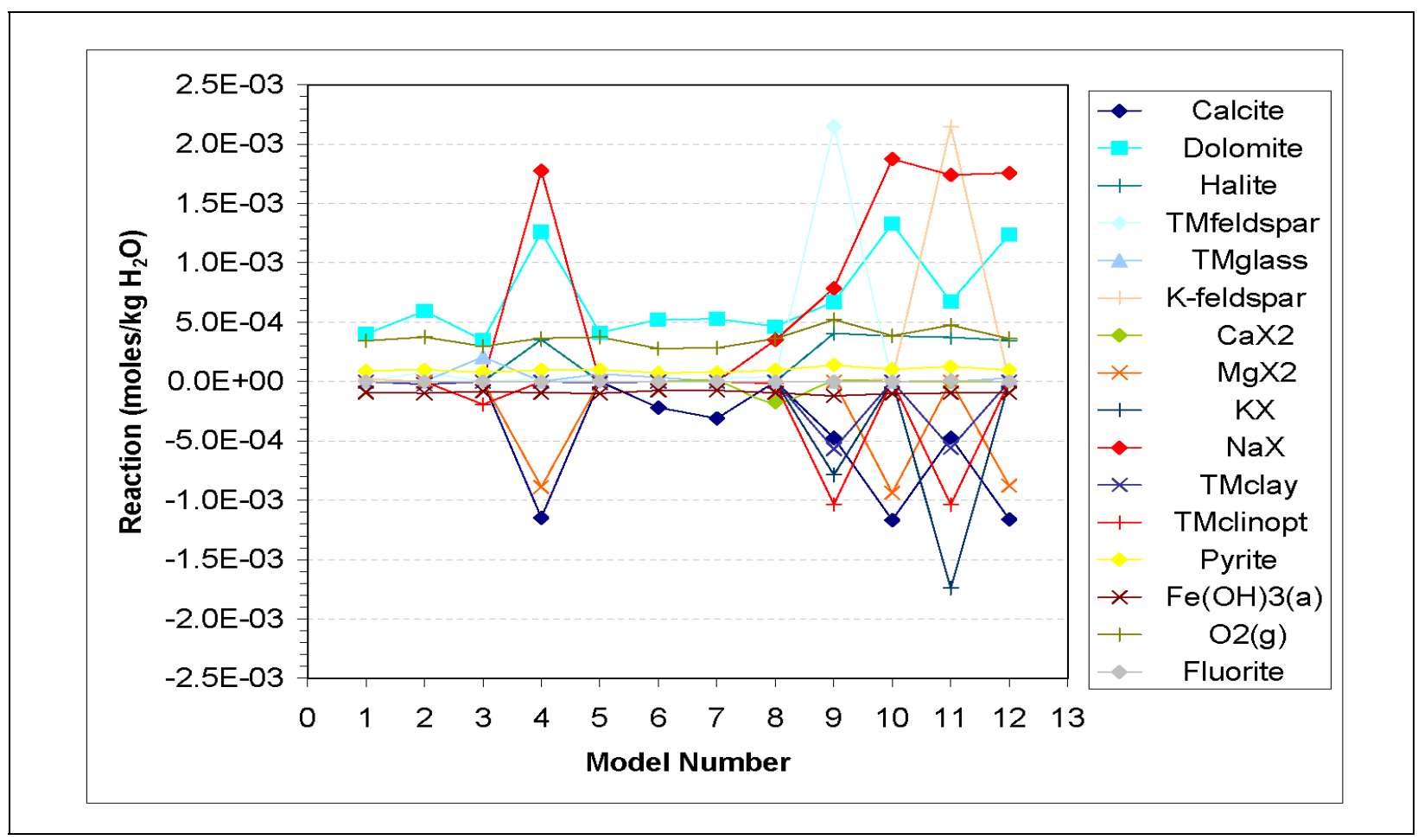

Figure 8-8

Reactions for WW-C Models with Groundwater from Eastern Yucca Flat 


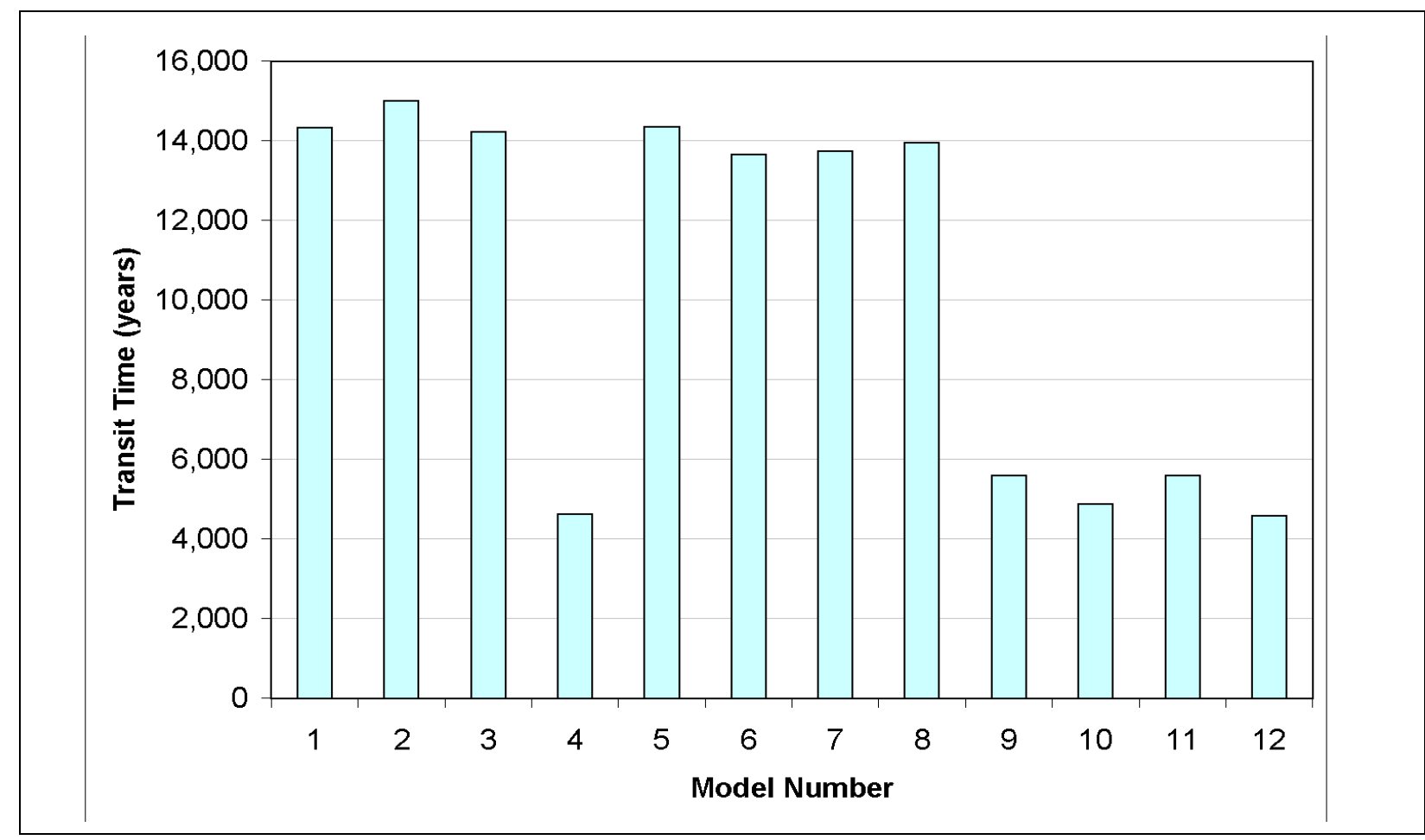

Figure 8-9

Composite Travel Times to WW-C for Models with Water from Eastern Yucca Flat

Table 8-6

Travel Times from Individual Wells to WW-C for Models with Eastern Yucca Flat Waters

\begin{tabular}{|c|c|c|c|c|}
\hline Site & $\begin{array}{c}\text { Travel Time } \\
\text { (Years) }\end{array}$ & $\begin{array}{c}\text { Standard } \\
\text { Error }\end{array}$ & Lower 95\% & Upper 95\% \\
\hline \hline ER-3-1 & 1,029 & 2,099 & $-3,720$ & 5,778 \\
\hline ER-6-1\#2 & 7,504 & 1,285 & 4,597 & 10,411 \\
\hline TW-B & 29,672 & 2,477 & 24,068 & 35,276 \\
\hline
\end{tabular}

The final set of PHREEQC inverse models for WW-C considered possible sources of groundwater from western Yucca Flat. The groundwater in the LCA in western Yucca Flat is inferred to have a large component derived from local recharge, including possible sources on Rainier Mesa and upper Fortymile Wash. However, the inverse models for WW-C presented here only include ER-6-2 immediately to the northwest of WW-C, along with LCA groundwater from UE-10j-1 and groundwater from the volcanic confining unit at Well ER-2-1. The results from this set of models indicate that groundwater from UE-10j-1 can combine with either groundwater from the northwest at ER-6-2 or with vertical leakage from the volcanic confining unit at ER-2-1 to form the groundwater 
at WW-C (Figures 8-10 and 8-11). Note, however, that several of the models require significant (greater than $1 \mathrm{mmol} / \mathrm{L}$ ) dissolution and/or precipitation of one or more mineral phases for the mixing models to balance.

Composite travel times and travel times from individual wells to WW-C for this set of models are given in Figure 8-12 and Table 8-7, respectively. The regression analysis indicates that the travel time from nearby ER-6-2 to WW-C is relatively short (3,100 to 5,800 years), whereas travel time from UE-10j-1 to WW-C for this set of models is quite long (18,900 to 22,900 years), as estimated for the inverse models results described earlier. The estimated travel times of 26,900 to 33,500 years for groundwater in the volcanic confining unit at ER-2-1 to WW-C are similar to those found for TW-B to WW-C in an earlier set of models and result from the very low amount of ${ }^{14} \mathrm{C}$ in $\mathrm{WW}-\mathrm{C}(0.6 \mathrm{pmc})$. These long groundwater travel times from ER-2-1 to WW-C may reflect the slow rates of vertical leakage from the volcanic units to the LCA, as well as slow rates of horizontal transport within the LCA.

\subsection{Geochemical Modeling of Well ER-5-3\#2}

Well ER-5-3 \#2 in northeastern Frenchman Flat exhibits many of the same geochemical characteristics as ER-3-1, WW-C, and WW-C1, and may lie along the same LCA flow path as these wells. Hershey et al. (2005) recently evaluated potential mixing models for ER-5-3 \#2 using conservative tracer data. The model that was most consistent with the tracer data involved mixing of 85 percent ER-3-1 groundwater with 15 percent UE-5 PW-3 groundwater. The latter well is completed in the volcanic aquifer beneath northern Frenchman Flat. An alternative model was also presented that showed ER-5-3 \#2 groundwater may be mixture of 77 percent ER-3-1 and 23 percent USGS HTH-3. This result is significant in that it suggests ER-5-3 \#2 groundwater may be derived from two different LCA groundwaters. However, this particular model is invalid for $\delta^{18} \mathrm{O}$ because both end-member compositions are isotopically lighter than ER-5-3 \#2.

\subsubsection{PHREEQC Models for Well ER-5-3 \#2}

To investigate the possibility that southerly flow may occur between eastern Yucca Flat and northern Frenchman Flat, geochemical inverse models were created that consider groundwater from ER-6-1 \#2, WW-C, ER-3-1, and HTH-3 as potential upgradient sources of groundwater for Well ER-5-3 \#2 


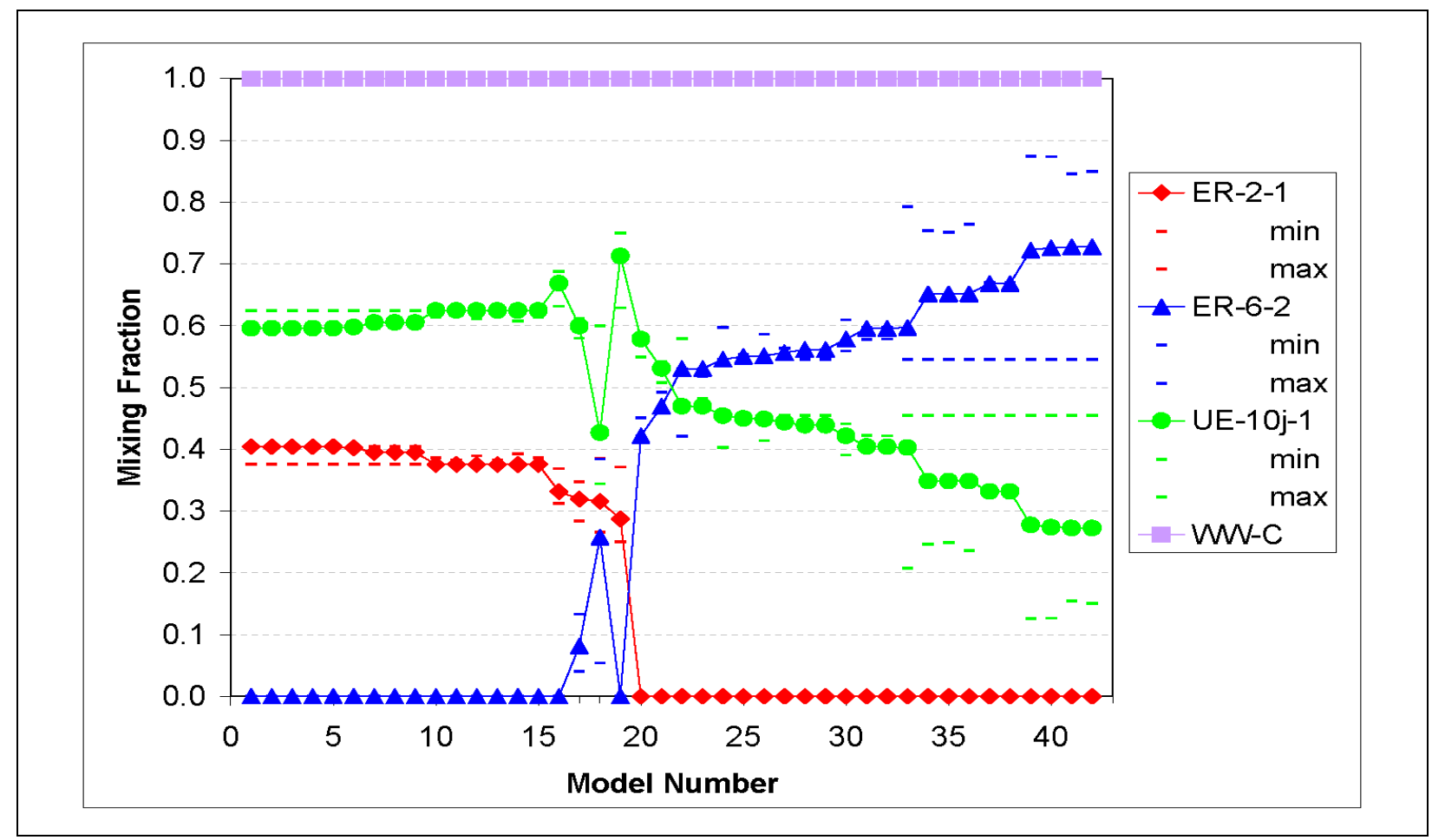

Figure 8-10

Mixing Fractions for WW-C Models with Groundwater from Western Yucca Flat

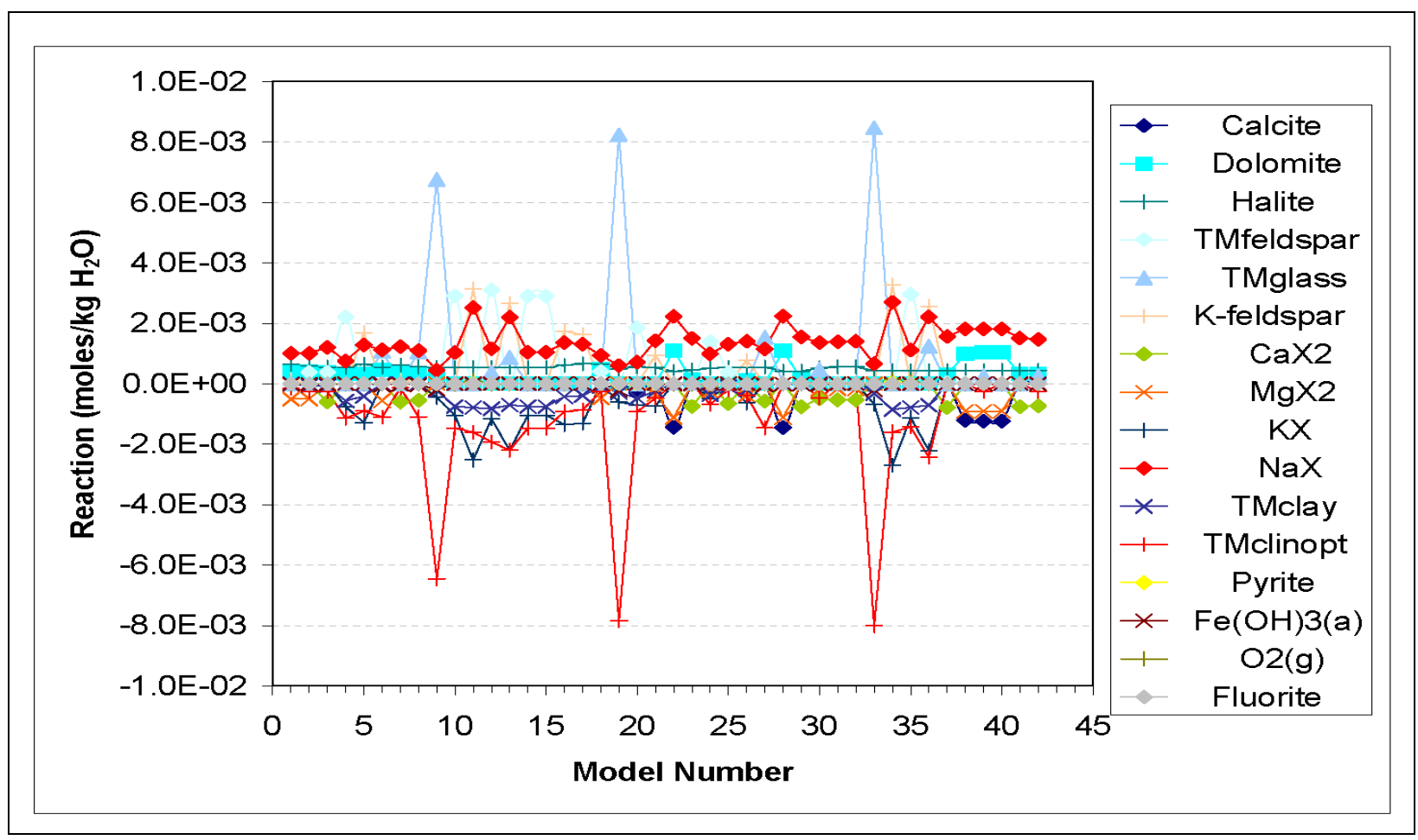

Figure 8-11

Reactions for WW-C Models with Groundwater from Western Yucca Flat 


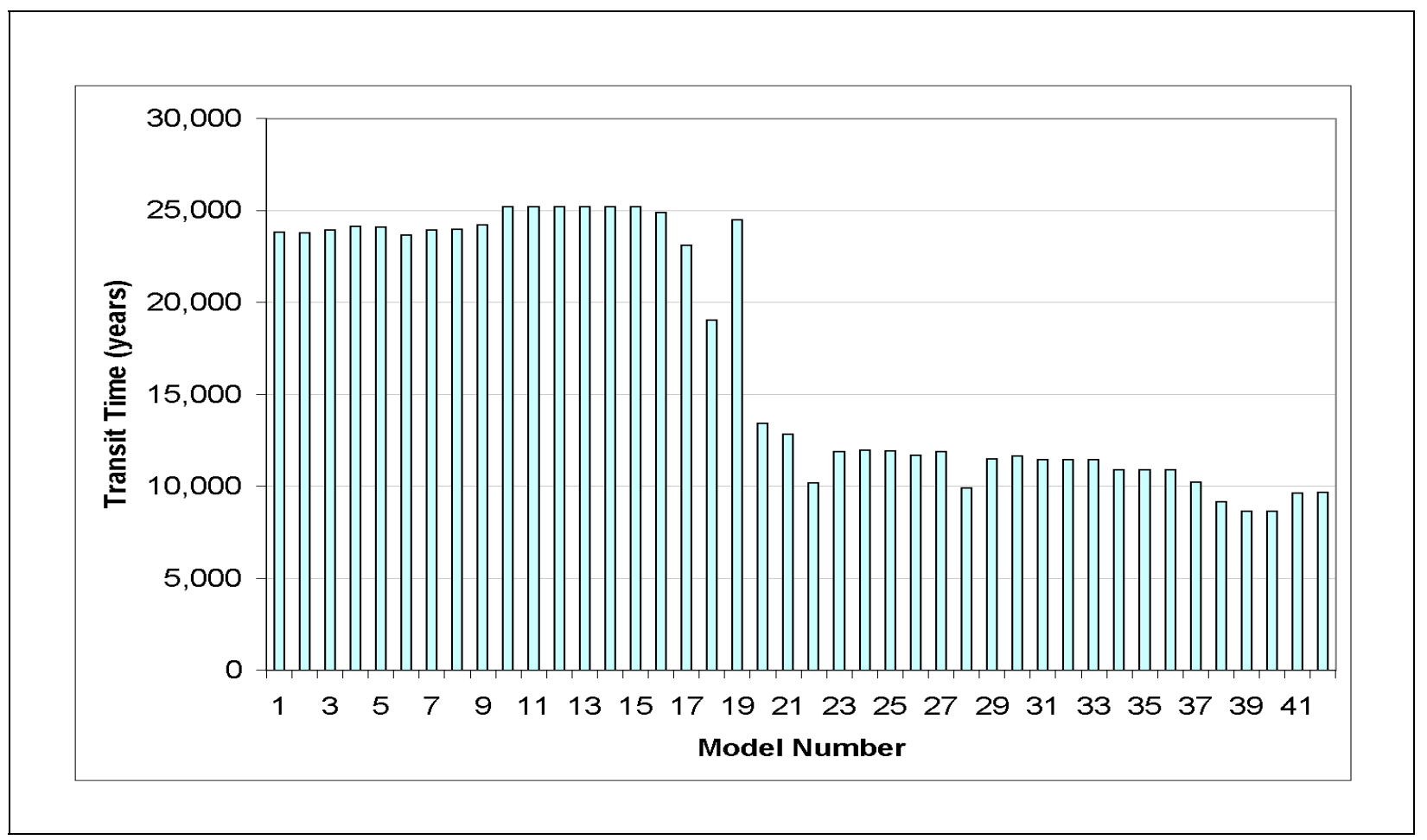

Figure 8-12

Composite Travel Times to WW-C for Models with Groundwater from Western Yucca Flat

Table 8-7

Travel Times from Individual Wells to WW-C for Models with Groundwater from Western Yucca Flat

\begin{tabular}{|c|c|c|c|c||}
\hline Site & $\begin{array}{c}\text { Travel Time } \\
\text { (Years) }\end{array}$ & $\begin{array}{c}\text { Standard } \\
\text { Error }\end{array}$ & Lower 95\% & Upper 95\% \\
\hline \hline ER-2-1 & 30,217 & 1,643 & 26,894 & 33,539 \\
\hline ER-6-2 & 4,433 & 674 & 3,070 & 5,796 \\
\hline UE-10j-1 & 20,895 & 995 & 18,882 & 22,908 \\
\hline
\end{tabular}

in northern Frenchman Flat. The inclusion of WW-C as a potential upgradient source of groundwater at Well ER-5-3 \#2 was motivated by $\delta \mathrm{D}, \delta^{18} \mathrm{O}$, and $\mathrm{Cl}$ data which indicate that groundwater at ER-5-3 \#2 is potentially a mixture of groundwater from WW-C and ER-3-1 (Figures 8-13 and 8-14 ). The results of these models indicate that groundwaters from nearby upgradient wells can combine in several different ways to create the groundwater at Well ER-5-3 \#2 (Figure 8-13). The first two models indicate that a minor amount (less than 10 percent) of the groundwater at Well ER-5-3 \#2 


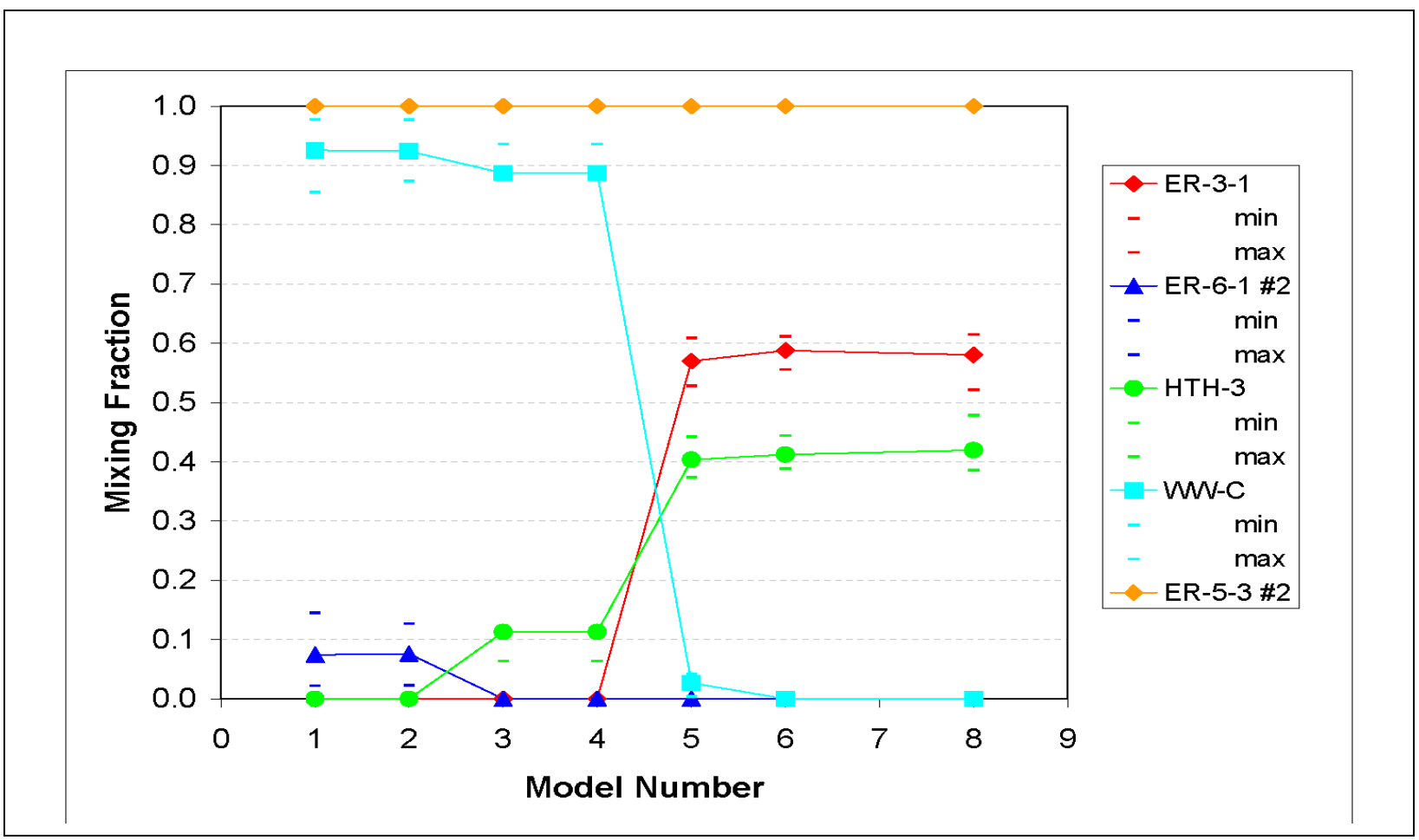

Figure 8-13

Mixing Fractions for ER-5-3 \#2 Models

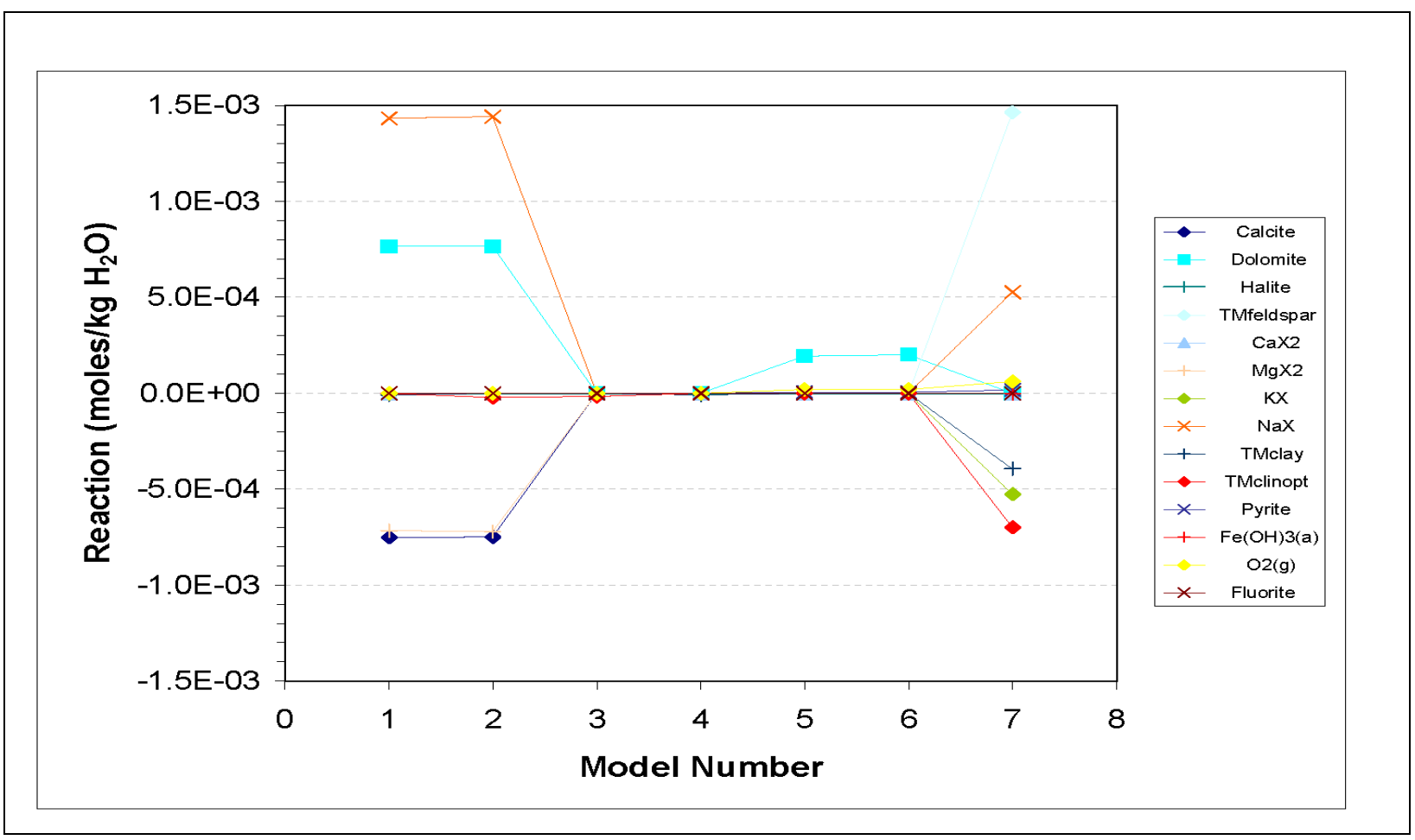

Figure 8-14

Reactions for ER-5-3 \#2 Models 
could be from ER-6-1 \#2, if most of the remaining groundwater were to originate from the vicinity of WW-C. Several of these inverse models require almost no water-rock interaction to explain the groundwater compositions at ER-5-3 \#2 (Figure 8-14).

The composite travel times for this set of inverse models are shown in Figure 8-15. The composite travel times for the first two models are negative, indicating that the models involving groundwater from only WW-C and ER-6-1 \#2 are infeasible, even though they are geochemically permissible in other respects. The inverse models involving groundwater from WW-C and HTH-3 result in positive travel times because the groundwater ${ }^{14} \mathrm{C}$ activity of $37 \mathrm{pmc}$ at $\mathrm{HTH}-3$ is sufficiently high (Appendix A) that the ${ }^{14} \mathrm{C}$ activity of the mixture is greater than that the ER-5-3 \#2 groundwater even when HTH-3 groundwater is present in only minor amounts. However, because these models involve groundwater from the north (WW-C) and east (HTH-3) but not the northeast (ER-3-1), these models may be physically less realistic than the last three models that involve groundwaters along two contiguous flow paths. The last three models involving groundwater from Wells ER-3-1 and HTH-3 (originally proposed by Hershey et al., 2005) are also appealing from the point of view that if water compositions are assumed to change smoothly between Wells ER-3-1 and HTH-3, groundwater at Well ER-5-3 \#2 could be derived by the simple flow of groundwater from the northeast without invoking the need for strongly convergent flow at ER-5-3 \#2. The models involving only ER-3-1 and HTH-3 as mixing components are also compatible with the Sr analysis described in the next section.

\subsubsection{Strontium and ${ }^{87} \mathrm{Sr} /{ }^{86} \mathrm{Sr}$ Modeling Results}

The Sr characteristics of LCA groundwater samples from the southeastern part of the study area are distinct from groundwater within the rest of the Yucca Flat basin (Section 3.2.5). As with $\delta \mathrm{D}$ and $\mathrm{Cl}$ data, groundwater from ER-3-1 has the highest $\mathrm{Sr}$ concentrations and ${ }^{87} \mathrm{Sr} /{ }^{86} \mathrm{Sr}$ values and is a reasonable choice for an upgradient mixing end-member (Figure 8-16). Values for ${ }^{87} \mathrm{Sr} /{ }^{86} \mathrm{Sr}$ decline in downgradient samples further to the south at WW-C and WW-C1 and in the LCA in Frenchman Flat at ER-5-3\#2 and HTH-3 implying mixing with non-radiogenic sources. Simple mixing with groundwater from Yucca Flat can account for lower ${ }^{87} \mathrm{Sr} /{ }^{86} \mathrm{Sr}$ values in downgradient samples but cannot explain the measured Sr concentrations, which remain elevated relative to the concentrations expected from mixing. Instead, southeastern Yucca Flat LCA samples fall outside of any mixing triangles calculated for ER-3-1 and other Yucca Flat end-members. Alternatively, lower ${ }^{87} \mathrm{Sr} /{ }^{86} \mathrm{Sr}$ 


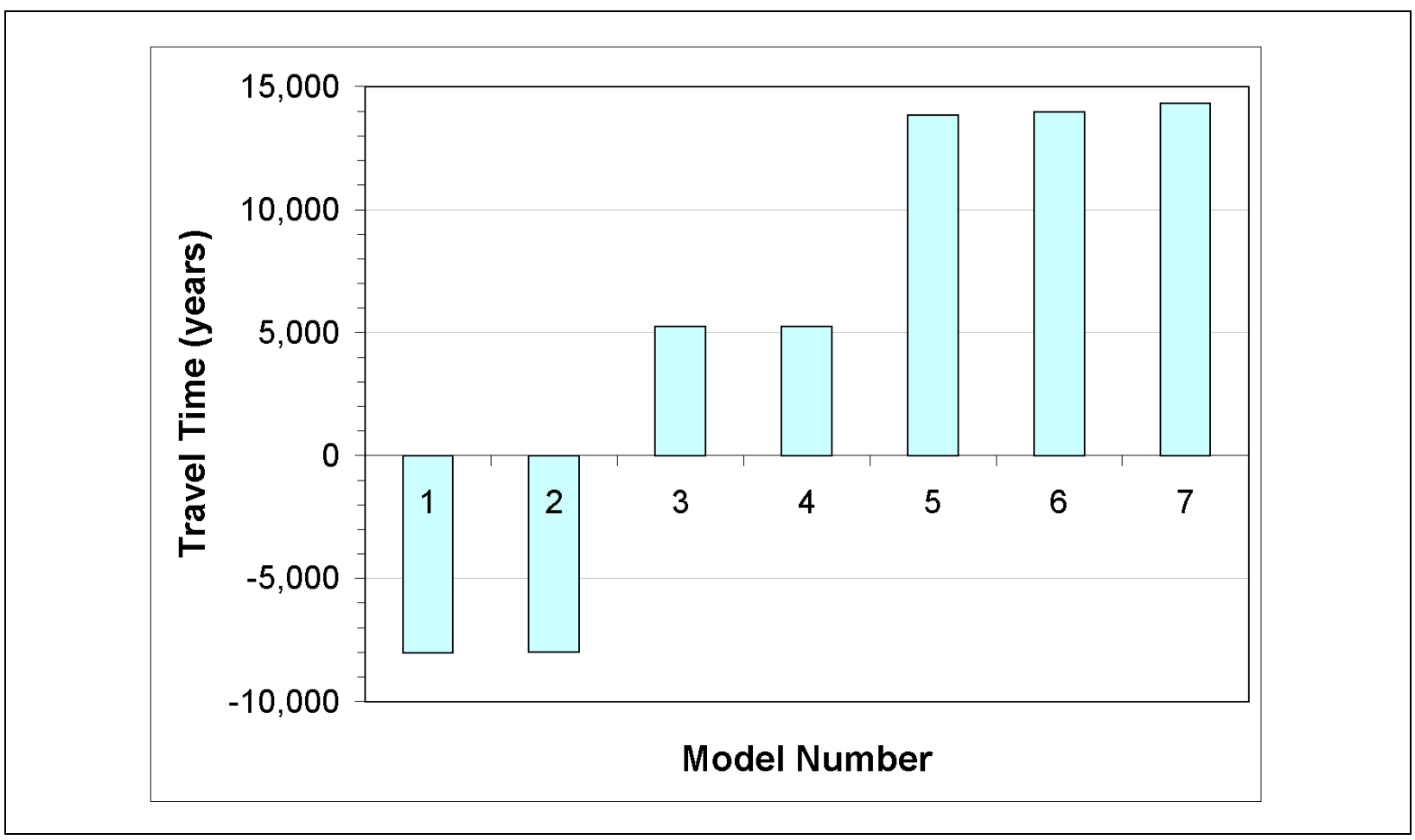

\section{Figure 8-15}

\section{Composite Travel Times to ER-5-3 \#2}

values might be explained by reaction with LCA rock containing low, marine-like ${ }^{87} \mathrm{Sr} /{ }^{86} \mathrm{Sr}$ values. However, the high Sr concentration in ER-3-1 groundwater requires that substantial amounts of non-radiogenic $\mathrm{Sr}$ be added to significantly decrease the ${ }^{87} \mathrm{Sr} /{ }^{86} \mathrm{Sr}$ value. As a result, $\mathrm{Sr}$ concentrations in downgradient samples should show increases rather than slight decreases as observed.

Strontium data are interpreted to represent mixing of groundwater along flow paths east of the Halfpint Range with little or no communication with LCA flow systems in Yucca Flat. Few samples of high-Sr groundwater are available for use as the non-radiogenic end-member. Results of simple mixing between ER-3-1 and HTH-3 are shown in Figure 8-16. Groundwater from ER-5-3\#2 represents a binary mixture of about 42 percent from ER-3-1 and 58 percent from HTH-3.

Groundwater from WW-C and WW-C1 has slightly lower Sr concentrations and can be derived from a mixture of about 30 percent ER-3-1, 45 to 55 percent HTH-3, and 15 to 25 percent volcanic aquifer water from nearby WW-4a. Although these mixing models can explain the Sr data, they do not produce satisfactory results based on ${ }^{87} \mathrm{Sr} /{ }^{86} \mathrm{Sr}$ versus $\delta \mathrm{D}$ or $\mathrm{Cl}$ concentrations (Figure 8-16). Lack of agreement indicates that appropriate end-members are not available or that additional geochemical 

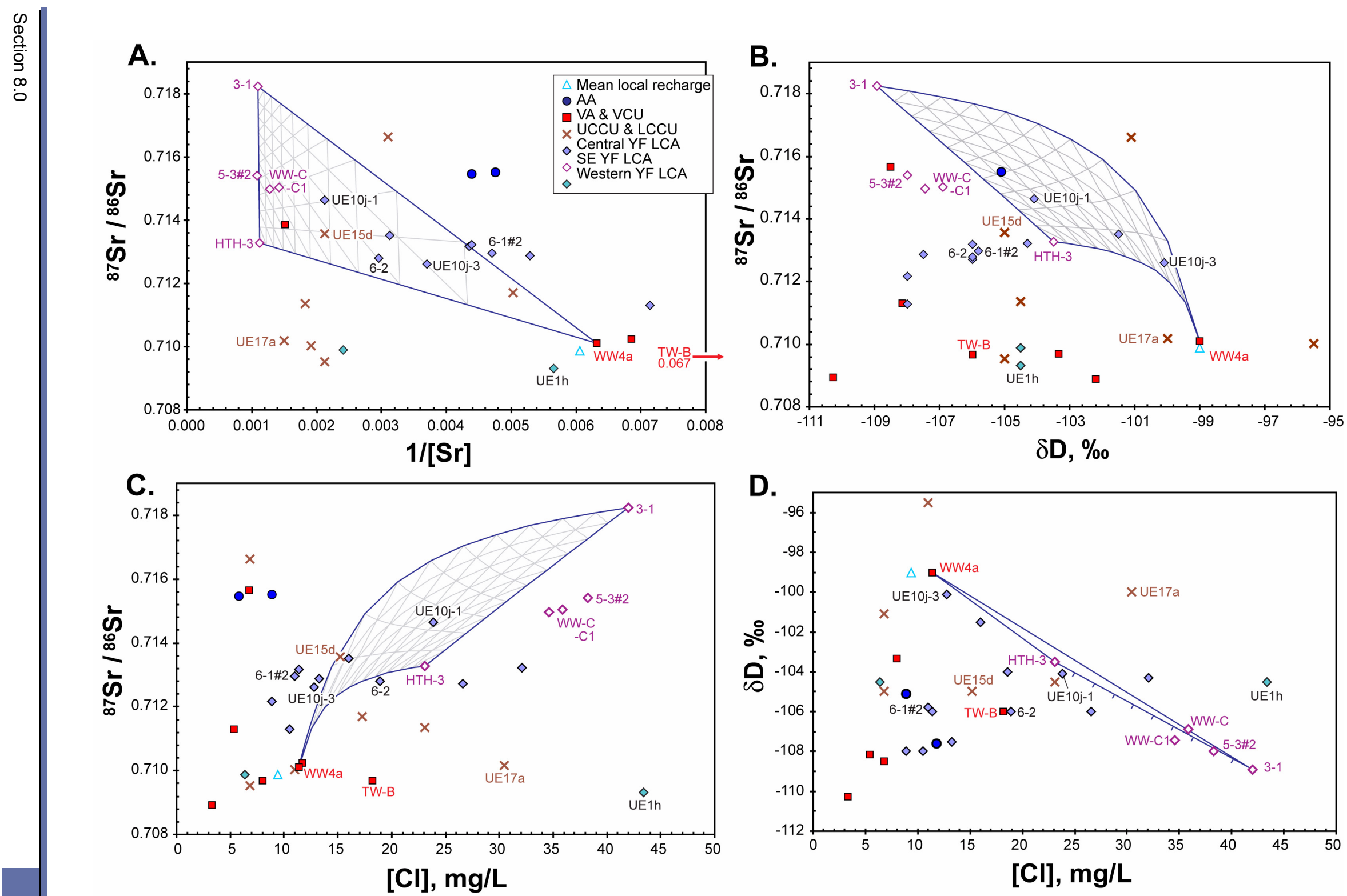

Figure 8-16

Relations Between ${ }^{87} \mathrm{Sr} /{ }^{86} \mathrm{Sr}$, Sr Concentration, $\delta D$, and $\mathrm{Cl}$ Concentration for Yucca Flat Groundwaters Emphasizing Samples from the Southeastern NTS

Note: Plots show three-component mixing results between LCA water from ER-3-1 and HTH-3, and volcanic aquifer water from WW-4a. 
processes are involved. Despite the discrepancy between $\mathrm{Sr}$ and the other conservative tracers, the five southeastern Yucca Flat LCA samples show a high degree of colinearity between $\delta \mathrm{D}$ and $\mathrm{Cl}$ (Figure 8-16). These relations are interpreted as additional evidence that groundwater flow east of the Halfpint Range including eastern Frenchman Flat is separate from groundwater flow within the Yucca Flat basin, except in the southernmost part of the Yucca Flat basin at WW-C.

\subsection{Summary}

Potential flow paths in southeastern Yucca Flat were tested geochemically with a series of analytical and numerical geochemical models and with graphical techniques. Analytical mixing models constructed for southeastern Yucca Flat groundwater indicate that many different mixing models involving groundwater contributions from all parts of the basin and beyond are permissible.

Well ER-3-1 penetrates the LCA east of Yucca Flat in the Halfpint Range and is upgradient of other wells in the southeastern Yucca Flat and northern Frenchman Flat area. By virtue of its upgradient location and because its chemical and isotopic composition are suitable for explaining apparent mixing trends, groundwater from ER-3-1 is used as mixing end-member for other LCA groundwaters in and near southeastern Yucca Flat. The stable isotope compositions of upgradient waters outside of southeastern Yucca Flat are similar to groundwater at ER-3-1, but their solute concentrations are considerably more dilute so conservative tracer mixing models involving $\mathrm{Cl}$ could not be developed for this well. The NETPATH and PHREEQC models incorporating water-rock reactions were developed to delineate potential upgradient sources for ER-3-1 groundwater. Successful NETPATH models included LCA groundwater from Pahranagat Valley (23-24 percent), LCA groundwater from northern Yucca Flat (55-58 percent), and groundwater from Emigrant Valley (18-22 percent). The NETPATH travel times for these models ranged from 16,500 to 16,800. The PHREEQC models produced similar contributions from Pahranagat Valley ( 0 to 21 percent) but predicted less flow from northern Yucca Flat (13 to 25) and more flow from Emigrant Valley (53 to 87) at ER-3-1. Composite groundwater travel times calculated from PHREEQC models (5,800 to 8,400 years for models with Ash Spring components and 3,800 to 4,300 years for models without an Ash Spring component) were shorter than travel times calculated by NETPATH because of the much larger contribution of Emigrant Valley groundwater (WT-4) in the PHREEQC models. Groundwater at WT-4 has a low ${ }^{14} \mathrm{C}$ 
activity $(0.99 \mathrm{pmc})$ that is similar to the ${ }^{14} \mathrm{C}$ activity at ER-3-1 $(0.7 \mathrm{pmc})$, so relatively little radioactive decay of ${ }^{14} \mathrm{C}$ can take place in ER-3-1 models with a dominant WT-4 component.

Models considering groundwater flow from northern Yucca Flat to southwestern Yucca Flat (WW-C) varied widely in the predicted mixing fractions of the contributing groundwaters. Groundwater from the LCCU in northern Yucca Flat (UE-15d) accounted for between 0 and 78 percent of the observed composition at WW-C, depending on the other mixing components. The mixing fraction of northern Yucca Flat LCA groundwater like that of UE-10j-1 ( 0 to 58 percent) or UE-10j-3 ( 0 to 42 percent) also varied widely. Models for WW-C showed similarly wide ranges in mixing contributions from eastern Yucca Flat (ER-3-1; 0 to 78 percent) and Emigrant Valley (WT-4; 0 to 58 percent). Although the possible mixing relationships are numerous, NETPATH and PHREEQC models predicted consistent composite travels times for groundwater flowing from northern Yucca Flat to southeastern Yucca Flat, ranging from 11,700 to 19,500 years.

Models for WW-C that considered groundwater flow from northern Yucca Flat together with a mixing component from the overlying volcanic aquifer showed somewhat more consistent results between the various models. The contribution of TW-B volcanic groundwater to LCA groundwater at WW-C ranged from 21 to 50 percent. Composite groundwater travel times for these models ranged from 10,500 to 15,000 years. The long travel times resulted from the relatively high amount of ${ }^{14} \mathrm{C}$ in TW-B (20 pmc) as compared to WW-C (0.6 pmc). Models incorporating ER-6-1 \#2 as a surrogate for groundwater flow from northern Yucca Flat also produced reasonable models for WW-C with much faster travel times (3,800 to 5,600 years) due to a significant contribution of ER-3-1 groundwater, which has a low ${ }^{14} \mathrm{C}(0.7 \mathrm{pmc})$ value similar to that of WW-C $(0.6 \mathrm{pmc})$.

Groundwater flow from western Yucca Flat to WW-C was also considered. Lower carbonate aquifer groundwater from western Yucca Flat (ER-6-2) contributed either a small proportion (0 to 2 percent) or a significant proportion (53 to 71 percent) to WW-C depending on the other mixing components in the model. A composite groundwater travel time for WW-C using ER-6-2 and ER-3-1 was 7,300 years. Composite travel times using ER-6-2 and UE-10j-1 ranged from 9,000 to 14,000 years. Another set of models considered mixing volcanic groundwater from western Yucca Flat (ER-2-1) with northern Yucca Flat LCA groundwater. These models produced travel times ranging from 
20,700 to 25,000 years again because of the higher ${ }^{14} \mathrm{C}$ in the volcanic aquifer (ER-2-1, 18 pmc) relative to the very low ${ }^{14} \mathrm{C}$ in the $\mathrm{LCA}$ at $\mathrm{WW}-\mathrm{C}$.

The Sr characteristics of LCA groundwater in the southeastern part of the flow system are distinct from other groundwaters within Yucca Flat. Interpretations of Sr data based on mixing models suggest groundwater flow paths east of the Halfpint Range have little communication with the LCA within Yucca Flat, except perhaps near the southernmost part of the basin at WW-C. Mixing models involving ER-3-1 can explain the observed $\mathrm{Sr}$ and ${ }^{87} \mathrm{Sr} /{ }^{86} \mathrm{Sr}$ data at WW-C reasonably well. However, the lack of agreement between the $\mathrm{Sr}$ and ${ }^{87} \mathrm{Sr} /{ }^{86} \mathrm{Sr}$ mixing models and the other geochemical models may indicate that appropriate end-members are not available or that water-rock reactions need to be included in the Sr models. Efforts are under way to acquire a more comprehensive dataset for rock $\mathrm{Sr}$ compositions in Yucca Flat. These data will permit more extensive testing of Sr isotope models in the future.

Groundwaters from wells completed in the LCA at ER-3-1 in the Halfpint Range, at WW-C and WW-C1 in southern Yucca Flat, and at ER-5-3 \#2 in northeastern Frenchman Flat have many similar chemical and isotopic characteristics that suggest the possibility of a common source. Numerous geochemical models can be developed to explain the chemical and isotopic composition of groundwater at WW-C. Because water-level contours suggest convergent groundwater flow toward WW-C from the west, north and east, all of these geochemical models for WW-C are considered reasonable.

Despite the fact that the models for WW-C are non-unique, the estimated travel times consistently indicate that north-south flow through the LCA in central Yucca Flat is very slow (1.4 to $1.9 \mathrm{~m} / \mathrm{yr}$ ). Likewise, the travel times indicate that leakage from the volcanic units to the LCA, combined with lateral flow in the LCA to WW-C is also very slow. Some estimated travel times suggest the possibility of relatively rapid flow from the vicinity of ER-3-1 to WW-C. The relatively short travel times estimated for the ER-3-1 to WW-C flow path is a consequence of the relatively small difference between the measured groundwater ${ }^{14} \mathrm{C}$ activities at Wells ER-3-1 (0.7 pmc) and WW-C (0.6 pmc). The low ${ }^{14} \mathrm{C}$ activities and larger relative uncertainty in the measurements, combined with the small differences in ${ }^{14} \mathrm{C}$ activities at these wells introduces uncertainty into the flow velocities and travel 
times for this flow path. However, even given this relatively high uncertainty, travel times from ER-3-1 to WW-C are probably short relative to the travel times from northern Yucca Flat to WW-C.

Hydraulic head contours in central Yucca Flat indicate the presence of a potentiometric trough that is aligned with major north-south trending faults in Yucca Flat (Figure 2-8). The presence of a similar trough extending over $80 \mathrm{~km}$ between Frenchman Flat and Ash Meadows has previously been described by Winograd and Pearson (1976). These authors found that ${ }^{14} \mathrm{C}$ ages of springs at the downgradient end of the trough were younger than those at springs adjacent to the trough, suggesting that groundwater flow was channelized and relatively more rapid within the trough. The location of WW-C at the downgradient end of the potentiometric trough in Yucca Flat, and the very long travel time and slow velocities estimated between Wells UE-10j and WW-C at the northern and southern ends of the trough, indicate that this trough does not represent a so-called "megachannel" in which groundwater flow is especially rapid. 


\section{0 evaluation of Western flow Paths}

In this section, potential groundwater flow paths and travel times on the west side of Yucca Flat the basin are examined. Conservative tracer models indicate that groundwater at Wells ER-12-1 and ER-12-2 likely originated from modern recharge in the vicinity of Rainier Mesa (Section 6.0). Hence, geochemical models developed in this chapter will only consider flow paths downgradient of these well sites.

\subsection{Geochemical Modeling of Well UE-2ce}

\subsubsection{Conservative Tracer Models for Well UE-2ce}

Well UE-2ce (LCA HSU) is located approximately $4 \mathrm{~km}$ south-southwest of ER-12-2 and is completed in the LCA near the Nash (U2ce) underground nuclear test. Well UE-2ce groundwater appears to contain a large fraction of locally-derived perched water on the basis of its $\delta \mathrm{D}$ and $\delta^{18} \mathrm{O}$ values (Figure 7-1). The best model identified (in terms of minimal variance between tracers) involved mixing of LCA water from UE-10j-1 with water from local recharge sources represented by ER-12-1 and Oak Spring:

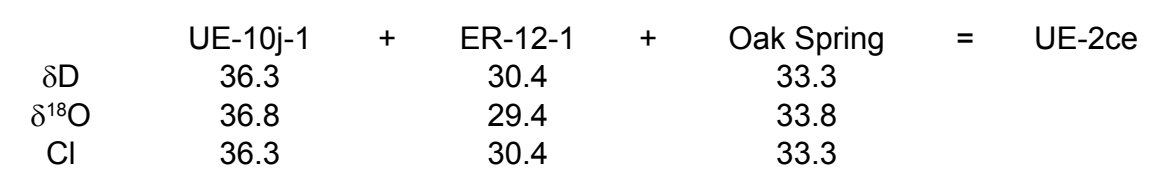

This model predicts that approximately 64 percent of the groundwater at UE-2ce originates from local recharge and approximately 36 percent is from the LCA in northern Yucca Flat (UE-10j-1). This suggests that northern Yucca Flat groundwater moves southward through the LCA in both eastern and western Yucca Flat. Strontium isotope data are unavailable to independently test this model. 


\subsubsection{Strontium and ${ }^{87} \mathrm{Sr} /{ }^{86} \mathrm{Sr}$ Models for Well UE-2ce}

No ${ }^{87} \mathrm{Sr} /{ }^{86} \mathrm{Sr}$ data are available for UE-2ce.

\subsubsection{NETPATH Models for Well UE-2ce}

The NETPATH models for UE-2ce used various combinations of local recharge components, including ER-12-1, Oak Spring, Captain Jack Spring, and Whiterock Spring, together with a northern Yucca Flat LCA source (UE-10j-1). The models were unsuccessful in predicting the observed groundwater composition at UE-2ce due to mineral dissolution / precipitation or ion exchange requirements in excess of the specified uncertainty limits.

\subsubsection{PHREEQC Models for Well UE-2ce}

Conservative tracer models for UE-2ce indicated that local recharge, as represented by ER-12-1 and Oak Spring, contribute most of the groundwater to the well. The PHREEQC models using ER-12-1 groundwater were unsuccessful, possibly because of the high $\mathrm{SO}_{4}$ concentration $(343 \mathrm{mg} / \mathrm{L})$ of this groundwater. However, substituting groundwater from other local springs (Whiterock and Captain Jack Springs) for ER-12-1 groundwater produced successful models. These models suggest that 60 to 80 percent of the groundwater at UE-2ce is derived from local recharge (Figures 9-1 and 9-2), in good agreement with conservative tracer models. Groundwater travel times could not be calculated because the ${ }^{14} \mathrm{C}$ data for UE-2ce was affected by underground nuclear testing.

\subsection{Geochemical Modeling of Well ER-2-1}

\subsubsection{Conservative Tracer Models for Well ER-2-1}

Well ER-2-1 is located just west of the Yucca Fault and was completed in the volcanic confining unit near a cluster of underground nuclear tests. During well development and testing, water levels declined substantially at low pumping rates (SNJV, 2004b) implying very low hydraulic conductivity in the volcanic confining unit at ER-2-1. Despite the close proximity of this well to several underground test cavities, a low-level ${ }^{3} \mathrm{H}$ activity $(228 \mathrm{pCi} / \mathrm{L})$ was measured in the water. These data suggest that groundwater in the volcanic confining unit in the vicinity of ER-2-1 may flow very slowly. The isotope composition of the groundwater $\left(\delta \mathrm{D}=-108\right.$ permil; $\delta^{18} \mathrm{O}=-14.3$ permil $)$ at 


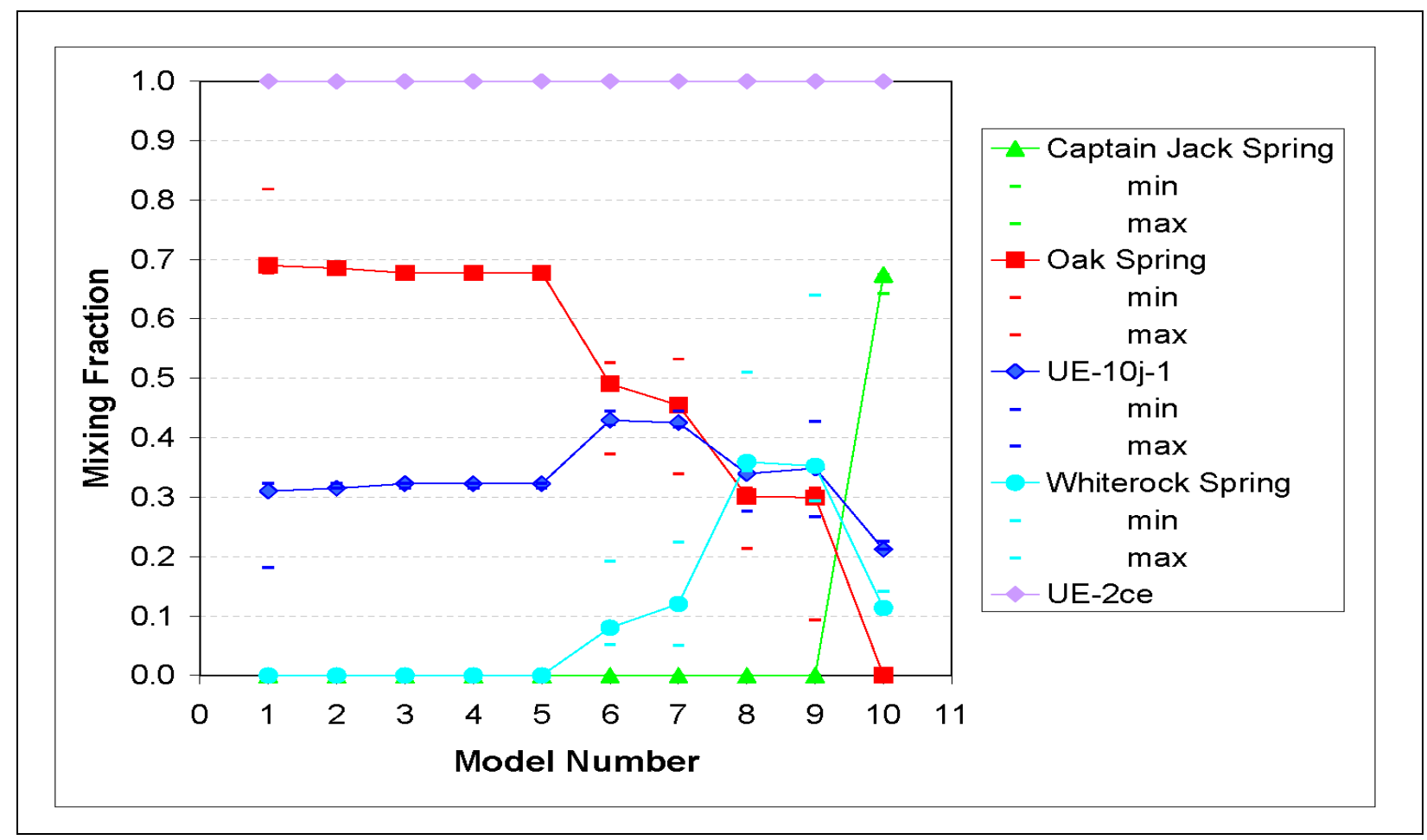

Figure 9-1

Mixing Fractions for UE-2ce Models

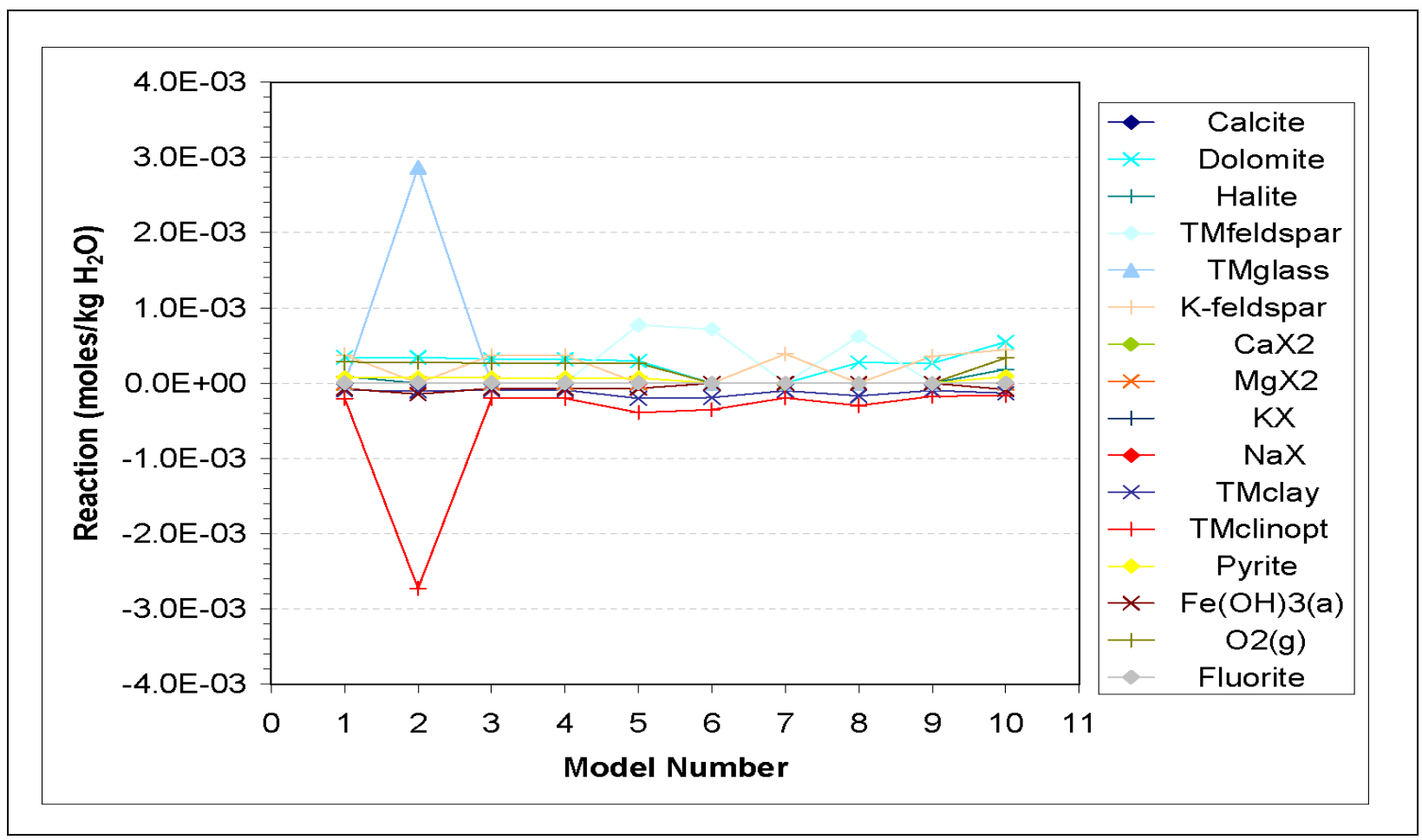

Figure 9-2

Reactions for UE-2ce Models 
ER-2-1 is much lower than modern precipitation measured at Rainier Mesa, suggesting that recharge in the volcanic confining unit in this area may have occurred under different climatic conditions.

Conservative models for ER-2-1 were largely unsuccessful. All ER-2-1 models require a large mixing fraction from HTH-1, which is completed in a volcanic aquifer on the south side of Rainier Mesa. As is the case with ER-2-1, groundwater from HTH-1 has very low stable isotope values $\left(\delta \mathrm{D}=-110\right.$ permil; $\delta^{18} \mathrm{O}=-15.0$ permil $)$ suggesting groundwater recharge under paleoclimatic conditions. Mixing HTH-1 with local perched water yielded the following model for ER-2-1:

$\begin{array}{cccccc} & \mathrm{HTH}-1 & + & \text { Oak Spring } & + & \text { Whiterock Spg } \\ \delta \mathrm{D} & 77.7 & 21.9 & 0.4 & \\ & & \text { ER-2-1 } \\ \delta^{18} \mathrm{O} & 72.2 & 20.4 & 7.5 \\ \mathrm{Cl} & 65.9 & 18.6 & 15.5\end{array}$

These results suggest that volcanic aquifer groundwater like that at HTH-1 can mix with 22 to 34 percent local perched water to derive the observed composition at ER-2-1. An alternative model was developed using HTH-1, ER-12-2, and UE-10 ITS:

$\begin{array}{cccccc} & \mathrm{HTH}-1 & + & \mathrm{ER}-12-2 & + & \text { UE-10 ITS } \\ \delta \mathrm{D} & 62.4 & & 14.5 & 23.1 & \\ \delta^{18 \mathrm{O}} & 52.8 & & 12.3 & 34.9 \\ \mathrm{Cl} & 62.4 & 14.5 & 23.1 & \end{array}$

This model is again dominated by HTH-1, but in this case, the other mixing components are from wells upgradient of ER-2-1 that are completed in the OSBCU/LTCU (UE-10 ITS) and UCCU (ER-12-2). It is uncertain whether ER-2-1 groundwater is actually a mixture of water from other local sources or simply an isolated mass of late Pleistocene age groundwater that was recharged under cooler, wetter climate conditions.

\subsubsection{Strontium and ${ }^{87} \mathrm{Sr} /{ }^{36} \mathrm{Sr}$ Models for Well ER-2-1}

Most samples of volcanic aquifer and volcanic confining unit groundwater have low $\mathrm{Sr}$ concentrations because of the high sorptive capacity of alteration phases such as zeolites. Therefore, ${ }^{87} \mathrm{Sr} /{ }^{86} \mathrm{Sr}$ values in these waters are more susceptible to small differences in end-member compositions or water-rock reactions so are less reliable as groundwater tracers. Nevertheless, most volcanic 
aquifer and volcanic confining unit samples in Yucca Flat have relatively uniform ${ }^{87} \mathrm{Sr} /{ }^{86} \mathrm{Sr}$ values with a mean and standard deviation of $0.70984 \pm 0.00083$ (7 of 8 analyses excluding U-3mi).

Groundwater from ER-2-1 has the highest ${ }^{87} \mathrm{Sr} /{ }^{86} \mathrm{Sr}$ value in this dataset (0.71131) and the lowest $\mathrm{Sr}$ concentration $(5.4 \mu \mathrm{g} / \mathrm{L})$. As such, it is difficult to use Sr data to evaluate mixing models based on conservative tracers. The elevated ${ }^{87} \mathrm{Sr} /{ }^{86} \mathrm{Sr}$ ratio could reflect addition of small amounts of more radiogenic Sr from UCCU, LCCU, or LCA groundwater sources in northern Yucca Flat, or small amounts of dissolution of minerals with elevated ${ }^{87} \mathrm{Sr} /{ }^{86} \mathrm{Sr}$. The low $\mathrm{Sr}$ concentration indicates that $\mathrm{Sr}$ exchange processes are either very efficient, or have had ample opportunity for exchange during flow through the volcanic aquifer and volcanic confining unit. These data are consistent with interpretations of little or no groundwater movement in the vicinity of ER-2-1.

\subsubsection{NETPATH Models for Well ER-2-1}

The NETPATH models for ER-2-1 used various combinations of local recharge components including ER-12-2, Oak Spring, Whiterock Spring, and HTH-1 together with northern Yucca Flat LCCU (UE-15d), OSBCU (UE-10-ITS \#3), UCCU (UE-17a), or UCA (UE-16d) mixing components. These models were unsuccessful due to a combination of excessive calcite or dolomite precipitation, $\mathrm{SiO}_{2}$ precipitation, cation exchange reactions, and combinations of dissolution or precipitation of feldspars and glass with dissolution or precipitation of clays and zeolites.

\subsubsection{PHREEQC Models for Well ER-2-1}

As discussed above, groundwater at ER-2-1 may have been recharged under different climatic conditions than present. To evaluate the conservative tracer models, PHREEQC models were created that considered groundwater at ER-2-1 as a potential mixture of various local recharge components (Figures 9-3 and 9-4). The resulting models confirm that groundwater from ER-2-1 can be interpreted to be a mixture of groundwater from HTH-1 (60 to 80 percent), Oak Spring (20 to 40 percent), and Whiterock Spring (0 to 10 percent), in good agreement with the conservative tracer models. 


\subsection{Geochemical Modeling of Well UE-1h}

\subsubsection{Conservative Tracer Models for Well UE-1h}

The next two LCA wells south of UE-2ce are Test Well D (TW-D) and UE-1q. These wells will be discussed separately in the next section of the report. Still further to the south is UE-1h. UE-1h is similar to the LCA groundwater in southeastern Yucca Flat in that it has unusually high $\mathrm{Cl}$ $(43.4 \mathrm{mg} / \mathrm{L})$ and a low ${ }^{36} \mathrm{Cl} / \mathrm{Cl}$ ratio $\left(1.61 \times 10^{-13}\right)$ similar to ER-3-1, but with $\delta \mathrm{D}$ and $\delta^{18} \mathrm{O}$ values that are distinctly higher than ER-3-1 (Figure 7-1). An actual hydrologic link to ER-3-1 is improbable because UE-1h sits on the west side of the Yucca and Topgallant Faults. However, the process that led to the $\mathrm{Cl}$ enrichment and low ${ }^{36} \mathrm{Cl} / \mathrm{Cl}$ ratios in these waters may be the same. Progressive leaching of ${ }^{36} \mathrm{Cl}$-absent $\mathrm{Cl}$ from the carbonate aquifer matrix results in increasing $\mathrm{Cl}$ and decreasing ${ }^{36} \mathrm{Cl} / \mathrm{Cl}$ along a groundwater flow path (Moran and Rose, 2003). Well UE-10j-1 in northern Yucca Flat also shows a modest $\mathrm{Cl}$ enrichment $(23.9 \mathrm{mg} / \mathrm{L})$ and low ${ }^{36} \mathrm{Cl} / \mathrm{Cl}$ ratio $\left(2.41 \times 10^{-13}\right)$. It is therefore possible that the $\mathrm{Cl}$ signature in UE-1h evolved from that of UE-10j-1 due to water-rock reaction along a north-south flow path in west-central Yucca Flat. Because of the high $\mathrm{Cl}$ concentration in UE-1h, it is not possible to develop conservative tracer models that include $\mathrm{Cl}$ as a mixing constraint. Mixing models that are based solely on $\delta \mathrm{D}$ and $\delta^{18} \mathrm{O}$ values tend to be highly non-unique, and many mixing scenarios are permissible. Nevertheless, stable isotope models provide a useful starting place for subsequent chemical modeling. One simple model for UE-1h involves mixing of UE-10j-1 and UE-16f:.

$$
\text { UE-1h }=(0.52) \text { UE-10j-1 }+(0.48) \text { UE-16f }
$$

Well UE-16f is completed in the UCCU along the western margin of Yucca Flat (just east of Syncline Ridge), approximately $8.5 \mathrm{~km}$ northwest of UE- $1 \mathrm{~h}$. The mixing fractions above were determined from the $\delta^{18} \mathrm{O}$ data only. Reported $\delta \mathrm{D}$ values for Wells UE-1h and UE-16f are identical, and the overall variation in $\delta \mathrm{D}$ for all three wells is only 0.4 permil. Hence, the $\delta \mathrm{D}$ data do not provide any meaningful constraints on the model. 


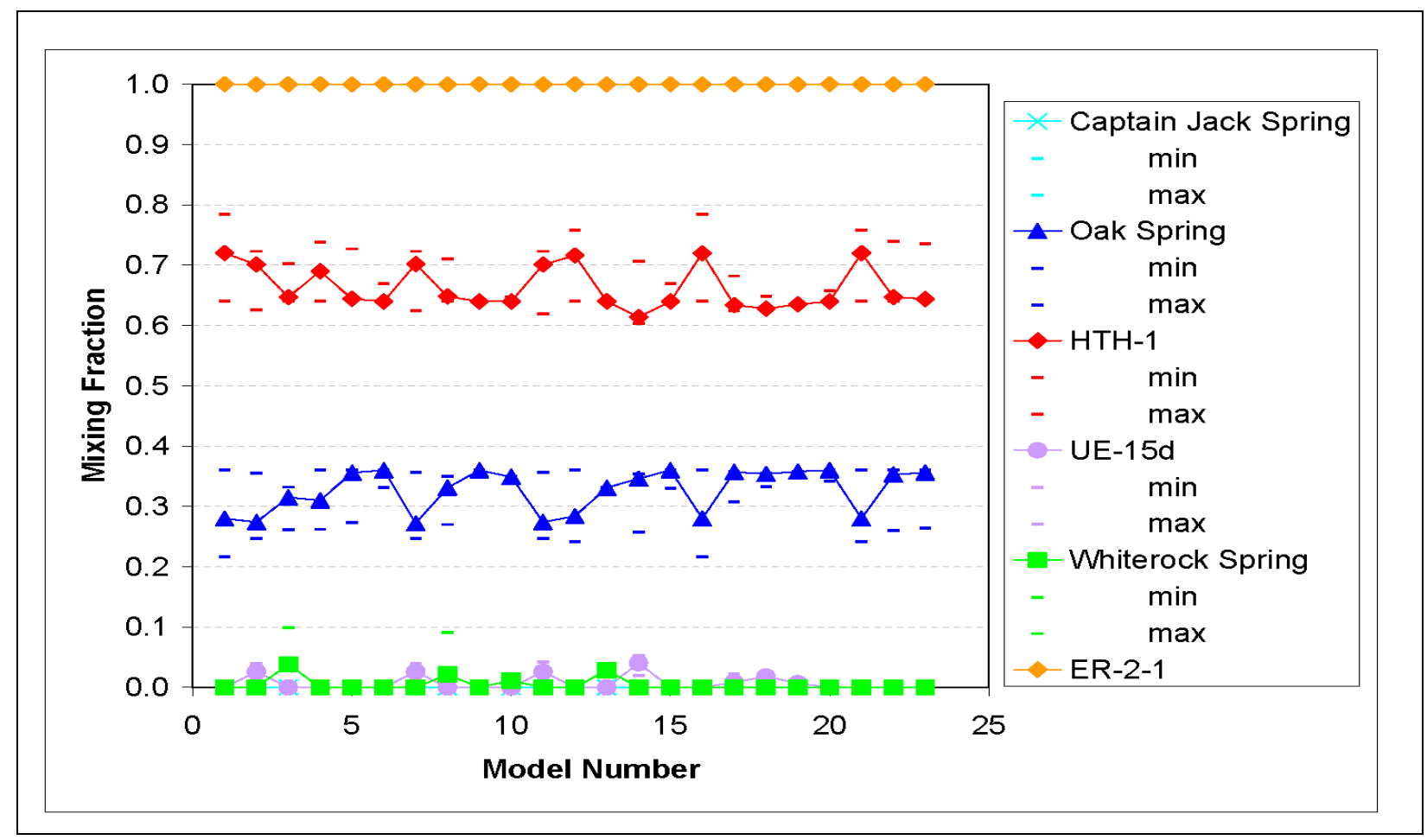

Figure 9-3

Mixing Fractions for ER-2-1 Models

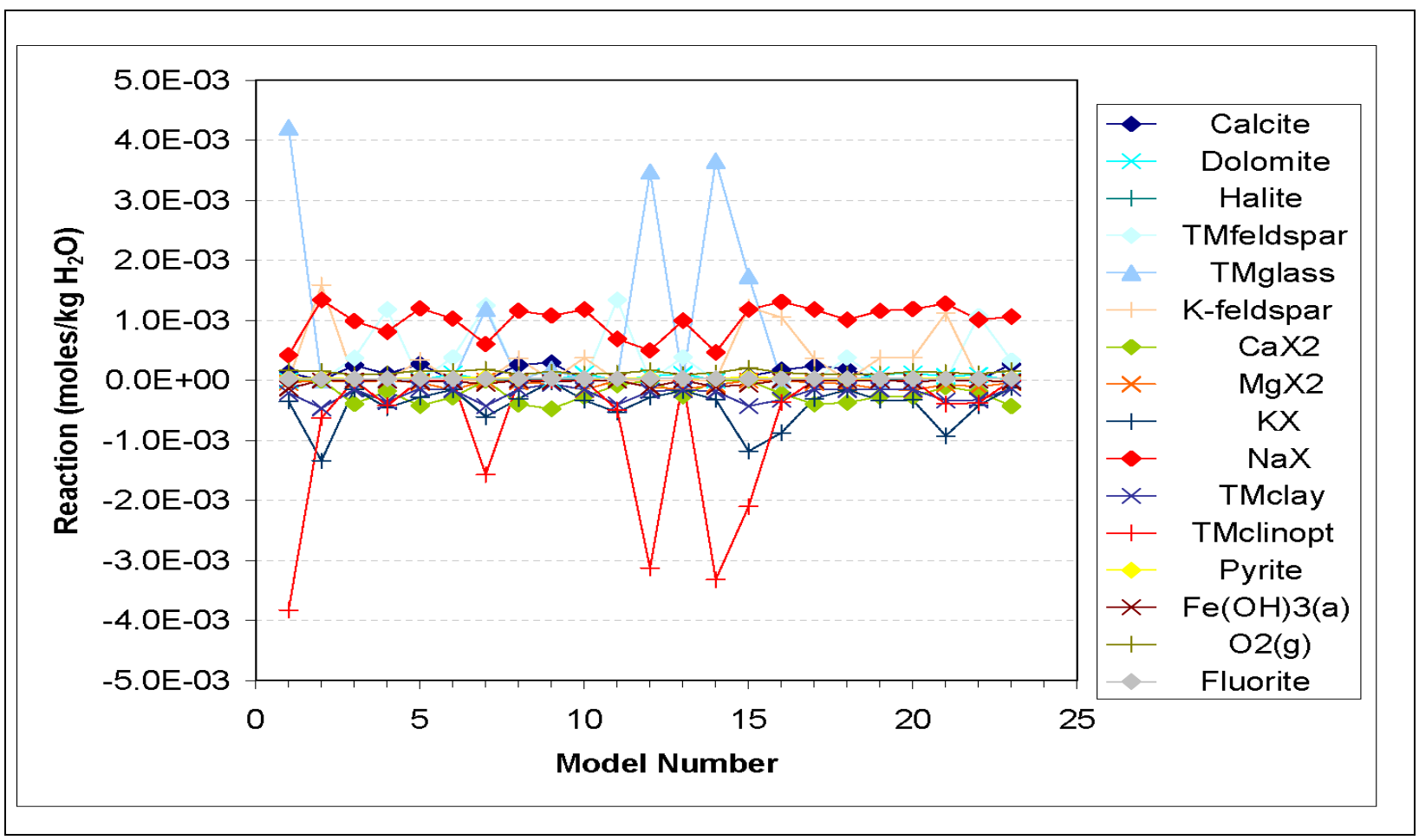

Figure 9-4

Reactions for ER-2-1 Models 
Another model for UE-1h mixes groundwater from UE-10j-1 and HTH-1. The latter well is a component in several of the models developed for other wells in western Yucca Flat and should be considered as a possible mixing end-member at UE-1h:

$\begin{array}{cccc} & \text { UE-10j-1 } & + & \mathrm{HTH}-1 \\ \delta \mathrm{D} & 93.5 & 6.5 \\ \delta^{18} \mathrm{O} & 86.0 & & 14.0\end{array}$

This model could accommodate a third mixing component, which would tend to reduce the differences in the $\delta \mathrm{D}$ and $\delta^{18} \mathrm{O}$ mixing fractions. Although $\mathrm{HTH}-1$ has a very high ${ }^{36} \mathrm{Cl} / \mathrm{Cl}$ ratio $\left(9.68 \times 10^{-13}\right)$, it is also low in $\mathrm{Cl}(3.3 \mathrm{mg} / \mathrm{L})$. Hence, the small mixing fraction from HTH-1 is not expected to have a detrimental impact on the CI signature at UE-1h.

\subsubsection{Strontium and ${ }^{87} \mathrm{Sr} /{ }^{86} \mathrm{Sr}$ Models for Well UE-1h}

The Sr isotopic characteristics of LCA groundwater from Wells UE-1c and UE-1h are distinct from other samples of LCA groundwater in Yucca Flat. These samples have moderate to high

Sr concentrations, but low ${ }^{87} \mathrm{Sr} /{ }^{86} \mathrm{Sr}$ values. Data for both samples plot outside of Sr mixing triangles involving UE-10j-1, mean local recharge, and volcanic aquifer end-members (Figure 6-3), implying that water from northern Yucca Flat with more radiogenic $\mathrm{Sr}$ is not a required component of these waters. Instead, $\mathrm{Sr}$ in these samples show greater affinities to UCCU groundwater from the western margin of the Yucca Flat basin (Figure 9-5), namely from nearby Wells UE-1b, UE-16d, UE-16f, and UE-17a. This is especially true for LCA groundwater from UE-1c, which is only 2 to $6 \mathrm{~km}$ downgradient from these UCCU wells. Addition of volcanic aquifer groundwater (e.g., HTH-1) with low $\mathrm{Sr}$ concentrations and ${ }^{87} \mathrm{Sr} /{ }^{86} \mathrm{Sr}$ values are capable of approximating the $\mathrm{Sr}$ characteristics for both UE-1c (HTH-1:UCCU mixing ratio of 15:85) and UE-1h (65:35). Strontium data do not support conservative tracer models for UE-1h, which require substantial amounts of water from UE-10j-1 with much more radiogenic Sr.

\subsubsection{NETPATH Models for Well UE-1h}

The NETPATH models developed for UE-1h using a combination of upgradient mixing endmembers were unsuccessful. Combinations of local recharge, LCA, volcanic aquifer, UCCU, and volcanic confining unit groundwater were attempted without success. Models failed because of a combination 


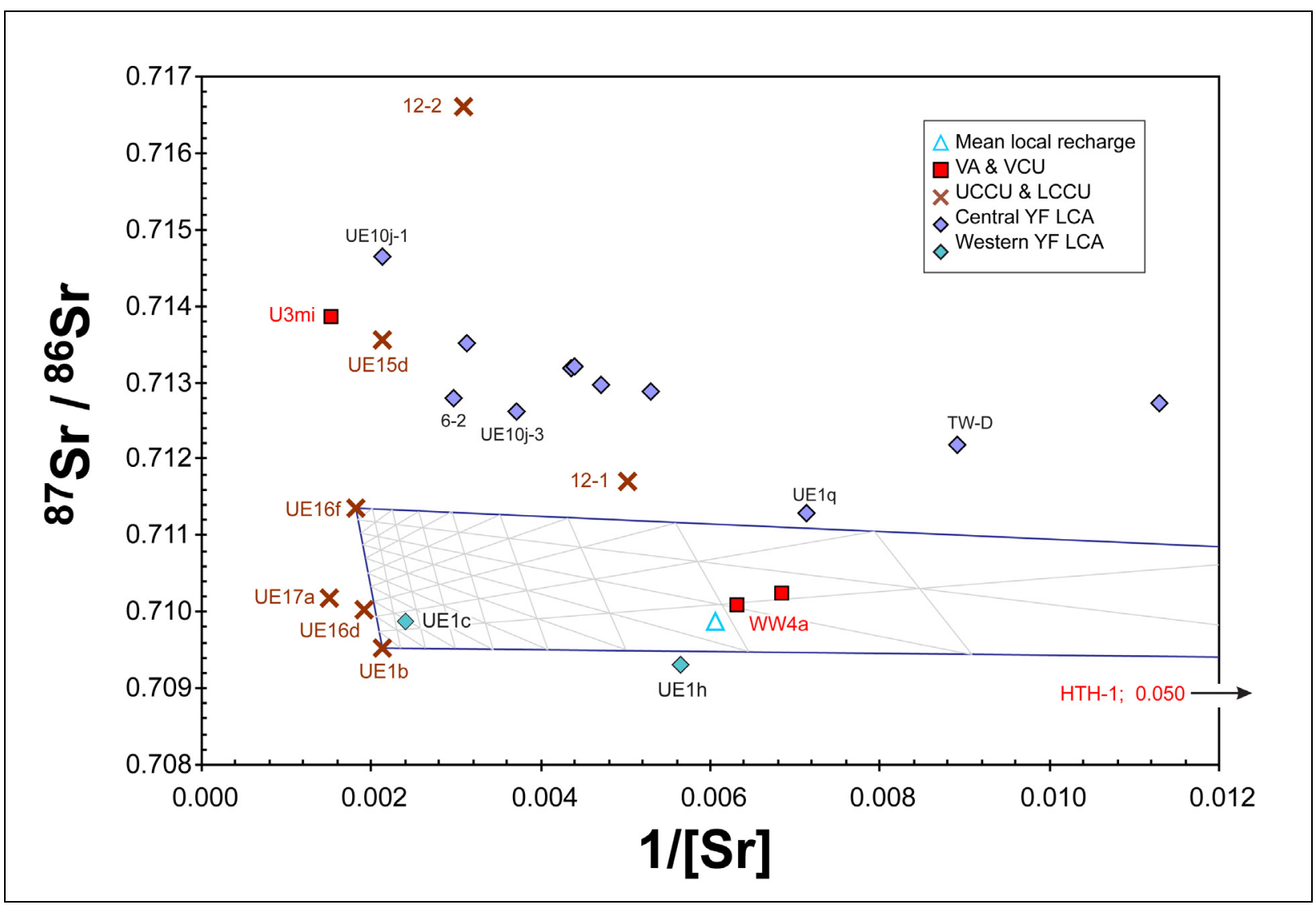

Figure 9-5

\section{Relations Between ${ }^{87} \mathrm{Sr} /{ }^{86} \mathrm{Sr}$ Values and Sr Concentration for Yucca Flat Groundwater Emphasizing Samples from Western Yucca Flat}

Note: Plot shows three component mixing results between UE-16f, UE-1b, and HTH-1.

of excessive precipitation of calcite, precipitation of dolomite, dissolution of halite, precipitation of $\mathrm{SiO}_{2}$, precipitation of gypsum, exchange of $\mathrm{Na}$ for $\mathrm{Ca}$ and $\mathrm{Mg}$ to increase the $\mathrm{Na}$ concentrations, and combinations of dissolution or precipitation of feldspars and glass with dissolution or precipitation of clays and zeolites.

\subsubsection{PHREEQC Models for Well UE-1h}

Well UE-1h is located in south-central Yucca Flat between the Carpetbag and Topgallant faults and penetrates the LCA. It is distinguished from most nearby groundwaters in the LCA by its low $\delta^{13} \mathrm{C}$ (-11.2 permil), which eliminates isotopically higher groundwater, such as $\mathrm{UE}-10 \mathrm{j}-1\left(\delta^{13} \mathrm{C}=-3.2\right.$ permil), as a significant mixing component. In fact, no inverse models could be found for UE-1h using its reported $\delta^{13} \mathrm{C}$ value, and it was necessary to increase the uncertainty on its reported $\delta^{13} \mathrm{C}$ 
value to \pm 2.0 permil before any models could be found. It was also necessary to adjust the reported $\mathrm{SO}_{4}$ value by charge balancing the solution before models could be found. In this case, the $\mathrm{SO}_{4}$ values increased substantially from 2.5 to $31.5 \mathrm{mg} / \mathrm{L}$. Because these changes were required in order to find reasonable models for UE-1h, the modeling results presented below should be considered critically.

Groundwater from several wells in the UCCU west of UE-1h has low $\delta^{13} \mathrm{C}$ values similar to that of UE-1h. These groundwaters were included in the inverse models as potential end-members. As noted above, groundwater at $\mathrm{UE}-1 \mathrm{~h}$ is also characterized by relatively high $\mathrm{Cl}$ concentrations and low ${ }^{36} \mathrm{Cl} / \mathrm{Cl}$ ratios. These data suggest that groundwater upgradient of $\mathrm{UE}-16 \mathrm{f}$ might contribute to groundwater at UE-1h. However, the relatively high Na concentration of $382 \mathrm{mg} / \mathrm{L}$ at UE-16f precludes it from being a major component of UE-1h. Groundwater from other wells in the Eleana Range (i.e., UE-16d) may be a major component of UE-1h provided HTH-1 is also included as an end-member (Figures 9-6 and 9-7). When groundwater from the volcanic confining unit at ER-2-1 is substituted for groundwater from HTH-1, groundwater from UE-2ce is also a possible component at UE-1h (Figures 9-8 and 9-9). The set of models involving ER-2-1, indicates that local recharge from the volcanic confining unit is a major component of the groundwater at UE-1h, in addition to local recharge entering the LCA along the margins of the basin at Wells UE-2ce and UE-10j-3.

Inverse models involving HTH-1 as the primary component of UE-1h groundwater appear to be compatible with the interpretations from the Sr data presented earlier that conclude groundwater from UE-1h can be formed from a sub-equal (65:35) mixture of groundwater from HTH-1 and the UCCU in the Eleana Range, west of UE-1h (Figure 9-5). Conversely, models with ER-2-1 and a significant component of UE-10j-3 groundwater appear to be ruled out by the Sr data. Unfortunately, neither set of models produces reasonable travel time estimates. Travel times for all models with HTH-1 groundwater are negative, as are travel times for all models with ER-2-1 groundwater that do not contain groundwater from UE-2ce. The reason for these negative travel times is the relatively high ${ }^{14} \mathrm{C}$ activity of $18 \mathrm{pmc}$ reported for Well UE-1h. This value is actually the average of two quite distinct values (12 and $24 \mathrm{pmc}$ ), the latter of which was reported for a well interval slightly deeper than the first. The use of 12 pmc rather than 18 pmc at Well UE-1h would have resulted in relatively short (but non-negative) travel times of 0 to 2,150 years for the models with the HTH-1 endmember. These travel times are probably too short for groundwater to have physically moved from HTH-1 to 


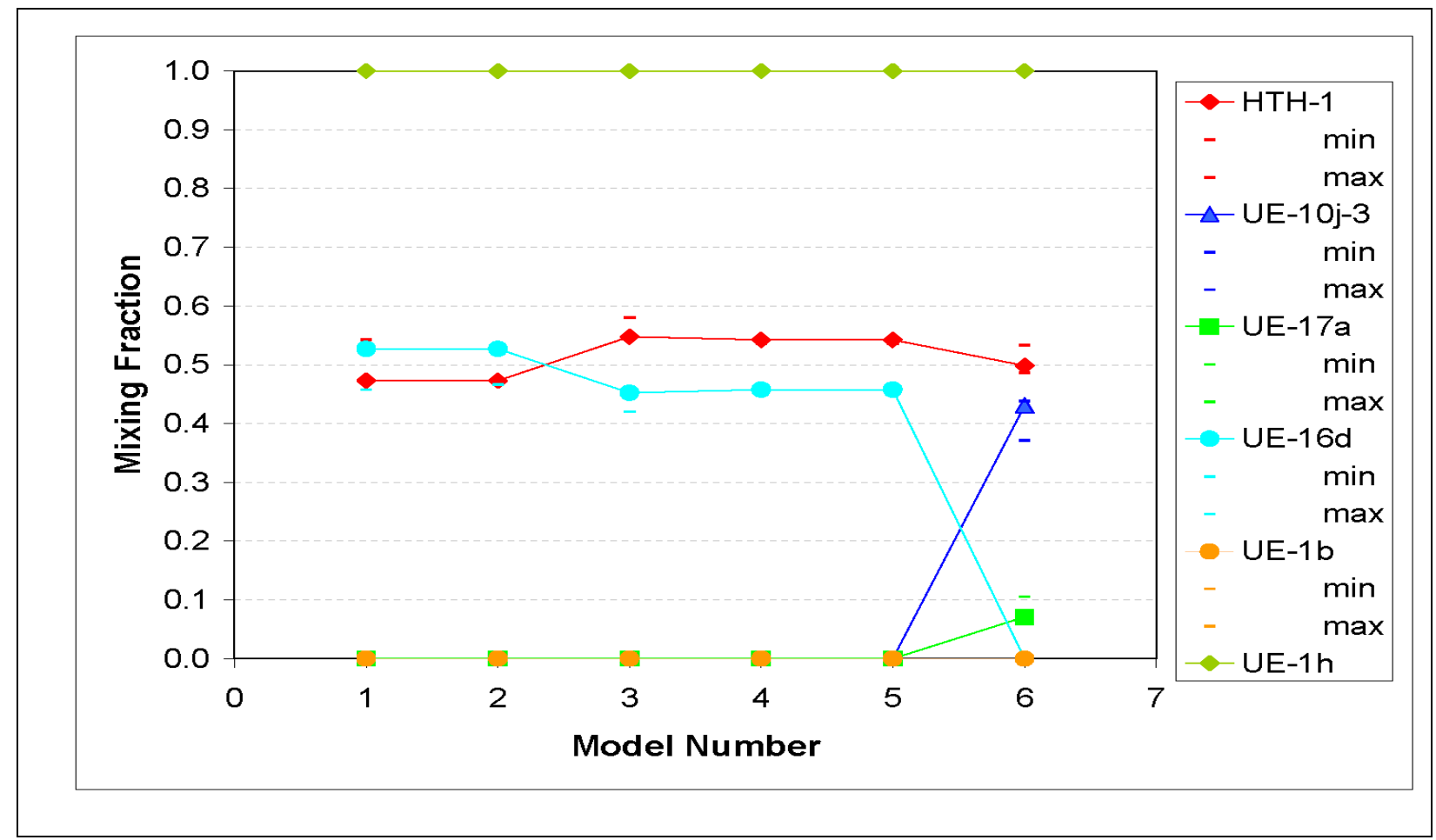

Figure 9-6

Mixing Fractions for UE-1h Models with HTH-1 Groundwater

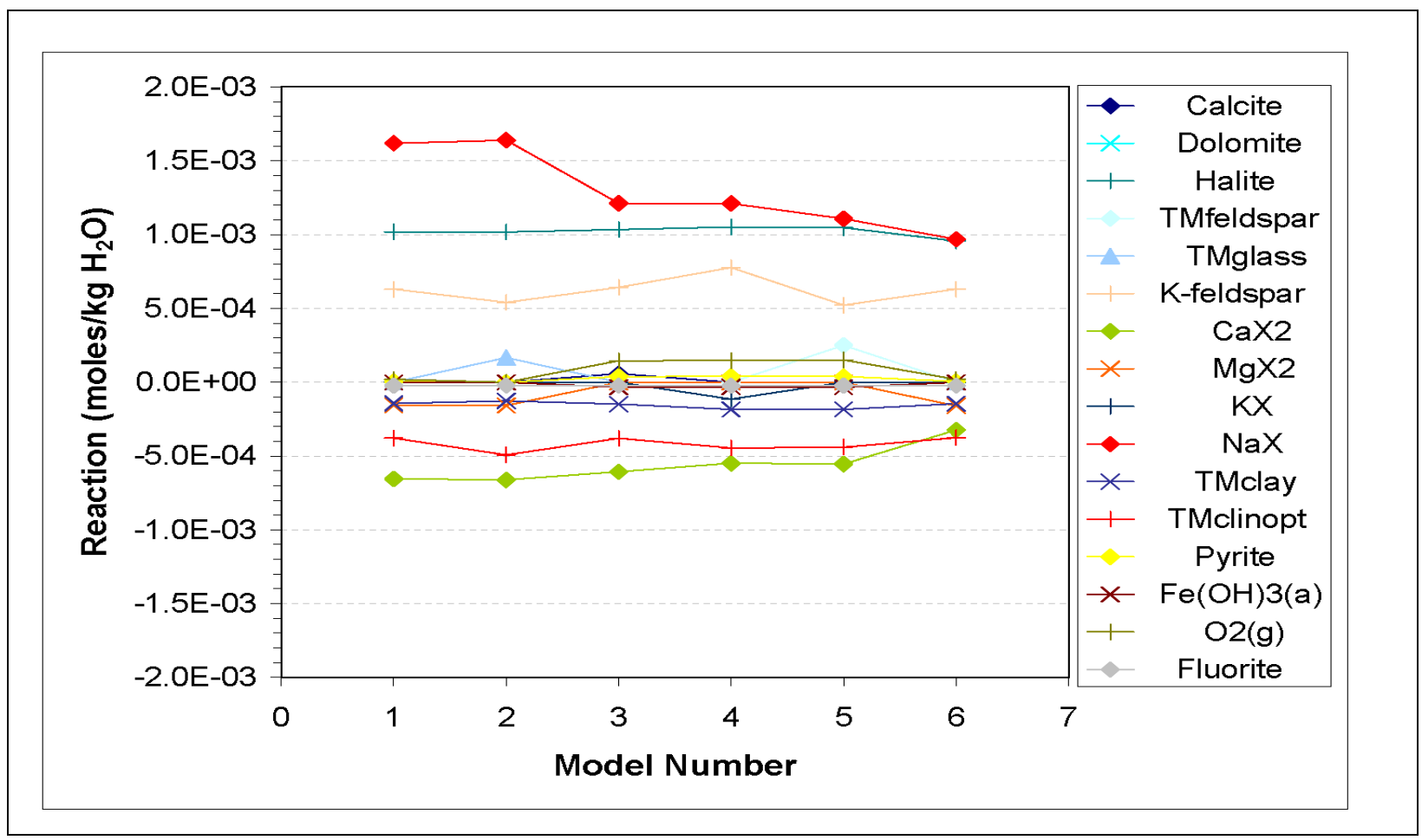

Figure 9-7

Reactions for UE-1h Models with HTH-1 Groundwater 


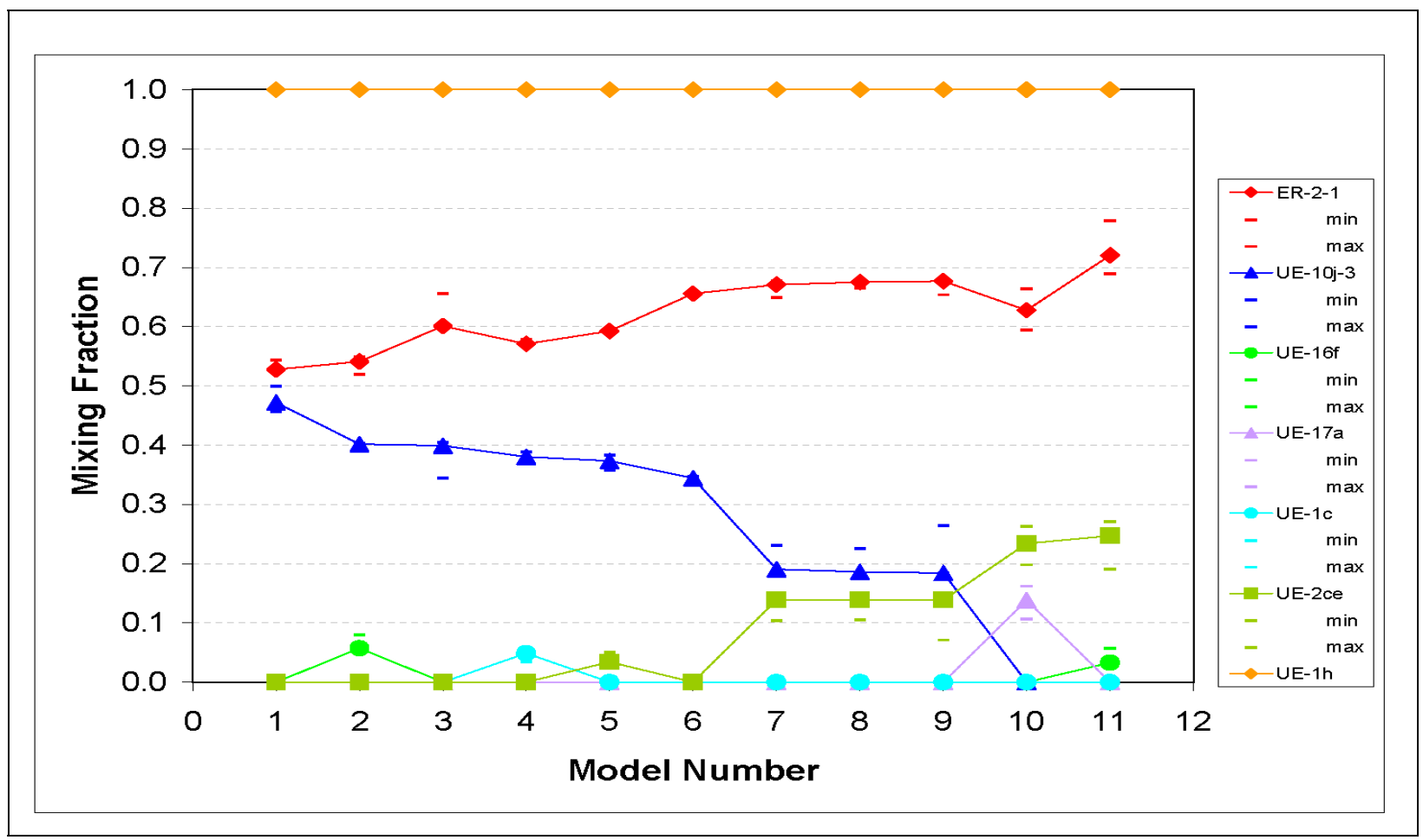

Figure 9-8

Mixing Fractions for UE-1h Models with ER-2-1 Groundwater

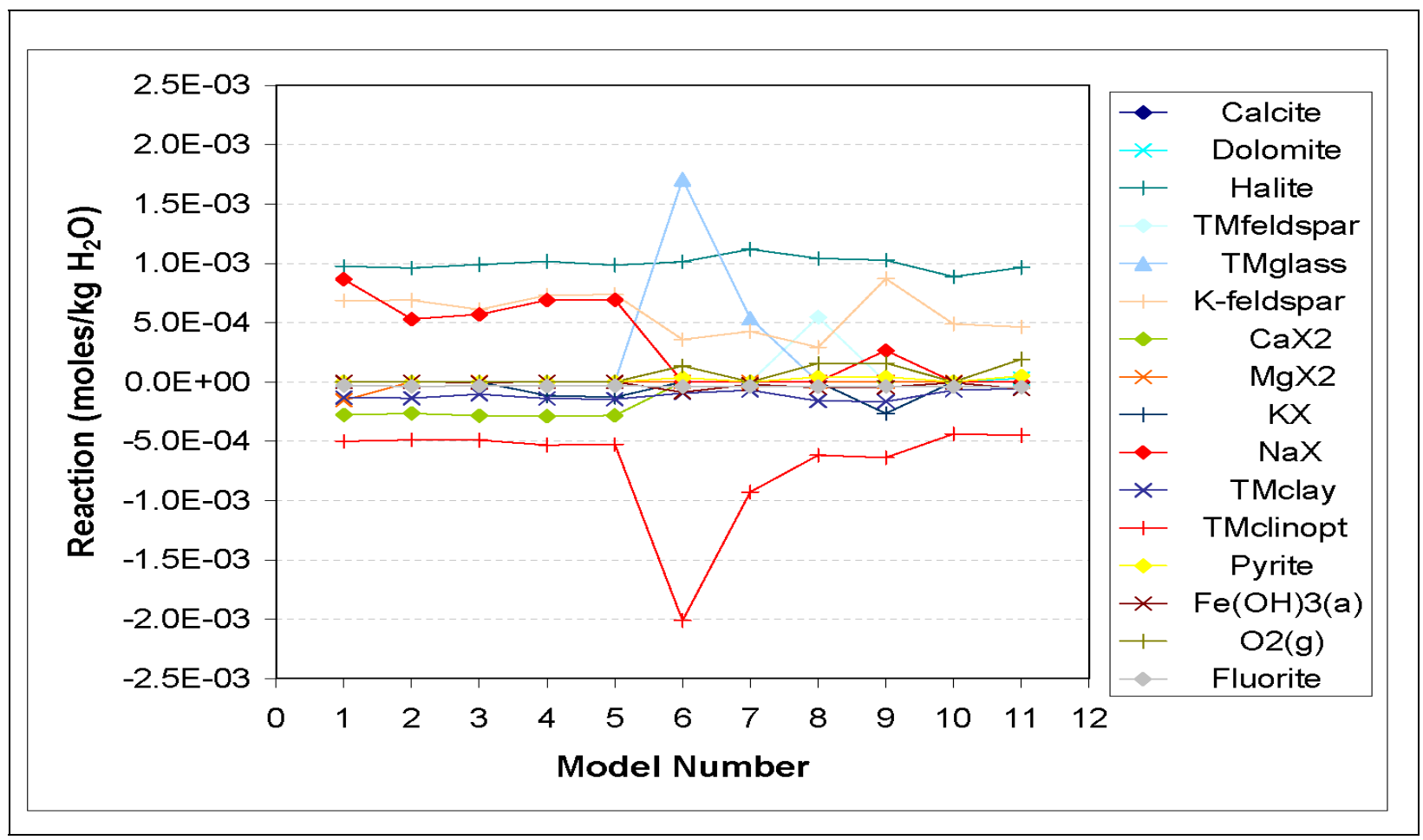

Figure 9-9

Reactions for UE-1h Models with ER-2-1 Groundwater 
UE-1h, suggesting that HTH-1 would more properly be interpreted as representing local paleo-recharge in the UE-1h models.

\subsection{Geochemical Modeling of Well ER-6-2}

\subsubsection{Conservative Tracer Models for Well ER-6-2}

Well ER-6-2 is located along the southwestern margin of Yucca Flat, approximately

$4.5 \mathrm{~km}$ south-southwest of UE-1h. Compared to UE-1h, the LCA water at ER-6-2 has lower stable isotope values (Figure 6-1), lower $\mathrm{Cl}(18.9 \mathrm{mg} / \mathrm{L})$, and a slightly higher ${ }^{36} \mathrm{Cl} / \mathrm{Cl}$ ratio $\left(2.00 \times 10^{-13}\right)$. The simplest model for ER-6-2 involves the mixing of UE-10j-1 and HTH-1:

$\begin{array}{cccc} & \mathrm{UE}-10 \mathrm{0}-1 & \mathrm{HTH}-1 \\ \delta \mathrm{D} & 69.4 & & 30.6 \\ \delta^{18} \mathrm{O} & 65.0 & & 35.0 \\ \mathrm{Cl} & 75.7 & & 24.3\end{array}$

This model predicts that ER-6-2 contains 65 to 76 percent UE-10j-1 water and 24 to 35 percent $\mathrm{HTH}-1$. The increased HTH-1 mixing fraction relative to UE-1h is consistent with the observed $\mathrm{Cl}$ dilution and increased ${ }^{36} \mathrm{Cl} / \mathrm{Cl}$ ratio at ER-6-2. ER-6-2 can also be modeled using a combination of wells that are located a shorter distance upgradient:

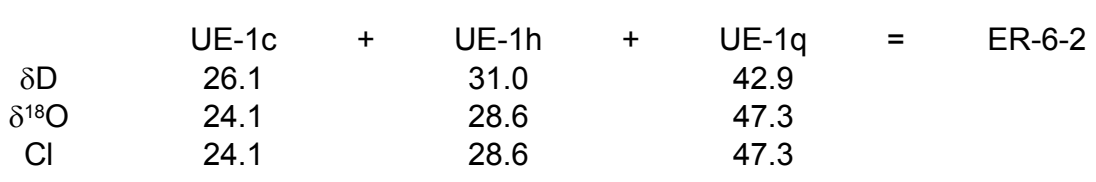

The mixing components used in this model are likely derivative of LCA water from UE-10j and groundwater that originated from recharge on the west side of Yucca Flat (though not necessarily during modern time at HTH-1).

\subsubsection{Strontium and ${ }^{87} \mathrm{Sr} /{ }^{86} \mathrm{Sr}$ Models for Well ER-6-2}

The LCA groundwater from ER-6-2 has high ${ }^{87} \mathrm{Sr} /{ }^{86} \mathrm{Sr}$ values that are within the range observed for east-central Yucca Flat LCA samples (Figure 9-5). The elevated ${ }^{87} \mathrm{Sr} /{ }^{86} \mathrm{Sr}$ value of 0.71280 is consistent with a substantial component of northern Yucca Flat LCA water as suggested by conservative tracer models. However, Sr data from ER-6-2 do not fall on a mixing line between 
UE-10j-1 and HTH-1 end-members because of the moderate Sr concentrations in ER-6-2 (337 $\mu \mathrm{g} / \mathrm{L})$. Addition of a third mixing component consisting of UCCU groundwater from the western margin of basin (e.g., UE-16f) results in a high degree of consistency between mixing proportions based on $\mathrm{Sr}$, $\delta \mathrm{D}$, and $\mathrm{Cl}$ data (Table 9-1), and implies approximately equal amounts of volcanic aquifer, UCCU, and LCA components. Strontium data do not support the results of the conservative tracer mixing model involving mixtures of LCA waters from nearby LCA Wells UE-1c, UE-1h, and UE-1q. All of these constituents have lower ${ }^{87} \mathrm{Sr} /{ }^{86} \mathrm{Sr}$ values than the value measured in ER-6-2 water.

Table 9-1 Mixing Percentages Needed To Produce Compositions Observed in ER-6-2 Based on ${ }^{87} \mathrm{Sr} /{ }^{86} \mathrm{Sr}$ Versus 1/Sr, $\delta D$, and $\mathrm{Cl}$

\begin{tabular}{|c|c|c|c|}
\hline Mixing End-Members & UE-10j-1 & HTH-1 & UE-16f \\
\hline \hline${ }^{87} \mathrm{Sr} /{ }^{86} \mathrm{Sr}$ vs. 1/Sr & 32 & 36 & 32 \\
\hline${ }^{87} \mathrm{Sr} /{ }^{86} \mathrm{Sr}$ vs. $\delta \mathrm{D}$ & 35 & 28 & 37 \\
\hline${ }^{87} \mathrm{Sr} /{ }^{86} \mathrm{Sr}$ vs. $\mathrm{Cl}$ & 38 & 23 & 39 \\
\hline
\end{tabular}

\subsubsection{NETPATH Models for Well ER-6-2}

The results of the NETPATH models for ER-6-2 are provided in Table 9-2. The NETPATH models incorporating water-rock reactions show that mixing northern Yucca Flat LCA groundwater with isotopically low local recharge (HTH-1) can produce groundwater in the LCA in western Yucca Flat at ER-6-2 but in proportions different than those calculated with conservative tracers. However, $\mathrm{Cl}$ concentrations for the modeled mixture are about half those measured in ER-6-2. Composite travel times for this mixture ranged from 14,500 to 15,500 years. Adding a component of western Yucca Flat UCCU groundwater to this mixture produced similar results but lowered the contribution from HTH-1 by 15 percent. This model produced much closer $\mathrm{Cl}$ concentrations to those at ER-6-2. Travel times for this mixture were within the range for the mixture without UCCU groundwater.

The conservative tracer model that predicted ER-6-2 could be modeled using UE-1c, UE-1h, and UE-1q groundwater failed to produce any reasonable NETPATH models. These models failed because of a combination of excessive dissolution of $\mathrm{SiO}_{2}$, dissolution of dolomite, exchange of $\mathrm{Na}$ for $\mathrm{Ca}$ and $\mathrm{Mg}$ to increase the $\mathrm{Na}$ concentrations, and combinations of dissolution or precipitation of feldspars and glass with dissolution or precipitation of clays and zeolites, 
One other NETPATH model for ER-6-2 was tested. This model incorporated northern Yucca Flat groundwater with volcanic groundwater like WW-4a (in CP Basin), and volcanic groundwater like UE-14b (in Mid Valley). Although this model showed that LCA groundwater at ER-6-2 in western Yucca Flat could be produced with this mixture, the modeled $\delta \mathrm{D}$ was outside the allowed uncertainty range. Travel times for this mixture could not be calculated because of a lack of ${ }^{14} \mathrm{C}$ data for UE-14b.

\section{Table 9-2}

Results of NETPATH Models for Well ER-6-2

\begin{tabular}{|c|c|c|c|c|c|c|c|}
\hline \multirow{2}{*}{\multicolumn{3}{|c|}{ End-Member Percentage }} & \multicolumn{4}{|c|}{ Modeled (Measured) Composition of ER-6-2 } & \multirow{2}{*}{$\begin{array}{c}\text { Travel Time } \\
\text { (Years) }\end{array}$} \\
\hline & & & $(-106)^{a}$ & $(-14.1)^{a}$ & $(18.9)^{a}$ & $(-4.3)^{a}$ & \\
\hline UE-10j-1 & HTH-1 & & $\delta \mathrm{D}$ (permil) & $\delta^{18} \mathrm{O}$ (permil) & $\mathrm{Cl}(\mathrm{mg} / \mathrm{L})$ & $\delta^{13} \mathbf{C}$ (permil) & 15,400 to \\
\hline $30-31$ & $69-70$ & & -108 & -14.5 & 9.5 to 9.7 & -4.5 to -4.4 & 15,500 \\
\hline UE-10j-1 & HTH-1 & UE-17a & & & & & \\
\hline 30 & 55 & 15 & -107 & -14.3 & 13.5 & -5.3 & 14,900 \\
\hline UE-1c & UE-1h & UE-1q & & & & & \\
\hline \multicolumn{8}{|c|}{ No reasonable models } \\
\hline UE-10j-1 & WW4a & UE-14b & & & & & \\
\hline $27-28$ & $61-64$ & $8-12$ & -102 to -101 & -13.2 to -13.1 & 14.2 to 14.5 & -4.8 & * \\
\hline
\end{tabular}

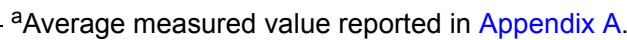

*Travel times could not be calculated because of a lack of $14 \mathrm{C}$ data for UE-14b.

\subsubsection{PHREEQC Models for Well ER-6-2}

Well ER-6-2 penetrates the LCA in the southwestern part of Yucca Flat near the CP Hills. Based on conservative tracer models, groundwater at ER-6-2 can be derived from local upgradient LCA groundwater from UE-1c, UE-1h and UE-1q, or by mixing HTH-1 with LCA groundwater from northern Yucca Flat at UE-10j-1. Variations of these models were investigated with PHREEQC (Figures 9-10 to 9-14). Additionally, because of its proximity to the CP Basin, groundwater in the LCA at ER-6-2 was modeled as a potential mixture of groundwater from the CP Basin and the Eleana Range (Figure 9-16).

The PHREEQC models involving local upgradient sources for ER-6-2 suggest that the mixture proposed on the basis of conservative tracer is feasible, although mixing percentages are somewhat different. In the PHREEQC models, the component from UE-1c is higher (48 to 75 percent) and the components from UE-1h and UE-1q smaller than those calculated by conservative tracers. Many of the models do not require a UE-1h groundwater component (Figures 9-10 and 9-11). This may be because of the low $\delta^{13} \mathrm{C}$ at UE-1h (-11.2 permil) as compared to the other wells. Composite travel times calculated for the set of models that lack a UE-1h component are between about 5,000 and 


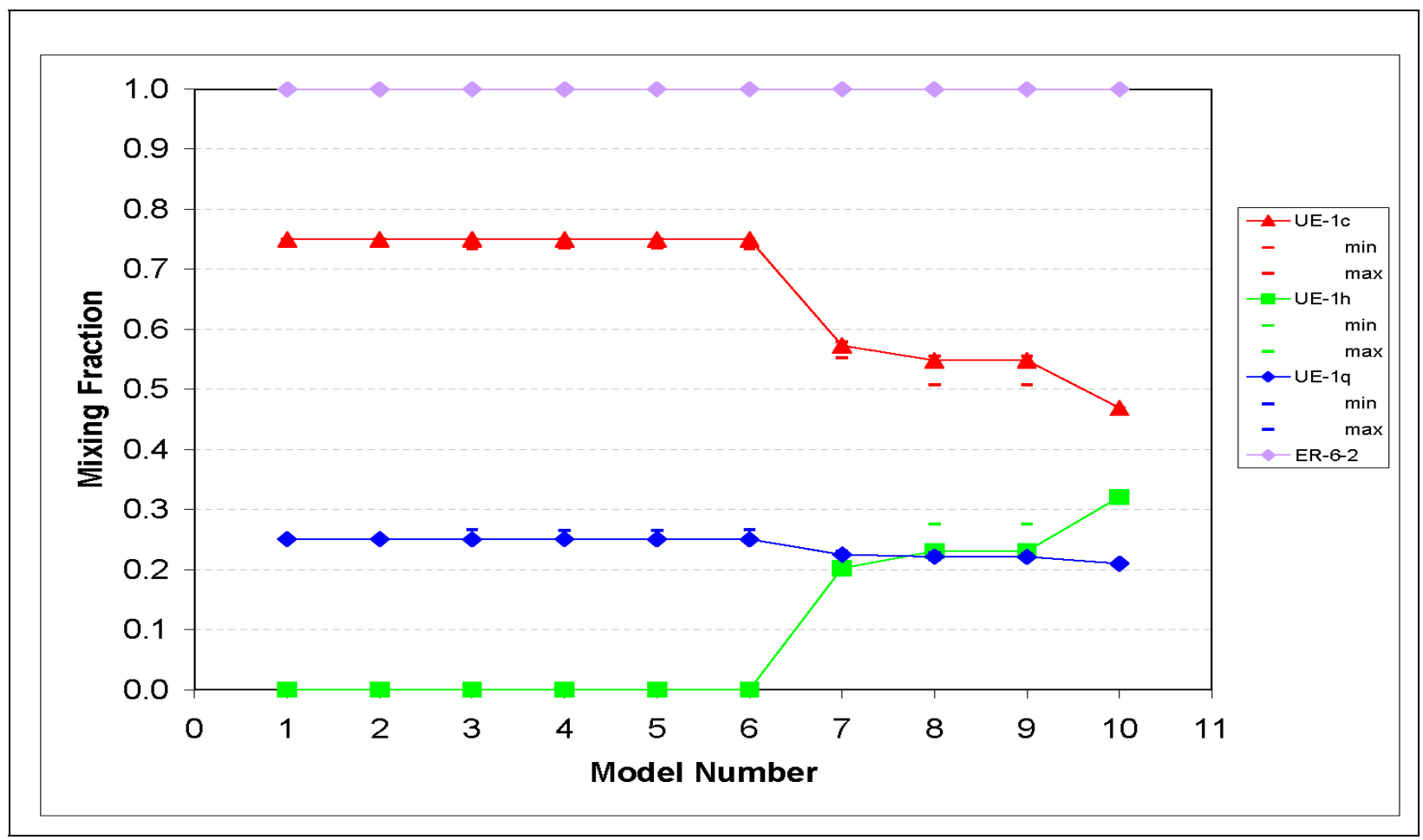

Figure 9-10

Mixing Fractions for ER-6-2 Models with Local LCA Groundwater

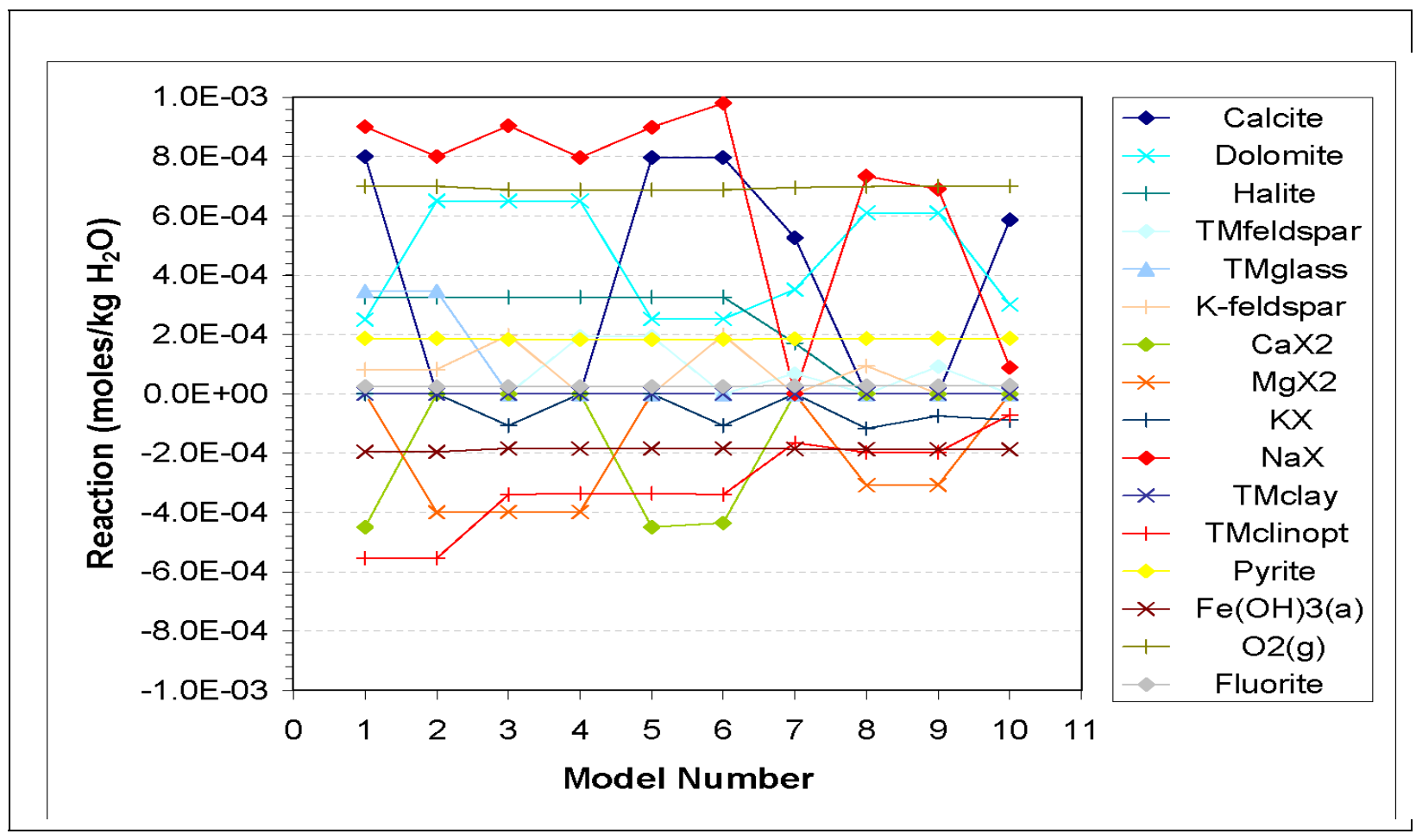

Figure 9-11

Reactions for ER-6-2 Models with Local LCA Groundwater 


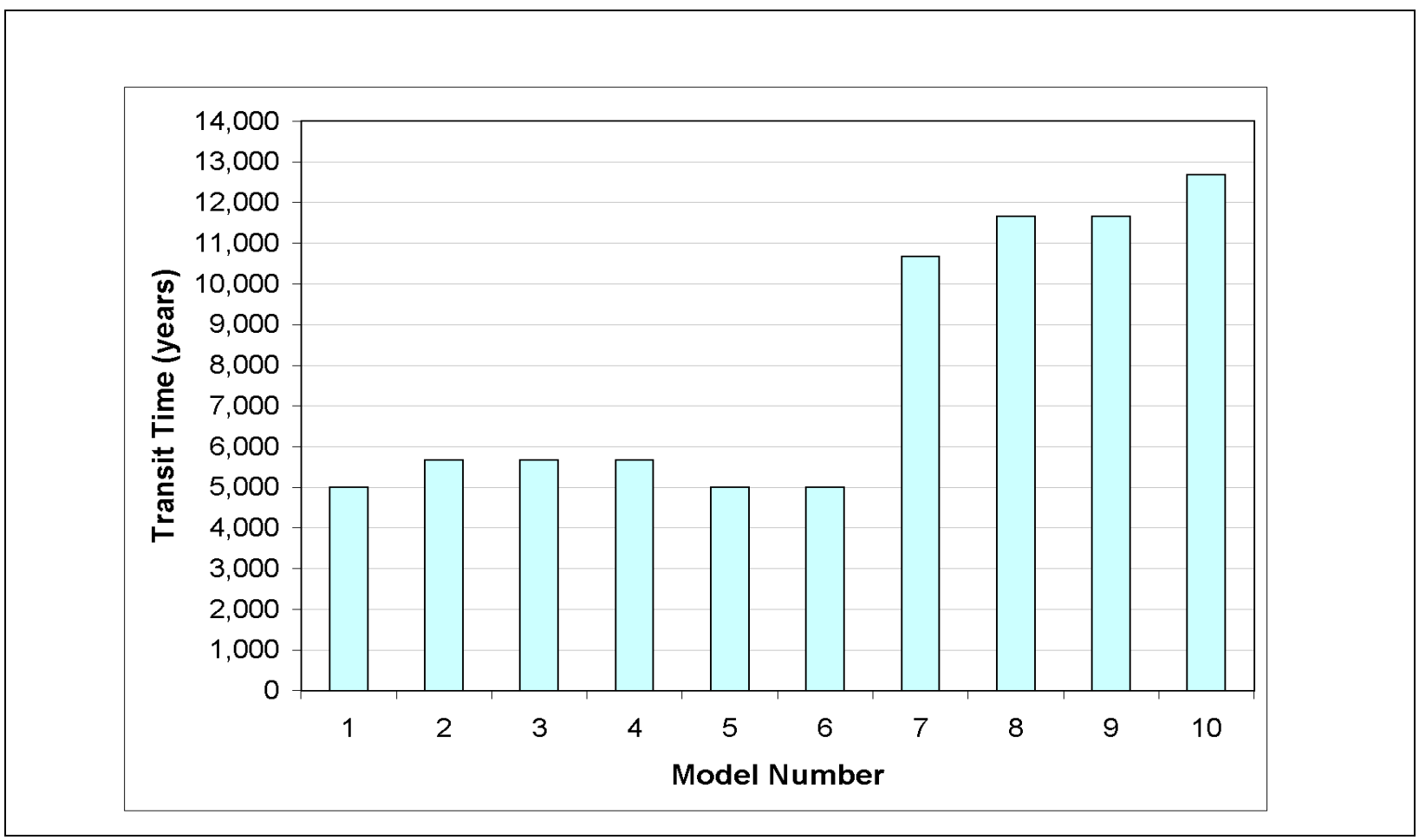

Figure 9-12

Composite Travel Times for ER-6-2 Models with Local LCA Groundwater

5,600 years (Figure 9-12). In models where a UE-1h component is present, travel times range from about 10,500 to 12,500 years. The large increase in travel times that occurs when a UE- $1 \mathrm{~h}$ component is present is caused by the relatively large ${ }^{14} \mathrm{C}$ activity (18 pmc) reported for UE- $1 \mathrm{~h}$, a factor that also made it difficult to calculate positive travel times for PHREEQC models of UE- $1 \mathrm{~h}$.

A second set of PHREEQC models investigates the possibility that ER-6-2 groundwater is derived from a mixture of groundwater from upper Fortymile Wash (HTH-1), local recharge in the Eleana Range (UE-17a), and regional underflow in the LCA (UE-10j-1) (Figures 9-13 and 9-14). The results of these PHREEQC models indicate that groundwater at Well ER-6-2 contains a major HTH-1 component (approximately 55 percent) along with a significant component of groundwater from UE-10j-1 (31 percent) and a smaller percentage of groundwater from UE-17a (14 percent). This result is consistent with the interpretation from the Sr data that groundwater at Well ER-6-2 must include a component of groundwater from the UCCU (UE-17a) with a relatively high $\mathrm{Sr}$ concentration and a relatively low ${ }^{87} \mathrm{Sr} /{ }^{86} \mathrm{Sr}$ ratio in order to account for the offset of ER-6-2 groundwater from a HTH-1/UE-10j-1 mixing line (Figure 9-5). The composite travel times for this set of models are slightly less than 15,000 years (Figure 9-15). 


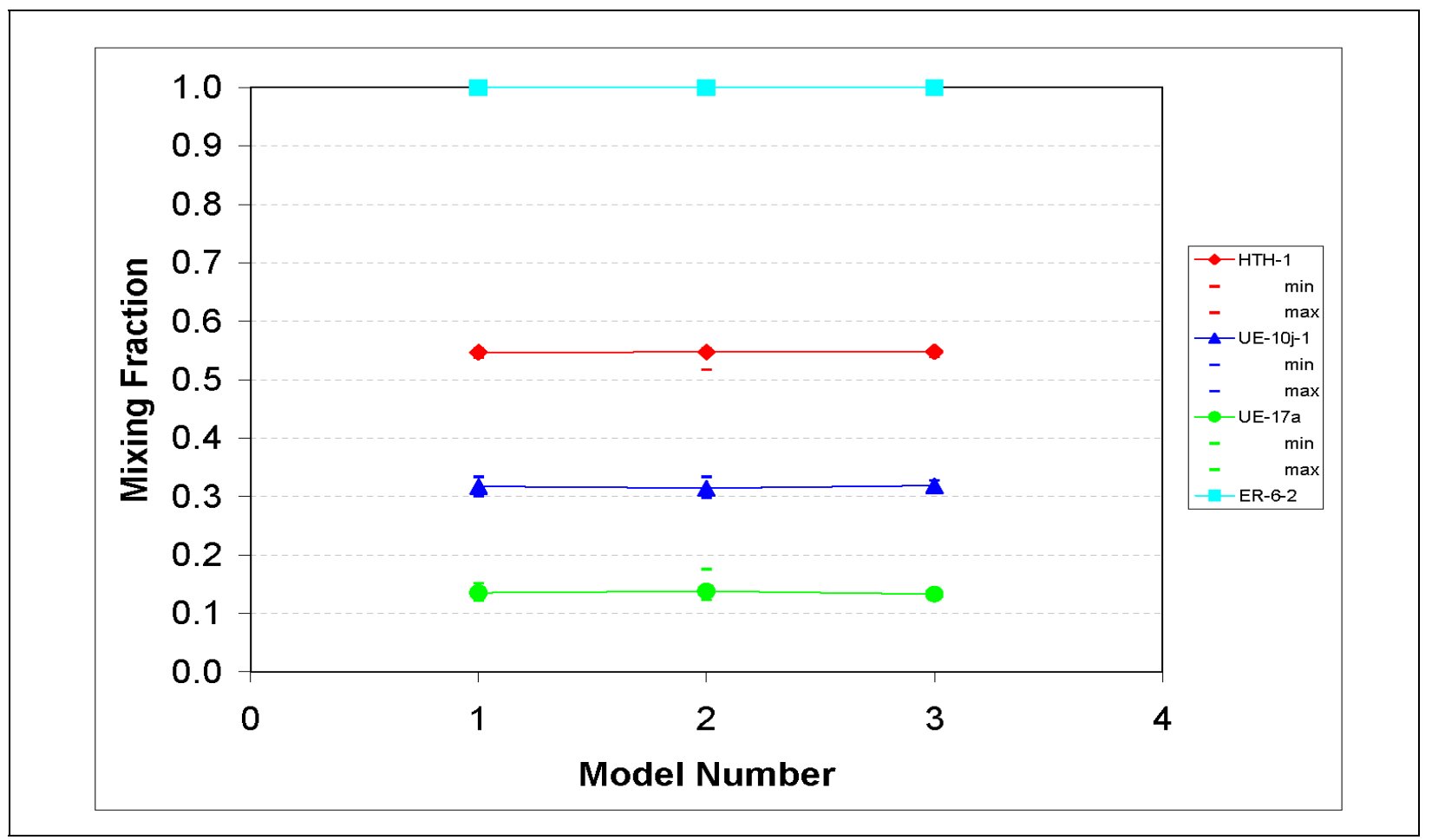

Figure 9-13

Mixing Fractions for ER-6-2 Models with Rainier Mesa and Eleana Range Water

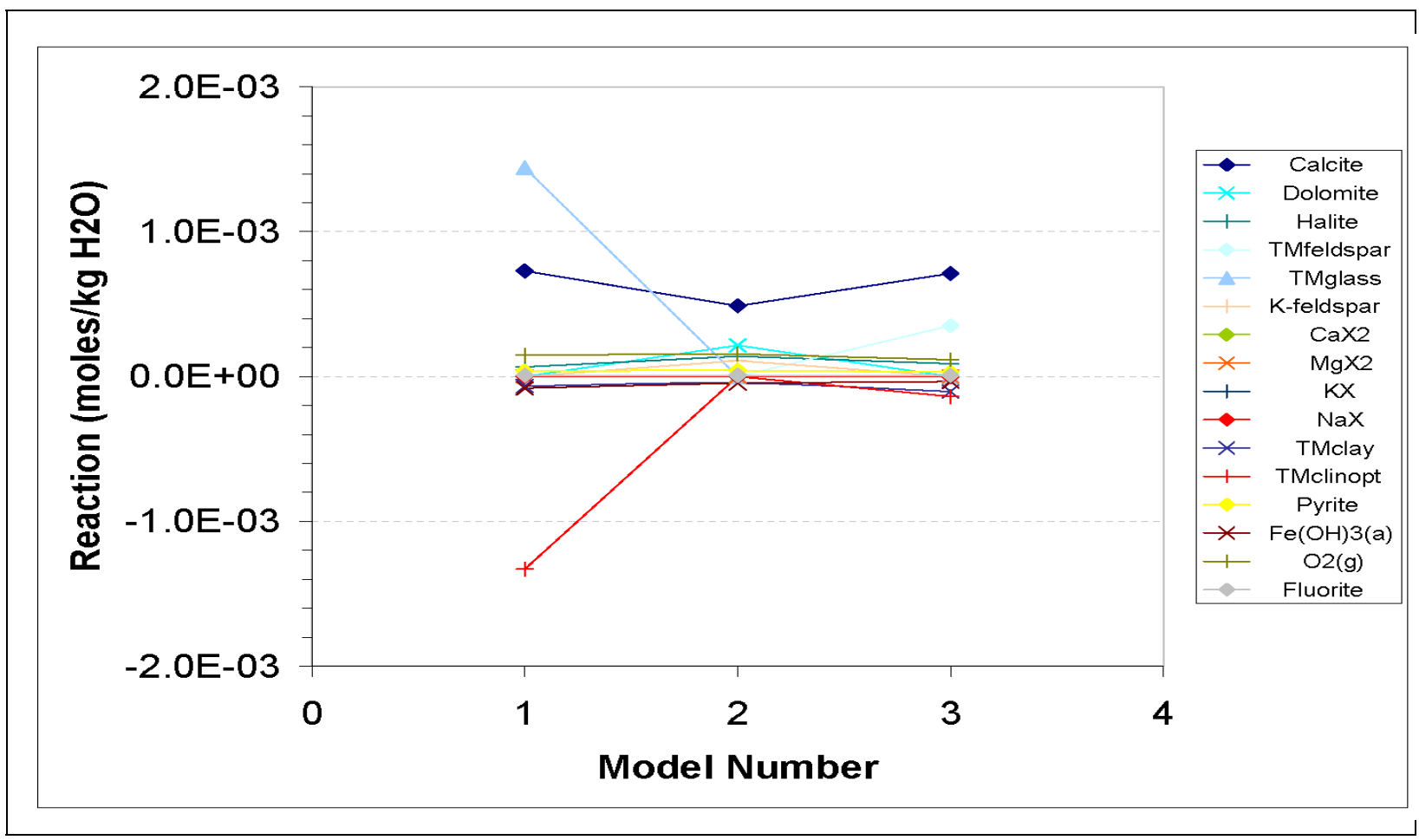

Figure 9-14

Reactions for ER-6-2 Models with Rainier Mesa and Eleana Range Groundwater 


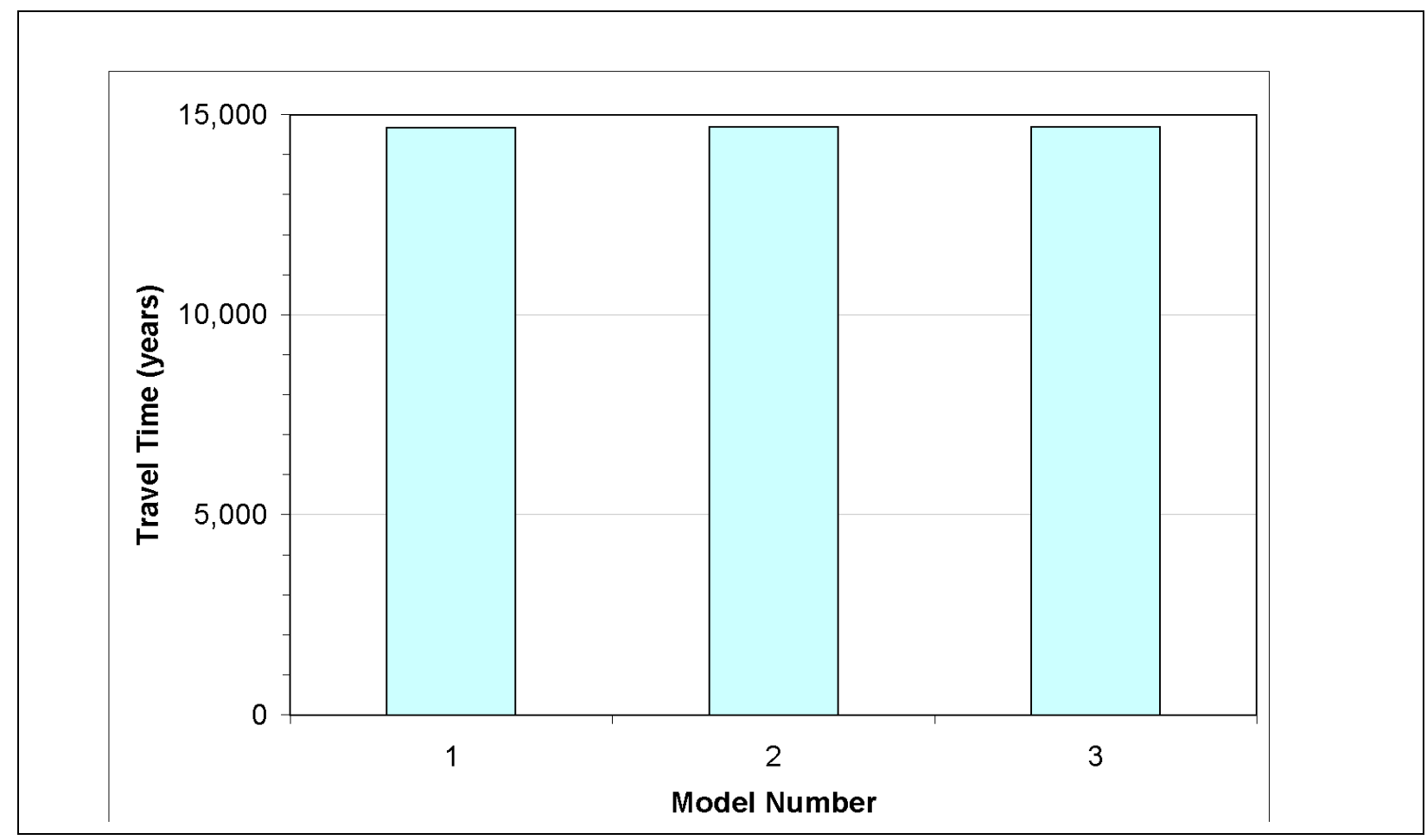

Figure 9-15

\section{Composite Travel Times for ER-6-2 Models with Rainier Mesa and Eleana Range Groundwater}

A third set of models investigates the possibility that groundwater from Mid Valley (UE-14b) mixes with groundwater from the CP Basin (WW-4 and WW-4a), groundwater in the Eleana Range (represented by UE-17a, UE-16d and UE-16f), and regional underflow in the LCA (UE-10j-1) to produce groundwater at ER-6-2 (Figures 9-16 and 9-17). The two models identified by PHREEQC for this set of mixing components suggest that groundwater at ER-6-2 can be derived by mixing groundwater from UE-14b (approximately 59 percent), groundwater from CP Basin at WW-4a (approximately 22 percent), and regional underflow in the LCA from UE-10j-1 (approximately 19 percent). For this set of models, no groundwater flow from either Rainier Mesa or the Eleana Range is required.

The conclusion regarding the origin of groundwater in the LCA at ER-6-2 is that it includes a major component of groundwater that is light in $\delta^{18} \mathrm{O}$ and $\delta \mathrm{D}$ and dilute in $\mathrm{Cl}$ compared to LCA groundwater presently in northern Yucca Flat at UE-10j-1. Several different areas adjacent to Yucca Flat — including Rainier Mesa/Fortymile Wash, the Eleana Range, and Shoshone Mountain — can potentially provide groundwater with these characteristics. However, the PHREEQC models that 


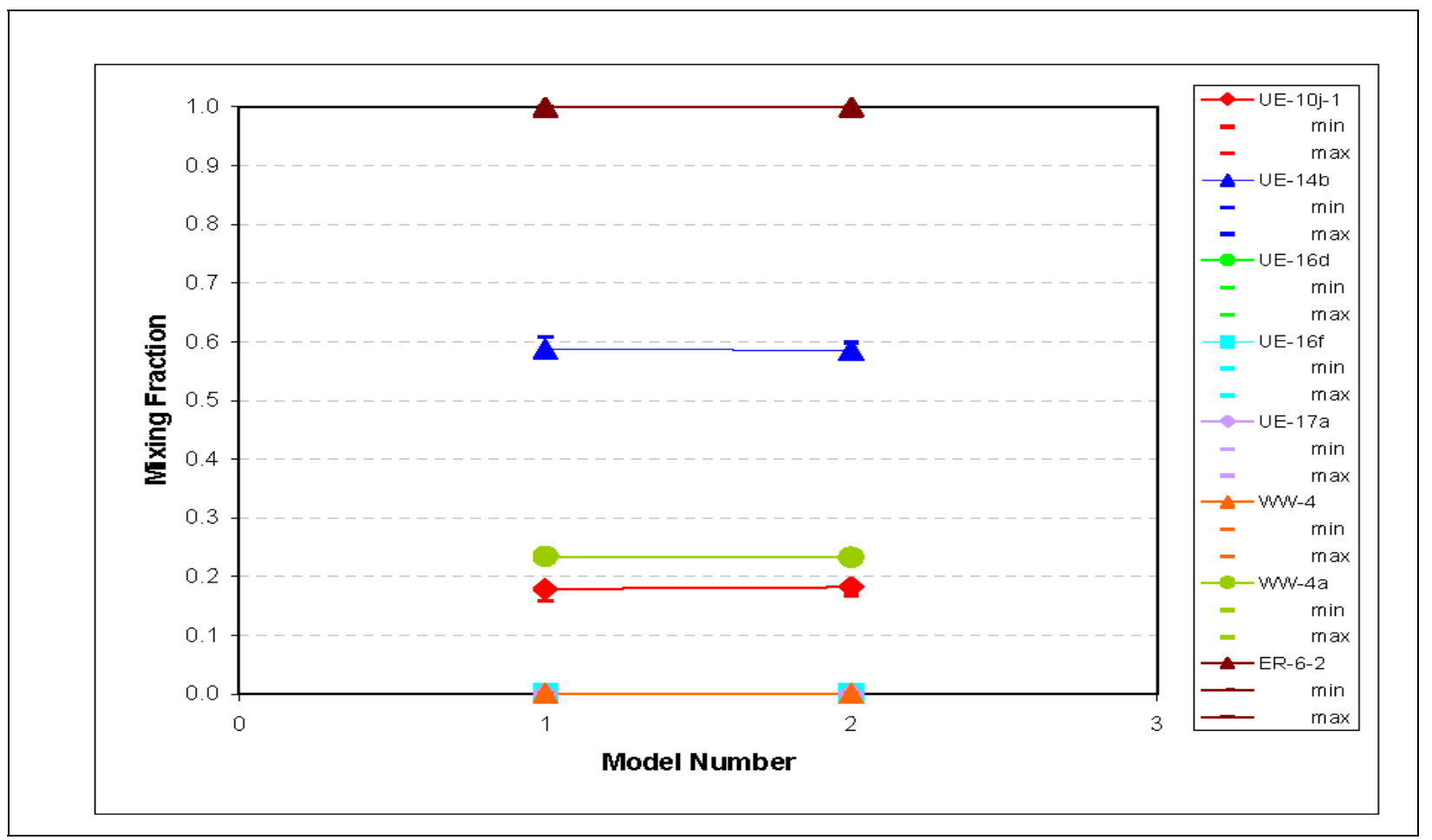

Figure 9-16

Mixing Fractions for ER-6-2 Models with CP Basin and Eleana Range Water

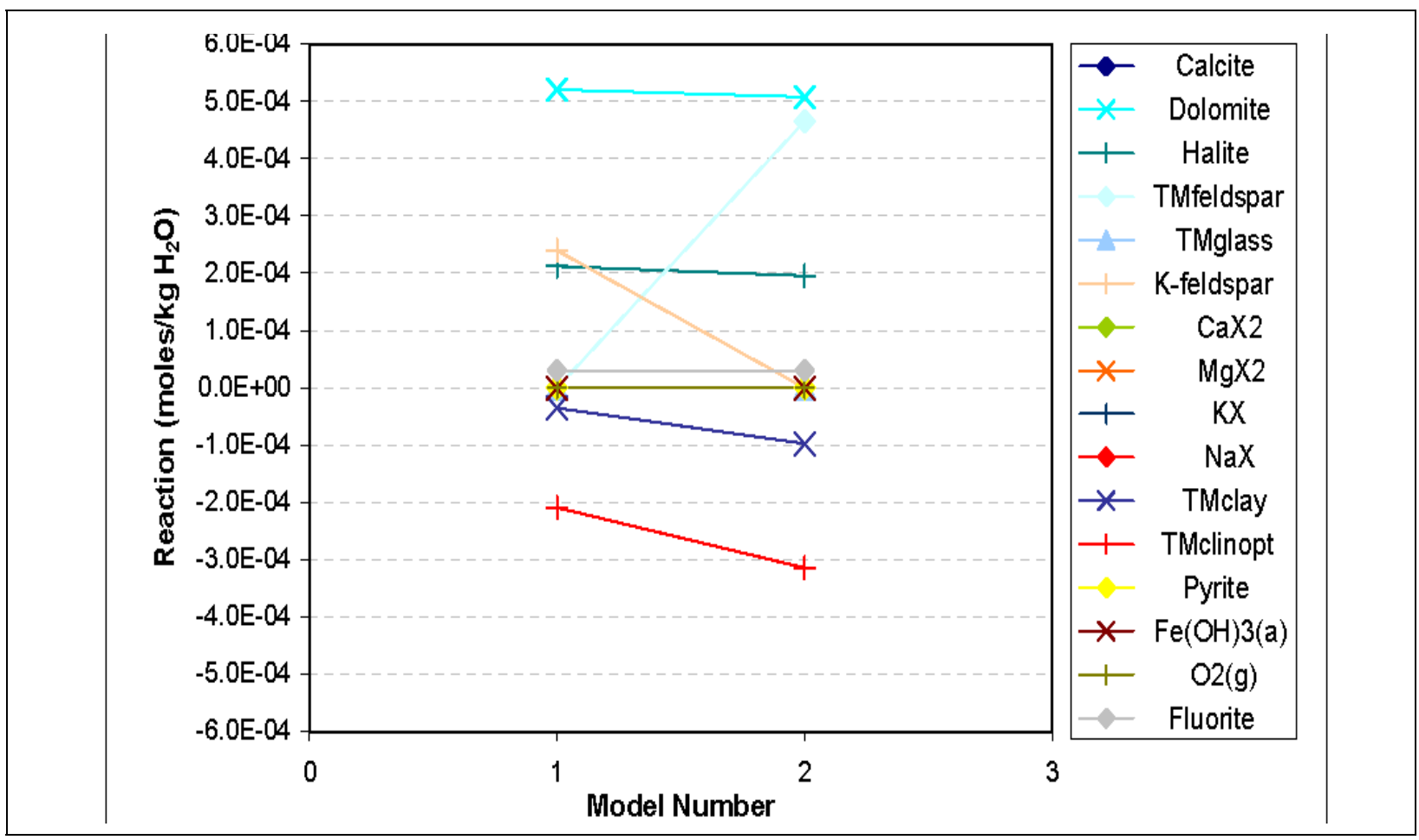

Figure 9-17

Reactions for ER-6-2 Models with CP Basin and Eleana Range Groundwater 
include groundwater from the Eleana Range (UE-17a), upper Fortymile Wash (HTH-1), and northern Yucca Flat (UE-10j-1) are consistent with Sr data from Well ER-6-2. On this basis, these models are preferred relative to the models involving Wells UE-1c, UE-1h and UE-1q. Unfortunately, no ${ }^{87} \mathrm{Sr} /{ }^{86} \mathrm{Sr}$ measurements were available to independently evaluate the models that include UE-14b groundwater using Sr data.

\subsection{Summary}

Analytical mixing models based on conservative tracer data indicate that groundwater in western Yucca Flat is derived predominantly from regional LCA underflow in northern Yucca Flat (as represented by groundwater from UE-10j-1), local recharge from the northern and western margins of the basin, and by groundwater similar to that found in upper Fortymile Wash (represented by Well HTH-1). The $\delta \mathrm{D}$ and $\delta^{18} \mathrm{O}$ of groundwaters in western Yucca Flat span a range of values that are considerably lighter than the values indicated by perched springs or by seeps in the tunnels at Rainier Mesa. To model groundwater compositions with $\delta \mathrm{D}$ and $\delta^{18} \mathrm{O}$ values that are lighter than those found in groundwater at UE-10j-1, it is necessary to consider groundwaters with $\delta \mathrm{D}$ and $\delta^{18} \mathrm{O}$ values that are considerably lighter than those indicated by the spring and seep data. For western Yucca Flat, groundwater from HTH-1 is used, sometimes in conjunction with modern spring data, to obtain the relatively light $\delta \mathrm{D}$ and $\delta^{18} \mathrm{O}$ values observed in groundwater from this area. Although groundwater from HTH-1 is indicated to be present at many wells in western Yucca Flat, its presence may or may not indicate that groundwater from upper Fortymile Wash flows into Yucca Flat. An alternative explanation may be that paleo-recharge in Yucca Flat was considerably lighter in $\delta \mathrm{D}$ and $\delta^{18} \mathrm{O}$ than modern spring data suggest. Although data from Yucca Flat does not show a clear trend between either $\delta \mathrm{D}$ or $\delta^{18} \mathrm{O}$ and time (as indicated by ${ }^{14} \mathrm{C}$ data), stable isotope profiles from the unsaturated zone at Yucca Mountain that show that isotope values become lighter with increasing depth (Yang et al., 1998). This observation, combined with longer-term records from calcite deposits at Devil's Hole at Ash Meadows (Winograd et al., 1992), and analysis of temporal trends in groundwater $\delta^{18} \mathrm{O}$ in the Yucca Mountain area (Benson and Klieforth, 1989), indicates that isotopic values were lighter during cooler climates such as those that existed at the end of the Pleistocene. Therefore, the presence of HTH-1 groundwater in a model may indicate the flow of groundwater from upper Fortymile Wash into Yucca Flat, or it may indicate the presence of paleo-recharge derived from local sources during the last pluvial period $(>10,000$ years ago). 
Well UE-2ce, which was completed in the LCA in western Yucca Flat and near the Nash underground nuclear test, was modeled as a mixture of local recharge and groundwater from northern Yucca Flat. Conservative tracers and PHREEQC models were in general agreement that local recharge was a significant component (up to 80 percent) of LCA groundwater at UE-2ce. However, chemical models using ER-12-1 as one of the local recharge components were unsuccessful because of high $\mathrm{SO}_{4}$ concentrations in ER-12-1. The NETPATH models incorporating water-rock reactions were unsuccessful because of excessive dissolution and/or precipitation of various minerals beyond specified uncertainty limits. Groundwater travel times to UE-2ce could not be calculated because the ${ }^{14} \mathrm{C}$ data for UE-2ce was affected by nearby underground nuclear testing. Strontium data were also lacking for UE-2ce.

Mixing models for ER-2-1, completed in the volcanic confining unit, met with only partial success. The isotopic signature of groundwater at ER-2-1, along with other hydrologic information, suggest that groundwater in the volcanic confining unit in the vicinity of ER-2-1 may be composed of groundwater recharge that occurred under paloclimatic conditions. The PHREEQC and conservative tracer models suggest that groundwater at ER-2-1 is composed predominantly of groundwater similar to that found in the volcanic aquifer at HTH-1 mixed with smaller amounts of local recharge as characterized by modern spring compositions. The NETPATH models incorporating water-rock reactions were unsuccessful because of excessive dissolution and/or precipitation of various minerals beyond specified uncertainty limits. Groundwater travel times could not be calculated because of a lack of ${ }^{14} \mathrm{C}$ data for local recharge.

Geochemical models for Well UE-1h were also only partially successful. Lower carbonate aquifer water at UE-1h in western Yucca Flat has a unique geochemical signature relative to other LCA groundwater in the rest of Yucca Flat. Well UE-1h has high $\mathrm{Cl}$ and $\mathrm{Sr}$ concentrations, low $\mathrm{SO}_{4}$ concentrations, and low ${ }^{87} \mathrm{Sr} /{ }^{86} \mathrm{Sr}, \delta^{13} \mathrm{C}, \delta \mathrm{D}$, and $\delta^{18} \mathrm{O}$ values. Because of its unique chemical and isotopic composition, mixing models for UE-1h based on conservative tracer could only be developed if $\mathrm{Cl}$ were excluded. No NETPATH models incorporating water-rock reactions were successful, and the PHREEQC models required an adjustment to the very light $\delta^{13} \mathrm{C}$ value and low $\mathrm{SO}_{4}$ concentration at UE-1h. Once these adjustments were made, PHREEQC produced mixing models involving HTH-1 and UE-16d groundwater that were in good agreement with interpretations from Sr data. These models indicated UE-1h groundwater could originate from subequal mixtures and HTH-1 
groundwater and groundwater from the UCCU in western Yucca Flat. The absence of an LCA component from northern Yucca Flat (UE-10j) or elsewhere at Well UE-1h indicates that this well may be located in an isolated structural block that is disconnected from the regional LCA in Yucca Flat. Meaningful groundwater travel times to UE-1h could not be calculated, either because the true end-members have not been identified or because of problems with the ${ }^{14} \mathrm{C}$ data from UE-1h.

Well ER-6-2 is an LCA well in southwestern Yucca Flat that produces groundwater chemically similar to other Yucca Flat LCA groundwater. All of the geochemical models were in relatively good agreement that ER-6-2 groundwater can be produced by mixing waters from the LCA in northern Yucca Flat, local paleo-recharge groundwater like HTH-1, and UCCU groundwater - although the proportions vary somewhat between the different modeling techniques. Composite groundwater travel times for this mixture average about 15,000 years. Conservative tracer and PHREEQC models suggest that ER-6-2 can also be produced by mixing other southwestern LCA groundwater but these models are either not supported by Sr data, or the necessary Sr data to evaluate these models are lacking. 


\section{0 evaluation of West-Central flow Paths}

Wells TW-D and UE-1q are both located on the west side of the Topgallant Fault in the west-central part of Yucca Flat, and are completed in the LCA. These waters have relatively low stable isotope values and dilute $\mathrm{Cl}$ concentrations compared to other LCA waters in western Yucca Flat. However, their most striking feature is their ${ }^{36} \mathrm{Cl} / \mathrm{Cl}$ ratios, which are unusually high for LCA groundwater. Figure 10-1 shows a plot of ${ }^{36} \mathrm{Cl} / \mathrm{Cl}$ versus $1 / \mathrm{Cl}$ values for groundwater samples from Yucca Flat and surrounding areas. Mixing trends are linear on this graph. Wells TW-D and UE-1q have the highest ${ }^{36} \mathrm{Cl} / \mathrm{Cl}$ ratios of any LCA groundwater shown on this plot. The only other LCA sample with a similar ratio is UE-1c, which is located only a few $\mathrm{km}$ to the southwest of TW-D and UE-1q.

The high ${ }^{36} \mathrm{Cl} / \mathrm{Cl}$ ratios in these waters are likely caused by mixing with high ${ }^{36} \mathrm{Cl} / \mathrm{Cl}$ water from one of the other HSUs. Although the data in Figure 10-1 include only three samples from volcanic HSUs (ER-2-1, TW-B, and HTH-1), all three samples are uniformly high in ${ }^{36} \mathrm{Cl} / \mathrm{Cl}$ (ranging from 7.19 to $\left.9.68 \times 10^{-13}\right)$. Similarly high ratios are also observed in the alluvial aquifer at UE-1a $\left(8.63 \times 10^{-13}\right)$ and in the UCCU at ER-12-1 $\left(7.80 \times 10^{-13}\right)$. These ratios are all considerably higher than the modern atmospheric ratio for southern Nevada (approximately 5 x 10 10; Fabryka-Martin et al., 1993) and may reflect groundwater recharge during the last pluvial period (late Pleistocene), during which time the atmospheric production of ${ }^{36} \mathrm{Cl}$ was greater because of the reduced strength in the earth's magnetic field (Mazaud et al., 1991). This interpretation was previously used to explain the high ${ }^{36} \mathrm{Cl} / \mathrm{Cl}$ ratios in Frenchman Flat groundwater samples (Tyler et al., 1996).

If it is assumed that the elevated ${ }^{36} \mathrm{Cl} / \mathrm{Cl}$ ratios in TW-D and UE-1q reflect mixing with groundwater from one of these other HSUs, then two independent mixing pathways are conceivable: (1) lateral mixing along a flow path, and (2) vertical mixing caused by leakage from overlying units. The proximity of TW-D and UE-1q to the major north-south trending faults near the center of the basin makes the second alternative a strong possibility. Unfortunately, there are no means of directly testing the vertical transport hypothesis, because there are no wells completed in the alluvial or volcanic aquifers in the immediate vicinity of TW-D or UE-1q. Note, however, that UE-1c is 


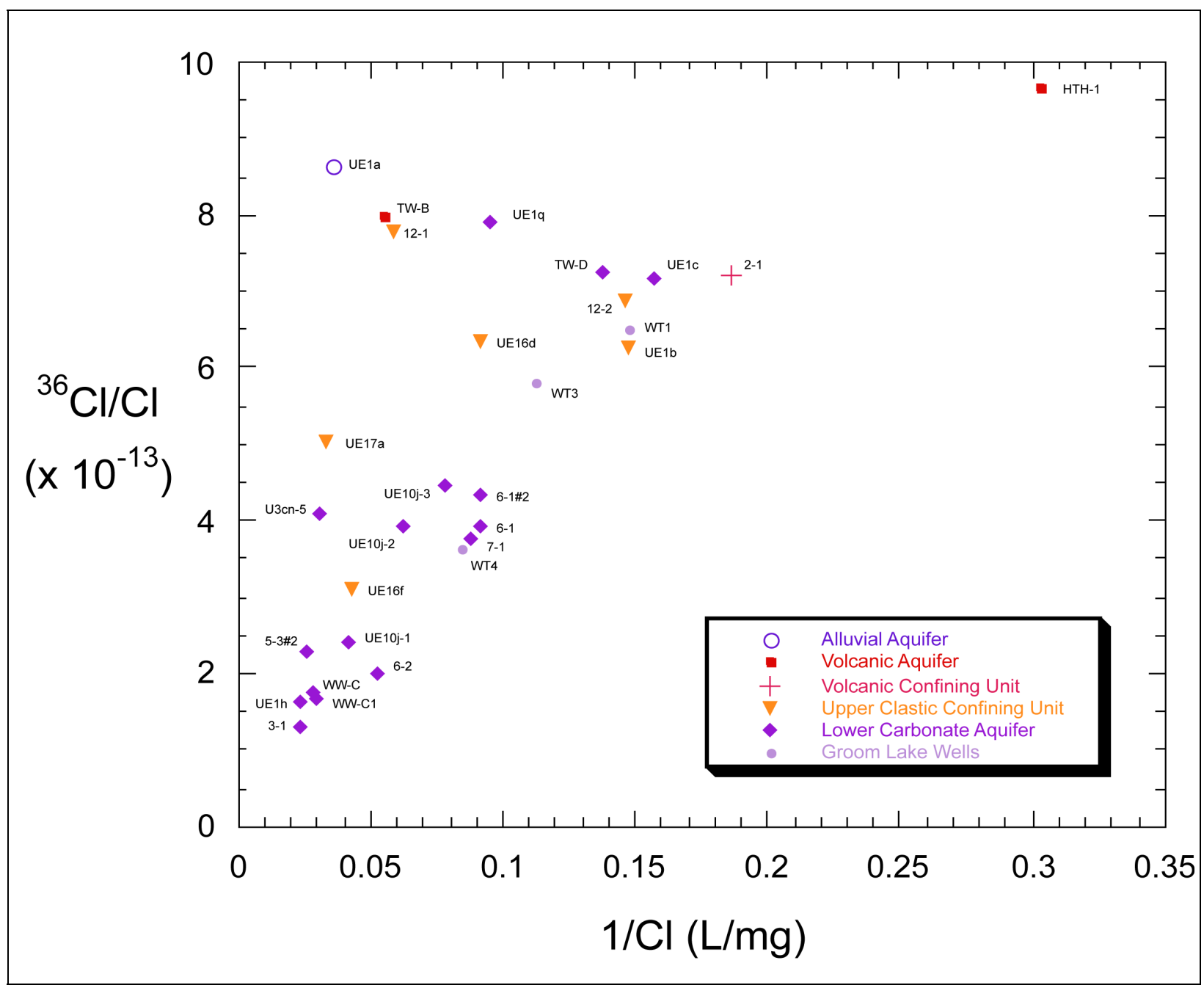

Figure 10-1

\section{Plot of ${ }^{36} \mathrm{Cl} / \mathrm{Cl}$ Ratios Versus Inverse CI Values for Groundwater in Yucca Flat and Surrounding Areas}

completed in both the volcanic aquifer and the LCA3 and has a ${ }^{36} \mathrm{Cl} / \mathrm{Cl}$ ratio very similar to that of TW-D and UE-1q. This may reflect vertical mixing of a high ${ }^{36} \mathrm{Cl}$ groundwater from the volcanic unit and a low ${ }^{36} \mathrm{Cl}$ groundwater from the LCA, but again, no clear proof is available to demonstrate that this is the case.

In this chapter, various mixing models are tested for TW-D and UE-1q using representative groundwater compositions from western and northern Yucca Flat. In some cases, one or more of the compositions used in a model are hypothetical "surrogates" for an expected mixing component. For example, ER-2-1 groundwater is used as a representative VCU component in some mixing scenarios. 
While it is unlikely that any ER-2-1 groundwater is actually present at TW-D or UE-1q, compositionally similar groundwater may occur in the VCU that overlies the LCA at these sites.

\subsection{Geochemical Modeling of Wells TW-D and UE-1q}

\subsubsection{Conservative Tracer Models for Wells TW-D and UE-1q}

A simple two-component mixing model can be developed for TW-D using ER-2-1 (VCU water) and UE-10j-1 (LCA water):

$\begin{array}{cccc} & \text { ER-2-1 } & \text { UE-10j-1 } \\ \delta \mathrm{D} & 95.1 & 4.9 & \\ \delta^{18 \mathrm{O}} & 86.7 & 13.3 \\ \mathrm{Cl} & 89.7 & 10.3 & \end{array}$

Well ER-2-1 clearly dominates this model (87 to 95 percent of the mix). Adding local perched water to the model (Captain Jack Spring) has almost no influence on the results:

$\begin{array}{cccccc} & \text { ER-2-1 } & + & \text { UE-10j-1 } & + & \text { Captain Jack Spring } \\ \delta \mathrm{D} & 95.3 & 4.2 & 5 & \text { TW-D } \\ \delta^{18} \mathrm{O} & 88.4 & 10.3 & 1.3 \\ \mathrm{Cl} & 88.4 & 10.3 & 1.3\end{array}$

Well HTH-1 is also a useful end-member for testing these models because it has very low Cl; very high ${ }^{36} \mathrm{Cl} / \mathrm{Cl}$ ratio; and like ER-2-1, it may represent groundwater recharged under paloclimatic conditions. It has the highest ${ }^{36} \mathrm{Cl} / \mathrm{Cl}$ ratio and lowest $\mathrm{Cl}$ concentration of any Yucca Flat groundwater (Figure 10-1). A reasonably good model was developed for TW-D using a combination of HTH-1, UE-10j-1 and perched water from Captain Jack Spring:

$\begin{array}{ccccc} & \mathrm{HTH}-1 & +\mathrm{UE}-10 \mathrm{j}-1 & + & \text { Captain Jack Spring } \\ \delta \mathrm{D} & 67.7 & 18.0 & 14.3 \\ \delta^{18} \mathrm{O} & 60.8 & 16.1 & 23.1 \\ \mathrm{Cl} & 63.2 & 16.8 & 20.0\end{array}$

The volcanic aquifer component from HTH-1 again dominates this model (61 to 68 percent), but less so than in the ER-2-1 model. The relative amounts of LCA water from UE-10j-1 (16 to 18 percent) and perched water from Captain Jack Spring (14 to 23 percent) are substantially increased over the ER-2-1 model. 
Models that are similar to those developed for TW-D can also be created for UE-1q, although ER-2-1 can no longer be used as the volcanic HSU end-member because its $\delta^{18} \mathrm{O}$ value is isotopically heavier (less negative) than the value for UE-1q (Figure 7-1). The following models are more or less identical in terms of their outcome.

\begin{tabular}{|c|c|c|c|c|c|c|c|}
\hline & $\mathrm{HTH}-1$ & + & UE-10j-1 & + & Captain Jack Spring & $=$ & UE-1q \\
\hline$\delta D$ & 63.6 & & 34.5 & & 1.9 & & \\
\hline$\delta^{18} \mathrm{O}$ & 64.5 & & 35.1 & & 0.4 & & \\
\hline $\mathrm{Cl}$ & 64.1 & & 34.8 & & 1.1 & & \\
\hline & $\mathrm{HTH}-1$ & + & UE-10j-1 & + & Oak Spring & $=$ & UE-1q \\
\hline$\delta \mathrm{D}$ & 63.8 & & 34.5 & & 1.7 & & \\
\hline$\delta^{18} \mathrm{O}$ & 65.6 & & 32.7 & & 1.7 & & \\
\hline $\mathrm{Cl}$ & 63.8 & & 34.5 & & 1.7 & & \\
\hline & $\mathrm{HTH}-1$ & + & UE-10j-1 & + & UE-16d & $=$ & UE-1q \\
\hline$\delta \mathrm{D}$ & 64.4 & & 34.5 & & 1.1 & & \\
\hline$\delta^{18} \mathrm{O}$ & 64.7 & & 34.7 & & 0.6 & & \\
\hline $\mathrm{Cl}$ & 63.7 & & 34.2 & & 2.1 & & \\
\hline
\end{tabular}

In these models, the HTH-1 mixing fraction varies from only 64 to 66 percent, and overlaps with the range of values in the equivalent TW-D model. The LCA component from UE-10j-1 also shows little variation in its mixing ratio (33 to 35 percent), but is approximately double the amount predicted by the TW-D model. The perched water component is consistently small (less than 1 to 2 percent), and though UE-16d groundwater is not perched, it is almost certainly locally derived from northern Shoshone Mountain.

\subsection{NETPATH Modeling Results}

Three different NETPATH models incorporating water-rock reactions were tested for TW-D (Table 10-1). Only one of the models produced valid results within the specified uncertainty limits. This model - incorporating isotopically low volcanic groundwater like HTH-1, northern Yucca Flat LCA water, and local recharge - was in good agreement with the corresponding conservative tracer model. This model suggests that TW-D groundwater is composed of a significant portion of volcanic groundwater with a lesser amount of local recharge and a small portion of northern Yucca Flat LCA groundwater. Due to a lack of $\delta^{13} \mathrm{C}$ and ${ }^{14} \mathrm{C}$ data for local recharge at Captain Jack Spring, groundwater travel times could not be calculated. A variation of this model was also successful when local recharge was an insignificant contributor to the mixture. This model, without Captain Jack Spring, produced composite travel times from 13,100 to 13,200 years. The other two models 
Table 10-1

Results of NETPATH Models for Test Well - D

\begin{tabular}{|c|c|c|c|c|c|c|c|}
\hline \multirow{2}{*}{\multicolumn{3}{|c|}{ End-Member Percentage }} & \multicolumn{4}{|c|}{ Measured (Modeled) Composition of TW-D } & \multirow{2}{*}{$\begin{array}{c}\text { Travel Time } \\
\text { (Years) }\end{array}$} \\
\hline & & & \multirow{2}{*}{$\frac{(-108)^{\mathrm{a}}}{\delta \mathbf{D}(\text { permil) }}$} & $(-14.2)^{\mathrm{a}}$ & \multirow{2}{*}{$\frac{(7.3)^{\mathrm{a}}}{\mathrm{Cl}(\mathrm{mg} / \mathrm{L})}$} & \multirow{2}{*}{$\frac{(-5.5)^{\mathrm{a}}}{\delta^{13} \mathrm{C} \text { (permil) }}$} & \\
\hline ER-2-1 & $\begin{array}{c}\text { UE-10j-1 } \\
\text { Reasonable }\end{array}$ & Models & & $\delta^{18} \mathrm{O}$ (permil) & & & \\
\hline ER-2-1 & UE-10j-1 & $\begin{array}{l}\text { Captain Jack } \\
\text { Spring }\end{array}$ & & & & & \\
\hline & Reasonable & Models & & & & & \\
\hline HTH-1 & UE-10j-1 & $\begin{array}{c}\text { Captain Jack } \\
\text { Spring }\end{array}$ & & & & & \\
\hline 83 & 17 & 0 & -109 & -14.7 & 6.8 & -5.7 to -5.6 & $\begin{array}{c}13,100 \text { to } \\
13,200\end{array}$ \\
\hline $49-68$ & $15-16$ & $16-36$ & -108 to -106 & -14.4 to -13.9 & 6.8 to 7.4 & * & * \\
\hline
\end{tabular}

. ${ }^{a}$ Average measured value reported in Appendix A.

${ }^{*} \delta^{13} \mathrm{C}$ could not be modeled due to the lack of $\delta^{13} \mathrm{C}$ data for Oak Spring and Cliff Spring.

identified by conservative tracers were unsuccessfully modeled by NETPATH when incorporating water-rock reactions because of excessive precipitation of $\mathrm{SiO}_{2}$, and combinations of dissolution or precipitation of feldspars and glass with dissolution or precipitation of clays and zeolites.

Four different combinations of end members were modeled with NETPATH for UE-1q (Table 10-2). Compared to the conservative tracer models, less LCA groundwater, and more local recharge was required in the NETPATH models, except in the case where UE-16d was a mixing component. For these models, groundwater travel times could not be calculated because of a lack of $\delta^{13} \mathrm{C}$ and ${ }^{14} \mathrm{C}$ data for the local recharge component. For the mixture of isotopically light volcanic water (HTH-1) with northern Yucca Flat LCA groundwater and UCA groundwater from UE-16d (zero percent contribution), NETPATH calculated composite groundwater travel times ranged from 5,500 to 5,600 years.

One other model, substituting LCA groundwater from UE-2ce for UE-10j-1, also produced successful models. This model required slightly less volcanic groundwater and slightly more LCA groundwater than the model with UE-10j-1. Groundwater travel times could not be calculated due to a lack of $\delta^{13} \mathrm{C}$ and ${ }^{14} \mathrm{C}$ data. 
Table 10-2

Results of NETPATH Models for Well UE-1q

\begin{tabular}{|c|c|c|c|c|c|c|c|}
\hline \multirow{2}{*}{\multicolumn{3}{|c|}{ End-Member Percentage }} & \multicolumn{4}{|c|}{ Measured (Modeled) Composition of UE-1q } & \multirow{2}{*}{$\begin{array}{l}\text { Travel Time } \\
\text { (Years) }\end{array}$} \\
\hline & & & $(-108)^{a}$ & $(-14.5)^{\mathrm{a}}$ & $(11)^{\mathrm{a}}$ & $(-5.5)^{\mathrm{a}}$ & \\
\hline HTH-1 & UE-10j-1 & \begin{tabular}{|c|} 
Captain \\
Jack Spring
\end{tabular} & $\delta \mathbf{D}$ (permil) & $\delta^{18} \mathrm{O}$ (permil) & $\mathrm{Cl}(\mathrm{mg} / \mathrm{L})$ & $\delta^{13} \mathrm{C}$ (permil) & \\
\hline $69-75$ & $11-12$ & $14-20$ & -109 to -107 & -14.5 to -14.2 & 5.9 to 6.3 & * & * \\
\hline HTH-1 & UE-10j-1 & Oak Spring & & & & & \\
\hline $36-75$ & $8-11$ & $14-56$ & -109 to -105 & -14.5 to -13.6 & 6.1 to 8.0 & * & * \\
\hline HTH-1 & UE-10j-1 & UE-16d & & & & & \\
\hline $87-88$ & $12-13$ & 0 & -110 & -14.8 & 5.8 to 6.0 & -6.2 to -6.1 & 5,500 to 5,600 \\
\hline HTH-1 & UE-2ce & Oak Spring & & & & & \\
\hline 44 & 26 & 20 & -105 & -13.7 & 8.1 & * & * \\
\hline
\end{tabular}

${ }^{\text {a }}$ Average measured value reported in Appendix $\mathrm{A}$.

${ }^{*} \delta^{13} \mathrm{C}$ could not be modeled due to the lack of $\delta^{13} \mathrm{C}$ data for Oak Spring and Cliff Spring.

\subsection{PHREEQC Models of High ${ }^{36} \mathrm{Cl}$ LCA Groundwater in West-Central Yucca Flat}

The PHREEQC models confirm that conservative tracer models for TW-D are feasible when reactive species are included (Figures 10-2 to 10-5). Mixing percentages for groundwater from either HTH-1 (50 to 70 percent) or ER-2-1 groundwater (approximately 75 percent), groundwater from Captain Jack Spring (15 to 40 percent), and groundwater from UE-10j-1 (10 to 20 percent) are in good agreement with the percentages estimated with the conservative tracer models. No halite is dissolved in the models, a result that is consistent with the high ${ }^{36} \mathrm{Cl} / \mathrm{Cl}$ ratio in groundwater at TW-D. No ${ }^{36} \mathrm{Cl} / \mathrm{Cl}$ data were available from Captain Jack Spring to test the mixing models for consistency with the ${ }^{36} \mathrm{Cl} / \mathrm{Cl}$ versus $\mathrm{Cl}$ data shown in Figure 10-1. However, the inverse models for $\mathrm{TW}-\mathrm{D}$ involving $\mathrm{HTH}-1$ would require a ${ }^{36} \mathrm{Cl} / \mathrm{Cl}$ ratio of approximately $15 \times 10^{-13}$ at Captain Jack Spring to match the ${ }^{36} \mathrm{Cl} / \mathrm{Cl}$ ratio at TW-D, whereas the inverse models for TW-D involving ER-2-1 would require a ${ }^{36} \mathrm{Cl} / \mathrm{Cl}$ ratio of approximately $17.5 \times 10^{-13}$ at Captain Jack Spring.

Groundwater ${ }^{36} \mathrm{Cl} / \mathrm{Cl}$ ratios as high as these calculated values have not been measured except where contamination from weapons tests has occurred, a consideration that implies other factors, such as uncertainty in $\mathrm{Cl}$ concentrations for dilute groundwater such as HTH-1, would need to be considered to successfully model the ${ }^{36} \mathrm{Cl} / \mathrm{Cl}$ ratio at TW-D.

Similarly elevated ${ }^{36} \mathrm{Cl} / \mathrm{Cl}$ ratios have been observed in young groundwater samples from other locations in southern Nevada. For example, a ${ }^{36} \mathrm{Cl} / \mathrm{Cl}$ ratio of $12 \times 10^{-13}$ was observed at 


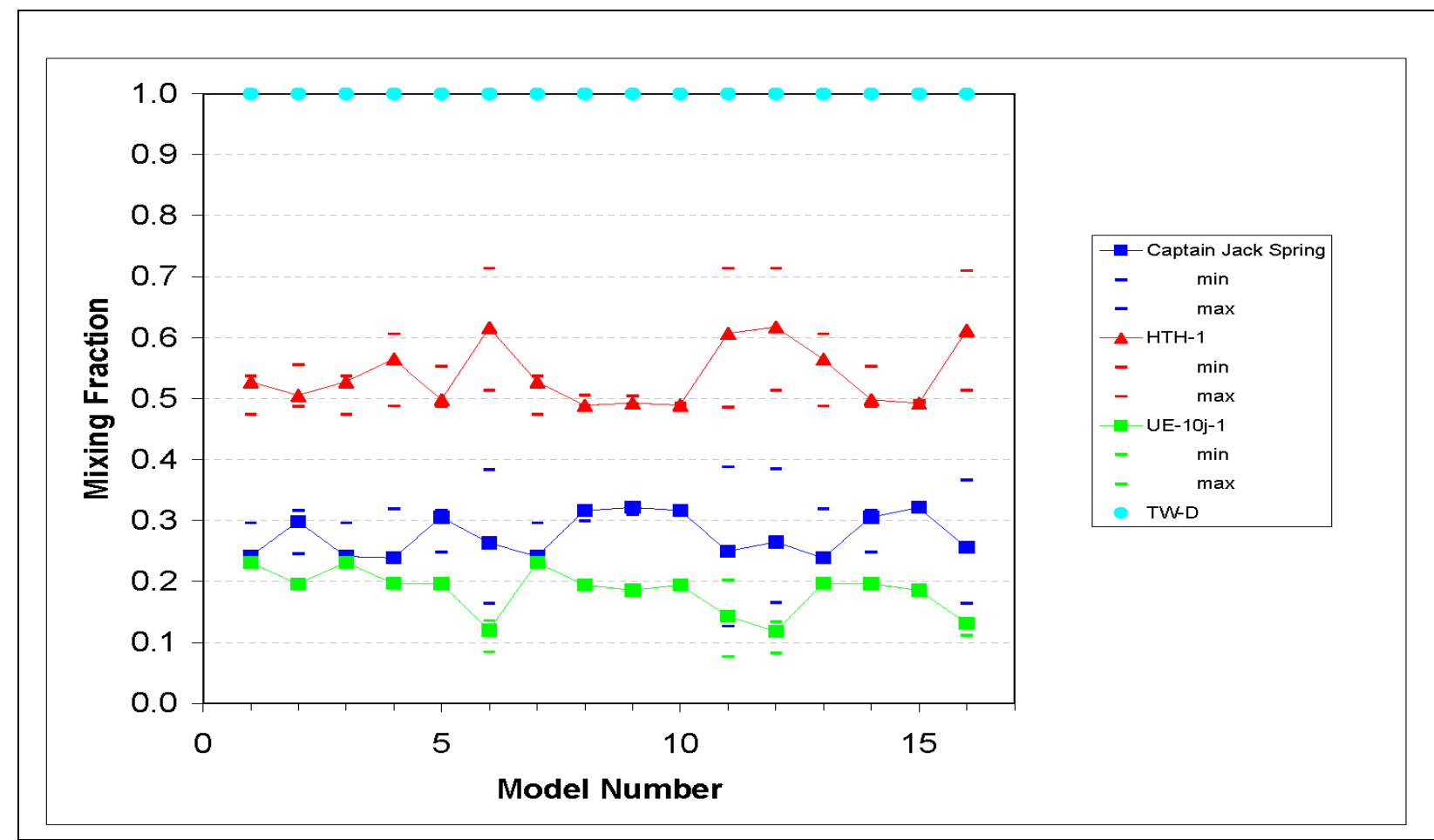

Figure 10-2

Mixing Fractions for TW-D Models with HTH-1 Groundwater

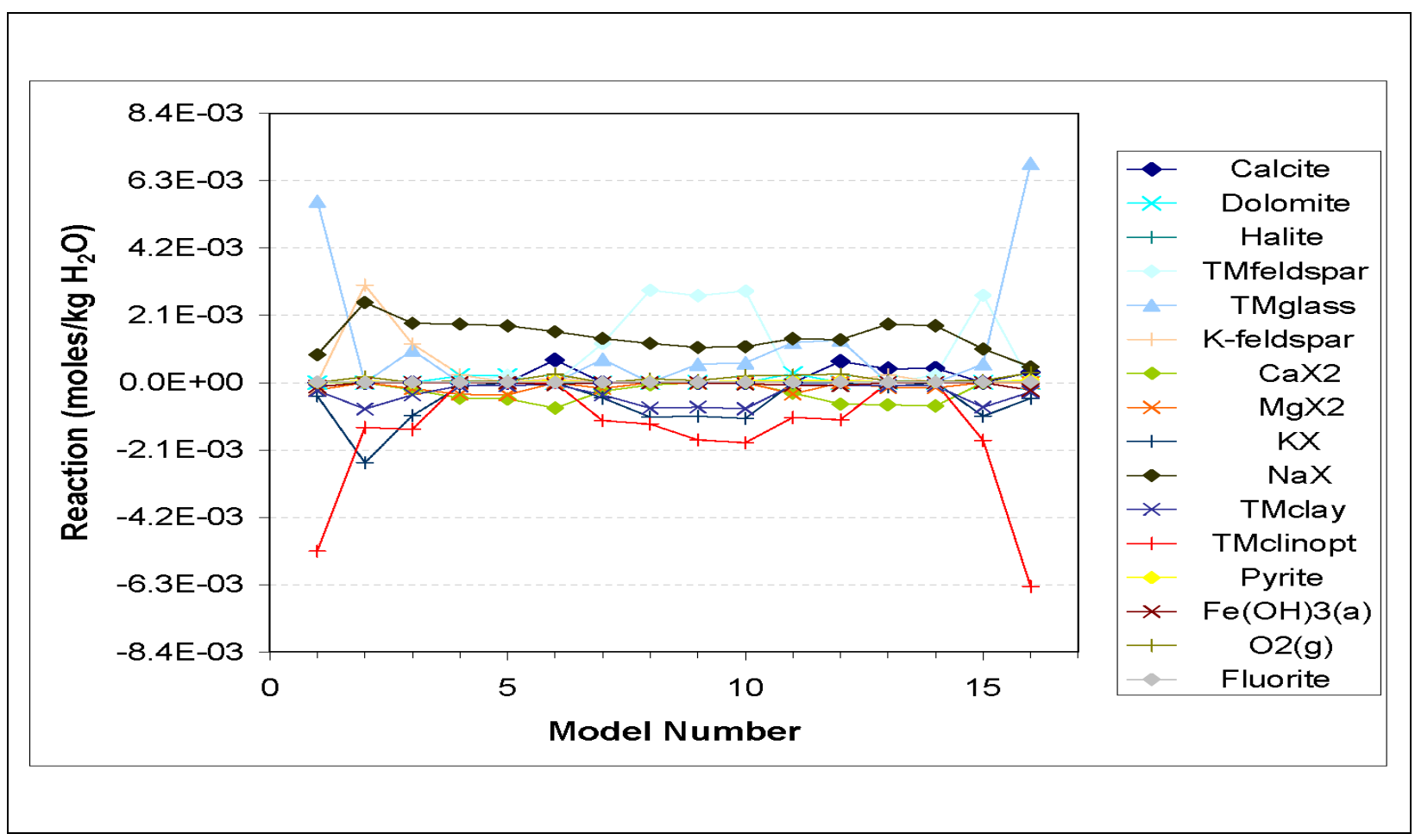

Figure 10-3

Reactions for TW-D Models with HTH-1 Groundwater 


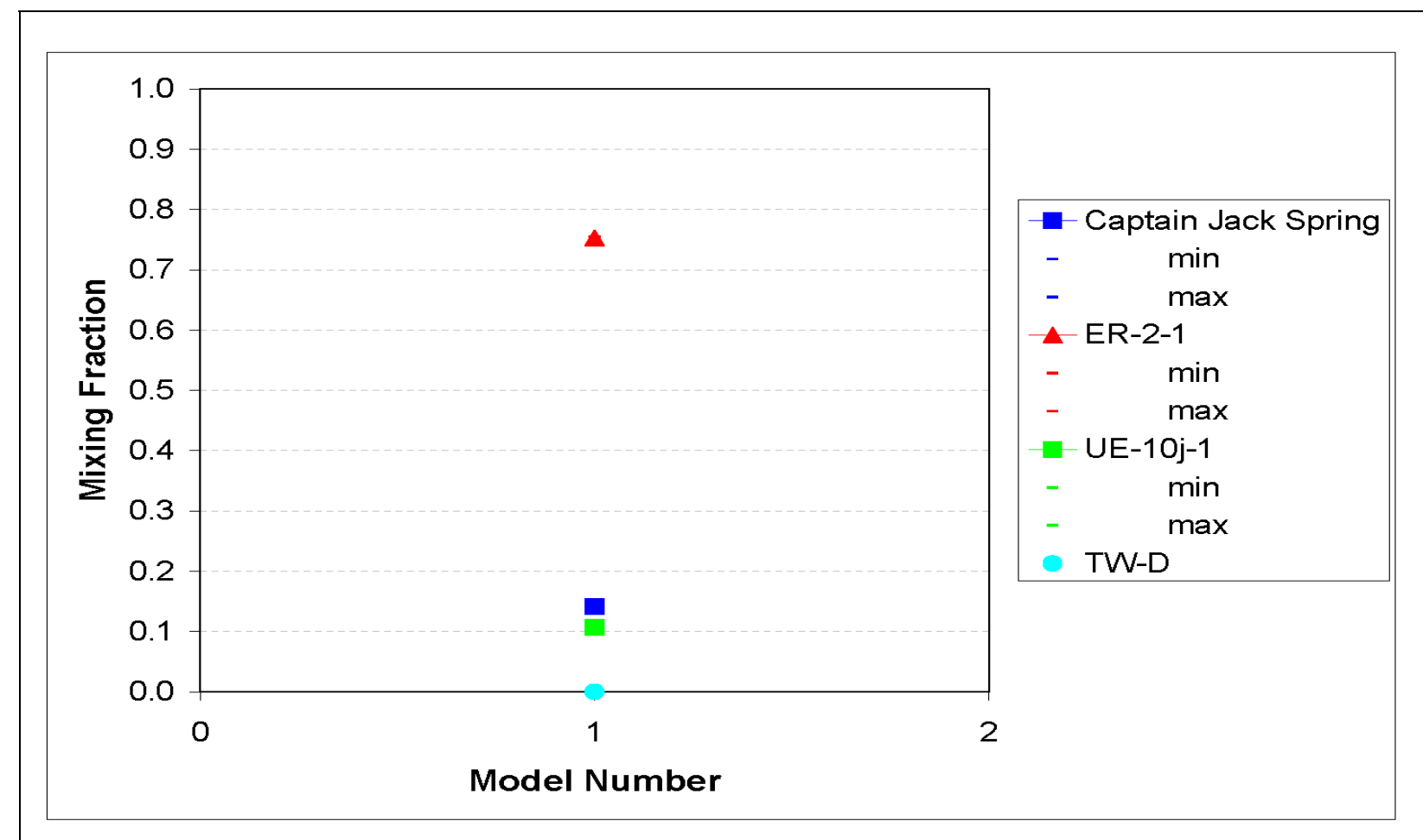

Figure 10-4

Mixing Fractions for TW-D Models with ER-2-1 Groundwater

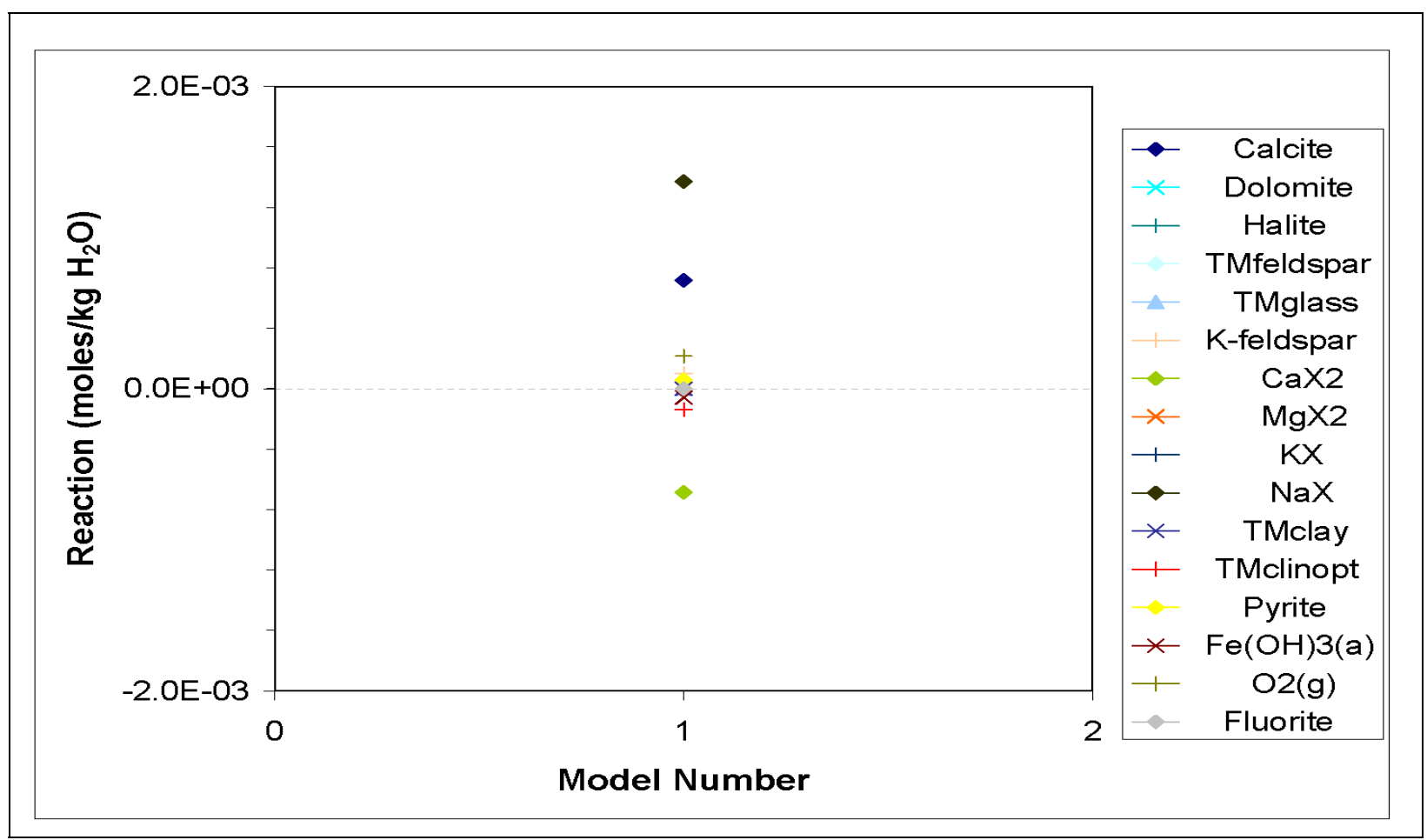

Figure 10-5

Reactions for TW-D Models with ER-2-1 Groundwater 
Well ER-EC-7 in Beatty Wash (Thomas et al., 2002), and a more extreme ratio of $35 \times 10^{-13}$ was measured for Oreana Spring, a perched spring located near Pahranagat Valley (Rose et al., 1997). Other chemical and isotopic parameters indicate that both ER-EC-7 and Oreana Spring were fairly recently recharged. The unusually high ${ }^{36} \mathrm{Cl} / \mathrm{Cl}$ ratios in these waters are interpreted as "bomb pulse" signatures, inherited from atmospheric thermonuclear testing in the 1950s and early 1960s. Although comparable ${ }^{36} \mathrm{Cl} / \mathrm{Cl}$ ratios have not been demonstrated for perched springs in Yucca Flat, the predicted ratios based on inverse modeling are not without precedent.

The PHREEQC inverse models indicate that groundwater at UE-1q is derived from approximately 70 percent HTH-1 groundwater with the remainder derived from either a combination of Oak Spring and UE-10j-1, or groundwater from UE-2ce plus a small amount of Oak Spring groundwater (Figures $10-6$ to $10-7$ ). The groundwater ${ }^{36} \mathrm{Cl} / \mathrm{Cl}$ ratio has not been measured at Oak Spring, and the ${ }^{36} \mathrm{Cl} / \mathrm{Cl}$ ratio at $\mathrm{UE}-2 \mathrm{ce}$ was severely impacted by the nearby Nash underground nuclear test $\left({ }^{36} \mathrm{Cl} / \mathrm{Cl}=16,200 \times 10^{-13}\right)$. The inverse models with no UE-2ce component require Oak Spring groundwater to have a ${ }^{36} \mathrm{Cl} / \mathrm{Cl}$ ratio of $13.5 \times 10^{-13}$.

\subsubsection{Strontium and ${ }^{87} \mathrm{Sr} /{ }^{86} \mathrm{Sr}$ Modeling Results}

Strontium data, in general, support the conclusion that LCA groundwater at TW-D and UE-1q consists of substantial amounts of volcanic aquifer groundwater and local recharge mixed in with LCA flow from northern Yucca Flat. Mixtures dominated by ER-2-1 groundwater with small amounts of UE-10j-1 do not reproduce the measured Sr characteristics of sample TW-D; however, Sr, $\delta \mathrm{D}$, and $\mathrm{Cl}$ mixing models converge if the Sr concentration in ER-2-1 is increased to about $85 \mu \mathrm{g} / \mathrm{L}$ rather than the measured value of only $5.4 \mu \mathrm{g} / \mathrm{L}$. Good agreement between three-component mixing results for sample TW-D is obtained for both Sr and conservative tracer data using HTH-1, UE-10j-1, and mean local recharge as end-members (Table 10-3). Concurrence between mixing results derived from $\mathrm{Sr}$ and conservative tracer data is poorer for UE-1q than for TW-D. Results based on Sr data require less of an LCA component to obtain the lower ${ }^{87} \mathrm{Sr} /{ }^{86} \mathrm{Sr}$ values observed in UE-1q. The choice of mean local recharge versus UCA groundwater (UE-16d) as the third mixing component does not significantly impact the amount of UE-10j-1 required but does change the amount of HTH-1.

Mixtures involving more of the volcanic aquifer component and less of the local recharge component are considered more likely because of the location of UE-1q, in the middle of the basin, which is 


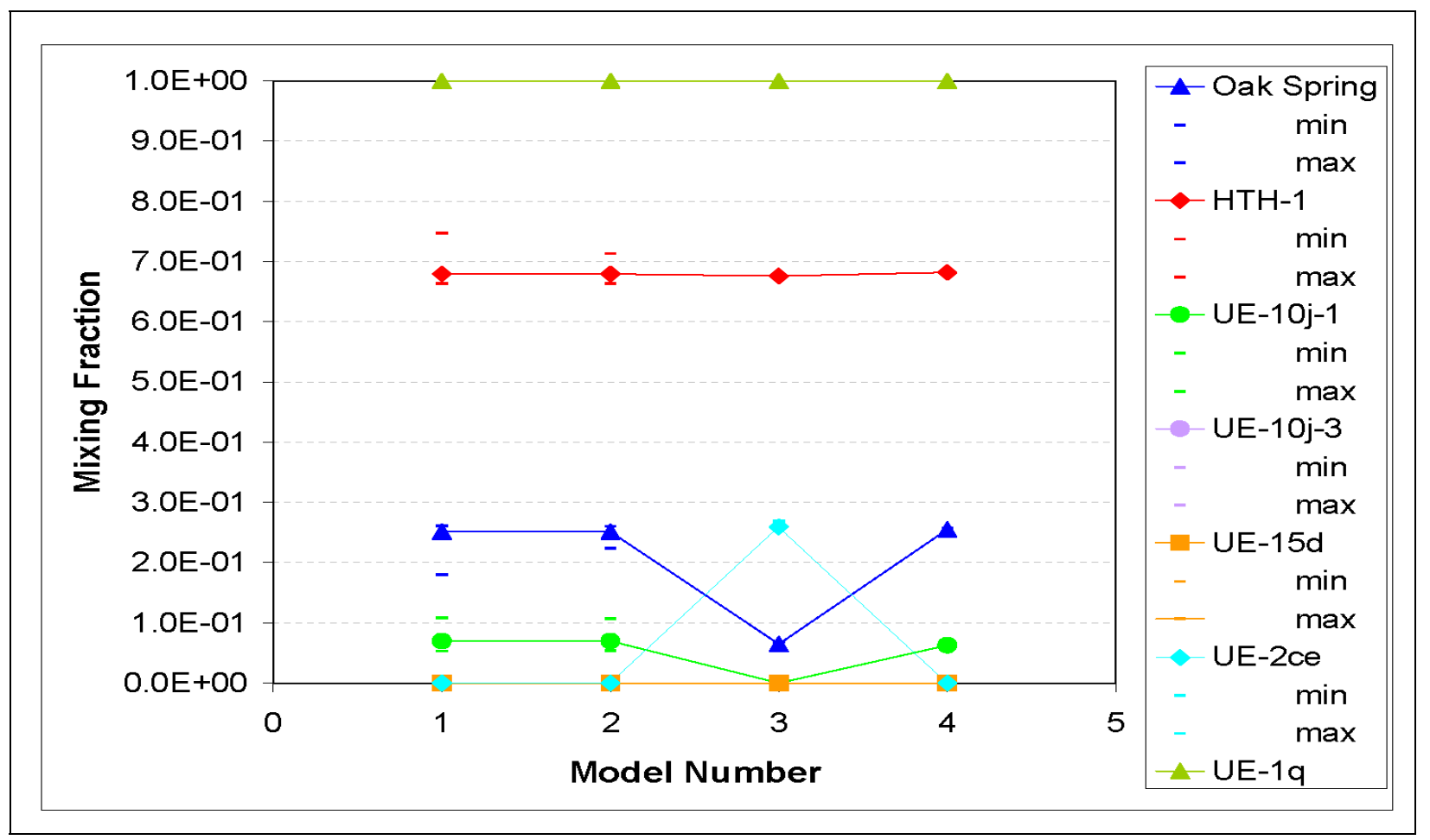

Figure 10-6

Mixing Fractions for Well UE-1q Models

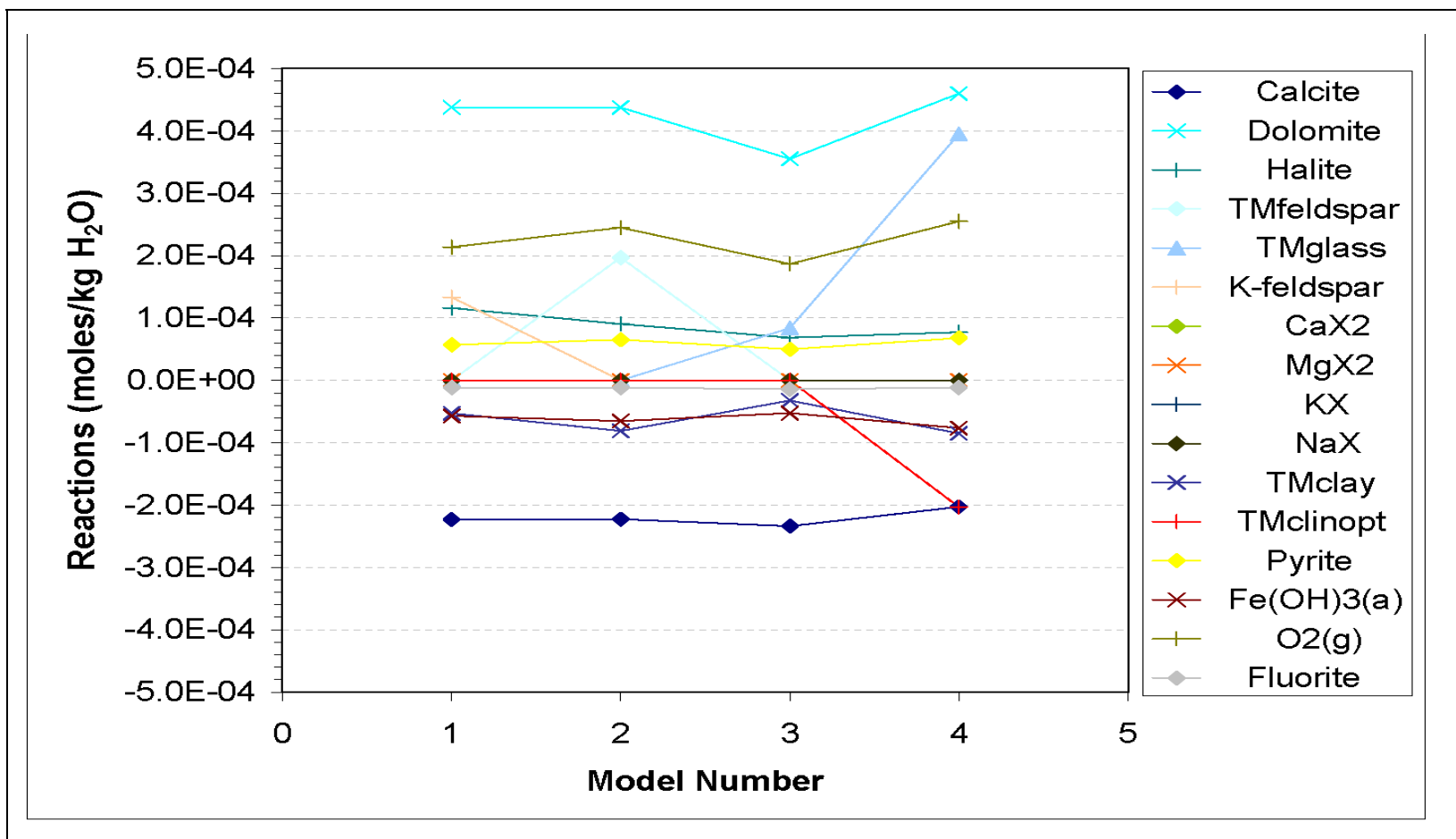

Figure 10-7

Reactions for Well UE-1q Models 
Table 10-3

Mixing Percentages for Wells Test Well - D and UE-1q Based on ${ }^{87} \mathrm{Sr} /{ }^{86} \mathrm{Sr}$ Versus $1 / \mathrm{Sr}$

\begin{tabular}{|c|c|c|}
\hline \multicolumn{3}{|c|}{ Percentage / Deviation of Mixing Component for Test Well - D } \\
\hline HTH-1 & UE-10j-1 & Captain Jack Spring \\
$60 /-4$ & $12 /-5$ & $28 /+9$ \\
\hline \multicolumn{3}{|c|}{ Percentage / Deviation of Mixing Component for UE-1q } \\
\hline HTH-1 & UE-10j-1 & Captain Jack Spring or Oak Spring \\
$35 /-29$ & $10 /-25$ & $55 /+54$ \\
\hline HTH-1 & UE-10j-1 & UE-16d \\
$74 /+10$ & $9 /-25$ & $17 /+16$ \\
\hline
\end{tabular}

away from upland recharge areas. Therefore, of the three conservative tracer models proposed for UE-1q, mixing of HTH-1, UE-10j-1, and UE-16d is best supported by available Sr data.

\subsection{Summary}

Groundwater from TW-D and UE-1q have high ${ }^{36} \mathrm{Cl} / \mathrm{Cl}$ ratios $\left(7\right.$ to $\left.8 \times 10^{-13}\right)$ that are relatively unique for groundwater from the LCA. In most LCA groundwaters, halite dissolution tends to decrease ${ }^{36} \mathrm{Cl} / \mathrm{Cl}$ ratios below present-day meteoric values of about $5 \times 10^{-13}$ (Figure 10-1). This observation indicates that groundwater in the LCA at TW-D and UE-1q did not originate primarily by flow through the LCA from the north, where groundwater ${ }^{36} \mathrm{Cl} / \mathrm{Cl}$ ratios are generally below $5 \times 10^{-13}$ (Figure 10-1). Alternative groundwater paths include vertical recharge through or around gaps in the VCU, or easterly flow through the Eleana Formation in western Yucca Flat, where some groundwaters have similarly elevated ${ }^{36} \mathrm{Cl} / \mathrm{Cl}$ ratios (Figure 10-1).

Both TW-D and UE-1q appear to contain a dominant mixing fraction derived from the volcanic HSUs, with a maximum LCA component of approximately 18 percent at TW-D and approximately 35 percent at UE-1q. The large amount of volcanic aquifer water in TW-D and UE-1q probably accounts for the elevated ${ }^{36} \mathrm{Cl} / \mathrm{Cl}$ ratios of these waters. Whether this component is introduced through vertical leakage or lateral transport cannot be clearly determined with the existing data. The relatively low amounts of LCA groundwater in TW-D and UE-1q could reflect the relatively low rates of LCA inflow into the basin relative to local recharge, or the hydraulic isolation of the LCA block containing TW-D and UE-1q due to surrounding block-bounding faults. 


\subsection{LIMITATIONS}

Geochemical flow path evaluations depend on adequate data coverage, both laterally and vertically, within the study region. Within the Yucca Flat/Climax Mine CAU, the wells with the parameter suite necessary to support geochemical flow path analysis and characterization are irregularly distributed. This is compounded by a sparse representation of groundwater samples collected from most HSUs, particularly the alluvial and volcanic aquifers. Well samples included in the dataset were often collected as composites, either from wells with single completions that transect multiple HSU boundaries, or from wells with multiple completions that were all pumped simultaneously. Many wells draw from a large vertical cross section of saturated media, possibly resulting in homogenization of the water composition within the borehole (Fenelon, 2005). This limits the ability to uniquely define the geochemical characteristics of groundwater within a specific HSU, either locally or regionally, and may have resulted in some of the groundwater mixing that is inferred to have taken place through hydrodynamic processes.

Groundwater data included in this study represent a time period from the late 1950s to 2005, and in many cases (approximately 25 percent of the sampling locations), data for a given well or spring are limited to samples collected more than 20 years ago. These older datasets are limited in that the entire parameter suite used for the geochemical investigations is lacking. In particular, Sr data for groundwater and aquifer rocks, ${ }^{36} \mathrm{Cl}$ data for groundwater and aquifer rocks, $\mathrm{DI}^{14} \mathrm{C}$ data for groundwater, and $\mathrm{DO}^{14} \mathrm{C}$ data for groundwater are not available for the older samples. This lack of a consistent dataset for all of the available wells in the Yucca Flat/Climax Mine limits the ability to develop unique modeling solutions to possible groundwater flow paths.

Geochemical modeling of groundwater flow into the LCA in northern Yucca Flat was hindered by a lack of data for LCA groundwater upgradient and outside of Yucca Flat. In particular, the origin of deep LCA water at UE-10j-1 could not be determined with the existing dataset. Interpretations of input of local recharge to Yucca Flat are also limited because most perched springs (and some wells in the upland recharge areas) do not have $\delta^{13} \mathrm{C}$ and ${ }^{14} \mathrm{C}$ data for calculating groundwater travel times. 
Additionally, limited $\delta \mathrm{D}$ and $\delta^{18} \mathrm{O}$ data for several important perched springs including Oak and Captain Jack Springs have peculiar average isotopic signatures that are substantially different from other perched springs in the area. These average isotopic signatures are calculated on only a handful of analyses, and previous studies have indicated that the isotopic signature of perched springs at the NTS is highly variable (Ingraham et al., 1991). To obtain an adequate average isotopic signature for these perched springs, more sampling and analysis of spring discharge is needed.

Finally, Sr data, another tool capable of contributing to delineation of groundwater flow or evaluation of water-rock reactions, are available from only a limited number of wells in northern Yucca Flat, and from a small subset of perched springs or other upgradient regional groundwater samples. A better understanding of Sr concentrations and ${ }^{87} \mathrm{Sr} /{ }^{86} \mathrm{Sr}$ compositions is needed for both groundwater and rock samples. In particular, Sr data for aquifer rocks would improve the ability to assess the impacts of water-rock reaction in reactive transport models. 


\subsection{CONCLUSIONS}

Currently available geochemical and isotopic data were used to evaluate groundwater flow in the Yucca Flat/Climax Mine CAU. Geochemical models using conservative tracers $\left(\delta \mathrm{D}, \delta^{18} \mathrm{O}\right.$, and $\left.\mathrm{Cl}\right)$ were first used to identify potential groundwater source areas, flow paths, and mixing processes. Possible flow paths were then evaluated using $\mathrm{Sr}$ and ${ }^{87} \mathrm{Sr} /{ }^{86} \mathrm{Sr}$ data and the geochemical modeling programs PHREEQC and NETPATH. The models developed using PHREEQC and NETPATH attempt to explain the geochemical evolution of groundwater by identifying the proportions of groundwater from various upgradient wells that may be present in groundwater at a downgradient well.

The geochemical compositions of perched springs and local precipitation were evaluated in an attempt to establish a composition representative of local recharge. Although perched groundwater associated with small springs and seeps are useful as a proxy for the average composition of local recharge (if the water has not experienced large amounts of post-discharge evaporation), a broad range in $\delta \mathrm{D}$ and $\delta^{18} \mathrm{O}$ values is observed that is not strongly correlated with geographic location. For this reason, a single composition that uniquely represents local recharge in this area could not be determined. Rather than relying on a single inferred "local recharge" composition, models were developed using observed compositions of perched waters in the study area. Models sometimes required a combination of two perched water sources to accommodate the observed downgradient water composition. The composition of "mean local recharge" for ${ }^{87} \mathrm{Sr} /{ }^{86} \mathrm{Sr}$ and $\mathrm{Sr}$ was approximated based on a mean of six perched water samples from the NTS.

Conceptual flow models were developed on the basis of observed hydraulic head relationships and broad distinctions in the geochemical character of groundwater in particular areas of the Yucca Flat basin. For this reason, each set of models tends to focus on a particular geographic sub-region within the basin. These include northern Yucca Flat, eastern Yucca Flat, southeastern Yucca Flat, western Yucca Flat, and vertical transport near the center of the basin. 
The geochemical models and graphical analyses presented in this report demonstrate that most of the groundwater in Yucca Flat can originate from either paleo- or modern recharge, underflow in the LCA from the north or northwest, and leakage of alluvial or volcanic aquifer groundwater from Emigrant Valley through the Halfpint Range. In contrast, inflow into Yucca Flat through the granitic rocks of Climax Stock in the northernmost part of the basin appears to be negligible. Paleo-recharge is distinguished from modern recharge by its lighter $\delta^{18} \mathrm{O}$ and $\delta \mathrm{D}$ composition, but both modern and paleo-recharge are characterized by relatively dilute concentrations of major ions and relatively light $\delta^{13} \mathrm{C}$ and high ${ }^{14} \mathrm{C}$ activities compared to groundwater in the LCA. Groundwater originating from either paleo- or modern recharge within the Yucca Flat area is a prominent part of the groundwater system, particularly in northwestern and western Yucca Flat, where high-elevation areas at Rainier Mesa, upper Fortymile Wash, the Eleana Range, and Shoshone Mountain lie adjacent to the basin. The prominence of groundwater that has apparently recharged through volcanic or siliciclastic rocks and flowed into the LCA in Yucca Flat reflects the limited inflow through the LCA into northern Yucca Flat and its subsequent spreading and dilution in the large volume of LCA within the basin. As discussed below, the limited inflow through the LCA into Yucca Flat is also reflected in the extremely long groundwater transit times that have been calculated for the basin. Locally, the presence of a dominant component of volcanic aquifer-like water in the LCA may also reflect the hydraulic isolation of individual blocks of LCA by surrounding faults.

In addition to the aforementioned groundwater sources, there is also some evidence that groundwater from east of Yucca Flat, characterized by groundwater from Well ER-3-1, becomes a prominent part of the groundwater system in the southernmost part of the Yucca Flat basin near WW-C. Apparently, groundwater with the chemical and isotopic composition of Well ER-3-1 is prevented from entering the Yucca Flat basin further to the north by the blocking effects of the LCCU, but it sweeps southwestward into the basin toward the southern end of the Halfpint Range where the LCCU is absent. Groundwater flow from Well ER-3-1 to WW-C in the southeastern part of Yucca Flat appears to preclude the possibility of groundwater leaving Yucca Flat (and the NTS) by flowing to the southeast.

Because most of the groundwater within Yucca Flat can be derived from mixing dilute paleo- or modern recharge with groundwater underflow through the LCA or inflow from Emigrant Valley, it is perhaps not surprising that inverse geochemical models are non-unique and that the groundwater 
composition at a given well can be explained by mixing groundwater from different combinations of wells. One significant finding that emerges from these models is that, despite the many combinations of mixing models that are possible, particularly for WW-C at the southern end of Yucca Flat (where hydraulic head contours indicate convergent groundwater flow along a potentiometric trough), the groundwater transit times are extremely long. The estimated groundwater transit times of approximately 16,000 to 24,000 years from Well UE-10j in northern Yucca Flat to WW-C in southern Yucca Flat result in estimated linear groundwater velocities of approximately 1.3 to $1.9 \mathrm{~m} / \mathrm{yr}$ over this $30 \mathrm{~km}$ distance. These velocities are consistent with groundwater transit times of $\sim 5,800$ to 7,200 years and groundwater velocities of 1.4 to $1.7 \mathrm{~m} / \mathrm{yr}$ estimated for the LCA between Wells ER-7-1 and wells ER-6-1 and ER-6-1 \#2 in eastern Yucca Flat, which recent hydraulic tests have indicated are nonetheless connected by a highly conductive fault (SNJV, 2005). Likewise, an analysis of transit times from well ER-2-1 and Test Well B to WW-C indicates that vertical leakage through the volcanic confining unit, combined with lateral flow in the LCA to WW-C, requires approximately 24,000 to 35,000 years. The extremely long transit times, even for flow in the LCA, are attributed to the extremely small inflow of groundwater into the basin from the north, rather than to low hydraulic conductivity in the highly faulted LCA. Only in the southeastern part of Yucca Flat, where groundwater transit times are on the order of 1,000 to 3,000 years between Well ER-3-1 and WW-C, does the groundwater transit time analysis indicate substantially higher groundwater flow velocities (4.3 to $13 \mathrm{~m} / \mathrm{yr}$ ). The possibly rapid flow of groundwater from east of the basin into the southeastern part of Yucca Flat is consistent with the absence of the LCCU in the southeast portion of the basin and the relatively stagnant flow conditions with the upgradient parts of the Yucca Flat basin itself. 


\subsection{REFERENCES}

Allison, G.B., C.J. Barnes, and M.W. Hughes. 1983. "The Distribution of Deuterium and ${ }^{18} \mathrm{O}$ in Dry Soils. 2. Experimental.” In Journal of Hydrology. 64: 377-397.

BN, see Bechtel Nevada.

Andrews, J.N., J. Ch. Fontes, J.L. Michelot, and D. Elmore. 1986. "In-situ Neutron Flux, ${ }^{36} \mathrm{Cl}$ Production and Groundwater Evolution in Crystalline Rocks at Stripa, Sweden." In Earth and Planetary Science Letter, Letter, 77: 49-59.

Barnes, C.J., and G.B. Allison. 1983. "The Distribution of Deuterium and ${ }^{18} \mathrm{O}$ in Dry Soils. 1. Theory." In Journal of Hydrology, 60: 141-156.

Barnes, H., F.N. Houser, and F.G. Poole. 1963. Geologic Map of the Oak Spring Quadrangle, Nye County, Nevada. U.S. Geological Map GQ-214, scale 1:24,000.

Bath, G.D., C.E. Tehran, J.G. Resemblance, and M.J. Bulgarian. 1983. Geologic and Geophysical Investigations of Climax Stock Intrusive, Nevada: Magnetic Investigations, Open-File Report 83-377: 40-57. Denver, CO: U.S. Geological Survey.

Bechtel Nevada. 2002. A Hydrostratigraphic Model and Alternatives for the Groundwater Flow and Contaminant Transport Model of Corrective Action Units 101 and 102: Central and Western Pahute Mesa, Nye County, Nevada, Report DOE/NV/11718-706. Prepared for the U.S. Department of Energy, National Nuclear Security Administration Nevada Site Office. Las Vegas, NV

Bechtel Nevada. 2006. A Hydrostratigraphic Model and Alternatives for the Groundwater Flow and Contaminant Transport Model of Corrective Action Unit 97: Yucca Flat-Climax Mine, Lincoln and Nye Counties, Nevada, Report DOE/NV/11718-1119. Prepared for the U.S. Department of Energy, National Nuclear Security Administration Nevada Site Office. Las Vegas, NV.

Benedict, Jr. F.C., T.P. Rose, and X. Zhou. 2000. Mineralogical, Chemical, and Isotopic Characterization of Fracture-Coating Minerals in Borehole Samples from Western Pahute Mesa and Oasis Valley, Nevada, Report UCRL-152919. Prepared for the U.S. Department of Energy, Nevada Operations Office. Livermore, CA: Lawrence Livermore National Laboratory. 
Benedict, Jr. F.C., T.P. Rose, J.M. Thomas, R. Waddell, and R. Jacobson. 2003. Geochemistry Technical Basis Document, Report Publication No. 45205, DOE/NV/13609-34. Prepared for the U.S. Department of Energy, National Nuclear Security Administration Nevada Site Office. Las Vegas, NV: Desert Research Institute.

Benson, L. and H. Klieforth. 1989. "Stable Isotopes in Precipitation and Ground Water in the Yucca Mountain Region, Southern Nevada: Paleoclimatic Implications." In Aspects of Climate Variability in the Pacific and the Western Americas, Geophysical Monograph 55. p. 41-59. Washington, DC: American Geophysical Union.

Bentley, H.W., F.M. Phillips, and S.N. Davis. 1986. "Chlorine-36 in the Terrestrial Environment." In P. Fritz and J.Ch. Fontes (eds.), Handbook of Environmental Isotope Geochemistry, Volume 2, The Terrestrial Environment, B. Elsevier, p. 427-480. Amsterdam.

Bish, D.L. 1989. Evaluation of Past and Future Alterations in Tuff at Yucca Mountain, Nevada, Based on the Clay Mineralogy of Drill Cores USW G-1, G-2, and G-3. Report LA-10667-MS. Los Alamos, NM: Los Alamos National Laboratory.

Blankennagel, R.K., and J.E. Weir, Jr. 1973. Geohydrology of the Eastern Part of Pahute Mesa, Nevada Test Site, Nye County, Nevada, Professional Paper 712-B. Washington, DC: U.S. Geological Survey.

Blouin, S., L. Costin, and K. Wohletz. 2003. "Geotechnical Site Characteristics for HARD HAT and PILE DRIVER." In Hard Rock Database Review and Proceedings of the HDRD Workshop, 28 October - 1 November 2002, Defense Nuclear Weapons School, Kirtland AFB, NM, vol. 1: Unclassified Material. Defense Threat Reduction Agency Report DTRIAC-SR-03-001-V1, Fort Belvoir, VA, Hard Rock Data Review Task 4: 45 p.

Broxton, D.E., D.L. Bish, and R.G. Warren. 1987. "Distribution and Chemistry of Diagenetic Minerals at Yucca Mountain, Nye County, Nevada." In Clays and Clay Minerals, 35, (2), 89-110. Long Island City, NY: Pergamon Press.

Burke, W.H., R.E. Denison, E.A. Hetherington., R.B. Koepnick, N.F. Nelson, and J.B. Otto. 1982. "Variation of Seawater ${ }^{87} \mathrm{Sr} /{ }^{86} \mathrm{Sr}$ throughout Phanerozoic Time." In Geology, vol. 10: 516-519.

Cashman, P.H., and J.H. Trexler, Jr. 1991. "The Mississippian Antler Foreland and Continental Margin in Southern Nevada - The Eleana Formation Reinterpreted." In Paleozoic Paleogeography of the Western United States II, Society of Economic Paleontologists and Mineralogists, Pacific Section, vol. 67: 271-280.

Clark, I.D., and P. Fritz. 1997. Environmental Isotopes in Hydrogeology. Boca Raton, FL: Lewis Publishers.

Claassen, H.C. 1997. "Late-Wisconsin Paleohydrology of the West-Central Amargosa Desert, Nevada, U.S.A. In Chemical Geology Isotope Geosciences Sec. 1986. vol. 58: 311-323. 
Cole, J.C. 1997. Major Structural Controls on the Distribution of Pre-Tertiary Rocks, Nevada Test Site Vicinity, Southern Nevada, Open-File Report 97-533. Denver, CO: U.S. Geological Survey.

Cole, J.C., and P.H. Cashman. 1999. Structural Relationships of Pre-Tertiary Rocks in the Nevada Test Site Region, Southern Nevada, Professional Paper 1607. Denver, CO: U.S. Geological Survey.

Connolly, J.A. 1981. "Hydrothermal Alteration in the Climax Granite Stock of the Nevada Test Site.” Master's thesis, Arizona State University, Tempe, AZ.

Craig, H. 1961. "Isotopic Variations in Meteoric Waters.” In Science, vol. 133: 1702-1703. Washington, DC: American Association for the Advancement of Science.

Craig, H., L.I. Gordon, and Y. Horibe. 1963. "Isotope Exchange Effects in the Evaporation of Water. 1. Low Temperature Experimental Results." In Journal of Geophysical Research, 68: 5079-5087.

Criss, R.E. 1999. "Principles of Stable Isotope Distribution.” Oxford University Press, New York, $254 \mathrm{p}$.

DOE/NV, see U.S. Department of Energy, Nevada Operations Office.

DRI, see Desert Research Institute.

Dansgaard, W. 1964. “Stable Isotopes in Precipitation.” In Tellus, 16: 436-468.

Davisson, M.L., D.K. Smith, J. Kenneally, and T.P. Rose. 1999. "Isotope Hydrology of Southern Nevada Groundwater: Stable Isotopes and Radiocarbon." In Water Resources Research, vol. 35 (1): 279-294.

DePaolo, D.J., M.E. Conrad, K. Maker, and G.W. Gee. 2004. "Evaporation Effects on Oxygen and Hydrogen Isotopes in Deep Vadose Zone Pore Fluids at Hanford, Washington." In Vadose Zone Journal, 3: 220-232.

Drellack, S.L., Jr., and P.H. Thompson. 1990. Selected Stratigraphic Data for Drill Holes in LANL Use Areas of Yucca Flat, NTS, Report DOE/NV-10322-39. Prepared for the U.S. Department of Energy, Nevada Operations Office. Las Vegas, NV: Fenix \& Scisson, Inc.

Drellack, S.L., L.B. Prothro, K.E. Roberson, B.A. Schier, and E.H. Price. 1997. Analysis of Fractures in Volcanic Cores from Pahute Mesa, Nevada Test Site, Report DOE/NV/11718-160. Prepared for the U.S. Department of Energy, Nevada Operations Office. Las Vegas, NV: Bechtel Nevada.

FFACO, see Federal Facility Agreement and Consent Order. 
Fabryka-Martin, J., S.J. Wightman, W.J. Murphy, M.P. Wickham, M.W. Caffee, G.J. Nimz, J.R Southon, and P. Sharma. 1993. Distribution of Chlorine-36 in the Unsaturated Zone at Yucca Mountain: An Indicator of Fast Transport Paths. Paper presented at FOCUS '93 Site Characterization and Model Validation. Las Vegas, NV.

Faure, G. 1986. Principles of Isotope Geology, Second Edition. John Wiley \& Sons, New York, 589 p.

Federal Facility Agreement and Consent Order. 1996 (as amended). Agreed to by the State of Nevada, the U.S. Department of Energy, and the U.S. Department of Defense.

Fenelon, J.M. 2005. Analysis of ground-water levels and associated trends in Yucca Flat, Nevada Test Site, Nye County, Nevada, 1951-2003: U.S. Geological Survey Scientific Investigations Report 2005-5175, 87 p.

GeoTrans, Inc. 1995. A Fracture/Porous Media Model of Tritium Transport in the Underground Weapons Testing Areas, Nevada Test Site, Report DE-AC08-92NV10972. Prepared for the U.S. Department of Energy, Nevada Operations Office. Boulder, CO.

Gibbons, A.B., E.N. Hinrichs, W.R. Hansen, and R.W. Lemke. 1963. Geology of the Rainier Mesa Quadrangle, Nye County, Nevada, Map GQ-215, scale 1:24,000. Washington, DC:

U.S. Geological Survey.

Hainsworth, L.J., A.C. Mignerey, G.R. Helz, P. Sharma, and Others. 1994. "Modern Chlorine-36 Deposition in Southern Maryland, USA." In Nuclear Instruments \& Methods in Physics Research, Section B - Beam Interactions with Materials and Atoms, 92: 345-349.

Hale, G.S., D.A. Trudeau, and C.S. Savard. 1995. Water-Level Data from Wells and Test Holes Through 1991, and Potentiometric Contours as of 1991 for Yucca Flat, Nevada Test Site, Nye County, Nevada, Water-Resources Investigations Report 95-4177. Denver, CO: U.S. Geological Survey.

Hansen, D.J., P.D. Greger, C.A. Wills, and W.K. Ostler. 1997. Nevada Test Site Wetlands Assessment, Report DOE/NV/11718-124. Prepared for the U.S. Department of Energy, Nevada Operations Office. Las Vegas, NV: Bechtel Nevada.

Harrill, J.R., J.S. Gates, and J.M. Thomas. 1988. Major Groundwater Flow Systems in the Great Basin Region of Nevada, Utah, and Adjacent States, ATLAS-HA-694-C, scale: 1,000,000. Denver, CO: U.S. Geological Survey.

Hawkins, W.L., D.A. Trudeau, and T.M. Mihevc. 1989. "Hydrologic Testing in Exploratory Drill Hole UE4t, Yucca Flat, the Nevada Test Site." In Fifth Symposium on Containment of Underground Nuclear Explosions, CONF-8909163, vol. 2: 141-159. Santa Barbara, CA: Mission Research Corporation. 
Hem, J.D. 1985. Study and Interpretation of the Chemical Characteristics of Natural Water, USGS Water-Supply Paper 2254, 3rd. ed., p. 118. Denver, CO: U.S. Geological Survey.

Hershey, R.L., W. Howcroft, and P.W. Reimus, 2003. Laboratory Experiments to Evaluate Diffusion of ${ }^{14} \mathrm{C}$ into Nevada Test Site Carbonate Aquifer Matrix. Report Publication No. 45180. Reno, NV: Desert Research Institute.

Hershey, R.L., and S.Y. Archeampong. 1997. Estimation of Groundwater Velocities from Yucca Flat to the Amargosa Desert Using Geochemistry and Environmental Isotopes. Report Publication No. 45157. Prepared for the U.S. Department of Energy, Nevada Operations Office. Reno, NV: Desert Research Institute.

Hershey, R.L., B.F. Lyles, and J.W. Hess. 1991. "Stable-Isotopic Evidence of Warm-Season Recharge to the Spring Mountains, Southern Nevada." In Geological Society of America Bulletin, Abstracts with Programs, vol. 23 (5): A381.

Hershey, R.L., J.M. Thomas, T.P. Rose, J.B. Paces, I.M. Farnham, and F.C. Benedict, Jr. 2005. Evaluation of Groundwater Movement in the Frenchman Flat CAU Using Geochemical and Isotopic Analysis. Report Publication No. 45207, DOE/NV/13609-36. Prepared for the U.S. Department of Energy, National Nuclear Security Administration Nevada Site Office. Las Vegas, NV: Desert Research Institute.

Hevesi, J.A., A.L. Flint, and L.E. Flint. 2003. Simulation of Net Infiltration and Potential Recharge Using a Distributed Parameter Watershed Model for the Death Valley Region, Nevada and California. Water-Resources Investigations Report 03-4090. Sacramento, CA: U.S. Geological Survey.

Houser, F.N., and F.G. Poole. 1960. Preliminary Geologic Map of the Climax Stock and Vicinity, Nye County, Nevada, Map I-328, scale 1:4,800. Washington, DC: U.S. Geological Survey.

IT, see IT Corporation.

Ingraham, N.L., and B.E. Taylor. 1991. "Light Stable Isotope Systematics of Large-Scale Hydrologic Regimes in California and Nevada." In Water Resources Research, vol. 27(1): 77-90.

Ingraham, N.L., R.L. Jacobson, B.F. Lyles, and J.W. Hess. 1990. Stable Isotopic Study of Precipitation and Spring Discharge on the Nevada Test Site, Water Resources Center, Report Publication No. 45078, DOE/NV/10845-03. Prepared for the U.S. Department of Energy, Nevada Operations Office. Las Vegas, NV: Desert Research Institute.

Ingraham, N.L., B.F. Lyles, R.L. Jacobson, and J.W. Hess. 1991. "Stable Isotopic Study of Precipitation and Spring Discharge in Southern Nevada." In Journal of Hydrology, vol. 125: 243-258. 
Isherwood. D., J. Harrar, and E. Raber. 1982. Characterization of Climax Granite Ground Water, Report UCRL-53309. Livermore, CA: Lawrence Livermore National Laboratory.

IT Corporation. 1995. Written Communication prepared for DOE/NV. Subject: "Pre-Completion Hydrologic Testing Documentation Package for Well UE-10j." Prepared for the U.S. Department of Energy, Nevada Operations Office. Las Vegas, NV.

IT Corporation. 1996a. Hydrologic Parameters Data Documentation Package (Phase I, Data Analysis Documentation, Volume IV), Report ITLV/10972--181. Prepared for the U.S. Department of Energy, Nevada Operations Office. Las Vegas, NV.

IT Corporation. 1996b. Potentiometric Data Documentation Package (Phase 1, Data Analysis Documentation, Volume II), Report ITLV/10972--181. Prepared for the U.S. Department of Energy, Nevada Operations Office. Las Vegas, NV.

IT Corporation. 1996c. Regional Geologic Model Data Documentation Package (Phase I, Data Analysis Documentation, Volume I, Parts 1 and 2), Report ITLV/10972--181. Prepared for the U.S. Department of Energy, Nevada Operations Office. Las Vegas, NV.

IT Corporation. 1996d. Wells ER-6-1 and ER-6-2 Core Fracture Analyses and Geophysical Log Comparisons, Report ITLV/10972--171. Prepared for the U.S. Department of Energy, Nevada Operations Office. Las Vegas, NV.

IT Corporation. 1998. Summary of Micrographic Analysis of Fracture-Coating Phases on Drill Cores from Pahute Mesa, Nevada Test Site, Report DOE/NV/13052-050, U.S. Department of Energy, Nevada Operations Office. Las Vegas, NV.

IT Corporation. 2002. Yucca Flat Hydrogeologic Investigation Wells Drilling and Completion Criteria, Report ITLV/13052--164. Prepared for the U.S. Department of Energy, National Nuclear Security Administration Nevada Operations Office. Las Vegas, NV.

Johnson, T.M. and D.J. DePaolo. 1994. "Interpretation of Isotopic Data in Groundwater-Rock Systems: Model Development and Application to Sr Isotope Data from Yucca Mountain." In Water Resources Research, vol. 30: 1571-1587.

Johnson, T.M., and D.J. DePaolo. 1997. "Rapid Exchange Effects on Isotope Ratios in Groundwater Systems 1. Development of A Transport-Dissolution-Exchange Model." In Water Resources Research, vol. 33: 187-195.

Johnson, T.M., R.C. Roback, T.L. McLing, T.D. Bullen, D.J. DePaolo, C. Doughty, R.J. Hunt, R.W. Smith, L.D. Cecil, and M.T. Murrell. 2000. "Groundwater 'Fast Paths' in the Snake River Plain Aquifer: Radiogenic Isotope Ratios as Natural Groundwater Tracers.” In Geology, vol. 28: 871-874. 
Kenneally J. 1995. Preliminary Report Evaluating the Use of Strontium and Chloride Concentrations and ${ }^{87} \mathrm{Sr} /{ }^{86} \mathrm{Sr}$ Ratios as Analogs for the Dissolution of Inorganic Carbon, Unpublished report, 14 p. Livermore, CA: Lawrence Livermore National Laboratory.

Kwicklis, E.M., T.P. Rose, and F.C. Benedict, Jr. 2005. Evaluation of Groundwater Flow in the Pahute Mesa - Oasis Valley Flow System Using Groundwater Chemical and Isotopic Data. Report LA-UR-05-4344. Los Alamos, NM: Los Alamos National Laboratory.

LLNL, see Lawrence Livermore National Laboratory.

Laczniak, R.L., J.C. Cole, D.A. Sawyer, and D.A. Trudeau. 1996. Summary of Hydrogeologic Controls on the Movement of Groundwater at the Nevada Test Site, Nye County, Nevada, Water Resources Investigations Report 96-4109. Carson City, NV: U.S. Geological Survey.

Langmuir, D. 1978. "Uranium Solution-Mineral Equilibria at Low Temperatures with Applications to Sedimentary Ore Deposits." In Geochim. Cosmochim. Acta, vol. 42: 547-569.

Ludwig, K.R., K.R. Simmons, B.J. Szabo, I.J. Winograd, J.M. Landwehr, A.C. Riggs, and R.J. Hoffman. 1992. "Mass-spectrometric ${ }^{230} \mathrm{Th}^{-234}{ }^{23}-{ }^{238} \mathrm{U}$ Dating of the Devils Hole Calcite Vein." In Science, 258: 284-287.

Lyles, B.F., J. Edkins, R.L. Jacobson, and J.W. Hess. 1990. Time-Series Analysis of Ion and Isotope Geochemistry of Selected Springs of the Nevada Test Site, Nye County, Nevada, Water Resources Center, Report Publication, No. 45068, DOE/NV/10384-27. Prepared for the U.S. Department of Energy, Nevada Operations Office. Las Vegas, NV: Desert Research Institute.

Lyles, B.F., W.A. McKay, J.B. Chapman, and S.W. Tyler. 1991. Hydrologeologic Characterization of Wells HTH-1, UE18r, UE6e, and HTH-3, Nevada Test Site, Water Resources Center, Report Publication No. 45087, DOE/NV/10845-08. Prepared for the U.S. Department of Energy, Nevada Operations Office. Las Vegas, NV: Desert Research Institute.

Maldonado, F. 1977. Summary of the Geology and Physical Properties of the Climax Stock, Nevada Test Site, Open-File Report 77-356. Denver, CO: U.S. Geological Survey.

Maloszewski, P., and A. Zuber. 1991. "Influence of Matrix Diffusion and Exchange Reactions on Radiocarbon Ages in Fissured Carbonate Aquifers." In Water Resources Research, 27(8): 1937-1945.

Mazaud, A., C. Laj, E. Bard, M. Arnold, and E. Tric. 1991. "Geomagnetic Field Control of ${ }^{14} \mathrm{C}$ Production Over the Last $80 \mathrm{KY}$ : Implications for the Radiocarbon Time-Scale." In Geophysical Research Letters, 18: 1885-1888.

McNutt, R.H. 2000. "Strontium Isotopes." In Environmental Tracers in Subsurface Hydrology, Chapter 8: 233-259. 
Mifflin, M.D., and M.M. Wheat. 1979. "Pluvial Lakes and Estimated Pluvial Climates of Nevada." In Nevada Bureau of Mines and Geology Bulletin, 94: 57.

Moran, J.E., and T.P. Rose. 2003. “A Chlorine-36 Study of Regional Groundwater Flow and Vertical Transport in Southern Nevada." In Environmental Geology, 43: 592-605.

Mozeto, A.A., P. Fritz, and E.J. Reardon. 1984. "Experimental Observations on Carbon Isotope Exchange in Carbonate-Water Systems." In Geochemica et Cosmochimica Acta, 48: 495-504.

NNSA/NSO, see U.S. Department of Energy, National Nuclear Security Administration Nevada Site Office.

Nevada Bureau of Mines and Geology. 1996. County Digital Geologic Mapping Project - Final Report, Open_File Report 97-I, scale 1:250,000.

Orkild P.P., M.J. Baldwin, and D.R. Townsend. 1983. Geologic and Geophysical Investigations of Climax Stock Intrusive, Nevada: Geologic Investigations, Open-File Report 83-37: 1-24. Denver, CO: U.S. Geological Survey.

Osmond, J.K., and Cowart, J.B. 1976. "The Theory and Uses of Natural Uranium Isotopic Variations in Hydrology.” In Atomic Energy, Rev. 14, 621-679.

Paces, J.B., K.R. Ludwig, Z.E. Peterman, and L.A. Neymark. 2002. “ “234U/238U Evidence for Local Recharge and Patterns of Ground-Water Flow in the Vicinity of Yucca Mountain, Nevada, USA." In Applied Geochemistry, vol. 17: 751-779.

Parkhurst, D.L., and C.A.J. Appelo. 1999. User's Guide to PHREEQC - A Computer Program for Speciation, Batch-Reaction, One-Dimensional Transport, and Inverse Geochemical Calculations, Version 2. USGS Water Resources Investigation Report 99-4259, Denver, CO: U.S. Geological Survey.

Peterman, Z.E., C.E. Hedge, and H.A. Tourtelot. 1970. "Isotopic Composition of Strontium in Sea Water Throughout Phanerozoic Time." In Geochim. Cosmochim. Acta, vol. 34: 105-120.

Peterman, Z.E. 2004. Written communication to J.B. Paces (USGS) regarding data from core at Yucca Mountain UE-25 a\#3 in Jackass Flat east of Fortymile Wash. 8 December.

Peterman, Z.E., B.L. Widmann, B.D. Marshall, J.N., Aleinikoff, K. Futa, and S.A. Mahan. 1994 "Isotopic Tracers of Gold Deposition in Paleozoic Limestones, Southern Nevada" in Proceedings of the Fifth Annual International Conference, High-Level Radioactive Waste Management, Las Vegas, NV, May 22-26, 1994, American Nuclear Society, LaGrange Park, IL, 1316-1323. 
Peterman, Z.E., R.W. Spengler, F.R. Singer, and R.P. Dickerson. 1996. Geochemistry of Outcrop Samples from the Raven Canyon and Paintbrush Canyon Reference Sections, Yucca Mountain, Nevada. U.S. Geological Survey Open-File Report 94-550. Denver, CO: U.S. Geological Survey.

Phillips, F.M. 2000. “Chlorine-36.” In Environmental Tracers in Subsurface Hydrology. P.G. Cook and A.L. Herczeg (eds.). Kluwer, Boston. pp 299-348.

Plummer, L.N., E.C. Prestemon, and D.L. Parkurst. 1994. An Interactive Code (NETPATH) for Modeling Net Geochemical Reactions Along a Flow Path, Version 2.0, USGS Water Resource Investigation Report 94-4169. Denver, CO: U.S. Geological Survey.

Plummer, M.A., F.M. Phillips, J.T. Fabryka-Martin, H.J. Turin, P.E. Wigand, and P. Sharma. 1997. Chlorine-36 in Fossil Rat Urine: An Archive of Cosmogenic Nuclide Deposition During the Past 40,000 Years, In Science, vol. 277: 538-541.

Porcelli, D., and P.W. Swarzenski. 2003. "The Behavior of U- and Th-series Nuclides in Groundwater.” In B. Bourdon, G.M. Henderson, C.C. Lundstrom, and S.P. Turner (eds.), Uranium-Series Geochemistry, Rev. Mineral. Geochem. 52: 317-361.

Prothro, L.B., and S.L. Drellack. 1997. Nature and Extent of Lava-Flow Aquifers Beneath Pahute Mesa, Nevada Test Site, Report DOE/NV/11718-156. Prepared for the U.S. Department of Energy, Nevada Operations Office. Las Vegas, NV: Bechtel Nevada.

Prothro, L.B. 2005. Mineralogic Zonation Within the Tuff Confining Unit, Yucca Flat, Nevada Test Site. Report DOE/NV/11718-995. Prepared for the U.S. Department of Energy, Nevada Operations Office. Las Vegas, NV: Bechtel Nevada.

Quade, J., T.E. Cerling, and J.R. Bowman. 1989. "Systematic Variations in the Carbon and Oxygen Isotopic Composition of Pedogenic Carbonate Along Elevation Transects in the Southern Great Basin, United States." Geological Society of America Bulletin, v. 101, 464-475.

Quade, J., M.D. Mifflin, W.L. Pratt, and L. Burckle. 1995. "Fossil Spring Deposits in the Southern Great Basin and Their Implications for Changes in Water-Table Levels near Yucca Mountain, Nevada, during Quaternary Time.” In Geological Society of America Bulletin, 107: 213-230.

Quade, J., R.M. Forester, W.L. Pratt, and C. Carter. 1998. "Black Mats, Spring-fed Streams, and Late-Glacial-age Recharge in the Southern Great Basin.” In Quaternary Research, 49: 129-148.

Reimus, P.W., R.L. Hershey, D. Decker, S.D. Ware, C. Papelis, S. Earman, A. Abdel-Fattah, M. Haga, D. Counce, S. Chipera, and C. Sedlacek. 2005. Tracer Transport Properties in the Lower Carbonate Aquifer of Yucca Flat. Prepared for the U.S. Department of Energy, Nevada Operations Office. Las Vegas, NV. 
Rose, T.P., J.M. Kenneally, D.K. Smith, M.L. Davisson, G.B. Hudson, and J.H. Rego. 1997. "Chemical and Isotopic Data for Groundwater in Southern Nevada." Lawrence Livermore National Laboratory Report, UCRL-ID-128000, 35 p.

Rose, T.P., D.K. Smith, and J.K. Werner, Jr. 2000. "Lithologic, Mineralogic, and Petrographic Characterization of Alluvium from the U-1a 102C and 102D Drifts of the U-1a Tunnel Complex, Nevada Test Site." In D.K. Smith and G.F. Eaton (eds.), Hydrologic Resources Management Program and Underground Test Area FY 1999 Progress Report, UCRL-ID-139226, 77-110. Livermore, CA: Lawrence Livermore National Laboratory.

Rose, T.P., F.C. Benedict, Jr., J.M. Thomas, W.S. Sicke, R.L. Hershey, J.B. Paces, I.M. Farnham, and Z.E. Peterman. 2002. Geochemical Data Analysis and Interpretation of the Pahute MesaOasis Valley Groundwater Flow System, Nye County, Nevada. Preliminary report to the U.S. Department of Energy, National Nuclear Security Administration Nevada Operations Office.

Rose, T.P., G.F. Eaton, and A.B. Kersting. 2003. Stable Isotope Investigation of Precipitation and Recharge Processes in Central Nevada, Report UCRL-ID-154357. Prepared for the U.S. Department of Energy, National Nuclear Security Administration Nevada Site Office. Livermore, CA: Lawrence Livermore National Laboratory.

Rosholt, J.N. 1983. "Isotopic Composition of Uranium and Thorium in Crystalline Rocks." In J. Geophys. Research, 88: 7315-7330.

Russell, C.E., and T. Minor. 2002. Reconnaissance Estimates of Recharge Based on an Elevation-Dependent Chloride Mass-Balance Approach, Report DOE/NV/11508-37. Prepared for the U.S. Department of Energy, National Nuclear Security Administration Nevada Operations Office. Las Vegas, NV: Desert Research Institute.

Russell, C.E., D. Gillespie, J.C.Cole, S.L. Drellack, L.B. Prothro, P.H. Thompson, R.L. McCall, G.A Pawloski, and R. Carlson. 1996. ER-12-1 Completion Report, DOE/NV/10845-36, DRI-45120. Prepared for the U.S. Department of Energy, National Nuclear Security Administration Nevada Operations Office.

Ryerson, F.J., and B.J. Qualheim. 1983. Mineralogical and Petrological Investigation of Pre-Test Core Samples from the Spent Fuel Test - Climax, Laboratory Report UCID-19976. Livermore, CA: Lawrence Livermore National Laboratory.

Ryerson, F.J., and J.M. Beiriger. 1985. Mineralogic and Petrologic Investigation of Post-Test Core Samples from the Spent Fuel Test-Climax, Report UCRL-53625. Livermore, CA: Lawrence Livermore National Laboratory.

SNJV, see Stoller-Navarro Joint Venture.

Sanford, W.E. 1997. “Correcting for Diffusion in Carbon-14 Dating of Ground Water." In Groundwater, 35(2): 357-361. 
Sawyer, D.A., R.J. Fleck, M.A. Lanphere, R.G. Warren, and D.E. Broxton. 1994. "Episodic Caldera Volcanism in the Miocene Southwest Nevada Volcanic Field: Revised Stratigraphic Caldera Framework, 40Ar/39Ar Geochronology and Implications for Magnetism and Extension." In Geological Society of America Bulletin, 67(10): 1304-1318.

Schoff, S.L., and J.E. Moore. 1964. Chemistry and Movement of Ground Water; Nevada Test Site, Report TEI-838, p.75. Denver, CO: U.S. Geological Survey.

Sheppard, S.C., K.V. Ticknor, and W.G. Evenden. 1998. "Sorption of Inorganic ${ }^{14} \mathrm{C}$ on to Calcite, Montmorillonite and Soil. In Applied Geochemistry." 13: 43-47.

Slate, J.L., M.E. Berry, P.D. Rowley, C.J. Fridrich, K.S. Fridrich, J.B. Morgan, O.D. Workman, G.L. Young,. V.S. Dixon, E.H. Williams, D.A. McKee, T.G. Ponce, W.C. Hildenbrand, S.C. Swadley, E.B. Lundstrom, R.G. Ekren, J.C. Warren, R.J. Cole, M.A. Fleck, D.A. Lanphere, S.A. Sawyer, D.J. Minor, R.J. Grunwald, C.M. Laczniak, J.C. Menges, A.S. Yount, and A.S. Jayko. 1999. Digital Geologic Map of the Nevada Test Site and Vicinity, Nye, Lincoln, and Clark Counties, Nevada, and Inyo County, California, Open-File Report 99-554-A. Denver, CO:

U.S. Geological Survey.

Snyder, R.P. 1977. Geology of the Gold Meadows Stock, Nevada Test Site, Report USGS-474-179: 10. Denver, CO: U.S. Geological Survey.

Spaulding, W.G. 1985. "Vegetation and Cimates of the Last 45,000 Years at the Nevada Test Site and Vicinity." U.S. Geological Survey Professional Paper 1329, 83 p.

Stoller-Navarro Joint Venture. 2004a. Analysis of Well ER-7-1 Testing, Yucca Flat FY 2003 Testing Program, Nevada Test Site, Nevada, Report S-N/99205--021. Prepared for the U.S. Department of Energy, National Nuclear Security Administration Nevada Site Office. Las Vegas, NV.

Stoller-Navarro Joint Venture. 2004b. Letter Report: Analysis of Well ER-2-1 Hydraulic Testing, Yucca Flat FY 2003, Nevada Test Site, Nevada, Report DOE/NV--992. Prepared for the U.S. Department of Energy, National Nuclear Security Administration Nevada Site Office. Las Vegas, NV.

Stoller-Navarro Joint Venture. 2004c. Letter Report: Mineralogical and Isotopic Analysis of Fracture-Coating and Alteration Minerals in the Climax Stock, Nevada Test Site. Robert Dickerson and Timothy Rose. Prepared for the U.S. Department of Energy, National Nuclear Security Administration Nevada Site Office. Las Vegas, NV.

Stoller-Navarro Joint Venture. 2004d. Letter Report: Underground Test Area Project, Mineralogical and Isotopic Analysis of Fracture-Coating and Alteration Minerals in the Yucca Flat Confining Unit, Nevada Test Site. Prepared for the U.S. Department of Energy, National Nuclear Security Administration Nevada Site Office. Las Vegas, NV. 
Stoller-Navarro Joint Venture. 2004e. Phase II Hydrologic Data for the Groundwater Flow and Contaminant Transport Model of Corrective Action Units 98: Frenchman Flat, Nye County, Nevada. Prepared for the U.S. Department of Energy, National Nuclear Security Administration Nevada Site Office. Las Vegas, NV.

Stoller-Navarro Joint Venture. 2005a. Analysis of Hydraulic Responses from the ER-6-1 Multiple-Well Aquifer Test, Yucca Flat FY 2004 Testing Program, Nevada Test Site, Nye County, Nevada, Report S-N/99205--051. Prepared for the U.S. Department of Energy, National Nuclear Security Administration Nevada Site Office. Las Vegas, NV.

Stoller-Navarro Joint Venture. 2005b. Geochem05.mdb and a User's Guide to the Comprehensive Water Quality Database for Groundwater in the Vicinity of the Nevada Test Site, Report S-N/99205--059. Prepared for the U.S. Department of Energy, National Nuclear Security Administration Nevada Site Office. Las Vegas, NV.

Thomas, J.M., A.H. Welch, and M.D. Dettinger. 1996. Geochemistry and Isotope Hydrology of Representative Aquifers in the Great Basin Region of Nevada, Utah, and Adjacent States, Professional Paper 1409-C. Denver, CO: U.S. Geological Survey.

Thomas, J.M, F.C. Benedict, Jr., T.P. Rose, R.L. Hershey, J.B. Paces, Z.E. Peterman, I.M. Farnham, K.H. Johannesson, A.K. Singh, K.J. Stetzenbach, G.B. Hudson, J.M. Kenneally, G.F. Eaton, and D.K. Smith. 2002. Geochemical and Isotopic Interpretations of Groundwater Flow in the Oasis Valley Flow System, Southern Nevada, Report Publication No. 45190. Prepared for the U.S. Department of Energy, National Nuclear Security Administration Nevada Operations Office. Las Vegas, NV: Desert Research Institute.

Thordarson, W., and I.J. Winograd. 1961. Abridged Log of Ground-Water Test Well 1 Stockade Wash, Nevada Test Site, Nevada, Water-Resources Investigations, Report 82-4085. Denver, CO: U.S. Geological Survey.

Thorstenson, D.C., E.P. Weeks, H. Haas, E. Busenberg, L.N. Plummer, and C.A. Peters. 1998. "Chemistry of Unsaturated Zone Gases Sampled in Open Boreholes at the Crest of Yucca Mountain, Nevada: Data and Basic Concepts of Chemical and Physical Processes in the Mountain.” In Water Resources Research, 34, (6), 1507-1529. Washington, DC: American Geophysical Union.

Trexler, J.H., Jr., J.C. Cole, and P.H. Cashman. 1996. "Middle Devonian-Mississippian Stratigraphy On and Near the Nevada Test Site: Implications for Hydrocarbon Potential." In AAPG Bulletin, vol. 80 (11): 1736-1762.

Tyler, S.W., J.B. Chapman, S.H. Conrad, D.P. Hammermeister, D.O. Blout, J.J. Miller, M.J. Sully, and J.M. Ginanni. 1996. "Soil-Water Flux in the Southern Great Basin, United States: Temporal and Spatial Variations Over the Last 120,000 Years." In Water Resources Research, vol. 32 (6): 1481-1499. 
U.S. Department of Energy, National Nuclear Security Administration Nevada Site Office. 2004. Completion Report for Well ER-12-2, DOE/NV--11718-846. Las Vegas, NV.

U.S. Department of Energy, Nevada Operations Office. 1997. Regional Groundwater Flow and Tritium Transport Modeling and Risk Assessment of the Underground Test Area, Nevada Test Site, Nevada, Report DOE/NV--477. Las Vegas, NV.

U.S. Department of Energy, Nevada Operations Office. 1998. Routine Radiological Environmental Monitoring Plan, Report DOE/NV/11718-244. Las Vegas, NV: Bechtel Nevada

U.S. Department of Energy, Nevada Operations Office. 2000a. Corrective Action Investigation Plan for Corrective Action Unit 97: Yucca Flat/Climax Mine, Nevada Test Site, Nevada, Report DOE/NV--659. Las Vegas, NV.

U.S. Department of Energy, Nevada Operations Office. 2000b. United States Nuclear Tests, July 1945 through September 1992, DOE/NV--209, Rev. 15. Las Vegas, NV.

Waddell, R.K., J.H. Robinson, and R.K. Blankennagel. 1984. Hydrology of Yucca Mountain and Vicinity, Nevada-California: Investigative Results Through Mid-1983, Water-Resources Investigations Report 84-4267. Denver, CO: U.S. Geological Survey.

Walker, G.E. 1962. Ground Water in the Climax Stock, Nevada Test Site, Nye County, Nevada, Trace Element Investigations Report TEI-813. Washington, DC: U.S. Geological Survey.

Ware, S.D., A. Abdel-Fattah, M. Ding, P.W. Reimus, C. Sedlacek, M.J. Haga, E. Garcia, and S. Chipera. 2005. Radionuclide Sorption and Transport in Fractured Rocks of Yucca Flat, Nevada Test Site. Report LA-UR-05-9279, Los Alamos, NM: Los Alamos National Laboratory.

Warren, R.G., D.A. Sawyer, F.M. Byers, Jr., and G.L. Cole. 1998. A Petrographic/Geochemical Database and Structural Framework for the Southwestern Nevada Volcanic Field, CD ROM. Los Alamos NM: Los Alamos National Laboratory.

White, A.F., and N.J. Chuma. 1987. "Carbon and Isotopic Mass Balance Models of Oasis Valley-Fortymile Canyon Groundwater Basin, Southern Nevada." In Water Resources Research. Vol. 23 (4): 571-582.

White, A.F., H.C. Claassen, and L.V. Benson. 1980. "The Effect of Dissolution of Volcanic Glass on the Water Chemistry in a Tuffaceous Aquifer, Rainier Mesa, Nevada." In Geochemistry of Water. Geological Survey Water-Supply Paper 1535-Q, Washington, DC: U.S. Government Printing Office.

Winograd, I.J., and I. Friedman. 1972. "Deuterium as a Tracer of Regional Groundwater Flow, Southern Great Basin, Nevada and California." In Geological Society of America Bulletin, vol. 83: 3691-3708. 
Winograd, I.J., and F.J. Pearson. 1976. “Major Carbon 14 Anomaly in a Regional Carbonate Aquifer: Possible Evidence for Megascale Channeling, South Central Great Basin." In Water Resources Research, Vol.12(6):1125 - 1142.

Winograd, I.J., and W. Thordarson. 1975. Hydrogeologic and Hydrochemical Framework, South-Central Great Basin, Nevada-California, with Special Reference to the Nevada Test Site, Professional Paper 712-C. Washington, DC: U.S. Geological Survey.

Winograd, I.J., T.B. Coplen, J.M. Landwehr, A.C. Riggs, K.R. Ludwig, B.J. Szabo, P.T. Kolesar, and K.M. Revesz. 1992. "Continuous 500,000-Year Climate Record from Vein Calcite in Devils Hole, Nevada." In Science, 258, 255-260. Washington, DC: American Association for the Advancement of Science. TIC: 237563.

Winograd, I.J., A.C. Rigs, and T.B. Coupling. 1998. "The Relative Contributions of Summer and Cool-Season Precipitation to Groundwater Recharge, Spring Mountains, Nevada, USA." In Hydrogeology Journal, vol. 6: 77-93.

Yang, I.C., G.W. Rattray, and P. Yu. 1996. Interpretation of Chemical and Isotopic Data from Boreholes in the Unsaturated Zone at Yucca Mountain, Nevada, Water-Resources Investigations Report 96-4058. Denver, CO: U.S. Geological Survey. ACC: MOL.19980528.0216.

Yang, I.C., P. Yu, G.W. Rattray, J.S. Ferarese, and J.N. Ryan. 1998. Hydrochemical Investigations in Characterizing the Unsaturated Zone at Yucca Mountain, Nevada. Water-Resources Investigations Report 98-4132. Denver, CO: U.S. Geological Survey. ACC: MOL.19981012.0790. 
Appendix A

Data Used for Yucca Flat Geochemical Evaluations 
Table A.1-1

Major-Ion Data for Yucca Flat Geochemical Evaluation

(Page 1 of 5)

\begin{tabular}{|c|c|c|c|c|c|c|c|c|c|c|c|c|c|c|c|c|c|c|c|c|c|c|c|c|c|c|c|c|c|c|c|}
\hline \multirow{2}{*}{ Site Identification } & \multicolumn{3}{|c|}{$\begin{array}{c}\mathrm{HCO}_{3}, \mathrm{Lab} \\
(\mathrm{mg} / \mathrm{L})\end{array}$} & \multicolumn{3}{|c|}{$\begin{array}{c}\mathrm{CO}_{3}, \mathrm{Lab} \\
(\mathrm{mg} / \mathrm{L})\end{array}$} & \multicolumn{3}{|c|}{$\begin{array}{c}\mathrm{HCO}_{3}, \text { Field } \\
\text { (mg/L) }\end{array}$} & \multicolumn{2}{|c|}{$\begin{array}{c}\mathrm{CO}_{3}, \text { Field } \\
(\mathrm{mg} / \mathrm{L})\end{array}$} & \multicolumn{3}{|c|}{$\begin{array}{c}\mathrm{SO}_{4} \\
(\mathrm{mg} / \mathrm{L})\end{array}$} & \multicolumn{3}{|c|}{$\begin{array}{c}\mathrm{Cl} \\
(\mathrm{mg} / \mathrm{L})\end{array}$} & \multicolumn{3}{|c|}{$\begin{array}{c}\mathrm{Mg} \\
(\mathrm{mg} / \mathrm{L})\end{array}$} & \multicolumn{3}{|c|}{$\begin{array}{c}\mathrm{Na} \\
(\mathrm{mg} / \mathrm{L})\end{array}$} & \multicolumn{3}{|c|}{$\begin{array}{c}\mathrm{K} \\
(\mathrm{mg} / \mathrm{L})\end{array}$} & \multicolumn{3}{|c|}{$\begin{array}{c}\mathrm{Ca} \\
(\mathrm{mg} / \mathrm{L})\end{array}$} & \multirow[t]{2}{*}{\begin{tabular}{l|} 
C/B \\
Lab
\end{tabular}} & \multirow[t]{2}{*}{\begin{tabular}{|c|} 
C/B \\
Field
\end{tabular}} \\
\hline & Avg & SD & $n$ & Avg & SD & $n$ & Avg & SD & $\mathrm{n}$ & Avg & SD & \begin{tabular}{|l|l|}
$\mathrm{n}$ & Avg \\
\end{tabular} & SD & $\mathrm{n}$ & Avg & SD & $n$ & Avg & SD & $\mathrm{n}$ & Avg & SD & $n$ & Avg & SD & $n$ & Avg & SD & $\mathrm{n}$ & & \\
\hline Adaven Spring & 290 & & & 0.1 & & & & & & & & & & & & & & & & & & & & & & & & & & & \\
\hline \multicolumn{32}{|l|}{ Alum Spring } \\
\hline April Fool Spring & 406 & & & & & & 417 & & & & & 110 & & & 16 & & & 51 & & & 28 & & & 3.7 & & & 79 & & & \begin{tabular}{|l|}
-0.1 \\
\end{tabular} & 0.8 \\
\hline Army \#1 Water Well & 255 & 21 & 36 & 0.3 & & & 253 & 5 & 3 & & & 52 & 2 & 36 & 17 & 3 & 33 & 23 & 2 & 37 & 38 & 3 & 36 & 5.6 & 0.9 & 37 & 42 & 5 & 36 & 0.4 & 0.1 \\
\hline Ash Spring & 253 & 20 & 3 & 0.3 & & & 250 & & & & & 34.5 & 0.6 & 4 & 12 & 6 & 4 & \begin{tabular}{|l|}
14.3 \\
\end{tabular} & 0.7 & 4 & 30 & 3 & 4 & 6.8 & 1.0 & 3 & 50 & 7 & \begin{tabular}{|l|}
4 \\
\end{tabular} & \begin{tabular}{|l|}
1.0 \\
\end{tabular} & 0.4 \\
\hline Bullwhack Spring & 398 & & & & & & & & & & & 151 & & & 11 & & & 60 & & & 18 & & & 2.0 & & & 89 & & & -1 & \\
\hline Cane Spring, FF & 189 & 10 & 29 & & & & & & & & & 34 & 9 & 28 & 22 & 4 & 28 & \begin{tabular}{|l|}
10.4 \\
\end{tabular} & 0.9 & 28 & 42 & 3 & 28 & \begin{tabular}{|l|}
6.4 \\
\end{tabular} & 0.5 & 29 & 36 & 3 & 28 & 0.1 & \\
\hline Cane Spring, GR & 360 & & & & & & & & & & & 136 & & & 18 & & & 48 & & & 24 & & & 2.4 & & & 84 & & & 0.0 & \\
\hline Captain Jack Spring & 78 & 30 & 7 & & & & & & & & & 12 & 4 & 7 & 6.1 & 0.9 & 7 & 0.9 & 0.5 & 7 & 32 & 9 & 7 & 2.5 & 0.9 & 7 & 4 & 1 & 7 & \begin{tabular}{|l|}
-0.4 \\
\end{tabular} & \\
\hline \multicolumn{32}{|l|}{ Carpenter Spring } \\
\hline Cattle Spring & 261 & & & & & & & & & & & 39 & & & 16 & & & 11 & & & 41 & & & 5.3 & & & 56 & & & -1 & \\
\hline Cliff Spring, BR & 110 & & & & & & & & & & & 20 & & & 14 & & & \begin{tabular}{|l|}
1.2 \\
\end{tabular} & & & 44 & & & 0.6 & & & 10 & & & 2 & \\
\hline Cliff Spring, GR & 271 & & & & & & & & & & & 51 & & & 6.5 & & & 11 & & & 18 & & & 0.9 & & & 76 & & & 1 & \\
\hline Cow Camp Spring & & & & & & & 290 & 14 & 2 & & & 19 & 14 & 2 & 29 & 1 & 2 & 33 & 3 & 2 & 23 & 3 & 2 & \begin{tabular}{|l|}
0.7 \\
\end{tabular} & 0.1 & 2 & 49 & 1 & 2 & & -2 \\
\hline Cresent Spring & 373 & & & & & & 368 & & & & & 15 & & & 11 & & & 11 & & & 21 & & & 2.9 & & & 94 & & & 2 & 1 \\
\hline Crystal Spring & 251 & 9 & 3 & 0.7 & & & 253 & 5 & 5 & & & 35 & 4 & 7 & 9.0 & 0.6 & 7 & 22 & 2 & 7 & 24 & 3 & 7 & 5.1 & 0.4 & 7 & 44 & 1 & 7 & -0.4 & \begin{tabular}{|l||}
-0.2 \\
\end{tabular} \\
\hline De Jesus Spring & 261 & 37 & 2 & & & & & & & & & 52 & 16 & 2 & 13 & 1 & 2 & 32 & 18 & 2 & 19 & 1 & 2 & 3.1 & 0.8 & 2 & 46 & 8 & 2 & 1 & \\
\hline Desert Dry Lake Well \#1 & 206 & & & & & & 218 & 15 & 2 & & & 46 & 2 & 2 & 8.6 & 0.4 & 2 & 27 & 0.5 & 2 & 34 & 2 & 2 & 5.8 & 0.2 & 2 & 21 & 1 & 2 & 2 & 4 \\
\hline ER-12-1 & 221 & 13 & 4 & 0.3 & & & & & & & & 343 & 9 & 7 & 17 & 0.4 & 7 & 64 & 4 & 7 & 37 & 2 & 7 & 3.6 & 0.5 & 7 & 94 & 6 & 7 & -2 & \\
\hline ER-12-2 & 300 & 12 & 4 & 5 & 3 & 4 & 286 & & & & & 27.3 & 0.5 & 4 & 6.8 & 0.2 & 4 & 1.8 & 0.3 & 4 & 114 & 5 & 4 & 3.1 & 0.7 & 4 & 5.5 & 0.9 & 4 & 4 & 1 \\
\hline ER-19-1 & & & & 96 & & & & & & & & 44 & & & 19 & & & \begin{tabular}{|l|}
1.2 \\
\end{tabular} & & & 82 & & & 3.9 & & & 16 & & & 2 & \\
\hline ER-2-1 & 144 & 22 & 4 & 24 & 10 & 4 & 118 & & & 28 & & 16.5 & 0.6 & 4 & 5.4 & 0.6 & 4 & \begin{tabular}{|l|}
0.3 \\
\end{tabular} & 0.2 & 4 & 75 & 3 & 4 & \begin{tabular}{|l|}
4.9 \\
\end{tabular} & 0.7 & 4 & 2.8 & 0.7 & 4 & 3 & -1 \\
\hline \begin{tabular}{|l|} 
ER-3-1 \\
\end{tabular} & 584 & \begin{tabular}{|l|}
106 \\
\end{tabular} & 4 & 0.2 & \begin{tabular}{|l|}
0.1 \\
\end{tabular} & 2 & & & & & & 67 & 2 & 4 & 42 & 1 & 4 & 34 & 1 & 4 & \begin{tabular}{|l|}
139 \\
\end{tabular} & 4 & 3 & \begin{tabular}{|l|}
18.3 \\
\end{tabular} & 0.8 & 4 & 91 & 3 & 4 & -6 & \\
\hline \begin{tabular}{|l|} 
ER-5-3 \\
\end{tabular} & 176 & \begin{tabular}{|l|}
24 \\
\end{tabular} & 6 & \begin{tabular}{|l|}
7.3 \\
\end{tabular} & 8 & 2 & & & & & & 39 & 4 & 6 & 14 & 1 & 6 & \begin{tabular}{|l|}
3.4 \\
\end{tabular} & 0.3 & 5 & 64 & 10 & 4 & \begin{tabular}{|l|}
5.0 \\
\end{tabular} & 0.9 & \begin{tabular}{|l|}
7 \\
\end{tabular} & 12 & 2 & 5 & 9 & \\
\hline ER-5-3 \#2 & 626 & 50 & 4 & 0.1 & & & & & & & & 69 & 3 & 4 & 38.3 & 0.5 & 4 & 30 & 2 & 4 & 129 & 14 & 4 & \begin{tabular}{|l|}
17.0 \\
\end{tabular} & 0.9 & 4 & 80 & 4 & 4 & 2 & \\
\hline \begin{tabular}{|l|} 
ER-5-4 \\
\end{tabular} & 268 & 32 & 3 & 25 & 15 & 3 & & & & & & 120 & 0 & 3 & 27 & 1 & 3 & 0.1 & 0.1 & 3 & \begin{tabular}{|l|}
161 \\
\end{tabular} & 32 & 3 & 10 & 2 & 4 & 2.0 & 0.2 & 4 & \begin{tabular}{|l|}
9.2 \\
\end{tabular} & \\
\hline \begin{tabular}{|l} 
ER-5-4 \#2 \\
\end{tabular} & 360 & 17 & 4 & 22 & 8 & 4 & 275 & & & 11 & & 117 & 5 & 4 & \begin{tabular}{|l|}
52.0 \\
\end{tabular} & 0.1 & 4 & 0.2 & 0.1 & 2 & \begin{tabular}{|l|}
319 \\
\end{tabular} & 11 & 4 & 6 & 1 & 4 & 0.6 & 0.1 & 2 & \begin{tabular}{|l|}
-1.2 \\
\end{tabular} & \begin{tabular}{|l|}
-8.0 \\
\end{tabular} \\
\hline \begin{tabular}{|l|} 
ER-6-1 \\
\end{tabular} & 238 & 26 & 6 & 0.1 & & & 228 & 27 & 3 & & & 33.4 & 0.8 & 5 & 11 & 1 & 6 & 12 & 1 & 8 & 46 & 3 & 6 & \begin{tabular}{|l|}
7.8 \\
\end{tabular} & 0.5 & 6 & 33 & 1 & 8 & 2 & $|-0.1|$ \\
\hline ER-6-1 \#2 & 244 & \begin{tabular}{|l|}
0.2 \\
\end{tabular} & 4 & \begin{tabular}{|l|}
0.6 \\
\end{tabular} & & & 219 & & & & & 34.3 & 0.5 & 4 & 11 & 1 & 4 & \begin{tabular}{|l|}
13.3 \\
\end{tabular} & 0.5 & 4 & 44 & 3 & 4 & 7.5 & 0.8 & 4 & 33 & 1 & 4 & 3 & -2 \\
\hline \begin{tabular}{|l|} 
ER-6-2 \\
\end{tabular} & 373 & 19 & 5 & 0.7 & & & 261 & & & & & 58 & 4 & 5 & 19 & 3 & 5 & 20 & 1 & 5 & 63 & 7 & 5 & \begin{tabular}{|l|}
10.8 \\
\end{tabular} & 0.4 & 5 & 58 & 5 & 5 & 3 & -11 \\
\hline
\end{tabular}


Table A.1-1

Major-Ion Data for Yucca Flat Geochemical Evaluation

(Page 2 of 5)

\begin{tabular}{|c|c|c|c|c|c|c|c|c|c|c|c|c|c|c|c|c|c|c|c|c|c|c|c|c|c|c|c|c|c|c|c|c|}
\hline \multirow{2}{*}{ Site Identification } & \multicolumn{3}{|c|}{$\begin{array}{c}\mathrm{HCO}_{3}, \mathrm{Lab} \\
\text { (mg/L) }\end{array}$} & \multicolumn{3}{|c|}{$\begin{array}{c}\mathrm{CO}_{3}, \mathrm{Lab} \\
(\mathrm{mg} / \mathrm{L})\end{array}$} & \multicolumn{3}{|c|}{$\begin{array}{c}\mathrm{HCO}_{3}, \text { Field } \\
(\mathrm{mg} / \mathrm{L})\end{array}$} & \multicolumn{3}{|c|}{\begin{tabular}{|c|}
$\mathrm{CO}_{3}$, Field \\
$(\mathrm{mg} / \mathrm{L})$
\end{tabular}} & \multicolumn{3}{|c|}{$\begin{array}{c}\mathrm{SO}_{4} \\
\text { (mg/L) }\end{array}$} & \multicolumn{3}{|c|}{$\begin{array}{c}\mathrm{Cl} \\
(\mathrm{mg} / \mathrm{L})\end{array}$} & \multicolumn{3}{|c|}{$\begin{array}{c}\mathrm{Mg} \\
(\mathrm{mg} / \mathrm{L})\end{array}$} & \multicolumn{3}{|c|}{$\begin{array}{c}\mathrm{Na} \\
(\mathrm{mg} / \mathrm{L})\end{array}$} & \multicolumn{3}{|c|}{$\begin{array}{c}\mathrm{K} \\
(\mathrm{mg} / \mathrm{L})\end{array}$} & \multicolumn{3}{|c|}{$\begin{array}{c}\mathrm{Ca} \\
\text { (mg/L) }\end{array}$} & \multirow[t]{2}{*}{$\begin{array}{l}\text { C/B } \\
\text { Lab }\end{array}$} & \multirow[t]{2}{*}{$\begin{array}{c}\text { C/B } \\
\text { Field }\end{array}$} \\
\hline & Avg & SD & $\mathbf{n}$ & Avg & SD & $\mathbf{n}$ & Avg & SD & $\mathbf{n}$ & Avg & SD & $\mathrm{n}$ & Avg & SD & $\mathbf{n}$ & Avg & SD & $\mathbf{n}$ & Avg & SD & $\mathbf{n}$ & Avg & SD & $\mathbf{n}$ & Avg & SD & $\mathbf{n}$ & Avg & SD & $\mathbf{n}$ & & \\
\hline ER-7-1 & 241 & 6 & 4 & 0.6 & & & 209 & & & & & & 34.1 & 0.2 & 4 & 11 & 1 & 4 & 14 & 0.5 & 4 & 47 & 4 & 4 & 7 & 1 & 4 & 34 & 5 & 4 & 0.2 & -5 \\
\hline Hagestad \#1 & 32 & 8 & 2 & 59 & 25 & 2 & & & & & & & 36 & 17 & 2 & 7 & 2 & 2 & & & & 79 & & & 4.2 & 0.3 & 2 & 1.6 & & & -2 & \\
\hline Hiko Spring & 263 & 13 & 3 & 1 & & & 272 & 14 & 2 & & & & 36 & 2 & 3 & 10 & 1 & 2 & 23.2 & 0.2 & 3 & 27 & 2 & 3 & 7.1 & 0.5 & 3 & 46 & 2 & 3 & -1 & 0.1 \\
\hline Indian Spring, BR & 160 & & & & & & & & & & & & 19.8 & & & 8.3 & & & 6.4 & & & 19 & & & 4.9 & & & 37 & & & -0.2 & \\
\hline Indian Spring, GR & 173 & & & & & & & & & & & & 31 & & & 9.4 & & & 7.1 & & & 39 & & & 0.9 & & & 30 & & & -1 & \\
\hline Marble \#3 & 310 & & & & & & & & & & & & 24 & & & 5.0 & & & 47 & & & 15 & & & 3.8 & & & 25 & & & -1 & \\
\hline Miner Spring & 485 & & & & & & & & & & & & 585 & & & 53 & & & 153 & & & 97 & & & 12 & & & 97 & & & -1 & \\
\hline Naquinta Spring & 180 & & & & & & & & & & & & 12 & & & 5.7 & & & 11 & & & 25 & & & 1.1 & & & 32 & & & -2 & \\
\hline \multicolumn{33}{|l|}{ New Tikaboo Spring } \\
\hline Oak Spring & 113 & 2 & 5 & & & & & & & & & & 11 & 1 & 5 & 9.2 & 0.7 & 5 & 4.4 & 0.2 & 5 & 20.6 & 0.8 & 5 & 6.2 & 0.1 & 5 & 17.8 & 0.6 & 5 & 1 & \\
\hline \multicolumn{33}{|l|}{ Old Tikaboo Spring } \\
\hline Penoyer Well & 157 & & & 0.1 & & & & & & & & & 40.8 & & & 40 & & & 3.3 & & & 31 & & & 12.3 & & & 50 & & & 2 & \\
\hline Pine Spring, GR & 222 & & & 5 & & & & & & & & & 23.7 & & & 12 & & & 8.2 & & & 54 & & & 2.5 & & & 32 & & & -0.5 & \\
\hline Pluto 1 & 150 & & & & & & & & & & & & 46.9 & & & 24 & & & 10 & & & 36 & & & 7.7 & & & 41 & & & 0.1 & \\
\hline Pluto 5 & 218 & & & & & & & & & & & & 54 & & & 12 & & & 22 & & & 26 & & & 4.3 & & & 55 & & & -0.1 & \\
\hline Pyramid Spring & 196 & & & 0.1 & & & 204 & & & & & & 30.6 & 0.6 & 2 & 11 & 1 & 2 & 5.3 & 0.5 & 2 & 43 & 4 & 2 & 1.1 & 0.4 & 2 & 48 & 7 & 2 & -6 & -4 \\
\hline Quail Spring, GR & 166 & & & & & & & & & & & & 206 & & & 11 & & & 19 & & & 29 & & & 1.9 & & & 86 & & & 1 & \\
\hline Quartz Spring & 420 & 35 & 3 & & & & & & & & & & 85 & 22 & 3 & 31 & 7 & 3 & 40 & 2 & 3 & 62 & 14 & 3 & 2.9 & 0.8 & 3 & 72 & 5 & 3 & 1 & \\
\hline Rabbitbrush Spring & 197 & & & & & & & & & & & & 27 & & & 9.0 & & & 9 & & & 25 & & & 3.5 & & & 42 & & & 0.5 & \\
\hline Reveille Spring & 164 & & & 0.1 & & & & & & & & & & & & & & & & & & & & & & & & & & & & \\
\hline Rock Spring & 348 & & & & & & & & & & & & 35 & & & 5.8 & & & 19 & & & 13 & & & 1.7 & & & 87 & & & 1 & \\
\hline Rose Bud Spring & 400 & & & & & & & & & & & & 150 & & & 11 & & & 60 & & & 18 & & & 2.0 & & & 89 & & & -1 & \\
\hline Sand Spring, PW & 263 & 37 & 3 & 5 & 9 & 3 & & & & & & & 36 & 24 & 3 & 14 & 2 & 3 & 42 & 4 & 3 & 18 & 1 & 3 & 4.3 & 0.6 & 3 & 31 & 11 & 3 & 0.3 & \\
\hline Sand Spring, SSV & 111 & & & 33 & & & 126 & & & 37 & & & 22 & & & 3.6 & & & 11 & & & 37 & & & 11.4 & & & 16 & & & 0.1 & 5 \\
\hline Savio Spring & 268 & & & & & & & & & & & & 26 & & & 10 & & & 14 & & & 24 & & & 6.2 & & & 55 & & & 1 & \\
\hline \multicolumn{33}{|l|}{ Sharp Spring } \\
\hline Spring Above Adaven & & & & & & & 324 & & & & & & 18 & & & 4.8 & & & 25 & & & 14 & & & 2.2 & & & 63 & & & & 1 \\
\hline Spring at Reville & & & & & & & 216 & & & & & & 27 & & & 11 & & & 1.8 & & & 26 & & & \begin{tabular}{|l|}
0.6 \\
\end{tabular} & & & 62 & & & & 1 \\
\hline Test Well \#7 & 286 & & & & & & & & & & & & 2 & & & 8.0 & & & 0.2 & & & 113 & & & 4.6 & & & 1 & & & -0.2 & \\
\hline The Seeps Spring & & & & & & & & & & & & & & & & & & & & & & & & & & & & & & & & \\
\hline Tim Spring & 143 & 4 & 2 & & & & & & & & & & 38 & 1 & 2 & 11 & 0.0 & 2 & 27 & 1 & 2 & 13.2 & 0.2 & 2 & 2.92 & \begin{tabular}{l|l}
0.02 \\
\end{tabular} & 2 & 18.8 & 0.4 & 2 & -1 & \\
\hline Tippipah Spring & 86 & 6 & 9 & & & & 90 & 7 & 6 & & & & 18 & 3 & 15 & 7.4 & 0.8 & 15 & 0.4 & 0.2 & 14 & 39.8 & 3 & 15 & 2.9 & 0.3 & 15 & 5.0 & 0.8 & 15 & 1 & 2 \\
\hline
\end{tabular}


Table A.1-1

Major-Ion Data for Yucca Flat Geochemical Evaluation

(Page 3 of 5)

\begin{tabular}{|c|c|c|c|c|c|c|c|c|c|c|c|c|c|c|c|c|c|c|c|c|c|c|c|c|c|c|c|c|c|c|c|c|}
\hline \multirow{2}{*}{ Site Identification } & \multicolumn{3}{|c|}{$\begin{array}{c}\mathrm{HCO}_{3}, \mathrm{Lab} \\
(\mathrm{mg} / \mathrm{L})\end{array}$} & \multicolumn{3}{|c|}{$\begin{array}{c}\mathrm{CO}_{3}, \text { Lab } \\
\text { (mg/L) }\end{array}$} & \multicolumn{3}{|c|}{$\begin{array}{c}\mathrm{HCO}_{3}, \text { Field } \\
\text { (mg/L) }\end{array}$} & \multicolumn{3}{|c|}{$\begin{array}{c}\mathrm{CO}_{3}, \text { Field } \\
\text { (mg/L) }\end{array}$} & \multicolumn{3}{|c|}{$\begin{array}{c}\mathrm{SO}_{4} \\
(\mathrm{mg} / \mathrm{L})\end{array}$} & \multicolumn{3}{|c|}{$\begin{array}{c}\mathrm{Cl} \\
(\mathrm{mg} / \mathrm{L})\end{array}$} & \multicolumn{3}{|c|}{$\begin{array}{c}\mathrm{Mg} \\
(\mathrm{mg} / \mathrm{L})\end{array}$} & \multicolumn{3}{|c|}{$\begin{array}{c}\mathrm{Na} \\
(\mathrm{mg} / \mathrm{L})\end{array}$} & \multicolumn{3}{|c|}{$\begin{array}{c}\mathrm{K} \\
(\mathrm{mg} / \mathrm{L})\end{array}$} & \multicolumn{3}{|c|}{$\begin{array}{c}\mathrm{Ca} \\
(\mathrm{mg} / \mathrm{L})\end{array}$} & \multirow[t]{2}{*}{\begin{tabular}{|l|} 
C/B \\
Lab
\end{tabular}} & \multirow[t]{2}{*}{$\begin{array}{r}\mathrm{C} / \mathrm{B} \\
\text { Field }\end{array}$} \\
\hline & Avg & SD & $\mathbf{n}$ & Avg & SD & $\mathbf{n}$ & Avg & SD & n & Avg & SD & $\mathrm{n}$ & Avg & SD & $n$ & Avg & SD & $\mathbf{n}$ & Avg & SD & n & Avg & SD & $\mathbf{n}$ & Avg & SD & $\mathbf{n}$ & Avg & SD & $\mathbf{n}$ & & \\
\hline Topopah Spring & 52 & 9 & 6 & & & & & & & & & & 7.6 & 0.9 & 5 & 2.9 & 1.2 & 6 & 1.4 & 0.1 & 6 & 11 & 1 & 6 & 6.0 & 0.9 & 6 & 6.7 & 0.4 & 6 & 1 & \\
\hline U12.03 UG-3 & 134 & 3 & 4 & & & & & & & & & & 14 & 2 & 4 & 10.5 & 0.9 & 4 & 4.6 & 0.5 & 4 & 25 & 1 & 3 & 4.9 & 0.9 & 3 & 23 & 6 & 4 & 2 & \\
\hline U12e Tunnel & \begin{tabular}{|l|}
171 \\
\end{tabular} & 6 & 17 & 3 & 2 & 14 & & & & & & & 23 & 5 & 19 & 9.2 & 1.0 & 19 & 0.53 & 0.04 & 18 & 74 & 1 & 17 & 3.5 & 1.2 & 19 & 5.9 & 0.8 & 18 & 1 & \\
\hline U12n Tunnel & 146 & 29 & 33 & 9 & 7 & 27 & & & & & & & 24 & 11 & 33 & 10 & 3 & 35 & 0.7 & 0.4 & 34 & 63 & 8 & 34 & \begin{tabular}{|l|l|}
7.3 \\
\end{tabular} & 1.3 & 34 & \begin{tabular}{|l|}
10.2 \\
\end{tabular} & 3 & 34 & 1 & \\
\hline \multicolumn{33}{|l|}{ U12n Tunnel } \\
\hline U-12t data & 122 & 22 & 24 & 5 & & & & & & & & & 22 & 6 & 23 & 10.4 & 0.9 & 24 & 2.1 & 1 & 23 & 43 & 12 & 23 & 6 & 1 & 23 & 11.2 & 5 & 24 & 5 & \\
\hline U-15.01 Shaft, C-30 & 167 & & & & & & & & & & & & 750 & & & 77 & & & 118 & & & 72 & & & 5.5 & & & 161 & & & -1 & \\
\hline U-15.01 Shaft, C-36 & 316 & & & & & & & & & & & & 325 & & & 52 & & & 63 & & & 56 & & & 4.8 & & & 126 & & & -2 & \\
\hline U-15.01 Shaft, CGW-1 & 163 & & & & & & & & & & & & 1060 & & & 77 & & & 0.9 & & & 250 & & & \begin{tabular}{|l|}
3.4 \\
\end{tabular} & & & 283 & & & 3 & \\
\hline U-15.01 Shaft, NH-01 & \begin{tabular}{|l|}
65 \\
\end{tabular} & & & & & & & & & & & & 850 & & & 160 & & & \begin{tabular}{|l|}
4.8 \\
\end{tabular} & & & 229 & & & 3.8 & & & 240 & & & 2 & \\
\hline U-15.01 Shaft, UG-02 & 165 & & & & & & & & & & & & 480 & & & 70 & & & 1.5 & & & 214 & & & 4.7 & & & 114 & & & -2 & \\
\hline U-2bs & 198 & 13 & 2 & & & & & & & & & & 25 & 5 & 2 & \begin{tabular}{|l|}
7.5 \\
\end{tabular} & 2.6 & 2 & \begin{tabular}{|l|}
0.5 \\
\end{tabular} & 0.3 & 2 & 79 & 0.0 & 2 & 6.0 & 0.6 & 2 & 3.1 & 0.9 & 2 & 3 & \\
\hline U-3cn \#5 & 263 & 46 & 13 & 7 & & & 271 & & & & & & 36 & 3 & 15 & 32 & 7 & 14 & 19 & 3 & 15 & 56 & 4 & 14 & 9 & 1 & 15 & 32 & 7 & 15 & 3 & 2 \\
\hline U-3cn PS \#2 & 272 & 23 & 4 & 0.6 & & & & & & & & & 21 & 2 & 4 & 8.0 & 0.8 & 4 & 3.4 & 0.1 & 4 & 92 & 6 & 4 & 19.3 & 1.5 & 4 & 14.5 & 0.4 & 4 & -2 & \\
\hline U-3mi & & & & & & & & & & & & & & & & & & & \begin{tabular}{|l|}
3.7 \\
\end{tabular} & & & 122 & & & \begin{tabular}{|l|}
8.0 \\
\end{tabular} & & & 19 & & & & \\
\hline U-4u PS \#2A & 155 & 13 & 3 & 0.4 & 0.3 & 2 & & & & & & & 11 & 1 & 3 & 6.0 & 0.8 & 3 & 5 & 5 & 3 & 73 & 6 & 3 & 20 & 11 & 3 & 12 & 5 & 3 & \begin{tabular}{|l|}
-16 \\
\end{tabular} & \\
\hline UE-10 ITS \#3 & 543 & & & 2 & & & & & & & & & 43 & & & 10 & & & 0.4 & & & 209 & & & 21.5 & & & 8 & & & 1 & \\
\hline UE-10j & 363 & 60 & 2 & 0.1 & & & & & & & & & 60 & & & 19 & 4 & 2 & 33 & 11 & 2 & 51 & 11 & 2 & 9 & 4 & 2 & 81 & 38 & 2 & -8 & \\
\hline UE-10j, Zone \#1 & \begin{tabular}{|l|}
552 \\
\end{tabular} & 68 & 2 & 0.1 & & & & & & & & & 79 & 5 & 2 & 23.9 & 0.2 & 2 & 45 & 3 & 2 & 68 & 6 & 2 & 13 & 1 & 2 & \begin{tabular}{|l|}
107 \\
\end{tabular} & 8 & 2 & -4 & \\
\hline UE-10j, Zone \#2 & 403 & & & 0.1 & & & & & & & & & 67 & & & 16 & & & 30 & & & 43 & & & 8.3 & & & 68 & & & 3 & \\
\hline UE-10j, Zone \#3 & 322 & 38 & 2 & 0.2 & & & & & & & & & 59 & 3 & 2 & 12.8 & 0.4 & 2 & 27 & 2 & 2 & 37 & 3 & 2 & 7.3 & 0.6 & 2 & 60 & 6 & 2 & -1 & \\
\hline UE-11a & 217 & & & & & & & & & & & & 60 & & & 25 & & & 2.7 & & & 106 & & & 4.7 & & & 9.1 & & & 1 & \\
\hline UE-14b & 118 & 5 & 4 & 2.4 & 2 & 4 & & & & & & & 79 & 10 & 5 & 7.1 & 0.4 & 5 & 0.7 & 0.6 & 5 & 77 & 7 & 5 & 1.4 & 0.5 & 5 & 11 & 4 & 5 & 0.4 & \\
\hline UE-15d Water Well & 368 & 31 & 13 & & & & & & & & & & 44 & 10 & 15 & 15 & 2 & 15 & 16 & 2 & 15 & 81 & 16 & 14 & 16 & 1 & 14 & 48 & 8 & 15 & -1 & \\
\hline UE-15j & 908 & & & & & & & & & & & & 123 & & & 39 & & & 12 & & & 310 & & & 56 & & & 46 & & & 1 & \\
\hline UE-15j A-5 & 882 & 21 & 3 & & & & & & & & & & 112 & 2 & 3 & 37.7 & 0.6 & 3 & 12 & 0.0 & 3 & 297 & 20 & 3 & 51 & 3 & 3 & 47 & 0.6 & 3 & 1 & \\
\hline UE-16d (Eleana) & 340 & 40 & 13 & & & & 269 & 12 & 3 & & & & 59 & 1 & 13 & 11 & 2 & 16 & 24 & 2 & 16 & 31 & 4 & 15 & 6.7 & 0.5 & 15 & 76 & 6 & 16 & -1 & \begin{tabular}{|l|}
-10 \\
\end{tabular} \\
\hline UE-16f (Eleana) & 799 & & & 132 & & & & & & & & & 1.7 & & & 20 & & & \begin{tabular}{|l|}
0.4 \\
\end{tabular} & & & 412 & & & 1.41 & & & 1.5 & & & 0.1 & \\
\hline UE-17a (Eleana) & 301 & 160 & 4 & 2 & 2 & 3 & & & & & & & 99 & 47 & 4 & 30 & 9 & 4 & 21 & 12 & 4 & 147 & 104 & 4 & 5 & 3 & 4 & 29 & 16 & 4 & -9 & \\
\hline UE-1a & 386 & 87 & 2 & 0.3 & & & & & & & & & 1 & & & 29 & 3 & 2 & 28 & 6 & 2 & 55 & 6 & 2 & 10.5 & 2.6 & 2 & 45 & 5 & 2 & $\mid-0.3$ & \\
\hline UE-1b & 248 & & & & & & & & & & & & 20 & & & \begin{tabular}{|l|}
6.8 \\
\end{tabular} & 1.3 & 2 & \begin{tabular}{|l|}
13.6 \\
\end{tabular} & 0.1 & 2 & 31.4 & 0.2 & 2 & \begin{tabular}{|l|}
11.1 \\
\end{tabular} & 0.6 & 2 & \begin{tabular}{|l|}
37.7 \\
\end{tabular} & 0.4 & 2 & 1 & \\
\hline
\end{tabular}




\section{Table A.1-1}

(Page 4 of 5)

\begin{tabular}{|c|c|c|c|c|c|c|c|c|c|c|c|c|c|c|c|c|c|c|c|c|c|c|c|c|c|c|c|c|c|c|c|c|}
\hline \multirow{2}{*}{ Site Identification } & \multicolumn{3}{|c|}{$\begin{array}{c}\mathrm{HCO}_{3}, \mathrm{Lab} \\
(\mathrm{mg} / \mathrm{L})\end{array}$} & \multicolumn{3}{|c|}{$\begin{array}{c}\mathrm{CO}_{3}, \mathrm{Lab} \\
(\mathrm{mg} / \mathrm{L})\end{array}$} & \multicolumn{3}{|c|}{$\begin{array}{c}\mathrm{HCO}_{3}, \text { Field } \\
\text { (mg/L) }\end{array}$} & \multicolumn{3}{|c|}{\begin{tabular}{|c|}
$\mathrm{CO}_{3}$, Field \\
$(\mathrm{mg} / \mathrm{L})$
\end{tabular}} & \multicolumn{3}{|c|}{$\begin{array}{c}\mathrm{SO}_{4} \\
\text { (mg/L) }\end{array}$} & \multicolumn{3}{|c|}{$\begin{array}{c}\mathrm{Cl} \\
(\mathrm{mg} / \mathrm{L})\end{array}$} & \multicolumn{3}{|c|}{$\begin{array}{c}\mathrm{Mg} \\
(\mathrm{mg} / \mathrm{L})\end{array}$} & \multicolumn{3}{|c|}{$\begin{array}{c}\mathrm{Na} \\
(\mathrm{mg} / \mathrm{L})\end{array}$} & \multicolumn{3}{|c|}{$\begin{array}{c}\mathrm{K} \\
(\mathrm{mg} / \mathrm{L})\end{array}$} & \multicolumn{3}{|c|}{$\begin{array}{c}\mathrm{Ca} \\
(\mathrm{mg} / \mathrm{L})\end{array}$} & \multirow[t]{2}{*}{$\begin{array}{l}\text { C/B } \\
\text { Lab }\end{array}$} & \multirow[t]{2}{*}{\begin{tabular}{|c|}
$C / B$ \\
Field \\
\end{tabular}} \\
\hline & Avg & SD & $\mathbf{n}$ & Avg & SD & $\mathbf{n}$ & Avg & SD & $\mathbf{n}$ & Avg & SD & n & Avg & SD & $\mathbf{n}$ & Avg & SD & $\mathbf{n}$ & Avg & SD & $\mathbf{n}$ & Avg & SD & $\mathbf{n}$ & Avg & SD & $\mathbf{n}$ & Avg & SD & n & & \\
\hline UE-1c & 241 & 4 & 2 & & & & & & & & & & 33 & 1 & 2 & 6.3 & 1.0 & 4 & 13.6 & 0.3 & 4 & 34 & 1 & 4 & 12.6 & 0.3 & 4 & 36 & 2 & 4 & 1 & \\
\hline UE-1h & 270 & & & 2 & & & & & & & & & 3 & & & 43.4 & 0.3 & 2 & 9 & 2 & 2 & 101 & 1 & 2 & 24 & 1 & 2 & 13 & 3 & 2 & -5 & \\
\hline UE-1q & 197 & 12 & 3 & 1 & & & 195 & & & & & & 24 & 3 & 2 & 11 & 6 & 4 & 14 & 1 & 4 & 39 & 11 & 4 & 7 & 3 & 4 & 24 & 6 & 4 & -3 & -3 \\
\hline UE-2ce & 405 & 31 & 3 & 0.09 & & & \begin{tabular}{|l|}
402 \\
\end{tabular} & & & & & & 11 & 19 & 4 & 17 & 50 & 3 & 25 & 8 & 5 & 40 & 10 & 5 & 21 & 6 & 5 & 53 & 22 & 5 & 2 & 2 \\
\hline \multicolumn{33}{|l|}{ UE-4t } \\
\hline UE-5 PW-1 & 154 & 10 & 5 & 2 & 1 & 2 & 125 & 4 & 2 & & & & 35 & 2 & 17 & 10 & 1 & 17 & 5 & 0.4 & 7 & 56 & 3 & 20 & 6.2 & 0.3 & 7 & 14.3 & 1.6 & 7 & \begin{tabular}{|l|l}
4.7 \\
\end{tabular} & -2.4 \\
\hline UE-5 PW-2 & 157 & 9 & 6 & 6 & 4 & 2 & 122 & & & & & & 28 & 1 & 14 & 9.1 & 1.8 & 15 & 6.2 & 0.7 & 6 & 50 & 3 & 15 & 5.4 & 0.3 & 6 & \begin{tabular}{|l|}
16.6 \\
\end{tabular} & 1.3 & 6 & \begin{tabular}{|l|l|}
4.3 \\
\end{tabular} & -6.2 \\
\hline UE-5 PW-3 & 150 & 21 & 8 & 3 & 5 & 3 & 116 & 22 & 3 & & & & 31 & 2 & 16 & 9.0 & 0.9 & 17 & 5.6 & 0.8 & 8 & 54 & 3 & 18 & 5 & 1 & 8 & 16.2 & 1.1 & 8 & 5.6 & -3.1 \\
\hline UE-5c Water Well & 172 & 15 & 13 & 6 & 4 & 6 & 160 & 33 & 2 & 7 & & & 44 & 8 & 13 & 12 & 8 & 13 & 1.8 & 0.5 & 13 & 86 & 6 & 12 & 6.2 & 0.7 & 12 & 8.1 & 0.9 & 8 & \begin{tabular}{|l|l|}
0.4 \\
\end{tabular} & -1.4 \\
\hline UE-5n & 162 & 13 & 5 & 10 & 9 & 5 & \begin{tabular}{|l|}
172 \\
\end{tabular} & & & 9 & & & 32 & 6 & 6 & 14 & 3 & 6 & \begin{tabular}{|l|}
1.8 \\
\end{tabular} & 0.4 & 7 & 81 & 5 & 6 & 8.4 & 0.5 & 7 & \begin{tabular}{|l|}
7.1 \\
\end{tabular} & 1.5 & 7 & \begin{tabular}{|l|}
-0.5 \\
\end{tabular} & 0.9 \\
\hline UE-6d & 245 & & & 0.5 & & & & & & & & & 19 & & & 8.2 & & & 10 & & & 58 & & & 11.6 & & & 21 & & & 1 & \\
\hline UE-7nS & 167 & 47 & 4 & 0.4 & & & 207 & & & & & & 0.8 & 0.7 & 3 & 27 & 6 & 3 & \begin{tabular}{|l|}
3.5 \\
\end{tabular} & 0.4 & 5 & 58 & 6 & 5 & 4.6 & 0.4 & 4 & 20 & 1 & 5 & -5 & 4 \\
\hline USGS HTH \#1 & \begin{tabular}{|l|}
97 \\
\end{tabular} & 15 & 24 & 15 & 5 & 22 & \begin{tabular}{|l|}
113 \\
\end{tabular} & 15 & 7 & & & & 7 & 2 & 20 & 3.3 & 0.3 & 23 & \begin{tabular}{|l|}
0.2 \\
\end{tabular} & 0.1 & 22 & 50.4 & 2 & 24 & 0.6 & 0.3 & 21 & 2.1 & 2 & 23 & 2 & -4 \\
\hline USGS HTH \#10 & 198 & 4 & 3 & & & & & & & & & & 14.3 & 0.6 & 3 & 5.7 & 0.9 & 3 & 18.0 & 1 & 3 & 7.2 & 0.4 & 3 & 1.9 & 1.2 & 2 & 38 & 2 & 3 & 0.1 & \\
\hline USGS HTH \#3 & 336 & 11 & 2 & & & & 323 & & & & & & 75 & 12 & 2 & 23 & 0.1 & 2 & 20.4 & 0.9 & 2 & 81.3 & 2 & 2 & 8.4 & 1.1 & 2 & 50 & 2 & 2 & -1 & -2 \\
\hline USGS HTH \#4 & 197 & & & & & & & & & & & & 17 & & & 6.1 & & & 17 & & & 13 & & & 2.5 & & & 34 & & & \begin{tabular}{|l|l|}
0.4 \\
\end{tabular} & \\
\hline USGS HTH E & 58 & & & 1.8 & & & & & & & & & 1.1 & & & 8.2 & & & 0.6 & & & 17 & & & 1.7 & & & 10 & & & -2.1 & \\
\hline USGS HTH F & 264 & & & & & & 254 & 15 & 2 & & & & 79 & 8 & 3 & 13 & 6 & 3 & \begin{tabular}{|l|}
16.7 \\
\end{tabular} & 0.6 & 3 & 63 & 3 & 3 & 9.1 & 0.7 & 3 & 46 & 2 & 3 & -1 & -2 \\
\hline USGS Test Well B & 163 & 16 & 4 & 0.7 & 0.5 & 3 & 122 & & & & & & 24 & 4 & 4 & 18 & 3 & 4 & 0.59 & 0.03 & 3 & 75 & 4 & 4 & 3.5 & 0.4 & 4 & 6 & 0.6 & 4 & \begin{tabular}{|l|}
0.4 \\
\end{tabular} & -10 \\
\hline USGS Test Well D & 238 & 24 & 7 & 2 & 1 & 3 & & & & & & & 30 & 8 & 5 & 7.3 & 1.1 & 7 & 5.0 & 0.5 & 7 & 84 & 4 & 7 & 8.3 & 0.5 & 7 & 12 & 1 & 7 & \begin{tabular}{|l|}
-0.1 \\
\end{tabular} & \\
\hline USGS Water Well A & 212 & 8 & 23 & & & & & & & & & & 19 & 3 & 25 & 9 & 6 & 25 & 7 & 1 & 25 & 52 & 3 & 25 & 9.0 & 1.6 & 25 & 22 & 3 & 15 & 1 & \\
\hline USGS Water Well C & 544 & 85 & 37 & 0.2 & & & & & & & & & 66 & 5 & 36 & 36 & 6 & 39 & 30 & 4 & 38 & 127 & 7 & 35 & 15.0 & 3.3 & 34 & 67 & 10 & 37 & -1 & \\
\hline USGS-MX Coal Valley Well & & & & & & & 239 & 20 & 2 & & & & 24 & 3 & 2 & 5.8 & 0.2 & 2 & 19.1 & 0.2 & 2 & 19 & 2 & 2 & 4.5 & 0.1 & 2 & 38 & 1 & 2 & & 4 \\
\hline Water Well 1 & 165 & & & & & & & & & & & & 38 & & & 5.9 & & & \begin{tabular}{|l|}
1.6 \\
\end{tabular} & & & 73 & & & 9 & & & 5.5 & & & -1 & \\
\hline Water Well 2 & 202 & 28 & 18 & & & & & & & & & & 20 & 6 & 18 & 7.4 & 1.9 & 17 & 15 & 3 & 18 & 28 & 2 & 17 & 6.6 & 0.6 & 17 & 30 & 8 & 12 & \begin{tabular}{|l|}
-0.5 \\
\end{tabular} & \\
\hline Water Well 4 & 150 & 15 & 12 & 8 & 7 & 3 & & & & & & & 42 & 2 & 12 & 12 & 2 & 13 & 8.0 & 0.9 & 13 & 50 & 1 & 11 & 5.0 & 0.2 & 11 & 23 & 1 & 12 & 1 & \\
\hline Water Well 4A & 150 & 12 & 7 & 2 & 3 & 3 & 145 & & & & & & 40 & 3 & 7 & 11 & 1 & 7 & \begin{tabular}{|l|}
7.5 \\
\end{tabular} & 0.7 & 7 & 52 & 3 & 7 & 5.6 & 0.4 & 7 & 24 & 2 & 7 & -3 & -5 \\
\hline Water Well 5A & 332 & 28 & 10 & 22 & 10 & 10 & 229 & & & 22 & & & 26 & 6 & 10 & 11 & 2 & 10 & 0.7 & 0.2 & 8 & 158 & 9 & 10 & 5.9 & 0.5 & 8 & 2.2 & 0.5 & 9 & \begin{tabular}{|l|}
0.1 \\
\end{tabular} & -13 \\
\hline Water Well 5B & 166 & 19 & 29 & 10 & 7 & 14 & 102 & & & 7 & & & 55 & 7 & 29 & 23 & 2 & 28 & 2 & 0.7 & 28 & 98 & 17 & 28 & 11.3 & 1.3 & 26 & 7 & 3 & 29 & -0.1 & -13 \\
\hline Water Well 5C & 281 & 54 & 37 & 20 & 9 & 21 & 244 & 121 & 2 & 7 & & & 26 & 4 & 38 & 10 & 2 & 38 & 0.8 & 0.9 & 34 & 138 & 42 & 37 & 6.7 & 1.2 & 35 & 2 & 2 & 38 & \begin{tabular}{|l|}
-0.7 \\
\end{tabular} & -9.7 \\
\hline Water Well C-1 & 548 & 94 & 27 & 3 & 4 & 2 & 580 & & & & & & 66 & 2 & 26 & 35 & 3 & 28 & 30 & 2 & 26 & 124 & 5 & 27 & 14 & 1 & 26 & 69 & 10 & 27 & \begin{tabular}{|l|}
-0.7 \\
\end{tabular} & -1.1 \\
\hline Watertown 1 & 176 & 16 & 5 & 0.2 & 0.2 & 2 & & & & & & & 24 & 9 & 4 & 6.8 & 1.3 & 5 & 1.7 & 0.5 & 5 & 71 & 4 & 5 & 8.6 & 0.4 & 4 & 5 & 1 & 5 & \begin{tabular}{|l|}
0.4 \\
\end{tabular} & \\
\hline
\end{tabular}


Table A.1-1

Major-Ion Data for Yucca Flat Geochemical Evaluation

(Page 5 of 5)

\begin{tabular}{|c|c|c|c|c|c|c|c|c|c|c|c|c|c|c|c|c|c|c|c|c|c|c|c|c|c|c|c|c|c|c|c|c|}
\hline \multirow{2}{*}{ Site Identification } & \multicolumn{3}{|c|}{$\begin{array}{c}\mathrm{HCO}_{3}, \mathrm{Lab} \\
(\mathrm{mg} / \mathrm{L})\end{array}$} & \multicolumn{3}{|c|}{$\begin{array}{c}\mathrm{CO}_{3}, \mathrm{Lab} \\
(\mathrm{mg} / \mathrm{L})\end{array}$} & \multicolumn{3}{|c|}{$\begin{array}{c}\mathrm{HCO}_{3}, \text { Field } \\
\text { (mg/L) }\end{array}$} & \multicolumn{3}{|c|}{$\begin{array}{c}\mathrm{CO}_{3}, \text { Field } \\
(\mathrm{mg} / \mathrm{L})\end{array}$} & \multicolumn{3}{|c|}{$\begin{array}{c}\mathrm{SO}_{4} \\
\text { (mg/L) }\end{array}$} & \multicolumn{3}{|c|}{$\begin{array}{c}\mathrm{Cl} \\
(\mathrm{mg} / \mathrm{L})\end{array}$} & \multicolumn{3}{|c|}{$\begin{array}{c}\mathrm{Mg} \\
(\mathrm{mg} / \mathrm{L})\end{array}$} & \multicolumn{3}{|c|}{$\begin{array}{c}\mathrm{Na} \\
(\mathrm{mg} / \mathrm{L})\end{array}$} & \multicolumn{3}{|c|}{$\begin{array}{c}\mathrm{K} \\
(\mathrm{mg} / \mathrm{L})\end{array}$} & \multicolumn{3}{|c|}{$\begin{array}{c}\mathrm{Ca} \\
(\mathrm{mg} / \mathrm{L})\end{array}$} & \multirow[t]{2}{*}{$\begin{array}{l}\text { C/B } \\
\text { Lab }\end{array}$} & \multirow[t]{2}{*}{\begin{tabular}{|c|} 
C/B \\
Field
\end{tabular}} \\
\hline & Avg & SD & $\mathbf{n}$ & Avg & SD & $n$ & Avg & SD & $\mathbf{n}$ & Avg & SD & $\mathbf{n}$ & Avg & SD & $\mathrm{n}$ & Avg & SD & $\mathbf{n}$ & Avg & SD & $\mathbf{n}$ & Avg & SD & $\mathrm{n}$ & Avg & SD & $\mathbf{n}$ & Avg & SD & $\mathbf{n}$ & & \\
\hline Watertown 2 & 211 & 6 & 2 & 2 & & & & & & & & & 17 & 3 & 2 & 6.3 & 0.5 & 2 & 1.1 & 0.1 & 2 & 85 & 2 & 2 & 9.6 & 0.6 & 2 & 4 & 2 & 2 & -0.1 & \\
\hline Watertown 3 & 188 & 15 & 12 & 0.1 & 0.3 & 6 & & & & & & & 22 & 10 & 11 & 8.9 & 2.1 & 12 & 4.1 & 2 & 12 & 56 & 4 & 12 & 6.9 & 0.6 & 7 & 18 & 3 & 12 & 1 & \\
\hline Watertown 4 & 533 & 66 & 2 & 0.2 & & & 507 & & & & & & 69 & 1 & 2 & 12 & 1 & 2 & 23 & 2 & 2 & 82.5 & 0.7 & 2 & 23.9 & 1.3 & 2 & 83.0 & 0.04 & 2 & 2 & \begin{tabular}{|l|}
-0.5 \\
\end{tabular} \\
\hline Well 3 Water Well & 194 & 3 & 8 & & & & & & & & & & 21 & 1 & 8 & 5.8 & 1.2 & 8 & 12 & 1 & 8 & 39 & 1 & 8 & 7.6 & 0.4 & 8 & 20 & 1 & 8 & 0.4 & \\
\hline Wheelbarrow Spring & 164 & & & & & & & & & & & & 22 & & & 15 & & & 6.0 & & & 42 & & & 3.6 & & & 24 & & & -1 & \\
\hline White Rock Spring, SR & & & & & & & 275 & 21 & 2 & & & & 12 & & & 10 & 1 & 2 & 30 & 1 & 2 & 14.5 & 0.7 & 2 & 7.2 & 0.3 & 2 & 37.5 & 0.7 & 2 & & -1 \\
\hline Whiterock Spring, YF & 80 & 5 & 53 & & & & 57 & 25 & 3 & & & & 31 & 5 & 55 & 10 & 2 & 56 & 0.7 & 0.4 & 54 & 43 & 5 & 56 & 6 & 0.9 & 56 & 6 & 1 & 56 & 1 & -8 \\
\hline Wiregrass Spring & 386 & & & & & & 367 & 13 & 8 & & & & 7 & 1 & 10 & 3.0 & 0.4 & 10 & 34 & 1 & 11 & 2.9 & 0.2 & 10 & 1.6 & 1.5 & 10 & 70 & 2 & 10 & 2 & -1 \\
\hline
\end{tabular}

\section{Avg = Average}

$\mathrm{BR}=$ Belted Range

$\mathrm{C} / \mathrm{B} \mathrm{Lab}=$ Charge balance calculated using $\mathrm{HCO}_{3}$ and $\mathrm{CO}_{3}$ measured in the lab

$\mathrm{C} / \mathrm{B}$ Field = Charge balance calculated using $\mathrm{HCO}_{3}$ and $\mathrm{CO}_{3}$ measured in the field

$\mathrm{GR}=$ Groom Range

$\mathrm{mg} / \mathrm{L}=$ Milligrams per liter

$n=$ Number of samples included in the average and standard deviation

$\mathrm{PW}=$ Pintwater Range

$\mathrm{SD}=$ Standard Deviation

$\mathrm{SR}=$ Sheep Range

SSV $=$ Sand Spring Valley

YF = Yucca Flat 
Table A.1-2

Isotope Data for Yucca Flat Geochemical Evaluation

(Page 1 of 5)

\begin{tabular}{|c|c|c|c|c|c|c|c|c|c|c|c|c|c|c|c|}
\hline \multirow[t]{2}{*}{ Site Identification } & \multicolumn{3}{|c|}{$\begin{array}{c}\mathrm{H}-2 / 1 \\
\text { (permil) }\end{array}$} & \multicolumn{3}{|c|}{ 0-18/16 (permil) } & \multicolumn{3}{|c|}{$\begin{array}{l}\mathrm{C}-13 / 12 \\
\text { (permil) }\end{array}$} & \multicolumn{3}{|c|}{$\mathrm{C}-14$ (pmc) } & \multicolumn{3}{|c|}{$\mathrm{Cl}-36 / \mathrm{Cl}$ (ratio) } \\
\hline & Avg & SD & $\mathbf{n}$ & Avg & SD & $n$ & Avg & SD & $n$ & Avg & SD & $n$ & Avg & SD & $n$ \\
\hline Adaven Spring & -108 & & & -14.1 & & & -10.0 & & & & & & & & \\
\hline Alum Spring & -87 & & & -9.6 & & & -9.6 & & & & & & & & \\
\hline April Fool Spring & -94 & 5 & 3 & -11.2 & 1.3 & 3 & -8.2 & 0.4 & 2 & & & & & & \\
\hline Army \#1 Water Well & -101 & 2 & 8 & -13.5 & 0.3 & 6 & -6.0 & 0.7 & 4 & 4 & 1.3 & 3 & $4.25 \mathrm{E}-13$ & $3.7 \mathrm{E}-15$ & 2 \\
\hline Ash Spring & -109 & 2 & 5 & -14.2 & 0.1 & 2 & -6.0 & 1.2 & 3 & 6.3 & 0.5 & 3 & $6.51 \mathrm{E}-13$ & & \\
\hline Bullwhack Spring & -90 & 3 & 2 & -9.3 & 1.3 & 2 & -6.4 & & & & & & & & \\
\hline Cane Spring, FF & -90 & 2 & 25 & -11.0 & 0.5 & 35 & -9.6 & 0.9 & 10 & 86 & 9.3 & 2 & & & \\
\hline Cane Spring, GR & -90 & 3 & 2 & -11.3 & 2.6 & 2 & -7.6 & & & & & & & & \\
\hline Captain Jack Spring & -102 & 1 & 2 & -12.6 & 0.8 & 7 & & & & & & & & & \\
\hline Carpenter Spring & -95 & & & -11.9 & & & & & & & & & & & \\
\hline Cattle Spring & -88 & 4 & 2 & -8.8 & 0.8 & 2 & -11.4 & & & & & & & & \\
\hline Cliff Spring, BR & -97 & & & -13.0 & & & & & & & & & & & \\
\hline Cliff Spring, GR & -92 & 6 & 2 & -12.0 & 1.6 & 2 & -10.9 & 0.6 & 2 & & & & & & \\
\hline Cow Camp Spring & -93 & 2 & 3 & -12.7 & 0.2 & 3 & & & & & & & & & \\
\hline Cresent Spring & -95 & & & -12.6 & & & -8.5 & & & & & & & & \\
\hline Crystal Spring & -108.6 & 0.9 & 9 & -14.35 & 0.05 & 4 & -5.9 & 0.9 & 5 & 7.0 & 1.1 & 2 & & & \\
\hline De Jesus Spring & -96 & 6 & 2 & -12.6 & 0.8 & 2 & -10.3 & 2.5 & 2 & & & & & & \\
\hline Desert Dry Lake Well \#1 & -98.5 & 0.7 & 2 & -13.0 & 0.1 & 2 & -5.3 & & & 1 & & & & & \\
\hline ER-12-1 & -94 & & & -12.5 & 0.1 & 3 & -9.6 & 0.6 & 2 & 11 & 0.1 & 2 & $7.80 \mathrm{E}-13$ & & \\
\hline ER-12-2 & -101.1 & 0.1 & 2 & -13.7 & 0.2 & 2 & -5.5 & 0.9 & 2 & 2 & & & $6.90 \mathrm{E}-13$ & & \\
\hline ER-19-1 & -105 & & & -13.9 & & & -14.3 & & & & & & & & \\
\hline ER-2-1 & -108 & 2 & 2 & -14.3 & 0.1 & 2 & -11.5 & 0.8 & 2 & 18 & & & $7.19 \mathrm{E}-13$ & & \\
\hline ER-3-1 & -109 & 3 & 3 & -14.1 & 0.1 & 3 & -2.3 & 0.9 & 3 & 1 & 0.1 & 3 & $1.31 \mathrm{E}-13$ & $3.7 \mathrm{E}-15$ & 2 \\
\hline ER-5-3 & -108 & 1 & 2 & -14.0 & 0.1 & 2 & -7.9 & 0.1 & 2 & 9 & & & 8.42E-13 & & \\
\hline ER-5-3 \#2 & -108 & 3 & 2 & -14.1 & 0.1 & 2 & -4.4 & 0.1 & 2 & 2 & & & $2.29 \mathrm{E}-13$ & & \\
\hline ER-5-4 & -108 & 2 & 2 & -13.7 & 0.1 & 2 & -4.6 & 0.1 & 2 & 1.5 & & & $3.94 \mathrm{E}-13$ & & \\
\hline ER-5-4 \#2 & $\begin{array}{l}-102 \\
\end{array}$ & 2 & 2 & -13.3 & 0.0 & 2 & -0.1 & 0.4 & 2 & 1 & & & $1.76 \mathrm{E}-13$ & & \\
\hline ER-6-1 & -106 & 2 & 2 & -14.0 & 0.0 & 3 & -6.7 & 0.6 & 2 & 2.2 & 0.2 & 2 & $3.92 \mathrm{E}-13$ & & \\
\hline ER-6-1 \#2 & -106 & 1 & 2 & -14.1 & 0.1 & 2 & -6.2 & 0.4 & 2 & 2.4 & & & 4.33E-13 & & \\
\hline
\end{tabular}


Table A.1-2

Isotope Data for Yucca Flat Geochemical Evaluation

(Page 2 of 5)

\begin{tabular}{|c|c|c|c|c|c|c|c|c|c|c|c|c|c|c|c|}
\hline \multirow[t]{2}{*}{ Site Identification } & \multicolumn{3}{|c|}{$\begin{array}{c}\mathrm{H}-2 / 1 \\
\text { (permil) }\end{array}$} & \multicolumn{3}{|c|}{ 0-18/16 (permil) } & \multicolumn{3}{|c|}{$\begin{array}{l}\text { C-13/12 } \\
\text { (permil) }\end{array}$} & \multicolumn{3}{|c|}{$\mathrm{C}-14$ (pmc) } & \multicolumn{3}{|c|}{$\mathrm{Cl}-36 / \mathrm{Cl}$ (ratio) } \\
\hline & Avg & SD & $\mathbf{n}$ & Avg & SD & $\mathbf{n}$ & Avg & SD & $\mathbf{n}$ & Avg & SD & $\mathbf{n}$ & Avg & SD & $\mathbf{n}$ \\
\hline ER-6-2 & -106 & & & -14.1 & 0.1 & 2 & -4.3 & 0.4 & 2 & & & & $2.00 \mathrm{E}-13$ & & \\
\hline ER-7-1 & -106 & 0.0 & 2 & -14.0 & 0.1 & 2 & -6.3 & 0.6 & 2 & 5.3 & & & $3.77 \mathrm{E}-13$ & & \\
\hline \multicolumn{16}{|l|}{ Hagestad \#1 } \\
\hline Hiko Spring & -109 & 2 & 7 & -14.4 & 0.7 & 4 & -5.9 & 1.0 & 3 & 6.2 & 0.4 & 2 & $6.08 \mathrm{E}-13$ & & \\
\hline Indian Spring, BR & -96 & & & -13.2 & & & & & & & & & & & \\
\hline Indian Spring, GR & -83 & 8 & 2 & -9.3 & 1.5 & 2 & -5.5 & & & & & & & & \\
\hline \multicolumn{16}{|l|}{ Marble \#3 } \\
\hline Miner Spring & -82 & & & -8.9 & & & & & & & & & & & \\
\hline Naquinta Spring & -89 & & & -10.7 & & & -7.7 & & & 62 & & & & & \\
\hline New Tikaboo Spring & -86 & & & -10.3 & & & -8.2 & & & & & & & & \\
\hline Oak Spring & -101 & 7 & 2 & -12.5 & 0.3 & 5 & & & & & & & & & \\
\hline Old Tikaboo Spring & -84 & & & -8.5 & & & -5.2 & & & & & & & & \\
\hline Penoyer Well & -118 & & & -15.1 & & & -8.9 & & & 25 & & & & & \\
\hline Pine Spring, GR & -80 & & & -8.9 & & & -7.6 & & & & & & & & \\
\hline \multicolumn{16}{|l|}{ Pluto 1} \\
\hline Pluto 5 & -76 & & & -7.1 & & & & & & & & & & & \\
\hline Pyramid Spring & -100 & & & -13.0 & & & -10.4 & & & 107 & & & & & \\
\hline Quail Spring, GR & -91 & 2 & 2 & -11.2 & 1.0 & 2 & -10.6 & & & & & & & & \\
\hline Quartz Spring & -86 & 2 & 3 & -11.1 & 0.5 & 3 & -10.3 & 1.7 & 3 & 98 & & & & & \\
\hline Rabbitbrush Spring & -88 & 1 & 2 & -10.1 & 1.6 & 2 & -11.5 & & & & & & & & \\
\hline Reveille Spring & -95 & & & -12.5 & & & -11.0 & & & & & & & & \\
\hline Rock Spring & -86 & & & -10.9 & & & -9.8 & & & 81 & & & & & \\
\hline \multicolumn{16}{|l|}{ Rose Bud Spring } \\
\hline Sand Spring, PW & -88 & & & -11.9 & & & -5.3 & & & & & & & & \\
\hline Sand Spring, SSV & -107 & & & 14.3 & & & 3.2 & & & & & & & & \\
\hline \multicolumn{16}{|l|}{ Savio Spring } \\
\hline Sharp Spring & -86 & & & -9.5 & & & -9.0 & & & & & & & & \\
\hline Spring Above Adaven & -103 & & & -13.9 & & & & & & & & & & & \\
\hline
\end{tabular}


Table A.1-2

Isotope Data for Yucca Flat Geochemical Evaluation

(Page 3 of 5)

\begin{tabular}{|c|c|c|c|c|c|c|c|c|c|c|c|c|c|c|c|}
\hline \multirow{2}{*}{ Site Identification } & \multicolumn{3}{|c|}{$\begin{array}{c}\mathrm{H}-2 / 1 \\
\text { (permil) }\end{array}$} & \multicolumn{3}{|c|}{ 0-18/16 (permil) } & \multicolumn{3}{|c|}{$\begin{array}{l}\text { C-13/12 } \\
\text { (permil) }\end{array}$} & \multicolumn{3}{|c|}{$\mathrm{C}-14$ (pmc) } & \multicolumn{3}{|c|}{$\mathrm{Cl}-36 / \mathrm{Cl}$ (ratio) } \\
\hline & Avg & SD & $\mathbf{n}$ & Avg & SD & $\mathbf{n}$ & Avg & SD & $\mathbf{n}$ & Avg & SD & $\mathbf{n}$ & Avg & SD & $\mathbf{n}$ \\
\hline \multicolumn{16}{|l|}{ Spring at Reville } \\
\hline \multicolumn{16}{|l|}{ Test Well \#7 } \\
\hline The Seeps Spring & -98 & & & -13.3 & & & & & & & & & & & \\
\hline Tim Spring & -99 & 1 & 2 & -13.1 & 0.1 & 2 & -8.5 & 0.6 & 2 & & & & & & \\
\hline Tippipah Spring & -95 & 5 & 2 & -12.3 & 1.0 & 6 & & & & & & & & & \\
\hline Topopah Spring & -88 & & & -12.3 & 0.6 & 7 & & & & & & & & & \\
\hline \multicolumn{16}{|l|}{ U12.03 UG-3 } \\
\hline U12n.03 Tunnel & -97.5 & 1.9 & 47 & -13.4 & 0.3 & 47 & & & & & & & & & \\
\hline U12n.05 Tunnel & -94.4 & 1.6 & 44 & -13.0 & 0.3 & 44 & & & & & & & & & \\
\hline “U12e main (0+100’ bulkhead) & -103.6 & & & -13.7 & & & & & & & & & & & \\
\hline *U12e south (0+1350' bulkhead) & -102.5 & & & -13.6 & & & & & & & & & & & \\
\hline "U-12n (0+1940’ bulkhead) & -101.3 & & & -13.4 & & & & & & & & & & & \\
\hline${ }^{*} \mathrm{U}-12 \mathrm{t}$ (0+1700' bulkhead) & -102.5 & & & -13.8 & & & & & & & & & & & \\
\hline${ }^{*} \mathrm{U}-12 \mathrm{t}(0+2100$ ' bulkhead $)$ & -101.1 & & & -13.7 & & & & & & & & & & & \\
\hline \multicolumn{16}{|l|}{ U-15.01 Shaft, C-30 } \\
\hline \multicolumn{16}{|l|}{ U-15.01 Shaft, C-36 } \\
\hline U-15.01 Shaft, CGW-1 & -93 & & & -12.7 & & & -4.1 & & & & & & & & \\
\hline \multicolumn{16}{|l|}{ U-15.01 Shaft, NH-01 } \\
\hline \multicolumn{16}{|l|}{ U-15.01 Shaft, UG-02 } \\
\hline \multicolumn{16}{|l|}{$\mathrm{U}-2 \mathrm{bs}$} \\
\hline U-3cn \#5 & -104 & 2 & 2 & -14.1 & 0.03 & 2 & -6.8 & 1.0 & 2 & 3 & & & $4.08 \mathrm{E}-13$ & & \\
\hline U-3cn PS \#2 & -103.3 & 0.6 & 3 & -13.9 & 0.1 & 4 & -6.8 & 1.2 & 3 & & & & 1.24E-09 & & \\
\hline \multicolumn{16}{|l|}{ U-3mi } \\
\hline U-4u PS \#2A & -101.5 & 0.1 & 2 & -13.0 & 0.1 & 3 & -9.1 & 0.5 & 3 & & & & 4.45E-08 & & \\
\hline UE-10 ITS \#3 & -107 & & & -13.5 & & & & & & & & & & & \\
\hline UE-10j & -104 & & & -13.3 & 0.2 & 2 & -5.0 & & & 7 & 5.3 & 2 & $2.76 \mathrm{E}-13$ & & \\
\hline UE-10j, Zone \#1 & -104 & 4 & 2 & -13.6 & 0.1 & 2 & -3.6 & 1.3 & 2 & 7 & 0.0 & 2 & $2.41 \mathrm{E}-13$ & & \\
\hline UE-10j, Zone \#2 & -102 & 5 & 2 & -13.2 & 0.1 & 2 & -5.7 & 0.9 & 2 & 11 & & & $3.91 \mathrm{E}-13$ & & \\
\hline UE-10j, Zone \#3 & -100 & 4 & 2 & -12.8 & 0.1 & 3 & -7.7 & 0.3 & 3 & 13 & 0.0 & 2 & $4.45 \mathrm{E}-13$ & & \\
\hline
\end{tabular}


Table A.1-2

Isotope Data for Yucca Flat Geochemical Evaluation

(Page 4 of 5)

\begin{tabular}{|c|c|c|c|c|c|c|c|c|c|c|c|c|c|c|c|}
\hline \multirow{2}{*}{ Site Identification } & \multicolumn{3}{|c|}{$\begin{array}{c}\mathrm{H}-2 / 1 \\
\text { (permil) }\end{array}$} & \multicolumn{3}{|c|}{ 0-18/16 (permil) } & \multicolumn{3}{|c|}{$\begin{array}{l}\text { C-13/12 } \\
\text { (permil) }\end{array}$} & \multicolumn{3}{|c|}{$\mathrm{C}-14$ (pmc) } & \multicolumn{3}{|c|}{$\mathrm{Cl}-36 / \mathrm{Cl}$ (ratio) } \\
\hline & Avg & SD & $\mathbf{n}$ & Avg & SD & $\mathbf{n}$ & Avg & SD & $\mathbf{n}$ & Avg & SD & $\mathbf{n}$ & Avg & SD & $\mathbf{n}$ \\
\hline UE-11a & -111 & & & -14.3 & & & & & & & & & & & \\
\hline UE-14b & -110 & 2 & 5 & -14.4 & 0.04 & 5 & -9.9 & 0.1 & 2 & & & & & & \\
\hline UE-15d Water Well & -105 & 5 & 3 & -14.2 & 0.1 & 3 & -4.1 & & & 6 & & & & & \\
\hline \multicolumn{16}{|l|}{ UE-15j } \\
\hline \multicolumn{16}{|l|}{ UE-15j A-5 } \\
\hline UE-16d (Eleana) & -95.5 & 0.7 & 2 & -12.6 & 0.2 & 5 & -8.9 & 1.3 & 5 & 7 & 0.8 & 2 & $6.36 \mathrm{E}-13$ & & \\
\hline UE-16f (Eleana) & -104.5 & 0.7 & 2 & -14.0 & 0.8 & 3 & -9.8 & 2.0 & 3 & 3 & & & $3.12 \mathrm{E}-13$ & & \\
\hline UE-17a (Eleana) & -100 & 0.0 & 2 & -13.1 & 0.4 & 3 & -10.6 & 0.8 & 3 & 3 & 2 & 3 & $5.03 E-13$ & $1.3 \mathrm{E}-13$ & 3 \\
\hline UE-1a & -103.3 & 0.6 & 3 & -13.6 & 0.1 & 3 & -8.6 & & & 61 & & & $8.63 \mathrm{E}-13$ & & \\
\hline UE-1b & -105 & 0.0 & 3 & -13.8 & 0.1 & 2 & -4.5 & & & 16 & & & $6.26 \mathrm{E}-13$ & & \\
\hline UE-1c & -105 & 1 & 4 & -13.6 & 0.5 & 4 & -5.0 & 0.5 & 2 & 3 & 0.0 & 2 & $7.18 \mathrm{E}-13$ & 5.9E-15 & 2 \\
\hline UE-1h & -104.5 & 0.7 & 2 & -13.8 & 0.1 & 2 & -11.2 & 1.3 & 2 & 18 & 8 & 2 & $1.61 \mathrm{E}-13$ & $1.4 \mathrm{E}-14$ & 2 \\
\hline UE-1q & -108 & 1 & 2 & -14.5 & 0.4 & 3 & -5.5 & 4.3 & 2 & 8 & & & $7.90 \mathrm{E}-13$ & & \\
\hline UE-2ce & -100 & & & -12.9 & & & -5.3 & & & & & & & & \\
\hline UE-4t & -103 & 2 & 2 & -13.8 & 0.1 & 2 & & & & & & & & & \\
\hline UE-5 PW-1 & -107 & 1 & 2 & -13.7 & 0.1 & 2 & -8.0 & 0.7 & 5 & 20 & 6 & 4 & $8.42 \mathrm{E}-13$ & & \\
\hline UE-5 PW-2 & -106 & & & -13.8 & & & -8.6 & 0.6 & 2 & 30.4 & 4.7 & 2 & $5.27 \mathrm{E}-13$ & & \\
\hline UE-5 PW-3 & -104 & 1 & 4 & -13.5 & 0.1 & 4 & -7.6 & 0.3 & 5 & 18.0 & 2.6 & 3 & $6.78 \mathrm{E}-13$ & & \\
\hline UE-5c Water Well & -106 & 1 & 3 & -13.8 & 0.1 & 3 & -7.5 & 0.3 & 3 & 6.6 & 0.1 & 2 & $6.13 \mathrm{E}-13$ & & \\
\hline UE-5n & -106 & 3 & 9 & -13.3 & 0.2 & 9 & -8.0 & 1.2 & 3 & 18.8 & & & $5.96 \mathrm{E}-10$ & $5.57 \mathrm{E}-11$ & 3 \\
\hline UE-6d & -110 & & & -13.8 & & & & & & & & & & & \\
\hline UE-7nS & -106 & & & -14.0 & & & -2.0 & & & & & & & & \\
\hline USGS HTH \#1 & -110 & 1 & 15 & -15.0 & 0.2 & 16 & -11.2 & 1.0 & 3 & 30 & & & $9.68 \mathrm{E}-13$ & & \\
\hline \multicolumn{16}{|l|}{ USGS HTH \#10 } \\
\hline USGS HTH \#3 & -103.5 & 0.7 & 2 & -14.2 & 0.0 & 2 & -9.2 & & & 37 & & & & & \\
\hline \multicolumn{16}{|l|}{ USGS HTH \#4 } \\
\hline USGS HTHE & -112 & & & -14.6 & & & & & & & & & & & \\
\hline USGS HTH F & & & & & & & & & & & & & & & \\
\hline
\end{tabular}


Table A.1-2

Isotope Data for Yucca Flat Geochemical Evaluation

(Page 5 of 5)

\begin{tabular}{|c|c|c|c|c|c|c|c|c|c|c|c|c|c|c|c|}
\hline \multirow[t]{2}{*}{ Site Identification } & \multicolumn{3}{|c|}{$\begin{array}{c}\mathrm{H}-2 / 1 \\
\text { (permil) }\end{array}$} & \multicolumn{3}{|c|}{ 0-18/16 (permil) } & \multicolumn{3}{|c|}{$\begin{array}{l}\text { C-13/12 } \\
\text { (permil) }\end{array}$} & \multicolumn{3}{|c|}{$\mathrm{C}-14$ (pmc) } & \multicolumn{3}{|c|}{ Cl-36/CI (ratio) } \\
\hline & Avg & SD & $n$ & Avg & SD & $n$ & Avg & SD & $n$ & Avg & SD & $n$ & Avg & SD & $n$ \\
\hline USGS Test Well B & -106.0 & 0.8 & 4 & -13.8 & 0.3 & 4 & -10.4 & 0.4 & 2 & 20 & & & $8.00 \mathrm{E}-13$ & & \\
\hline USGS Test Well D & -108 & 4 & 2 & -14.2 & 0.1 & 2 & -5.5 & & & 3 & & & & & \\
\hline USGS Water Well A & -107 & & & -13.0 & & & -8.9 & & & 6 & & & & & \\
\hline USGS Water Well C & -107 & 2 & 9 & -14.0 & 0.6 & 9 & -4.0 & 0.3 & 2 & 1 & & & $1.76 \mathrm{E}-13$ & & \\
\hline USGS-MX Coal Valley Well & -109 & 1 & 2 & -14.6 & 0.1 & 2 & & & & & & & & & \\
\hline \multicolumn{16}{|l|}{ Water Well 1} \\
\hline Water Well 2 & -103 & 1 & 3 & -13.5 & 0.6 & 3 & -11.2 & & & 10 & & & & & \\
\hline Water Well 4 & -94 & & & -12.6 & 0.1 & 2 & -10.9 & & & 19 & 1.1 & 2 & $6.16 \mathrm{E}-13$ & & \\
\hline Water Well 4A & -99 & 3 & 2 & -12.8 & 0.1 & 2 & -8.8 & 0.6 & 2 & 18 & & & $6.47 \mathrm{E}-13$ & & \\
\hline Water Well 5A & -108 & 4 & 2 & -13.6 & 0.3 & 2 & -4.6 & 0.4 & 2 & 2.6 & & & $8.43 E-13$ & & \\
\hline Water Well 5B & -107 & 3 & 4 & -13.5 & 0.5 & 3 & -10.4 & 1.2 & 3 & 13.1 & & & $7.83 \mathrm{E}-13$ & & \\
\hline Water Well 5C & -108 & 2 & 4 & -13.9 & 0.4 & 4 & -6.0 & 0.1 & 3 & 3.3 & 0.2 & 2 & $6.96 \mathrm{E}-13$ & & \\
\hline Water Well C-1 & -107 & 3 & 6 & -13.9 & 0.7 & 5 & -4.7 & 1.2 & 2 & 1 & 0.2 & 2 & $1.66 \mathrm{E}-13$ & & \\
\hline Watertown 1 & -109 & & & -14.6 & & & -5.3 & & & 12 & & & $6.53 \mathrm{E}-13$ & & \\
\hline \multicolumn{16}{|l|}{ Watertown 2} \\
\hline Watertown 3 & -105 & & & -13.7 & & & -6.5 & 0.8 & 2 & 27 & & & $5.82 \mathrm{E}-13$ & & \\
\hline Watertown 4 & -108 & & & -14.3 & & & -2.3 & & & 1 & & & $3.62 \mathrm{E}-13$ & & \\
\hline \multicolumn{16}{|l|}{ Well 3 Water Well } \\
\hline Wheelbarrow Spring & -93 & & & -12.0 & & & & & & & & & & & \\
\hline White Rock Spring, SR & -84 & 2 & 2 & -9.8 & 0.1 & 2 & -8.3 & & & & & & & & \\
\hline Whiterock Spring, YF & -95 & 2 & 65 & -12.5 & 0.5 & 85 & -11.4 & 1.8 & 20 & 91 & & & & & \\
\hline Wiregrass Spring & -94 & 2 & 10 & -12.8 & 0.1 & 11 & -10.4 & 0.4 & 2 & 97 & & & & & \\
\hline
\end{tabular}

* Impounded tunnel water samples were collected on 8/23/99 (U-12e), 8-24-99 (U-12t), and 8-25-99 (U-12n). 
Table A.1-3

Field Measurement Data for Yucca Flat Geochemical Evaluation

(Page 1 of 5 )

\begin{tabular}{|c|c|c|c|c|c|c|c|c|c|c|c|c|c|c|c|}
\hline \multirow[t]{2}{*}{ Site Identification } & \multicolumn{3}{|c|}{$\mathrm{T}\left({ }^{\circ} \mathrm{C}\right)$} & \multicolumn{3}{|c|}{ pH } & \multicolumn{3}{|c|}{ pH, Field } & \multicolumn{3}{|c|}{$\begin{array}{c}\text { Specific } \\
\text { Conductance } \\
(\mu \mathrm{S} / \mathrm{cm})\end{array}$} & \multicolumn{3}{|c|}{$\begin{array}{l}\text { Total Dissolved } \\
\text { Solids (mg/L) }\end{array}$} \\
\hline & Avg & SD & $\mathbf{n}$ & Avg & SD & $\mathbf{n}$ & Avg & SD & $\mathbf{n}$ & Avg & SD & $\mathbf{n}$ & Avg & SD & $\mathbf{n}$ \\
\hline Adaven Spring & 9.9 & & & 7.1 & & & & & & 500 & & & & & \\
\hline Alum Spring & & & & & & & & & & & & & & & \\
\hline April Fool Spring & 12.5 & & & 8.0 & & & 7.3 & & & 777 & & & & & \\
\hline Army \#1 Water Well & 31 & 1 & 13 & 7.3 & 0.3 & 155 & 7.3 & 0.1 & 5 & 533 & 76 & 152 & 327 & 26 & 27 \\
\hline Ash Spring & 35.1 & 2.2 & 7 & 7.6 & 0.2 & 4 & 7.0 & & & 475 & 19 & 3 & 347 & 66 & 3 \\
\hline Bullwhack Spring & & & & 7.3 & & & & & & 845 & & & & & \\
\hline Cane Spring, FF & 13 & 2 & 18 & 7.7 & 0.2 & 29 & 7.0 & 0.6 & 5 & 452 & 33 & 28 & & & \\
\hline Cane Spring, GR & 13.0 & & & 7.6 & & & 7.6 & & & 809 & 2 & 2 & & & \\
\hline Captain Jack Spring & 11 & 6 & 6 & 7.4 & 0.2 & 7.0 & 7.3 & 0.3 & 3 & 160 & 39 & 7 & & & \\
\hline Carpenter Spring & 16.0 & & & & & & & & & & & & & & \\
\hline Cattle Spring & 16.5 & & & 8.0 & & & 8.0 & & & 528 & 3 & 2 & & & \\
\hline Cliff Spring, BR & & & & 7.9 & & & & & & 244 & & & & & \\
\hline Cliff Spring, GR & 13.0 & & & 7.7 & & & & & & 508 & & & & & \\
\hline Cow Camp Spring & 12 & 3 & 2 & 8.1 & 0.1 & 2 & 7.6 & 0.0 & 2 & 568 & 46 & 2 & 312 & 28 & 2 \\
\hline Cresent Spring & 11.7 & & & 8.0 & & & 7.3 & & & 489 & & & & & \\
\hline Crystal Spring & 27.6 & 0.5 & 10 & 7.8 & 0.4 & 6 & 7.41 & 0.07 & 4 & 480 & 20 & 5 & 314 & 57 & 4 \\
\hline De Jesus Spring & 13 & 3 & 2 & 7.9 & 0.5 & 2 & 7.9 & 0.2 & 2 & 536 & 69 & 2 & 345 & & \\
\hline Desert Dry Lake Well \#1 & 19.4 & 0.5 & 2 & 8.1 & 0.3 & 2 & 8.0 & 0.1 & 2 & 447 & 7 & 2 & 310 & & \\
\hline ER-12-1 & 25 & & & 7.7 & 0.2 & 3 & & & & 987 & 12 & 3 & 758 & 42 & 2 \\
\hline ER-12-2 & 35.2 & & & 8.2 & 0.1 & 4 & 7.6 & & & 557 & 30 & 4 & 347 & 21 & 3 \\
\hline ER-19-1 & & & & 10.7 & & & & & & 504 & & & 271 & & \\
\hline ER-2-1 & 21.3 & & & 9.1 & 0.3 & 4 & 9.2 & & & 360 & 14 & 4 & 337 & 32 & 3 \\
\hline ER-3-1 & 41 & 5 & 2 & 6.7 & 0.1 & 3 & & & & 1,216 & 23 & 4 & 730 & 56 & 3 \\
\hline ER-5-3 & 30.0 & & & 8.4 & 0.5 & 6 & & & & 363 & 73 & 6 & 306 & 15 & 5 \\
\hline ER-5-3 \#2 & 33.8 & & & 7.1 & 0.3 & 4 & & & & 1,115 & 29 & 4 & 687 & 6 & 3 \\
\hline ER-5-4 & 30.2 & & & 8.9 & 0.2 & 3 & & & & 885 & 5 & 3 & 570 & 14 & 2 \\
\hline ER-5-4\#2 & 38.1 & & & 8.68 & 0.05 & 4 & 8.57 & & & 1,362 & 76 & 4 & 847 & 12 & 3 \\
\hline ER-6-1 & 41 & 3 & 2 & 7.8 & 0.4 & 5 & 7.27 & 0.05 & 2 & 485 & 23 & 6 & 331 & 87 & 6 \\
\hline
\end{tabular}


Table A.1-3

Field Measurement Data for Yucca Flat Geochemical Evaluation

(Page 2 of 5)

\begin{tabular}{|c|c|c|c|c|c|c|c|c|c|c|c|c|c|c|c|}
\hline \multirow[t]{2}{*}{ Site Identification } & \multicolumn{3}{|c|}{$\mathrm{T}\left({ }^{\circ} \mathrm{C}\right)$} & \multicolumn{3}{|c|}{ pH } & \multicolumn{3}{|c|}{ pH, Field } & \multicolumn{3}{|c|}{$\begin{array}{c}\text { Specific } \\
\text { Conductance } \\
(\mu \mathrm{S} / \mathrm{cm})\end{array}$} & \multicolumn{3}{|c|}{$\begin{array}{l}\text { Total Dissolved } \\
\text { Solids (mg/L) }\end{array}$} \\
\hline & Avg & SD & $\mathbf{n}$ & Avg & SD & $\mathbf{n}$ & Avg & SD & $\mathbf{n}$ & Avg & SD & $\mathbf{n}$ & Avg & SD & $\mathbf{n}$ \\
\hline ER-6-1\#2 & 39.9 & & & 7.7 & 0.1 & 3 & 7.2 & & & 467 & 41 & 4 & 303 & 12 & 3 \\
\hline ER-6-2 & 34.9 & & & 7.6 & 0.1 & 5 & 7.0 & & & 642 & 63 & 5 & 436 & 25 & 4 \\
\hline ER-7-1 & 49.4 & & & 7.7 & 0.1 & 4 & 7.4 & & & 492 & 13 & 4 & 307 & 6 & 23 \\
\hline Hagestad \#1 & 15.6 & & & 10.7 & 0.6 & 2 & & & & 497 & 181 & 2 & 277 & 30 & 2 \\
\hline Hiko Spring & 26.7 & 0.2 & 4 & 8.0 & 0.2 & 3 & 7.4 & 0.0 & 2 & 514 & 40 & 2 & 445 & & \\
\hline Indian Spring, BR & 10.3 & & & 7.5 & & & & & & 299 & & & & & \\
\hline Indian Spring, GR & 14.4 & & & 8.1 & & & 8.1 & & & 358 & 2.8 & 2 & & & \\
\hline Marble \#3 & 21.7 & & & 7.9 & & & & & & 522 & & & 323 & & \\
\hline Miner Spring & & & & 7.9 & & & & & & 1,710 & & & & & \\
\hline Naquinta Spring & 16.5 & & & 8.2 & & & & & & 308 & & & & & \\
\hline \multicolumn{16}{|l|}{ New Tikaboo Spring } \\
\hline Oak Spring & 14 & 3 & 5 & 7.3 & 0.2 & 5 & 7.0 & 0.6 & 4 & 228 & 5.6 & 5 & & & \\
\hline \multicolumn{16}{|l|}{ Old Tikaboo Spring } \\
\hline Penoyer Well & 13.1 & & & 7.3 & & & & & & 450 & & & & & \\
\hline Pine Spring, GR & 20.2 & & & 8.5 & & & & & & 424 & & & & & \\
\hline Pluto 1 & & & & 8.0 & & & & & & 459 & & & & & \\
\hline Pluto 5 & & & & 7.9 & & & & & & 558 & & & 386 & & \\
\hline Pyramid Spring & 16 & 5 & 2 & 7.3 & & & 7.8 & & & 455 & 56.6 & 2 & 287 & & \\
\hline Quail Spring, GR & 15 & 0.0 & 2 & 7.8 & & & 7.8 & & & 669 & 1.4 & 2 & & & \\
\hline Quartz Spring & 15 & 5 & 3 & 8.0 & 0.2 & 3 & 7.7 & 0.5 & 2 & 828 & 85 & 4 & & & \\
\hline Rabbitbrush Spring & 14 & & & 7.9 & & & 7.9 & & & 378 & 4 & 2 & & & \\
\hline Reveille Spring & 11.1 & & & 7.3 & & & & & & 404 & & & & & \\
\hline Rock Spring & 16 & & & 7.8 & & & & & & 580 & & & & & \\
\hline Rose Bud Spring & 10.3 & & & 7.3 & & & & & & 850 & & & & & \\
\hline Sand Spring, PW & & & & 8.3 & 0.5 & 3 & & & & 513 & 62 & 3 & & & \\
\hline Sand Spring, SSV & 18.5 & & & 9.3 & & & 9.3 & & & 332 & & & & & \\
\hline Savio Spring & & & & 8.3 & & & & & & 470 & & & & & \\
\hline \multicolumn{16}{|l|}{ Sharp Spring } \\
\hline Spring Above Adaven & 12.5 & & & 8.3 & & & 7.5 & & & 513 & & & 316 & & \\
\hline
\end{tabular}


Table A.1-3

Field Measurement Data for Yucca Flat Geochemical Evaluation

(Page 3 of 5)

\begin{tabular}{|c|c|c|c|c|c|c|c|c|c|c|c|c|c|c|c|}
\hline \multirow[t]{2}{*}{ Site Identification } & \multicolumn{3}{|c|}{$\mathrm{T}\left({ }^{\circ} \mathrm{C}\right)$} & \multicolumn{3}{|c|}{ pH } & \multicolumn{3}{|c|}{ pH, Field } & \multicolumn{3}{|c|}{$\begin{array}{c}\text { Specific } \\
\text { Conductance } \\
(\mu \mathrm{S} / \mathrm{cm})\end{array}$} & \multicolumn{3}{|c|}{$\begin{array}{l}\text { Total Dissolved } \\
\text { Solids (mg/L) }\end{array}$} \\
\hline & Avg & SD & $\mathbf{n}$ & Avg & SD & $\mathbf{n}$ & Avg & SD & $\mathbf{n}$ & Avg & SD & $\mathbf{n}$ & Avg & SD & $\mathbf{n}$ \\
\hline Spring at Reville & 0.1 & & & & & & 7.6 & & & 427 & & & 302 & & \\
\hline Test Well \#7 & 20.6 & & & 7.3 & & & & & & 466 & & & 289 & & \\
\hline \multicolumn{16}{|l|}{ The Seeps Spring } \\
\hline Tim Spring & 15 & 1 & 2 & 8.1 & 0.1 & 2 & 8.1 & 0.4 & 2 & 361 & 1 & 2 & & & \\
\hline Tippipah Spring & 11 & 3 & 12 & 7.4 & 0.2 & 10 & 7.0 & 0.2 & 8 & 192 & 25 & 15 & 175 & 29 & 10 \\
\hline Topopah Spring & 15 & 9 & 8 & 7.1 & 0.3 & 6 & 6.91 & 0.04 & 2 & 103 & 16. & 7 & & & \\
\hline U12.03 UG-3 & & & & 7.5 & 0.1 & 3 & 7.4 & & & 270 & 5 & 4 & 203 & 8 & 4 \\
\hline U12e Tunnel & 16 & 4 & 2 & 8.2 & 0.6 & 19 & 8.11 & 0.01 & 2 & 331 & 57 & 19 & 277 & 111 & 18 \\
\hline U12n Tunnel & 17 & 4 & 3 & 8.4 & 0.5 & 36 & 7.8 & 0.5 & 3 & 347 & 61.7 & 34 & 250 & 50 & 26 \\
\hline U12t Tunnel & 16 & & & 7.7 & 0.4 & 23 & 7.7 & 0.4 & 4 & 268 & 19 & 23 & 220 & 53 & 23 \\
\hline \multicolumn{16}{|l|}{ U-15.01 Shaft, C-30 } \\
\hline \multicolumn{16}{|l|}{ U-15.01 Shaft, C-36 } \\
\hline \multicolumn{16}{|l|}{ U-15.01 Shaft, CGW-1 } \\
\hline \multicolumn{16}{|l|}{ U-15.01 Shaft, NH-01 } \\
\hline \multicolumn{16}{|l|}{ U-15.01 Shaft, UG-02 } \\
\hline U-2bs & 26 & 0.4 & 2 & 7.1 & 0.4 & 2 & & & & 389 & 0.0 & 2 & 275 & 4.2 & 2 \\
\hline U-3cn \#5 & 45 & & & 7.3 & 0.4 & 89 & & & & 550 & 126 & 90 & 343 & 62 & 12 \\
\hline U-3cn PS \#2 & 34.6 & 0.8 & 2 & 7.8 & 0.2 & 4 & 7.6 & & & 678 & 72 & 76 & 462 & 122 & 76 \\
\hline U-3mi & 33 & & & 8.1 & & & & & & & & & & & \\
\hline U-4u PS \#2A & 28 & & & 7.8 & 0.6 & 2 & 7.4 & 0.4 & 3 & 372 & 38 & 4 & 209 & & \\
\hline UE-10 ITS \#3 & & & & 8.3 & & & & & & 927 & & & 621 & & \\
\hline UE-10j & 28.9 & 4.7 & 2 & 7.0 & 0.4 & 2 & & & & 862 & 309 & 2 & 398 & & \\
\hline UE-10j, Zone \#1 & 32.7 & & & 6.4 & & & & & & 1,079 & 12 & 2 & 627 & & \\
\hline UE-10j, Zone \#2 & 32.3 & & & 6.7 & & & & & & 725 & & & & & \\
\hline UE-10j, Zone \#3 & 32.1 & & & 7.1 & 0.2 & 2 & & & & 625 & 51 & 2 & 394 & & \\
\hline UE-11a & & & & 8.1 & & & & & & 536 & & & 365 & & \\
\hline UE-14b & & & & 8.5 & 0.3 & 5 & & & & 401 & 35 & 5 & 296 & & \\
\hline UE-15d Water Well & 34 & 2 & 5 & 7.1 & 0.5 & 32 & 7.6 & 0.4 & 2 & 686 & 66 & 29 & 381 & 76 & 8 \\
\hline
\end{tabular}


Table A.1-3

Field Measurement Data for Yucca Flat Geochemical Evaluation

(Page 4 of 5)

\begin{tabular}{|c|c|c|c|c|c|c|c|c|c|c|c|c|c|c|c|}
\hline \multirow[t]{2}{*}{ Site Identification } & \multicolumn{3}{|c|}{$\mathrm{T}\left({ }^{\circ} \mathrm{C}\right)$} & \multicolumn{3}{|c|}{ pH } & \multicolumn{3}{|c|}{ pH, Field } & \multicolumn{3}{|c|}{$\begin{array}{c}\text { Specific } \\
\text { Conductance } \\
(\mu \mathrm{S} / \mathrm{cm})\end{array}$} & \multicolumn{3}{|c|}{$\begin{array}{l}\text { Total Dissolved } \\
\text { Solids (mg/L) }\end{array}$} \\
\hline & Avg & SD & $\mathbf{n}$ & Avg & SD & $\mathbf{n}$ & Avg & SD & $\mathbf{n}$ & Avg & SD & $\mathbf{n}$ & Avg & SD & $\mathbf{n}$ \\
\hline UE-15j & 45 & & & 6.8 & & & 6.6 & & & 2,530 & & & 1,090 & & \\
\hline UE-15j A-5 & 44.6 & 0.5 & 2 & 6.9 & 0.3 & 3 & & & & 2,110 & 528 & 3 & 1,030 & 10 & 3 \\
\hline UE-16d (Eleana) & 20.8 & 3.6 & 3 & 7.4 & 0.4 & 14 & 7.5 & 0.3 & 3 & 690 & 46 & 14 & 380 & 28 & 15 \\
\hline UE-16f (Eleana) & 24.8 & 3.1 & 4 & 8.9 & 0.5 & 3 & 8.4 & 0.3 & 2 & 1,483 & 260 & 5 & 1,032 & 54 & 3 \\
\hline UE-17a (Eleana) & 22.3 & 3.0 & 14 & 7.8 & 0.4 & 3 & 7.8 & 0.2 & 7 & 1,042 & 409 & 14 & 597 & 332 & 4 \\
\hline UE-1a & 25.4 & & & 7.7 & 0.5 & 2 & & & & 760 & 96 & 2 & 392 & 62 & 2 \\
\hline UE-1b & 27.4 & & & 7.7 & 0.5 & 2 & & & & 440 & 11 & 2 & 262 & 63 & 2 \\
\hline UE-1c & 26.7 & 0.7 & 10 & 7.5 & 0.7 & 23 & 7.3 & 0.1 & 8 & 460 & 66 & 31 & 284 & 63 & 4 \\
\hline UE-1h & 25.3 & & & 8.2 & & & & & & 1,029 & & & 515 & & \\
\hline UE-1q & 27.7 & 4.5 & 5 & 7.9 & 0.1 & 2 & 8.2 & 0.2 & 4 & 424 & 35 & 4 & 227 & & \\
\hline UE-2ce & 32.9 & 0.5 & 2 & 7.9 & 0.7 & 3 & 7.0 & 0.5 & 3 & 552 & 165 & 2 & 336 & 100 & 8 \\
\hline \multicolumn{16}{|l|}{ UE-4t } \\
\hline UE-5 PW-1 & 20.3 & 3.2 & 2 & 8.5 & 0.2 & 2 & 8.2 & 0.2 & 13 & 374 & 23 & 14 & 275 & 54 & 10 \\
\hline UE-5 PW-2 & 23.3 & & & 8.5 & & & 8.3 & 0.3 & 13 & 364 & 37 & 14 & 243 & 51 & 10 \\
\hline UE-5 PW-3 & 20.9 & 3.6 & 3 & 8.5 & 0.5 & 4 & 8.4 & 0.2 & 16 & 359 & 23 & 18 & 247 & 50 & 10 \\
\hline UE-5c Water Well & 25.2 & 1.0 & 31 & 8.1 & 0.4 & 34 & 8.5 & 0.03 & 2 & 468 & 181 & 34 & 308 & 44 & 8 \\
\hline UE-5n & 25.7 & 2.8 & 3 & 8.8 & 0.1 & 5 & 8.7 & 0.00 & 2 & 419 & 35 & 6 & 214 & & \\
\hline UE-6d & & & & 8.3 & & & & & & 440 & & & & & \\
\hline Ue-7nS & 34.7 & 1.9 & 4 & 7.6 & 0.7 & 47 & 7.6 & 0.1 & 2 & 567 & 114 & 49 & 261 & 49 & 4 \\
\hline USGS HTH \#1 & 23 & 3 & 17 & 9.0 & 0.3 & 20 & 9.1 & 0.2 & 16 & 232 & 15 & 36 & 143 & 14.2 & 5 \\
\hline USGS HTH \#10 & 27.7 & 0.7 & 2 & 7.5 & 0.3 & 3 & & & & 384 & 59 & 3 & 192 & 13 & 3 \\
\hline USGS HTH \#3 & 36 & 2 & 2 & 7.3 & & & 7.4 & & & 710 & & & 444 & & \\
\hline USGS HTH \#4 & & & & & & & 7.5 & & & & & & 212 & & \\
\hline USGS HTHE & & & & 8.4 & & & & & & 130 & & & & & \\
\hline USGS HTH F & 64.5 & 0.7 & 5 & 6.9 & 0.5 & 11 & 7.3 & & & 577 & 177 & 10 & 367 & 25 & 3 \\
\hline USGS Test Well B & 20.1 & & & 8.2 & 0.4 & 88 & & & & 369 & 62 & 87 & 209 & 29 & 2 \\
\hline USGS Test Well D & 23.9 & & & 7.9 & 0.5 & 24 & & & & 480 & 95 & 24 & 286 & 36 & 5 \\
\hline USGS Water Well A & 26.5 & 0.5 & 9 & 7.5 & 0.3 & 157 & 7.9 & 0.2 & 3 & 397 & 52 & 154 & 285 & 39 & 18 \\
\hline USGS Water Well C & 34.7 & 3.0 & 213 & 7.0 & 0.4 & 223 & 7.1 & 0.3 & 6 & 1,020 & 148 & 218 & 632 & 69 & 53 \\
\hline
\end{tabular}


Table A.1-3

Field Measurement Data for Yucca Flat Geochemical Evaluation

(Page 5 of 5)

\begin{tabular}{|c|c|c|c|c|c|c|c|c|c|c|c|c|c|c|c|}
\hline \multirow[t]{2}{*}{ Site Identification } & \multicolumn{3}{|c|}{$\mathrm{T}\left({ }^{\circ} \mathrm{C}\right)$} & \multicolumn{3}{|c|}{ pH } & \multicolumn{3}{|c|}{ pH, Field } & \multicolumn{3}{|c|}{$\begin{array}{c}\text { Specific } \\
\text { Conductance } \\
(\mu \mathrm{S} / \mathrm{cm})\end{array}$} & \multicolumn{3}{|c|}{$\begin{array}{l}\text { Total Dissolved } \\
\text { Solids (mg/L) }\end{array}$} \\
\hline & Avg & SD & $\mathbf{n}$ & Avg & SD & $\mathbf{n}$ & Avg & SD & $n$ & Avg & SD & $\mathbf{n}$ & Avg & SD & n \\
\hline $\begin{array}{l}\text { USGS-MX Coal Valley } \\
\text { Well }\end{array}$ & 23.1 & 0.1 & 2 & 7.6 & 0.1 & 2 & 7.4 & 0.3 & 2 & 421 & 27 & 2 & 268 & 13 & 2 \\
\hline Water Well 1 & 24.4 & & & 7.8 & & & & & & 338 & & & 272 & & \\
\hline Water Well 2 & 34.6 & 0.2 & 3 & 7.4 & 0.3 & 119 & 7.5 & 0.1 & 2 & 408 & 65 & 118 & 218 & 52 & 10 \\
\hline Water Well 4 & 28.2 & 5.4 & 40 & 7.6 & 0.3 & 48 & & & & 635 & 202 & 45 & 280 & 26 & 11 \\
\hline Water Well 4A & 26.5 & & & 8.1 & 0.2 & 3 & 7.9 & & & 395 & 13 & 3 & 285 & 11 & 6 \\
\hline Water Well 5A & 22.9 & 0.5 & 3 & 8.7 & 0.2 & 10 & 8.8 & 0.1 & 3 & 651 & 39 & 10 & 475 & 74 & 10 \\
\hline Water Well 5B & 24.9 & 1.1 & 40 & 8.1 & 0.4 & 45 & 8.4 & 0.3 & 7 & 507 & 63 & 45 & 340 & 25 & 25 \\
\hline Water Well 5C & 24.6 & 1.4 & 176 & 8.4 & 0.5 & 186 & 8.7 & 0.1 & 7 & 579 & 118 & 188 & 386 & 36 & 28 \\
\hline Water Well C-1 & 36.2 & 1.6 & 8 & 7.2 & 0.5 & 43 & 6.9 & 0.2 & 3 & 1,020 & 112 & 42 & 609 & 55 & 19 \\
\hline Watertown 1 & 23.9 & 1.0 & 4 & 7.9 & 0.2 & 5 & & & & 336 & 6 & 3 & 278 & 8 & 3 \\
\hline Watertown 2 & 28.0 & 2.3 & 2 & 8.3 & & & & & & 396 & 23 & 2 & 307 & 16 & 2 \\
\hline Watertown 3 & 23.0 & 0.8 & 6 & 7.8 & 0.2 & 12 & & & & 360 & 34 & 7 & 280 & 5 & 5 \\
\hline Watertown 4 & 30.4 & 7.6 & 2 & 6.9 & 0.01 & 2 & & & & 1,003 & 138 & 2 & 565 & & \\
\hline Well 3 Water Well & 22.4 & 1.1 & 6 & 7.8 & 0.2 & 8 & 7.9 & 0.1 & 2 & 378 & 20 & 8 & 273 & 10 & 8 \\
\hline Wheelbarrow Spring & 13.8 & & & 8.1 & & & & & & 324 & & & & & \\
\hline White Rock Spring, SR & 12.5 & 3.5 & 2 & 7.8 & 0.2 & 2 & 7.5 & 0.1 & 2 & 473 & 27 & 2 & 302 & & \\
\hline Whiterock Spring, YF & 13 & 2.7 & 35 & 7.4 & 0.3 & 53 & 7 & 0.6 & 10 & 214 & 36 & 57 & 195 & 37 & 8 \\
\hline Wiregrass Spring & 8.4 & 3.5 & 9 & 7.7 & 0.2 & 10 & 7.32 & 0.04 & 8 & 580 & 61 & 10 & 315 & 11 & 8 \\
\hline
\end{tabular}

Avg $=$ Average

$\mathrm{BR}=$ Belted Range

${ }^{\circ} \mathrm{C}=$ Degrees Celsius

$\mathrm{C} / \mathrm{B} \mathrm{Lab}=$ Charge balance calculated using $\mathrm{HCO}_{3}$ and $\mathrm{CO}_{3}$ measured in the lab

$\mathrm{C} / \mathrm{B}$ Field $=$ Charge balance calculated using $\mathrm{HCO}_{3}$ and $\mathrm{CO}_{3}$ measured in the field

$\mathrm{GR}=$ Groom Range

$\mathrm{mg} / \mathrm{L}=$ Milligrams per liter $n=$ Number of samples included in the average and standard deviation

$\mathrm{PW}=$ Pintwater Range

$\mathrm{SD}=$ Standard Deviation

SR = Sheep Range

SSV = Sand Spring Valley

YF = Yucca Flat

$\mu \mathrm{S} / \mathrm{cm}=$ Microsiemens per centimete 
Table A.1-4

Strontium and Uranium Data for Yucca Flat Geochemical Evaluation (Page 1 of 4 )

\begin{tabular}{|c|c|c|c|c|}
\hline SITE_ID & $\begin{array}{c}\text { Strontium } \\
(\mu \mathrm{g} / \mathrm{L})\end{array}$ & ${ }^{87} \mathrm{Sr} /{ }^{86} \mathrm{Sr}$ & $\begin{array}{l}\text { Uranium } \\
(\mu \mathrm{g} / \mathrm{L})\end{array}$ & $\begin{array}{c}{ }^{234} \mathrm{U} /{ }^{238} \mathrm{U} \\
\text { Activity Ratio }\end{array}$ \\
\hline \multicolumn{5}{|l|}{ Alluvial Aquifer (AA) } \\
\hline Desert Dry Lake Well \#1 & 463 & & 2.6 & 2.46 \\
\hline Penoyer Well & 400 & & 2.0 & \\
\hline Sand Spring, SSV & 294 & & & \\
\hline USGS Water Well A & 223 & & 5.2 & \\
\hline Watertown 3 & 210 & 0.71551 & 3.2 & \\
\hline Watertown 4 & 1,020 & 0.72567 & 4.0 & \\
\hline Well 3 Water Well & 228 & 0.71547 & 3.5 & \\
\hline \multicolumn{5}{|l|}{ Clastic Confining Unit (CCU) } \\
\hline ER-12-1 & 199 & 0.71169 & 1.61 & 7.05 \\
\hline ER-12-2 & 323 & 0.71662 & 0.02 & 6.27 \\
\hline ER-19-1 & 67 & & & \\
\hline UE-15d Water Well & 470 & 0.71356 & 10.3 & 3.10 \\
\hline UE-15j & 1,250 & & & \\
\hline UE-15j A-5 & 1,120 & & & \\
\hline UE-16f & 550 & 0.71136 & & \\
\hline UE-17a (Eleana) & 666 & 0.71017 & 0.6 & \\
\hline UE-1b & 470 & 0.70953 & 4.3 & \\
\hline \multicolumn{5}{|c|}{ Lower Carbonate Aquifer (LCA) and Lower Carbonate Aquifer- Yucca Flat Upper Plate (LCA3) } \\
\hline Army \#1 Water Well & 750 & 0.71200 & 2.52 & 3.00 \\
\hline Army 6 & 90 & 0.71117 & 0.3 & \\
\hline Ash Springs & 429 & 0.71415 & 2.60 & 2.44 \\
\hline Crystal Spring & 250 & 0.71087 & 4.9 & 3.08 \\
\hline ER-3-1 & 917 & 0.71824 & 4.04 & 3.76 \\
\hline ER-5-3 \#2 & 926 & 0.71540 & 5.23 & 3.27 \\
\hline
\end{tabular}


Table A.1-4

Strontium and Uranium Data for Yucca Flat Geochemical Evaluation

(Page 2 of 4 )

\begin{tabular}{|c|c|c|c|c|}
\hline SITE_ID & $\begin{array}{l}\text { Strontium } \\
(\mu \mathrm{g} / \mathrm{L})\end{array}$ & ${ }^{87} \mathrm{Sr} /{ }^{86} \mathrm{Sr}$ & $\begin{array}{c}\text { Uranium } \\
(\mu \mathrm{g} / \mathrm{L})\end{array}$ & $\begin{array}{c}{ }^{234} \mathrm{U} /{ }^{238} \mathrm{U} \\
\text { Activity Ratio }\end{array}$ \\
\hline ER-6-1 & 189 & 0.71288 & 3.06 & 4.14 \\
\hline ER-6-1 \#2 & 213 & 0.71296 & 2.89 & 4.19 \\
\hline ER-6-2 & 337 & 0.71280 & 2.18 & 4.43 \\
\hline ER-7-1 & 230 & 0.71318 & 4.72 & \\
\hline Hiko Spring & 347 & 0.71108 & 4.72 & 3.17 \\
\hline U-3cn \#5 & 227 & 0.71321 & 1.14 & 3.76 \\
\hline UE-10j & 432 & 0.71451 & 5.92 & 5.01 \\
\hline UE-10j, Zone \#1 & 470 & 0.71464 & 5.51 & 5.02 \\
\hline UE-10j, Zone \#2 & 320 & 0.71352 & 3.92 & 4.96 \\
\hline UE-10j, Zone \#3 & 270 & 0.71261 & 3.46 & 4.93 \\
\hline UE-1c & 415 & 0.70988 & 4.2 & \\
\hline UE-1h & 177 & 0.70932 & 0.1 & \\
\hline UE-1q & 140 & 0.71129 & 2.3 & 4.90 \\
\hline UE-7nS & 89 & 0.71272 & 0.47 & 2.45 \\
\hline USGS HTH \#10 & & & 0.6 & \\
\hline USGS HTH \#3 & 890 & 0.71328 & 2.8 & \\
\hline USGS HTH E & & & 2.5 & \\
\hline USGS HTH F & 545 & & 4 & \\
\hline USGS Test Well D & 112 & 0.71218 & 0.7 & \\
\hline USGS Water Well C & 704 & 0.71503 & 6.7 & \\
\hline USGS-MX Coal Valley Well & 245 & & 3.7 & \\
\hline Water Well 2 & 79 & & 1.1 & \\
\hline Water Well C-1 & 780 & 0.71498 & 6.9 & \\
\hline UE-2ce & 188 & & 0.4 & \\
\hline \multicolumn{5}{|l|}{ Perched Spring } \\
\hline April Fool Spring & 465 & & 2.6 & 2.36 \\
\hline
\end{tabular}


Table A.1-4

Strontium and Uranium Data for Yucca Flat Geochemical Evaluation

(Page 3 of 4)

\begin{tabular}{|c|c|c|c|c|}
\hline SITE_ID & $\begin{array}{c}\text { Strontium } \\
(\mu \mathrm{g} / \mathrm{L})\end{array}$ & ${ }^{87} \mathrm{Sr} /{ }^{86} \mathrm{Sr}$ & $\begin{array}{l}\text { Uranium } \\
(\mu \mathrm{g} / \mathrm{L})\end{array}$ & $\begin{array}{c}{ }^{234} \mathrm{U} /{ }^{238} \mathrm{U} \\
\text { Activity Ratio }\end{array}$ \\
\hline Cane Spring, FF & 120 & 0.70972 & 1.79 & 3.81 \\
\hline Cane Spring, GR & & & 2.3 & \\
\hline Captain Jack Spring & 4.4 & 0.71006 & 0.36 & 2.18 \\
\hline Cliff Spring, GR & 38 & 0.71008 & & \\
\hline Cow Camp Spring & 280 & & 1.7 & 3.2 \\
\hline Cresent Spring & 321 & & 16.6 & 2.89 \\
\hline De Jesus Spring & 305 & & 5.9 & \\
\hline Indian Spring, BR & & & 5.2 & \\
\hline Indian Spring, GR & & 0.71097 & & \\
\hline Oak Spring & & & 0.4 & \\
\hline Pyramid Spring & 700 & & & \\
\hline Quartz Spring & 470 & & & \\
\hline Sand Spring, PW & 240 & & & \\
\hline Tim Spring & 90 & & & \\
\hline Tippipah Spring & 24.1 & & 0.9 & \\
\hline Topopah Spring & 23.5 & & & \\
\hline White Rock Spring, SR & 140 & 0.70854 & 1.65 & 1.90 \\
\hline Whiterock Spring, YF & 28 & & 1.26 & 1.91 \\
\hline Wiregrass Spring & 73 & 0.70987 & 0.57 & 2.05 \\
\hline \multicolumn{5}{|l|}{ Upper Carbonate Aquifer (UCA) } \\
\hline UE-16d (Eleana) & 522 & 0.71003 & 2.12 & 5.31 \\
\hline \multicolumn{5}{|l|}{ Volcanic Aquifer (VA) } \\
\hline ER-5-3 & 70 & 0.71025 & 9.1 & 3.40 \\
\hline UE-14b & 35 & & & \\
\hline USGS HTH \#1 & 20 & 0.70893 & 1.1 & \\
\hline USGS HTH \#4 & & & 0.5 & \\
\hline
\end{tabular}


Table A.1-4

Strontium and Uranium Data for Yucca Flat Geochemical Evaluation

(Page 4 of 4 )

\begin{tabular}{|c|c|c|c|c|}
\hline SITE_ID & $\begin{array}{l}\text { Strontium } \\
(\mu \mathrm{g} / \mathrm{L})\end{array}$ & ${ }^{87} \mathrm{Sr} /{ }^{86} \mathrm{Sr}$ & $\begin{array}{c}\text { Uranium } \\
(\mu g / L)\end{array}$ & $\begin{array}{c}{ }^{234} \mathrm{U} /{ }^{238} \mathrm{U} \\
\text { Activity Ratio }\end{array}$ \\
\hline USGS Test Well B & 15 & 0.70968 & 0.9 & \\
\hline Water Well 4 & 146 & 0.71024 & 5.36 & \\
\hline Water Well 4A & 158 & 0.71010 & 5.7 & 3.85 \\
\hline Watertown 1 & 33 & 0.71566 & 0.3 & \\
\hline Watertown 2 & 60 & & 1.0 & \\
\hline \multicolumn{5}{|l|}{ Volcanic Confining Unit } \\
\hline ER-2-1 & 5 & 0.71131 & 1.86 & 2.91 \\
\hline ER-5-4 \#2 & 2 & 0.70890 & 34.3 & 1.30 \\
\hline Hagestad \#1 & 0.2 & & 0.4 & \\
\hline Marble \#3 & $<200$ & & 2.2 & \\
\hline Test Well \#7 & $<100$ & & 0.5 & \\
\hline U12.03 UG-3 & 20 & & & \\
\hline U12e Tunnel & 42 & & 4.4 & \\
\hline U12n Tunnel & 27 & & & \\
\hline U12t Tunnel & 28 & & & \\
\hline $\mathrm{U}-2 \mathrm{bs}$ & 64 & & & \\
\hline U-3cn PS \#2 & 15.4 & 0.70970 & 13.5 & 2.70 \\
\hline U-3mi & 660 & 0.71386 & 18.6 & \\
\hline U-4u PS \#2A & 46 & & 5.0 & \\
\hline
\end{tabular}

$\mathrm{BR}=$ Belted Range

$\mathrm{FF}=$ Frenchman Flat

$\mathrm{GR}=$ Groom Range

$\mathrm{PW}=$ Pintwater Range

$\mathrm{SR}=$ Sheep Range

SSV = Sand Spring Valley

YF = Yucca Flat

$\mu \mathrm{g} / \mathrm{L}=$ Micrograms per liter 
Table A.1-5

Select Trace and Minor Element Data for Yucca Flat Geochemical Evaluation

(Page 1 of 5)

\begin{tabular}{|c|c|c|c|c|c|c|c|c|c|c|c|c|c|c|c|}
\hline \multirow[t]{2}{*}{ Site Identification } & \multicolumn{3}{|c|}{$\begin{array}{c}\mathrm{SiO}_{2} \text {, Dissolved } \\
(\mathrm{mg} / \mathrm{L})\end{array}$} & \multicolumn{3}{|c|}{$\begin{array}{l}\mathrm{SiO}_{2} \text {, Total } \\
(\mathrm{mg} / \mathrm{L})\end{array}$} & \multicolumn{3}{|c|}{$\begin{array}{c}\mathrm{NO}_{3} \\
\text { (mg/L) }\end{array}$} & \multicolumn{3}{|c|}{$\begin{array}{c}\mathrm{Br} \\
(\mathrm{mg} / \mathrm{L})\end{array}$} & \multicolumn{3}{|c|}{$\begin{array}{c}F \\
(\mathrm{mg} / \mathrm{L})\end{array}$} \\
\hline & Avg & SD & $\mathbf{n}$ & Avg & SD & $\mathbf{n}$ & Avg & SD & $\mathbf{n}$ & Avg & SD & $\mathbf{n}$ & Avg & SD & $\mathbf{n}$ \\
\hline \multicolumn{16}{|l|}{ Adaven Spring } \\
\hline \multicolumn{16}{|l|}{ Alum Spring } \\
\hline April Fool Spring & 28 & & & & & & 0.3 & & & & & & 0.6 & & \\
\hline Army \#1 Water Well & 20 & 3 & 27 & 20 & 1 & 4 & 1.3 & 0.4 & 15 & 0.10 & 0.04 & 4 & 1.0 & 0.1 & 34 \\
\hline Ash Spring & 30 & 1 & 3 & & & & 3.1 & & & & & & 0.8 & 0.0 & 2 \\
\hline Bullwhack Spring & 25 & & & & & & & & & & & & & & \\
\hline Cane Spring, FF & 64 & 2 & 29 & & & & 15 & 2 & 27 & & & & & & \\
\hline Cane Spring, GR & 21 & & & & & & & & & & & & & & \\
\hline Captain Jack Spring & 35 & 8 & 7 & & & & 1.8 & 1.4 & 5 & & & & & & \\
\hline \multicolumn{16}{|l|}{ Carpenter Spring } \\
\hline Cattle Spring & 33 & & & & & & & & & & & & & & \\
\hline Cliff Spring, BR & 35 & & & & & & 0.3 & & & & & & & & \\
\hline Cliff Spring, GR & 28 & & & & & & & & & & & & & & \\
\hline Cow Camp Spring & 16 & 1 & 2 & & & & & & & & & & 0.20 & 0.00 & 2 \\
\hline Cresent Spring & 61 & & & & & & 1.5 & & & & & & 0.2 & & \\
\hline Crystal Spring & 24 & 1 & 6 & & & & 1.2 & & & 0.09 & 0.0 & 2 & 0.35 & 0.04 & 6 \\
\hline De Jesus Spring & 15.8 & 0.3 & 2 & & & & 20 & 14 & 2 & & & & & & \\
\hline Desert Dry Lake Well \#1 & 48.8 & 0.4 & 2 & & & & 30 & 27 & 2 & & & & 0.58 & 0.04 & 2 \\
\hline ER-12-1 & 20 & 3 & 3 & 19 & 1 & 5 & 0.12 & 0.03 & 2 & 0.42 & 0.03 & 2 & 0.25 & 0.05 & 5 \\
\hline ER-12-2 & 22 & 4 & 6 & 22 & 1 & 3 & $<0.2$ & & & $<0.2$ & & & 2.3 & 0.3 & 4 \\
\hline ER-19-1 & 71 & & & & & & & & & 1.6 & & & 2.2 & & \\
\hline ER-2-1 & 59 & 11 & 5 & 111 & 28 & 3 & 2.4 & & & & & & 1.9 & 0.2 & 4 \\
\hline ER-3-1 & 35 & 2 & 4 & & & & & & & & & & 1.2 & 0.4 & 6 \\
\hline ER-5-3 & 55 & 5 & 5 & 53 & 2 & 3 & 7.0 & & & 0.2 & 0.1 & 3 & 2.6 & 0.4 & 5 \\
\hline ER-5-3 \#2 & 29 & 1 & 3 & 30 & 0.0 & 3 & & & & 0.17 & 0.02 & 3 & 1.2 & 0.1 & 4 \\
\hline ER-5-4 & 77 & 3 & 2 & 78 & 2 & 2 & 4 & & & 0.22 & & & 6.4 & 0.3 & 2 \\
\hline ER-5-4\#2 & 75 & 5 & 5 & 82 & 9 & 3 & & & & $<0.2$ & & & 61 & 2 & 4 \\
\hline ER-6-1 & 29 & 6 & 10 & 27 & 6 & 5 & 0.5 & 0.2 & 2 & 0.7 & 0.1 & 5 & 0.75 & 0.05 & 8 \\
\hline
\end{tabular}


Table A.1-5

Select Trace and Minor Element Data for Yucca Flat Geochemical Evaluation (Page 2 of 5)

\begin{tabular}{|c|c|c|c|c|c|c|c|c|c|c|c|c|c|c|c|}
\hline \multirow{2}{*}{ 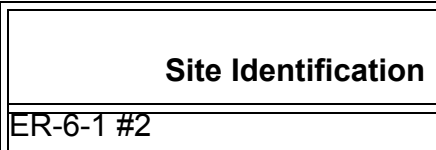 } & \multicolumn{3}{|c|}{$\begin{array}{c}\mathrm{SiO}_{2}, \text { Dissolved } \\
\text { (mg/L) }\end{array}$} & \multicolumn{3}{|c|}{$\begin{array}{c}\mathrm{SiO}_{2}, \text { Total } \\
(\mathrm{mg} / \mathrm{L})\end{array}$} & \multicolumn{3}{|c|}{$\begin{array}{c}\mathrm{NO}_{3} \\
(\mathrm{mg} / \mathrm{L})\end{array}$} & \multicolumn{3}{|c|}{$\begin{array}{c}\mathrm{Br} \\
(\mathrm{mg} / \mathrm{L})\end{array}$} & \multicolumn{3}{|c|}{$\begin{array}{c}F \\
(\mathrm{mg} / \mathrm{L})\end{array}$} \\
\hline & 33 & 2 & 7 & 32 & 0.0 & 3 & 1.1 & & & 0.4 & 0.3 & 4 & 0.77 & 0.03 & 4 \\
\hline ER-6-2 & 31 & 2 & 5 & 30 & 0.0 & 3 & 0.8 & 0.8 & 2 & 0.4 & 0.4 & 2 & 1.40 & 0.07 & 5 \\
\hline ER-7-1 & 33 & 6 & 6 & 37 & 1 & 3 & 0.07 & & & 0.05 & & & 0.81 & 0.01 & 4 \\
\hline Hagestad \#1 & 58 & 8 & 2 & & & & 0.3 & & & & & & 0.90 & 0.14 & 2 \\
\hline Hiko Spring & 32.7 & 0.5 & 2 & & & & 1.3 & & & & & & 0.57 & 0.04 & 2 \\
\hline Indian Spring, BR & 62 & & & & & & 0.8 & & & & & & & & \\
\hline \multicolumn{16}{|l|}{ Indian Spring, GR } \\
\hline Marble \#3 & 46 & & & & & & 2.9 & & & & & & 0.7 & & \\
\hline \multicolumn{16}{|l|}{ Miner Spring } \\
\hline \multicolumn{16}{|l|}{ Naquinta Spring } \\
\hline \multicolumn{16}{|l|}{ New Tikaboo Spring } \\
\hline Oak Spring & 57 & 1 & 5 & & & & 2 & 3 & 3 & & & & & & \\
\hline \multicolumn{16}{|l|}{ Old Tikaboo Spring } \\
\hline Penoyer Well & 83 & & & & & & & & & & & & 0.3 & & \\
\hline \multicolumn{16}{|l|}{ Pine Spring, GR } \\
\hline Pluto 1 & 54 & & & & & & 31.2 & & & & & & & & \\
\hline Pluto 5 & 58 & & & & & & 46 & & & & & & & & \\
\hline Pyramid Spring & 28 & & & & & & 3.4 & & & & & & 0.30 & 0.00 & 2 \\
\hline \multicolumn{16}{|l|}{ Quail Spring, GR } \\
\hline Quartz Spring & 51 & 8 & 3 & & & & 13 & 6 & 3 & & & & 0.56 & 0.06 & 2 \\
\hline \multicolumn{16}{|l|}{ Rabbitbrush Spring } \\
\hline \multicolumn{16}{|l|}{ Reveille Spring } \\
\hline \multicolumn{16}{|l|}{ Rock Spring } \\
\hline \multicolumn{16}{|l|}{ Rose Bud Spring } \\
\hline Sand Spring, PW & 16 & 2 & 3 & & & & 14 & 4 & 3 & & & & 0.3 & 0.1 & 2 \\
\hline Sand Spring, SSV & 35 & & & & & & 0.2 & & & & & & 1.7 & & \\
\hline \multicolumn{16}{|l|}{ Savio Spring } \\
\hline Sharp Spring & & & & & & & & & & & & & & & \\
\hline
\end{tabular}


Table A.1-5

Select Trace and Minor Element Data for Yucca Flat Geochemical Evaluation

(Page 3 of 5)

\begin{tabular}{|c|c|c|c|c|c|c|c|c|c|c|c|c|c|}
\hline \multirow{2}{*}{\begin{tabular}{|c|} 
Site Identification \\
Spring Above Adaven
\end{tabular}} & \multicolumn{3}{|c|}{$\begin{array}{c}\mathrm{SiO}_{2}, \text { Dissolved } \\
(\mathrm{mg} / \mathrm{L})\end{array}$} & $\begin{array}{c}\mathrm{SiO}_{2}, \text { Total } \\
(\mathrm{mg} / \mathrm{L})\end{array}$ & \multicolumn{3}{|c|}{$\begin{array}{c}\mathrm{NO}_{3} \\
(\mathrm{mg} / \mathrm{L})\end{array}$} & \multicolumn{3}{|c|}{$\begin{array}{c}\mathrm{Br} \\
(\mathrm{mg} / \mathrm{L})\end{array}$} & \multicolumn{3}{|c|}{$\begin{array}{c}F \\
(\mathrm{mg} / \mathrm{L})\end{array}$} \\
\hline & 28 & & & & 6.9 & & & & & & 0.2 & & \\
\hline Spring at Reville & 34 & & & & 5.8 & & & & & & 0.1 & & \\
\hline Test Well \#7 & 1.4 & & & & & & & & & & 2.4 & & \\
\hline \multicolumn{14}{|l|}{ The Seeps Spring } \\
\hline Tim Spring & 24 & 18 & 2 & & 20 & & & & & & 0.2 & & \\
\hline Tippipah Spring & 47 & 12 & 14 & & 6 & 2 & 9 & 0.1 & & & 0.24 & 0.09 & 10 \\
\hline Topopah Spring & 49 & 13 & 6 & & 2 & 2 & 4 & & & & & & \\
\hline U12.03 UG-3 & 66 & 1 & 4 & & 0.47 & 0.03 & 4 & & & & 0.2 & 0.1 & 4 \\
\hline U12e Tunnel & 42 & 5 & 19 & & 2.2 & 0.4 & 18 & 0.08 & 0.01 & 16 & 0.3 & 0.1 & 19 \\
\hline U12n Tunnel & 52 & 5 & 36 & & 2.5 & 1.5 & 34 & 0.08 & 0.02 & 31 & 0.2 & 0.1 & 27 \\
\hline U12t Tunnel & 54 & 7 & 23 & & 3.4 & 1.9 & 23 & 0.14 & 0.05 & 16 & 0.1 & 0.1 & 24 \\
\hline \multicolumn{14}{|l|}{ U-15.01 Shaft, C-30 } \\
\hline \multicolumn{14}{|l|}{ U-15.01 Shaft, C-36 } \\
\hline U-15.01 Shaft, CGW-1 & & & & & & & & & & & 0.9 & & \\
\hline \multicolumn{14}{|l|}{ U-15.01 Shaft, NH-01 } \\
\hline U-15.01 Shaft, UG-02 & & & & & & & & & & & 1.4 & & \\
\hline U-2bs & 53 & 1 & 2 & & 0.6 & 0.3 & 2 & & & & 1.30 & 0.00 & 2 \\
\hline U-3cn \#5 & 56 & 24 & 15 & & 0.3 & 0.1 & 5 & & & & 0.8 & 0.3 & 15 \\
\hline U-3cn PS \#2 & 55 & 6 & 75 & & 5.4 & 0.7 & 3 & 0.4 & 0.2 & 2 & 0.76 & 0.04 & 4 \\
\hline U-3mi & 117 & & & & & & & & & & & & \\
\hline U-4u PS \#2A & 60 & 17 & 3 & & 18.9 & 0.6 & 2 & & & & 0.9 & 0.2 & 3 \\
\hline UE-10 ITS \#3 & 62 & & & & 5.5 & & & & & & & & \\
\hline UE-10j & 34 & 9 & 2 & & 4.0 & & & & & & 0.30 & & \\
\hline UE-10j, Zone \#1 & 41 & 3 & 2 & & & & & 0.1 & & & 0.33 & & \\
\hline UE-10j, Zone \#2 & 36 & & & & & & & & & & 0.33 & & \\
\hline UE-10j, Zone \#3 & 32 & 3 & 2 & & & & & 0.1 & & & 0.35 & 0.04 & 2 \\
\hline UE-11a & 58 & & & & 1.0 & & & & & & & & \\
\hline UE-14b & 43.8 & 0.3 & 4 & & 9.4 & 0.5 & 4 & & & & & & \\
\hline UE-15d Water Well & 36 & 20 & 14 & & 1.4 & 0.6 & 4 & & & & 1.5 & 0.4 & 10 \\
\hline
\end{tabular}


Table A.1-5

Select Trace and Minor Element Data for Yucca Flat Geochemical Evaluation

(Page 4 of 5)

\begin{tabular}{|c|c|c|c|c|c|c|c|c|c|c|c|c|c|c|c|}
\hline Site Identification & $\mathrm{SiO}$ & $\begin{array}{l}\text { Dis: } \\
\text { mg/l }\end{array}$ & & & $\begin{array}{l}\mathrm{D}_{2}, \mathrm{~T} \\
\mathrm{mg} /\end{array}$ & & & $\begin{array}{c}\mathrm{NO}_{3} \\
(\mathrm{mg} / \mathrm{L}\end{array}$ & & & $\begin{array}{c}\mathrm{Br} \\
\text { (mg/L }\end{array}$ & & & $\begin{array}{c}F \\
(\mathrm{mg} / \mathrm{L})\end{array}$ & \\
\hline UE-15j & 36 & & & & & & & & & & & & 3.3 & & \\
\hline UE-15j A-5 & 33 & 1 & 3 & & & & 1.6 & 2.1 & 2 & & & & 3.1 & 0.2 & 3 \\
\hline UE-16d (Eleana) & 30 & 4 & 13 & 29.7 & 0.3 & 4 & 0.2 & 0.1 & 2 & & & & 0.5 & 0.1 & 12 \\
\hline UE-16f (Eleana) & 5 & 2 & 5 & & & & 0.01 & & & & & & & & \\
\hline UE-17a (Eleana) & 12 & 1 & 3 & & & & & & & & & & 2.2 & 1.7 & 7 \\
\hline UE-1a & 19.1 & 0.2 & 2 & & & & 0.04 & & & & & & & & \\
\hline UE-1b & 83 & 3 & 2 & & & & 2.7 & & & & & & & & \\
\hline UE-1c & 93 & 5 & 4 & & & & 2.4 & & & & & & 0.5 & & \\
\hline UE-1h & 11 & 1 & 2 & & & & & & & & & & & & \\
\hline UE-1q & 51 & & & 25 & 25 & 2 & & & & & & & 0.4 & 0.1 & 2 \\
\hline UE-2ce & 47 & & & & & & & & & & & & 0.3 & 0.3 & 4 \\
\hline UE-4t & & & & & & & & & & 0.06 & & & & & \\
\hline UE-5 PW-1 & 51 & 3 & 2 & 58 & 4 & 5 & 27 & 23 & 8 & & & & 1.2 & 0.2 & 13 \\
\hline UE-5 PW-2 & 31 & & & 60 & 1 & 5 & 21 & 17 & 6 & & & & 1.0 & 0.2 & 11 \\
\hline UE-5 PW-3 & 49 & 14 & 3 & 59 & 1 & 4 & 42 & 25 & 7 & & & & 1.1 & 0.2 & 13 \\
\hline UE-5c Water Well & 67 & 11 & 10 & 71 & & & 7.0 & 2.3 & 4 & & & & 1.9 & 0.2 & 12 \\
\hline UE-5n & 51 & 8 & 5 & & & & 7.1 & 4.1 & 5 & & & & 0.75 & 0.04 & 3 \\
\hline UE-6d & 53 & & & & & & 7.6 & & & & & & & & \\
\hline Ue-7nS & 21 & & & 21 & & & & & & & & & 0.9 & 0.1 & 4 \\
\hline USGS HTH \#1 & 19 & 4 & 22 & 23 & 1 & 4 & 0.04 & 0.01 & 8 & & & & 1.20 & 0.00 & 4 \\
\hline USGS HTH \#10 & 15 & 1 & 3 & & & & 2.3 & 0.8 & 3 & & & & 0.20 & 0.00 & 2 \\
\hline USGS HTH \#3 & 21 & 5 & 2 & & & & 0.9 & & & & & & 1.5 & & \\
\hline USGS HTH \#4 & 43 & & & & & & & & & & & & & & \\
\hline USGS HTH F & 36 & 2 & 3 & & & & 1.2 & 0.6 & 2 & & & & 3.2 & 0.2 & 3 \\
\hline USGS Test Well B & 17 & 1 & 4 & & & & 0.1 & 0.1 & 3 & & & & 0.9 & & \\
\hline USGS Test Well D & 44 & 2 & 5 & 50.8 & 0.2 & 2 & 0.20 & 0.03 & 2 & & & & 1.33 & 0.05 & 5 \\
\hline USGS Water Well A & 75 & 7 & 11 & 23 & 1 & 3 & 5.5 & 2.4 & 11 & & & & 0.7 & 0.3 & 24 \\
\hline USGS Water Well C & 35 & 12 & 24 & & & & 0.3 & 0.3 & 13 & 1.6 & 0.0 & 2 & 1.1 & 0.2 & 29 \\
\hline
\end{tabular}


Table A.1-5

Select Trace and Minor Element Data for Yucca Flat Geochemical Evaluation

(Page 5 of 5)

\begin{tabular}{|c|c|c|c|c|c|c|c|c|c|c|c|c|c|c|c|}
\hline \multirow{2}{*}{\begin{tabular}{|c|} 
Site Identification \\
USGS-MX Coal Valley Well
\end{tabular}} & \multicolumn{3}{|c|}{$\begin{array}{c}\mathrm{SiO}_{2} \text {, Dissolved } \\
\text { (mg/L) }\end{array}$} & \multicolumn{3}{|c|}{$\begin{array}{l}\mathrm{SiO}_{2}, \text { Total } \\
\text { (mg/L) }\end{array}$} & \multicolumn{3}{|c|}{$\begin{array}{c}\mathrm{NO}_{3} \\
(\mathrm{mg} / \mathrm{L})\end{array}$} & \multicolumn{3}{|c|}{$\begin{array}{c}\mathrm{Br} \\
(\mathrm{mg} / \mathrm{L})\end{array}$} & \multicolumn{3}{|c|}{$\begin{array}{c}F \\
(\mathrm{mg} / \mathrm{L})\end{array}$} \\
\hline & 36.3 & 0.4 & 2 & & & & 12 & & & 0.07 & & & 0.40 & 0.00 & 2 \\
\hline Water Well 1 & 71 & & & & & & 1.8 & & & & & & 2.1 & & \\
\hline Water Well 2 & 56 & 16 & 9 & 12 & 5 & 2 & 5 & 1 & 8 & 0.1 & & & 0.41 & 0.06 & 11 \\
\hline Water Well 4 & 63 & 3 & 7 & 62 & 2 & 4 & 15 & 6 & 6 & 1.1 & & & 0.75 & 0.09 & 12 \\
\hline Water Well 4A & 67 & 3 & 2 & 64 & 2 & 4 & 16 & 3 & 2 & & & & 0.8 & 0.2 & 7 \\
\hline Water Well 5A & 52 & 9 & 10 & & & & 5 & 1 & 7 & & & & 1.6 & 0.6 & 10 \\
\hline Water Well 5B & 64 & 38 & 15 & 59 & 2 & 4 & 10 & 5 & 17 & & & & 0.8 & 0.1 & 28 \\
\hline Water Well 5C & 53 & 7 & 18 & 54 & 3 & 4 & 6 & 2 & 16 & & & & 0.9 & 0.2 & 35 \\
\hline Water Well C-1 & 30 & 2 & 17 & 30.4 & 0.4 & 4 & 0.3 & 0.1 & 11 & 0.2 & & & 1.10 & 0.09 & 22 \\
\hline Watertown 1 & 79 & 7 & 4 & & & & 1.7 & 0.2 & 3 & & & & 2.1 & 0.2 & 4 \\
\hline Watertown 2 & 75 & 22 & 2 & & & & 1.9 & 0.3 & 2 & & & & 2.1 & 0.1 & 2 \\
\hline Watertown 3 & 78 & 2 & 7 & & & & 3.9 & 1.4 & 7 & & & & 1.0 & 0.3 & 10 \\
\hline Watertown 4 & 22 & 1 & 2 & & & & & & & & & & 1.4 & 0.1 & 2 \\
\hline Well 3 Water Well & 65 & 16 & 8 & & & & 6.4 & 0.7 & 7 & & & & 0.92 & 0.07 & 8 \\
\hline Wheelbarrow Spring & 29 & & & & & & & & & & & & & & \\
\hline White Rock Spring, SR & 46 & 2 & 2 & & & & & & & & & & 0.20 & 0.00 & 2 \\
\hline Whiterock Spring, YF & 47 & 10 & 56 & & & & 6 & 1.7 & 50 & & & & 0.41 & 0.14 & 8 \\
\hline Wiregrass Spring & 11.9 & 0.3 & 10 & & & & 4.1 & 1.6 & 5 & 0.02 & 0.01 & 2 & 0.17 & 0.07 & 10 \\
\hline
\end{tabular}

$\mathrm{mg} / \mathrm{L}=$ Milligrams per liter 


\section{DISTRIBUTION}

$\underline{\text { Copies }}$

Bill R. Wilborn

$1 \mathrm{HC}$

Environmental Restoration Division

U.S. Department of Energy

National Nuclear Security Administration

Nevada Site Office

P.O. Box 98518, MS/505

Las Vegas, NV 89193-8518

Nicole Y. Carson

$4 \mathrm{HC}$

Technical Information Officer

Office of Environmental Management

U.S. Department of Energy

National Nuclear Security Administration

Nevada Site Office

P.O. Box $98518, \mathrm{MS} / 505$

Las Vegas, NV 89193-8518

Tim P. Rose

$1 \mathrm{HC}$

Lawrence Livermore National Laboratory

7000 East Avenue, L-231

Livermore, CA 94550-9234

Gayle Pawloski

$1 \mathrm{HC}$

Lawrence Livermore National Laboratory

7000 East Avenue, L-221

Livermore, CA 94550-9234

Mavrik Zavarin

$1 \mathrm{HC}$

Lawrence Livermore National Laboratory

7000 East Avenue, L-221

Livermore, CA 94550-9234

Zell Peterman

$1 \mathrm{HC}$

U. S. Geological Survey

21 Center Ave

Denver Federal Center

Denver, CO 80225 
$\underline{\text { Copies }}$

Jim Paces

$1 \mathrm{HC}$

U.S. Geological Survey

Denver Federal Center

Box 25046, MS-963

Lakewood, CO 80225

Edward M. Kwicklis

$1 \mathrm{HC}$

Los Alamos National Laboratory

Hydrology, Geochemistry, and Geology Group, EES-6

Earth and Environmental Sciences Division

Bikini Atoll Rd., SM-30

Los Alamos, NM 87545

Andrew V. Wolfsberg

$1 \mathrm{HC}$

Los Alamos National Laboratory

Hydrology, Geochemistry, and Geology Group, EES-6

Earth and Environmental Sciences Division

Bikini Atoll Rd., SM-30

Los Alamos, NM 87545

Chuck E. Russell

$1 \mathrm{HC}$

Desert Research Institute

755 E. Flamingo

Las Vegas, NV 89119

Ron Hershey

$1 \mathrm{HC}$

Desert Research Institute

2215 Raggio Parkway

Reno, NV 89512

Roger L. Jacobson

$1 \mathrm{HC}$

Desert Research Institute

2215 Raggio Parkway

Reno, NV 89512

John P. McCord

$1 \mathrm{HC}$

Stoller-Navarro Joint Venture

7710 W. Cheyenne, Bldg. 3

Las Vegas, NV 89129 


\section{$\underline{\text { Copies }}$}

Greg Ruskauff

$1 \mathrm{HC}$

Stoller-Navarro Joint Venture

7710 W. Cheyenne, Bldg. 3

Las Vegas, NV 89129

Bill Fryer

$1 \mathrm{HC}$

Stoller-Navarro Joint Venture

990 S. Public Rd., Suite A

Lafayette, CO 80026

Parviz Montazer

$1 \mathrm{HC}$

Stoller-Navarro Joint Venture

7710 W. Cheyenne, Bldg. 3

Las Vegas, NV 89129

Irene Farnham

$1 \mathrm{HC}$

Stoller-Navarro Joint Venture

7710 W. Cheyenne, Bldg. 3

Las Vegas, NV 89129

Stoller-Navarro Joint Venture

$1 \mathrm{HC}$

Central Files

7710 W. Cheyenne, Bldg. 3

Las Vegas, NV 89129 